\title{
Revista Dialectus
}

Revista de Filosofia E-ISSN: 2317-2010

Número 14 (2019), jan.-jul. 2019.

Dossiê Herbert Marcuse

43

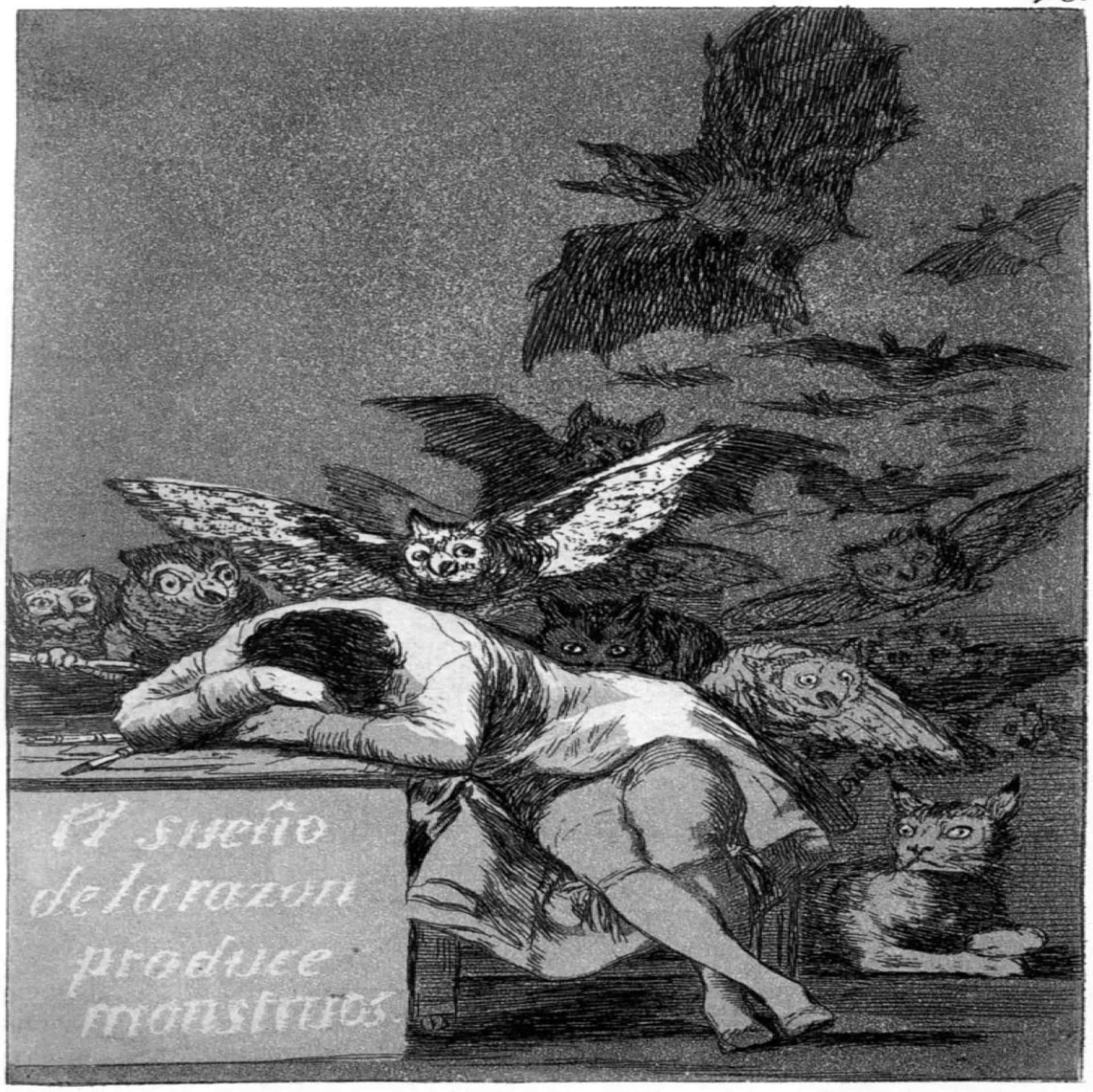




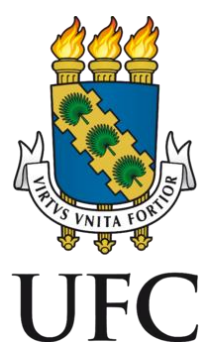

Revista Dialectus

Revista de Filosofia

E-ISSN: 2317-2010

Periódico vinculado ao Programa de Pós-Graduação em Filosofia da Universidade Federal do Ceará - UFC

Revista Dialectus - Revista de Filosofia. Fortaleza, ano 8, n. 14, jan.-jul. 2019. Arte da Capa: $O$ sono da razão produz monstros (1797-1799), Francisco de Goya. 


\section{Universidade Federal do Ceará}

\section{Reitor}

Henry de Holanda Campos

Vice-reitor

Custódio Luís Silva de Almeida

Pró-reitor de Pesquisa e Pós-Graduação Antônio Gomes de Souza Filho

Diretor do Instituto de Cultura e Arte Sandro Thomaz Gouveia

\section{Coordenador do PPG - Filosofia}

Hugo Filgueiras de Araújo

Vice-coordenadora do PPG - Filosofia

Maria Aparecide de Paiva Montenegro 


\section{Revista Dialectus - Revista de Filosofia \\ E-ISSN: 2317-2010}

\section{EDITORES-CHEFES}

Eduardo Ferreira Chagas, Universidade Federal do Ceará, UFC/CNPq

Hildemar Rech, Universidade Federal do Ceará, UFC

Manoel Jarbas Vasconcelos Carvalho, Universidade Federal do Rio Grande do Norte, UFRN

\section{EDITORES GERENTES}

Amsterdan Duarte, Universidade Federal do Ceará, UFC

Eduardo Ferreira Chagas, Universidade Federal do Ceará, UFC/CNPq

Manoel Jarbas Vasconcelos Carvalho, Universidade Federal do Rio Grande do Norte, UFRN

Renato Almeida Oliveira, Universidade Estadual Vale do Acaraú, UVA

Wildiana Kátia Monteiro Jovino, Universidade Estadual do Ceará, UECE/UAB

\section{EDITORES DE LAYOUT}

Albertino Servulo, Universidade Federal do Ceará, UFC

Douglas Santana, Universidade Federal do Ceará, UFC

\section{EDITORES DE SEÇÃO}

Douglas Santana, Universidade Federal do Ceará, UFC

Ronaldo Martins Oliveira, Universidade Federal do Ceara, UFC

\section{COMITÊ EDITORIAL}

Dr. Eduardo Ferreira Chagas, Universidade Federal do Ceará, UFC/CNPq

Dr. Hildemar Rech, Universidade Federal do Ceará, UFC

Dr. José Edmar Lima Filho, Universidade Estadual Vale do Acaraú, UVA, Brasil

Dr. Manoel Jarbas Vasconcelos Carvalho, Universidade Federal do Rio Grande do Norte, UFRN

Ms. Maria Artemis Ribeiro Martins, Instituto Federal do Ceará, IFCE

Ms. Natália Ayres, Instituto Federal do Ceará, IFCE

Dr. Renato Almeida Oliveira, Universidade Estadual Vale do Acaraú, UVA

Dra. Wildiana Kátia Monteiro Jovino, Universidade Estadual do Ceará, UECE/UAB 


\section{COMITÊ CIENTÍFICO}

Adriana Veríssimo Serrão, Universidade de Lisboa, UL

Agemir Bavaresco, Pontíficia Universidade Católica do Rio Grande do Sul, PUCRS

Alfredo de Oliveira Moraes, Universidade Federal de Pernambuco, UFPE

Anselm Jappe, Accademia di Belle Arti di Frosinone, Itália

Antonio Glaudenir Brasil Maia, Universidade Estadual Vale do Acaraú, UVA

Arlei de Espíndola, Universidade Estadual de Londrina, Brasil

Caio Navarro Toledo, Universidade Estadual de Campinas, UNICAMP

Christian Iber, Pontificia Universidade Católica do Rio Grande do Sul, PUCRS

Christoph Türcke, Hochschule für Grafik und Buchkunst Leipzig, Alemanha

Deyve Redyson Melo dos Santos, Universidade Federal da Paraíba, UFPB

Elisete M. Tomazetti, Universidade Federal de Santa Maria, UFSM

Ester Vaisman, Universidade Federal de Minas Gerais, UFMG

Fábio Maia Sobral, Universidade Federal do Ceará, UFC

Hector Benoit, Universidade Estadual de Campinas, UNICAMP

Humberto Calloni, Universidade Federal do Rio Grande, FURG

Ivan Domingues, Universidade Federal de Minas Gerais, UFMG

José Rômulo Soares, Universidade Estadual do Ceará, UECE

Juliano Cordeiro da Costa Oliveira, Universidade Federal do Piauí, UFPI

Justino de Sousa Júnior, Universidade Federal do Ceará, UFC

Lígia Regina Klein, Universidade Federal do Paraná, UFPR

Lucíola Andrade Maia, Universidade Estadual do Ceará, UECE

Marcio Gimenes de Paula, Universidade de Brasília, UNB

Marcos José de Araújo Caldas, Universidade Federal Rural do Rio de Janeiro, UFRRJ

Marcos Lutz Müller, Universidade Estadual de Campinas, UNICAMP

Maria Artemis Ribeiro Martins, Instituto Federal do Ceará, IFCE

Maria Tereza Callado, Universidade Estadual de Ceará, UECE

Marly Carvalho Soares, Universidade Estadual do Ceará, UECE

Mauro Castelo Branco de Moura, Universidade Federal da Bahia, UFBA

Mário Duayer, Universidade Estadual do Rio de Janeiro, UERJ

Michael Löwy, Centre National des Recherches Scientifiques, CNRS, França

Natália Ayres, Instituto Federal do Ceará, IFCE

Osvaldo Coggiola, Universidade de São Paulo, USP

Paulo Henrique Furtado de Araújo, Universidade Federal Fluminense, UFF

Roberto Leher, Universidade Federal do Rio de Janeiro, UFRJ

Rosalvo Schütz, Universidade Estadual do Oeste do Paraná - UNIOESTE

Ruy Gomes Braga Neto, Universidade de São Paulo, USP

Silvana Maria Santiago, Universidade Estadual do Rio Grande do Norte, UERN

Siomara Borba Leite, Universidade do Estado do Rio de Janeiro, UERJ

Sylvio de Sousa Gadelha Costa, Universidade Federal do Ceará, UFC

Valério Arcary, Instituto Federal de Educação, Ciência e Tecnologia de São Paulo, IFSP

Wildiana Kátia Monteiro Jovino, Universidade Estadual do Ceará, UECE/UAB 
Revista Dialectus - Revista de Filosofia

E-ISSN: 2317-2010

\section{Endereço postal}

Revista Dialectus

Programa de Pós-Graduação em Filosofia

Universidade Federal do Ceará - UFC

Rua Abdenago Rocha Lima, s/n, Campus do Pici

Fortaleza - Ceará

CEP: 60455-320

\section{Contato Principal}

Eduardo Ferreira Chagas

Doutor em Filosofia

Universidade Federal do Ceará - UFC

E-mail: ef.chagas@uol.com.br

\section{Contato para Suporte Técnico}

Telefone: 8533669224

E-mail: revistadialectus@yahoo.com.br 


\section{SUMÁRIO}

\section{EDITORIAL}

O PENSAMENTO DE HERBERT MARCUSE

\section{DOSSIÊ: O PENSAMENTO DE HERBERT MARCUSE}

1. MARCUSE E O ALERTA À CONTRARREVOLUÇÃO PREVENTIVA

Robespierre de Oliveira (UEM)

2. HERBERT MARCUSE E A TEORIA CRÍTICA: PARA ALÉM DA PERSPECTIVA NORMATIVA DA ESCOLA DE FRANKFURT Silvio Ricardo Carneiro (UFABC)

3. HERBERT MARCUSE E OS ANOS 1960: POSSIBILIDADES PARA A TRANSGRESSÃO NA SOCIEDADE CAPITALISTA Maria Ribeiro do Valle (UNESP) e Pablo Almada (UEL)

4. DA OBSOLETA CARÊNCIA DE DOMINAÇÃO A UM NOVO PRINCÍPIO DE REALIDADE SEGUNDO MARCUSE Manoel Dionizio Neto $(U F C G)$

5. CONTRIBUIÇÕES TEÓRICAS DE MARCUSE SOBRE AS NOVAS FORMAS DE CONTROLE E DOMINAÇÃO NAS SOCIEDADES CAPITALISTAS Paulo Sérgio Soares (UFT) e Rafael Silva Oliveira (ITOP)

6. OS LIMITES DA TOLERÂNCIA: UMA ANÁLISE A PARTIR DAS CONCEPÇÕES DE MARCUSE John Aquino (IFCE)

7. TEORIA CRÍTICA E OS (DES)CAMINHOS DA TECNOCIÊNCIA: REFLEXÕES MARCUSEANAS

Maria de Fátima Severiano (UFC), Pablo Benevides (UFC) $e$

Valdemir Queiroz Neto (UFC)

8. VIDA E MORTE, PROGRESSO E UTOPIA EM HERBERT MARCUSE Marília Mello Pisani (UFABC)

9. A ARTE DA FANTASIA, A PARTIR DE HERBERT MARCUSE Imaculada Kangussu (UFOP)

10. O TEATRO ADMINISTRADO NA SOCIEDADE UNIDIMENSIONAL Leonardo de Castro e Isabella Ferreira (UFMS)

11. EROS ÀS AVESSAS: PANSEXUALISMO E DESSUBLIMAÇÃO REPRESSIVA Rafael Cordeiro Silva (UFU) 
12. AS MINORIAS COMO O NEGATIVO, O MOVIMENTO DAS MULHERES E O ESPAÇO DIGITAL

Deborah Antunes (UFC)

\section{FLUXO CONTÍNUO}

13. A CARTA DE FEUERBACH A HEGEL

Adriana Veríssimo Serrão (Universidade de Lisboa)

14. O MÉTODO NARRATIVO DE HERMANN HESSE E O TRATAMENTO DAS IDEIAS DE NIETZSCHE

Raylane Marques (UFMG) e Eduardo Chagas (UFC/CNPq)

15. HISTÓRIAS DE OUTUBRO: TROTSKI E A REVOLUÇÃO RUSSA

Fábio José de Queiroz (URCA) e Frederico Costa (UECE)

16. A RELAÇÃO TRABALHO-EDUCAÇÃO NO PENSAMENTO DE MARX: UM ESTUDO DOS MANUSCRITOS ECONÔMICO-FILOSÓFICOS (1844)

José Salvador de Almeida (UFC) e Eduardo Chagas (UFC/CNPq)

\section{TRADUÇÕES}

17. PREFÁCIO À EDIÇÃO FRANCESA DE “O HOMEM UNIDIMENSIONAL” Alberto Dias Gadanha (UECE), Djibril Ernesto Pereira (UFC) $e$

Renê Ivo da Silva Lima (UFC)

18. DA ONTOLOGIA À TECNOLOGIA: AS TENDÊNCIAS DA SOCIEDADE INDUSTRIAL

João Paulo Andrade Dias (UNICAMP)

\section{RESENHAS}

19. FÍSICA DE ARISTÓTELES 


\section{EDITORIAL \\ O PENSAMENTO DE HERBERT MARCUSE}

John Karley de Sousa Aquino

Alberto Dias Gadanha

Eduardo Ferreira Chagas

Hildemar Luiz Rech

Manoel Jarbas Vasconcelos Carvalho

Herbert Marcuse (1898-1979) para muitos, está relacionado às pretensões juvenis dos anos sessenta e às esperanças revolucionárias da época. Sua trajetória filosófica caracterizou-se sempre pela compreensão da prática da transformação da sociedade contemporânea e de suas relações de dominação numa sociedade livre e emancipada. A qualidade e o conteúdo de seus textos lhe rendeu ainda na década de 60, o título de maître à penser dos estudantes radicalizados na França, Alemanha e Estados Unidos. Com a atenuação da guerra fria e o decreto ideológico do fim das ideologias, o que significava a aceitação e admiração passou a lhe render hostilidades e a condenação ao ostracismo filosófico. Em contraste aos autores que sempre teriam algo a nos dizer, como os clássicos Platão, Aristóteles, Hegel ou Kant; Marcuse chegou a ser considerado um filósofo com prazo de validade determinada, tornando-se anacrônico citá-lo ou insistir atualmente na leitura de suas obras.

Quando a proposta de emancipação humana desaparece do horizonte histórico com o fracasso das experiências socialistas do leste europeu e o avanço acelerado do neoliberalismo por todo o globo, parece não haver mais alternativas ao modus operandi da vida contemporânea e insistir no estudo de um teórico que sempre buscou apontar alternativas de superação a realidade existente parece ser não só um erro político, mas também acadêmico e profissional.

Conhecido mundialmente nos anos 60, Marcuse na Universidade da Califórnia, no Campus de San Diego, tornou-se um dos principais pontos de resistência à guerra do Vietnã e das lutas pelos direitos civis. Em 1968 Marcuse foi eleito a principal referência teórica do marxismo para a juventude radicalizada na Europa e nos Estados Unidos e tornou-se um dos três $\mathrm{M}$ inscritos nos muros de Paris no maio de 68. Rapidamente converteu-se em um subproduto da indústria cultural e foi nesse clima que Marcuse chegou ao Brasil, através das traduções dos seus livros Eros e Civilização e O Homem Unidimensional, sendo lido como um teórico da contracultura.

A recepção de Marcuse no Brasil foi feita as pressas, com objetivo pragmático, a saber, uma tentativa de justificar teoricamente a decisão dos grupos de esquerda radicais que 
defendiam a luta armada contra a ditadura, além de ter sido interpretado equivocadamente como um teórico contra cultural por certa esquerda festiva. Por sua fundamentação marxista, por seu apoio público às lutas dos trabalhadores, apoio às minorias e aos movimentos de libertação nacional, é possível compreender que não é fortuita sua exclusão de certos círculos acadêmicos brasileiros, o que poderia explicar a ausência de Marcuse no volume dedicado no Brasil à Escola de Frankfurt na conhecida coleção Os Pensadores.

Em nossa interpretação a recepção brasileira da obra de Marcuse foi negativa devido o contexto cultural adverso, em meio a repressão da ditadura militar e as traduções mal elaboradas, feitas às pressas para serem vendidas, não foi possível uma leitura atenciosa e criteriosa da filosofia de Marcuse e por isso tanto leitores quanto críticos do mesmo o leram e interpretaram apressadamente e algumas vezes, equivocadamente. Com o passar do tempo, com a expansão da pesquisa de sua obra verifica-se que é possível, agora com a devida paciência e dedicação, lermos Marcuse e desfazermos determinados mal entendidos e garantir um lugar ao sol para o autor em meio à produção filosófica nacional.

A publicação de um Dossiê dedicado à teoria crítica de Herbert Marcuse na Revista Dialectus, vem ao encontro desse processo de reabilitação do nosso autor. Reunimos um conjunto de artigos de conceituados pesquisadores da obra do frankfurtiano Herbert Marcuse das mais diversas áreas, da filosofia, sociologia, psicologia, enfim, uma coletânea de artigos no espírito programático da teoria crítica de sintetizar especulação filosófica e pesquisa empírica.

$\mathrm{O}$ artigo que abre nosso dossiê é do professor Robespierre de Oliveira, um dos tradutores da obra marcuseana no Brasil. No artigo Marcuse e o alerta à contrarrevolução preventiva ele tematiza a questão da contrarrevolução que foi discutida em vários textos de Marcuse. Seu objetivo é identificar a contribuição de Marcuse a essa questão prática da esquerda contemporânea. Para Robespierre as propostas de "Grande Recusa" e "nova sensibilidade" elaboradas por Marcuse visariam romper os limites impostos pela dominação existente a partir das necessidades vitais dos próprios indivíduos.

Em seguida o professor Silvio Ricardo Gomes Carneiro propõe uma contraposição da teoria crítica de Marcuse à versão mais contemporânea da Teoria Crítica, representada pela perspectiva normativa de Jürgen Habermas e Axel Honneth. Seu artigo Herbert Marcuse e a Teoria Crítica: Para além da perspectiva normativa da Escola De Frankfurt problematiza a insuficiência do atual modelo crítico de Habermas e Honneth diante dos desafios contemporâneos através das reflexões de Marcuse sobre os limites da democracia burguesa que será o mote para pensar uma perspectiva de Teoria Crítica diversa da normatividade.

\begin{tabular}{|c|c|c|c|c|}
\hline Rovista Dialectus & Ano 8 & n. 14 & Janeiro - Julho 2019 & p. $8-14$ \\
\hline
\end{tabular}


Por sua vez, em uma leitura mais "sociológica" de Marcuse a professora Maria Ribeiro do Valle e o professor Pablo Almada discutem a contribuição de Herbert Marcuse para a compreensão dos conflitos e protestos que ocorreram durante os anos 1960, com ênfase no entendimento do filósofo alemão com relação ao movimento estudantil mundial época. Para os autores no artigo Herbert Marcuse e os anos 60: possibilidades para a transgressão na sociedade capitalista Marcuse elaborou uma percepção sociológica acerca dos movimentos sociais e estudantis que valorizou as capacidades críticas e emancipatórias que estavam sendo postuladas por meio dos protestos daquela década abrindo caminho para a renovação da esquerda pela "nova esquerda".

Manoel Dionizio Neto no artigo Da obsoleta carência de dominação a um novo Princípio de realidade segundo Marcuse tendo como referência fundamental Eros e Civilização busca a compreensão a respeito das condições em que se deu a formação da cultura e o desenvolvimento da civilização a partir da interpretação marcusiana do pensamento de Freud. Refletindo sobre a hipótese marcuseana de que a "mais-repressão" perdeu sua razão de ser devido os próprios progressos materiais e técnicos da civilização capitalista o autor pensa sobre a possibilidade de um novo Princípio de Realidade, quando não se tem mais a carência dessa dominação. Uma instigante exposição da interpretação filosófica de Marcuse da pscinálise freudiana.

Em uma sociedade cada vez mais conectada pela internet e ao mesmo tempo vigiada, possibilitando uma maior administração social dos indivíduos pelo status quo os professores Paulo Sérgio Soares e Rafael Silva Oliveira apresentam um debate em torno das formas de controle social emergentes nas sociedades capitalistas, que estão voltadas para dominar os indivíduos pela satisfação das necessidades superimpostas e, contraditoriamente, movimentar as engrenagens do sistema. No artigo Contribuições teóricas de Marcuse sobre as novas formas de controle e dominação nas sociedades capitalistas investiga-se em que medida a técnica e a tecnologia contribuem para instituir as novas formas de controle social a partir do conceito de racionalidade tecnológica. O objetivo é apontar as contradições da razão em meio ao ambiente tecnológico existente atualmente.

$\mathrm{O}$ que acontece quando conservadores com opiniões preconceituosas, que outrora defenderam a censura, reclamam seu direito à liberdade de expressão? O que dizer quando homofóbicos como políticos e pastores da "bancada da bíblia" exigem que suas declarações sejam toleradas em respeito ao direito inalienável que eles têm de emitir suas opiniões sejam elas quais forem? Quando nossos preconceituosos e intolerantes conservadores recorrem aos

\begin{tabular}{|c|c|c|c|c|}
\cline { 2 - 5 } Q Dovista & Ano 8 & n. 14 & Janeiro - Julho 2019 & p. 8-14 \\
\hline
\end{tabular}


ideais modernos de tolerância e liberdade de expressão os limites desses ideais iluministas ficam expostos e é hora de refletirmos sobre isso. Essa é a proposta do artigo Os limites da tolerância: uma análise a partir das concepções de Herbert Marcuse do professor John Karley Aquino que pretende delimitar os limites do conceito liberal de tolerância e propor um contra conceito, o de tolerância concreta, com limites definidos que determina a diferença entre o tolerável e o intolerável, desmascarando o caráter ideológico do conceito liberal de tolerância que se tornou repressivo.

Abordando a questão da técnica e tecnologia no pensamento de Marcuse o artigo escrito a várias mãos Teoria Crítica e os (des)caminhos da tecnociência: reflexões marcuseanas da professora Maria de Fátima Severiano e dos professores Pablo Severiano Benevides e Valdemir Pereira de Queiroz Neto tem por objetivo discutir a problemática do progresso técnico favorecido pelas produções científicas a partir do referencial teórico da Escola de Frankfurt, especialmente as contribuições de Herbert Marcuse. Trata-se de uma pesquisa teórica, de natureza qualitativa e de inspiração crítica, em que os autores se valem da proposta da teoria crítica, cuja abordagem micrológica concebe o particular como um valioso índice que remete ao todo.

Em um belíssimo texto escrito em parte contra a irresponsável "sociedade do automóvel" e embalada pelo luto das mortes sem sentido que poderiam ter sido evitadas, a professora Marília Melo Pisani nos lega um emocionante artigo intitulado Vida e morte, progresso e utopia em Herbert Marcuse. No artigo Pisani apresenta a crítica da sociedade industrial de Herbert Marcuse em dois movimentos. Tomando como caso particular a indústria automobilística como generalização de uma forma de vida (e de morte), assim como o debate realizado sobre esse tema na década de 1970 e discute o lugar da utopia no pensamento de Herbert Marcuse como base para pensar os movimentos sociais contemporâneos.

A questão da arte, que para Marcuse em seus últimos escritos constituía a "última linguagem negativa" está presente no nosso Dossiê nos artigos da Professora Imaculada Kangussu que em A arte da fantasia a partir de Herbert Marcuse apresenta as relações entre arte e fantasia, a partir da leitura que Marcuse faz de Freud. Em seguida, explicita e enfatiza a potência da fantasia relativa à produção de imagens libertadoras, para concluir com a ideia de que a liberdade experimentada através das obras de arte constitui a imagem da possibilidade de um mundo melhor, de que outro mundo é possível para além do existente. Ainda sobre a estética marcuseana o artigo $\boldsymbol{O}$ Teatro administrado na sociedade unidimensional da professora Isabella Fernanda Ferreira e do artista e educador Leonardo Augusto Madureira de Castro faz

\begin{tabular}{|c|c|c|c|c|}
\cline { 2 - 5 } Q Q Dialectus & Ano 8 & n. 14 & Janeiro - Julho 2019 & p. $8-14$ \\
\hline
\end{tabular}


considerações acerca da arte na sociedade administrada e a interferência da tecnologia na arte. Segundo os autores Marcuse identificaria na arte os vestígios da industrialização, vestígios estes dos quais o Teatro não está imune e pelos quais também é modificado, instrumentalizado e administrado, uma vez que em seu processo de produção atende à mencionada sociedade administrada e a partir disso pensar quais as contradições da arte, sobretudo do teatro, permitiriam contornar esse controle administrativo e pôr em relevo o potencial utópico da arte.

Em um contexto pós-revolução sexual em que diversos tabus sexuais caíram e falsos moralismos foram contestados, a liberação sexual que parecia ter um potencial social explosivo foi comercializada, transformando-se em uma mercadoria e parte dos comerciais de TV. Diante disso o professor Rafael Cordeiro Silva discute sobre o conceito de Eros e sua politização no pensamento de Marcuse. Em Eros às avessas: pansexualismo e dessublimação repressiva o autor explana o conceito de Eros como uma categoria social no pensamento de Herbert Marcuse e como a dessublimação repressiva comprometeu o potencial libertador da sexualidade em suas manifestações perversas e cotidianas.

A professora Deborah Antunes Christina Antunes nos presenteia com um belo artigo de síntese entre a abordagem conceitual e pesquisa empírica próprio da teoria crítica. No escrito As minorias como o negativo, o movimento das mulheres e o espaço digital a pesquisadora realiza um estudo empírico inspirado na ideia da necessidade de mergulharmos nos detalhes concretos para compreender a realidade e, desse modo, ter a possibilidade de operar transformações efetivas em sua base. Trata-se de uma análise realizada a partir de um debate de um grupo feminista no Facebook em busca de suas possibilidades emancipadoras, adentrando na esfera de uma tradição mais empírica dos estudos em Teoria Crítica, sem deixar de lado a reflexão conceitual.

Para completar nosso Dossiê temos duas traduções de textos inéditos do filósofo Herbert Marcuse. O primeiro é a tradução do Prefácio à edição francesa de “O Homem Unimensional (1967)” feita pelos membros do Grupo de Pesquisa Atualidade do Pensamento Político de Marcuse (UECE) Alberto Dias Gadanha, Djibril Ernesto Pereira e Renê Ivo da Silva Lima e o outro é a tradução do ensaio de Marcuse Da ontologia à tecnologia. As tendências da sociedade industrial de 1960 realizada por João Paulo Andrade Dias.

O atual número da Revista Dialectus ainda conta com uma sessão de artigos do fluxo contínuo que abordam as mais variadas questões e assuntos filosóficos.

A professora Adriana Veríssimo Serrão nos concede de Portugal um interessante artigo sobre a carta que o jovem Ludwig Feuerbach enviou ao seu mestre Hegel no final de

\begin{tabular}{|c|c|c|c|c|}
\cline { 2 - 5 } Q Q Alaloctus & Ano 8 & n. 14 & Janeiro - Julho 2019 & p. 8-14 \\
\hline
\end{tabular}


1828 juntamente com sua dissertação De ratione, una, universali, infinita apresentada à Universidade de Erlangen. No artigo A Carta de Feuerbach a Hegel a autora afirma que a carta é um documento de especial interesse para a compreensão da biografia intelectual de Feuerbach. Ao final do artigo consta a tradução da carta de Feuerbach a Hegel.

Em $O$ Método narrativo de Hermann Hesse e o tratamento das ideias de Nietzsche da historiadora Raylane Marques Sousa e professor Eduardo Ferreira Chagas se expõe o método utilizado por Hermann Hesse para composição de sua narrativa, mostrando os vários momentos em que ele o empregou em obras determinantes de sua fase tardia e o tratamento que deu, particularmente, às ideias de Nietzsche. Segundo os autores a forma de Hermann Hesse de orientar a narrativa revela seu modo de interpretar a realidade.

De maneira ceceroriana Frederico Jorge Ferreira Costa e Fábio José de Queiroz levam a sério a histórica como magistra vitae no seu artigo Histórias de outubro: Trotski e a revolução russa e a partir disso analisam o papel desempenhado por Trotski na Revolução de Outubro tomando como referência não somente sua ação militante durante os acontecimentos de 1917, mas, do mesmo modo, seu subsídio teórico marxista a esse importante movimento revolucionário do século XX. Para eles a teoria e a prática do revolucionário russo ainda tem algo a dizer aos movimentos anticapitalistas do século XXI.

Fechando a sessão de fluxo contínuo o artigo A relação trabalho-educação no pensamento de Marx: um estudo dos Manuscritos econômico-filosóficos (1844) de José Salvador de Almeida e Eduardo Ferreira Chagas que explora o aspecto pedagógico do trabalho da perspectiva do jovem Marx. Os autores buscam evidenciar que existe uma relação íntima entre trabalho-educação no pensamento de Marx, pois a educação deve proporcionar ao homem (trabalhador) uma relação imediata e de reconhecimento entre o trabalho (atividade vital consciente e livre) e a produção, isto é, entre o trabalhador e os objetos da produção, relação essa que é obscurecida devido o caráter alienado do trabalho na sociedade capitalista.

Por fim, encerrando nosso Dossiê Ideusa Celestino Lopes traz uma resenha da tradução italiana da obra Física de Aristóteles. É importante dizer que a obra resenhada ainda não foi completamente traduzida para o português, apenas os livros I e II.

Com a publicação desse Dossiê dedicado ao pensamento de Herbert Marcuse a Revista Dialectus agradece e se orgulha por poder reunir neste volume as preciosas colaborações, o que nos permitirá contribuir fortemente com a divulgação das pesquisas mais atuais sobre a teoria crítica marcuseana, auxiliando naquilo que Marcuse chamou de "a longa marcha pelas instituições" que nós, progressistas das diversas vertentes, deveríamos realizar em

\begin{tabular}{|c|c|c|c|c|}
\hline QRovista Dialectus & Ano 8 & n. 14 & Janeiro - Julho 2019 & p. $8-14$ \\
\hline
\end{tabular}


John Karley de Sousa Aquino / Alberto Dias Gadanha / Eduardo F. Chagas / Hildemar Luiz Rech / Manoel Jarbas Vasconcelos Carvalho

um cenário adverso de contrarrevolução permanente. Além disso, demonstra que aqui, nas terras alencarinas, no nordeste brasileiro, igualmente se produz cultura, se faz ciência e dedicase à especulação filosófica, reforçando o valor da autonomia e da criatividade intelectual que para Marcuse eram fundamentais para fomentar o processo emancipatório.

\begin{tabular}{|l|c|c|c|c|}
\cline { 2 - 4 } Q & Ano 8 & n. 14 & Janeiro - Julho 2019 & p. 8 - 14 \\
\hline
\end{tabular}




\title{
MARCUSE E O ALERTA À CONTRARREVOLUÇÃO PREVENTIVA
}

\author{
Robespierre de Oliveira ${ }^{1}$
}

\begin{abstract}
Resumo:
A questão da contrarrevolução foi discutida em vários textos de Marcuse. O objetivo deste artigo é apresentar sua contribuição à elucidação desse problema e sua atualidade. Para Marcuse, a contrarrevolução na sociedade capitalista industrial avançada não se organiza necessariamente em oposição a uma revolução existente, mas sim em oposição à possibilidade de qualquer transformação social para maiores liberdades e direitos, isto é, emancipação social. A contrarrevolução preventiva é um fator na administração do capitalismo tardio para garantia de seu domínio em face das crises econômicas cíclicas. Deste modo, ora esse processo é dissimulado, ora é aberto, com menor ou maior agravamento da violência social. Mesmo atento ao processo de recrudescimento contra as forças de libertação, Marcuse procurava frestas para a emancipação humana. Suas propostas de Grande Recusa e nova sensibilidade visam romper os limites impostos pela dominação existente a partir das necessidades vitais dos próprios indivíduos.
\end{abstract}

Palavras-chaves: Marcuse. Sociedade unidimensional, contrarrevolução, tolerância repressiva, resistência.

\section{MARCUSE AND THE ALERT TO THE PREEMPTIVE COUNTERREVOLUTION}

\begin{abstract}
:
Marcuse discussed the issue of counterrevolution in many texts. The aim of this article is to present his contribution to the elucidation of this problem and its actuality. For Marcuse, counterrevolution in advanced industrial capitalist society is not organized necessarily in opposition to an existent revolution, but in opposition to the possibility of any social change for more liberties and rights, social emancipation. Preemptive counterrevolution is a factor in the administration of late capitalism to the guarantee of its rule in face of cyclical economic crises. This way, sometimes this process is covert, sometimes it is open, with less or more aggravation of social violence. Even in the process of resurgence against the forces of liberation, Marcuse was looking for gaps for human emancipation. His proposals of Great Refusal and new sensibility are aimed at breaking the limits imposed by the existing domination, coming from the vital needs of the individuals themselves.
\end{abstract}

Keywords: Marcuse. One-dimensional society. Counterrevolution. Repressive tolerance. Resistance.

The Western world has reached a new stage of development: now, the defense of the capitalist system requires the organization of counterrevolution at home and abroad. In its extreme manifestations, it practices the horrors of the Nazi regime. Wholesale massacres in Indochina, Indonesia, the Congo, Nigeria, Pakistan, and the Sudan are unleashed against everything which is called "communist" or which is in revolt against governments subservient to the imperialist countries. Cruel persecution prevails in the Latin American countries under fascist and military dictatorships. Torture has become a normal instrument of 'interrogation' around the world. The agony of religious wars revives at the height of Western civilization, and a constant flow of arms from the rich countries to the poor helps to perpetuate the oppression of national and social liberation. (Marcuse, Counterrevolution and Revolt, 1972).

1 Professor Associado da UEM. Doutor em Filosofia da USP. Pós-doutorado na CUNY (City University of New York). Membro da International Herbert Marcuse Society. Tradutor de Marcuse. Autor de O papel da filosofia na teoria crítica de Herbert Marcuse, São Paulo, EdUnesp, 2012. E-mail: roliveira@ uem.br. 
Herbert Marcuse foi um dos primeiros a discutir o problema da contrarrevolução e da contenção na sociedade industrial avançada. Após a Segunda Guerra Mundial, Marcuse elaborou um texto, posteriormente denominado "33 teses", que deveria ser publicado na Revista de Pesquisa Social, a qual já havia sido descontinuada e não retomada. A derrota do Nazifascismo havia sido prometida como a construção de mundo melhor, de mais liberdade e democracia, sem guerras e violência, porém isto não aconteceu. As tensões, principalmente, entre a União Soviética e Estados Unidos levaram a um novo tipo de guerra, a Guerra Fria (1947-1991). Em certo sentido, seria o início de uma era contrarrevolucionária preventiva, contra qualquer possibilidade de libertação, entendida como "comunismo". Para os países capitalistas e sociedades industriais avançadas, a ameaça de comunismo justificava a organização da sociedade para prevenir tal ameaça. O Tratado do Atlântico Norte (OTAN) foi estabelecido em 1949 para este propósito, expandindo o poderio militar dos EUA pelo mundo. A ameaça do comunismo foi combatida na Guerra da Coreia (1950-53) e do Vietnã (1955-75), para mencionar duas guerras conhecidas, e vários golpes militares pelo mundo (como na América Latina) e intervenções militares em muitos países. Em suas "33 teses", Marcuse afirmou

Depois da derrota militar de Hitler e do fascismo (que foi uma forma prematura e isolada de reorganização capitalista), o mundo dividiu-se num campo neofascista e num campo soviético. O que resta das formas democrático-liberais será esmagada entre os dois campos ou absorvida por eles (Marcuse, 1999, p. 217).

Para Stanley Aronowitz, ${ }^{2}$ a predição de Marcuse não teria sido realizado na medida em que se considere o avanço da democracia entre muitos países, incluindo aqueles que foram comunistas. Entretanto, Aronowitz não observa que países que ele menciona como Argentina, México e Brasil se tornaram democráticos após um longo período ditatorial. Muitos países sofreram golpes de Estado enquanto Marcuse estava vivo. O processo democrático nestes países, tanto quanto nos países ex-comunistas, aconteceu muitos anos após sua morte. Mesmo assim, esse processo democrático não chegou a se consolidar efetivamente. Contudo, Aronowitz observa que a concepção de Marcuse de fascismo difere da usual

But consider how Marcuse's conception differs from the accepted views of fascism. Of course, U.S. society is not marked by a program of systematic terror against racialized minorities, although, as we have seen, the number of incidents of police

2 Stanley Aronowitz, The Unknown Marcuse In.: Social Text 58, Vol. 17, No.1, Spring 1999. 133154.

\begin{tabular}{|l|l|l|l|l|}
\cline { 2 - 4 } & Ano 8 & n. 14 & Janeiro-Julho 2019 & p. $15-33$ \\
\hline
\end{tabular}


violations of the rights of black men has escalated in proportion as poverty and unemployment deepens in the cities. But in other respects-such as the intensification of individualism, the decline of the labor movement and other social groups, and the emergence of a cultural environment of puritanical antisexuality-U.S. society has all the earmarks of a growing authoritarianism (Aronowitz, 1999, 152).

Mesmo não considerando a sociedade estadunidense como "fascista", por não ser marcada por um "programa de terror sistemático contra minorias", Aronowitz reconhece que a sociedade dos EUA possua características de um crescente autoritarismo. Marcuse havia percebido isso quando viu frustradas suas propostas e de seus colegas no departamento de Estado dos EUA, a OSS (Office of Strategic Services), para a desnazificação da Alemanha no pós-guerra. Tais propostas incluíam a redemocratização da Alemanha com base na liberdade sindical e apoio a movimento populares. O governo dos EUA preferiu, ao invés, colocar exnazistas de terceiro ou quarto escalão nos governos, coibir movimentos populares e sindicatos, com medo da expansão comunista. Este medo também levou a uma perseguição interna e externa de possíveis comunistas (McCarthyismo). Isto foi obra da Guerra Fria.

Depois da Segunda Guerra, houve muitos movimentos de libertação colonial. Alguns deles tornaram-se países comunistas, como Angola e Moçambique. Os EUA sentiram esta ameaça muito próxima de seu quintal com a revolução cubana (1953-59), que recebeu apoio da União Soviética. Assim, para evitar uma "nova Cuba", os EUA fizeram esforços pela América Latina, com a CIA, apoiando muitas ditaduras militares, incluindo Brasil, Argentina e Chile. Estas ditaduras causaram a morte de milhares de pessoas, tortura, destruíram a cultura, o desenvolvimento e a vida de gerações. Em troca, os EUA expandiram sua cultura, filmes e música, para moldar tais povos pela indústria cultural.

Theodor W. Adorno e Max Horkheimer elaboraram sua crítica a indústria cultural em seu famoso livro A dialética do esclarecimento (1947), mostrando o declínio da arte como fonte de conhecimento e elevação espiritual e seu uso cada vez mais ideológico, reforçando a estrutura de dominação social vigente. No mesmo ano, Horkheimer também publicou o seu Eclipse da Razão, no qual mostrava que a razão ofuscada se tornara instrumental e propicia para a dominação ao invés da emancipação. Marcuse, por sua vez, em Algumas implicações sociais da tecnologia moderna (1941), registrara o poder da tecnologia como meio ideológico de dominação, elaborando o conceito de razão tecnológica. Estas elaborações foram fundamentais para o estudo sobre a contenção da sociedade industrial avançada realizado por Marcuse nos anos 1950 e que veio a lume em O homem unidimensional (1964).

\begin{tabular}{|c|c|c|c|c|}
\cline { 2 - 4 } & Ano 8 & n. 14 & Janeiro-Julho 2019 & p. $15-33$ \\
\hline
\end{tabular}


Em seu livro, Marcuse critica fundamentalmente o caráter ideológico da sociedade unidimensional. Deste modo, critica a proclamação de Daniel Bell do "fim da ideologia" e se opõe a The Warfare State de Fred J. Cook, que trata do poderio bélico estadunidense, e The Hidden Persuaders de Vance Packard, que trata do largo uso da propaganda comercial para a imposição do consumo. O crescimento pós-guerra nos EUA implicou no aumento do consumo de mercadorias, incluindo bens culturais, principalmente por meio da televisão. Nesse período, constituiu-se o que conhecemos como mídia, a conjunção de meios de comunicação, com larga exploração de imagens. Assim, Marcuse denominou sociedade unidimensional a "sociedade da mobilização total, que ganha forma nas mais avançadas áreas da civilização industrial, combina em produtiva união as características do Estado de Bem-Estar Social (Welfare State) e do Estado de Guerra (Warfare State)." (Marcuse, 2015, p. 215) Em certo sentido, para ele tratava-se de fazer uma contrapartida de seu outro livro Soviet Marxism (1958). Marcuse explicou, em carta a Raya Dunaevskaya, autora de Marxism and Freedom (1958), sua intenção de escrever $O$ homem unidimensional, cujo título inicial seria Estudos da Ideologia da Sociedade Industrial Avançada (1958). Eu cito:

I may have told you that my new book with the tentative title Studies in the Ideology of Advanced Industrial Society, is some sort of western counterpart of Soviet Marxism - that is to say it will deal, not only with ideology but also with the corresponding reality. ${ }^{3}$

A negação das ideologias constitui uma ideologia mesma que visa reforçar a estrutura de dominação. Parte desta ideologia reside na linguagem orwelliana ${ }^{4}$ e no caráter afirmativo da cultura, transformada em "dessublimação repressiva". Para Marcuse, o universo do discurso está se fechando. A linguagem é ideologicamente usada para esconder a realidade, frequentemente fingindo e clamando alguma outra coisa. Como "guerra é paz" e "liberdade é escravidão", “ignorância é força", a segurança é uma palavra para garantir liberdade, mas liberdade com mais vigilância, força policial e espionagem. Os indivíduos precisam sentir-se livre ao serem mais e mais isolados no abrigo de suas casas. Os significados políticos das palavras são mudados de acordo com a conveniência daqueles que estão no poder. Deste modo, a democracia totalitária usa a propaganda para glorificar "liberdade", "democracia", "tolerância", "igualdade", entre outras palavras. O significado destas palavras, no entanto, não

3 Carta de Marcuse a Raya Dunayevskaya 8-6-1960 In: Anderson, Kevin and Rockwell, Russell. (eds.) The Dunayevskaya-Marcuse-Fromm Correspondence 1954-1978. Dialogues on Hegel, Marx and Critical Theory. Lanham, Boulder, Lexington, New York, Toronto, Plymouth (UK), Lexington Books, 2012, p. 59. 4 Referência a George Orwell, 1984.

\begin{tabular}{|c|c|c|c|c|}
\hline Rovista Didectus & Ano 8 & n. 14 & Janeiro - Julho 2019 & p. $15-33$ \\
\hline
\end{tabular}


possui o mesmo conteúdo na realidade do que no discurso. Quando o governo ou a mídia utilizam tais palavras, elas indicam realmente significados diferentes daquele estabelecido na história humana, até opostos. Apesar de proclamar e possuir uma aparência de democracia, o governo estadunidense configura-se mais como um governo autoritário, daí o termo "democracia totalitária", termo já existente na história da filosofia. Refere-se à estrutura democrática, instituições, constituição, eleições, absolutamente coordenada e administrada de tal modo que o povo é apenas um acessório para legitimar decisões já tomadas ou garantir os interesses daqueles que estão no poder. Por meio das eleições, o povo acredita que votou de acordo com seus próprios interesses e consciência, mesmo que não seja verdade. A ascensão de Hitler ao poder, após uma tentativa frustrada de golpe, foi por meio das eleições, o que apareceu ao mundo, na época, como parte do processo democrático. A estrutura política dos EUA acaba por reduzir as campanhas eleitorais a apenas dois partidos que se revezam no poder, por serem os únicos capazes financeiramente de produzir campanhas de massa, em detrimento de todos os demais partidos existentes. Da mesma forma, a elaboração de leis e sua aplicação podem ser restritas a uma camada social embora sejam ditas universais. ("A lei é para todos".)

Edward Bernays, sobrinho de Sigmund Freud, publicou em 1928 o livro Propaganda, que inspirou líderes políticos, como Joseph Goebbels, ministro da Propaganda do III Reich. De acordo com Bernays, as pessoas na sociedade democrática agem, pensam e consomem segundo o que lhes foi dito para agirem, pensarem e consumirem, embora acreditem que seu comportamento, pensamento e consumo seja escolha própria. Há poderes ocultos na sociedade que determinam os hábitos dos indivíduos, como a propaganda e os comerciais. Assim, é possível manipular-se toda uma sociedade. ${ }^{5}$ Goebbels seguiu os princípios de Bernays, criando o inimigo comum, os judeus, para mobilizar a Alemanha em torno da unidade: um só povo, um só império, um só Führer. Tratava-se de um processo de "coordenação" (coordination), palavra que Marcuse utilizou para traduzir o significado de "Gleichschaltung". Segundo Charles Reitz, "A Gleichschaltung era a prática fascista de forçar cada um na sociedade a 'andar na linha' e toda oposição política a se submeter." (Reitz, 2014, p. 3) A total mobilização, promovida pela Gleichschaltung, devia proteger o estado de coisas existente, seja

Entre os exemplos de manipulação promovidos pelo próprio Bernays, podem ser citados o convencimento de bacon e ovos serem parte de um café da manhã saudável, incitar as mulheres a fumarem cigarros como meio de liberdade e autoafirmação, e a destituição do governo da Guatemala em 1954, acusado falsamente de comunista. 
numa visão política ou econômica. Na sociedade industrial avançada, o consumismo é um modo ideológico para mobilizar as pessoas a justificarem para si mesmas o sistema que as oprime.

O consumo de mercadorias determina o comportamento, o pensamento e a sensibilidade dos indivíduos. Os indivíduos realizam sua felicidade, em parte, pelo consumo de mercadorias, como um carro novo, uma roupa nova, pelo tipo de alimentação e bebida, pelos livros, músicas e filmes que consomem. Na medida em que esse consumo atrela os indivíduos ao sistema de dominação, seriam falsas necessidades para além das necessidades básicas. Marcuse afirma a diferença entre necessidades verdadeiras ou falsas.

\footnotetext{
There are 'false' and 'real' needs - the former are those which serve to perpetuate toil, aggressiveness, and the powers that be (such as the need to buy a new automobile every other or third year, the need to relax before television, to work in an armament factory, to eat enriched and soggy bread, the need to "keep up with the neighbors") (Marcuse, 2001, p. 52).
}

O consumo de artefatos tecnológicos ampliou-se para a sociedade industrial avançada de tal modo que as pessoas não sabem mais como viver sem a tecnologia. Segundo Marcuse, em Algumas implicações sociais da tecnologia moderna, a tecnologia não é neutra. Para ele, a tecnologia é entendida como um modo de produção que organiza a vida do todo. Na sua produção, a tecnologia já possui a determinação de seus interesses, é imbuída de ideologia. Isso desenvolve uma racionalidade tecnológica que poderia ser entendida como uma racionalidade derivada do sistema de produção, visando eficiência, produtividade e lucro. A maioria da tecnologia de uso cotidiano veio do uso militar. Para Walter Benjamin, ${ }^{6}$ a realização da tecnologia está na guerra. Assim, sua adaptação à vida social não é neutra, mas organizada, classificada, coordenada, administrada. A racionalidade tecnológica pode combinar a objetividade racional com fins irracionais, como os campos de extermínio nazistas.

Deste modo, para Marcuse, há um vínculo entre o Estado de Guerra e o Estado de Bem-Estar. ${ }^{7}$ Marcuse inicia $\mathbf{O}$ homem unidimensional expressando isto:

Uma não liberdade confortável, muito agradável, racional e democrática prevalece na civilização industrial avançada, um sinal do progresso técnico. Na verdade, o que poderia ser mais racional que a supressão da individualidade na mecanização de performances socialmente necessárias, mas penosas; que a concentração de

6 Benjamin, Walter. "Theories of German Fascism" In New German Critique, trans. Jerolf Wikoff, Spring 1979, n. 17, pp. 120-128.

7 Como no livro 1984 de George Orwell, uma guerra distante é necessária para garantir uma vida pacífica.

\begin{tabular}{|l|c|c|c|c|}
\cline { 2 - 4 } & Ano 8 & n. 14 & Janeiro-Julho 2019 & p. $15-33$ \\
\hline
\end{tabular}


empreendimentos individuais em corporações mais efetivas, mais produtivas; que a regulação da livre competição entre sujeitos econômicos desigualmente equipados; que a restrição de prerrogativas e soberanias nacionais que impedem a organização internacional dos recursos. Que este ordenamento tecnológico envolva também uma coordenação política e intelectual pode ser uma evolução lamentável, mas ainda promissora (Marcuse, 2015, p. 41).

A sociedade da total administração, que abrange a vida total dos indivíduos com mídia e propaganda, é um desenvolvimento da racionalidade tecnológica. ${ }^{8}$ Adorno, Hrokheimer e Marcuse escreveram sobre o declínio da individualidade no mundo contemporâneo. Os indivíduos parecem ser parte de um todo na medida em que podem consumir não apenas suas mercadorias, mas também ideais e visões políticas acabadas (ready-made). A mídia colabora nesse processo, distribuindo imagens e formas prontas. Segundo Douglas Kellner, ${ }^{9}$ a cultura mídia é fundamentalmente imagética, ela constrói identidades às quais os indivíduos aderem. Assim, há uma estrutura unilateral, quase totalitária, na sociedade, na medida em que a diversidade é coordenada para se adaptar ao todo. É a sociedade unidimensional.

Esta coordenação (Gleichschaltung) articula o Estado de Bem-Estar com o Estado de Guerra. O Estado de Bem-Estar seria caracterizado tanto pelos benefícios sociais garantidos pelo Estado, como educação, saúde, previdência, seguro desemprego, moradia, entre outros, quanto pela garantia de acesso a bens de consumo. Isso se caracteriza, principalmente, por políticas públicas. Entretanto, o Estado de Bem-Estar foi paulatinamente sendo desmontado em função da política neoliberal, de tal modo que os indivíduos deveriam arcar sozinhos com despesas antes garantidas pelo Estado, como educação e saúde. Assim, a desigualdade econômica aumentou e até o consumo foi reduzido. Este movimento ocorreu nos anos 1970, última década de vida de Marcuse, que mesmo assim anteviu o estava para vir em suas palestras

8 Em "Some Social Implications of Modern Technology", Marcuse dá um exemplo: "A man who travels by automobile to a distant place chooses his route from the highway maps. Towns, lakes and mountains appear as obstacles to be bypassed. The countryside is shaped and organized by the highway: what one finds en route is a byproduct or annex of the highway. Numerous signs and posters tell the traveler what to do and think; they even request his attention to the beauties of nature or the hallmarks of history. Others have done the thinking for him, and perhaps for the better. Convenient parking spaces have been constructed where the broadest and most surprising view is open. Giant advertisements tell him when to stop and find the pause that refreshes. And all of this is indeed for his benefit, safety and comfort; he receives what he wants. Business, technics, human needs and nature are welded together into one rational and expedient mechanism. He will fare best who follows its directions, subordinating his spontaneity to the anonymous wisdom which ordered everything for him." In Marcuse, Technology, War and Fascism, p. 46.

${ }^{9}$ Kellner, Douglas. Media Culture. Cultural Studies, Identity and Politics between the Modern and Postmodern. London and New York, Routledge, 1995.

\begin{tabular}{|c|c|c|c|c|}
\hline Gevista Dialectus & Ano 8 & n. 14 & Janeiro-Julho 2019 & p. $15-33$ \\
\hline
\end{tabular}


dadas em Vincennes. ${ }^{10}$ Por outro lado, o Estado de Guerra foi fortalecido. Após a Segunda Guerra, os EUA configuraram-se em potência militar expandindo-se mundialmente. O confronto com a URSS, a Guerra Fria, produziu uma espécie de corrida bélica. Houve conflitos e guerras localizadas, como a da Coreia e do Vietnã. ${ }^{11}$ O Estado de Guerra busca mobilizar a sociedade ressaltando o patriotismo e a necessidade de segurança interna e externa. Assim, cursos universitários eram voltados para a indústria bélica. Para a Guerra do Vietnã, havia sorteios de convocação ao vivo na TV. A mesma TV mostrou os horrores da guerra o que iniciou um movimento contrário à guerra. A sociedade mobilizou-se em grupos a favor e contra, resultando no fim da guerra nos anos 1970. A mobilização do Estado de Guerra também aparece na esfera interna do Estado, com vigilância e mesmo em termos policiais. E o Pentágono parece ter adquirido uma autonomia em relação ao presidente dos EUA, o que configuraria o Deep State. Assim, o Estado de Guerra manteve-se e continua forte até hoje espalhado pelo mundo, nas guerras do Iraque, nos ataques da OTAN, na guerra contra o terrorismo.

Certamente, o Estado de Guerra é peça fundamental à contrarrevolução, dividindose na atuação da CIA e das forças armadas. Ele teve papel fundamental em golpes de Estado na América Latina e em outros continentes. Apoiou iniciativas contra a Revolução Cubana e Nicaraguense, invadiu Granada. Marcuse chegou a afirmar em suas Palestras em Vincennes que o Pentágono seria uma grande empresa única

No longer only by way of the subsidies directly or indirectly, but the government itself has become directly a major economic unit. The Pentagon in the United States today is the biggest single industrial enterprise (Marcuse In.: Jansen e Reitz, 2015, p. 40).

É de se notar que Marcuse também se refere ao próprio governo como uma unidade econômica. Sheldom Wolin escreveu Politics and Vision em 1960, livro que possui afinidades com Marcuse, ${ }^{12}$ embora Wolin seja liberal. Particularmente, Wolin afirma a existência de

10 Ver JANSEN, Peter-Erwin and REITZ, Charles. (eds) Herbert Marcuse's 1974 Paris Lectures at Vicennes University from Marcuse Archives. Global Capitalism and Radical Opposition. Introduction by Sarah Surak and afterwords by Douglas Kellner. Maryland USA, Salisbury University, 2015. Ver também meu comentário "Globalização, Contrarrevolução e Nova Sensibilidade: Leitura Das Palestras De Paris De 1974 de Marcuse" In: Piracicaba, Comunicações, maio-agosto de 2017, v. 24, n. 2, pp. 127-136.

11 Segundo Chomsky, criou-se o "sistema do Pentágono", que teria força e uma certa autonomia para enfrentar o inimigo externo. Durante a Guerra Fria, esse inimigo comum era o comunismo; após, somente em fins dos anos 1990, o "terrorismo islâmico" foi eleito em substituição ao comunismo como tal inimigo (Chomsky, 1991).

12 Ver Maley, Terry. "Human Emancipation and The Historical Fate Bourgeois Democracy" In Maley, Terry (ed.) One-dimensional Man 50 years on: The Struggle Continues, Nova Scotia,

\begin{tabular}{|c|c|c|c|c|}
\hline Q Rovista Dialectus & Ano 8 & n. 14 & Janeiro-Julho 2019 & p. 15 - 33 \\
\hline
\end{tabular}


superpoderes que ameaçam a estrutura democrática, a qual seria fugidia. De fato, segundo ele, as empresas tomam o poder do Estado e controlam o governo de tal modo que o cidadão não teria o mesmo poder. Segundo Wolin,

\begin{abstract}
The modern regime, regardless of form, is shaped by the need to maintain continuous functions: promotion of the economy, law enforcement, military preparedness, revenue collection, protection and control of systems of communication. It is a design for administration rather than democracy. When democracy is settled into a stable form, such as prescribed by a written constitution, it is also settled down and rendered predictable. Then it becomes the stuff of manipulation: of periodic elections that are managed and controlled, of public opinion that is shaped, cajoled, misled, and then polled, and of a legal system that dictates how much democracy is to be permitted (Wolin, 2004, p.601)
\end{abstract}

Esta visão aproxima-se daquela de Horkheimer, Adorno e Marcuse segundo a qual o governo é tomado por uma máfia (rackets). A democracia totalitária, como dito acima, atua na manipulação popular mantendo a ilusão democrática. Marcuse, em suas Palestras de Vincennes, afirma que a desintegração da burguesia como poder dominante leva a uma indiferenciação entre negócios legais e ilegais. ${ }^{13}$ Eu cito:

\begin{abstract}
At the same time I think we can observe in the United States a phenomenon of great importance which I would like to call the decomposition, even disintegration, of the bourgeoisie as a dominant class. Of course, the bourgeoisie still is the dominant class, but as such it has undergone significant changes. The difference between legitimate and illegitimate business is constantly being obfuscated, and the economic and political power of the so-called Mafia extends itself to all branches of economic and political life (Marcuse In Jansen e Reitz, 2015, p. 2).
\end{abstract}

Se esta teoria é correta, poderíamos pensar que os agentes políticos agem como a máfia agia no começo do século XX. Lucky Luciano e Al Capone foram responsáveis por estabelecer a máfia nos EUA. Eles adotaram métodos de organização capitalista para gerenciamento de suas atividades combinados com violência. Assim, eles possuíam uma imagem pública respaldada por agentes públicos comprados, policiais, juízes e políticos. Al Capone, inclusive, ajudava populações carentes com doações, o que melhorava sua imagem. Viviam luxuosamente entre a high society. Ao mesmo tempo, massacravam seus opositores e

Manitoba, Fernwood Publishing, 2017. Neste artigo, Maley discute a relação de Wolin e Marcuse, entre outros.

${ }^{13}$ Poderíamos pensar a intermediação entre empresas e políticos, principalmente por meio de trocas de favores, corrupção, como parte desse processo. Atualmente, há o caso de empresas que se promovem politicamente a ponto de não necessitarem mais de intermediação.

\begin{tabular}{|l|l|l|l|l|}
\hline Qevista Qialectus & Ano 8 & n. 14 & Janeiro-Julho 2019 & p. $15-33$ \\
\hline
\end{tabular}


quem não cumpria seus desígnios. A máfia institucionalizada agiria de forma semelhante, sendo a violência executada de forma legal por agentes do Estado, e, quando não, seria acobertada "legalmente".

A violência é parte da estrutura do Estado. Não há propriamente interesse em acabar com a violência, mas administrá-la. Policiais, por vezes, chegam a ser mais violentos que os civis abordados por eles, sejam criminosos ou não. Nos EUA, como em outros países, a discriminação racial tende ao racismo, velado ou não, em que negros são tratados como culpados a priori. ${ }^{14}$ Contra o segregacionismo, Martin Luther King Jr., entre outros, liderou o movimento por direitos civis nos anos 1960, que, mesmo após conquistas significativas, continua ainda hoje sendo causa importante entre os negros que ainda não conseguiram plenamente seu reconhecimento social. A violência contra mulheres, indígenas, LGBTQs, possui um movimento semelhante de segregação, desigualdade social, e luta por direitos.

Marcuse advogou contra a violência, tanto contra as mulheres, negros, quanto contra a violência da guerra. Mas ele não defendia a não-violência frente aos ataques de agentes do Estado, mas a contra-violência, isto é, o direito de se defender se for atacado. Marcuse assinala que se exige a não violência dos mais fracos. Eu cito:

\begin{abstract}
Even in the advanced centers of civilization, violence actually prevails; it is practiced by the police, in the prisons and mental institutions, in the fight against racial minorities; it is carried, by the de- fenders of metropolitan freedom, into the backward countries. This violence indeed breeds violence. But to refrain from violence in the face of vastly superior violence is one thing, to renounce a priori violence against violence, on ethical or psychological grounds (because it may antagonize sympathizers) is another. Non-violence is normally not only preached to but exacted from the weak - it is a necessity rather than a virtue, and normally it does not seriously harm the case of the strong (Marcuse, 1965, p. 102).
\end{abstract}

Assim, estes ficam sujeitos à violência praticada na sociedade. O Estado liberal pressupõe a proteção dos vulneráveis, daí a ênfase nos direitos humanos. Entretanto, geralmente isto não ocorre. Suprime-se o outro, como a questão do encarceramento massivo de negros nos EUA, que gera lucros para presídios privados. Para Marcuse, não se pode considerar como igual a violência de nazistas e racistas e a contra-violência de seus opositores. Não há equivalência dos "dois lados". A tolerância repressiva supõe tolerar aqueles que são contra os direitos

1450 anos após a marcha pelos direitos civis de Selma a Montgomery, os afro-americanos ainda lutam por igualdade e reconhecimento. O movimento “Black Lives Matter", surgido após as mortes de Mike Brown e Eric Garner pela polícia, iniciou uma nova onda pelos direitos civis.

\begin{tabular}{|c|c|c|c|c|}
\hline Romita Dialectus & Ano 8 & n. 14 & Janeiro - Julho 2019 & p. $15-33$ \\
\hline
\end{tabular}


humanos, contra as "minorias", contra os diferentes, contra a democracia, contra o que é universalmente ético. ${ }^{15}$

É de se observar como a mídia insufla casos de violência criando uma espécie de paranoia em que as pessoas buscam soluções individuais, como transformar a casa num tipo de bunker, com cerca elétrica, câmaras, ou se armar. A sensibilidade dos indivíduos é afetada e direcionada para a agressividade. $\mathrm{O}$ fascismo aproveita-se desta situação ao apontar um inimigo comum em defesa dos cidadãos "de bem". Segundo Erich Fromm, os homens ${ }^{16}$ possuem medo da liberdade, por serem extremamente dependentes. Os homens preferem submeter-se a uma autoridade, seja de Deus, do governo, ou quem for do que se virarem sozinhos. Eu cito:

\footnotetext{
They [People] cannot go on bearing the burden of "freedom from"; they must try to escape from freedom altogether unless they can progress from negative to positive freedom. The principal social avenues of escape in our time are the submission to a leader, as has happened in Fascist countries, and the compulsive conforming as is prevalent in our own democracy (Fromm, 2001, pp. 115/116).
}

O anseio por líderes ou conformidade aos poderes estabelecidos na sociedade "democrática", instituições, o anseio por autoridade, faria parte de um aspecto infantil dos seres humanos que possuem medo de serem livres e autônomos, ao mesmo tempo em que querem a aparência de liberdade. Em Obsolescence of Psychoanalysis (1963), Marcuse mostra como a deficiência na constituição do ego nos indivíduos da família contemporânea produziria o enfraquecimento da figura do pai, a qual seria de vital importância para a psique do indivíduo segundo Freud. Uma sociedade sem pai seria psicótica, podendo facilitar governos autoritários. Assim, líderes como Stálin e Hitler buscavam se colocar como "pais" da nação. Entretanto, líderes, autoritários ou não, nem sempre correspondem à figura do pai, mesmo que posem como se fossem. Alguns nem chegam à figura do "grande irmão".

O controle social da liberdade ("aparência de liberdade") torna-se fundamental na sociedade unidimensional. Parte da ilusão de liberdade consiste na possibilidade de escolher entre objetos previamente determinados, a escolha é limitada. Assim, escolhe-se produtos no mercado, estilos de música, filmes, livros, roupas, políticos e partidos, etc. E, geralmente, no fundo, não há muita diferença entre os objetos a escolher. O controle da liberdade ocorre

15 Nos EUA, alguns grupos invocam o direito de liberdade de religião para não aceitar receber, servir, ou reconhecer, homossexuais.

16 "Homens" referem-se a todos os seres humanos por força da linguagem, isto é, as mulheres também estão incluídas aí.

\begin{tabular}{|l|l|l|l|c|}
\cline { 2 - 4 } Govita & Ano 8 & n. 14 & Janeiro - Julho 2019 & p. $15-33$ \\
\hline
\end{tabular}


principalmente quando os indivíduos passam a querer mais do que lhes é ofertado, quando demandam direitos e reconhecimento. ${ }^{17}$ A sociedade unidimensional busca pressionar os indivíduos a padrões estabelecidos. A democracia totalitária funciona com o controle de quanta liberdade o povo deveria ter, dando-lhes o que é necessário para manter o establishment. Mesmo em que em certos períodos ceda e reconheça novos direitos dando mais liberdade aos indivíduos, em outros períodos não vacila em reprimir essa liberdade se for considerada ameaça ao establishment. Segundo Marcuse,

À negação da liberdade, até mesmo da possibilidade de liberdade, corresponde a concessão de liberdades quando elas fortalecem a repressão. A medida em que à população é permitido romper a paz onde quer que ainda haja paz e silêncio, ser feia e enfeiar as coisas, abusar da familiaridade, ofender a boa forma é assustadora. É assustadora porque expressão esforço lícito e mesmo organizado para rejeitar o Outro em seu próprio direito, para impedir a autonomia até mesmo numa esfera pequena e reservada da existência. Nos países superdesenvolvidos, uma parte cada vez maior da população se torna uma audiência cativa - capturada não por um regime totalitário, mas pelas liberdades dos cidadãos cuja mídia de entretenimento e elevação obriga o Outro a participar de seus, sons, visões e cheiros (Marcuse, 2015, p. 230).

E mais adiante:

Sem dúvida, tal situação seria um pesadelo insuportável. Se por um lado as pessoas podem suportar a produção contínua de armas nucleares, partículas radioativas e gêneros alimentícios questionáveis, por outro, elas não podem (pela mesma razão!) tolerar serem privadas do entretenimento e da educação que as tornam capazes de reproduzir as disposições para sua defesa e/ou destruição. O não-funcionamento da televisão e da mídia do mesmo tipo pode assim começar a atingir o que as contradições inerentes do capitalismo não puderam - a desintegração do sistema. A criação de necessidades repressivas desde há muito tem se tornado parte do trabalho socialmente necessário - necessário no sentido de que sem ele o modo estabelecido de produção não poderia ser sustentado. Não são os problemas da psicologia nem os da estética que estão em jogo, mas sim a base material da dominação (Marcuse, 2015, 231).

A pressão econômica e social que se faz sobre os indivíduos, os leva a se isolarem e demandarem segurança, pensando em seus próprios interesses imediatos. Em certo sentido, isso explicaria a ascensão de Hitler ao poder, entre outros. Por volta de 1972, Marcuse escre veu The Historical Fate of Bourgeois Democracy, analisando as eleições dos EUA que levaram Richard Nixon ao poder. Ele repete sua afirmação das "33 Teses". Para ele, o desenvolvimento da democracia burguesa é mais provável que leve ao neofascismo do que ao socialismo. Ele

\footnotetext{
${ }^{17}$ Por exemplo, quando o indivíduo não quer reduzir sua sexualidade ao masculino ou ao feminino, ou determinar a família como composta do pai, mãe e filhos quando sua realidade é distinta disso.

\begin{tabular}{|c|c|c|c|c|}
\hline Gevista Dialectus & Ano 8 & n. 14 & Janeiro-Julho 2019 & p. 15-33 \\
\hline
\end{tabular}
}


mantém que na democracia burguesa há manipulação de mentes. Seguindo seu escrito "Repressive Tolerance" (1965), ele afirma:

Moreover, the people are manipulated, brainwashed; the media, practically their only source of information, reflect and express government interests and policies - or rather those of the capitalist Establishment, which does not exclude some criticism within limits (Marcuse, 2001, p. 169).

Citando Freud, Wilhelm Reich, Erich Fromm, e sua própria interpretação da psicanálise, Marcuse percebe que os indivíduos estão se tornando mentalmente doentes. Para ele, as pessoas são masoquistas por apoiarem o fascismo ou um Estado de Guerra. ${ }^{18}$ De acordo com ele, ${ }^{19}$ a sociedade não apenas regra sobre o princípio de prazer, mas também sobre o instinto (Triebe) de morte. Freud também escreveu sobre isso em $\mathbf{O}$ mal-estar na civilização (1927). Os indivíduos têm necessidade de uma válvula de escape para sua acumulação de energia, como sexo ou violência. A sociedade governa esta válvula, especialmente sobre violência e agressão, com a administração de esportes, guerras e crimes. As pessoas sofrem sob as regras da sociedade. As pessoas convivem todo dia com violência, pobreza, destruição, doença, morte e roubo; e tudo isso aparece como banal. Os indivíduos parecem não se importar sobre o que está acontecendo ao redor delas, isolando-se do resto do mundo. Isso poderia levar ao fascismo, na medida em que os indivíduos começam a olhar os outros com preconceito. ${ }^{20}$ Eles se tornam cada vez mais conservadores na medida em que olham para o mundo exterior e para os estrangeiros e diferentes como uma ameaça. Assim, eles apoiam regras, leis e políticas conservadoras. Na democracia totalitária, "o povo vota livremente em seus governantes, mesmo quando não está em questão manter ou conseguir um emprego - eles se identificam com seus governantes.” (Marcuse, 2001, p. 170) Mesmo se eles sabem que seus governantes não são administradores honestos, ainda podem confiar neles. Aceitam a corrupção dentro do Estado enquanto continuam recebendo suas mercadorias e benefícios.

Após An Essay on Liberation (1969), Marcuse publicou Counterrevolution and Revolt (1972), demonstrando sua preopação com a situação aberta da contrarrevolução. A

18 "The mental structure involved here is the sadomasochistic character. Erich Fromm, following Freud, has developed this concept in sociopsychological terms (Studien über Autorität und Familie, ed. Max Horkheimer, Paris, Alcan, 1936, pp. 77-136. See also, Fromm, Escape From Freedom, New York, Rinehart and Co., 1941).” (Marcuse, 2001, p. 170).

19 Eros and civilization (1955) and Aggressiveness in Advanced industrial Society (1967).

20 Para mais discussões sobre o preconceito ver Stephen J. Bronner, The Bigot -Why Prejudice Still Persists. New Haven e Londres, Yale University, 2014.

\begin{tabular}{|c|c|c|c|c|}
\hline Govista Dialectus & Ano 8 & n. 14 & Janeiro-Julho 2019 & p. $15-33$ \\
\hline
\end{tabular}


eleição de Nixon estava nesse horizonte, assim como Margaret Thatcher na Inglaterra, que inauguraram o período do neoliberalismo. Tratou-se de um período de endurecimento também interno, tanto do ponto de vista econômico quanto cultural. Charles Reitz comenta:

\begin{abstract}
Nonetheless, it was Marcuse who, forty years ago, first warned of the global economic and cultural developments that are now much more obvious given capitalism's crescendo of economic failures since 2008. Political and philosophical tendencies that are often referred to as "neoliberalism" and/or "neo-conservatism" in much analytical work today, Marcuse clearly understood back then as organized counterrevolution (Marcuse 1972) (Reitz In Jansen e Reitz, 2015, 96).
\end{abstract}

Nesse mesmo texto, Reitz mostra com dados como o poder aquisitivo dos trabalhadores estadunidenses diminuiu nos últimos 50 anos. O comentário feito é feito em cima do texto das palestras de Marcuse em Vincennes em 1974. Entre outros pontos, Marcuse critica o que viria a ser o processo de globalização e a chamada sociedade pós-industrial. Embora esse processo tenha se completado muito tempo após a morte de Marcuse, sua visão é certeira ao criticar a terceirização dos trabalhadores. Diversas empresas norte-americanas apostaram em produzir suas mercadorias na China e em outros países asiáticos, devido aos baixos custos, inclusive de mão de obra. O reflexo disso foi o declínio da industrialização nos EUA, que passou a ter uma predominância de trabalhadores de serviço e agropecuária. Certamente, indústrias estratégicas, como comunicações e militar, foram preservadas. O declínio da industrialização desarticulou mais ainda movimentos sindicais de trabalhadores, o que facilitou mais os ataques do governo.

Marcuse também discute o papel da oposição. A resistência surge da necessidade dos indivíduos, necessidade biológica inclusive. Marcuse salientava o papel da Grande Recusa e da sensibilidade dos indivíduos. Assim, os negros iniciaram no final dos anos 1950 um movimento por direitos civis; as mulheres recolocam suas pautas; homossexuais iniciaram na década de 1970 seu movimento por reconhecimento. Muitos desses movimentos foram reprimidos violentamente. Em parte, eles poderiam ser caracterizados como revoltas na medida em que suas pautas eram específicas, havia dificuldade de diálogo entre eles, e não havia uma organização propriamente revolucionária.

Em seu livro de 1972, Marcuse critica a esquerda por seu "marxismo petrificado", isto é, a esquerda ainda mantinha práticas padronizadas do início do século $\mathrm{XX}$ e uma interpretação dogmática da teoria. Na medida em que o capitalismo muda para se adaptar a suas crises cíclicas e sobreviver, o movimento marxista deveria também renovar suas críticas. A

\begin{tabular}{|c|c|c|c|c|}
\cline { 2 - 4 } Govista & Ano 8 & n. 14 & Janeiro-Julho 2019 & p. 15-33 \\
\hline
\end{tabular}


configuração tecnológica, com o uso da automação, a pós-industrialização, globalização, ressignificaram o papel dos trabalhadores no capitalismo tardio. Questões como o papel da mídia, a indústria cultural, que manipulam comportamentos, corações e mentes dos indivíduos, também deveriam ser analisados e criticados. A denominação de "marxismo cultural"21 utilizada pela esquerda tradicional (de partidos) para criticar, principalmente, os pensadores da Escola de Frankfurt expõe a própria inabilidade da esquerda tradicional em compreender o papel da cultura na manipulação ideológica do capitalismo industrial avançado. Fromm e Reich, por exemplo, afirmavam de modos diferentes que não é possível entender o fascismo apenas do ponto de vista econômico ou político, também seria necessário pensa-lo do ponto de vista psicológico, e poderia ser acrescentado do ponto de vista cultural. Assim, a ascensão de Hitler e Mussolini ao poder teve a ver com uma totalidade de aspectos autoritários da sociedade alemã e italiana e a questão da consciência é fundamental para esse entendimento. A esquerda tradicional também teve dificuldades em acompanhar movimentos novos como os mencionados de negros, mulheres, homossexuais, e também o movimento ecológico. Dado seu enfraquecimento ou ausência a direita e a extrema direita cresceram.

Em 2011, a Primavera Árabe parecia ser uma nova luz a movimentos de libertação, assim como o movimento Occupy em Wall Street. Grécia, Turquia, Brasil, entre outros países, experimentaram revoltas pela libertação, pela exigência de reconhecimento e direitos. Esses movimentos utilizaram-se de tecnologias como as redes sociais. Desenvolveram um processo de solidariedade global, que se poderia aproximar do conceito de Eros effect que Katsiaficas ${ }^{22}$ desenvolveu para descrever os movimentos de 1968. Essas revoltas foram descritas por Marcuse como consciência anticapitalista, mesmo que inconsciente.

\footnotetext{
The result of the ever more explosive contradiction is the gradual development of what we may call an anti-capitalist consciousness; the development of anti-capitalist consciousness and of an anti-capitalist mental structure, unconscious, among the population in the metropoles, a consciousness still largely unorganized, spontaneous, without definite goals, but, in any case, the consciousness, and instincts, drives, 'compulsions,' which very definitely come into conflict with the operational values required to sustain the capitalist system (Marcuse In Jansen e Reitz, 2015, p. 56).
}

${ }^{21}$ Hoje a extrema direita também utiliza essa denominação para criticar os frankfurtianos, mas por razões diversas da esquerda tradicional.

${ }^{22}$ George Katasiaficas, Imagination of the New Left - A Global analysis of 1968. (Cambridge, Mass., South End Press, 1987)

\begin{tabular}{|c|c|c|c|c|}
\hline Govista Dialectus & Ano 8 & n. 14 & Janeiro-Julho 2019 & p. $15-33$ \\
\hline
\end{tabular}


Entretanto, ao mesmo tempo, a direita e a extrema direita logo se apropriaram das mesmas tecnologias e souberam como articular suas propostas para sua contrarrevolução contra a cessão de direitos e liberdades demandadas. Esses grupos de direita e extrema direita insuflaram o ódio contra homossexuais, negros, mulheres, imigrantes, refugiados, e contra a própria esquerda tradicional e ao marxismo em geral, acusando-os de deturpar os valores tradicionais da sociedade. São grupos conservadores, contra qualquer mudança social, que, ao defenderem seus interesses, defendem os interesses das classes dominantes.

A contrarrevolução hoje está se espalhando em todo o mundo. Reitz e Spartan chamam a atenção para o caráter predatório do capitalismo. ${ }^{23}$ A crise mundial e a ida para uma via cada vez mais direitista e conservadora resultam do aumento da exploração e acumulação capitalista. Na medida em que os $99 \%$ da população querem acessar sua partilha real nesta sociedade, a repressão surge para suprimi-los. A guerra contra o terrorismo produziu mais terrorismo. Muitos refugiados não têm solidariedade enquanto ficam em campos isolados. Semtetos nas grandes cidades são tratados do mesmo modo. As pessoas se revoltam porque precisam. Não é algo retórico, mas um sentimento interno. Resistência é necessária, mas precisa ser organizada de tal modo que mude o modo opressivo da vida. Mais ainda: é necessário lutar contra a imposição de notícias falsas (Fake News), pós-verdade, e falso conhecimento. O fascismo se alimenta da ignorância. Chegam a criticar verdades adquiridas pela humanidade, como a questão da forma da Terra ou a evolução humana. Marcuse defende a contra-educação, que significa lutar contra a imposição de conhecimentos pré-formatados em dogmas, como religião fez durante o período medieval. Os fundamentalismos exigem um conhecimento baseado exclusivamente em seu livro, seja a Bíblia, o Corão ou outro. Nega-se o pensamento crítico. Ataca-se os professores. Contra isso, Marcuse acredita no papel de uma educação crítica e humanista, além do adestramento técnico profissional da educação unidimensional. A educação crítica não é impositiva, ao contrário, visa os indivíduos a pensarem sobre suas próprias condições. Visa a história humana, mostrando o lado dos vencidos, dos oprimidos. Visa a reflexão sobre a própria realidade. Trata-se de uma tarefa difícil na medida em que a educação ocorre no processo social, não apenas na escola, pois a mídia tem um papel totalizante,

${ }^{23}$ Reitz, Charles and Spartan, Stephen. "The Political Economy of Predation and Counterrevolution: Recalling Marcuse on the Radical Goals of Socialism" In Reitz, Charles (ed.) Crisis and

Commonwealth: Marx, Marcuse, McLaren. Lathan, Boulder, Nova York, Toronto, Plymouth (UK), Lexington Books, 2013. pp. 19-42.

\begin{tabular}{|c|c|c|c|c|}
\hline Romista Dialectus & Ano 8 & n. 14 & Janeiro - Julho 2019 & p. $15-33$ \\
\hline
\end{tabular}


mas é uma tarefa a ser feita, como resistência. Diante dos horrores da contrarrevolução, os intelectuais deveriam tomar uma posição. Cito, Marcuse:

\begin{abstract}
Today the real possibilities of human freedom are so real and the crimes of the society which prevents their realization are so blatant that the philosopher, the educator can no longer avoid taking sides, and that means alliance, solidarity with those who are no longer capable and no longer willing to have their future, to have their existence determined and defined by the requirements of the status quo. ${ }^{24}$
\end{abstract}

Mais ainda, se resistência e mudança social podem ser feitas, Marcuse responde: "Ainda pode ser feito. Se você se sente desesperado, desesperançado, apático, então, você desistiu para a propaganda do establishment. Cabe a você negar esta propaganda!”.

IT CAN STILL BE DONE. If you feel only despair, hopelessness, apathy, then, you have given in to Establishment propaganda. It is still up to you to deny this propaganda! $!^{25}$

\title{
Referências:
}

ANDERSON, Kevin e ROCKWELL, Russell. (eds.) The DunayevskayaMarcuse-Fromm Correspondence 1954-1978. Dialogues on Hegel, Marx and Critical Theory. Lanham, Boulder, Lexington, New York, Toronto, Plymouth (UK), Lexington Books, 2012.

ARONOWITZ, Stanley, “The Unknown Marcuse” In: Social Text 58, Vol. 17, No.1, Spring 1999. 133-154.

BENJAMIN, Walter. "Theories of German Fascism” In New German Critique, trans. Jerolf Wikoff, Spring 1979, n. 17, pp. 120-128.

Illuminations. Trans. Harry Zohn. Introduction by Hannah Arendt. Preface Leon Wiseltier. New York, Schocken Books, 1968.

BERNAYS, Edward. Propaganda, Liveright, 1928.

BRONNER, Stephen J. The Bigot -Why Prejudice Still Persists. New Haven and London, Yale University, 2014.

${ }^{24}$ Marcuse, "Beyond One-dimensional Man" In: Herbert Marcuse. Towards a Critical Theory of Society. Douglas Kellner (ed) Nova York e Londres, Routledge, 2001. p. 119.

${ }^{25}$ Marcuse, Herbert. "Lecture on Higher Education and Politics, Berkeley, 1975" In Kellner et alii. Marcuse's Challenge to Education. Lathan, Boulder, Nova York, Toronto, Plymouth (UK), Rowman e Littlefield, 2009. p. 43.

\begin{tabular}{|c|c|c|c|c|}
\hline Q Rovista Dialectus & Ano 8 & n. 14 & Janeiro-Julho 2019 & p. $15-33$ \\
\hline
\end{tabular}


CHOMSKY, Noam. Deterring Democracy. Londres e Nova York, Verso, 1991.

FROMM, Erich. Fear of Freedom. (Escape from Freedom). Londres e Nova York, Routledge, 2001 (1942).

JANSEN, Peter-Erwin and REITZ, Charles. (eds) Herbert Marcuse's 1974 Paris Lectures at Vicennes University from Marcuse Archives. Global Capitalism and Radical Opposition. Introduction by Sarah Surak and afterwords by Douglas Kellner. Salisbury University, Maryland, USA, 2015.

KATASIAFICAS, George, Imagination of the New Left - A Global analysis of 1968. Cambridge, Mass., South End Press, 1987.

KELLNER, Douglas. Media Culture. Cultural Studies, Identity and Politics between the Modern and Postmodern. London and New York, Routledge, 1995.

KELLNER, LEWIS, PEIRCE AND CHO (eds), Marcuse's Challenge to Education. Lanham, Boulder, Nova York, Toronto, Plymouth, UK, Rowman \& Littlefield Publishers, Inc., 2009.

MALEY, Terry. "Human Emancipation and The Historical Fate Bourgeois Democracy" In.: MALEY, Terry (ed.) One-dimensional Man 50 years on: The Struggle Continues, Nova Scotia, Manitoba, Fernwood Publishing, 2017. pp. 209-227.

MARCUSE, Herbert. Technology, War and Fascism. Douglas Kellner (ed). Nova York e Londres, Routledge, 1998, 217. (Collected Papers, vol.1).

Towards a Critical Theory of Society. Douglas Kellner (ed), Nova York e Londres, Routledge, 2001. (Collected Papers, vol. 2).

. The New Left and The 1960s. Douglas Kellner (ed.) Nova York e Londres, Routledge, 2005. (Collected Papers, vol 3).

Philosophy, Psychoanalysis and Emancipation. Douglas Kellner e Clayton Pierce (eds.) Nova York e Londres, Routledge, 2011. (Collected Papers, vol 5).

Tecnologia, Guerra e Fascismo. Organização e Introdução de Douglas Kellner. Tradução Maria Vidal Borba. São Paulo, EdUnesp, 1999.

Counterrevolution and Revolt. Boston, Beacon Press, 1972.

\begin{tabular}{|c|c|c|c|c|}
\cline { 2 - 4 } & Ano 8 & n. 14 & Janeiro-Julho 2019 & p. $15-33$ \\
\hline
\end{tabular}


. O homem unidimensional - Estudos da ideologia da sociedade industrial avançada. Trad. Robespierre de Oliveira, Rafael Cordeiro Silva, Deborah Antunes. São Paulo, Edipro, 2015.

Eros and Civilization. Boston, Beacon Press, 1955.

"Repressive Tolerance", In Wolff, Robert P.; Moore Jr., Barrington; and Marcuse, Herbert. A Critique of Pure Tolerance. Boston, Beacon Press, 1965.

REITZ, Charles. Celebrating Herbert Marcuse's One-Dimensional Man: Deprovicialization and the Recovery of Philosophy. Nova York, Columbia University, 2014.

REITZ, Charles (ed.) Crisis and Commonwealth: Marx, Marcuse, McLaren. Lathan, Boulder, Nova York, Toronto, Plymouth (UK), Lexington Books, 2013.

WOLIN, Sheldom. Politics and Vision. Continuity and Innovation in Western Political Thought. Princeton e Oxford, Princeton University Press, 1960, 2004. (edição expandida).

\begin{tabular}{|l|c|c|c|c|}
\cline { 2 - 4 } & Ano 8 & n. 14 & Janeiro-Julho 2019 & p. $15-33$ \\
\hline
\end{tabular}




\title{
HERBERT MARCUSE E A TEORIA CRÍTICA: PARA ALÉM DA PERSPECTIVA NORMATIVA DA ESCOLA DE FRANKFURT
}

\author{
Silvio Ricardo Gomes Carneiro ${ }^{1}$
}

\begin{abstract}
Resumo:
Nosso ensaio procura compreender o sentido atual da Teoria Crítica de Herbert Marcuse. De início, fazemos a contraposição de Marcuse à versão mais contemporânea da Teoria Crítica, representada pela perspectiva normativa de Jürgen Habermas e Axel Honneth. Notamos, em seguida, a insuficiência deste modelo crítico diante dos desafios contemporâneos, conforme a crítica de John Abromeit e Amy Allen. Ambos apresentam os limites da segunda geração para compreender o avanço do pensamento conservador. Recuperamos aqui as reflexões de Marcuse sobre os limites da democracia burguesa nos anos 1970. Este será o mote para pensarmos uma perspectiva de Teoria Crítica diversa da normatividade. A experiência crítica de Marcuse é marcada pelo contorno dos acontecimentos e dos corpos, o conteúdo material das questões morais - elementos centrais para o embate contra a cultura do medo que alimenta o autoritarismo nas vias democráticas.
\end{abstract}

Palavras-chave: Herbert Marcuse. Normatividade. Democracia. Teoria Crítica. Autoritarismo.

\section{HERBERT MARCUSE AND CRITICAL THEORY: BEYOND THE NORMATIVE PERSPECTIVE OF THE FRANKFURT SCHOOL}

\begin{abstract}
:
We intend to present some aspects of the Herbert Marcuse's Critical Theory in contemporary times. At first, we show the opposition between Marcuse and the last version of Critical Theory, developed by the normative perspective in Jürgen Habermas and Axel Honneth. Then, we show the insufficiencies of the normative perspective in front of the contemporary challenges, according to John Abromeit and Amy Allen. Both of them present some limits of the normative Critical Theory to understand the actual phenomena of conservative thinking. From this point, we need to propose a Critical Theory different from its Normative perspective. Marcuse's critic experience presents such differences: his criticism to bourgeoise democracy follow the dynamic of the events and the expressions of the body. Such elements are central to present the "material content of the moral issues", an important perspective to the conquest of the fear, the social affect that harbor the authoritarianism in democratic ways.
\end{abstract}

Keywords: Herbert Marcuse. Normativity. Democracy. Critical Theory. Authoritarianism.

\section{Introdução}

Qual mensagem na garrafa nos deixa um autor como Herbert Marcuse? Pensemos com essa questão, de início, a estranha compreensão sobre a atualidade de um autor marcado pelas experiências do século passado. Se observarmos os livros desse autor, podemos concluir que muitas das experiências derivam da realidade dos anos 1960 e 1970. A tecnologia

1 Silvio Ricardo Gomes Carneiro é professor do Centro de Ciências Naturais e Humanidades da Universidade Federal do ABC. Pesquisador do grupo NEXOS: Teoria Crítica e Pesquisa Interdisciplinar e da Rede Escola Pública e Universidade. Também é membro associado da International Herbert Marcuse Society. E-mail: silviocarneiro@gmail.com. 
utilizada na indústria daquele tempo, os modos de consumo de um Estado de Bem-Estar social, o clima de Guerra Fria: tudo parece imagens de uma fotografia já desbotada. No entanto, o impacto do pensamento de Marcuse parece ressoar em seu diálogo com movimentos sociais que explodem em nosso tempo junto a uma série de experiências e que ampliam nossa compreensão das lutas políticas. Nesse sentido, compreendemos aqui algo que a psicanálise concebe como "estranhamento": nas mensagens deixadas por Marcuse localizamos algo que nos é simultaneamente tão perto e tão longe.

Assim, o exercício pelo qual podemos introduzir uma reflexão sobre a mensagem marcuseana na garrafa atravessa a experiência de nossa reflexão para se questionar: afinal, o que faz da experiência marcuseana algo vivo para nosso tempo? Embora existam muitas lições do período, não seria o conteúdo nostálgico sobre os gloriosos anos 1960, da juventude rebelde em afinidade eletiva com a letra de Eros e civilização ou O homem unidimensional. Há algo mais potente nesse encontro que atravessa o conteúdo histórico e localizado na experiência daquele tempo a reforçar o eco do pensamento de Marcuse em nosso tempo como um alarme de incêndio. E isso não está no referencial do passado apenas, como se agora estivéssemos vivendo uma espécie de versão atualizada de um filme antigo: como se agora vivêssemos a repetição da Guerra Fria (sem uma União Soviética); como se nosso mundo do trabalho não estivesse há muito tempo já atravessado por racionalidades tecnológicas mais complexas do que a indústria e o Estado daqueles tempos; como se a ideologia neoliberal não se apropriasse de novos materiais sociais em conformidade com novas estruturas subjetivas; ou ainda, em contrapartida a todo esse cenário, como se as lutas antiglobalização e as formas de organização progressistas também não encontrassem novas formas de emancipação e solidariedade. Acreditamos que a leitura atualizada de Marcuse supere a nostalgia e avance junto a sua experiência militante em aliança com seus exercícios críticos. Talvez essa advertência inicial já nos adiante bastante uma melhor localização da atualidade de Marcuse no mapa contemporâneo.

Pois bem: qual filtro utilizaremos para fazer da mensagem na garrafa uma imagem em constelação com nosso tempo? Talvez, de início, a distância entre as experiências críticas de ontem e de hoje pode ser enfrentada menos pelos conteúdos denunciados ou anunciados na obra marcuseana do que pela forma aberta adotada pela atitude crítica de Marcuse. Claro, essa aposta não deslegitima os elementos que a experiência crítica marcuseana atravessou (muito do que criticava ainda marca presença em nosso tempo). Mas é possível

\begin{tabular}{|c|c|c|c|c|}
\cline { 2 - 4 } Q Q Dialectus & Ano 8 & n. 14 & Janeiro - Julho 2019 & p. 34 - 51 \\
\hline
\end{tabular}


calibrar ainda melhor nosso foco ao retomar o ponto de partida de $O$ homem dimensional, como um exemplo interessante de um impulso recorrente da Teoria Crítica de nosso autor. Pois sua atualidade não está, de imediato, no diagnóstico mais realista do presente (tarefa da Teoria Tradicional) e sim, no modo como enfrenta os desafios de seu tempo. A obra de Marcuse é, pois, atual na sua atitude crítica. Não é por outra razão que $O$ homem unidimensional tem em sua introdução as inquietações sobre si mesmo: a "paralisia da crítica".

\section{Marcuse e o destino da crítica}

Apresentar-se assim não é oferecer o discurso pessimista como saída, incorporando a impotência intelectual diante do abismo do mundo. De outro modo, significa mobilizar todos os elementos, revisar os pressupostos da Teoria Crítica, repensar a filosofia social de modo contínuo e notar a dinâmica constante dos conceitos, as mediações ora abertas, ora impedidas, e mesmo as possibilidades de emancipação sem ilusões de fuga, mas junto à possibilidade histórica de sua obsolescência. Em um de seus primeiros textos para o Instituto de Pesquisas Sociais, Marcuse considera que a "teoria crítica, por fim, é crítica contra si mesma e contra seus próprios defensores sociais" (MARCUSE, 1997, p. 157). Com isso, não defende uma crítica abstrata a todos os princípios. De outro modo, nosso autor extrai as consequências do que Horkheimer já indicava em "Teoria Tradicional e Teoria Crítica”, diferenciando estas duas teorias, em grande medida, pelo "comportamento crítico" [kritische Verhalten].

Neste ensaio, que em grande medida orienta as bases da Teoria Crítica da primeira geração de Frankfurt, Horkheimer marca a diferença da Teoria que concebe como "tradicional" (em grande medida vinculada às linhas cientificistas do positivismo) em defesa de sua teoria crítica. A teoria tradicional admite como existente sua "participação no processo renovador da vida da totalidade" atuando em uma sociedade que funciona. Assim, a posição do cientista tem em vista a meta da realização do estado racional com bases nas raízes da miséria presente. Algo que mobiliza sua defesa do progresso industrial e tecnológico contra as agruras da humanidade. Todavia, adverte Horkheimer, "o modo de ser dessa miséria não oferece a imagem de sua superação" (1983, p. 137). Isto é, o cientista da Teoria Tradicional deixa de lado os custos de seu progresso, não observa a miséria promovida contraditoriamente pelo seu desenvolvimento, de modo que "o mesmo sujeito que quer impor os fatos de uma realidade melhor pode também representa-la" e, nesse sentido, promove a miséria que sua teoria produz (HORKHEIMER,

\begin{tabular}{|l|l|l|l|l|}
\hline Gevista Qialectus & Ano 8 & n. 14 & Janeiro - Julho 2019 & p. $34-51$ \\
\hline
\end{tabular}


1983, p. 137). A Teoria Tradicional, pois, se efetiva à imagem e semelhança do status quo que a sustenta, mantendo o fundo de miséria que a produz.

Outra trilha é perseguida pela Teoria Crítica. Seu ponto de partida é a oposição da realidade dada, seu diagnóstico não é a reprodução da imagem social, sua miséria não é um desvio da racionalidade estabelecida. O "comportamento crítico" parte desse ponto: uma "contradição consciente" em que a imagem do progresso acompanha a história de dominação. É olhar, pois, o retrato social pelo seu "negativo", observando que as imagens estabelecidas se sustentam no espectro de tensões. Nesse esforço de superar as tensões sem encobri-las pelo horizonte do progresso, a miséria toma a forma de estruturante social. Ao mesmo tempo, o sujeito crítico se encontra imerso neste todo contraditório, cuja tensão entre a miséria e o progresso exige dele uma atitude crítica intrinsecamente ligada à responsabilidade de produzir um saber que pese a si mesmo como parte dessa produção social. O que sustenta essa perspectiva crítica, pois, é o "comportamento crítico" que configura um sujeito na negação de sua realidade e de si mesmo como parte desta realidade, um conceito de humanidade que contraria a si na medida mesma em que a experiência é atravessada por um mundo que não é dela. É uma realidade estruturada na divisão social em que a miséria estruturante é seu produto desumano. Nesta atitude, o pensamento crítico se efetiva no modo negativo da realidade: a partir da miséria, o teórico crítico encontra os rastros da emancipação e no progresso estabelecido os signos de uma vida precária.

É esta atitude crítica que acompanha Marcuse em seu capítulo introdutório de $O$ homem unidimensional: “A Paralisia da Crítica: sociedade sem oposição”. Por esse subtítulo não devemos compreender o sinônimo de uma sociedade sem conflitos, ou mesmo, em linguagem marxista, a ausência da dominação própria a uma sociedade dividida hierarquicamente entre classes. Marcuse quer indicar um problema grave no coração da teoria crítica: uma sociedade sem oposição é a ilusão de uma sociedade estabelecida em uma aparente realidade sem contradições e, portanto, sem o dispositivo central do pensamento crítico: sem os elementos que propicia a negação do Establishment. Com isso, Marcuse quer refletir sobre o destino da Teoria Crítica em uma realidade pela qual os conflitos sociais (e suas categorias) foram absorvidos por uma dinâmica social que os integra como parte de seu progresso: sob a marca da racionalidade unidimensional tudo se submete ao desempenho e à eficiência de um único modelo social em que o jogo de classes se submete à operacionalidade integrada a uma única estrutura social. Conforme lembra Marcuse, antigas categorias que nos primeiros anos do

\begin{tabular}{|l|l|l|l|l|}
\hline Qevista Qialectus & Ano 8 & n. 14 & Janeiro - Julho 2019 & p. 34 - 51 \\
\hline
\end{tabular}


capitalismo seriam vistas como antagônicas (como família, sociedade versus Estado) passam a ser integrantes de um mesmo campo de relações em vista do progresso único do sistema. ${ }^{2}$ Eis o que Marcuse identifica como o caráter unidimensional que atravessa a sociedade e o pensamento: elemento que bloqueia o "comportamento crítico" alimentado, em grande medida pelo horizonte negativo que outrora orientava todo processo emancipatório.

Em um tal grau de integração, Marcuse questiona-se por sua própria experiência de modo a retirar a teoria crítica da paralisia. Tarefa que oferece enormes dificuldades. Não é simples, como sugere no Prefácio Político (1966) quando lembra que o potencial negativo das liberdades ainda não realizadas. Em uma sociedade unidimensional, com o grau tecnológico e as vias sociais abertas por este, não faz mais sentido falar sobre libertação aos homens livres da classe média branca, não faz mais sentido falar de repressão sexual quando homens e mulheres gozam de uma liberdade sexual jamais vista antes. A crítica à modernidade se paralisa em campos que thes eram muito familiares. Aos poucos, Marcuse se aproxima do "inferno" que toda essa liberdade ilumina: o preço que todo esse progresso social cobra nos guetos, nos rincões dos continentes em uma nova ordem imperial. Decerto, é possível que haja tecnologia capaz de abastecer o mundo e mapear os bolsões de miséria. Mas a que preço?

Fazer-se esta pergunta não é um exercício de simples retórica: implica em mudanças nas categorias básicas da teoria crítica: implica uma nova ordem de juízo capaz de enfrentar a realidade objetiva e seu novo jogo unidimensional. Em breves termos, a introdução de $O$ homem unidimensional indica esta operação: recupera o sentido de crítica enquanto juízo de valores em dois níveis. Primeiramente, um juízo que pressupõe a priori a vida humana como um valor digno de ser vivido. Mas também, em segundo, um juízo que pressupõe que em uma dada sociedade, existem possibilidades específicas de melhoria da vida humana e modos e meios específicos para realizar estas possibilidades (MARCUSE, 1991, p. XLI). Em outras palavras, Marcuse procura recuperar a orientação crítica pela qual o juízo deve se fiar entre um a priori erótico que valoriza a vida humana na sociedade, mas também reconhece que, $a$ posteriori, o status quo não é uma realidade monolítica e cristalizada. Pelo contrário, está prenhe de possibilidades de mudança. A teoria crítica de Marcuse se desenvolve pois, entre a

2 Devemos lembrar aqui que, mesmo no jogo de forças da Guerra Fria, o jogo seria operado entre duas potências no interior de uma mesma finalidade em disputa. A corrida espacial e o projeto de Guerra nas Estrelas submetem ambos os modelos sociais ao mesmo poderio de destruição bélico e controle social. Marcuse reconhece este paralelo das potências em $O$ homem unidimensional, assim como já havia associada a submissão da experiência soviética ao capitalismo em Marxismo Soviético, em seu estágio estalinista.

\begin{tabular}{|c|c|c|c|c|}
\hline Gevista Dialectus & Ano 8 & n. 14 & Janeiro - Julho 2019 & p. $34-51$ \\
\hline
\end{tabular}


vida humana como valor universal a priori e as rupturas com o estado de dominação materialmente possibilitadas pelas próprias condições culturais, políticas e econômicas desenvolvidas historicamente. Todo o problema passa a operar, no entanto, quando a crítica perde o antigo solo negativo das oposições sociais. Na realidade unidimensional, pensamento e sociedade operam na dinâmica das oposições integradas, de modo que a demanda por liberdades pode ser a cifra que reforça o domínio social.

O impasse que Marcuse alcança em $O$ homem unidimensional é um capítulo à parte entre as gerações seguintes da Escola de Frankfurt, que buscam determinar o papel da crítica. Muitos deles, a partir da leitura de Habermas, compreendem todo o aparato do juízo crítico fundamentado no campo normativo. Axel Honneth compreende que "um problema central da Teoria Crítica da sociedade é a conexão entre a intenção teórico-normativa e a moralidade historicamente situada." (2007, p. 80). Assim, o juízo crítico de valor que Marcuse descreve em $O$ homem unidimensional representaria para Honneth um exemplo desse procedimento: a intenção teórico-normativa de um a priori erótico em conexão com as possibilidades efetivas de transformação social em um contexto histórico situado.

Seria o enquadramento normativo de Habermas e Honneth o mais correto para descrever a Teoria Crítica de Marcuse? Compreendamos melhor essa passagem para, em seguida, pensarmos um pouco a presença de Marcuse diante dos desafios da atualidade.

\section{O giro normativo}

Decerto, as últimas gerações da Escola de Frankfurt foram absorvidas pela perspectiva normativa de seus diagnósticos do presente. ${ }^{3}$ Sobre isso, Axel Honneth ressalta que a Teoria Crítica da Sociedade se vincula a um "tipo de pensamento social que partilha uma forma particular de crítica normativa" pela qual podemos nos informar sobre as "instâncias préteóricas [vorwissenschafltiche Instanz] em que sua própria perspectiva crítica está ancorada extra-teoricamente como um interesse empírico ou uma experiência moral" (HONNETH, 2007, p. 63-64). Em outras palavras, uma teoria crítica cujas bases se consolidam tanto no desenvolvimento da observação empírica das ciências sociais e psicológicas quanto na consolidação de critérios éticos que propiciem um julgamento sobre as injustiças sociais. Assim, na anterior diferença entre a Teoria Tradicional e a Teoria Crítica, a perspectiva

\footnotetext{
${ }^{3}$ Não apenas Habermas, mas podemos destacar também as pesquisas seguintes de Axel Honneth, Seyla Benhabib ou Rainer Forst.
}

\begin{tabular}{|c|c|c|c|c|}
\hline Gevista Dialectus & Ano 8 & n. 14 & Janeiro - Julho 2019 & p. $34-51$ \\
\hline
\end{tabular}


normativa desta possibilitaria considerar a subjetividade em sua relação social, de modo a refletir tanto as bases sociais e psicológicas que constituem as relações no mundo da vida, mas também conferir uma dimensão prática com a aplicação orientada para uma práxis futura. Enfim, o diagnóstico crítico destas últimas gerações lança a Teoria Crítica para uma ação orientada normativamente, reconhecendo os conflitos sociais em um horizonte regulamentado pela base empírica de um saber contemporâneo sobre a intersubjetividade e a expectativa ética da justiça moldada pelo reconhecimento.

Nesse sentido, podemos compreender quando Honneth compreende o projeto da teoria crítica na análise das expectativas normativas de sujeitos em relação, cujo desapontamento "se torna uma fonte constante de demandas morais que vão além das formas especificamente estabelecidas de dominação." (HONNETH, 2007, p. 69) Muito embora esta descrição remeta aos procedimentos normativos de Habermas, identificamos também aqui o modo como Honneth apresenta sua gramática dos conflitos sociais. Em seu Disrespect: the normative foundations of Critical Theory, Honneth apresenta a oposição normativa do reconhecimento/desrespeito como o eixo de seu diagnóstico social. Ora, os conflitos sociais seriam efeitos do déficit de reconhecimento mediante os quais as demandas sociais passam a ser apresentadas. Com isso, Honneth procura trazer à luz os modelos políticos de conflitos que atravessam as lutas de classes e os movimentos por direitos civis. ${ }^{4}$ Por conseguinte, o esforço diagnóstico da teoria crítica segue a expectativa normativa em que "modelos institucionalizados de reconhecimento social geram demandas justificadas nos modos como os sujeitos se tratam.”(HONNETH, 2007, p. XIII). Apoiado em modelos antropológicos e psicológicos dos processos de socialização, Honneth apresenta não apenas os déficits de reconhecimento social, mas também propõe horizontes de reconhecimento que atravessam as dimensões dos afetos, dos direitos e mesmo do ethos social em que estão implicadas as relações intersubjetivas (HONNETH, 2003).

Com isso, Honneth indica um distanciamento das formulações que seriam próprias à primeira geração de Frankfurt. Segundo Honneth (e Habermas), seus antecessores apresentam uma "fraqueza", pois o programa da filosofia social propiciada por Horkheimer sofre de um "reducionismo funcional" nas "premissas histórico-filosóficas" profundamente enraizadas na tradição marxista de uma racionalidade instrumental que organiza a sociedade capitalista 4 Sobre essa retomada dos movimentos sociais na teoria crítica contemporânea, ver o debate entre Axel Honneth
e Nancy Fraser em Redistribution or Recognition? A Political-Philosophical Exchange.

\begin{tabular}{|l|l|l|l|l|}
\hline Gevista Qialectus & Ano 8 & n. 14 & Janeiro - Julho 2019 & p. 34 - 51 \\
\hline
\end{tabular}


(HONNETH in GIDDENS et al, 1999, p. 516-517). Isso implica compreender a vertente crítica da primeira geração em uma relação ainda fixada nos parâmetros de uma filosofia do sujeito, uma vez que na instrumentalização o que está em jogo é o domínio do sujeito sobre o objeto, o que também significa a reificação dos sujeitos sociais. Não há espaço, de início, a outros sistemas sociais presentes no mundo da vida, reduzindo a história da humanidade em um "desdobramento desenvolvimentista do procedimento societal da natureza" (HONNETH in GIDDENS et al, 1999, p. 517). No limite, conclui Habermas (mas também, Honneth), a teoria crítica da primeira geração reduz funcionalmente sua orientação normativa a uma "contradição performativa" (HABERMAS, 2000, p. 170). Todo o desdobramento de seus diagnósticos gira em torno do modelo histórico-filosófico da racionalidade instrumental e, por isso, resultam em um modelo crítico paralisado de Horkheimer, Adorno e mesmo Marcuse. Nas palavras de Honneth:

\begin{abstract}
Uma vez que nenhum outro tipo de ação social é concedido, ao lado do trabalho societário, Horkheimer [mas também os demais membros desta geração] só pode levar sistematicamente em conta as formas instrumentais de prática societária no nível da teoria da sociedade, perdendo assim de vista essa dimensão da prática diária na qual os sujeitos socializados geram e desenvolvem criativamente orientações de ações comuns de um modo comunicativo. (HONNETH in GIDDENS et al., 1999, p. 518, colchetes nossos).
\end{abstract}

Consideremos aqui não apenas a marca que Honneth procura assinalar entre as gerações, mas a atitude crítica que acompanha seu gesto. Decerto, o autor procura avançar sobre os impasses que um novo contexto histórico-social oferece à teoria crítica. O que Habermas procurou estabelecer é um horizonte normativo que leve em consideração a ordem de relações intersubjetivas que ocupam e dinamizam a esfera pública. Honneth acompanha em sua gramática dos conflitos sociais muitas das lições habermasianas baseadas no reconhecimento intersubjetivo mediado pela esfera comunicativa - passo que a geração de Horkheimer não deu (HONNETH in GIDDENS et al, 1999, p. 518). Detendo-se um pouco mais na gramática do reconhecimento, Honneth afirma

As condições de um processo para alcançar a compreensão livre da dominação não podem mais ser empregadas como um critério para o que tem sido observado como uma 'desordem' ou um desenvolvimento patológico da vida social; antes, o critério

\begin{tabular}{|c|c|c|c|c|}
\hline Gevista Qialectus & Ano 8 & n. 14 & Janeiro - Julho 2019 & p. 34 - 51 \\
\hline
\end{tabular}


agora se torna a condição intersubjetiva do desenvolvimento da identidade humana (2007, p. 74).

Seriam, pois, os processos de autorrealização dos indivíduos em seus processos de socialização um dos critérios pelos quais Honneth abrange sua formulação crítica. Daí a importância de um ethos social que reconheça a justiça na dinâmica pessoal e social, inclusive na esfera do trabalho, mas também em toda a ordem normativa que atravessa os movimentos sociais étnico-raciais, de gênero e demais direitos civis e culturais. Impulso crítico que se apresenta à contrapelo dos sentidos de injustiça presentes nas dimensões individuais dos afetos, mas também intersubjetivas do campo jurídico ou mesmo culturais que habitam os valores sociais.

Novamente, a teoria crítica passa por uma revisão de seus pressupostos, em vistas do diagnóstico de seu tempo. Em debate com Nancy Fraser, muito desse "giro normativo" é justificado por Honneth pelos desafios de uma nova série de movimentos sociais que clamam não apenas por uma justiça econômico-política distributiva, mas também pelo reconhecimento dos valores culturais. ${ }^{5}$ Conforme este autor, seria essa nova dimensão dos conflitos sociais que exigem da Teoria Crítica um reforço cada vez maior em seus fundamentos normativos. Afinal, “os esforços multifatoriais de uma luta por reconhecimento são aqueles que capacitarão a Teoria Crítica a justificar suas pretensões normativas” (HONNETH, 2007, p. 77). Esta abertura a uma normatividade orientada por múltiplos fatores é o que Honneth não consegue identificar na ordem filosófico-histórica que identifica na primeira geração de Frankfurt. Resta saber em que medida na "fraqueza" da primeira geração de Frankfurt reside de fato um déficit normativo para os desafios contemporâneos e o novo cenário que se apresenta em dias de populismos conservadores.

\section{Críticas à normatividade}

Em tempos mais recentes, a perspectiva normativa da Teoria Crítica vem sendo revisada ou mesmo criticada a partir de limites impostos pelos tempos contemporâneos. Destaco aqui a objeção apresentada por John Abromeit que, na ocasião da ascensão de Donald Trump à presidência dos EUA, questionou-se pelos limites da perspectiva normativa da Teoria Crítica no cenário neoliberal ou ultraliberal que então se anunciava. Em que medida, questiona

\footnotetext{
${ }^{5}$ Ver o debate em FRASER E HONNETH, Redistribution or Recognition? A Political-Philosophical Exchange.
}

\begin{tabular}{|c|c|c|c|c|}
\hline Gevista Dialectus & Ano 8 & n. 14 & Janeiro - Julho 2019 & p. $34-51$ \\
\hline
\end{tabular}


Abromeit, as perspectivas de Habermas e Honneth nos ajudam a compreender os retrocessos sociais destas formas neoliberais de 'modernização', tais como a Grande Recessão de 2008 e o ressurgimento do populismo de direita na Europa e nos EUA? Em outras palavras: baseada no horizonte normativo de expectativas previstas em um campo institucional das lutas por reconhecimento, seria a teoria crítica de base normativa ainda capaz de promover uma perspectiva que supere a dinâmica contemporânea do pensamento conservador?

Decerto, a desregulamentação institucional em defesa da livre iniciativa do mercado e da competição entre indivíduos parece não operar mais sob o crivo da legitimação normativa. Em contrapartida, Abromeit lembra que em grande medida, a perspectiva normativa que a defesa liberal do fortalecimento das instituições democráticas presente no projeto iluminista de Habermas, torna secundário o processo histórico de dominação reduzido ao diagnóstico de patologias. Em um processo de revisão dos fundamentos e contextualização histórica das diferentes gerações de Teoria Crítica, o artigo de Abromeit identifica as diferenças e sugere limites para o fundamento normativo. Diante das crises frequentes do capitalismo, do aumento massivo de desigualdades e da proliferação dos movimentos populistas de direita, a perspectiva de um projeto inacabado de modernidade que alimenta o campo normativo do diagnóstico habermasiano, faz Abromeit lançar suspeitas e recuperar, diante destes limites, elementos presentes na primeira geração (ABROMEIT, 2017, p. 4).

Ora, segundo Abromeit, ao instaurar o campo normativo no núcleo da Teoria Crítica, a perspectiva que Habermas formula acaba perdendo um eixo importante para a compreensão de tais crises: o risco do autoritarismo no interior da própria democracia. Decerto, é importante lembrar, tanto Habermas quanto a geração que o segue estão engajados no combate aos revisionismos históricos conservadores e procuram responder aos movimentos regressivos da contemporaneidade. O problema, pois, está em outro plano: seria a resposta mediada pelo campo normativo suficiente? O que Abromeit procura identificar como limite da perspectiva normativa é, de início, o ponto cego produzido pelo alcance diagnóstico que tem como horizonte um projeto inacabado de Modernidade. Em grande medida, para Habermas, a crise em nada está implicada no projeto de Modernidade, uma vez que envolveria fatores variados e independentes de uma narrativa única de filosofia da história. A Modernidade se apresenta como um horizonte normativo em aberto e as crises não resultam necessariamente desta trajetória histórico-normativa. Fica de fora a própria miséria estruturante dos processos

\begin{tabular}{|l|l|l|l|l|}
\hline Govista Qialectus & Ano 8 & n. 14 & Janeiro - Julho 2019 & p. 34 - 51 \\
\hline
\end{tabular}


modernos - o que aproxima Habermas mais do campo da Teoria Tradicional do que daquele próprio à Teoria Crítica.

Com efeito, este ponto cego acompanha o giro normativo que sustenta a defesa habermasiana de reforço das instituições liberal-democráticas contra potenciais pré-modernos que habitam as esferas político-econômicas. Nesse sentido, Habermas explicaria a tendência nazista assentar suas raízes no território alemão e não na França e na Inglaterra (onde uma estrutura moderna de Estado já havia avançado). Compreende assim a tese da Sonderweg: "a falha da classe média alemã" (representada pela sua social-democracia) em destruir as instituições feudais anacrônicas acabou por não estabelecer um Estado moderno com instituições políticas liberal-democráticas, como naqueles outros países europeus (ABROMEIT, 2017, p. 2). Em resposta a esse descompasso, Habermas defende o estabelecimento de um campo normativo para o equilíbrio institucional, como sua aposta pela Constituição da União Europeia (HABERMAS, 2001).

Diante desse lance, Abromeit traz uma questão de fundo: e se a própria ideia de uma normatividade não carrega consigo os efeitos da impotência desta perspectiva diante da ascensão de movimentos autoritários e populistas no coração das sociedades democráticas e modernas? Aqui, a suspeita converge com a análise de Amy Allen, para quem o ponto cego da perspectiva normativa se localiza na ideia de "progresso", que permanece intocada no projeto de Modernidade(s) que a segunda geração de Frankfurt ainda sustenta (ALLEN, 2016, p. 54). ${ }^{6}$ Em seu The end of progress: decolonizing the Normative foundations of Critical Theory, Allen destaca o vínculo entre a perspectiva normativa e uma ideia de progresso que avance sobre as manifestações pré-modernas, não modernas ou tradicionais. Assim, para a autora, as teorias críticas de Habermas e Honneth acabam comprometidas com a defesa de alguma ideia de progresso histórico "para fundamentar sua aproximação singular com a normatividade e, pois, para ser verdadeiramente crítico" (ALLEN, 2016, p. 21-22). No entanto, continua Allen em vistas dos processos modernos de colonização, "a linguagem do progresso e do desenvolvimento é a linguagem da opressão e da dominação para dois terços da população mundial" (ALLEN, 2016, p. 22). Nesse sentido, a perspectiva normativa exige uma crítica sobre

6 Considerando que o próprio Habermas, ao tratar o projeto de Modernidade como "inacabado", permite a revisão contínua deste conceito, de modo a defender em seus trabalhos mais recentes a ideia de múltiplas modernidades. Para Allen, no entanto, essa reformulação ainda é insuficiente: o modelo de progresso normativo persiste seja em uma única ou em múltiplas modernidades (ALLEN, 2016, p. 79-90).

\begin{tabular}{|c|c|c|c|c|}
\hline QRovista Dialectus & Ano 8 & n. 14 & Janeiro - Julho 2019 & p. $34-51$ \\
\hline
\end{tabular}


seus próprios pressupostos: uma crítica do progresso presente em autores da primeira geração de Frankfurt e deixada como ponto cego na teoria crítica normativa de Habermas e Honneth.

Ora, é esta perspectiva de progresso que, segundo Abromeit, torna insuficiente a perspectiva normativa mediante fenômenos contemporâneos do autoritarismo e do populismo conservadores. A suspeita pela insuficiência da normatividade é válida, neste contexto, que se desenrolava desde os anos 1970, quando o neoliberalismo ganha força e se torna um projeto político de desregulamentação da vida social em prol da mais bruta competição do livre mercado. Em contrapartida, esse mesmo movimento torna interessante os autores da primeira geração de Frankfurt, como Adorno, que em 1959 considerava "a sobrevivência do NacionalSocialismo na democracia potencialmente mais ameaçadora do que a sobrevivência de tendências fascistas contra a democracia" (ADORNO, 1995, p. 30). Talvez vivamos num período sui generis em que, dialeticamente, o autoritarismo contra a democracia sobreviva na democracia. De todo modo, esse movimento faz com que o retorno à primeira geração apresente um interesse peculiar para nosso tempo, recuperando o "estranhamento" da mensagem que Marcuse (mas também seus colegas de Frankfurt) escreveram na garrafa que encontramos agora: o que implica fazer uma crítica à democracia em vistas da democracia? Seria esse o ponto cego que a perspectiva normativa contém?

\section{Marcuse e a crítica à democracia}

Diante do mesmo impasse sobre o destino da normatividade na Teoria Crítica, Arnold Farr afirma que Marcuse representa um "ponto cego" na relação entre as teorias críticas das primeira e segunda gerações da Escola de Frankfurt. Afinal,

\footnotetext{
Diferentemente de Horkheimer e Adorno, a teoria crítica de Marcuse não nos conduz para a paralisia política da dominação total e da administração total. Diferentemente de Habermas, Marcuse não separa de maneira ingênua a esfera da racionalidade instrumental (sistema) da esfera da racionalidade comunicacional (mundo da vida). (FARR, 2013, p. 281).
}

Em consequência, prossegue Farr, está presente em Marcuse um projeto mais radical do que ambas as posições. Em seu juízo crítico que tensiona o valor a priori da vida digna e as potências a posteriori de transformação social, Marcuse "leva à sério" o papel da dominação e da racionalidade instrumental tanto no nível econômico-político quanto no nível

\begin{tabular}{|c|c|c|c|c|}
\hline Gevista Qialectus & Ano 8 & n. 14 & Janeiro - Julho 2019 & p. 34 - 51 \\
\hline
\end{tabular}


do mundo da vida (basta notar o caráter unidimensional presente tanto as relações sociais quanto o campo da linguagem e do pensamento do status quo). Além disso, seu diagnóstico de paralisia da crítica serve como advertência para uma nova orientação crítica em busca da subjetividade radical e transformadora, as potencialidades de transformação nas engrenagens unidimensionais - o que o afasta do diagnóstico de Adorno e Horkheimer. Deste ponto de vista, questionamos o enquadramento normativo que a segunda geração da Escola de Frankfurt procura delimitar o pensamento marcuseano. Seu "ponto cego" nessa narrativa talvez nos ofereça mais elementos, sobretudo em tempos que este referencial passa a ser questionado pelos novos desafios de um contexto social do populismo conservador.

Em seu ensaio "O destino histórico da democracia burguesa"7, Marcuse - que não retornou à Alemanha com o fim da II Guerra Mundial, permanecendo nos Estados Unidos - acompanha de perto as mazelas da democracia estadunidense e sua inversão para a política imperialista. Neste ensaio, Marcuse se questiona pelos motivos que fazem uma camada expressiva da população eleger um representante que alimenta a "cultura da morte". Ela não está manifesta nos discursos de Nixon, mas também nos noticiários diários de violência, das taxas de morte na Guerra do Vietnã, ou mesmo na defesa, como ultima ratio, da "solução final" (o extermínio dos inimigos) (MARCUSE, 2001, p. 172). A democracia burguesa que Marcuse passa a analisar, pois, não é efeito simplesmente de instituições pré-modernas que precisam ser reformuladas. Ao atravessar as mais diversas esferas sociais e institucionais, o que persiste é o fortalecimento de discursos da violência, expressões presentes nas opções pela morte dos discursos cotidianos propagados pela mídia, como a mãe de três estudantes do Estado do Kent, os quais estavam em protesto. Para ela, seus filhos deveriam ser "retirados à força" no caso de não obedecerem aos guardas (MARCUSE, 2001, p. 172). O exemplo é interessante pois mostra as interferências da cultura da violência entranhadas nas diversas instâncias sociais, incluindo aqui a relação (tão elementar para Honneth) entre a mãe e seus filhos.

De maneira muito similar aos pressupostos de uma perspectiva normativa, o empírico se apresenta nessa descrição de Marcuse aliado às possibilidades de transformação

7 O ensaio datado de 1972 não foi publicado por Marcuse. Trata de compreender como a população americana elegeu o discurso beligerante de Nixon a despeito de toda a mobilização contra o militarismo e o autoritarismo que o candidato representava. Os editores dos Collected Papers de Herbert Marcuse, que reúne diversos inéditos do autor, sugerem que o fato deste ensaio não ser publicado pode ser explicado pelo contexto histórico que segue à eleição de Nixon, o escândalo de Watergate, que levou ao processo de seu impeachment. Apesar de não ter publicado, insistimos que muitas das teses apresentadas então sustentam outros ensaios de grande relevância publicado pelo autor (em especial, Tolerância Repressiva) e que, em grande medida, explica suas análises publicadas sobre o caso Watergate.

\begin{tabular}{|l|l|l|l|l|}
\hline Gevista Qialectus & Ano 8 & n. 14 & Janeiro - Julho 2019 & p. $34-51$ \\
\hline
\end{tabular}


social (ou seus impedimentos). Nesta descrição, no entanto, algo escapa dos pressupostos normativos: há um bloqueio no reconhecimento intersubjetivo e, mais ainda, um reforço de instâncias próprias à cultura da violência, do medo e da morte - o que Marcuse pretende descrever como uma cultura "sadomasoquista" presente nas instâncias da democracia burguesa. Remete aqui ao território de ambiguidades tão bem explorado pelo Marquês de Sade, para quem, desde as raízes históricas da democracia burguesa e seu regime de contratos, "crueldade, injustiça e vício são recompensadas invariavelmente, enquanto virtude, moralidade, justiça são invariavelmente punidas" (MARCUSE, 2001, p. 173). Com isso, nosso autor não se resigna a descrever a democracia como um sistema imperfeito de vícios, mas procura entender nas raízes morais de sua crítica as possibilidades políticas que tanto sustentam o status quo quanto rendem as revoltas para transcende-lo.

Não é o fiel da balança normativa que vai orientar a compreensão de Marcuse sobre o fenômeno do neofascismo. Sobretudo, em uma condição social que perde o caráter objetivo que sustentaria uma perspectiva normativa da Teoria Crítica. Diante de uma justiça sadomasoquista, o espelhamento entre o justo e o injusto, entre o respeito e o desrespeito deixa de ser a medida que fornece diagnósticos. Vejam os casos da "função ambivalente dos direitos civis": embora eles tenham de ser defendidos por todos os meios, Marcuse também nota como estes direitos têm servido aos governos proto-fascistas que os controlam de maneira cada vez mais aberta. Manifestação de violências e ameaças aos grupos sociais surgem como manifestações da liberdade de expressão. Segundo nosso autor: a "noção de objetividade, tão central às operações da sociedade civilizada, tem sido invalidada (mais ainda, tornada em seu oposto)" pelo próprio governo. Na dissolução objetiva que orienta a opinião, o que acaba se promovendo é "agressividade, opressão, crime" de modo a tornar público as "mais ultrajantes exortações à violência - a violência sadomasoquista arraigada no Establishment" (MARCUSE, 2001, p. 177).

Não seria justamente esta objetividade a matriz para uma perspectiva normativa da Teoria Crítica? Ou seja, para contrariar a dissimulação da objetividade pelo autoritarismo presente em vias da democracia burguesa, a melhor resposta não seria a defesa de critérios normativos constituídos histórico-materialmente pela gramática dos conflitos sociais? Esta poderia ser uma questão trazida pela reflexão honnethiana. Mas, ao analisar a resposta de Marcuse ao problema da dissimulação da objetividade pelo autoritarismo em vias democráticoburguesas, percebemos que o campo normativo é insuficiente. Subverter esta ideologia

\begin{tabular}{|l|l|l|l|l|}
\hline Q Pevista Qialectus & Ano 8 & n. 14 & Janeiro - Julho 2019 & p. $34-51$ \\
\hline
\end{tabular}


sadomasoquista exige forças mais poderosas do que o esclarecimento normativo. Essa estratégia encurrala a própria Esquerda que segue em defesa da democracia como um "mal menor", reduzindo cada vez mais as possibilidades de emancipação ao território democrático do status quo (MARCUSE, 2001, p. 177). De outro modo, é preciso enfrentar o afeto social central na cultura sadomasoquista: é preciso conquistar o medo (MARCUSE, 2001, p. 173) que está manifesta na dor, no sofrimento e na perda manifestas quando o status quo é ameaçado.

Decerto, a abertura crítica que Marcuse opera procura se afastar da grade normativa que lhe renderia a insuficiente proposição de reformas institucionais. Elemento evidentemente insuficiente em um contexto histórico em que a democracia burguesa encontra suas vias autoritárias, sobretudo, com a dissolução de limites institucionais, com o "desaparecimento da distinção entre negócios, máfia e política", fazendo da "corrupção" um termo sem a menor significação política (MARCUSE, 2001, p. 176) e abrindo espaço, como vimos, para o campo aberto das violências sadomasoquistas. No entanto, isso não significa que Marcuse abandone elementos centrais para a formulação da experiência política. De outro modo, minimizar as questões morais é um erro político. Pois, no campo moral está implicada a possibilidade de, ao mesmo tempo, utilizar as instituições democráticas enquanto combate as forças que, na democracia, fazem das pessoas os arautos das tendências conservadoras, reacionárias e mesmo neofascistas (MARCUSE, 2001, p. 178). Isto é, será pelo reconhecimento dos "conteúdos materiais das questões morais" (anterior ao caráter formal e normativo das injustiças) que a cultura sadomasoquista pode ser enfrentada (MARCUSE, 2001, p. 179).

\section{Conclusão: Decifrando a mensagem, hoje.}

Mas o que seria tal "conteúdo material"? De imediato, Marcuse apresenta a materialidade da moral como "a substância e o potencial políticos" contidos na questão moral (MARCUSE, 2001, p. 179). Aos poucos, ele procura trazer uma melhor compreensão mediante os exemplos em que o campo moral exerce papel central nas lutas sociais. A solidariedade, por si só, seria uma palavra isolada e até um bom valor de mercado em tempos como o nosso, em que corporações acabam fazendo da vulnerabilidade social um grande motivo de investimento de capitais. No entanto, seu conteúdo político é recuperado junto às significativas lutas sociais: não apenas quando os grupos sociais se manifestam em massa e contribuem entre si por suas causas, mas também quando a solidariedade rompe a identificação da classe trabalhadora (bem como os movimentos estudantil, negro, feminista, indígenas etc.) com os interesses da classe

\begin{tabular}{|l|l|l|l|l|}
\hline Qevista Qialectus & Ano 8 & n. 14 & Janeiro - Julho 2019 & p. 34 - 51 \\
\hline
\end{tabular}


dominante (MARCUSE, 2001, p. 179), e promovem, assim, camadas "sub-revolucionárias" presentes em todo processo revolucionário (MARCUSE, 2001, p. 182).

Talvez, na descrição que Marcuse faz a seus estudantes em Berkeley sobre os dias do Maio francês, notaremos um exercício crítico potente. Sua narrativa não era um enquadramento do movimento estudantil aos paradigmas teóricos de Eros e civilização. Em busca do conteúdo material e político dessa luta, Marcuse parte da descrição de como as vozes e os corpos passam a ocupar os espaços nas ruas de Paris e Nantèrre. A solidariedade destes corpos deixa de ser uma ideia. Há nesse embate um conteúdo material que se expressa como um modo de viver. Nesse sentido, descreve Marcuse:

chegou o tempo em que centenas de milhares e, como vemos agora, milhões de pessoas não queriam continuar fazendo a mesma coisa nunca mais: não queriam levantar de manhã e ir para o emprego e passar pela mesma rotina e escutar as mesmas ordens e concordar com as mesmas condições de trabalho e ter os mesmos desempenhos. Eles simplesmente se recusaram a fazer. Alguns ficaram em suas casas, outros saíram para passear e outros tentaram fazer algo (MARCUSE, 2005, p. 45).

Tal descrição de indeterminações está longe de ser o retrato de um progresso normativo. Uma filosofia que pensa a partir da espontaneidade dos movimentos sociais voltase para a ordenação material de suas relações e valores. Não à toa, em sua descrição do Maio Francês, Marcuse assinala as relações entre corpos: primeiro estudantes, depois a adesão de trabalhadores e trabalhadoras ao movimento. Decerto, este não é um encadeamento lógico dos fatos. Existem contradições em meio aos corpos estudantis e laborais, presentes mesmo quando enfrentam em conjunto o Establishment. Mas, talvez, é este encontro de contradições que torna potente um movimento como esse, para Marcuse. O campo moral não se neutraliza, mas se evidencia em seu conteúdo material e político dos corpos em luta.

Em seu livro mais recente sobre as políticas nas ruas, Judith Butler sugere algo semelhante ao que está em jogo na descrição de Marcuse. Segundo a autora:

a política não se define por tomar lugar exclusivamente na esfera pública, distinta da esfera privada, mas atravessa essas linhas repetidas vezes, chamando atenção para a maneira como a política já está nas casas, nas ruas, na vizinhança ou, de fato, nos espaços virtuais que estão igualmente livres da arquitetura da casa e da praça (BUTLER, 2018, p. 80-81).

\begin{tabular}{|c|c|c|c|c|}
\hline Gevista Qialectus & Ano 8 & n. 14 & Janeiro - Julho 2019 & p. 34 - 51 \\
\hline
\end{tabular}


Butler nota que a política não é, de imediato, um espaço normativo, mas um exercício diverso que leva em consideração a organização material dos espaços. Não existe política sem corpos (mesmo quando desaparecidos, eles têm voz). Creio que tal presença dos corpos é o que está na descrição de Marcuse sobre o Maio Francês. Sua Teoria Crítica rompe os quadros normativos e nisso opera um ponto cego: pois o que está em questão não é o diagnóstico da Modernidade, mas a necessidade provocada pelo contorno dos acontecimentos e dos corpos. Escutar os corpos em sua revolta: por isso, Marcuse vai mais além da normatividade. Em contrapartida, exige uma teoria crítica orientada pela ordem material dos acontecimentos. Assim, não é o progresso normativo que identifica o pensamento crítico marcuseano, mas o conteúdo material da moral: sua substância e potencialidade políticas presentes nos corpos e nos acontecimentos.

\section{Referências:}

ABROMEIT, J. Right-wing populism and the limits of normative critical theory. In: Logos: a journal of modern society and culture, vol. 16, $\mathrm{n}^{\circ}$ 1-2, 2017, http://logosjournal.com/2017/rightwing-populism-and-the-limits-of-normative-criticaltheory/ (acessado em 15/12/2018).

ADORNO, T. W. "O que significa elaborar o passado". In: ADORNO, T. W. Educação e emancipação. Tradução de Wolfgang Leo Maar, Rio de Janeiro: Paz e Terra, 1995.

ALLEN, A. The end of progress: decolonizing the normative foundations of critical theory. New York: Columbia University Press, 2016.

BENHABIB, S. Critique, norm, and utopia: a study on the Foundations of Critical Theory. New York: Columbia University Press, 1986.

BUTLER, J. Corpos em aliança e a política das ruas: Notas para uma teoria performativa de assembleia, tradução de Fernanda S. Miguens, Rio de Janeiro: Civilização Brasileira, 2018.

CARNEIRO, S. A paralisia da crítica e a democracia como tabu. In: Revista Fevereiro, vol. 7 , http://www.revistafevereiro.com/pag.php?r=07\&t=08 (acessada em 15/12/2018).

FARR, A. In search of radical subjectivity: rereading Marcuse after Honneth. In: Radical philosophy review, vol. 16, $\mathrm{n}^{\circ} 1,2013$.

FORST, R. Justificação e crítica: perspectiva de uma teoria crítica da política. Tradução de Denilson L. Werle, São Paulo: Ed. UNESP, 2018.

\begin{tabular}{|l|c|c|c|c|}
\cline { 2 - 4 } Govista & Ano 8 & n. 14 & Janeiro - Julho 2019 & p. 34 - 51 \\
\hline
\end{tabular}


FRASER, N e HONNETH, A. Redistribution or recognition? A political-philosophical exchange, translated by Joel Golb et al., London, New York; Verso, 2004.

HABERMAS, J. O discurso filosófico da modernidade: doze lições. Tradução de Luiz Reppa et al. São Paulo: Martins Fontes, 2000.

. Why Europe needs a constitution? In: New left review, vol. 11, sept-oct 2001, https://newleftreview.org/II/11/jurgen-habermas-why-europe-needs-a-constitution (acessado em 15/12/2018).

HONNETH, A. Teoria crítica. In: GIDDENS, A et al. (org.). Teoria social hoje. Tradução de Gilson C. C. de Souza, São Paulo, Ed. UNESP, 1999, p. 503-552.

Luta por reconhecimento: a gramática moral dos conflitos sociais, tradução de Luiz Repa, São Paulo: Ed. 34, 2003. Press, 2007.

Disrespect: the normative foundations of critical theory. Cambridge, Malden: Polity

HORKHEIMER, M. Teoria tradicional e teoria crítica. In: BENJAMIN, W. et al. Os pensadores, traduções de José L. Grünnewald et al. São Paulo: Ed. Abril Cultural, 1983, p. 117-154.

MARCUSE, H. Eros and civilization: a philosophical inquiry into Freud. Boston: Beacon Press, 1966.

. Soviet marxism: a critical analysis. New York: Columbia University Press, 1985.

One-dimensional man: studies in the ideology of advanced industrial societies.

London: New York: Routledge, 1991.

Filosofia e teoria crítica. In: MARCUSE, H., Cultura e sociedade. Traduções de Wolfgang L. Maar et al. Volume 1. São Paulo: Paz e Terra, 1997, p. 137-160.

. The historical fate of bourgeois democracy. In: MARCUSE, H. Towards a critical theory of society - collected papers of Herbert Marcuse. Volume 2. London, New York: Routledge, 2001, p. 163-186.

Reflections on French revolution. In: MARCUSE, H. The new left and the 1960s collected papers of Herbert Marcuse. Volume 3. London, New York: Routledge, 2005, p. 40-45.

\begin{tabular}{|c|c|c|c|c|}
\hline QRovista Dialectus & Ano 8 & n. 12 & Janeiro - Julho 2019 & p. $34-51$ \\
\hline
\end{tabular}




\title{
HERBERT MARCUSE E OS ANOS 1960: POSSIBILIDADES PARA A TRANSGRESSÃO NA SOCIEDADE CAPITALISTA
}

\author{
Maria Ribeiro do Valle ${ }^{1}$ \\ Pablo Almada ${ }^{2}$
}

\begin{abstract}
Resumo:
O presente artigo analisa a contribuição de Herbert Marcuse para a compreensão dos conflitos e protestos que ocorreram durante os anos 1960, com ênfase no entendimento do filósofo alemão com relação ao movimento estudantil global. Entende-se que, em um contexto marcado pelo domínio imperialista dos Estado Unidos e de composição hegemônica do pensamento unidimensional, Marcuse elaborou uma percepção sociológica acerca dos movimentos sociais e estudantis, valorizando as capacidades críticas e emancipatórias que estavam sendo postuladas por meio dos protestos daquela década. Por sua vez, é Marcuse quem abre caminhos para a compreensão de uma viragem política demarcada pela New Left, a qual deve ser levada em consideração na compreensão da atualidade dos problemas levantados por tais protestos e manifestos.
\end{abstract}

Palavras-chaves: Herbert Marcuse. Movimento Estudantil. Nova Esquerda. 1968. Imperialismo.

\section{HERBERT MARCUSE AND THE 1960s: POSSIBILITIES FOR TRANSGRESSION IN THE CAPITALIST SOCIETY}

\begin{abstract}
:
This article analyzes the contribution of Herbert Marcuse to the understanding of the conflicts and protests of the 1960s, investigating the understanding of the German philosopher in relation to the global student movement. In a context marked by the US imperialist domination and hegemonic composition of onedimensional thinking, Marcuse developed a sociological perception of social and student movements, highlighting the critical and emancipatory capacities were being postulated by the protests of the decade. On the other hand, it was Marcuse who opened theoretical paths for the understanding of a political shift demarcated by the New Left, which must be taken into account in the research on the actuality of the problems raised by such protests and manifestos.
\end{abstract}

Keywords: Herbert Marcuse. Students Movement. New Left. 1968. Imperialism.

Durante a chamada Guerra Fria, o capital internacional criou várias frentes de combate para impedir o avanço do comunismo. A emblemática intervenção dos EUA na Guerra do Vietnã (1961-1975) foi um marco importante para a compreensão desse período, já que houve avanços em seus objetivos militares, econômicos, ideológicos e geopolíticos. O cerco contra a China comunista - outro obstáculo ao expansionismo norte-americano. despertava um forte interesse junto às nações do Terceiro Mundo por conta da "guerra de guerrilhas", que pela ótica norte-americana deveria ser combatida a

\footnotetext{
1 Professora Livre Docente do Departamento de Sociologia da UNESP- FCLAR. E-mail: maria.valle@unesp.br.

2 Professor do Departamento de Ciências Sociais da UEL. E-mail: pabloera@ gmail.com.
} 
qualquer custo. O Vietnã foi um campo de provas para novas armas e táticas antiguerrilha, com a finalidade de impor a continuidade das práticas neocolonialistas norteamericanas sobre os povos da Ásia, África e América Latina. As conspirações agressivas contra Cuba, o apoio a Israel contra os países árabes, a participação efetiva nos golpes militares da América Latina, o controle sobre a Coréia do Sul, Formosa e Filipinas, as ameaças contra o Camboja, a clandestina penetração na Índia e na Indonésia e a ocupação militar da República Dominicana foram outros eventos geopolíticos que demarcaram o poderio norte americano, congregando protestos de vários setores sociais em defesa do Terceiro Mundo e a repressão violenta dessas manifestações por todo o globo.

A correlação entre a vitória do socialismo em Cuba e o aumento da colaboração militar oferecida pelos norte-americanos, destinada à contra-insurreição, tornava-se exemplar com a ocupação da República Dominicana, em 1965, por sua artilharia e por suas unidades móveis, incluindo forças aéreas e terrestres, que sustentavam a "ditadura legal" de Balaguer contra o poder popular armado (PETRAS, 1967, p. 16-31). Frente à ameaça do alastramento da guerrilha na América Latina, os Estados Unidos orientaram golpes militares na Argentina (1962), no Brasil (1964), na Bolívia (1964) e no Peru (1968), enfatizando o chamado "combate ao inimigo interno".

A ofensiva política, ideológica, econômica e militar americana, durante os anos 60, ocorre também em uma vasta área da Ásia e da África: no levante de Ghana, no qual o governo de N'Krumah havia sido deposto; no crescimento das forças da reação em vários dos países que estavam em luta contra o neocolonialismo; no triunfo sangrento do anti-comunismo da Indonésia em 1965, quando cerca de 500 mil pessoas foram massacradas depois que Suharto chega ao poder, significando uma grande vitória para a contra-revolução na Ásia; no golpe militar direitista na Grécia; no conflito judeu-árabe, onde houve o alinhamento da política de Israel - que teve sua economia dependente das doações americanas durante a Guerra Fria - à orientação norte-americana contra a luta pela emancipação dos povos árabes (DEUTSCHER, 1968, p. 5-24).

No entanto, a contestação dessas práticas ganhava bastante destaque no meio estudantil. Os estudantes norte-americanos se mobilizaram após 1964 de várias formas, principalmente, criando comitês contra a guerra do Vietnã, que cresceram significativamente nos campus a partir de 1966, havendo também intervenções contra o Partido Democrata e em apoio aos Black Panthers (HARMAN, 1998). Na Alemanha, desde os ocorridos da morte de Breno Ohnesorg, em 1967, o movimento estudantil

\begin{tabular}{|c|c|c|c|c|}
\cline { 2 - 4 } & Ano 8 & n. 14 & Janeiro - Julho 2019 & p. 52 - 69 \\
\hline
\end{tabular}


ganhava contornos cada vez mais anti-imperialistas e solidários com os países do Terceiro Mundo (BROWN, 2009). No México, a fúria das forças armadas desencadeou uma rara carnificina, quando mais de trezentas pessoas foram mortas durante uma manifestação estudantil na Praça das Três Culturas em 2 de outubro de 1968, e várias outras são vítimas do terror que se instalava através de prisões e torturas (REIS FILHO \& MORAES, 1998, p. 40).

Essas mobilizações globais atentavam para a crescente militarização dos Estados Unidos nos anos 1960, que incidiu diretamente nas nações "subdesenvolvidas", conforme as "missões militares" tornavam-se efetivas em mais de 50 países (McCARTY, 1968, p. 41-43). Por outro lado, surgiam movimentos solidariedade internacional, com destaque para o protagonismo estudantil dos países centrais e de países periféricos.

Um caminho de libertação mundial começava a ser trilhado através das lutas dos povos colonizados pela independência, e, simultaneamente, nos EUA, o "poder negro" se rebelava contra o preconceito racial e o movimento estudantil, lado a lado com os professores e integrantes da Nova Esquerda ${ }^{3}$, ocupava as universidades e tomava as ruas em manifestações que repudiavam a intervenção americana no Vietnã. A guerra do Vietnã inspirou a possibilidade da alteração da correlação de forças a partir da união e participação do povo no enfrentamento contra a maior potência mundial, numa "guerra justa" contra o imperialismo norte-americano - cuja intervenção, no sudeste asiático, atingia seu ponto máximo em 68.

Com a morte de Che Guevara em 67, apesar dos revezes da guerrilha latinoamericana, ressurgiu com intensidade o interesse por suas análises sobre as estratégias da revolução na América Latina (REIS FILHO \& MORAES, 1998, p 33-4). O foco guerrilheiro, ou seja, a luta armada, irrompia como alternativa à via pacífica e à legalidade constitucional propagadas pelos partidos comunistas. A "revolução cultural", iniciada na segunda metade da década de 1960, foi acalentada pelos estudantes na China e de diversos outros países (REIS FILHO \& MORAES, 1998, p 43-4). As propostas de Mao, que para muitos resgatavam as teses marxistas originais, eram o motor de lutas anti-imperialistas e populares, bem como endossavam a crise dos partidos políticos ocidentais. A linha de massas defendida por Mao fará parte dos debates e ações da esquerda estudantil favorável

3 A Nova Esquerda dos EUA nos anos 60 é composta fundamentalmente por estudantes universitários, professores, ativistas negros e feministas e, assim como a Nova Esquerda européia, não é nada entusiasta do socialismo soviético, contrariamente à Velha Esquerda intelectual dos anos 30 que nutria uma admiração pela União Soviética e se vinculava ao movimento operário industrial organizado.

\begin{tabular}{|c|c|c|c|c|}
\hline Rovista Q Didectus & Ano 8 & n. 14 & Janeiro - Julho 2019 & p. $52-69$ \\
\hline
\end{tabular}


à revolução centrada na integração da luta militar com a ampla participação das massas (MARTINS FILHO, 1987, p. 188-191).

Sob a égide da utopia revolucionária, o movimento estudantil eclodiu em vários países (REIS FILHO \& MORAES, 1998, p 32-44). Encontramos algumas bandeiras comuns, mas em cada país, não podem ser desconsideradas as questões políticas locais. Nos EUA os estudantes revoltam-se diante da possibilidade de combater no Vietnã. Com a morte de Martin Luther King, em abril de 68, os protestos do movimento negro atingem imensa proporção. Os estudantes e os negros - que na guerra representam o maior número de mortos - unem-se nas manifestações de rua. Na Alemanha e na França, os estudantes também se rebelam contra a política norte-americana de guerra no sudeste asiático. Berlim Ocidental, capitalista, embora localizada na Europa do comunismo, assistirá à recusa estudantil, quer do American way of life, quer do stalinismo autoritário. O Maio Francês se destacará pela repulsa ao autoritarismo em todas as esferas sociais, particularmente nas estruturas das universidades. As barricadas são erguidas contra a ação policial e as autoridades. Nas rebeliões destes três países está fortemente presente a recusa ao colonialismo, através da defesa dos argelinos pelos estudantes em seu desejo de emancipação durante a Guerra da Argélia, e ao imperialismo norteamericano, principalmente no Vietnã.

Nos anos 1960, o anti-imperialismo é visto pelos estudantes não apenas como o rechaço do capitalismo colonialista, mas também do socialismo soviético. A seu ver movimentos do Terceiro Mundo ${ }^{4}$ souberam “(...) demonstrar que, em graus e modalidades diferentes, também o imperialismo dos EUA, com a conivência do seu pretenso arqui-inimigo, a União Soviética, era responsável pela condição de dependência, ditadura, pobreza, miséria ou guerra civil da sua nação"(GROPPO, 2005, p. 84). As lutas anti-imperialistas são identificadas, então, como a luta dos povos do Terceiro Mundo por sua independência.

O mundo socialista não escapará, assim, às agitações estudantis de 68 , que buscam o rompimento com a dominação burocrática. Na Tchecoslováquia, os conflitos merecerão destaque internacional. A URSS invade a cidade de Praga, em agosto de 68, como represália às críticas ao socialismo real e às propostas de ampliação da liberdade de organização partidária defendidas pelo governo Tcheco durante a "Primavera de Praga".

4 O Terceiro Mundo buscava uma identidade à parte da bipolarização da Guerra Fria, demonstrando a consciência do fato de ele ser alvo da ambição destas superpotências.

\begin{tabular}{|c|c|c|c|c|}
\hline Rovista Q Dialectus & Ano 8 & n. 14 & Janeiro - Julho 2019 & p. $52-69$ \\
\hline
\end{tabular}


Na América Latina, as lutas estudantis estão presentes na maioria dos países: Argentina, Bolívia, Chile, Guatemala, Peru, Uruguai e México, onde o perigo do alastramento da guerrilha é combatido com golpes militares que recebem o apoio e orientação dos Estados Unidos.

A importância da polêmica em torno da violência polariza também os intelectuais. A democracia socialista volta a ser tematizada por expoentes da intelectualidade como Jean Paul Sartre e Herbert Marcuse. As utopias anticapitalistas do século XIX - particularmente a marxista - são revisitadas, embora haja a rejeição de qualquer ortodoxia e a forte descrença no socialismo real. Sartre e Marcuse estarão engajados em 68. Suas ideias estarão ecoando no movimento estudantil, como vimos, em vários países.

\section{Da "unidimensionalidade" à transgressão revolucionária}

Em A Ideologia da Sociedade Industrial, publicado em 1964, Marcuse aborda o total esvaziamento, nas sociedades contemporâneas altamente desenvolvidas, quer da teoria crítica quer da prática política alicerçadas nas possibilidades históricas de transformação social (MARCUSE, 1978). Na sociedade unidimensional, onde a tecnologia, a cultura, a política e a economia estão fundidas num sistema onipresente capaz de atrelar eficazmente o progresso técnico à estrutura de dominação, o aparato produtivo tende a tornar-se totalitário, chegando a determinar até mesmo as necessidades e as aspirações individuais.

O ceticismo presente nos escritos de Marcuse de 1964 começa a ser superado com a emergência de protestos que envolvem novos atores sociais - por um lado as revoluções contra a intolerável herança do colonialismo e seu prolongamento pelo neocolonialismo, e, por outro, a revolta da juventude. Embora ele não perca de vista o totalitarismo da sociedade unidimensional e os seus eficientes poderes de controle, bem como a integração dos trabalhadores às benesses da mesma, passa a vislumbrar a possibilidade da “(...) recusa organizada em continuar trabalhando com os instrumentos materiais e intelectuais que estão sendo agora usados contra o homem - para a defesa da liberdade e prosperidade daqueles que dominam o resto". (MARCUSE, 1966, p. 22).

A dimensão negativa, até então eficaz e democraticamente contida, ressurge, mudando sua localização social e trazendo de volta ao horizonte político a possibilidade

\begin{tabular}{|c|c|c|c|c|}
\cline { 2 - 4 } & Ano 8 & n. 14 & Janeiro - Julho 2019 & p. 52 - 69 \\
\hline
\end{tabular}


de realização da teoria e da prática revolucionárias, ou seja, do fim da utopia. O papel das novas formas de oposição que, para Marcuse, devem “(...) explorar com atenção qualquer possível rachadura na gigantesca concentração de poder na sociedade estabelecida" (MARCUSE, 1969, p. 31-2) passa a ser central. Apesar dos efetivos sinais de desgaste do capitalismo monopolista, ele adverte que elas não podem minimizar a capacidade de reorganização do sistema através da contra-revolução preventiva (MARCUSE, 1981, p. 11-2) e devem trabalhar no sentido de despertar a consciência

\begin{abstract}
Com relação à horrível política de um sistema cujo poder e pressão crescem com a ameaça de total aniquilamento, que utiliza as forças produtivas a seu dispor para a reprodução da pilhagem e da opressão, e que, para a proteção da sua abundância, equipa o chamado mundo livre com ditaduras militares e policiais (MARCUSE, 1968, p. 89-90).
\end{abstract}

Ainda não há, apesar da eclosão dos movimentos estudantis, de libertação colonial, dos direitos civis, dos hippies, uma organização solidária que promova a confluência de tendências tão diversas. As contestações econômicas, políticas e culturais, tanto no Ocidente como no Oriente, são consideradas por Marcuse, que em momento algum deixa de reconhecer as suas limitações, forças que permitem vislumbrar a realização da utopia, desde que estejam dirigidas à ruptura do sistema.

Ao defender o fim da utopia, Marcuse afirma continuar sendo o marxismo o guia da oposição, que deve se empenhar para atualizar os seus conceitos com o intuito de evidenciar as possibilidades de superação da ordem existente. Um dos elementos cruciais para a realização da sociedade livre é o de identificar os portadores sociais da transformação na conjuntura dos anos 60 pois o operariado americano, na sua grande maioria integrado ao sistema, é hostil a qualquer proposta da Nova Esquerda que ponha em xeque o status quo. Também em países como a França e a Itália, onde o movimento trabalhista, submetido às orientações do Partido Comunista e dos sindicatos restringem suas perspectivas à melhoria da situação vigente do operariado, abandonam a perspectiva da negação radical do capitalismo (MARCUSE, 1968; 1981). Contudo

A impossibilidade de determinar uma classe revolucionária nos países capitalistas que apresentam um desenvolvimento tecnológico mais elevado não significa, de modo algum, que o marxismo tenha se transformado em uma utopia. Os portadores sociais da transformação (e isso é marxismo ortodoxo) se formam no curso do próprio processo de transformação, não se podendo contar jamais com a existência de forças revolucionárias ready-made, prontas e acabadas, por assim dizer, no momento em que tem início o movimento revolucionário (situação afortunada e não muito fácil de se verificar). Todavia,

\begin{tabular}{|c|c|c|c|c|}
\cline { 2 - 4 } Q Dovista & Ano 8 & n. 14 & Janeiro - Julho 2019 & p. 52 - 69 \\
\hline
\end{tabular}


acredito que haja um critério válido, o qual consiste em estabelecer se as forças materiais e intelectuais necessárias à realização da transformação estão tecnicamente presentes, apesar dos obstáculos colocados à sua utilização racional pela organização das forças produtivas. Eu creio, aliás, que seja este o sentido no qual se pode hoje falar efetivamente de um fim da utopia (MARCUSE, 1969, p. 16).

Alertar para as contradições do capitalismo de monopólio ou explicitá-las passa a ser um fator primordial da nova oposição que, embora totalmente diversa das forças ortodoxas marxistas da transformação social, deve conservar como prioridade a recusa da ordem social existente. A Nova Esquerda nos Estados Unidos ${ }^{5}$, composta por um grupo de intelectuais desde o início desta década, vincula-se à organização SDS Students for a Democracy Society. Paralelamente ao movimento negro, ela torna-se o centro dinâmico das reivindicações políticas, abrindo caminho para a emergência dos movimentos hippies, feministas e homossexuais. Já a organização mais representativa da juventude negra é a SNCC - Student Nonviolent Coordination Committee - que, assim como a SDS, surge primeiramente como suporte para os grupos pacifistas e para os movimentos dos direitos civis, respeitando os limites democráticos através da resistência passiva e da rebeldia sem violência física. Sob a forte influência de Martin Luther King, a SNCC luta contra a segregação no campus universitário. Apesar das diferenças entre as duas principais organizações estudantis, podemos notar que, frente à conjuntura mais ampla, a SDS e a SNCC estão unidas em torno das questões nevrálgicas deste momento: as lutas contra a guerra no Vietnã e contra a discriminação dos negros.

A partir de 1964 o movimento da juventude negra se torna mais extenso, violento e radical, sob a influência da militância de Malcolm X, líder negro e revolucionário nacionalista, que prega a luta armada em legítima defesa e o panafricanismo. O slogan Black Power, que passa a ser utilizado pelo SNCC, ecoa em motins como o de 1965 em Watts e aqueles que marcam os verões sangrentos de 1966 e de 1967. Estes levantes são divulgados como um passo significativo na escalada da guerra racial, levando muitos americanos a acreditar na existência da guerrilha urbana. Uma das justificativas para a utilização da violência decorre da própria insuficiência das leis dos direitos civis de 1964e do direito de voto de 1965. Do ponto de vista estratégico, contudo, não há unanimidade entre os grupos de esquerda, que permanecem internamente divididos entre a luta parlamentar e o confronto. $\mathrm{O}$ papel da violência na história passa a

5 Sobre a Nova Esquerda e a conjuntura dos movimentos de contestação nos EUA nos anos 1960 ver principalmente: GITLIN (1993); ISSERMAN (1993); ISSERMAN \& KAZIN (2000), MILLER (1987).

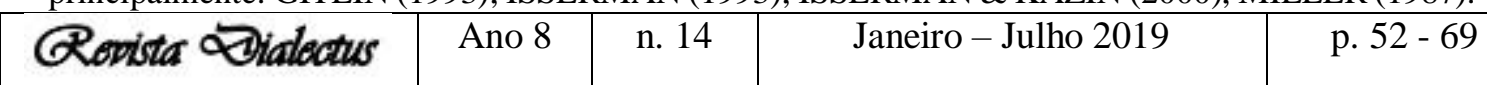


ocupar o centro do debate, atuando como um divisor de águas frente à defesa da revolução.

Assim, os ativistas do SNCC, do SDS e parte dos intelectuais militantes da Nova Esquerda passam a vislumbrar a possibilidade de aliança com as forças revolucionárias do Terceiro Mundo. A influência da luta armada maoísta torna-se bastante presente nos movimentos de contestação norte-americanos. Para a maioria da esquerda - e não apenas para os discípulos de Mao -, a luta contra a guerra e o movimento negro estão efetivamente ligados, contribuindo para o aumento da adesão à política do confronto que, apesar de ser rechaçada por alguns líderes veteranos da Nova Esquerda, começa a ocupar o espaço anteriormente destinado à estratégia pregada pelas organizações dos direitos civis. A argumentação contrária à violência revolucionária não encontra respaldo nos campi universitários, principalmente em 1968, o ano da barricada, quando as manifestações incorporam formas de desobediência civil como, por exemplo, a queima das convocações para a guerra do Vietnã que, neste ano, é palco da maior ofensiva dos EUA - o Tet. As investidas policiais atingem várias pessoas, matando três delas, durante os motins de fevereiro, desencadeando uma reação ainda mais violenta, quando os ativistas negros passam a atirar em locais públicos (GITLIN, 1993, p. 313-4). Cresce o medo de estarem sendo vigiados pelo FBI. Os estudantes brancos e parte significativa da Nova Esquerda se unem aos Panteras Negras, que surgem com o apoio da SNCC e cujo líder Stokley Carmichael prega a luta armada, o boicote às eleições presidenciais, recusando as formas de resistência passiva. Os conflitos armados entre a polícia e os negros "radicais" tomam as ruas. A guerra civil parece ameaçar a "paz" norteamericana.

Marcuse mostra que, apesar de toda a concentração de poder do sistema vigente, estão vindo à tona diferentes formas de contestação. A nova oposição, ao seu ver, é marcada por características bastante peculiares, pois não é

Com exceção de alguns pequenos grupos, ortodoxamente marxista ou socialista. Caracteriza-se por uma profunda desconfiança contra todas as ideologias, contra, também, a ideologia socialista, pela qual muitos acreditam, de certo modo, ter sido traídos e da qual estão desiludidos. A nova esquerda ainda com exceção de pequenos grupos - ademais, não está fixada de modo algum na classe operária como classe revolucionária. Além disso, não pode, de modo geral, ser definida em termos de classe. É composta de intelectuais, de grupos do movimento pelos direitos civis e da juventude, principalmente de elementos radicais da juventude (MARCUSE, 1968, p. 80-1).

\begin{tabular}{|c|c|c|c|c|}
\cline { 2 - 4 } & Ano 8 & n. 14 & Janeiro - Julho 2019 & p. 52 - 69 \\
\hline
\end{tabular}


Ao analisar a pouca ortodoxia destas forças sociais de transformação, Marcuse mostra que, além dos integrantes da Nova Esquerda, delas fazem parte também os marginalizados, ou mais especificamente os subprivilegiados (MARCUSE, 1968, p. 82) que não podem ter sequer suas necessidades mais elementares satisfeitas, apesar do capitalismo altamente desenvolvido. Fazem parte deste grupo as minorias nacionais e raciais, os presos - que através de rebeliões nas penitenciárias de Oregon, Raleigh, Ohio, Columbia, Atlanta, em 1968, procuram chamar a atenção da opinião pública para o tratamento que lhes é dispensado -, e as massas do Terceiro Mundo.

Apesar da diversidade das reivindicações do movimento estudantil em cada país, ele tem como objetivo comum o protesto contra o capitalismo e seus cúmplices no Terceiro Mundo. Compreende-se, então, a importância atribuída por Marcuse ao $\mathrm{ME}^{6}$, concebendo-o “(...) enquanto classe intelectual, destinada a fornecer os quadros dirigentes da sociedade atual" (MARCUSE, 1969, p. 25). Ou seja, devido à sua posição privilegiada, as organizações estudantis podem contribuir para o desenvolvimento de uma consciência radical como a base de partida para uma luta mais ampla (MARCUSE, 1981, p. 59). Ao posicionar-se favoravelmente aos protestos que eclodem no final dos anos 60, Marcuse integra-se ativamente na militância política que ele mesmo está propondo a todos os intelectuais empenhados em buscar a ruptura deste sistema, através da união da teoria e prática, principalmente diante da integração da classe trabalhadora ao capitalismo monopolista.

Marcuse mantém aqui a análise da Ideologia da sociedade industrial que “(...) reproduz na consciência e na estrutura pulsional dos indivíduos necessidades materiais e espirituais legitimadoras do sistema" (LOUREIRO, 1999, p. 8), mas, a partir da eclosão dos diversos protestos e rebeliões tanto nos países industriais avançados quanto nos terceiro-mundistas, passa a acreditar que eles podem atuar como um estopim para a emancipação da humanidade. O alto desenvolvimento das forças produtivas atingido pela história cria objetivamente esta possibilidade, sendo o trabalho educativo o mais necessário, devido à importância da mobilização de amplas massas politizadas. Os intelectuais, não apenas por razões culturais, mas por serem economicamente e materialmente privilegiados, devem desempenhar este trabalho junto ao operariado

6 Marcuse também em suas correspondências com Adorno em 1969 defende a importância do movimento estudantil naquela conjuntura específica, contrapondo-se ao posicionamento político inclusive de colegas seus frankfurtianos, particularmente o de Adorno, frente aos protestos estudantis (ADORNO \& MARCUSE, 1997). 
integrado, incapaz de qualquer ação política que não seja a de contribuir para a solidez do status quo, e aos excluídos do Terceiro Mundo.

Entre aqueles que estão fora dos mecanismos integradores, o proletariado do Terceiro Mundo, constitui o grupo social que ocupa uma posição determinante no processo de produção e de reprodução dos bens materiais e sobre o qual se descarrega todo o peso da opressão, vivendo em condições similares as do operariado europeu do século XIX. Existem também camadas inteiras que talvez não possam sequer ser classificadas, como as minorias raciais e nacionais, os desempregados permanentes, os pobres, os que não têm nada que possa ser tributado e os presos, que representam a negação viva do sistema (MARCUSE, 1999, p. 49). Estes grupos, sendo as maiores vítimas do terror e da força mais brutal do sistema, podem abrir fissuras na ordem estabelecida, contribuindo para uma possível, embora remota, solução revolucionária. O aflorar dos movimentos negros, dos motins nos presídios, e da luta no Terceiro Mundo explicita que trazer o povo para o centro das decisões políticas não significa apenas uma explosão instintiva, irracional. Eles estão produzindo novas formas de contra educação, de desmascaramento de uma sociedade que concilia a pluralidade democrática com o totalitarismo, mostrando constantemente a necessidade do protesto, da denúncia, podendo inclusive despertar para a luta o trabalhador integrado, que não percebe que a elevação de seu nível de vida foi alcançada com a intensificação do trabalho alienado e que, portanto, o status quo por ele legitimado é o mesmo que perpetua sua fadiga. A vanguarda intelectual, que recusa a ordem vigente e tem dela uma visão mais global, também deve atuar como catalisadora destas novas forças, através da educação política. Está presente aqui a ideia de revolução, na esteira da teoria marxista, no sentido em que ela tem sua realização possível na junção daqueles que, livres das benesses do sistema, são movidos pela necessidade com a teoria crítica, vislumbrando uma possível solução a partir da aliança do Terceiro Mundo com os novos sujeitos da oposição dos países industriais desenvolvidos.

\section{A busca pelo "outro": a New Left}

Ainda, se faz necessário aludir como o pensamento de Marcuse é influenciado por e influente na emergente New Left, por conta de suas formulações acerca dos "novos sujeitos históricos de mudança”. Conforme se vincula a noção de que os movimentos

\begin{tabular}{|c|c|c|c|c|}
\cline { 2 - 4 } & Ano 8 & n. 14 & Janeiro - Julho 2019 & p. 52 - 69 \\
\hline
\end{tabular}


estudantis estariam se desalinhando das questões eurocêntricas capitalistas, haveria a valorização de novas experiências que estavam se dando nos países do Sul global. Esse deslocamento é o ponto de partida para se perceber a emergência de um novo movimento na esquerda ocidental. Se muitas das reivindicações de 1968 fracassaram, especialmente o projeto de democratização das universidades, houve, por conseguinte, a abertura de novas dimensões políticas, como "novos espaços, onde se necessitava de novas ideias e práticas", ou mesmo, novas sensibilidades para com a política (ELEY, 2000, p. 419).

Na raiz desse problema se encontrariam pelo menos duas oposições táticas que marcariam as tomadas de posição para os movimentos de esquerda e de oposição não alinhados aos soviéticos. A primeira oposição, bastante presente na Europa Ocidental, se daria entre a oposição extraparlamentar versus oposição parlamentar. Do lado da oposição extraparlamentar, a cisão se aprofundaria entre luta armada versus luta pacífica, o que poderia implicar ou não em aproximações entre a vertente parlamentar e a tática pacífica. Contudo, os movimentos de cunho trotskista, maoísta ou mesmo a adoção de "táticas armadas" acabaram tendo uma vida curta em muitos lugares. Na Alemanha e na Itália, o cunho de um movimento por autonomia preencheu bastante desses espaços, com práticas que buscavam a desalienação da vida cotidiana, sua descolonização e a busca de possibilidades de uma democracia mais horizontal, mas resultou também numa intensificação das lutas anticapitalistas (KATSIAFICAS, 2006). Como irá se verificar, os movimentos da esquerda mais radicais prefiguraram no Brasil de maneira ativa até 1972, e, em Portugal até pouco tempo depois do 25 de Abril. Mas, em ambos os casos, a luta por dentro das instituições acabou por direcionar grande parte das mobilizações sociais, sobretudo naquilo que concerne às conquistas e consolidação da democracia.

Questões ligadas à sociedade civil, "educação, trabalho social, assistência à saúde, legislação, funcionalismo público, profissões, sindicatos", que proporiam, paulatinamente, a derrubada da força e da resistência do Estado (ELEY, 2000, p. 419) foram ancoradas como pautas de reivindicações desse movimento de esquerda, deslocando a generalidade das lutas sociais anteriores às questões da política imediata: a conquista da democracia, o fortalecimento das instituições, a ampliação dos processos democráticos eleitorais e participativos. A oposição extraparlamentar, grosso modo, abdicou da ação direta, da organização comunitária, da aproximação entre política e vida cotidiana, ou mesmo, da crítica às diferenciações de gênero, elaboradas pelos movimentos feministas. As vias eleitorais conseguiram o reestabelecimento da socialdemocracia,

\begin{tabular}{|c|c|c|c|c|}
\cline { 2 - 4 } & Ano 8 & n. 14 & Janeiro - Julho 2019 & p. 52 - 69 \\
\hline
\end{tabular}


assentada no desalinhamento no interior da esquerda, a separação entre a "velha" esquerda, alinhada do Partido Comunista Soviético e com força política entre as lideranças sindicais, de uma "nova esquerda", mais voltada às novas experiências no campo da política ${ }^{7}$, fator significativo que demarcará novas sensibilidades e caminhos a serem trilhados.

Com origem oficial nos Estados Unidos, a partir dos movimentos de luta por direitos civis, a New Left conseguiu um significativo apoio de vários setores civis e políticos, principalmente por conta dos Black Panthers, ou pela solidariedade com o Vietnã e contra o imperialismo norte-americano, ou mesmo no sentido da consolidação dos direitos civis, ampliando a noção de esquerda anteriormente utilizada. O marco de surgimento europeu, os manifestos de 1968, apresentaram várias similitudes com as ideias norte-americanas, em especial, a crítica à sociedade de consumo e o deslocamento dos sujeitos tradicionais ou a busca da concretude dos novos sujeitos sociais que pudessem implementar um papel de constante mobilização política e, assim, dar rumos aos novos caminhos iniciados pela esquerda.

Para Marcuse (1981), esse movimento político havia surgido num momento de contrarrevolução e, principalmente, tendo como pano de fundo as transformações da sociedade unidimensional, que deslocariam a participação da classe trabalhadora no movimento político, para a participação de outros grupos que até então não estariam contemplados nas mobilizações da esquerda mundial. Nesse sentido, a nova esquerda buscaria apreender as transformações culturais que estavam ocorrendo, porém enfatizaria as suas mobilizações políticas em torno dos intelectuais e não em torno da classe trabalhadora, o que resultaria num isolamento, mas também num projeto de negação da cultura do capitalismo avançado. A centralidade dessa nova esquerda, ao contrário dos antigos setores, seria cultural e não econômico-política.

O movimento da New Left surge através da Grande Recusa, uma visão qualitativamente diferente da sociedade, criando, por um lado, a possibilidade de observar o movimento através da solidariedade internacional, porém, por outro, responsável por desconectar as lutas sociais de seu todo (KATSIAFICAS, 1987). Uma definição apropriada sobre esse movimento político teria que levar em conta os "grupos políticos que estão situados à

7 Num registro bastante amplo, a nova esquerda na Europa se demarcou principalmente a partir do Maio Francês, quando, nas manifestações de 13 de maio uniram Georges Seguy, chefe da CGT francesa e o líder estudantil Daniel Cohn-Bendit, que representavam, unidos, a velha e a nova esquerda francesa.

\begin{tabular}{|c|c|c|c|c|}
\hline Rovita Dideotus & Ano 8 & n. 14 & Janeiro - Julho 2019 & p. $52-69$ \\
\hline
\end{tabular}


esquerda dos tradicionais partidos comunistas; eles não possuem ainda uma nova forma de organização, estão sem uma base e estão isolados da classe trabalhadora" (MARCUSE, 2005, p. 183). Os interesses políticos desses grupos permeiam o antiautoritarismo e a redefinição do conceito de revolução, trazendo para a discussão novas formas de liberdade e potencialidades para a superação do capitalismo avançado, com mudanças significativas na economia política, nos modos de produção, nas instituições, e, as novas necessidades e seu preenchimento. Ainda de início restritos aos Estados Unidos, alimentava-se a esperança de que esses movimentos congregavam em seu interior visões que pudessem colocar em xeque tanto o capitalismo unidimensional como o aparato burocrático soviético, denunciando a forma pela qual esses sistemas estariam se impondo, através da forte dominação autoritária. A viragem mostra-se como uma revolução cultural:

O movimento tomou a forma, então, de uma revolução cultural, desde o começo; ele concebeu a revolução do Século XX, como aquela em que, não só as demandas políticas e econômicas, mas também radicalmente outros desejos e esperanças seriam articulados: o desejo para um novo senso moral, para um ambiente mais humano, para uma completa "emancipação dos sentidos" (Marx), em outras palavras, uma libertação dos sentidos desde a compulsão para perceber as pessoas e as coisas apenas como objetos de troca. "Poder para a imaginação!" A New Left estava preocupado com a emancipação da imaginação das restrições da razão instrumental. Ao contrário de uma aliança entre realismo e conformismo, as forças da New Left criaram o slogan: "seja realista, peça o impossível". Isso é o que a forte componente estética do movimento originou: a arte foi vista como uma força produtiva emancipatória, como as experiências de outra (e imediatamente reprimida) realidade (MARCUSE, 2005, p. 184).

A contradição entre a realidade e o impossível faria com que se assumisse uma postura oscilante, entre o realismo, a estética e a utopia. Outrossim, a base cultural estabelecida veio a reduzir as determinações econômico-políticas em termos de aspectos culturais. Porém, novamente aqui entra o problema de tomar a emancipação apenas pela estética, de forma a não perceber as restrições tangentes. Se a New Left pudesse ser reduzida ao ponto que Marcuse a entende, então sua forma de ação estaria restrita aos países centrais, pois a dimensão artística desenvolvida, o discurso da Modernidade Cultural, seria o próprio fator ideológico de consolidação epistemológica e de imposição cultural. Mas, não é se voltando ao caminho ontológico de Marx que Marcuse consegue a resolução desse impasse, mas sim, entendendo que a New Left precisaria encontrar o seu sujeito social - e, nesse sentido, sua teoria parece se valer de um apriorismo da "imaginação" sobre a prática, conforme os sujeitos já previamente idealizados necessitariam apenas de ser encontrados. A preocupação com os excluídos, com os "outros", teria o intuito de compreender esses "novos sujeitos" que, através das lutas sociais, se articulariam contra

\begin{tabular}{|l|c|c|c|c|}
\hline Govista Dialectus & Ano 8 & n. 14 & Janeiro - Julho 2019 & p. 52 - 69 \\
\hline
\end{tabular}


o sistema capitalista, sobretudo, fora do espaço dos países centrais. O caminho da imaginação transcenderia as fronteiras políticas e sociais, no sentido de reestabelecer a utopia das reais possibilidades revolucionárias desse período. Se deveria levar em consideração, como afirma Marcuse (2005), que a noção de revolução empregada foi diferente daquela de décadas anteriores, por se basear na preocupação com o "Terceiro Mundo", por se basear no comunitarismo, na autonomia e na liberdade individual, e, por almejar uma sociedade internacional descentralizada das instituições políticas e econômicas e procurando novas formas de harmonia com a natureza, disposta através de um amálgama cultural, que uniria esses fatores. Em grande medida, isso congregou muitas das aspirações sociais em voga naquele momento, por se apoiar em valores de solidariedade internacional, inter-racial e na rejeição de valores da classe média (como acumulação de riqueza e poder) e, principalmente, por tentar reconstruir a vida cotidiana, através de uma maior sensibilidade cognitiva.

Porém, a grande contradição existente não foi absorvida pela teoria. No Sul global, o que estava sendo articulado era uma forma de revolução contra o imperialismo, e, portanto, concernente à exploração econômica das grandes potências. A ressonância do pensamento de Lênin sobre o imperialismo, que considerava-o não apenas como "etapa superior do capitalismo", mas sim, como fator que não poderia ser combatido unitariamente, sem referência ao desenvolvimento histórico e dialético do capitalismo, pois a dependência entre os Estados levaria a uma fase de desenvolvimento desigual e combinado, juntamente com os antagonismos imperialistas e as lutas pelo domínio colonial (BAMBIRRA \& SANTOS, 1980; LENIN, 2011). Essa perspectiva ficou bastante clara nas considerações de Che Guevara no encontro da I Conferência da Organização de Solidariedade dos Povos de África, Ásia e América Latina (OLAS), a chamada Tricontinental, ocorrida em 1966 em Havana, quando o líder revolucionário latino-americano evocou a união dos povos dos três continentes contra o imperialismo, evidenciando os vários tipos de imperialismo que incidiam sobre esses continentes, as lutas armadas dos povos locais, valorizando as lutas que colocassem em xeque "todo o aparato imperialista" (GUEVARA, 1966). Os movimentos anticoloniais de libertação nacional evidenciariam as lutas pela gradual libertação dos povos, mas apenas um movimento forte, contra o domínio imperialista dos Estados Unidos poderia ser vitorioso, porque atacaria o cerne político econômico dos problemas do capitalismo daquele momento. Sumariamente, por mais que esse movimento terceiro-mundista estivesse se

\begin{tabular}{|l|c|c|c|c|}
\cline { 2 - 4 } & Ano 8 & n. 14 & Janeiro - Julho 2019 & p. 52-69 \\
\hline
\end{tabular}


organizando, ele compunha uma demanda cuja sensibilidade para uma solidariedade internacional não o alcançaria. A New Left, em sua perspectiva europeia e norteamericana, se definia pela solidariedade internacional, pela perspectiva dos novos sujeitos, pela ruptura com o comunismo soviético e pela crítica ao capitalismo, que se aproximava da crítica de Marcuse à sociedade unidimensional. Questões como o autogoverno e a crítica à repressão no mundo capitalista, o encontro de novos agentes emancipadores e o enfoque da revolução cultural marcaram um efeito de contágio, o "eros effect", demarcando a existência de movimentos globais e quando "novas formas de poder emergiram em oposição à ordem estabelecida e novas visões do significado de liberdade foram formuladas na ação de milhões de pessoas" (KATSIAFICAS, 1987, p. 6). Marcuse teve algum sucesso em trilhar esse caminho, pois a percepção dos empecilhos alienantes do cotidiano, as chamadas mediações ou a denominada sociedade unidimensional, apesar de não terem sido suficientemente abordadas por Marcuse, compuseram, em larga escala, as críticas dos movimentos sociais. No sentido marcusiano, a New Left proporia uma nova cognição epistêmica da sociedade - especialmente, do indivíduo - sobre o mundo, mas não uma saída emancipatória ontológica.

\section{Conclusão}

50 anos depois de 1968 a perda de interesse pela cultura socialista e revolucionária atingiu também a obra de Herbert Marcuse, um dos autores mais lidos em todo o mundo, no final dos anos 60, inclusive no Brasil. Esse esquecimento não parece acidental, especialmente no período em que o pensamento único imposto pelo conservadorismo neoliberal alcançava uma dimensão hegemônica. A sua crítica coloca em xeque a produtividade, valor supremo em nossos tempos de mundialização do capital.

Este esquecimento talvez se explique também pela peculiaridade do espaço ocupado por Marcuse na Escola de Frankfurt, sendo ele um dos únicos integrantes do grupo a levar adiante o projeto da teoria crítica dos anos 30, visando politizar sua teoria e ligar a teoria à prática. Em contraste, Horkheimer e Adorno, abandonam a política radical dos anos 40 e procuram encobrir as raízes marxistas do Instituto, no contexto da Guerra Fria, barrando os projetos considerados políticos e marxistas demais. Podemos identificar estas divergências entre Adorno e Marcuse durante as rebeliões estudantis de 68, momento em que, para este último, a teoria tinha que se politizar através do apoio inequívoco ao ME,

\begin{tabular}{|l|c|c|c|c|}
\cline { 2 - 4 } & Ano 8 & n. 14 & Janeiro - Julho 2019 & p. 52 - 69 \\
\hline
\end{tabular}


à luta pela libertação dos países neo-coloniais e do combate ao imperialismo americano, sobretudo no Vietnã. Já Adorno, identificando traços fascistas no protesto dos estudantes na Alemanha que ocupam o Instituto, chega a chamar a polícia, para dispersá-los. Marcuse, ao contrário, afirma serem os estudantes cada vez mais importantes no processo de produção e, portanto, fazendo realmente parte da vanguarda de uma luta emancipatória, acreditando, ao mesmo tempo, dentro do horizonte teórico marxista, que a revolta tem sua principal origem na exploração econômica sofrida pelas classes trabalhadoras.

Vivenciamos, hoje, a situação de um capitalismo reforçado que conta com a China e a extinta URSS como mercados. A mundialização do capitalismo consolida-se através da exclusão violenta das grandes maiorias pobres da terra neste início de século. Acreditamos que recuperar a tradição hegeliano-marxista e a sua atualização constante, como faz Marcuse, é uma forma de manter vivo o debate acadêmico na contracorrente do neoliberalismo.

A adesão de Marcuse aos movimentos de protesto nos anos 60 e à necessidade da violência revolucionária para a transformação da ordem vigente, permite que a solução da questão social continue no centro do debate político através da abordagem dos dilemas da paralisia da crítica, da reconciliação da oposição, da derrota lógica do protesto, da contenção da transformação social, da integração da classe trabalhadora. Mesmo prevendo a iminência do mundo se tornar o material amorfo da administração total, continua envolvido com a retomada das teorias anticapitalistas do século XIX e de sua atualização para, não apenas, acreditamos, entender o contexto social, mas principalmente verificar se esta análise lhe permite continuar vislumbrando um futuro outro.

\section{Referências:}

ADORNO, Theodor e MARCUSE, Herbert. "As últimas cartas”. In: Revista Praga estudos marxistas, 3. São Paulo: Hucitec, 1997.

BAMBIRRA, Vania. SANTOS, Teotonio. dos. La estrategia y la táctica socialistas de Marx y Engels a Lenin (Vol. Tomo I). México D.F.: Ediciones Era, 1980.

BROWN, Thomas. "1968" east and west: divided Germany as a case study in transnational history. The american historical review, 114, 69-96, 2009.

\begin{tabular}{|l|c|c|c|c|}
\cline { 2 - 4 } Q Q Dialectus & Ano 8 & n. 14 & Janeiro - Julho 2019 & p. 52-69 \\
\hline
\end{tabular}


DEUTSCHER, Isaac. "Sobre o conflito judeu-árabe" - entrevista à new left review. in Teoria e prática, $n^{\circ} 3,1968$.

ELEY, Geoff. Forjando a democracia: a história da esquerda na Europa, 1850-2000. São Paulo: Editora Fundação Perseu Abramo, 2000.

GITLIN, Todd. The sixties - years of hope, days of rage. The New York times book review. USA: Bantam Books, 1993.

GROPPO, Luís Antônio. Uma onda mundial de revoltas: movimentos estudantis de 1968. Piracicaba: Editora UNIMEP, 2005.

GUEVARA, Ernesto. "Mensagem aos povos do mundo através da tricontinental". In: LOWY, Michel. O Marxismo na América Latina: uma antologia de 1909 aos dias atuais (pp. 285-288). São Paulo: Perseu Abramo, 2000.

HARMAN, Chris. The fire last time: 1968 and after. London: Bookmarks, 1998.

ISSERMAN, Maurice e KAZIN, Michael. America divided - The civil war of the 1960s. New York: Oxford, 2000.

ISSERMAN, Maurice. If I had a hammer - The death of the old left and the bird of the new left. New York: Illini Books, 1993.

KATSIAFICAS, Geoff. The Imagination of the new left: a global analysis of 1968. Cambridge: South End Press, 1987.

The subversion of politics: European autonomous social movements and the decolonization of everydat life. Edinbourg: AK Press, 2006.

KELLNER, Douglas. Herbert Marcuse and the crisis of marxism. Berkeley-Los Angeles: University of California Press, 1984.

LENIN, Vladmir. I. O Imperialismo, etapa superior do capitalismo. Campinas: Navegando Publicações, 2011.

LOUREIRO, Isabel (org.). Herbert Marcuse - a grande recusa hoje. Petrópolis: Vozes, 1999.

MARCUSE, Herbert. Eros e civilização - uma interpretação filosófica do pensamento de Freud. Guanabara: Koogan, $8^{\mathrm{a}}$ edição, sem data.

"Finalidades, formas e perspectivas da oposição estudantil nos Estados Unidos". In.: Revista civilização brasileira, Ano IV - nos. 21 e 22 - setembro/dezembro de 1968.

O fim da utopia. Rio de Janeiro, Paz e Terra, 1969.

A ideologia da sociedade industrial. Rio de Janeiro, Zahar editores, 1978.

\begin{tabular}{|l|c|c|c|c|}
\cline { 2 - 4 } & Ano 8 & n. 14 & Janeiro - Julho 2019 & p. 52-69 \\
\hline
\end{tabular}


Contra-revolução e revolta. Rio de Janeiro: Zahar, 1981.

- Perspectivas do Socialismo na Sociedade Industrial Avançada - Uma Contribuição ao Debate”. In.: LOUREIRO, Isabel. Herbert Marcuse - a grande recusa hoje. Petrópolis: Vozes, 1999.

The new left and the 1960s. Abingdon: Routledge, 2005.

MARTINS FILHO, João Roberto. Movimento estudantil e a ditadura militar: 19641968. Campinas, Papirus, 1987.

MCCARTHY, Eugene J. A militarização da América. In.: Revista civilização brasileira, Ano IV, $\mathrm{n}^{\circ} 21$ e 22 - setembro - dezembro, 1968.

MILLER, James. Democracy is in the streets. New York: Simon and Schuster, 1987.

PETRAS, James. República Dominicana: revolução e restauração. In: Teoria e prática, $\mathrm{n}^{\circ} 1,1967$.

REIS FILHO, Daniel Aarão. MORAES, Pedro. 1968, a paixão de uma utopia. Rio de Janeiro: Fundação Getúlio Vargas, 1998, $2^{a}$ edição.

\begin{tabular}{|l|c|c|c|c|}
\cline { 2 - 4 } & Ano 8 & n. 14 & Janeiro - Julho 2019 & p. 52-69 \\
\hline
\end{tabular}




\title{
DA OBSOLETA CARÊNCIA DE DOMINAÇÃO A UM NOVO PRINCÍPIO DE REALIDADE SEGUNDO MARCUSE
}

\author{
Manoel Dionizio Neto ${ }^{1}$
}

\begin{abstract}
Resumo:
Tendo como referência fundamental Eros e Civilização, de Herbert Marcuse, busca-se a compreensão do exposto por Sigmund Freud a respeito das condições em que se deu a formação da cultura e o desenvolvimento da civilização a partir da interpretação marcusiana do pensamento de Freud. Valendo-se então do exposto por Marcuse em sua obra, procura-se a fundamentação para o que fora exposto sobre a substituição do Princípio de Prazer pelo Princípio de Realidade que, com o avanço da civilização, deu lugar ao Princípio de Desempenho. Considera-se para tanto a significação das camadas mentais, identificadas por Freud como Id, Ego e Superego, para a compreensão da repressão dos instintos vitais que tornou possível o Princípio de Realidade, assim como se fez possível o Princípio de Desempenho graças à mais-repressão segundo a interpretação de Marcuse. Partindose do entendimento de que a dominação se fez necessária para que houvesse a efetivação da repressão sexual entre os primórdios da humanidade, vale então refletir sobre a possibilidade de um novo Princípio de Realidade, quando não se tem mais a carência dessa dominação, considerando-se para isto o estágio de desenvolvimento da civilização em nossos dias.
\end{abstract}

Palavras-chave: Marcuse; Freud; Princípio de Realidade; Princípio do Prazer; Dominação.

\section{FROM THE OBSOLETE LACK OF DOMINATION TO A NEW REALITY PRINCIPLE ACCORDING TO MARCUSE}

\begin{abstract}
:
The fundamental reference work Eros and Civilization, by Herbert Marcuse, is taken to understand Sigmund Freud's comprehension about the conditions for cultural formation and for development of civilization, from Marcuse's interpretation on Freud's thoughts. Based on Marcuse's book, we seek the foundation for replacement of the Pleasure Principle by the Reality Principle, which, as civilization advances, gave way to the Performance Principle. Therefore, we consider the significance of the mental layers, identified by Freud as Id, Ego and Superego, for understanding the repression of vital instincts that made possible the Reality Principle, as well as made possible the Performance Principle, thanks to the surplus repression, according to Marcuse's interpretation. From the understanding that domination was necessary for sexual repression in the beginnings of humanity, it is worth reflecting on the possibility of a new Reality Principle, when there is no longer need of this domination, considering the stage of development of civilization in the present day.
\end{abstract}

Keywords: Marcuse; Freud; Reality Principle; Pleasure Principle; Domination.

1 Manoel Dionizio Neto - Graduado em Filosofia pela UFPE (Licenciatura e Bacharelado), Mestrado em Filosofia pela UFPB e Doutorado em Educação pela UFSCar, é Professor Associado IV na Unidade Acadêmica de Ciências Sociais do Centro de Formação de Professores da UFCG (Universidade Federal de Capina Grande). Atua como professor de Filosofia e tem como referência o pensamento de Rousseau e a Teoria Crítica, com ênfase em Marcuse, Adorno e Horkheimer, bem como o existencialismo e a fenomenologia, ressaltando-se Sartre e Merleau-Ponty. E-mail: dionizioneto@uol.com.br. 


\section{Introdução}

No "Prefácio" a Eros e civilização, em 1966, Herbert Marcuse manifesta sua inquietação em relação às mudanças dos costumes requeridas por Wilhelm Reich em sua obra Revolução sexual. Mesmo não se tratando da efetivação desta revolução, vislumbrava-se muito com essas mudanças as projeções do próprio Marcuse que via a possibilidade do ser humano lidar de forma diferenciada com a gratificação do prazer inviabilizada pela histórica repressão sexual. Mas, ao prefaciar sua obra, Marcuse demonstra sua decepção: os avanços da sociedade industrial não conduziram o progresso para a reversão esperada na década de 1950, assim como não rompera a união entre produção e destruição nem a relação entre liberdade e repressão. Conforme as suas próprias palavras, não levou o homem "a aprender a gaya sciencia de como usar a riqueza social para moldar o mundo do homem de acordo com os seus Instintos Vitais, na luta combinada contra os provisores da Morte" (MARCUSE, 1981, p. 13).

Partindo desse desencanto com o otimismo com que escrevera a sua obra, refletimos sobre a carência de dominação que, segundo Marcuse, já se encontrava obsoleta naquela época. Perguntamos, então, por essa "carência de dominação" vista como obsoleta, bem como sobre as condições para um novo princípio de realidade. Hoje, depois de todas as mudanças dos costumes ocorridas a partir dos anos de 1960, seria possível retomarmos àquele otimismo, mesmo tomando como base outros referenciais, depois da certificação de que os avanços da ciência e da tecnologia não contribuíram para o que fora esperado?

Fala-se muito numa pós-modernidade ou numa modernidade líquida, como o faz Zygmunt Bauman, para quem estamos em meio a fluidez de um mundo, onde tudo pode acontecer sem que se possa contar com a estabilidade de alguma coisa. Até é possível falar numa pós-orgia, como o faz Jean Baudrillard. E não podemos esquecer das diferentes possibilidades de amar referidas por Carl R. Rogers. Podemos então pensar numa nova civilização conforme a projeção de Alvin Toffler? Marcuse lembra do preço pago pelo povo para a aquisição da liberdade. Até se pode comparar ao preço referido por Rousseau ao falar da troca de uma felicidade real por uma tranquilidade imaginária. Trata-se, pois, segundo Marcuse, de considerar a dependência da sociedade afluente de uma ininterrupta produção e do consumo do supérfluo. É esta mesma sociedade, segundo ele, que depende igualmente dos novos inventos, acompanhados do "obsoletismo planejado e dos meios de destruição", quando se inventa tudo com vistas à curta duração que faz da produção coisa descartável. A essa

\begin{tabular}{|c|c|c|c|c|}
\cline { 2 - 4 } & Ano 8 & n. 14 & Janeiro - Julho 2019 & p. $70-90$ \\
\hline
\end{tabular}


sociedade, os indivíduos são obrigados a se adaptarem. Como então falar da superação do princípio de desempenho por um novo princípio de realidade?

Marcuse lembra também que não se trata de falar de libertação para quem é livre, assim como se deve falar de excessiva repressão sexual, quando homens e mulheres praticam sexo como nunca o fizeram. De fato: comparemos as condições em que se praticam sexo hoje com as que estavam postas na década de 1960. E o que dizer do que ocorriam nas décadas anteriores? Hoje, é cada vez mais comum a vida marital dos namorados, no âmbito da heterossexualidade ou não. Se ainda se defende a virgindade da mulher, ou que ela só pratique sexo depois do casamento, a virgindade não é mais obrigatória. $\mathrm{O}$ mesmo se pode dizer em termos de vestuário: homens e mulheres se vestem como querem, com o mínimo de roupa possível, sem obstáculos às transparências ou sensualidade no modo de vestir. Seria, então, que já contamos com o novo princípio de realidade referido por Marcuse?

A resposta à pergunta acima nos remete à significação da dominação em nossos dias, e não podemos refletir sobre um novo princípio de realidade sem trazer para a reflexão o significado da carência de dominação. Por isso retomamos ao sentido da repressão como condição para a civilização, conforme o entendimento de Freud, e à passagem da repressão a uma mais-repressão como passagem ao princípio de desempenho.

Da repressão como condição à civilização à mais-repressão como condição ao princípio de desempenho.

\section{Da repressão como condição à civilização à mais-repressão}

Herbert Marcuse volta-se para o significado da repressão, quando invoca o pensamento de Freud para falar do ser humano como um ser historicamente reprimido. Pois ele chama a atenção para a conclusão a que chegara Freud ao falar da história do homem que, segundo ele, confunde-se com a história de sua repressão. Neste sentido, pode-se falar de uma coação da cultura, tanto em relação à existência social como em relação à existência biológica do ser humano. Pois, graças a essa coação, o progresso se faz possível, tornando-se assim viável a civilização. Isto é o mesmo que falar da incompatibilidade entre a liberação dos instintos básicos do homem e as possíveis associações humanas e a sua durabilidade. Ou seja, não se poderia falar de relações duradoras dos seres humanos, se eles se estivessem em plena liberdade sexual. A libertação dos instintos básicos, necessária para as livres relações sexuais, destruiria tudo que dissesse respeito à união, assim como destruiria tudo que pudesse fazer a comunhão

\begin{tabular}{|l|c|c|c|c|}
\cline { 2 - 5 } & Ano 8 & n. 14 & Janeiro - Julho 2019 & p. $70-90$ \\
\hline
\end{tabular}


deles. Ou seja, como diz Marcuse (1981, p. 33): “O Eros incontrolado é tão funesto quanto a sua réplica fatal, o instinto de morte". Por que, então, falar desse caráter destruidor, que pode ser visto no próprio Eros, se deixá-lo fora de controle? Segundo Marcuse, para Freud, ocorreria o seguinte: "Sua força destrutiva deriva do fato deles lutarem por uma gratificação que a cultura não pode consentir: a gratificação como tal e como um fim em si mesma, a qualquer momento" (Ibidem). Isto significa que Eros deve ser desviado dos seus objetivos, assim como se faz necessário inibi-lo em relação aos seus anseios. Pois, afinal, é preciso ter sempre em vista à civilização como algo imprescindível ao homem. E esta civilização não seria possível sem a repressão desses instintos básicos, ou seja, sem que Eros fosse reprimido: "A civilização começa quando o objetivo primário - isto é, a satisfação integral de necessidades - é abandonado" (Ibidem).

Fica assim claro que, para Freud, não seria possível a civilização sem a repressão. E não era disto que falava Thomaz Hobbes quando fez referência a um contrato entre os homens que garantisse a continuidade da vida e, portanto, da sociedade humana devidamente organizada, submetendo-se todos à vontade de um só? Afinal se tratava da eleição de um príncipe que pudesse garantir a segurança de todos. Mas, a que preço? O preço não seria assim a repressão necessária, para que todos se submetessem às determinações de um senhor? Assim, diferentes teorias, e mais ainda as intervenções das diferentes religiões ou dos diferentes modos de governo, têm apontado para a necessidade de controle do comportamento humano, evitando-se a manifestação da sexualidade como modo de aprisionamento de Eros, isto é, desses instintos básicos a que se reporta Marcuse ao trazer o pensamento de Freud para a sua interpretação. Falar desse aprisionamento dos instintos básicos é, na verdade, falar da repressão, e esta repressão, mesmo que inicialmente possa ser manifesta com seu caráter político, acaba esbarrando na repressão sexual propriamente dita. Mas, o que isto significa? O que nos permite falar dessa repressão sexual? Creio que Marilena Chaui (1984, p. 77) sintetiza muito bem o que se pode entender por isso:

De modo geral, entende-se por repressão sexual o sistema de normas, regras, leis e valores explícitos que uma sociedade estabelece no tocante a permissões e proibições nas práticas sexuais genitais (mesmo porque um dos aspectos profundos da repressão está justamente em não admitir a sexualidade infantil e não genital). Essas regras, normas, leis e valores são definidos explicitamente pela religião, pela moral, pelo direito e, no caso de nossa sociedade, pela ciência também.

\begin{tabular}{|c|c|c|c|c|}
\cline { 2 - 4 } & Ano 8 & n. 14 & Janeiro - Julho 2019 & p. $70-90$ \\
\hline
\end{tabular}


Como se faz, na prática, a aplicação desse sistema de normas, regras, leis e valores? Muitas vezes nos modos mais sutis pelos quais operam as instituições, no âmbito religioso e político, mas também em nome da ciência. E quando nos voltamos para o pensamento de Freud para compreender relação que, segundo ele, se dá necessariamente entre repressão e o progresso da civilização, precisamos considerar o que poderia ocorrer se os instintos básicos fossem completamente liberados. Pense-se naquela criança que tudo quer, e que, se ficar completamente livre para fazer o que quiser, não consciente do que possa acontecer posteriormente, destrua o que lhe for acessível, movida pela simples curiosidade ou o desejo de experienciar aquele momento numa relação específica com certos objetos desejados. Ressaltese aqui a não-consciência dos seus atos, isto é, não ter consciência do significado das suas ações. Essa criança não contribuiria de forma alguma para a permanência de um mundo já estabelecido, e muito menos para o progresso do que já estivesse devidamente produzido e, portanto, organizado. É nestes termos que pensamos o entendimento de Freud ao considerar a necessidade da repressão, como controle do egoísmo humano, pois, impulsionado por este, pensando somente na satisfação dos seus desejos, o homem destrói sem jamais contribuir para a estabilidade e muito menos para o progresso. É o que poderia ocorrer, por esse entendimento, se os homens se deixassem levar pelos seus desejos, o que significaria dizer se deixarem conduzir pela força do $I d$, isto é, pelo impulso do inconsciente. Isto significaria a liberação absoluta de Eros, que, descontrolado, acabaria conduzindo o ser humano para a sua própria destruição. Neste sentido, o princípio de vida acabaria se confundido com o princípio de morte. Para evitar esse descontrole de Eros, os homens apelaram para as diferentes possibilidades de repressão, formulando, inclusive, um sistema de normas, de leis e de valores que pudesse ser tomado como referência para a justificação dos seus atos repressivos. Ou como se tivesse algo a recorrer para convencer a criança a não destruir seus brinquedos, ou as coisas com que lidasse, visando apenas a satisfação dos seus instintos, como pura gratificação.

Para o estabelecimento dessas normas e dessas leis, criaram-se os mitos e as religiões, para difundirem valores, sustentados por dogmas, tabus e preconceitos. Mas não sendo isto suficiente, instituíram o Estado, bem como a Filosofia e a Ciência como meios de convencimento dos homens para a repressão dos seus instintos básicos, seja evitando a pura e simples manifestação deles, ou canalizando toda sua expressão para outros fins, como por exemplo, a estabilidade das relações sexuais com a instituição do casamento ou a necessidade de trabalhar para a garantia de subsistência e existência no mundo. Sendo, para isso, imprescindível a saúde do corpo e da alma, não teríamos como negar a relevância da

\begin{tabular}{|c|c|c|c|c|}
\cline { 2 - 4 } Q Revista Dialectus & Ano 8 & n. 14 & Janeiro - Julho 2019 & p. 70 - 90 \\
\hline
\end{tabular}


interpretação de mundo pela Filosofia e explicação e controle da natureza sob a orientação científica. Nisto, podemos dizer, fundamenta-se o entendimento de que a repressão, se não é louvável, certamente é indispensável para a continuidade da espécie humana e progresso de suas realizações, configuradas no advento e progresso da civilização. Com outras palavras, não seria possível sem o trabalho e o esforço para o controle dos impulsos vitais próprios do homem. Isto significa dizer, seguindo a interpretação de Marcuse, que os instintos animais forma convertidos em instintos humanos para que se viabilizasse o mundo da cultura à medida em que os homens se orientassem pelas determinações que lhe fossem exteriores. Ou seja: "O homem animal converte-se em ser humano somente através de uma transformação fundamental da sua natureza, afetando não só os anseios instintivos, mas também os 'valores' instintivos - isto é, os princípios que governam a consecução dos anseios" (MARCUSE, 1981, p. 34).

$\mathrm{O}$ advento desses princípios e a sua efetivação nas relações dos homens entre si e com a natureza, não seria possível sem o estabelecimento da dominação de uns homens pelos outros, ficando sua maioria, ou mesmo sua totalidade, sob o comando de um ou de uns poucos, que passaram a governar em nome do interesse de todos, mesmo quando, ao invés disso, governaram em função dos seus próprios interesses. Criou-se assim um sistema de dominação para a administração dos desejos humanos, evitando-se a sua plena gratificação, ao serem canalizados para os fins reconhecidos e aceitos pelo sistema dominante. Com isso se deu a passagem do princípio de prazer, que tem por fim a plena satisfação dos desejos, para o princípio de realidade, que visa o aprimoramento da civilização submetendo os desejos humanos às determinações de uma razão que ordena, deliberando sobre o que deve ou não ser permitido para a manutenção da ordem o do progresso. Assim sendo, esse sistema de dominação, ao eleger valores que pudessem ser requeridos para um bem-estar humano, fez-se também sistema de valores, segundo Marcuse, passando por uma transformação que se configurou da seguinte forma:

1. Da satisfação imediata passou para a satisfação adiada;

2. Do prazer passou para a restrição do prazer;

3. Do júbilo, enquanto atividade lúdica, passou para o esforço, que se tem como trabalho;

4. Da receptividade passou para a produtividade;

5. Da ausência de repressão passou para a segurança.

\begin{tabular}{|l|c|c|c|c|}
\cline { 2 - 4 } & Ano 8 & n. 14 & Janeiro - Julho 2019 & p. $70-90$ \\
\hline
\end{tabular}


Partindo desse entendimento, Marcuse diz que a transformação do sistema de valores culminou, segundo Freud, na transformação do princípio de prazer em princípio de realidade. Assim sendo, a luta do inconsciente, constituída pelos mais remotos processos mentais, inicialmente, dá-se pela obtenção do prazer, mas retrai-se, segundo Freud, como atividade mental para evitar qualquer operação que possa dar origem à dor, enquanto sensação de desprazer. Mas esta atividade mental, como expressão do princípio de prazer, entra em conflito com a realidade natural e humana. Com isso se dá a experiência traumática do indivíduo que passa a compreender a impossibilidade de "uma plena e indolor gratificação de suas necessidades", tornando-se assim uma "experiência de desapontamento". Depois disso, diz Marcuse (1981, p. 34): "um novo princípio de funcionamento mental ganha ascendência". Daí a seguinte reflexão: “O princípio de realidade supera o princípio de prazer: o homem aprende a renunciar ao prazer momentâneo, incerto e destrutivo, substituindo-o pelo prazer adiado, restringido, mas 'garantido"' (Ibidem, p. 35). Isso significa que o prazer, que poderia culminar em destruição por se tratar de um prazer momentâneo, não deixa de ser possível, porque foi apenas adiado e restringido, mas não destruído. Com isso, observa Marcuse, a transformação do princípio de prazer em princípio de realidade é uma conquista, porque é um "ganho duradouro", alcançado pela renúncia e restrição", o que significa dizer, de acordo com Freud, que ele não destrona o princípio de prazer, que é salvaguardado, mas apenas o modificado.

Assim, Freud nos diz, primeiro, que a civilização não seria possível sem a transformação do princípio de prazer em princípio de realidade; segundo, que essa transformação fora uma conquista da humanidade. Por outro lado, deixa entrever a possibilidade de manifestação do princípio de prazer, o que significa que ele continua presente, porém modificado, ou seja, adiado. Portanto, pergunta-se por que a humanidade não avançou em direção à plena libertação dos seus instintos básicos, em meio à cultura previamente firmada pela restrição do prazer como manifestação da repressão necessária ao advento e manutenção da civilização. E próprio Freud afirma que a história da humanidade é a história de sua repressão, ou seja, até hoje, não houve saída à sua plena gratificação.

Acompanhando a lógica da repressão, melhor compreendida a partir da exposição das camadas mentais identificadas pelo Id, o Ego e o Superego, somos levados por Marcuse a nos deparar com a transformação da repressão em mais-repressão. Já não se trata mais da necessidade de repressão como restrição ao prazer como vistas ao que se deve dispor dos princípios vitais para a produção da cultura. Não bastaria o homem ser reprimido sob a

\begin{tabular}{|l|l|l|l|l|}
\hline Qevista Qialectus & Ano 8 & n. 14 & Janeiro - Julho 2019 & p. $70-90$ \\
\hline
\end{tabular}


orientação para o trabalho necessário a essa produção. Fez-se também necessário o trabalho, fonte de acumulação de riqueza por parte de quem detivesse o comando para a exploração.

Compreende-se assim a transição do princípio de prazer para o princípio de realidade considerando-se a luta entre os instintos vitais, representados por Eros, e os instintos de morte, representados por Thanatos. Marcuse chama a atenção para a evolução do pensamento de Freud, quando deixa de pensar Eros apenas como um grupo de instintos sexuais em sua relação com o princípio de autopreservação, que, então, era concebido como um grupo de instintos de ego para pensá-lo a partir das camadas mentais, estando nela o Id como a camada fundamental e mais antiga como domínio do inconsciente, isto é, como domínio dos instintos primários. Ou seja, segundo Freud, o homem estava livre das formas e dos princípios constituintes do indivíduo que, além de consciente de si mesmo, era um ser social. Então, como estaria o Id e quais os seus fins? Responde Marcuse (1981, p. 47): "Não é afetado pelo tempo nem perturbado por contradições; ignora 'valores, bem e mal, moralidade'. Não visa à autopreservação: esforçase unicamente pela satisfação de suas necessidades instintivas, de acordo com o princípio de prazer". Assim sendo, o ego deixa de ser compreendido apenas como princípio de autopreservação, passando a ser concebido como parte do Id convertida em mediador entre o próprio $I d$ e o mundo que lhe é exterior, onde se encontram os valores que nos levam à compreensão do bem e do mal, permitindo-nos assim falar de moralidade, com bem expressam as palavras de Marcuse (Ibidem): "Sob a influência do mundo externo (o meio), uma parte do id, a que está equipada com os órgãos para a recepção e proteção contra os estímulos, desenvolve-se gradualmente até formar o ego. É ‘o mediador' entre o id e o mundo externo”.

O princípio de realidade se firma a partir do momento em que essa mediação entre o Id e o mundo exterior se faz pelo Ego através da introjeção desse mundo representada pelo Superego, compreendido como representação da sociedade no indivíduo. Ou seja: "No curso do desenvolvimento do ego, outra 'entidade' mental surge: o Superego. Tem origem na prolongada dependência da criança de tenra idade, em relação aos pais; a influência parental converte-se no núcleo permanente do superego" (MARCUSE, 1981, p. 48-49). Assim, o Ego, fazendo-se princípio de autopreservação do indivíduo, destrona o princípio de prazer que é por ele convertido em princípio de realidade. E isto significa que é graças à repressão dos instintos sexuais promovida pelo Ego que se estabelece o princípio de realidade. Todavia, a excessiva imposição do Superego, que consiste na imposição das exigências do presente e do pretérito, faz, por sua vez, a transformação da repressão em mais-repressão, que dá origem a excessiva necessidade de trabalho, que passa do que seria necessário para a produção da cultura para o

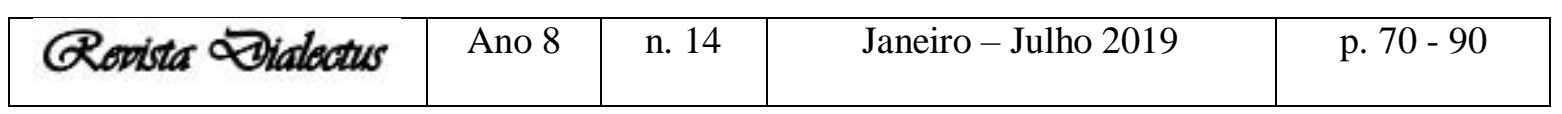


que se faz necessário como acumulação de riqueza. Isto só se faz possível pela exploração fundamentada no princípio de desempenho.

\section{Da carência de dominação ao princípio de desempenho}

Partindo-se do que disse Freud sobre a repressão dos instintos vitais, certificamo-nos de que foi preciso submeter Eros ao princípio de realidade para que se fizesse possível a civilização. Assim compreende-se por que, segundo ele, a história humana começou com a efetiva subjugação dos instintos à dominação do pai primordial, aquele que, na horda primordial, monopolizou o poder e o prazer, impondo aos seus filhos a renúncia, tendo eles que se dedicar ao trabalho, deixando todas as mulheres da horda para o pai, que passou a ser compreendido como arquétipo de dominação. Pois, segundo Freud, o primeiro grupo humano se estabeleceu e se manteve "pelo domínio imposto de um indivíduo sobre os outros". A respeito disto, Marcuse observa o seguinte: "Num dado momento da vida do gênero homem, a vida grupal foi organizada por dominação". Ou seja, "o homem que conseguiu dominar os outros era o pai, quer dizer, o homem que possuía as mulheres desejadas e que, com elas, gerara e conservara vivos os filhos e filhas". Daí se conclui que "O pai monopolizou para si próprio a mulher (o prazer supremo) e subjugou os outros membros da horda ao seu poder" (MARCUSE, 1981, p. 70).

Conforme dissemos acima, de acordo com o entendimento de Freud, essa dominação se fez necessária para que houvesse o advento e o desenvolvimento da civilização. Mas era preciso a ser sentida por todos nós, enquanto filhos desse "pai primordial". Por isso, os filhos se rebelaram contra ele, matando-o e devorando-o. Isto é, fez-se também necessária a morte do pai, para que ele pudesse ressuscitar na forma de sentimento de culpa expressa pelo Superego. Isso explica a luta que, segundo Freud, "é travada e decidida na luta dos instintos - literalmente, uma luta de vida ou morte - em que o soma e a psique, a natureza e a civilização participam" (MARCUSE, 1981, p. 41). Essa luta, por sua vez, expressa a substituição do princípio de prazer pelo princípio de realidade, configurando-se como o "acontecimento traumático no desenvolvimento no homem", visto tanto no âmbito do gênero (filogênese) como no âmbito individual (ontogênese) (Ibidem, p. 36). Esse "acontecimento traumático" diz muito bem o que aconteceu com a transformação do princípio de prazer em princípio de realidade: os desejos do homem, bem como a alteração da realidade que poderia se dar em função desses desejos, deixaram de pertencer ao próprio sujeito. A partir dessa transformação, os desejos do homem e

\begin{tabular}{|c|c|c|c|c|}
\hline Qovista Dialectus & Ano 8 & n. 14 & Janeiro - Julho 2019 & p. $70-90$ \\
\hline
\end{tabular}


a alteração da realidade 'passam a ser 'organizados' pela sociedade. E essa 'organização' reprime e transubstancia as suas necessidades instintivas originais". Assim sendo, diz Marcuse (Ibidem, p. 36), "Se a ausência de repressão é o arquétipo de liberdade, então a civilização é a luta contra essa liberdade".

Essa luta da civilização contra a liberdade se faz notar no indivíduo recalcado, que guarda consigo o "sentimento de culpa" em relação à morte do pai primordial, razão pela qual é a ele atribuído um papel decisivo no desenvolvimento da civilização, conforme o entendimento de Freud, que "estabelece uma correlação entre progresso e um crescente sentimento de culpa" (MARCUSE, 1981, p. 83). Assim sendo, para se compreender o desenvolvimento da civilização em seu presente, faz-se necessário conhecer o seu passado. E esse passado se faz conhecido à medida em que somos capazes de relacionar a nossa autorrepressão com o assassinato do pai primordial pelo conluio dos seus filhos, em que se fundamenta o “complexo de Édipo. Com outras palavras, diz Marcuse (Ibidem, p. 83-84):

\begin{abstract}
Recapitulamos sucintamente a pré-história do sentimento de culpa; tem sua "origem no complexo de Édipo e foi contraído quando o pai foi assassinado pelo conluio dos irmãos" [Freud]. Estes satisfizeram seu instinto agressivo; mas o amor que tinham pelo pai causou-lhes remorso, criou-lhes o superego por identificação e, portanto, gerou as "restrições que impediriam a repetição do feito" [Freud]. Subsequientemente, o homem abstém-se do feito; mas, de geração para geração, o impulso agressivo revive, dirigido contra o pai e seus sucessores, e, de geração para geração, a agressão tem de ser inibida de novo [...].
\end{abstract}

Assim, na história da civilização, encontramos as diferentes formas pelas quais se faz a repressão dos instintos vitais como se fosse resposta a uma necessidade de dominação que passou a ser sentida como sentimento de culpa, que se tornara possível graças à ambivalência do amor e ódio: a revolta contra a dominação paternal se dava juntamente com o desejo de ocupar o lugar do pai, o que somente fora alcançado pelo filho mais novo, ao tempo em que o patriarcado fora substituído pelo matriarcado, que afastou a possibilidade de repressão promovida pelo domínio masculino representado pelos irmãos. Estes movidos pelo sentimento de culpa fizeram retornar essa dominação masculina, agora numa outra perspectiva, quando o domínio do pai primordial se fez sentir na dominação de cada um dos filhos. Ou seja, certificamo-nos pelas palavras do próprio Freud (apud MARCUSE, 1981, p. 73) de que "Uma boa parte do poder que ficara devoluto pela morte do pai passou para as mulheres; seguiu-se o período de matriarcado". Todavia, há de se considerar que a liberdade, que se tornara possível com a libertação da mulher, seguiu-se à dominação masculina, isto é, a reafirmação do

\begin{tabular}{|c|c|c|c|c|}
\cline { 2 - 4 } Q Q Onialectus & Ano 8 & n. 14 & Janeiro - Julho 2019 & p. 70 - 90 \\
\hline
\end{tabular}


patriarcado. Isto significa dizer que o matriarcado fora "substituído por uma contra-revolução patriarcal, e esta última é estabilizada mediante a institucionalização da religião" (MARCUSE, 1981, p. 73).

Mas não podemos ignorar a revolução social que ocorreu no período matriarcal. Segundo Freud, depois dessa revolução, a ordem patriarcal foi restaurada, sendo o pai primordial substituído pelos novos pais. No entanto, vale considerar que estes "nunca conseguiram atingir a onipotência do pai primevo. Havia muitos e viviam em comunidades maiores do que fora a horda original; tinham de entender-se mutuamente, conviver e seguir as restrições impostas pelas instituições sociais" (FREUD apud MARCUSE, 1981, p. 74). Essas restrições aqui referidas se fizeram de forma notável pela institucionalização da religião com a substituição das divindades femininas pelos deuses masculinos. A partir daí a recorrência a estes passou a ser constante com vistas a regulamentação da prática sexual que desse sustentação a monogamia como garantia da permanência da propriedade privada sob o domínio de uma elite. Neste sentido, o controle da sexualidade pela religião pôde disciplinar o comportamento no sentido de que o sexo fosse destinado exclusivamente à procriação conforme à necessidade do mundo da produção efetivada pelo trabalho. E isto se fez pela exploração de uns homens pelos outros. Impusera-se a repressão sexual, feita em nome dos deuses masculinos, para garantir a exploração dos trabalhadores que não dispunham dos meios de produção. Assim, a repressão deixou de ser necessária ao desenvolvimento da civilização para ser imprescindível à exploração dos trabalhadores com vistas à geração de mais-valia ao patrão. Neste sentido, a família monogâmica e a propriedade privada foram fundamentais para o controle da sexualidade, como bem observa Marcuse (1981, p. 81):

A família monogâmica, com suas obrigações exigíveis do pai, restringe neste o seu monopólio de prazer; a instituição da propriedade privada transmissível por herança e a universalização do trabalho deram ao filho uma justificada expectativa do seu próprio prazer sancionado, de acordo com o seu desempenho socialmente útil.

Os cristãos, por exemplo, vincularam o sexo à morte e à procriação, porém deixando claro se tratar de pecado toda prática sexual, sobretudo se efetivada fora do casamento. Elevavase assim o pecado do sexo, quando se tratava das relações extraconjugais, bem como das relações pré-conjugais. Neste sentido, faziam-se necessárias a preservação da virgindade e o sexo restrito aos cônjuges, por ser um pecado menor. Esse controle da sexualidade remeteria os instintos sexuais não mais à produção da cultua, de forma que pudesse significar

\begin{tabular}{|c|c|c|c|c|}
\cline { 2 - 4 } & Ano 8 & n. 14 & Janeiro - Julho 2019 & p. $70-90$ \\
\hline
\end{tabular}


desenvolvimento da civilização, mas para a produção de mais-valia, que permitisse o enriquecimento de quem detivesse a dominação por ser dono dos meios de produção. Com isto se firmara a passagem do princípio de realidade ao princípio de desempenho, que tem por base, não a simples repressão sexual, mas a mais-repressão.

Com essa passagem do princípio de realidade ao princípio de desempenho, já não se tem a substituição do princípio de prazer pelo de realidade, mas a transformação do princípio de prazer em princípio de desempenho. Com isto, o monopólio do pai passou a ser a comedida autoridade educacional e econômica. Da mesma forma, a mãe passou a ser o objeto original da luta de Eros e Thanatos, isto é, o objeto da luta entre a vida e a morte. Quanto a isso, Marcuse (1981, p. 81) nos diz o seguinte: "Na horda primordial, a imagem da mulher desejada, a esposaamante do pai, era a imagem de Eros e Thanatos em união imediata, natural". Isto significa que o filho, vendo na mãe o Nirvana pré-natal, desfrutara da ausência de toda necessidade e de todo o desejo. Por isso ela passou a ser o objeto de luta entre Eros e Thanatos, uma vez que ambos passaram a ver nela a possiblidade de alcançar o Nirvana, seja pela plena satisfação do desejo ou pela morte. Mas, atingindo-se o estágio de desenvolvimento da civilização em que o princípio de prazer fora substituído pelo princípio de desempenho, fora dissolvida a identidade entre Eros e Thanatos, de forma que se pode falar agora da separação entre a mãe e a esposa. Neste sentido, pode-se dizer que o amor sensual do filho pela mãe fora inibido, sendo transformado no amor pela esposa e na ternura pela mãe. Posteriormente, o amor e a ternura se reencontrarem na esposa. Assim, diz Marcuse (Ibidem, p. 82): "No presente nível da civilização, dentro do sistema de inibições recompensadas, o pai pode ser superado sem que a ordem instintiva e social sofra violento abalo; agora, sua imagem e sua função perpetuam-se em cada filho - ainda que este o não conheça”. Isto significa, ainda segundo Marcuse (Ibidem), que a dominação não se limita mais às relações pessoais, mas, ao contrário: não só ultrapassou a esfera dessas relações como também "criou as instituições para a satisfação ordeira das necessidades humanas, numa escala crescente". No entanto, segundo ele, "é precisamente o desenvolvimento dessas instituições que está abalando os alicerces estabelecidos da civilização. Seus limites interiores aparecem na recente era industrial”.

Diante disto, irracionalidade do sentimento de culpa é, para Freud, tão racional quanto o é a necessidade de repressão para a própria civilização. Por isso, para se justificar a necessidade dessa repressão, recorre-se à religião que, em nome da necessidade do trabalho para a garantia de sobrevivência e da própria existência humana, canaliza a sexualidade para o empenho que se faz necessário no âmbito da produção econômica submetida à ética do

\begin{tabular}{|c|c|c|c|c|}
\cline { 2 - 4 } Govista Dialectus & Ano 8 & n. 14 & Janeiro - Julho 2019 & p. 70 - 90 \\
\hline
\end{tabular}


capitalismo, como bem observou Max Weber. Pois, ao referir-se a Lutero, diz Weber (2005, p. 76) que "a profissão concreta do indivíduo lhe aparece cada vez mais como uma ordem de Deus para ocupar na vida esta posição concerta que lhe reservou o desígnio divino". Neste sentido, pode-se dizer com Marcuse (1981, p. 85): “A civilização é, acima de tudo, progresso no trabalho - quer dizer, trabalho para o agenciamento e ampliação das necessidades da vida. Esse trabalho realiza-se, normalmente, sem satisfação alguma em si mesmo; para Freud, é desagradável e penoso". Coaduna-se assim a ascese com o trabalho, como mortificação da carne e restrição do sexo à procriação e à sublimação na produção econômica.

A relação que podemos ver nesse incentivo ao trabalho pela via da sublimação pode também ser vista no incentivo à abstinência sexual para se evitar a procriação para a qual o sexo fora destinado, segundo o próprio entendimento cristão. Esse entendimento se apoia na crença de que o dia do Juízo está próximo e, por isso, já não faz sentido procriar. Sendo a procriação a única razão para as relações sexuais, convinha, sim, que se abstivesse da prática sexual. Daí a razão pela qual inúmeras seitas proibiram as relações sexuais, pois, como diz Marilena Chaui (1984, p. 87), “já não havia por que nem para que perpetuar a espécie humana”. Enquanto isso, não seria possível continuar vivo sem as condições matérias de subsistência. Portanto, o trabalho seria imprescindível. Daí uma forte razão para se incentivar o trabalho, que passou a ser o grande purificador da vida suja, conforme o exposto pelos puritanos. Assim sendo, poderse-ia entender o seguinte: "O trabalho é a finalidade da vida e a vida em estado de graças é a vida operosa" (CHAUI, 1984, p. 150).

Assim se consolida o princípio de desempenho sustentado pela mais-repressão. A propósito disto, Anthony Giddens (1996, p. 181), ao referir-se ao pensamento de Marcuse, diz o seguinte: “Toda civilização presume a 'repressão básica' dos caminhos da vida e da morte, mas na sociedade moderna as exigências da disciplina econômica introduzem uma carga de repressão histórica e dispensável”. Ou seja, na sociedade moderna, identificada com o mundo do trabalho que tem a indústria como referência, não se pode ignorar a importância dessa repressão para a afirmação da exploração da mão-de-obra operária. Daí a observação de Giddens: “Ajustando-se ao 'princípio de realidade' de Freud, o indivíduo está, na verdade, respondendo às exigências de uma forma de dominação exploradora" (Ibidem, p. 181-182). Nas palavras do próprio Marcuse (1981, p. 89), está dito: “Supõe-se que os impulsos tanto agressivos como libidinais se satisfazem em trabalhar 'por meio da sublimação', e o caráter 'sadístico' culturalmente benéfico do trabalho tem sido freqüentemente enfatizado".

\begin{tabular}{|c|c|c|c|c|}
\cline { 2 - 4 } & Ano 8 & n. 14 & Janeiro - Julho 2019 & p. $70-90$ \\
\hline
\end{tabular}


Com outras palavras, pode-se dizer que não falta razão para se justificar a necessidade do trabalho, mesmo quando já não mais existe a carência de dominação, própria da hora primitiva, quando a civilização atingiu um grau elevadíssimo de refinamento.

\section{A obsoleta necessidade de dominação e o fim do princípio de desempenho}

Entendendo que já não se faz necessária a dominação para a manutenção da civilização em seu alto estágio de desenvolvimento, vale perguntar pelo que Freud pensou sobre a civilização. Em sua obra $O$ futuro de uma ilusão, ele diz querer significar por civilização humana "tudo aquilo em que a vida humana se elevou acima de sua condição animal", diferindo da vida dos animais (FREUD, 2006, p. 15). E, continuando, diz ainda que ela apresenta ao observador dois aspectos:

Por um lado, inclui todo o conhecimento e capacidade que o homem adquiriu com o fim de controlar as forças da natureza e extrair a riqueza desta para a satisfação das necessidades humanas; por outro, inclui todos os regulamentos necessários para ajustar as relações dos homens uns com os outros e, especialmente, a distribuição da riqueza disponível (Ibidem).

Como se vê, Freud não diz diretamente que a dominação não é mais necessária para a produção da cultura que, para ele, em nada difere da civilização - "desprezo ter que distinguir entre cultura e civilização" - diz ele. Mas Marcuse (1982, p. 23) chama a atenção para o seguinte: "Uma falta de liberdade confortável, suave, razoável e democrática prevalece na civilização industrial desenvolvida, um testemunho do progresso técnico". Ele constata isso ao observar o que está dito em suas palavras: “A tecnologia serve para instituir formas novas, mais eficazes e mais agradáveis de controle social e coesão social” (Ibidem, p. 18). Isto, de alguma forma, confirma o que já havia dito em Eros e Civilização, quando procura saber se existe precondições se pensar em um novo princípio de realidade sob o ponto de vista da qualidade e da não-repressão. Respondendo, confronta "a teoria psicanalítica do homem com algumas tendências históricas básicas", chegando às seguintes conclusões:

1) O próprio progresso da civilização, sob o princípio de desempenho, atingiu um nível de produtividade em que as exigências sociais à energia instintiva a ser consumida em trabalho alienado poderiam ser consideravelmente reduzidas. Por conseqüência, a contínua organização repressiva dos instintos parece ser menos necessitada pela luta pela existência do que pelo interesse em prolongar essa luta, isto é, pelo interesse em dominar. (MARCUSE, 1981, p.123)

2) A Filosofia representativa da civilização ocidental desenvolveu um conceito de razão que contém as características dominantes do princípio de desempenho. Contudo, a mesma

\begin{tabular}{|c|c|c|c|c|}
\cline { 2 - 4 } & Ano 8 & n. 14 & Janeiro - Julho 2019 & p. $70-90$ \\
\hline
\end{tabular}


Filosofia termina na visão de uma forma superior de razão que é a própria negação dessas características nomeadamente, receptividade, contemplação, fruição do prazer. Subentendida na definição do sujeito em termos de uma atividade cada vez mais transcendente e produtiva do ego, está a imagem da redenção do ego: o momento em que venha a repousar de toda a transcendência, num modo de ser que absorveu todo o devir, que está para si mesmo e consigo mesmo em toda alteridade". (Ibidem, p. 124)

Vemos que, primeiro, Marcuse constata que o interesse pelo prolongamento da repressão se vincula ao interesse de dominar, pura e simplesmente, ou seja, não-mais pela carência de dominação com vista à necessidade de produção cultural e desenvolvimento da civilização, mas pelo prazer que possa ser proporcionado pela dominação em si mesma; segundo, a afirmação de um modo de ser que absorveu todo devir sustentando-se num conceito de razão desenvolvido pela Filosofia representativa da civilização, estando nessa razão as características próprias do princípio de desempenho. Ou seja, fora desenvolvido um conceito de razão que serve como instrumento desse princípio de desempenho, ou seja, uma razão que justifica a necessidade de mais-repressão, sem a necessidade de dominação para o desenvolvimento da própria civilização.

A partir disso, Marcuse observa que não seria possível pensar na superação do princípio de desempenho que, para Freud, nada mais era que o próprio princípio de realidade. Mas Marcuse diz que, sendo conforme pensava Freud, não seria possível falar de um novo princípio de realidade: "Se a sexualidade é, em sua própria essência, antissocial e associal, e se a destrutividade é a manifestação de um instinto primário, então a idéia de um princípio de realidade não-repressivo não passaria de especulação ociosa" (MARCUSE, 1981, p. 124). Todavia, há se considerar uma contradição no pensamento de Freud. Ele deixa entrever a possibilidade de libertação humana, fazendo da Psicanálise um instrumento com que combate as neuroses provenientes dessa repressão que ele diz ser necessária ao princípio de realidade, não o distinguindo do princípio de desempenho. Pois eu mesmo observei que fora Freud quem descobriu que a cura da neurose não é devida a outra coisa senão à liberação da natureza e da instintividade do homem” (DIONIZIO NETO, 1988, p. 91). Ou seja, é preciso que se pense na qualidade de vida quando se vive sem-repressão, pois não se pode falar de neurose sem remetêla à repressão sexual. Daí verifica-se, no pensamento do próprio Freud, uma abertura para a libertação, pois "se o processo histórico propender para tornar obsoletas as instituições do princípio de desempenho, tenderá também para tornar obsoleta a organização dos instintos, isto é, para libertar os instintos das restrições e desvios requeridos pelo princípio de desempenho" (MARCUSE, 1981, p. 124), Isto significa haver "a possibilidade real de uma eliminação

\begin{tabular}{|c|c|c|c|c|}
\cline { 2 - 4 } & Ano 8 & n. 14 & Janeiro - Julho 2019 & p. $70-90$ \\
\hline
\end{tabular}


gradual da mais-repressão, pelo que uma crescente área de destrutividade poderia ser então absorvida ou neutralizada pela libido assim fortalecida" (Ibidem).

Mas não se pode ignorar as condições em que se dá a dominação em mundo industrializado, quer dizer, em mundo em que a civilização chegou ao seu mais alto nível de desenvolvimento. Assim já não se fala da dominação do pai primordial nem tampouco da dominação patriarcal pura e simplesmente. A dominação agora se dá no âmbito do sistema que está para além da dominação do Estado. Seguindo por esta linha de entendimento, Marcuse (1981, p. 91) pôde verificar o seguinte:

\footnotetext{
Desde o pai primordial, através do clã fraterno, até o sistema de autoridade institucionalizada que é característico da civilização madura, a dominação torna-se cada vez mais impessoal, objetiva, universal e também cada vez mais racional, eficaz e produtiva. Por fim, sob o domínio do princípio de desempenho plenamente desenvolvido, a subordinação apresenta-se como que efetivada através da divisão social do próprio trabalho (embora a força física e pessoal continue sendo uma instrumentalidade indispensável). A sociedade emerge como um sistema duradouro e em expansão de desempenhos úteis; a hierarquia de funções e relações adquire a forma de razão objetiva: a lei e a ordem identificam-se com a própria vida da sociedade. No mesmo processo, também a repressão é despersonalizada: a restrição e arregimentação do prazer passam agora a ser uma função (e resultado "natural”) da divisão social do trabalho.
}

Assim não podemos ignorar o caráter administrativo da dominação, ao tempo em que desapareceram por trás das instituições as imagens do pai, chefe, patrão, etc. Daí eu observo, a partir do exposto por Marcuse, que "os subordinados são subordinados de outros subordinados. Empregadores e empregados são controlados pela administração de um escritório”. Ou seja: “O responsável pela organização da vida de cada um é o 'sistema', sendo este a soma total das instituições que controlam, satisfaze, determinam a sua necessidade". E com isto se pode afirmar que "a revolta dos indivíduos, hoje, já não é contra o pai, o chefe, o patrão, mas contra as instituições, o sistema como um todo. (DIONIZIO NETO, 1988, p. 91).

Pensando, então, sobre o que significa hoje a necessidade de dominação para que seja canalizada a libido para o trabalho com vista à produção da cultura e, com isto, ocorra o desenvolvimento da civilização, é possível concluir com Marcuse que essa carência de dominação está obsoleta. Tendo se torando obsoleta, já não há mais razão para se continuar com a repressão dos instintos vitais, e muito menos se faz necessária a mais-repressão, que seve de base para o princípio de desempenho. Neste sentido, deveríamos, sim, considerar o necessário fim desse princípio de desempenho, quando a necessidade de dominação se fez obsoleta.

\begin{tabular}{|c|c|c|c|c|}
\cline { 2 - 4 } & Ano 8 & n. 14 & Janeiro - Julho 2019 & p. $70-90$ \\
\hline
\end{tabular}




\section{À guisa de conclusão: a sociedade sem-repressão sob o novo princípio de realidade}

Seria, então, possível pensar numa sociedade sem-repressão, que desse lugar a novo princípio de realidade? Ou já estamos nela? Isto é: já podemos dizer que, tendo se tornado obsoleta a necessidade de dominação, alcançamos a sociedade sem-repressão prevista por Marcuse? José Guilherme Merquior refere-se a esta previsão de Marcuse como utopia que, segundo ele, está situada para além do que ele chama "história viável". Apesar disso, ele diz existir: "é, naturalmente, a sociedade sem repressão. Ela pressupõe a abolição do trabalho e a inauguração de uma sociedade lúdica” (MERQUIOR, 1969, p. 36 - grifo do autor). Ressaltese aqui um equívoco a referência à "abolição do trabalho", pura e simplesmente. Na verdade, Marcuse pensa em abolição do trabalho alienado, ao modo referido por Marx em seus Manuscritos econômico-filosóficos. Todavia, pensando na perspectiva marcusiana, o que está posto entre nós, hoje, pode ser indicativo dessa sociedade lúdica, isto é, sem-repressão.

No início da década de 1970, Carl R. Roger publica Novas formas do amor: o casamento e suas alternativas. Nesta obra, o autor traz para a nossa reflexão um cuidadoso estudo sobre diferentes experiências de casamento ou de novas relações amorosas, que ele acreditava não serem diferentes por volta do ano 2000. No pós-ano 2000, o que dizer dessas experiências: seriam elas indicativo de que a mais-repressão deixou de existir, e contamos agora com a reconciliação dos princípios do prazer e de realidade? Bento Prado Jr., ao discorrer sobre o pensamento de Marcuse, volta-se para esta necessidade de reconciliação, colocando, segundo ele, os princípios de prazer e realidade em novos termos. Assim, diz ele: "O trabalho pacificador da dialética e a idéia de uma civilização não-repressiva que tal trabalho promove não ferem, segundo Marcuse, a vocação mais profunda do pensamento de Freud” (PRADO JR., 1990, p. 271). Ao contrário disto, diz este autor, parece que Marcuse deu o passo final que poderia ter sido dado pelo próprio Freud.

Alvin Toffler (1980, p. 23), no final do século XX, fala-nos da emergência de uma nova civilização: "Uma nova civilização está emergindo em nossas vidas e por toda a parte há cegos tentando suprimi-la". Mas como seria esta civilização? Teria alguma semelhança com o que pensara Marcuse sobre a sociedade sem-repressão? Toffler diz que esta civilização "traz consigo novos estilos de família, modos de trabalhar, amar e viver diferentes; uma nova economia; novos conflitos políticos; e, além de tudo isto, igualmente uma consciência alterada". Logo depois, acrescenta: "Fragmentos desta civilização já existem. Milhões de pessoas já estão sintonizando suas vidas com o ritmo de amanhã. Outros, aterrados diante do futuro, estão

\begin{tabular}{|l|l|l|l|l|}
\cline { 2 - 5 } Q Q Dialectus & Ano 8 & n. 14 & Janeiro - Julho 2019 & p. 70 - 90 \\
\hline
\end{tabular}


empenhados numa fuga inútil para o passado e tentam restaurar o mundo moribundo que lhes deu o ser" (p. Ibidem). Ou seja, com outras palavras, repete o que dissera Carl R. Roger, ao se referir à extensão do que estava acompanhando em relação às novas formas de amar.

Enquanto isso, Jean Baudrillard diz que hoje vivemos "uma espécie de epidemia do valor", ou seja, parece que tudo vale tudo ou que nada vale nada. Isto porque, segundo ele, o momento atual parece ser aquele que sugira depois da orgia. $\mathrm{O}$ que ele quis dizer com isso? Fazendo uso de suas próprias palavras, diz: "Se fosse caracterizar o atual estado de coisas, eu diria que é o da pós-orgia. A orgia é o momento explosivo da modernidade, o da libertação em todos os domínios". Ou seja: "Liberação política, liberação sexual, liberação das forças produtivas, liberação da mulher, da criança, das pulsações inconscientes, liberação da arte". Portanto, a modernidade explodiu como uma orgia total: "Total orgia de real, de racional, de sexual de crítica e de anticrítica, de crescimento e de crise de crescimento" (Baudrillard, 1990, p. 9). Será que estamos a falar de uma sociedade pós-moderna? Esta seria o lugar para o novo princípio de realidade anunciado por Marcuse?

Zigmunt Bauman prefere referir-se à liquidez da sociedade contemporânea. Uma sociedade que não está posta como pós-moderna, mas como modernidade líquida. Isto porque, segundo ele, trata-se de uma sociedade que se caracteriza pela fluidez, o que também a deixa leve. Pois, para ele, "fluidez" ou "liquidez" devem ser consideradas "como metáforas adequadas quando queremos captar a natureza da presente fase, nova de muitas maneiras, na história da modernidade" (BAUMAN, 2017, p. 9). Esta forma de pensar a sociedade contemporânea pode inclusive ser tomada como resposta ao próprio Marcuse, quando diz crer "que estamos diante de uma situação nova na história, porque temos que ser libertados de uma sociedade, rica, poderosa e que funciona relativamente bem..." (MARCUSE apud BAUMAN, 2017 , p. 25).

Seroa possível uma compatibilidade entre a fluidez referida por Bauman com a nãorepressão a que se refere Marcuse. Numa sociedade que se tornasse possível a reconciliação entre os princípios de prazer e de realidade, certamente existiriam para a liberdade sexual. E, neste sentido, trata-se de considerar a condição da sexualidade em meio a essa reconciliação dos princípios: "Sob condições não-repressivas, a sexualidade tende a tornar-se Eros - quer dizer, à auto-sublimação em relações duradouras e expansivas (incluindo relações de trabalho) que servem para intensificar e ampliar a gratificação instintiva” (MARCUSE, 1981, p. 193). Mas o próprio Marcuse diz o seguinte: “como pode a civilização gerar livremente a liberdade,

\begin{tabular}{|c|c|c|c|c|}
\cline { 2 - 4 } & Ano 8 & n. 14 & Janeiro - Julho 2019 & p. $70-90$ \\
\hline
\end{tabular}


quando a não-liberdade se tornou parte integrante da engrenagem mental? E, se assim não for, quem está autorizado a estabelecer e impor os padrões objetivos?” (Ibidem, p. 195).

Em sua obra A ideologia da sociedade industrial, Marcuse, de algum modo reflete sobre o significado da fluidez de uma sociedade em que se tem a dessublimação controlada. Consideradas as condições em que se dão as relações sexuais, a começar pela ambientação da permissividade para a sedução e a conquista, parece ser demarcado pela previsibilidade que nega a plena liberação sexual referida por Baudrillard. Inegavelmente, as pessoas se relacionam de forma leve, que expressa muito bem a fluidez referida por Bauman, mas Marcuse chama a atenção para o fato de que está tudo sob controle, mesmo quando isto ocorre de forma disfarçada, porém, liquidamente presente nos espaços em que se dão as relações. Pois já não se faz necessária a sublimação. Ao contrário, a dessublimação viabiliza a satisfação imediata. Todavia, há de se considerar a liberalização da sexualidade que se dá pela absorção do Princípio da Realidade pelo Princípio do Prazer. Apesar dessa liberalização da sexualidade se fazer "sob formas socialmente construtivas", é inegável a existência de formas repressivas de dessublimação, que "opera como o subproduto dos controles sociais da realidade tecnológica, que amplia a liberdade enquanto intensifica a dominação" (MARCUSE, 1981, p. 82).

Para Marcuse, há, na sociedade contemporânea, um elo entre a dessublimação e a tecnologia. Isto implica "modificação do uso social da energia instintiva" (Ibidem). Com esta modificação, diminui-se a eroticidade ao tempo em que se libera a energia sexual. Ao intensificar a energia sexual, "a realidade tecnológica limita o alcance da sublimação. Reduz também a necessidade de sublimação" (Ibidem, p. 83 - grifo do autor). Isto significa dizer que é cada vez maior o grau de liberdade sexual, como observa o próprio Marcuse (1981, p. 84): "Tem sido com frequência observado que a civilização industrial desenvolvida opera com um maior grau de liberdade sexual - 'opera' no sentido de essa liberdade se tornar um valor marcante e um fator de costumes". E diz mais: "Sem deixar de ser um instrumento de trabalho, o corpo tem permissão para exibir suas características sexuais no mundo de trabalho cotidiano e nas relações de trabalho". Assim sendo, pode-se constatar o seguinte:

As escriturárias e balconistas sensuais, o chefe de seção e o superintendente e atraentes e viris são mercadorias altamente comercializáveis, e a posse de amantes apropriadas - antes uma prerrogativa de reis, príncipes e lordes - facilita a carreira até mesmo de empregados de cargos menos importantes na comunidade comercial. (MARCUSE, 1981, p. 84).

Constata-se, dessa forma, persistência da repressão, mesmo numa sociedade em que as relações humanas se dão no seu modo mais líquido de ser. A mulher, prazer supremo da horda

\begin{tabular}{|c|c|c|c|c|}
\cline { 2 - 4 } Q Devistalectus & Ano 8 & n. 14 & Janeiro - Julho 2019 & p. 70 - 90 \\
\hline
\end{tabular}


primordial, alcançou o seu mais alto grau de emancipação, o que se pode confirmar pelo nível de liberação sexual em que ela se encontra. Mas, como vemos a partir do exposto por Marcuse, trata-se de uma liberação sexual submetida aos condicionamentos sociais, previsivelmente pensados para o controle da dessublimação. Ou seja, ao invés de reprimir o sexo e oferecer as condições para a sublimação, incentiva-se a sexualidade, porém reduzido o caráter erótico das relações. Por assim ser, faz-se a integração entre sexo e trabalho, da mesma forma que se integra o sexo nas relações públicas. Isto facilita a satisfação sexual, porém sob controle. Daí a afirmação de Marcuse (1981, p. 85): "Essa mobilização e administração da libido pode ser a responsável por muitos da submissão voluntária, da ausência de terror, da harmonia preestabelecida entre necessidades individuais e desejos, propósitos e aspirações socialmente necessários". Portanto, se podemos esperar pela superação desse controle a que ainda está submetida a satisfação sexual em uma sociedade em que tudo é fluido, ainda não se pode afirmar que tenha desaparecido, de uma vez por toda, a mais-repressão, que continua sustentando o princípio de desempenho, mesmo com a absorção do princípio de realidade pelo princípio do prazer.

\section{Referências}

BAUDRILLARD, Jean. A transparência do mal; ensaio sobre os fenômenos extremos. Tradução por Estela dos Santos Abreu. Campinas-SP: Papirus, 1990. 188 p. Tradução de: La transparence du mal. Ensai sur les phénomenes extrêmes.

BAUMAN, Zygmunt. Modernidade líquida. Tradução por Plínio Dentzien. Rio de Janeiro, 2017. Tradução de: Liquid Modernity.

CHAUI, Marilena. Repressão sexual: essa nossa (des)conhecida. São Paulo: Brasiliense, 1984.

DIONIZIO NETO, Manoel. A presença do hedonismo e do pragmatismo na visão ética contemporânea. Maceió: Ediculte, 1988. 142 p.

FREUD, Sigmund. O Futuro de uma Ilusão. In: FREUD, Sigmund. O Futuro de uma Ilusão, O mal-estar na civilização e outros trabalhos. Tradução José Octávio de Aguiar Abreu. Rio de Janeiro: Imago, 2006. p. 15-63. (Edição standard brasileira das obras psicológicas completas de Sigmund Freud, v. XXI - 1927-1931).

GIDDENS, Anthony. A transformação da intimidade: sexualidade, amor \& erotismo nas sociedades modernas. Tradução por Magda Lopes. 2a . Reimpressão. São Paulo: UNESP, 1996. 232 p. (Biblioteca Básica). Tradução de: Transformation of intimacy: sexuality, love \& eroticism in modern societies.

\begin{tabular}{|l|c|c|c|c|}
\cline { 2 - 4 } Q Oenistalactus & Ano 8 & n. 14 & Janeiro - Julho 2019 & p. $70-90$ \\
\hline
\end{tabular}


MARCUSE, Herbert. A ideologia da sociedade industrial. Tradução por Giasone Rebuá. 6. ed. Rio de Janeiro: Zahar, 1982. 240 p. (Atualidade). Tradução de: One-Dimensional Man Studies in the Ideology of Advanced Industrial Society.

MARCUSE, Herbert. Eros e civilização: uma interpretação filosófica do pensamento de Freud. Tradução por Álvaro Cabral. 8. ed. Rio de Janeiro: Zahar, 1981. 232 p. (Série Filosofia). Tradução de: Eros and civilization a philosophical inquiry into Freud.

MERQUIOR, José Guilerme. Arte e sociedade em Marcuse, Adorno e Banjamin: ensaio crítico sôbre a escola neohegeliana de Frankfurt. Rio de Janeiro-GB: Tempo Brasileiro, 1969. (Biblioteca Tempo Universitário, 15).

PRADO JR., Bento. Entre o alvo e o objeto do desejo: Marcuse, crítico de Freud. In: NOVAES, Adaulto (Org.). O desejo. São Paulo: Companhia das Letras, 1990. 503 p.

ROGERS, Carl R. Novas formas de amor; o casamento e suas alternativas. Tradução por Octavio Mendes Cajado. 6. ed. Rio de Janeiro: José Olympio, 1984. 240 p. Tradução de: Becoming partners: marriage and its alternatives.

TOFFLER, Alvin. A terceira onda. Tradução por João Távora. 15. ed. Rio de Janeiro: Record, 1980. Tradução de: The third wave.

WEBER, Max. A ética protestante e o "espírito" do capitalismo. Tradução por José Marcos Mariani de Macedo. $3^{\circ}$ reimpressão. São Paulo: Companhia das Letras, 2005.

\begin{tabular}{|c|c|c|c|c|}
\hline Qevista Dialectus & Ano 8 & n. 14 & Janeiro - Julho 2019 & p. $70-90$ \\
\hline
\end{tabular}




\title{
CONTRIBUIÇÕES TEÓRICAS DE MARCUSE SOBRE AS NOVAS FORMAS DE CONTROLE E DOMINAÇÃO NAS SOCIEDADES CAPITALISTAS
}

\author{
Paulo Sérgio Gomes Soares ${ }^{1}$ \\ Rafael Silva Oliveira ${ }^{2}$
}

\begin{abstract}
Resumo:
A luta pela permanência e estabilidade do capital está sendo travada na esfera cultural pela exploração da subjetividade dos indivíduos e daquilo que os faz ser o que são: a consciência. A partir da análise da Teoria Crítica da Sociedade do filósofo Herbert Marcuse, o artigo apresenta um debate que gira em torno das formas de controle social emergentes nas sociedades capitalistas, que estão voltadas para dominar os indivíduos pela satisfação das necessidades superimpostas e, contraditoriamente, movimentar as engrenagens do sistema. Investiga-se em que medida a técnica e a tecnologia contribuem para instituir as novas formas de controle social a partir do conceito de racionalidade tecnológica. O objetivo é apontar as contradições da razão em meio ao ambiente tecnológico, envolvendo a relação entre indivíduo e sociedade a partir da introjeção da cultura do consumo para a administração total da vida. A luta pela existência frente ao aparato de produção e consumo que impõe um padrão de vida crescente sofre a pressão do mundo administrado por forças estranhas ao controle dos indivíduos, comprometendo a sua emancipação por eliminar a crítica e impedir o livre desenvolvimento de suas faculdades. O debate mostra que as sociedades capitalistas reprimem, precondicionam e introjetam as falsas necessidades, minando as possibilidades reais de transformação qualitativa da sociedade.
\end{abstract}

Palavras-chave: Teoria Crítica. Racionalidade Tecnológica. Controle Social. Capitalismo. Cultura do Consumo.

\section{THEORETICAL CONTRIBUTIONS OF MARCUSE ON THE NEW FORMS OF CONTROL AND DOMINATION IN CAPITALIST COMPANIES}

\begin{abstract}
:
The struggle for permanence and stability of capital is being waged in the cultural sphere by the exploration of the subjectivity of individuals and of what makes them what they are: consciousness. From the analysis of the Critical Theory of Society of the philosopher Herbert Marcuse, the article presents a debate that revolves around the emerging forms of social control in capitalist societies, which are aimed at dominating individuals by satisfying superimposed needs and, contradictorily, moving the gears of the system. It is investigated to what extent technology and technology contribute to instituting the new forms of social control from the concept of technological rationality. The objective is to point out the contradictions of reason in the midst of the technological environment, involving the relationship between individual and society from the introjection of the culture of consumption to the total administration of life. The struggle for existence in the face of the apparatus of production and consumption which imposes a growing standard of living undergoes the pressure of the world administered by forces alien to the control of individuals, compromising their emancipation by eliminating criticism and impeding the free development of their faculties. The debate shows that capitalist societies repress, precondition and introject false needs, undermining the real possibilities of qualitative transformation of society.
\end{abstract}

Keywords: Critical Theory. Technological Rationality. Social Control. Capitalism. Culture of Consumption.

\footnotetext{
${ }^{1}$ Doutor em Educação (UFSCar/2012). Mestre em Epistemologia, Lógica e Filosofia da Ciência (UNESP/2004). Licenciado em Filosofia (UNESP/1997). Professor do Mestrado Profissional em Filosofia (PROF-FILO/UFT) e no Programa de Pós-Graduação Interdisciplinar em Prestação Jurisdicional e Direitos Humanos (UFT/ESMAT). E-mail: psoares@uft.edu.br.

2 Mestre em Filosofia (UFT/2019), especialista em Ética e Ensino de Filosofia na Educação Básica (UFT/2016). Licenciado em Filosofia (UFT/2014). Professor do Instituto Tocantinense de Pós-Graduação (ITOP). E-mail: rafael.siloli@gmail.com.
} 


\section{Introdução}

Atualmente, retomar o pensamento do filósofo frankfurtiano Herbert Marcuse (18981979) se faz necessário para compreender as contradições produzidas pelas sociedades capitalistas em seu atual estágio de desenvolvimento tecnológico. O pressuposto fundamental é que a luta pela permanência e estabilidade do capital não está sendo travada somente nas esferas política e econômica, mas, sobretudo, na esfera cultural pela exploração da subjetividade dos indivíduos e daquilo que os faz ser o que são: a consciência.

Essa pesquisa teórica fundamentada na Teoria Crítica procurou compreender a transformação da racionalidade individualista em racionalidade tecnológica e da racionalidade tecnológica em racionalidade política para assumir a administração total da vida dos indivíduos a partir da luta pela existência. A introjeção da racionalidade tecnológica ajustou os indivíduos aos precondicionamentos sociais e contribuiu para transformar os instintos, os desejos e os pensamentos humanos em atitudes desejáveis para a reprodução do sistema capitalista. $\mathrm{O}$ fenômeno da introjeção da cultura do consumo e os seus efeitos nas relações sociais se constituem em pressupostos para analisar a dinâmica e o desenvolvimento das sociedades capitalistas, avaliando como estão sendo utilizados os recursos naturais e intelectuais no curso do processo civilizatório.

A racionalidade tecnológica se transforma em racionalidade política quando o projeto do capitalismo antevê maneiras de utilizar a natureza e os indivíduos para se reproduzir. Nesse sentido, de um ponto de vista político, a técnica e a tecnologia são fundamentais para o controle da natureza e para conquistar e dominar os indivíduos cientificamente. Portanto, elas não podem ser vistas como neutras.

A hipótese investigada é de que nas sociedades capitalistas tendem a prevalecer o autoritarismo e a escassez, bem como o aumento do trabalho árduo, porque sempre novas formas de controle são criadas em estreita relação com a formação de uma racionalidade - a racionalidade tecnológica -, que é uma racionalidade técnica formada pelos padrões da máquina (tecnologia) para consolidar formas específicas de controle, dominação e submissão dos indivíduos a maneiras alienadas de vida, que vêm sendo introjetadas desde o advento da Revolução Industrial até os dias atuais com a revolução tecnológica digital.

O objetivo do artigo é expressar as tensões e contradições da razão em meio a um ambiente tecnológico que exige a submissão dos indivíduos aos interesses de um sistema que obstaculiza a libertação da consciência e, portanto, o processo de emancipação humana rumo

\begin{tabular}{|c|c|c|c|c|}
\cline { 2 - 5 } Q Dovista & Ano 8 & n. 14 & Janeiro - Julho 2019 & p. $91-109$ \\
\hline
\end{tabular}




\section{CONTRIBUICÕES TEÓRICAS DE MARCUSE SOBRE AS NOVAS...}

Paulo Sérgio Gomes Soares / Rafael Silva Oliveira

ao reino da liberdade. A ideia é desvelar como se efetiva a dominação dos indivíduos pela satisfação no consumo das falsas necessidades.

A ideologia das sociedades capitalistas se assenta na falsa consciência consolidada na troca da liberdade pelo conforto, ou seja, no consumo de necessidades superimpostas que cobram em troca o conformismo. A lógica da dominação social se fundamenta em um processo de produção e consumo que destrói as possibilidades reais de amenizar a luta pela existência.

O consumo alienado de necessidades superimpostas é um requisito básico para constituição e efetivação das diferentes formas de controle dos indivíduos nas sociedades capitalistas e este artigo mostra como elas produzem uma falta de liberdade confortável e democrática no atual estágio de desenvolvimento das forças produtivas. As necessidades superimpostas são compreendidas como falsas necessidades que impedem o livre desenvolvimento das faculdades humanas e a emancipação dos indivíduos.

Ao se submeterem ao sistema de produção e consumo e serem ajustados à racionalidade tecnológica, os indivíduos alimentam os meios de destruição de sua própria liberdade, tornandose dependentes dos preceitos que a sociedade impõe para se manterem inseridos nela. Enfim, constatou-se com base na análise da Teoria Crítica marcuseana que as falsas necessidades são as novas formas de controle social e, portanto, representam um sério problema para o processo, necessário e urgente, de emancipação humana.

A Teoria Crítica da Sociedade de Marcuse evidencia as contradições do nosso tempo histórico e procura desvelar alternativas que representem possibilidades reais de transformação do sistema vigente a partir da crítica. Em tese, a restituição da razão crítica pode viabilizar a negação para uma possível superação, no sentido de elevação, dessa sociedade, possibilitando o surgimento de outras alternativas históricas de florescimento social e novas formas de existência humana.

As perguntas que nortearam a investigação são as seguintes: atualmente, as sociedades capitalistas estão fazendo uso otimizado dos recursos naturais e intelectuais para minimizar a labuta pela existência? O atual estágio de desenvolvimento das forças produtivas permite dizer que o processo civilizatório, propugnado pelo capital, conduz a emancipação?

\section{A racionalidade tecnológica e a reprodução do capital}

\begin{tabular}{|l|l|l|l|l|}
\hline Govista 2 Dialectus & Ano 8 & n. 14 & Janeiro - Julho 2019 & p. $91-109$ \\
\hline
\end{tabular}


Em artigo intitulado Algumas implicações sociais da tecnologia moderna ${ }^{3}$, Marcuse (1999, p. 74) afirma que "a técnica por si só pode promover tanto o autoritarismo quanto a liberdade, tanto a escassez quanto a abundância, tanto o aumento quanto a abolição do trabalho árduo".

Constata-se que no processo de desenvolvimento tecnológico, uma nova racionalidade e novos padrões de individualidade se disseminaram na sociedade, modificando a concepção de indivíduo forjado pelo liberalismo no século XVIII, que "tinha de superar todo o sistema de ideias e valores que lhe era imposto, para encontrar e apossar-se de ideias e valores que se ajustassem a seu interesse racional" (MARCUSE, 1999, p. 75). Esse indivíduo que nenhuma autoridade externa deveria desrespeitar foi afetado pelo aparato da sociedade industrial, transformando a racionalidade individualista em racionalidade tecnológica. Esta última estabeleceu padrões de comportamento e julgamento que predispuseram os indivíduos a introjetar os ditames do sistema de produção e consumo, ou seja, a aceitarem os padrões e os valores externos da ordem social vigente.

Cabe, nesse primeiro momento, compreender a ideologia da sociedade industrial e como a racionalidade individualista foi transformada em racionalidade tecnológica para assumir a administração da vida dos indivíduos a partir da própria luta pela existência. Este artigo busca compreender esse fenômeno, partindo do pressuposto de que "ao manipular a máquina, o homem aprende que a obediência às instruções é o único meio de se obter resultados desejados. Ser bem-sucedido é o mesmo que adaptar-se ao aparato. Não há lugar para a autonomia" (MARCUSE, 1999, p. 80). A adaptação e a submissão razoável são características de uma racionalidade tecnológica objetivada em atitude desejável e todo esse processo contribuiu para transformar os instintos, os desejos e pensamentos humanos em canais que alimentam o aparato. “Os homens não vivem sua própria vida, mas desempenham tão-só funções preestabelecidas. Enquanto trabalham, não satisfazem suas próprias necessidades e faculdades, mas trabalham em alienação" (MARCUSE, 1975, p. 58).

Como, quando e porque os indivíduos começaram a apresentar padrões de reação confiáveis, comportamentos mecânicos, hábitos emocionais fixos e insensibilidade à perda da liberdade? Uma possível resposta, dentre outras, é que as organizações sociais capitalistas não

3 Segundo Kellner (1999), neste artigo publicado em inglês na revista do Instituto de Pesquisa Social, em 1941, contém o primeiro esboço de Marcuse sobre o papel da tecnologia nas sociedades industriais e antecipa sua análise sobre a temática, presente no livro intitulado A ideologia da sociedade industrial, que foi publicado originalmente em 1964 com o título One-Dimensional Man: Studies in the Ideology of Advanced Industrial Society. Utilizamos na escrita uma versão em português de 1973.

\begin{tabular}{|c|c|c|c|c|}
\hline Rovista Aidectus & Ano 8 & n. 14 & Janeiro - Julho 2019 & p. $91-109$ \\
\hline
\end{tabular}


mantêm o poder por meio da força, mas pela identificação dos indivíduos com o aparato. As formas de controle social são tecnológicas e se apresentam como a própria personificação da razão, representando o "bem" para todas as classes e interesses sociais. São formas de controle históricas de precondicionamento que caminham juntas com o desenvolvimento das forças produtivas.

Assim,

a máquina adorada não é mais matéria morta, mas se torna algo semelhante a um ser humano. E devolve ao homem o que ela possui: a vida do aparato social ao qual pertence. $\mathrm{O}$ comportamento humano se reveste da racionalidade do processo da máquina, e esta racionalidade tem um conteúdo social definido (MARCUSE, 1999, p. 81).

Pelo excerto fica evidente que tanto a técnica quanto a tecnologia não são neutros, pelo contrário, justificaram a ideologia da sociedade industrial. A tecnologia é concebida como um processo social no qual a técnica propriamente dita (isto é, o aparato técnico da indústria, transportes, comunicação) não passa de um fator parcial. A tecnologia, por sua vez, é "uma forma de organizar e perpetuar (ou modificar) as relações sociais, uma manifestação do pensamento e dos padrões de comportamento dominantes, um instrumento de controle e dominação" (MARCUSE, 1999, p. 73-74).

Trata-se de um instrumento de controle e dominação que criou um novo padrão de individualidade e se disseminou na sociedade como produto do desenvolvimento tecnológico e da produção em massa, avançando até os dias atuais, isto é, até o atual estágio de desenvolvimento das forças produtivas e do próprio capital, agora financeirizado. Hoje, a relação entre os indivíduos é mediada pelas tecnologias, a ponto de se identificarem de forma acrítica com o sistema. Todavia,

os equipamentos mecânicos que facilitam o contato entre os indivíduos também interceptam e absorvem sua libido, desta forma distanciando-o do reino por demais perigoso no qual o indivíduo se encontra livre da sociedade. O homem médio dificilmente se importa com outro ser vivo com a intensidade e persistência que demonstra por seu automóvel (MARCUSE, 1999, p. 81).

Ao se identificarem com o modo de existência que lhes foi imposto, diz-se que os indivíduos introjetaram a racionalidade tecnológica e que a identificação com as mercadorias tem representado, desde então, a troca da liberdade pelo conforto e, por conseguinte, o individualismo no sentido mais perverso que se possa imaginar. Com base no pensamento freudiano, Marcuse (1973, p 30) afirma que a "introjeção sugere uma variedade de processos relativamente espontâneos pelos quais um Eu (Ego) transfere o 'exterior' para o 'interior'”.

\begin{tabular}{|c|c|c|c|c|}
\cline { 2 - 5 } Q Dovista & Ano 8 & n. 14 & Janeiro - Julho 2019 & p. $91-109$ \\
\hline
\end{tabular}


Dessa forma, a autonomia da razão perde o seu sentido ao ser moldada pelas exigências técnicas do aparato que ela mesma criou. Quanto mais os indivíduos se comportam racionalmente conforme esse modelo de racionalidade -, tanto mais sucumbem aos aspectos frustrantes da cultura do consumo. A condição de irracionalidade a que os indivíduos foram reduzidos, contraditoriamente, tornou-se a base de sua sobrevivência. "Defrontamos novamente com um dos aspectos mais perturbadores da civilização industrial desenvolvida: o caráter racional de sua irracionalidade" (MARCUSE, 1973, p. 29).

Freud (1996) mostrou que o superego do homem é um aparato repressor interno e se apresenta como vantagem cultural preciosa, pois é por ele que os valores socioculturais são internalizados evitando medidas externas de coerção. Esse pressuposto, por um lado, serve ao processo civilizatório, pois retira o homem da condição de natureza e o coloca na condição cultural. A repressão transforma os indivíduos. Por outro lado, pode fazer com que os indivíduos introjetem a cultura dominante, no caso, a cultura do consumo, garantindo a reprodução do sistema capitalista enquanto reproduzem a sua existência.

Salta aos olhos tamanha alteração da individualidade. A relação entre o exterior, que deveria ser antagônico, e o interior do indivíduo, que parece ter perdido esse caráter de liberdade. O espaço privado foi invadido e desbastado pela realidade tecnológica. Assim, a identificação imediata e automática com o aparato parece anular a dimensão interior da mente, essa dimensão que faz o indivíduo ser o que ele é. “A perda dessa dimensão, na qual o poder de pensamento negativo - o poder crítico da Razão - está à vontade, é a contrapartida ideológica do próprio processo material no qual a sociedade industrial desenvolvida silencia e reconcilia a oposição" (MARCUSE, 1973, p 31).

Evidentemente, as transformações ocorridas nas sociedades industriais provocaram mudanças na consciência e na ação política das classes que se confrontam historicamente na sociedade: a burguesia e o proletariado. A estrutura e a função dessas duas classes foram alteradas, de tal modo que elas não parecem mais ser agentes de transformação histórica. Os antigos antagonistas parecem ter objetivos comuns, a saber, defender um padrão de vida que legitima e perpetua o status quo.

Diante do caráter total das conquistas da sociedade industrial desenvolvida, a Teoria Crítica parece desprovida de fundamento lógico para transcender essa sociedade. As categorias e termos pertencentes a essa teoria, que outrora foram criados em um período no qual a necessidade de recusa e subversão estava personificada na ação de forças sociais eficazes, contemporaneamente, foram reduzidas a críticas previstas dentro do status quo dominante e

\begin{tabular}{|c|c|c|c|c|}
\cline { 2 - 4 } Govista Dialectus & Ano 8 & n. 14 & Janeiro - Julho 2019 & p. $91-109$ \\
\hline
\end{tabular}


operacionais dentro da lógica do capital. A consciência feliz não fomenta a crítica para além do já previsto pelo sistema (KELLNER, 2011).

Portanto, ambas as classes sociais sucumbem à mesma lógica de dominação social ao cederem a pressão da vida administrada pela conquista da consciência feliz. Na falta desses agentes de transformação, a crítica é recuada para um alto nível de abstração, mas ainda assim, o filósofo ressalta a importância da Teoria Crítica diante desse cenário, pois “[...] a análise crítica continua insistindo em que a necessidade de transformação qualitativa é tão premente quanto em qualquer época. Necessária a quem? A resposta continua sendo a mesma: à sociedade como um todo, para cada um de seus membros” (MARCUSE, 1973, p. 16).

$\mathrm{O}$ fato de ambas as classes sociais sucumbirem à lógica do sistema não significa que a luta de classes chegou ao fim, mas tão somente que os indivíduos introjetraram os valores da cultura afirmativa $^{4}$, transformando a livre consciência em consciência feliz, que á a expressão mais clara da falsa consciência. Nesse ponto, vale ressaltar que a falsa consciência é o que constitui, propriamente, a ideologia da sociedade industrial. O conceito de ideologia foi muito bem definido nesses termos por Chaui (2013, p. 117):

\begin{abstract}
A ideologia é um conjunto lógico, sistemático e coerente de representações (ideias e valores) e de normas ou regras (de conduta) que indicam e prescrevem aos membros de uma sociedade o que devem pensar, o que devem valorizar e como devem valorizar, e que devem sentir e como devem sentir, o que devem fazer e como devem fazer. Ela é, portanto, um conjunto de ideias ou representações com teor explicativo (ela pretende dizer o que é a realidade) e prático ou de caráter prescritivo, normativo, regulador, cuja função é dar aos membros de uma sociedade dividida em classes uma explicação racional para as diferenças sociais, políticas e culturais, sem jamais atribuílas à divisão da sociedade em classes, determinada pelas divisões na esfera da produção econômica.
\end{abstract}

Vale ressaltar que a falsa consciência é o que constitui, propriamente, a ideologia nesse sentido apontado pela autora. Essa ideologia é a base para a transformação da racionalidade tecnológica em racionalidade política, como se vislumbra na seção seguinte.

\title{
2. A relação estreita entre a racionalidade política e as falsas necessidades
}

O padrão de vida crescente na sociedade capitalista, em seu atual estágio de desenvolvimento, sustém o controle da natureza e a dominação dos homens a partir do sistema

\footnotetext{
4 Marcuse desvenda a mecânica afirmativa da cultura como modo de garantir a subordinação do indivíduo ao universal dado, eternizando-o. Dizer que a cultura possui caráter afirmativo é questionar a sua negatividade, sua dimensão emancipatória (MAAR, 1997, p. 26).

\begin{tabular}{|l|c|c|c|c|}
\hline Qovista 2 ialectus & Ano 8 & n. 14 & Janeiro - Julho 2019 & p. $91-109$ \\
\hline
\end{tabular}
}


de produção e consumo. Esse modelo de organização social "antevê maneiras específicas de utilizar o homem e a natureza e rejeita outras maneiras", portanto, trata-se de um projeto de organização social entre outros, "mas, assim que o projeto se torna operante nas instituições e relações básicas, tende a tornar-se exclusivo e a determinar o desenvolvimento da sociedade em seu todo" (MARCUSE, 1973, p. 19).

A conquista da natureza levou à conquista dos indivíduos tecnologicamente. Marcuse deixa claro que a racionalidade tecnológica opera desde o seu conceito, politicamente. E esse caráter político é revelado quando ela "se torna o grande veículo de melhor dominação, criando um universo verdadeiramente totalitário no qual sociedade e natureza, corpo e mente são mantidos num estado de permanente mobilização para a defesa desse universo" (MARCUSE, 1973, p. 37). A dominação tecnológica possui um suporte político.

Por rejeitar outras maneiras de utilização dos recursos materiais e intelectuais, senão a transformação da natureza como mero material de controle e dos indivíduos como mera força de trabalho disponível para a dominação, Marcuse (1973, p. 19) entende que as sociedades capitalistas são totalitárias e unidimensionais, porque moldam "todo universo da palavra e da ação, a cultura intelectual e material. [...] No ambiente tecnológico, a cultura, a política e a economia se fundem num sistema onipresente que engolfa ou rejeita todas as alternativas". Em resumo, são totalitárias porque invadem todas as esferas da vida e unidimensionais porque impedem o florescimento de outras alternativas históricas de organização social diferentes da vigente.

A contradição é negada pela unidimensionalidade dessa sociedade, aspecto esse que foi resultado da eficiência e do poder da sociedade tecnológica/industrial que oprimiu o indivíduo a ponto dele perder os traços característicos da racionalidade crítica - autonomia, discordância, poder de negação, etc. (KELLNER, 1999). Os indivíduos foram presos numa única dimensão da realidade, surgindo assim o que Marcuse denominou de "homem unidimensional", que é subproduto de uma racionalidade e sociedade unidimensionais. Os indivíduos foram despidos de suas capacidades críticas pela racionalidade unidimensional sob a qual vivem e agora parecem renunciar à liberdade sob os ditames do aparato que introjetaram. O termo aparato designa as instituições, dispositivos e organizações da indústria que representam a ordem dominante.

Cabe ao aparato reduzir toda a potencialidade do pensamento crítico à unidimensionalidade e eliminar qualquer oposição eficaz ao todo. Sua função é reprimir, precondicionar e introjetar a falsa consciência. A forma como as sociedades capitalistas

\begin{tabular}{|c|c|c|c|c|}
\cline { 2 - 4 } Govista & Ano 8 & n. 14 & Janeiro - Julho 2019 & p. $91-109$ \\
\hline
\end{tabular}


organizam suas bases produtivas precisa ser totalitária e unidimensional, sem se configurar uma coordenação política terrorista, mas tão somente "uma coordenação técnico-econômica nãoterrorista que opera através da manipulação das necessidades por interesses adquiridos" (MARCUSE, 1973, p. 25).

O aparato técnico de produção e distribuição funciona como um sistema que determina, a priori, tanto o produto do aparato como as operações de sua manutenção e ampliação, ligadas a funções sociais e políticas específicas. Assim, a técnica e a tecnologia, materializadas nos produtos tecnológicos, desempenham um papel fundamentalmente político para a manutenção da ordem dominante e servem para instituir formas novas - eficazes e agradáveis - de controle e coesão social.

Os produtos doutrinam e manipulam; promovem uma falsa consciência que é imune à sua falsidade. E, ao ficarem esses produtos benéficos à disposição de maior número de indivíduos e de classes sociais, a doutrinação que eles portam deixa de ser publicidade; torna-se um estilo de vida. É um bom estilo de vida - muito melhor do que antes - e, como um bom estilo de vida, milita contra a transformação qualitativa (MARCUSE, 1973, p. 32).

As sociedades capitalistas são capazes de atender às necessidades dos indivíduos devido à forma como estão organizadas, voltadas para a produção e o consumo eficientes em meio à promessa de um padrão de vida crescente e de um estilo de vida conforme os padrões dominantes. A reprodução do sistema depende da repressão das possibilidades reais de transformação social. Para tanto, os precondicionamentos para a cultura do consumo se sobrepõem um após o outro de acordo com o próprio desenvolvimento histórico do capital.

Esse aspecto ideológico fica em silenciosa presença na mente dos indivíduos, dando a falsa sensação de uma plena consciência de que não há alternativa senão buscar por si mesmo concretizar um bom estilo de vida. O indivíduo se sente capaz, por meio do seu esforço e trabalho, de satisfazer todas as suas necessidades, quando, na verdade, não é ele que cria as suas necessidades, já que são necessidades superimpostas. Portanto, independe do quanto essas necessidades tenham sido próprias do indivíduo, o que importa é que foram reproduzidas e fortalecidas na luta pela existência e, mesmo que o indivíduo encontre satisfação em tais necessidades, estas continuam a ser produtos de uma sociedade cujo interesse dominante exige repressão.

Em última análise, a questão sobre quais necessidades devam ser falsas ou verdadeiras só pode ser respondida pelos próprios indivíduos, mas apenas em última análise; isto é, se e quando eles estiverem livres para dar a sua própria resposta. Enquanto eles forem mantidos incapazes de ser

\begin{tabular}{|c|c|c|c|c|}
\cline { 2 - 4 } Q Devistalectus & Ano 8 & n. 14 & Janeiro - Julho 2019 & p. 91 - 109 \\
\hline
\end{tabular}


autônomos, enquanto forem doutrinados e manipulados (até os seus próprios instintos) a resposta que derem a essa questão não poderá ser tomado por sua. E, por sinal, nenhum tribunal pode com justiça se arrogar o direito de decidir quais necessidades devam ser incrementadas e satisfeitas. Qualquer tribunal do gênero é repreensível, embora a nossa revulsão não elimine a questão: como podem as pessoas que tenham sido objeto de dominação eficaz e produtiva criar elas próprias as condições de liberdade? (MARCUSE, 1973, p. 27).

De acordo com o excerto, a repressão e os precondicionamentos tendem a eliminar a liberdade dos indivíduos com formas agressivas de doutrinamento e não cabe julgar quais necessidades devem ser satisfeitas, mas incisivamente denunciar a ideologia que está por trás desse fenômeno, tendo em vista que "quanto mais racional, produtiva, técnica e total se torna a administração repressiva da sociedade, tanto mais inimagináveis se tornam os modos e os meios pelos quais os indivíduos administrados poderão romper sua servidão e conquistar sua própria libertação" (MARCUSE, 1973, p. 28). Toda libertação depende da consciência de servidão e o surgimento dessa consciência é sempre obstaculizado pela predominância de falsas necessidades e satisfações que se tornam, em grande proporção, do próprio indivíduo. Portanto, a satisfação dos interesses individuais, longe de significar a expressão da liberdade, representa, na verdade, a perpetuação das relações de produção e consumo precondicionadas.

A mais eficaz forma de guerra contra a liberdade é a implantação de necessidades falsas que perpetuam formas obsoletas de luta pela existência. E pouco importa se a satisfação dessas necessidades é conseguida em um sistema totalitário ou não-totalitário, já que numa sociedade com padrão de vida crescente a crítica e o inconformismo são socialmente inúteis.

À medida que o capitalismo e a tecnologia foram se desenvolvendo, a sociedade industrial avançada foi exigindo um ajuste cada vez maior ao aparato econômico e social, além da submissão à crescente dominação e administração totais. Desta forma, uma "mecânica do conformismo" se espalhou pela sociedade (KELLNER, 1999, p. 26).

A intensidade, a satisfação e até o caráter das necessidades humanas, para além do nível biológico $^{5}$, sempre foram precondicionadas e destinadas a promover a mecânica do conformismo. Trata-se de falsas necessidades, cujo desenvolvimento e satisfação são heterônomos, já que o seu conteúdo e função social são determinados por forças externas que o indivíduo não tem controle algum.

\footnotetext{
5 “As únicas necessidades que tem direito indiscutível à satisfação são as necessidades vitais - de alimento, roupa e teto ao nível alcançável de cultura. $\mathrm{O}$ atendimento a essas necessidades é o requisito para a realização de todas as necessidades, tanto das sublimadas como das não-sublimadas” (MARCUSE, 1975, p. 27).
}

\begin{tabular}{|l|c|c|c|c|}
\hline Govista Dialectus & Ano 8 & n. 14 & Janeiro - Julho 2019 & p. 91 - 109 \\
\hline
\end{tabular}


Grande parte das necessidades comuns padronizadas de diversão, descanso, comportamento, consumo, etc., pertencem à categoria de falsas necessidades e perpetuam a labuta, a agressividade, a miséria e a injustiça. São falsas justamente porque escamoteiam a ideologia do sistema a partir da falsa consciência.

As necessidades humanas estão em estreita relação com o desenvolvimento das forças produtivas e das condições históricas objetivas, porém deveria envolver "padrões que se referem ao desenvolvimento ótimo do indivíduo, de todos os indivíduos, sob a ótima utilização dos recursos materiais e intelectuais à disposição do homem” (MARCUSE, 1973, p. 27). E não é o que se observa no atual estágio de desenvolvimento do capital, uma vez que não houve a suavização da luta pela existência; da mesma forma, a miséria dos indivíduos em diferentes partes do planeta, bem como a satisfação de suas necessidades vitais não são atendidas. Então, não são padrões universalmente válidos, pois decorre da falsa consciência em face da ideologia das sociedades capitalistas, cuja perspectiva política é dominar para se reproduzir sem que haja oposição. A saída apontada por Marcuse está na restituição da razão crítica, que é capaz de libertar a consciência dominada. Sobre a consciência ele diz o seguinte:

O homem tem de vê-la e passar da consciência falsa para a verdadeira, do interesse imediato para o interesse real. Só poderá fazê-lo se viver com a necessidade de modificar o seu estilo de vida, de negar o positivo, de recusar. É precisamente essa necessidade que a sociedade estabelecida consegue reprimir com a intensidade com que é capaz de "entregar as mercadorias" em escala cada vez maior, usando a conquista científica da natureza para conquistar o homem cientificamente (MARCUSE, 1973, p. 17).

Eis o problema, as sociedades capitalistas contemporâneas se mostram capazes de conter a transformação social qualitativa e de estabelecer instituições sociais diferentes a partir de outras concepções de existência humana (que poderiam promover um novo direcionamento nos processos produtivos) pela conquista científica dos indivíduos e da natureza. Tal conquista leva a supressão da crítica e apazigua os antagonistas sociais, estabelecendo um falso consenso que refuta toda a oposição por meio de um sistema tecnológico de dominação e coordenação social. "Essa contenção da transformação é, talvez, a mais singular realização da sociedade industrial desenvolvida" (MARCUSE, 1973, p. 16).

Nesse contexto, a Teoria Crítica enfrenta o seu principal problema, a saber, que a crítica negativa não faz sentido e beira a especulação diante da ideia de transformação social. E, para a Teoria Crítica a negatividade possui um papel fundamental como crítica e forma de evidenciar as contradições para acelerar o movimento das transformações sociais. No caso, a tensão que

\begin{tabular}{|c|c|c|c|c|}
\cline { 2 - 4 } Q Q Onialectus & Ano 8 & n. 14 & Janeiro - Julho 2019 & p. $91-109$ \\
\hline
\end{tabular}


observa está na exclusão da contradição entre o positivo e o negativo em prol de um falso consenso que só fortalece a unidimensionalidade.

Diante desse quadro, o papel da Teoria Crítica é apontar as possíveis alternativas históricas para transformação qualitativa da sociedade. Ela "[...] analisa a sociedade à luz de suas aptidões utilizadas e não-utilizadas ou malbaratadas para aprimorar a condição humana" (MARCUSE, 1973, p. 14). Em última instância, pretende compreender dialeticamente as várias maneiras possíveis e reais de organizar os recursos materiais e intelectuais com ótimo desenvolvimento e possibilidade de suavizar a luta pela existência. Para tanto, avalia os valores que alicerçam as diferentes propostas de organização social para mostrar: 1) se na organização social vigente a vida humana possui dignidade e vale a pena ser vivida; 2) se nela é possível melhorar a vida e se há meios específicos para realizá-la. Cabe analisar se a organização social dispõe de meios para minimizar a labuta pela existência, fazendo uso dos recursos materiais e intelectuais para otimizar a satisfação das necessidades básicas humanas e o desenvolvimento pleno das faculdades individuais.

É o que se investiga nesse artigo, não com a pretensão de apresentar respostas aos problemas emergentes nas sociedades capitalistas, mas de produzir alguma síntese das contradições do nosso tempo com base na racionalidade que permeia as relações humanas. Os pressupostos que Marcuse apresenta acerca da racionalidade tecnológica continuam atuais: não há como desprezar a ideologia capitalista e as contradições sociais que ela produz como o motor da história da humanidade. Além das contradições sociais, na seção seguinte, evidenciou-se a contradição entre a liberdade e a servidão - pensada a partir do pensamento freudiano -, com o intuito de compreender os aspectos psicológicos que fundamentam a dominação da subjetividade.

\section{A compatibilização teórica entre marxismo-freudismo}

O filósofo Herbert Marcuse se destacou como importante teórico do Instituto de Pesquisa Social, filiado à Universidade de Frankfurt. Ele contribuiu para a construção e consolidação de uma teoria social, que ficou conhecida como Teoria Crítica da Sociedade. Em artigo intitulado Filosofia e Teoria Crítica, publicado originalmente em 1937, como parte da elaboração do projeto teórico do Instituto de Pesquisa Social, Marcuse apontou alguns

\begin{tabular}{|c|c|c|c|c|}
\cline { 2 - 4 } & Ano 8 & n. 14 & Janeiro - Julho 2019 & p. $91-109$ \\
\hline
\end{tabular}


direcionamentos metodológicos que são próprios da Teoria Crítica e que o acompanhou ao longo de seus escritos:

[...] a Teoria Crítica da Sociedade está essencialmente vinculada ao materialismo. [...] Há sobretudo dois momentos que vinculam o materialismo à correta teoria da sociedade: a preocupação em torno da felicidade dos homens, e a convicção de que esta felicidade seja conseguida somente mediante uma transformação das relações materiais da existência (MARCUSE, 1997, p. 138).

O autor, como se nota pelo excerto, não faz concessões para o capital, ou seja, para haver transformações sociais qualitativas tem de haver mudanças na estrutura e nas relações materiais de existência. O sistema capitalista tem de esgotar as suas possibilidades e dar lugar a novas formas de existência e os estudos interdisciplinares propostos pelos frankfurtianos pode ser um caminho para vislumbrar possibilidades.

Quando Horkheimer assumiu a diretoria do Instituto de Pesquisa Social, em 1930, propôs um programa de trabalho que enfatizava, sobretudo, a interdisciplinaridade. A Teoria Crítica como fruto da compatibilização entre o pensamento marxista e o freudiano se apresentou como a grande novidade naquele período e abriu espaço para pensar um projeto denominado "materialismo interdisciplinar", que aglutinou em torno do Instituto de Pesquisa Social intelectuais de diversas áreas do conhecimento congregados em um trabalho conjunto de pesquisa como Herbert Marcuse, Max Horkheimer, Erich Fromm, Theodor Adorno, Walter Benjamin, dentre outros (MUSSE, 1997). "Nestes termos, uma das principais tarefas consistia numa adequada refundamentação do pensamento dialético-materialista: eis o eixo da atividade de investigação teórico-filosófica que caberia a Marcuse no ambiente frankfurtiano" (MAAR, 1997, p. 15).

A permanência e a estabilidade do capitalismo foi o que justificou a inclusão da teoria freudiana, entre outros saberes na elaboração conceitual da Teoria Crítica da Sociedade. A finalidade dessa compatibilização feita pelo materialismo interdisciplinar era possibilitar uma compreensão mais abrangente dos aspectos que mantinham a reprodução do sistema capitalista. Nesse sentido, a principal justificativa para o "marxismo-freudismo" se deu, principalmente, pelo fato dos aspectos psicológicos serem decisivos para compreender como um regime repressivo pode ser sustentado pelos oprimidos que vivem nele.

A questão do momento estático do capitalismo, isto é, do seu movimento de reprodução, veio à tona com bastante ênfase, justificando a necessidade, para além dos aspectos econômicos, de

\begin{tabular}{|c|c|c|c|c|}
\cline { 2 - 4 } & Ano 8 & n. 14 & Janeiro - Julho 2019 & p. $91-109$ \\
\hline
\end{tabular}


compreender os demais fatores, sobretudo os psicológicos, atuantes na permanência de um regime que beneficia apenas uma minoria (MUSSE, 1997, s/p).

Havia um pressuposto fundamental a ser compreendido, que era o fato da luta pela permanência e estabilidade do capital não estar sendo travada somente nas esferas política e econômica, mas sobretudo na esfera cultural.

Em livro intitulado O futuro de uma ilusão, Freud (1996) revelou a relação entre os fatores econômicos e os fatores psicológicos que contribuiu para o entendimento do porque a classe trabalhadora renunciou ao seu destino histórico de revolucionar a ordem vigente (FREITAG, 1988). Da mesma forma, a confluência entre marxismo e freudismo permitiu justificar como os indivíduos estão sendo recompensados pelos seus sacrifícios (trabalho) para sublimar a repressão. Marcuse aponta que a introjeção dos valores sociais vigentes na sociedade industrial foi fundamental para consolidar a racionalidade tecnológica.

A recompensa pelos sacrifícios está sugestivamente associada à troca da liberdade pelo conforto. Ou seja, houve a promoção de um conformismo geral pela falsa promessa de felicidade e de bem-estar social em estreita relação com a cultura do consumo.

A situação é delicada. Os consumidores são, afinal, portadores de uma nova exigência de felicidade. No mercado, para onde os conduzem seus desejos, estão condenados a se frustrarem, já que poucos - pouquíssimos! - dispõem de poder de compra suficiente para adquirirem o que supõem que deverá fazê-los felizes. (KONDER, 1998, p. 19).

Essa é a lógica perversa do sistema introjetada pelos indivíduos que, em grande medida, ainda representa, hoje, um problema na luta por emancipação, porque a promessa de felicidade não se cumpre para todos, mas para uma pequena parcela da população. A despeito disso, "uma falta de liberdade confortável, suave, razoável e democrática prevalece na civilização industrial desenvolvida, um testemunho de progresso técnico" (MARCUSE, 1973, p. 23).

Os indivíduos não somente se adaptaram a um padrão de vida crescente marcado pela fluidez na distribuição de mercadorias, mas se tornaram veículos de uma cultura. "O que principiou como submissão pela força cedo se converteu em servidão voluntária, colaboração em reproduzir uma sociedade que tornou a servidão cada vez mais compensadora e agradável ao paladar" (MARCUSE, 1975, p. 15). A contradição entre liberdade e servidão foi naturalizada e se tornou um veículo do progresso.

O pensamento freudiano, nesse aspecto, foi fundamental para interpretar as sociedades industriais, pois mostram a existência de um aspecto sociopsicológico que interfere na condição

\begin{tabular}{|c|c|c|c|c|}
\cline { 2 - 4 } Q Q Onialectus & Ano 8 & n. 14 & Janeiro - Julho 2019 & p. $91-109$ \\
\hline
\end{tabular}


política, - os indivíduos introjetam a ideologia dominante e reproduzem os controles externos exercidos pela sociedade capitalista. É fato, portanto, que o precondicionamento da subjetividade garante a reprodução do capital, isto é, ao lutar pela a existência os indivíduos reproduzem o sistema.

No livro Eros e Civilização: uma interpretação filosófica do pensamento de Freud, publicado em 1955, Marcuse emprega categorias freudianas para explicar como as condições psicológicas se converterem em condições políticas para a reprodução do capital.

\begin{abstract}
O homem animal converte-se em ser humano somente através de uma transformação fundamental da sua natureza, afetando não só os anseios instintivos, mas também os 'valores instintivos' - isto é - os princípios que governam a consecução dos anseios [...] Freud descreveu essa mudança como a transformação do princípio de prazer em princípio de realidade (MARCUSE, 1975, p. 34). Grifos do autor.
\end{abstract}

Essa passagem do princípio de prazer para o princípio de realidade - da ordem instintiva para a ordem racional - foi um acontecimento traumático no desenvolvimento do homem em sua individualidade (ontogeneticamente) e na coletividade (filogeneticamente). O princípio de realidade materializa-se em um sistema de instituições e o indivíduo inserido nesse sistema apreende os requisitos desse princípio, ou seja, a lei e a ordem, transmitindo-os às gerações seguintes. Com o estabelecimento do princípio de realidade o ser humano suprimiu o princípio de prazer: o que outrora era "um feixe de impulsos animais" foi convertido em um ego organizado. Nesse sentido, os indivíduos tornaram-se conscientes e propícios para introjetar uma racionalidade imposta de fora. Trata-se de uma luta contra a liberdade que ocorre na mente do homem, como uma "autorepressão" do indivíduo reprimido. "É essa dinâmica mental que Freud desvenda como a dinâmica da civilização" (MARCUSE, 1975, p. 37).

Para Marcuse (1975), um dos motivos da sociedade impor a modificação da estrutura instintiva é econômico, até porque ela não tem meios suficientes para sustentar a vida de seus membros sem o trabalho deles, porém "a livre gratificação das necessidades instintivas do homem é incompatível com a sociedade civilizada" (MARCUSE, 1975, p. 26). Dessa forma, nas sociedades capitalistas está previsto o desvio das energias das atividades sexuais dos indivíduos para o trabalho alienado.

O trabalho tornou-se agora geral, assim como as restrições impostas à libido: o tempo de trabalho, que ocupa a maior parte do tempo de vida de um indivíduo, é um tempo penoso, visto que o trabalho alienado significa ausência de gratificação, negação do princípio de prazer. A libido é desviada para desempenhos socialmente úteis, em que o indivíduo trabalha para si mesmo somente na medida em que trabalha para o sistema, empenhado em atividades que, na

\begin{tabular}{|c|c|c|c|c|}
\cline { 2 - 4 } Q Revista Dialectus & Ano 8 & n. 14 & Janeiro - Julho 2019 & p. $91-109$ \\
\hline
\end{tabular}


grande maioria dos casos, não coincidem com suas próprias faculdades e desejos (MARCUSE, 1975, p. 58).

De um ponto de vista psicológico, o processo de repressão internalizado pelo superego permitiu o processo civilizatório, mas, de um ponto de vista político, Marcuse mostra que a sociedade industrial conquistou os homens cientificamente, isto é, os homens reproduzem a eficiência do aparato tecnológico e vivem sob a constante repressão e mais-repressão para mantê-lo, consumindo mercadorias. A repressão produz modificações nos instintos necessários à perpetuação do processo civilizatório e a mais-repressão, por sua vez, designa as restrições requeridas pela dominação social contemporânea, distinguindo-se, portanto, da repressão. Foi preciso introjetar nos indivíduos os valores da cultura do consumo para implantar gradualmente um processo de administração total da vida. Isso porque o fenômeno da reprodução e perpetuação dos controles externos depende da internalização da repressão.

A administração científica das necessidades instintivas converteu-se, desde há muito, em fator vital na reprodução do sistema: a mercadoria que tem de ser comprada e usada traduz-se em objetos da libido [...] o povo, eficientemente manipulado e organizado, é livre; a ignorância e a impotência, a heteronomia introjetada, é o preço de sua liberdade. (MARCUSE, 1975, p. 14).

Percebe-se que a ideologia da sociedade industrial explorou e dominou a consciência do indivíduo por meio de processos de introjeção, reduziu e alterou a condição de um potencial opositor ao sistema a veículo de sua cultura.

Dessa forma, ideia de liberdade interior ganhou outra conotação sob os ditames repressivos da ideologia da sociedade industrial, tornando-se um poderoso instrumento de dominação. A escolha não é mais um parâmetro para determinar o grau de liberdade, mas o que pode ser escolhido entre uma ampla variedade de mercadorias e serviços que sustêm pleno controle sobre a vida. As necessidades superimpostas pelo sistema de produção testemunham a eficácia da internalização da repressão, inserindo um hábito de busca incessante por satisfação, que é por si mesmo, uma forma de compensação.

\section{Considerações finais}

A ideologia da sociedade industrial explorou o indivíduo naquilo que é especificamente seu: a consciência. Por meio de processos de introjeção transformou e moldou os indivíduos para a servidão voluntária, isto é, para se reproduzir enquanto a luta pela existência se

\begin{tabular}{|c|c|c|c|c|}
\cline { 2 - 4 } Q Q Onialectus & Ano 8 & n. 14 & Janeiro - Julho 2019 & p. $91-109$ \\
\hline
\end{tabular}


materializa no trabalho alienado em função dos interesses capitalistas. A mecânica do conformismo tem suprimido as possibilidades de oposição ao sistema e as perspectivas alternativas de organização social.

Nota-se que a unidimensionalidade fortaleceu o falso consenso e escondeu as contradições sociais. A troca da liberdade pelo conforto se tornou uma promessa de felicidade que se concretiza para poucos, mas tem servido aos propósitos da compensação e da sublimação para todos os indivíduos, a despeito da administração total da vida por meio da repressão e da mais repressão ter progressivamente se intensificado.

Em vista do exposto, a transformação social qualitativa depende da consciência da servidão e, a restituição da razão crítica é tarefa para Teoria Crítica realizar todos os dias, a fim de minimizar os impactos da mecânica do conformismo e para manter vivo o espírito de resistência, de recusa, de insubordinação de insubmissão ao sistema que explora a subjetividade e inviabiliza a passagem do reino da necessidade ao reino da liberdade. A luta, agora, é para transformar o nosso estilo de vida condicionado, de negar o positivo, de recusar! Diante do poder ideológico e da totalidade repressiva das sociedades capitalistas, evidenciar para negar continua a ser o passo fundamental para qualquer transformação social qualitativa.

Até o momento, observou-se que as sociedades capitalistas não minimizam a luta pela existência e nem utilizam os recursos materiais e intelectuais para melhorar a vida de todos os indivíduos, mas apenas de poucos que conseguem satisfazer plenamente suas pulsões. No atual estágio de desenvolvimento das forças produtivas, a revolução tecnológica tem produzido mais exclusão do mercado de trabalho do que proporcionado meios de luta justa pela existência de todos os indivíduos. No planeta, as economias que representam as periferias do capital não têm expectativas nem de inserção e nem de crescimento por meio do trabalho, senão os países ditos emergentes que estão na vanguarda da economia dependente com a nobre missão de produzir commodities (como é o caso do Brasil) para os países ricos e detentores dos meios de dominação - detentores dos meios necessários para a produção tecnológica.

Possivelmente, teremos de repensar a ideia de um exército de reserva e entender que as formas de exclusão do trabalho geram um exército de miseráveis sem expectativa, em meio à riqueza e desenvolvimento produzidos pela reestruturação produtiva com base na racionalidade tecnológica e no pensamento neoliberal encabeçado pelos organismos internacionais, como o Banco Mundial, o Fundo Monetário Internacional, Organização Mundial do Comércio, dentre outros.

\begin{tabular}{|c|c|c|c|c|}
\cline { 2 - 4 } Q Devista & Ano 8 & n. 14 & Janeiro - Julho 2019 & p. $91-109$ \\
\hline
\end{tabular}


Essa perspectiva representa a grande tensão do nosso tempo. A contradição que precisa ser pensada e repensada a fim de que se produzam sínteses a guisa de possíveis caminhos para a superação do capital, que já tem dado mostras de esgotamento das possibilidades civilizatórias. Problemas de todas as ordens explodem em todas as partes do mundo ambientais, sociais, culturais, políticos, religiosos. Serão problemas insolúveis?

\section{Referências:}

CHAUI, M. Manifestações ideológicas do autoritarismo brasileiro. Organizador André Rocha. Belo Horizonte/MG: Autêntica; São Paulo: Editora Fundação Perseu Abramo, 2013.

FREITAG, B. A Teoria Crítica: ontem e hoje. 2. ed. São Paulo: Brasiliense, 1988.

FREUD, S. O futuro de uma ilusão; O mal-estar na civilização e outros trabalhos (1927 1931). Edição Standard brasileira das obras psicológicas completas de Sigmund Freud. Vol. XXI. Rio de Janeiro: Imago, 1996.

KELLNER, D. Introdução. Tecnologia, guerra e fascismo: Marcuse nos anos 40. In: KELLNER, D. (editor). Tecnologia, guerra e fascismo: coletânea de artigos de Herbert Marcuse. São Paulo: UNESP, 1999.

On Marcuse: critique, liberation, and reschooling in the radical pedagogy of Herbert Marcuse. Sobre Marcuse: crítica, libertação e reeducação na pedagogia radical de Herbert Marcuse. In.: Revista Estudos e Pesquisas em Psicologia [online]. Vol.11, n . 1, 2011, p. 2355. http://pepsic.bvsalud.org/pdf/epp/v11n1/v11n1a03.pdf. Acessado em 10/10/2018

KONDER, L. O que é dialética. São Paulo: Brasiliense, 2006. p. $15-28$.

Marcuse, revolucionário. In.: Physis: Rev. saúde coletiva. 8(1). Rio de Janeiro, 1998,

MAAR, W. L. Marcuse: em busca de uma ética materialista. In: MARCUSE, H. Cultura e Sociedade. Vol. I. 1. ed. São Paulo: Paz e Terra, 1997.

MARCUSE, H. A ideologia da sociedade industrial: o homem unidimensional. 4. ed. Rio de Janeiro: Zahar, 1973.

Eros e Civilização: uma interpretação filosófica do pensamento de Freud. 6. ed. Rio de Janeiro: Zahar, 1975.

Filosofia e Teoria Crítica. In: MARCUSE, H. Cultura e Sociedade. Vol. I. 1. ed. São Paulo: Paz e Terra, 1997.

\begin{tabular}{|l|c|c|c|c|}
\cline { 2 - 4 } & Ano 8 & n. 14 & Janeiro - Julho 2019 & p. $91-109$ \\
\hline
\end{tabular}


Algumas implicações sociais da tecnologia moderna. In: KELLNER, D. (editor). Tecnologia, guerra e fascismo: coletânea de artigos de Herbert Marcuse. São Paulo: UNESP, 1999.

MUSSE. R. As raízes marxistas da Escola de Frankfurt. Conferência proferida em 14 de julho de 1997, na abertura do Curso de Extensão sobre a Escola de Frankfurt para o Curso de Direito, na Faculdade de Direito da UFPR. Disponível em: http://webcache.googleusercontent.com. Acessado em 11/01/16.

\begin{tabular}{|l|c|c|c|c|}
\cline { 2 - 4 } Q Q Dialectus & Ano 8 & n. 14 & Janeiro - Julho 2019 & p. 91 - 109 \\
\hline
\end{tabular}




\title{
OS LIMITES DA TOLERÂNCIA: UMA ANÁLISE A PARTIR DAS CONCEPÇÕES DE MARCUSE
}

\author{
John Karley de Sousa Aquino ${ }^{1}$
}

\begin{abstract}
Resumo:
O presente artigo tem por objetivo tematizar os limites da tolerância pura, definida por Herbert Marcuse como uma tolerância ilimitada, indefinida, que pressupõe que tudo deve ser tolerado, inclusive o intolerável, como expressões e práticas preconceituosas. Pretendemos a partir do artigo de Marcuse Crítica da tolerância repressiva (1965) delimitar os limites do conceito liberal de tolerância e propor um contra conceito, o de tolerância concreta, com limites definidos que determina a diferença entre o tolerável e o intolerável, desmascarando o caráter ideológico do conceito liberal de tolerância que se tornou repressivo.
\end{abstract}

Palavras-chave: Tolerância pura. Tolerância concreta. Herbert Marcuse.

\section{THE TOLERANCE LIMITS: AN ANALYSIS FROM THE CONCEPTIONS OF MARCUSE}

\begin{abstract}
:
The present paper aims to thematize the limits of pure tolerance, defined by Herbert Marcuse as an unlimited, indefinite tolerance, which presupposes that everything must be tolerated, including intolerable, as biased expressions and practices. We intend from Marcuse's paper Critique of Repressive Tolerance (1965) to delimit the limits of the liberal concept of tolerance and propose a counter concept, that of concrete tolerance, as defined limits that determines the difference between the tolerable and the intolerable, unmasking the liberal concept of tolerance that has become repressive.
\end{abstract}

Palavras-chave: Pure tolerance. Concrecte intolerance. Herbert Marcuse.

\section{Introdução}

Que não venham os despreziveis eunucos nos dizer que são iguais diante de um tribunal da moral um senhor de escravos que, mediante astúcia e violência, acorrenta um escravo, e um escravo que, mediante astúcia e violência, rompe os grilhões!

Trotsky, A moral deles e a nossa

Atualmente nos deparamos com um fenômeno interessante: conservadores com opiniões preconceituosas, que outrora defenderam a censura, reclamando seu direito à liberdade de expressão. Homofóbicos como políticos e pastores da "bancada da bíblia" exigem que suas declarações sejam toleradas em respeito ao direito inalienável que eles têm de emitir suas opiniões sejam elas quais forem. Quando nossos preconceituosos e intolerantes conservadores

\footnotetext{
${ }^{1}$ Doutorando em filosofia pelo programa de pós-graduação em filosofia da UFC. Professor EBTT/IFCE (campus Itapipoca). Vice-líder do grupo de pesquisa Atualidade do pensamento político de Marcuse (UECE) e membro dos grupos de pesquisa Centelha (IFCE) e do Grupo de Estudos marxistas (UFC). E-mail: johnksousa@gmail.com.
} 
recorrem aos ideais modernos de tolerância e liberdade de expressão os limites desses ideais iluministas ficam expostos e é hora de refletirmos sobre isso.

Essa noção de tolerância, de que tudo deve ser tolerado e respeitado é especificamente moderna, faz parte do arcabouço teórico e prático do liberalismo clássico. O conceito de tolerância é, tal como conhecemos hoje, moderno, portanto, burguês e protestante. Surge no contexto de guerras religiosas entre protestantes e católicos na Europa ${ }^{2}$. Naquele período diversos autores entre teólogos, filósofos, juristas, artistas etc., propunham e exigiam a separação entre religião e política, igreja e Estado, demandando a laicidade do Estado e principalmente o respeito à liberdade religiosa entre cristãos, tal reivindicação é o princípio da ideia moderna de tolerância que tem em John Locke, um burguês protestante, em sua famosa Carta sobre tolerância a expressão máxima.

É a essa tolerância que Hanna Arendt recorre em seu polêmico escrito sobre Elizabeth Eckford e os acontecimentos na cidade de Little Rock em 1957. Nos E.U.A. a segregação racial era legalizada em diversos estados do sul e havia escolas exclusivas para brancos e escolas exclusivas para negros. Em 1956 o Supremo Tribunal nos E.U.A. decidiu que a segregação racial nas escolas era ilegal. No entanto em Arkansas as escolas continuavam rejeitando a matrícula de alunos negros, mas em 1957 Elizabeth Eckford e mais oito alunos negros se matricularam em uma escola até então exclusiva para brancos e no dia 04 de setembro de 1957 é a primeira aluna negra a tentar a entrar em uma escola proibida para negros. Ela é vaiada, insultada e agredida por pais de alunos brancos que não aceitam que seus filhos estudem juntos com uma "pessoa de cor". O governador do Estado, declaradamente racista, optou, para evitar conflitos raciais, por fechar por um ano todas as escolas do estado. Após esse episódio Hanna Arendt escreve um artigo intitulado Sobre Little Rock em que reflete sobre o que aconteceu e faz um julgamento de valor sobre o acontecido. Esse artigo de Arendt é um exemplo de liberalismo ao defender explicitamente o direito dos pais brancos de não quererem que seus filhos frequentem a mesma escola que crianças negras, em poucas palavras, como diz Safatle, Hanna Arendt defende o direito dos racistas a "ter uma vida sem negros por perto"3. Para a filósofa Arendt, que se diz solidaria ao movimento dos negros na sua luta por direitos, a intervenção estatal nessa questão é inadmissível, pois viola a liberdade individual dos pais brancos da cidade de Arkansas e, para ela, "forçar os pais a mandar os filhos para uma escola

ABBAGNAMO, 1962, p. 924-925.

3 SAFATLE, O Preconceito é um exercício da liberdade?, in:.http://www.ihu.unisinos.br/78-noticias/572631-opreconceito-e-um-exercicio-da-liberdade

\begin{tabular}{|l|c|c|c|c|}
\hline Qovista Dialectus & Ano 8 & n. 14 & Janeiro - Julho 2019 & p. $110-120$ \\
\hline
\end{tabular}


integrada contra a sua vontade significa privá-los de direitos que claramente lhes pertencem em todas as sociedades livres - o direito privado sobre seus filhos e o direito social à livre associação" " Em poucas palavras: devemos tolerar os pais racistas, pois é um direito individual inalienável ser racista.

Essa mesma problemática reaparece novamente. Diante do que se convencionou chamar "onda conservadora" no Brasil em que presenciamos declarações homofóbicas, racistas, misóginas, xenofóbicas e elogios saudosistas a torturadores dos porões da ditadura em páginas de revistas, no congresso nacional, na TV aberta e nas redes sociais, em que a direita mais reacionária perdeu a vergonha de ser o que é, a saber, preconceituosa e avessa a tudo relativo aos "fracos" como os negros, mulheres, trabalhadores, gays etc, os limites da tolerância devem ser novamente tematizados e questionados. Afinal tudo deve ser tolerado? Temos a obrigação de respeitar todas as opiniões, convicções pessoais e comportamentos? Esses são problemas concretos relativos a um conceito filosófico desenvolvido na modernidade, o conceito de tolerância, conceito esse que propomos tematizar agora a partir das reflexões de Herbert Marcuse.

\section{I.}

Segundo Marcuse se no início da modernidade a tolerância era um valor progressista em contraponto a intolerância religiosa reinante na época, com o estabelecimento do capitalismo e da ascensão da burguesia à condição de classe dominante e principalmente com as experiências nazifascistas do século XX, o ideal liberal de tolerância tornou-se um conceito conservador e às vezes mesmo reacionário, "o que se pratica e proclama hoje como tolerância serve em suas mais eficazes manifestações à causa da opressão"5. Para Marcuse a exigência liberal de que tudo deve ser tolerado é abstrata, pois desconsidera os diversos tipos de opressões e práticas sádicas que são intoleráveis, como declarações e comportamentos racistas, machistas e homofóbicos, pois nem tudo é tolerável. Aliás, o próprio ideal de tolerância dos liberais que principia com Locke é repleto de exceções. Para o autor britânico não seriam toleráveis os que não são cristãos, a vadiagem dos desempregados ou dos mendigos (que para o pai do liberalismo deveriam ser internados em casas de trabalho forçado) e os ateus ${ }^{6}$. É somente com o

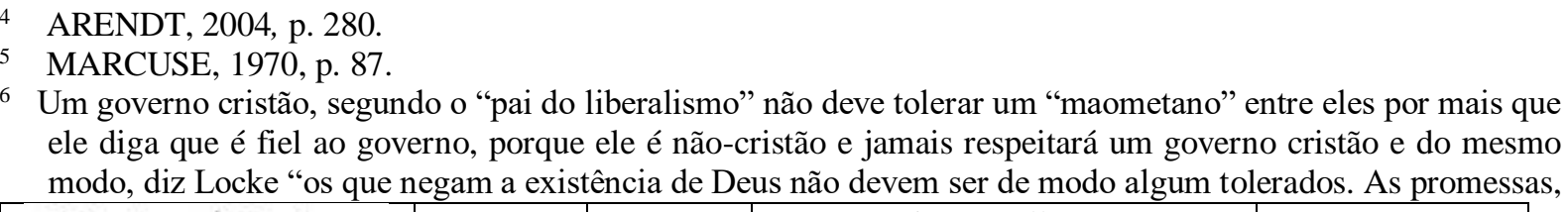

6 Um governo cristão, segundo o "pai do liberalismo" não deve tolerar um "maometano" entre eles por mais que ele diga que é fiel ao governo, porque ele é não-cristão e jamais respeitará um governo cristão e do mesmo modo, diz Locke "os que negam a existência de Deus não devem ser de modo algum tolerados. As promessas,

\begin{tabular}{|c|c|c|c|c|}
\hline Rovista Dialectus & Ano 8 & n. 14 & Janeiro - Julho 2019 & p. $110-120$ \\
\hline
\end{tabular}


desenvolvimento histórico e a constante ascensão da burguesia esclarecida, sobretudo com Voltaire, que os liberais passaram a defender que tudo deveria ser tolerado, inclusive a dominação de classe que agora a burguesia exercia ${ }^{7}$.

Para Marcuse no contexto social e político atual, isto é, do capitalismo tardio, uma sociedade tolerante somente é possível em que a intolerância racista, homofóbica, machista, fascista entre outras for intolerável, "alcança-se a conclusão de que a realização da tolerância exige a intolerância em relação às políticas, atitudes e opiniões predominantes" ${ }^{8}$. O conceito abstrato de tolerância, o de tolerância pura, para o qual tudo deve ser tolerado, tem que ser substituído pelo conceito concreto de tolerância, a saber, que nem tudo deve ser tolerado, pois a intolerância conservadora e preconceituosa é intolerável.

Enquanto o discurso oficial transmite e repete incessantemente mensagens de paz e respeito e sugere que devemos tolerar tudo, os intolerantes seguem agindo impunemente em palavras e ações, sendo tolerados em sua intolerância, assim como as democracias liberais toleraram o nazismo, Francisco Franco, Salazar e Pinochet. Para Marcuse existe uma diferença radical entre a tolerância abstrata, que é uma tolerância repressiva, que tolera o intolerável, e a tolerância concreta, libertadora, que não tolera o intolerável, mas tolera a intolerância dos oprimidos e explorados contra as palavras e atos de opressão e exploração. Segundo Marcuse é dever do intelectual apontar a contradição existente entre o que é dito e o que é feito, entre o discurso oficial e as práticas reais, expondo que,

Não existe hoje poder, autoridade ou governo que traduza a tolerância libertadora na prática, mas acredito constituir tarefa e dever do intelectual recordar e preservar as possibilidades históricas - que constitui sua missão romper a solidez da opressão a fim de abrir o espaço mental em que essa sociedade possa ser reconhecida pelo que é e pelo que faz. ${ }^{9}$

Uma sociedade tolerante em que não existem perseguições por motivos particulares e assuntos privados, como religião e sexualidade, permanece um objetivo não realizado e é a própria burguesia que na modernidade prometeu no lugar da intolerância da nobreza e da igreja a tolerância que impede sua realização ao tolerar a intolerância. A burguesa, mais uma vez, traiu sua própria promessa.

os pactos e os juramentos, que são os vínculos da sociedade humana, para um ateu não podem ter segurança ou santidade, pois a supressão de Deus, finda que apenas em pensamento, dissolve tudo" (LOCKE, 1978, p. 23-24).

7 “As transformações das sociedades democráticas adiantadas, que solaparam as bases do liberalismo econômico e político, alteraram também a função liberal da tolerância” (MARCUSE, 1970, p. 118).

$8 \quad$ MARCUSE, 1970, p. 87.

9 MARCUSE, 1970, p. 87.

\begin{tabular}{|l|c|c|c|c|}
\hline Qovista Dialectus & Ano 8 & n. 14 & Janeiro - Julho 2019 & p. $110-120$ \\
\hline
\end{tabular}


Uma sociedade tolerante em que não exista intolerância pressupõe o fim da intolerância existente e por isso, paradoxalmente, a precondição da tolerância de facto é a intolerância em relação à intolerância, “a eliminação da violência e a redução da opressão na medida necessária a fim de proteger homem e animal da crueldade e agressão são precondições da criação de uma sociedade humanitária"10. A intolerância a intolerância é que gera a verdadeira tolerância. Recorrendo a uma argumentação dialética em que o positivo é resultado da negação da negação, Marcuse afirma que enquanto as condições contrárias ao estabelecimento de uma sociedade tolerante persistir a tolerância permanecerá um objetivo incompleto, pois a tolerância a tudo é que permite a perpetuação da intolerância, "toleram-se políticas, condições e modos de conduta que não deviam ser admitidos porque impedem, se é que não destroem, as oportunidades de criação de uma vida sem medo e sem miséria" ${ }^{11}$. A tolerância com a dominação impede a emancipação, a tolerância com a divisão de classes impede o advento de uma sociedade sem classes, a tolerância com a miséria, com o trabalho infantil, com o racismo, machismo, xenofobia etc., preservam e perpetuam diversas formas de opressões que deveriam ser intoleráveis.

O que Marcuse nos chama atenção é sobre o seguinte problema: por trás do discurso de que devemos respeitar e tolerar tudo, de que por mais que eu não concorde com o que o outro pensa, diz e faz eu teria o dever de respeitar e defender o seu direito de pensar, dizer e fazer ${ }^{12}$, na verdade não estaríamos legitimando e justificando a intolerância reinante? Pior, até que ponto a tolerância pura, abstrata, não é sinônimo de omissão e conformismo?

Marcuse também chama atenção para o fato de que a tolerância defendida pelo status quo na prática é bastante seletiva, pois não se tolera tudo do mesmo modo. Determinadas palavras e ações são menos toleráveis, determinadas minorias e grupos são menos toleráveis que outros. Nos Estados Unidos, de onde Marcuse escrevia e vivia, e na África do Sul, a opressão do racismo branco sobre o negro foi e é diversas vezes tolerada, mas a reação e resposta dos negros contra o racismo institucionalizado ou não dificilmente foram toleradas e na verdade não foi tolerada de modo algum. Na África do Sul os limites da tolerância burguesa na prática foram expostos no massacre de Sharpeville (1960) quando a polícia do governo legalmente racista respondeu com rajadas de metralhadora um protesto pacífico de negros pelo respeito ao direito de ir e vir. Por sua vez a violência do opressor, seja ele racista ou imperialista

MARCUSE, 1970, p. 88.

MARCUSE, 1970, p. 88.

12 Evelyn Beatrice Hall atribui a Voltaire a frase que sintetizaria a liberdade de expressão e a tolerância as diferenças, "Eu desaprovo o que dizeis, mas defenderei até a morte vosso direito de dizê-lo".

\begin{tabular}{|c|c|c|c|c|}
\hline Rovista Dialectus & Ano 8 & n. 14 & Janeiro - Julho 2019 & p. $110-120$ \\
\hline
\end{tabular}


foi e teve que ser tolerada pelos oprimidos, mas não se teve tolerância alguma com a reação dos mesmos: quando os argelinos ou moçambicanos iniciaram suas guerras de libertação, por não tolerarem mais a dominação colonial e racial, os franceses e portugueses responderam com guerras de "pacificação" exigindo tolerância em relação à metrópole. Atualmente a lógica da tolerância seletiva permanece inalterada. O status quo tolera o massacre sionista em Gaza, mas condena a intifada palestina, toleramos o massacre da juventude negra e pobre da periferia e cotidianamente há expressões de intolerâncias com demonstrações públicas de afeto entre pessoas do mesmo sexo, mas consideramos exagero a passeata gay e ações afirmativas em favor das minorias. Na prática a tolerância pura, abstrata, é uma "tolerância repressiva"13. Diz Marcuse,

As autoridades em educação moral e psicologia vociferam contra a delinquência juvenil; vociferam menos, porém, contra a orgulhosa apresentação, em palavras, atos e imagens de foguetes cada vez mais poderosos, mísseis, bombas - a delinquência adulta de toda uma civilização. ${ }^{14}$

I.

Um dos grandes problemas identificados por Marcuse no conceito burguês de tolerância advindo da tradição liberal é que ele é um conceito indeterminado, indefinido. Quando um liberal declara que "tudo deve ser tolerado, devemos respeitar todas as diferenças", põe no mesmo saco o algoz e a vítima, o opressor e o oprimido, sem determinar se devemos tolerar o racismo ou não, por exemplo. Se seguirmos ipso facto a exigência liberal de tolerarmos e respeitarmos tudo indiscriminadamente, seremos obrigados a tolerar o racismo, crimes de guerra, o estupro, a violência doméstica, a pedofilia, assédio moral e sexual, em síntese, todas as formas de opressão e discriminação que nós, que estamos à esquerda no espectro político, somos contra.

A tolerância defendia pelos liberais é abstrata, portanto sem determinação, uma "tolerância pura" que se torna repressiva ao tolerar indiscriminadamente diversas formas de opressão. 'Denomino de tolerância 'abstrata' ou 'pura', diz Marcuse, “essa tolerância nãopartidária na medida em que ela se abstém de tomar partido - mas, ao fazê-lo, ela realmente defende o mecanismo de determinação já estabelecido"15. Tolerar a opressão, a o preconceito e a dominação do forte sobre o fraco é ser partidário da opressão, do preconceito e da dominação

13 MARCUSE, 1970, p. 89.

14 MARCUSE, 1970, p. 89.

15 MARCUSE, 1970, p. 91.

\begin{tabular}{|l|l|l|l|l|} 
Qovista Dialectus & Ano 8 & n. 14 & Janeiro - Julho 2019 & p. $110-120$ \\
\hline
\end{tabular}


do forte sobre o fraco. A neutralidade diante de uma situação de opressão faz de quem se autodeclara neutro um partidário (e por isso um não-neutro) da opressão. Como diz uma frase atribuída a Max Weber, "neutro é quem já se decidiu pelo lado do mais forte”. A tolerância concreta, libertadora, é a tolerância em relação a intolerância do oprimido diante da opressão e a intolerância diante da intolerância do opressor, ou seja, uma tolerância determinada, muito bem definida, que estabelece o que é e o que não é tolerável, "a tolerância que ampliou o escopo e conteúdo da liberdade sempre foi partidária - intolerante para com os protagonistas do status quo repressivo" 16 .

A própria burguesia liberal que levantou contra a aristocracia agrária a bandeira da tolerância, ela mesma não tolerava a aristocracia, o Estado absolutista, a imobilidade social, os privilégios de nascimento, a ausência de liberdade econômica etc. Defendia, portanto uma tolerância concreta, que não tolerava o que no contexto, na gênese da sociedade moderna, era intolerável. As revoluções burguesas, sobretudo a francesa, demonstram, na prática, como era a tolerância da burguesia em ascensão contra a nobreza do antigo regime.

Quando foi que a tolerância burguesa tornou-se tolerância repressiva? Quando a burguesia tornou-se classe dominante e foi capaz de em determinado período satisfazer as exigências gerais enquanto satisfazia seus interesses nos tempos áureos de sua dominação social, política e cultural, no século XIX, no período em que o "capital celebrava suas orgias"17. Segundo Marcuse, “confiante nas eficazes limitações subjacentes impostas pela estrutura de classes, a sociedade parecia praticar a tolerância geral" ${ }^{18}$. Na Inglaterra e nos Estados Unidos bem ou mal as liberdades individuais eram minimamente respeitadas, a oposição podia se expressar e tinha direito de reunião garantido, o que parecia, como diz Marcuse, que a tolerância era uma prática generalizadas nas sociedades liberais do século XIX. Parecia, mas não era. Era, como ainda hoje é, uma tolerância seletiva. Existia uma condição para a burguesia liberal do século XIX tolerar a liberdade de reunião e expressão da classe trabalhadora, era que os trabalhadores não ousassem passar da palavra a ação ${ }^{19}$, "nas sociedades liberais firmemente estabelecidas da Inglaterra e Estados Unidos, a liberdade de expressão e reunião era concedida até mesmo a inimigos radicais da sociedade contanto que não efetuassem a transição da palavra

${ }^{16}$ MARCUSE, 1970, p. 91.

17 MARX, 1983, p. 220.

${ }^{18}$ MARCUSE, 1970, p. 91.

19 "Mesmo quando toleradas dentro dos estreitos limites estabelecidos pela estrutura hierárquica da sociedade, são impotentes enquanto permanecem dentro desses limites" (MARCUSE, 1970, p. 119).

\begin{tabular}{|l|c|c|c|c|}
\hline Q Povista Dialectus & Ano 8 & n. 14 & Janeiro - Julho 2019 & p. $110-120$ \\
\hline
\end{tabular}


ao ato, do discurso a ação" ${ }^{20}$. Kant, um liberal clássico, no seu texto, Resposta à pergunta: $o$ que é o esclarecimento? sintetizou perfeitamente os limites da tolerância das classes dominantes, mesmo as mais liberais e tolerantes, "argumente, tanto quanto quiser e sobre tudo que você gosta, mas obedeça!"21. Quando passou a existir o perigo real da passagem da palavra ao ato as classes dominantes que pregavam a tolerância foram extremamente intolerantes. Os diversos golpes de estado e ditaduras militares no nosso breve século XX demonstram que a burguesia não era tão tolerante com a oposição e com as "diferenças" como ela dizia. O nazifascismo foi a resposta intolerante da burguesia acuada pelo perigo da revolução que não poderia e nem pode ser tolerada.

\section{I.}

No processo sócio-histórico de realização da liberdade existem obstáculos que se mantidos impedem a emancipação, preservando a dominação e as relações de opressão de diversas maneiras. Dessa maneira o sujeito histórico da libertação, a classe dominada, não deve permitir que práticas discriminatórias que reproduzem a opressão sejam preservadas ou existam, assim como as diversas relações de dominação não devem ser toleradas, mas destruídas. Os obstáculos em direção a uma sociedade livre e igualitária não devem ser tolerados, mas retirados do caminho, tudo que impede o progresso em direção à emancipação deve ser desobstruído. Aqueles comprometidos com a tolerância concreta "não pode(m) proteger falsas palavras e falsos atos que contradizem e combatem as possibilidades de libertação" ${ }^{\text {22 }}$. Seria um equívoco um militante negro contra o racismo defender o direito do racista de expressar sua intolerância racial em atos ou mesmo em palavras. Tudo o que contradiz a liberdade e a tolerância concreta é intolerável, pois a tolerância com o intolerável é cumplicidade com a dominação e a opressão, é a tolerância repressiva, o oposto da tolerância libertadora, para tal concepção de tolerância, a concreta, "certas coisas não podem ser ditas, certas ideias não podem ser expressadas, certas políticas não podem ser propostas, certa conduta não pode ser permitida sem transformar a tolerância num instrumento de contínua servidão"23. Todas as manifestações coletivas e individuais de intolerância não devem ser toleradas para que seja possível o estabelecimento de uma sociedade verdadeiramente tolerante. Não é possível

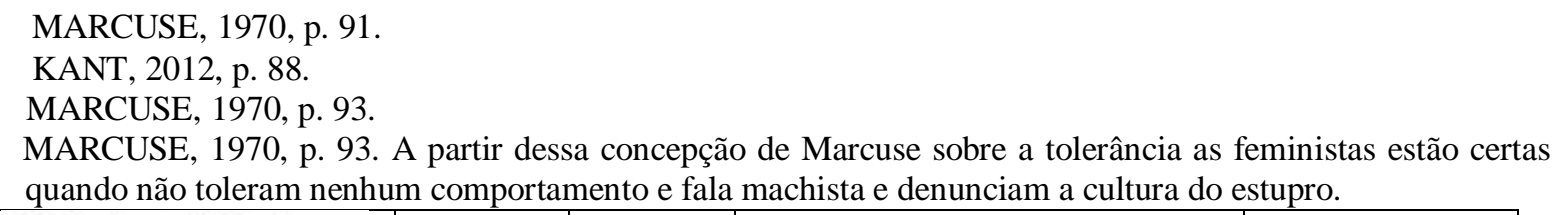

\begin{tabular}{|l|c|c|c|c|}
\hline Rovista Dialectus & Ano 8 & n. 14 & Janeiro - Julho 2019 & p. $110-120$ \\
\hline
\end{tabular}


construir uma sociedade sem machismo quando se tolera o comportamento e declarações machistas que reproduzem continuamente a opressão contra as mulheres.

Em nossa sociedade pragmática, em que a distância entre discurso e ação se encurtou, um discurso intolerante facilmente pode se traduzir em comportamentos intolerantes, principalmente se vindo de figuras públicas que por sua "autoridade" acabam por legitimar as práticas de grupos e indivíduos intolerantes. Devido tal perigo tornou-se necessário a total intolerância com os chamados discurso de ódio que podem e muitas vezes refletem na prática. Os discursos de ódio legitimam as práticas de ódio, de intolerância e opressão ${ }^{24}$ e por isso a proposta de Marcuse de que a esquerda não deve tolerar discursos de ódio, não deve tolerar a intolerância nem mesmo no plano discursivo, pois quando se reprime um discurso xenofóbico podemos evitar perseguições reais aos estrangeiros ${ }^{25}$ e práticas discriminatórias. Diz Marcuse,

No passado e em diferentes circunstâncias, os discursos de líderes fascistas e nazistas constituíram um prólogo de massacres. A distância entre a propaganda e a ação, entre a organização e a sua vazão sobre o povo tornou-se curta demais. Mas a propagação das ideias podia ter sido detida antes de ser demasiado tarde: se a tolerância democrática tivesse sido suspensa quando os futuros líderes se lançaram em campo, a humanidade teria evitado Auschwitz e uma guerra mundial. ${ }^{26}$

Hitler, Mussolini as demais hordas nazifascistas não surgiram do nada, surgiram em reuniões, grupos minoritários, jornais e a partir de propagandas que foram toleradas. Eles foram conquistando um espaço que não deveriam ganhar. Não só a prática fascista, mas o discurso fascista deve ser rechaçado e condenado, isto é, não deve ser tolerado. Não é justificável nenhuma tolerância com discurso e práticas intolerantes. Nem mesmo o recurso liberal ao respeito à liberdade de expressão justifica a tolerância com discursos de ódio.

Uma verdadeira tolerância, libertadora, e não uma tolerância repressiva, como a dos liberais, é aquela que tolera as palavras e ações de grupos que exigem ou simbolizam a

24 No Brasil após o hediondo estupro de uma jovem de 16 anos por 30 homens não faltaram pessoas tentando justificar o crime, responsabilizando a vítima por se expor (sic) a tal situação vexatória, pelo fato dela ser usuária de drogas, por já ser "acostumada" a sair com vários homens e por usar roupas "indevidas". Os discursos de ódio tentam legitimar práticas e comportamentos intoleráveis. O advogado do namorado da vítima, que participou do estupro coletivo declarou, para os jornais que na concepção dele "O conceito jurídico de estupro tem ganhado uma elasticidade nos últimos tempos que eu acho indevida, particularmente" (in:. http://g1.globo.com/rio-de-janeiro/noticia/2016/05/um-dos-suspeitos-do-caso-de-estupro-coletivo-se-entregano-rio.html).

25 No Brasil, em Roraima, na cidade de Mucajaí, manifestante atearam fogo em um abrigo municipal para venezuelanos. A justificativa era que os venezuelanos eram perigosos e estavam trazendo insegurança para as famílias da cidade (In:. https://exame.abril.com.br/brasil/manifestantes-queimam-pertences-de-venezuelanosem-roraima/). Esse crime aconteceu justamente após a proliferação de discursos preconceituosos contra os venezuelanos proferido por figuras públicas da extrema-direita brasileira.

26 MARCUSE, 1970, p. 113.

\begin{tabular}{|l|l|l|l|l|}
\hline Q Povista Qialectus & Ano 8 & n. 14 & Janeiro - Julho 2019 & p. $110-120$ \\
\hline
\end{tabular}


possibilidade de uma civilização não-repressiva e que não tolera os grupos intolerantes, conservadores e reacionários, de modo que a tolerância libertadora que cria as condições para uma sociedade verdadeiramente livre e tolerante pressupõe “(a) intolerância contra os movimentos de direita e tolerância com os movimentos de esquerda" ${ }^{27}$. Em uma sociedade em que a intolerância foi institucionalizada, como no apartheid sul-africano ou as leis de segregação racial nos estados do sul dos E.U.A., seria compactuar com a intolerância oficial tolerar as leis e instituições que legalizam a intolerância. A resposta correta daqueles que lutam pela tolerância concreta e por uma sociedade sem opressões deveria ser a não tolerância em relação a essas leis e instituições intoleráveis. Pregar o respeito e tolerância enquanto na prática o que existe é uma tolerância seletiva e uma intolerância com os fracos é ser conivente com a opressão e as diversas formas de dominação e discriminação.

A tolerância é um ideal, um ideal moderno, iluminista, que ainda estamos para realizar. A nossa realidade não permite que a tolerância seja praticada como ela deveria ser, como se propôs originalmente que devia ser a tolerância: ampla geral e irrestrita. A nossa realidade, racista, machista, homofóbica e intransigente inviabiliza que tudo seja tolerado e mais uma vez “(...) o ideal empalideceu em face da realidade" ${ }^{28}$.

\section{Conclusão}

A intolerância com a opressão e todas as formas de dominação são pré-requisitos para a substituição de uma sociedade desigual e repressiva como a nossa. A "opção pelos pobres" 29 como diz a teologia da libertação tem princípio quando não toleramos mais a miséria material e espiritual, quando não toleramos mais que crianças sejam obrigadas a trabalhar e meninas pobres sejam obrigas a se prostituir, quando não toleramos a violência doméstica que as trabalhadoras estão expostas, quando não toleramos que crianças durmam com fome e que pessoas morram em filas de hospitais, em síntese, quando não toleramos mais a desumanidade da sociedade capitalista. Nesse sentido a concepção liberal de tolerância é inaceitável, "essa espécie de tolerância é desumana" 30 . Se quisermos uma sociedade em que "cada um dar o que pode e recebe o que precisa", em que o machismo, racismo, homofobia e qualquer forma de intolerância não existem ou não são realmente toleradas, então precisamos, diz Marcuse, ser

\footnotetext{
27 MARCUSE, 1970, p. 112.

28 MARX, 1983, p. 220.

29 "Toda a Bíblia, desde o relato de Caim e Abel, está marcada pelo amor de predileção de Deus pelos fracos e maltratados da história humana" GUTIÉRREZ, 1991, p. 309.

30 MARCUSE, 1970, p. 103.
}

\begin{tabular}{|l|c|c|c|c|}
\hline Rovista Q Dialectus & Ano 8 & n. 14 & Janeiro - Julho 2019 & p. $110-120$ \\
\hline
\end{tabular}


“intolerantes, militantemente intolerantes e desobedientes às normas de condutas que tolera a destruição e a repressão" 31 . Toda solidariedade aos professores perseguidos pelo projeto fascista "Escola sem partido" e "nenhuma liberdade aos inimigos da liberdade" 32.

\section{Referências:}

ABBAGNAMO, Nicola. Dicionário de Filosofia. Tradução de Alfredo Bosi com a colaboração de Maurice Cunio et al. $2^{\circ}$ Edição. São Paulo: Mestre Jou, 1962.

ARENDT, Hanna. Sobre Little Rock. In: Responsabilidade e julgamento: escritos morais e éticos. Tradução de Rosaura Eichemberg. São Paulo: Companhia das letras, 2004.

GUTIERREZ, Gustavo. Pobres y opción fundamental. In: I. Ellacuría; J. Sobrino (eds.) Mysterium liberationis: conceptos fundamentales de la teología de la liberación. San Salvador: UCA, tomo I, 1991.

KANT, Immanuel. Resposta à pergunta $\mathrm{O}$ que é o iluminismo? Tradução de Claúdio J.A. Rodrigues. In: Filosofia da história: Textos extraídos das obras completas de Kant. $1^{\circ}$ Edição. São Paulo: Ícone, 2012.

LOCKE, John. Carta acerca da tolerância. In: : Coleção Os pensadores. Tradução de Anoar Aiex e E. Jacy Monteiro. $2^{\circ}$ Edição. São Paulo: Abril Cultural, 1978.

MARCUSE, Herbert. Crítica da tolerância repressiva. In: Crítica da tolerância pura. Tradução de Ruy Jungmann. Rio de Janeiro: Zahar Editores, 1970.

MARX, Karl. O Capital: Crítica da economia política. Tradução de Regis Barbosa e Flávio R. Kothe. São Paulo: Abril Cultura, 1983.

MARCUSE, 1970, p. 126.

32 Saint Just no seu discurso em favor à condenação à morte do Rei Luís XVI.

\begin{tabular}{|c|c|c|c|c|}
\cline { 2 - 4 } Q Oenista & Ano 8 & n. 14 & Janeiro - Julho 2019 & p. $110-120$ \\
\hline
\end{tabular}




\title{
TEORIA CRÍTICA E OS (DES)CAMINHOS DA TECNOCIÊNCIA: REFLEXÕES MARCUSEANAS
}

\author{
Maria de Fátima Vieira Severiano ${ }^{1}$ \\ Pablo Severiano Benevides2 \\ Valdemir Pereira de Queiroz Neto ${ }^{3}$
}

\begin{abstract}
Resumo:
O presente artigo tem por objetivo discutir a problemática do progresso técnico favorecido pelas produções científicas a partir do referencial teórico da Escola de Frankfurt, especialmente as contribuições de Herbert Marcuse. Para tal propósito, os conceitos de Teoria Crítica, Progresso Técnico, Progresso Humanitário e Racionalidade Instrumental são discutidos, problematizando a relação entre ciência e a racionalidade privilegiada pelo mercado com relevantes impactos nas produções da ciência contemporânea. Metodologicamente, trata-se de uma pesquisa teórica, de natureza qualitativa e de inspiração crítica, em que nos valemos da proposta da teoria crítica, cuja abordagem micrológica concebe o particular como um valioso índice que remete ao todo. Em seu desenvolvimento, discutimos as atuais formas de produção científica, a partir das relações entre razão instrumental e tecnologia, explorando as noções de técnica e tecnologia e atualizando essa discussão com as questões relacionadas à onipresença dos aparatos tecnológicos. Concluímos que há significativo direcionamento das produções alinhadas à racionalidade instrumental que determina a eficiência, produtividade e lucratividade como valores centrais para a manutenção do sistema capitalista e impede o desenvolvimento de contribuições para a melhoria da sociedade, mantendo a injustiça e a desigualdade social.
\end{abstract}

Palavras-chave: Teoria Crítica. Progresso. Produções Científicas. Tecnologia.

\section{CRITICAL THEORY AND THE (DE)TOURS OF SCIENCE: MARCUSEAN REFLECTIONS}

\begin{abstract}
:
The present article has the objective of discussing the matter of technical progress favored by the scientific productions from the theoretical perspective of the Frankfurt School, specially the contributions of Herbert Marcuse. To achieve such purpose, the concepts of Critical Theory, Technical Progress, Humanitarian

1 Professora titular da Universidade Federal do Ceará no Departamento de Psicologia e Programa de PósGraduação, com pesquisas na área de Psicologia Social relacionadas à Teoria Crítica, Cultura do consumo, Novas Tecnologias e Temporalidades Contemporâneas. É psicóloga, graduada pela Universidade Federal do Ceará (1982), com Doutorado em Ciências Sociais Aplicadas à Educação pela Universidade Estadual de Campinas - UNICAMP (1999) e com doutorado sanduíche no Depto. de Psicologia Social da Facultad de Ciencias Politicas y Sociologia da Universidad Complutense de Madrid. E-mail: fatimaseveriano@gmail.com.

2 Professor Permanente do Programa de Pós-Graduação em Psicologia da UFC - Fortaleza e Professor Adjunto III do Curso de Psicologia da UFC - Sobral. Pós-doutor em Filosofia da Educação pela Universitat de Barcelona (2016), Doutor em Educação pela Universidade Federal do Ceará (2013), Mestre em Filosofia (2008) e Graduado em Psicologia pela mesma instituição. Dedica-se aos temas relacionados ao neoliberalismo, às formas contemporâneas de exercício do poder, da dominação e das resistências, à biopolítica, aos estudos foucaultianos e às relações entre Psicologia Social e as teorias críticas e pós-críticas contemporâneas. E-mail: pabloseverianobenevides@ hotmail.com.

3 Professor Adjunto da Universidade Federal do Ceará - Campus Quixadá, possui graduação em Psicologia (UFC), mestrado em Psicologia na linha de pesquisa de Cultura e Subjetividade Contemporânea pela UFC e Doutorado em Psicologia (UFC), desenvolvendo estudos com ênfase em Psicologia Social, atuando principalmente nos seguintes temas: cultura contemporânea, sociedade de consumo, tempo livre, esportividade, cultura do narcisismo, indústria cultural e novas tecnologias. E-mail: valdemirpsiqueiroz@gmail.com.
\end{abstract}


Progress and Instrumental Rationality are discussed, addressing the problem of the relation between science and the rationality privileged by the market with relevant impact on contemporaneous scientific productions. Methodologically, it is an theoretical research of qualitative nature and critical inspiration, in which we are guided by the Critical Theory proposal, whose micrological approach conceives the particular as a valuable index addressed to the whole scenario. In its development, firstly, current forms of scientific productions are discussed and from the relations among instrumental rationality, technology e and a machinated human, we explore concepts of technique and technology and its onipresence. It has been concluded that there is a significant furtherance of productions aligned to the instrumental rationality which determines efficiency, productivity and profitability as essential values to the maintenance of the capitalist system and it impedes the development of contributions to the improvement of society, resulting in social inequality and injustice.

Keywords: Critical Theory, Progress, Scientific Productions. Technology.

\section{Introdução}

O presente artigo busca refletir acerca da onipresente mediação da tecnologia na sociedade contemporânea em suas determinações histórico-sociais, de modo a questionar certa noção de "progresso" a ela vinculada, bem como suas implicações para a emancipação humana. Para tal, serão discutidos alguns conceitos, tais como o de técnica, o de racionalidade instrumental e os conceitos de progresso tecnológico e progresso humanitário - situando, portanto, o trabalho no horizonte da Teoria Crítica; e, em especial, em uma filiação mais específica ao pensamento de Herbert Marcuse.

As transformações técnicas, sociais e econômicas que permearam o movimento filosófico do Iluminismo estabeleceram ideais com base nos quais a humanidade passou a ser orientada - ideais estes que estavam em franca em oposição à sociedade antecessora, predominantemente regida pelos mitos e dogmas. Assim, o conhecimento científico, apoiado fundamentalmente pela metodologia do positivismo e pelos avanços técnicos emergentes à época, propiciou ao homem um maior controle sobre as forças da natureza. Surge, então, um novo discurso de desencantamento do mundo cujo subsolo fundamental é a racionalidade tecnocientífica. Os benefícios trazidos em nome da ciência expandiram o horizonte espaçotemporal do homem. O conhecimento desenvolveu-se, apoderou-se da natureza e ultrapassou os limites de seu ideário com pretensões emancipatórias, dando por tantas vezes vazão à destruição racionalmente planejada e justificada. A Primeira Grande Guerra expôs um embate entre os mais avançados e desenvolvidos países. Expôs também a necessidade de reflexão sobre os fins da ciência e um questionamento em face ao entusiasmo para com as frentes em que o conhecimento poderia se desenvolver e se especializar, em nome do progresso. Segundo alerta Soares (2002), “[...] temos construído várias estratégias de ação individuais e/ou coletivas que podem nos conduzir na direção oposta dos nossos verdadeiros interesses ou, simplesmente, nos levar a uma marcha insensata e autodestrutiva" (p. 38).

\begin{tabular}{|c|c|c|c|c|}
\hline Govista Dialectus & Ano 8 & n. 14 & Janeiro - Julho 2019 & p. 121-146 \\
\hline
\end{tabular}


Assim, assumimos a reflexão frankfurtiana segundo a qual a racionalidade em que se apoia o progresso técnico, apesar de alegar a promoção de certos benefícios para a humanidade, ao não incluir uma reflexão ética sobre os seus fins, mistifica-se em vista de seu distanciamento da realidade da vida humana. A ciência, hoje, mantém o homem em um estado de submissão às "verdades" constituídas em modelos científicos "inquestionáveis" à semelhança dos antigos mitos que ela mesma se propôs a eliminar. Deste modo, o homem voltou ao estado de encantamento com um mundo de produções fantásticas, mas alienado de sua compreensão.

Preocupado com os (des)caminhos que a ciência percorre em seu propósito de "iluminar" o progresso e o desenvolvimento da sociedade, este estudo intenta reestabelecer e atualizar a crítica, em especial aquela marcuseana, como elemento necessário para pôr em xeque o credo depositado na ciência, ainda que a desconfiança e a suspeita se mantenham como condição para tal. Mediante o referencial teórico frankfurtiano, refletiremos acerca do tipo de racionalidade operada a favor das descobertas tecnocientíficas, questionando as implicações destas para a dinâmica social contemporânea e seus desdobramentos éticos. Por estarmos interessados em discutir os posicionamentos da Teoria Crítica sobre os conceitos de razão, técnica e progresso, de modo a balizar nosso debate sobre a produção científica que se converte em mercadoria tecnológica para uso humano, este trabalho tem por base por uma concepção de ciência politicamente implicada com os ideais humanitários de igualdade e orientada para o diagnóstico do presente, com vistas a possíveis transformações da sociedade.

Assim, com o alinhamento teórico-metodológico à Teoria Crítica, especialmente aquele vinculado à Herbert Marcuse, tornamos clara a nossa posição em favor da emancipação humana, "[...] ao mesmo tempo possível e bloqueada pela organização social vigente” (LIMA, 2010, p.32). A discussão que se segue também tem por meta denunciar a dominação que se dá pela via da tecnociência, cuja crítica desvela o paradoxo de uma racionalidade científica voltada para o mercado e alheia aos ideais emancipatórios.

\section{A problemática do progresso e a Critica à Ciência em Herbert Marcuse}

O pensamento de Marcuse (2001) evidencia uma atitude crítica partilhada pelos pensadores da Escola de Frankfurt que tem em seu arcabouço teórico fundamentais influências do pensamento marxista, além da visão freudiana de homem - trata-se, pois, da concepção de um sujeito do inconsciente caracterizado pelo conflito entre as forças pulsionais e os sacrifícios demandados pela vida em sociedade. Para Marcuse, na civilização moderna ocidental, o progresso é entendido prioritariamente como quantitativo e instrumental, na medida em que

\begin{tabular}{|c|c|c|c|c|}
\hline Rovista Dialectus & Ano 8 & n. 14 & Janeiro - Julho 2019 & p. $121-146$ \\
\hline
\end{tabular}


tem como objetivo prioritário uma crescente riqueza social. Os esforços empreendidos para aumentar os meios de satisfação das necessidades humanas estão fortemente relacionados com a criação dessas necessidades como fruto do desenvolvimento da civilização. Deste modo, Marcuse identifica que o progresso dominante em nossa sociedade, nomeado por ele "progresso técnico", diferencia-se do progresso por ele designado como "progresso humanitário". Neste último, teríamos contribuições voltadas para o aperfeiçoamento qualitativo humano, focando igualmente em "uma existência mais livre e mais feliz" (p. 100).

Sobre as relações entre progresso técnico e humanitário, Marcuse (2001) afirma que o segundo tem como precondição o primeiro, pois, a "[...] ascensão da humanidade a partir da escravidão e da miséria a uma liberdade cada vez maior pressupõe o progresso técnico" ( p.100), porém, não seria de modo automático que um levaria ao outro. É denunciado, assim, que a riqueza social obtida pela via do progresso técnico não é repartida ou experimentada de modo igual na sociedade e que os "[...] crescentes conhecimentos e capacidades dos seres humanos" (p. 100) são empregados a serviço da dominação do homem pelo homem, trazendo prejuízos para a emancipação dos sujeitos, além de relegar o progresso humanitário ao plano da utopia. Para o pensador frankfurtiano, a sociedade industrial moderna conserva como mais alto valor a produtividade, “[...] não somente no sentido de aumentar a produção de bens materiais e intelectuais, mas também no sentido de uma dominação universal da natureza” ( p.102).

Assim, defendemos uma ciência identificada com a conquista do progresso humanitário, consoante ao que foi descrito por Marcuse (2001):

[...] o progresso consiste na história, na realização da liberdade humana, na moralidade: cada vez mais homens se tornariam mais livres, e a própria consciência da liberdade seria um estímulo como que para um aumento no âmbito da liberdade. Assim, o resultado do progresso seria que os homens se tornariam cada vez mais humanos, verificando-se uma regressão na escravatura, na arbitrariedade, na opressão, na dor. A este conceito qualitativo de progresso podemos chamar a ideia do progresso humanitário (p. 100).

Segundo Marcuse (2001), se o progresso técnico é pré-requisito para o progresso humanitário, uma vez que este tornou-se aliado unicamente ao fator econômico como juiz de sua produtividade, resta uma ausência de direcionamento para o saneamento das questões humanitárias que permitiriam maior igualdade e liberdade aos homens - seja em relação ao mercado (na condição de consumidores), seja em relação ao trabalho (na condição de produtores explorados). Dessa maneira, o incremento técnico parece aprofundar a dominação e

\begin{tabular}{|c|c|c|c|c|}
\cline { 2 - 4 } Q Q Onialectus & Ano 8 & n. 14 & Janeiro - Julho 2019 & p. $121-146$ \\
\hline
\end{tabular}


a exploração cada vez mais sutil das consciências, suprimindo seu potencial para a formação de homens mais livres. Nas palavras de Marcuse (2001):

o progresso técnico parece ser a pré-condição de todo progresso humanitário que consiste na realização da liberdade humana: um número cada vez maior de seres humanos torna-se livre. $\mathrm{O}$ resultado do progresso aqui consiste na humanização progressiva dos homens (p. 113).

De modo prevalente, entendemos que o progresso humanitário é negligenciado, permanecendo ofuscado, quando não paralisado pelo progresso técnico - este que deveria, justamente, criar as condições e premissas básicas, em face da riqueza social acumulada, para impulsionar o progresso humanitário. De tal sorte que o progresso humanitário parece estar à deriva e sua relação com o progresso técnico resta enfraquecida e conflituosa, uma vez que este é pensado desvinculado de suas necessidades sociais. O progresso humanitário, assim, permanece no âmbito da promessa, tendo sido deslocado para o campo da utopia, tal como nos observou Marcuse: “[...] o elemento qualitativo do progresso se vê cada vez mais levado a seguir o caminho da utopia” (p.133), uma vez que jamais triunfa sobre o progresso técnico. $\mathrm{O}$ triunfo da técnica no modo de conceber o progresso tem implicações políticas que devem ser consideradas nesta análise. Marcuse (1973) manifesta-se de modo a evidenciar as consequências das criações humanas para a realidade que estabelecemos e prossegue com seu posicionamento:

O a priori tecnológico é um a priori político na medida em que a transformação da natureza compreende a do homem, e na medida em que as "criações feitas pelos homens" provêm de um conjunto social e a ele retornam. (...) quando a técnica se torna a forma universal da produção material, ela circunscreve uma cultura inteira; ela projeta uma totalidade histórica - um "mundo" (p. 150).

A grande contribuição dos frankfurtianos é exatamente denunciar a capacidade da ciência de se desumanizar e promover o aprofundamento da barbárie, valendo-se de sua reputação de promotora do desenvolvimento tecnológico para, internamente, contrabandear para seus produtos: a exploração objetiva (dos trabalhadores) e subjetiva (dos consumidores). Desenha-se, assim, os fortes contornos de uma sociedade desigual e com desenvolvimento humanitariamente precário. Parte desse processo resulta em uma confusão sobre essa ideia de progresso, uma vez que, em virtude do privilégio concedido ao desenvolvimento científico pautado no progresso técnico, este é confundido com o progresso em si. Isto favorece o esquecimento do progresso humanitário e promove sua exclusão da agenda assumida pela ciência moderna. Para Horkheimer (2007), “a racionalização progressista tende [...] a obliterar

\begin{tabular}{|l|l|l|l|l|}
\hline Gevista Dialectus & Ano 8 & n. 14 & Janeiro - Julho 2019 & p. $121-146$ \\
\hline
\end{tabular}


a própria substância da razão em nome da qual se apoia a causa do Progresso" (p. 8). Este problema também é comentado por Sfez (1996) ao destacar que: “[...] o progresso tecnológico é identificado com o próprio progresso e não é um simples instrumento do progresso. Só a tecnologia pode ter um efeito real sobre a ordem social, considerada como um vasto empreendimento" (p. 114).

O progresso apresenta-se em dois polos diametralmente opostos. De um lado, colecionam-se "milagres", "salvações" e produtos capazes de auxiliar o homem no desenvolvimento de suas potencialidades e na realização de atividades antes pensadas como impossíveis. E por outro lado, espalha destruição, morte e "catástrofes", como afirma Benjamin (1986). Dissertar sobre o progresso é estar no centro de um processo "[...] tanto fascinante e sedutor quanto repulsivo e aterrador" (SOARES, 1997, p. 3). Assim, de modo similar, um paradoxo é trazido à evidência por Marcuse (2001), na medida em que este se questiona sobre o próprio sentido do conceito de progresso e o modo como são orientadas as necessidades humanas, trazendo ao cerne da questão estas necessidades que se configuram como norteadoras de progresso.

[...] quando o conceito de necessidade engloba tanto alimentação, roupa, moradia quanto bombas, máquinas caçaníqueis e a destruição de produtos invendáveis, então podemos afirmar como certo que o conceito é tão desonesto quanto inútil para determinar o que seria uma produtividade legítima, e temos o direito de deixar em aberto a pergunta: produtividade pra quê? (MARCUSE, 2001, p. 102).

Ao tentar responder a esse questionamento, somos levados à suposição de que tal produtividade é o combustível de nossa sociedade e que, sem ela, a sociedade movida pelas relações e trocas comerciais vai experimentar níveis de circulação de capital inferiores e decrescentes. A paralisação da crítica e o desprezo diante da necessidade de refletir sobre a filosofia que reside por traz da produção de conhecimento científico levam a crer, segundo Etienne Klein (2007), que, “[...] a ciência se transformou numa empresa exclusivamente produtivista" (p. 269). Em Horkheimer (2007) encontramos fundamento para a problemática da desumanização do homem resultante de sua maquinização respaldada pelo progresso técnico-científico. Segundo ele,

parece que enquanto o conhecimento técnico expande o horizonte da atividade e do pensamento humanos, a autonomia do homem enquanto indivíduo, a sua capacidade de opor resistência ao crescente mecanismo de manipulação de massas, o seu poder de imaginação e o seu juízo independente sofreram aparentemente uma redução. $O$ avanço dos recursos técnicos de informação se acompanha de um processo de desumanização (p. 7).

\begin{tabular}{|c|c|c|c|c|}
\cline { 2 - 4 } & Ano 8 & n. 14 & Janeiro - Julho 2019 & p. $121-146$ \\
\hline
\end{tabular}


Temos, portanto, uma significa articulação entre a maquinização operada pelo progresso científico e neutralização que este aplica sobre si mesmo. Marcuse (2001) constatou “[...] na formulação filosófica do conceito de progresso uma tendência manifesta a neutralizar o próprio progresso" (p. 101). Tal concepção de progresso, livre de valorações e apoiado em uma frágil e falsa neutralidade, é a contribuição de Comte e sua ciência positivista. Como consequência disto, nos é explicado que "[...] o progresso passou a estar relacionado com a solução ou a contemporização de problemas imediatos e pontuais, e não mais com o núcleo qualitativo e significativo da vida, como ocorria no Iluminismo" (LEOPOLDO E SILVA, 2008, p. 169). Sobre a pretensa neutralidade atribuída também à ciência moderna como instância representante do progresso, Marcuse (2009) denuncia que: “[...] a ciência está ameaçada pelos seus próprios progressos, ameaçada por seu avanço como instrumento de um poder livre de valores, em vez de um instrumento de conhecimento e verdade" (p. 164).

É interessante pensar que, enquanto a ciência positivista propaga valores de neutralidade em relação às produções em acordo com sua orientação filosófica, oculta em si uma predileção pelo progresso técnico e uma escolha conveniente e excludente do progresso humanitário. Quando falamos dos avanços da tecnociência, então, essa polarização, que não deveria ser contrária ou excludente, parece se ampliar e, assim, retirar completamente a possibilidade de progresso humanitário de seus propósitos, ao passo que legitima o progresso técnico como decisão racional e imparcial. Ao comentar sobre isso, Matos (2006, apresenta a ideia de Adorno sobre os aspectos ideológicos da técnica e da racionalidade que a opera. Segundo ela, na obra Discretas Esperanças,

nova figura da ideologia, "o véu tecnológico" e o capital se associam em um mundo no qual tudo se apresenta como decisão técnica. Concentracionário, é administrado, "é prisão a céu aberto". Para Adorno, o cientismo, defesa acrítica e inquestionável dos primados e práticas da ciência - é ciência que acarreta adesão ao fatum na própria ciência, na política, no mercado. A ideologia da racionalidade tecnológica gera cega obediência às exigências do desenvolvimento capitalista, pois a técnica se pretende neutra e imparcial a ideologia transforma-se em potência invisível (p. 79).

Sobre as verdades e os produtos que a ciência produz e legitima, um ponto a ser refletido é relativo precisamente nossa incapacidade de perceber a lógica que operacionaliza e fundamenta tais produções. Massivamente, permanecemos apáticos e aparentemente deficitários em nossa capacidade de questionar a visão de mundo e de homem que nos vendem. Assim, a realidade parece ser planejadamente manufaturada para nosso consumo fascinado pelos objetos produzidos cientificamente. Parecemos incapazes de desconfiar dos valores

\begin{tabular}{|c|c|c|c|c|}
\cline { 2 - 4 } Q Oonista & Ano 8 & n. 14 & Janeiro - Julho 2019 & p. $121-146$ \\
\hline
\end{tabular}


criados e legitimados que nos são ofertados nos produtos das "vitrines" por sua associação à ciência. Menos ainda, parecemos capazes de suspeitar das práticas e interesses que determinam a produção científica nos dias de hoje. De tão naturalizadas e celebradas, essas práticas não ensejam nenhum desconforto ou estranhamento. Sobre isso, Marcuse (1999) alerta, em sua denúncia sobre a gradual adesão da ciência à racionalidade tecnológica, e consequentemente mercadológica: "a ciência moderna desenvolveu-se em conflito com os poderes que se opunham à liberdade de pensamento; hoje a própria ciência encontra-se em aliança com os poderes que ameaçam a autonomia humana e frustram a tentativa de realizar uma existência livre e racional" (p. 163).

A vanguarda dos produtores de tecnologia e seus produtos mais avançados servem a uma parcela reduzida da população. É aquela elite tecnológica e financeira, entretanto, que comanda a produção de mercadorias para a satisfação de necessidades criadas pelo próprio sistema de produção que mobiliza os desejos mediante a "autoridade" dos meios de comunicação. Isto acontece não unicamente com os produtos puramente tecnológicos, mas também com fármacos, veículos, educação, moradia etc. Compreendemos, no entanto, que a tecnologia de "ponta" é experimentada de modo bastante restritivo, tornando, por exemplo, o acesso a tratamentos de saúde com certas drogas impossível para um homem de rende mediana.

Entendemos que o mercado abriga várias demandas manufaturadas e as ciências suprem as necessidades de criação de novidades na busca por sucesso de vendas a converter-se em lucro. A tecnologia instrumentaliza as empresas nesse processo de criação de produtos ofertados como distintivos socioculturais. Sobre esse processo de criação de novidades para a movimentação do mercado, concordamos com Novaes (2009), ao nos dizer que a estratégia "[...] da aceleração total econômica e tecnológica se fundava no princípio da seleção, e que o sujeito humano ia desaparecer no vetor da tecnologia. Podemos, pois, concluir que as transformações da técnica têm mais impacto na nossa maneira de viver do que a política" (p. 32). Aqui, percebemos que a técnica, com seus valores de eficiência e aceleração, formatam o nosso modo de viver e por isso é afirmado que está, não à frente ou acima da política, mas inserida na política, na produção, na educação e em todos os campos do viver humano como política de desenvolvimento e modus operandi; constituindo-se em uma nova forma de dominação.

Os frankfurtianos empreenderam a crítica à racionalidade tecnológica, que apesar de ter promovido extraordinários recursos para domínio da natureza pelo humano, por outro, criou meios de aniquilar a raça humana. Os desdobramentos científicos como fruto desta

\begin{tabular}{|c|c|c|c|c|}
\cline { 2 - 5 } Q Povista & Ano 8 & n. 14 & Janeiro - Julho 2019 & p. $121-146$ \\
\hline
\end{tabular}


racionalidade específica são analisados e ponderados para questionar se estes estariam, de fato, cumprindo sua promessa de "iluminar" a humanidade e emancipar os homens de todas as modalidades de dominação. O desprezo acerca da reflexão sobre os fins últimos do progresso, seus aspectos éticos, humanitários e qualitativos, resulta em desigualdades sociais estendidas a todo o planeta. Observamos em diversas partes do globo a luta por sobrevivência contra a fome e contra doenças com alto índice de mortalidade, consideradas inofensivas e controladas em regiões favorecidas economicamente. Afinal, a direção do processo histórico de nossas civilizações condiciona que o locus de nascimento de uma pessoa no nosso planeta determinará o nível de exploração e dominação a que ela estará submetida, ou destinará ao indivíduo os meios para que este dê continuidade à dominação de outrem. A dialética do esclarecimento indica exatamente isto: “[...] o progresso ameaça anular o que se supõe ser o seu próprio objetivo: a ideia de homem" (HORKHEIMER, 2007, p. 7). Adorno (1992), aprofunda a discussão ao afirmar que:

nessa questão está envolvida toda a dialética do esclarecimento, ela é tão racional quanto irracional: racional, na medida em que torna consciente a idolatria, irracional ao voltar-se contra seu próprio objetivo, o qual só está presente onde não precisa se justificar diante de Instância alguma ou mesmo diante de intenção alguma ( p.105).

O posicionamento teórico dos pensadores da Escola de Frankfurt é o de negar qualquer neutralidade científica. Adorno e Horkheimer (1991), na "Dialética do Esclarecimento", empreendem uma análise aprofundada dos elementos da racionalidade do mundo moderno para denunciá-los como uma nova forma de dominação, caracterizada pela previsibilidade e uniformização das consciências. A crítica filosófica da cultura realizada, neste contexto, demonstra o fracasso do programa do esclarecimento, cuja promessa de salvar o mundo dos grilhões da superstição, da ignorância e do medo através da soberania do homem e de seu domínio sobre a natureza, resultaram frustrados. O Esclarecimento, segundo esses autores, apresentou-se predominantemente em sua face coercitiva: O homem, em sua tentativa de domínio sobre a natureza, findou por desenvolver um domínio totalitário sobre os próprios homens. A razão, ao pretender conciliar-se com a realidade, terminou por degradar-se a si mesma, transformando-se em uma razão encurtada, formalizada e fatídica: uma razão instrumental, mera justificação mistificadora do imediato, estranha à realidade concreta dos homens e ao seu mundo de vida. O único critério de verdade deste tipo de racionalidade passou a ser o seu valor operativo, ou seja, sua capacidade de eficácia na dominação da natureza. Isto porque a razão, ao alienar-se da reflexão sobre seus fins e valores, despoja-se de qualquer juízo

\begin{tabular}{|c|c|c|c|c|}
\cline { 2 - 4 } & Ano 8 & n. 14 & Janeiro - Julho 2019 & p. $121-146$ \\
\hline
\end{tabular}


ético, político ou valorativo sobre o homem, perdendo seus poderes de crítica e transformandose num instrumento de legitimação da ordem dominante e de adequação do homem aos limites do fato estabelecido. Entretanto, vale ressaltar que não era à razão em si que estes autores criticaram, mas um tipo de racionalidade que passou a predominar principalmente após a consagração da epistemologia do Positivismo, no século XIX, enquanto a "legítima" representante da Ciência Moderna.

Horkheimer (1983) estabelece importantes diferenças entre "teoria tradicional" e "teoria crítica" para compreensão da práxis científica defendida pelos pensadores da referida Escola. Esta última é caracterizada como dotada de uma atitude que mobiliza a produção teórica a intervir na prática, negando a realidade positivada como a única possível, a fim de que as possibilidades de transformação emerjam, opondo-se, desta maneira, à ideologia de neutralidade própria da teoria tradicional. A teoria crítica concebe a relação entre sujeito da ciência e objeto da ciência como orgânica e politicamente implicada. Considera o sujeito do conhecimento em sua condição de "[...] analista e crítico da situação, buscando colaborar na intervenção e no redirecionamento do processo histórico em favor da emancipação dos homens em uma ordem social justa e igualitária” (FREITAG, 1988, p. 42). Sobre a inaptidão da teoria tradicional para proporcionar mudanças significativas na sociedade, Horkheimer (1983) evidencia que a ciência, assim como outros campos de trabalho, reproduz a dinâmica da divisão de trabalho mantenedora da sociedade capitalista. Segundo ele,

\begin{abstract}
a representação tradicional de teoria é abstraída do funcionamento da sociedade, tal como este ocorre a um nível dado da divisão do trabalho. Ela corresponde à atividade científica tal como é executada ao lado de todas as demais atividades sociais, sem que a conexão entre as atividades individuais se tome imediatamente transparente. Nesta representação surge, portanto, não a função real da ciência nem o que a teoria significa para a existência humana, mas apenas o que significa na esfera isolada em que é feita sob as condições históricas. Na verdade, a vida da sociedade é um resultado da totalidade do trabalho nos diferentes ramos de profissão, e mesmo que a divisão do trabalho funcione mal sob o modo de produção capitalista, os seus ramos, e dentre eles a ciência, não podem ser vistos como autônomos e independentes (p. 123).
\end{abstract}

Deste modo, obtemos uma compreensão maior acerca da heteronomia operada sobre o trabalho científico, resultando em proposições consoantes à manutenção das contradições que perduram a revelia do potencial libertador da razão. Paralisam-se, assim, os ímpetos capazes de conduzir a sociedade a mudanças promotoras de maior justiça social por intermédio de produções científicas implicadas com a melhoria da sociedade em seu caráter opressor. Sobre a singularidade da teoria crítica, Horkheimer explica que:

\begin{tabular}{|l|l|l|l|l|}
\cline { 2 - 5 } & Ano 8 & n. 14 & Janeiro - Julho 2019 & p. $121-146$ \\
\hline
\end{tabular}


a sua oposição ao conceito tradicional de teoria não surge nem da diversidade dos objetos nem da diversidade dos sujeitos. Para os representantes desse comportamento, os fatos, tais como surgem na sociedade, são frutos do trabalho. E, como tais, não são exteriores no sentido em que o são para o pesquisador ou profissional, que se imagina a si mesmo como um pequeno cientista. Para eles é importante um nova organização do trabalho. Os fatos concretos que estão dados na percepção devem despojar-se do caráter de mera facticidade na medida em que forem compreendidos como produtos do homem que, como tais, deveriam estar sob o controle humano e que, em todo o caso, passarão futuramente a este controle (p. 132).

O posicionamento ora descrito é de enorme relevância para que se desmistifique a pretensa neutralidade do discurso científico por via da qual a dominação se insere e se mantém velada. Oriunda das ciências naturais, esta neutralidade é posta em dúvida e o positivismo é criticado como uma modalidade inadequada de explicar os fenômenos humanos e sociais, em virtude da impossibilidade de estabelecer uma separação entre sujeito e objeto do conhecimento, ou mesmo, desejar tal separação. A ciência positivista é compreendida como uma interpretação da realidade desprovida de seus aspectos histórico-culturais, condicionantes dos fenômenos estudados, legitimando, assim, a ordem social presentificada. Por isso, para reverter esse quadro de produção científica, segundo Horkheimer (1983), é preciso “[...] passar para uma concepção que elimine a parcialidade que resulta necessariamente do fato de retirar os processos parciais da totalidade da práxis social” (p. 124). Em sua obra As Razões do Iluminismo, Rouanet (1987) assinala que, contemporaneamente, a razão se exprime, tal como agente da dominação, em oposição ao seu projeto inicial de emancipação do homem. Segundo o referido autor:

as vanguardas do alto modernismo perderam sua capacidade de escandalizar e se transformaram em establishment; os grandes mitos oitocentistas do progresso em flecha e a emancipação da humanidade pela ciência ou pela revolução são hoje considerados anacrônicos; a razão, instrumento com que o Iluminismo queria combater as trevas da superstição e do obscurantismo, é denunciada como principal agente da dominação (p. 230).

Exprimimos, portanto, a noção de que, em alguns momentos, o espírito crítico direcionado aos dogmas não se manteve operando com igual rigor sobre os fins da própria ciência. Esse "descuido" foi e é capaz de conduzir cegamente a humanidade a própria tragédia, na medida em que a não reflexão crítica sobre a própria finalidade da ciência pode torná-la um novo mito (ADORNO E HORKHEIMER, 1991), promover a submissão dos homens e instrumentalizar a criação de produtos capazes de causar a destruição da vida no planeta. Os embates bélicos ocorridos nos últimos 100 anos mostraram que, em matéria de capacidade de destruição, o homem é um grande perigo para a humanidade. Esta foi a preocupação que animou

\begin{tabular}{|c|c|c|c|c|}
\cline { 2 - 4 } Q Q Onialectus & Ano 8 & n. 14 & Janeiro - Julho 2019 & p. $121-146$ \\
\hline
\end{tabular}


Adorno e Horkheimer ao problematizar os ideais do esclarecimento, os quais, segundo eles, resultaram frustrados. A dialética do esclarecimento representa esse desenvolvimento humano contraditório, no qual progresso e regressão, construção e destruição, justificam-se ambos, pelo advento da razão. Em suas palavras:

no sentido mais amplo do progresso do pensamento, o esclarecimento tem perseguido sempre o objetivo de livrar os homens do medo e de investi-los na posição de senhores. Mas a terra totalmente esclarecida resplandece sob o signo de uma calamidade triunfal. O programa do esclarecimento era o desencantamento do mundo[...].Contudo, a credulidade, a aversão à dúvida, a temeridade no responder, o vangloriar-se com o saber, a timidez no contradizer, o agir por interesse, a preguiça nas investigações pessoais, o fetichismo verbal,[...] impediram um casamento feliz do entendimento humano com a natureza das coisas (p. 19).

A relação entre calculabilidade, utilidade e esclarecimento é problematizada por Adorno e Horkheimer (1991) para evidenciar que a ciência moderna se muniu de uma racionalidade peculiar para operar no mundo e pela via da redução ao calculável, útil e praticável fez uso da lógica formal para produzir o conhecimento esclarecido. Percebemos aqui, nas palavras dos teórico-críticos da Escola de Frankfurt, uma negligência ou falha do esclarecimento com aquilo que se exprime como diverso, irredutível e complexo. Nesta crítica feita à mistificação do esclarecimento expressam seu desagravo:

[...] o esclarecimento só reconhece como ser e acontecer o que se deixa captar pela unidade. Seu ideal é o sistema do qual se pode deduzir toda e cada coisa. (...) A multiplicidade das figuras se reduz à posição e à ordem, a história ao fato, as coisas à matéria. A lógica formal era a grande escola da unificação. Ela oferecia aos esclarecedores o esquema da calculabilidade do mundo. (...) O número tornou-se o cânon do esclarecimento (p. 22).

Neste ponto, vemos que este caráter singular e inapreensível dos fenômenos, não ajustável às fórmulas e aos cálculos, denuncia uma racionalidade incompleta e parcial, apoiando-se num pretenso discurso de imparcialidade para descortinar as "verdades". Observamos que essa abordagem positivista dominante na ciência moderna privou-se de considerar um compêndio de conhecimentos e valores sobre o humano e sua história, com sérias implicações para a compreensão do fenômeno humano em sua totalidade, tornando-se um modelo pragmático e reducionista. Como nos confirmam Adorno e Horkehimer (1991), a busca dos cientistas pelo conhecimento, em face do critério da calculabilidade, está distanciada do sentido e do conceito, imprescindíveis para a compreensão do homem e sua existência:

poder e conhecimento são sinônimos. [...] O que importa não é aquela satisfação que, para os homens, se chama 'verdade', mas a 'operation', o procedimento eficaz.[...] No trajeto para a ciência moderna, os homens renunciaram ao sentido e substituíram o conceito pela fórmula, a

\begin{tabular}{|l|l|l|l|l|}
\hline Gevista Qialectus & Ano 8 & n. 14 & Janeiro - Julho 2019 & p. $121-146$ \\
\hline
\end{tabular}


causa pela regra e probabilidade. [...] A filosofia buscou sempre, desde Bacon, uma definição moderna de substância e qualidade, de ação e paixão, do ser e da existência, mas a ciência já podia passar sem semelhantes categorias. [...] O que não se submete ao critério da calculabilidade e da utilidade torna-se suspeito para o esclarecimento (p. 18-19).

Desta maneira, posicionamo-nos contrários ao progresso meramente técnico, calculista e utilitarista, em prol de repensá-lo em seu viés qualitativo, na defesa da emancipação humana bloqueada por esta racionalidade dominante. Como afirma Olgária Matos (2006), acreditamos que, para tal objetivo libertador, “[...] requer revolucionar a ciência e a técnica, tornadas forças produtivas e fundamento da legitimação política do capitalismo tardio, colonizadoras de todo o mundo da vida segundo uma racionalidade instrumental" (p. 17). Com este posicionamento, a autora corrobora a ideia de Marcuse sobre o componente político da técnica, legitimando, assim, o sistema de exploração do humano no capitalismo vigente.

Matos (2006) prossegue com sua definição e reúne dominação, violência e sacrifício da natureza como características por intermédio das quais a racionalidade dominante se concretiza, criando inclusive uma “[...] justificativa intelectual para o massacre dos nativos do Novo mundo [...] pelo desconhecimento do método, do raciocínio por hipóteses, e verificações da Razão Instrumental" (p. 92). Apresentar um modo de pensamento distinto, orientado por outros valores, é ameaçador ao primado da técnica e, inúmeras vezes, a racionalidade instrumental, justifica sua barbárie. Se essa racionalidade já foi capaz de fundamentar aniquilações no passado em nome do progresso e da liberdade, no presente, esse fundamento se direciona igualmente contra aquilo que foge ao seu domínio. Vale ressaltar aqui a aderência historicamente estabelecida entre a ciência e a guerra que favorece o desenvolvimento bélico elevando a capacidade de destruição do ser humano. Além das máquinas nucleares, atômicas, “inteligentemente mortíferas" como produções científicas, a transformação do homem em sua relação com as máquinas e os desenvolvimentos tecnocientíficos também ocorre impulsionada pelo militarismo. Como evidência dessa relação, Crary (2014) denuncia os estudos militares feitos para um controle sobre a redução ou eliminação do tempo de sono e, consequente, aumento do tempo de vigília a ser dedicado à sobrevivência, inicialmente na guerra, e com possível aplicação cotidiana posterior, para os sujeitos civis na "guerra do capitalismo". Afinal, "no paradigma neoliberal globalista, dormir é, acima de tudo, para os fracos" (p. 23). Ele relata que:

devem se entender os estudos sobre privação de sono no contexto de uma busca por soldados cujas capacidades físicas se aproximaram cada vez mais da eficácia de aparatos e redes não humanos. O complexo científico militar vem se dedicando a pesquisa de formas de cognição

\begin{tabular}{|l|l|l|l|l|}
\cline { 2 - 4 } Q Povista & Ano 8 & n. 14 & Janeiro - Julho 2019 & p. $121-146$ \\
\hline
\end{tabular}


ampliada que prometem aprimorar a interação entre homem e máquina simultaneamente, as forças armadas têm financiado diversas outras áreas de investigação do cérebro, bancando inclusive o desenvolvimento de uma droga contra o medo (p. 13).

Ainda sobre a relação entre ciência e guerra no contexto histórico global, Crary (2014) estabelece a segunda guerra mundial como grande marco para o estabelecimento do mundo global, tecnológico e comunicacional em que vivemos. Em suas palavras:

\begin{abstract}
a Segunda Guerra Mundial, em seu caráter destrutivo e impacto global, constituiu um evento inédito de homogeneização, no qual foram destruídos por completo territórios, identidades e tecidos sociais ultrapassados. Ela criou, na medida do possível, uma tábula rasa que seria a plataforma da atual fase da globalização do capitalismo. A segunda guerra mundial foi o cadinho no qual se forjaram novos paradigmas de comunicação, informação e controle, e no qual se consolidaram as conexões entre pesquisa científica, corporações nacionais e poder militar (p. 77).
\end{abstract}

Observamos hoje, como consequência do continuum histórico agora descrito, que as guerras são motivadas pela dominação capaz de incrementar a produção e os fluxos de capital. Podemos citar aqui a noção de que algumas das guerras mais recentes, como no Iraque e Afeganistão, guardavam em sua fundamentação a ideia de que era preciso libertar os povos de regimes totalitários, mesmo que pela paradoxal via da bárbarie ${ }^{2}$. Assim, percebemos a contradição em submeter outros povos à liberdade por uma via repressiva, pensada segundo o modelo ocidental liberal, portanto, uma liberdade heterônoma que se impõe de modo violento. Sobre esta força da libertação de povos para a fruição das 'maravilhas ocidentais globalizadas' vividas no consumo de bens, serviços e entretenimentos, o próprio Marcuse (1973), já nos advertira para os riscos da pseudoliberdade:

sob o jugo de um todo repressivo, a liberdade pode ser transformada em poderoso instrumento de dominação. $\mathrm{O}$ alcance da escolha aberta ao indivíduo não é o fator decisivo para a determinação do grau de liberdade humana, mas o que pode ser escolhido e o que é escolhido peIo indivíduo (p. 28).

Observamos nesse processo de relativização da liberdade, que ela é complacente com a dominação e justificada economicamente. Contemporaneamente, como efeito destas elaborações e condições históricas que favoreceram a legitimação do saber científico, a racionalidade instrumental está materializada na maneira de o homem compreender o mundo,

2 Para um aprofundamento, conferir o texto “Adorno e a Crítica da Barbárie: um Olhar Psicanalítico" de Sérgio Paulo Rouanet na obra "Escola de Frankfurt: inquietudes da razão e da emoção" (2010) organizado por Jorge Coelho Soares.

\begin{tabular}{|c|c|c|c|c|}
\cline { 2 - 4 } Q Q Dialectus & Ano 8 & n. 14 & Janeiro - Julho 2019 & p. $121-146$ \\
\hline
\end{tabular}


explicá-lo e sobre ele agir, descartando aquilo que não se submete ao cálculo, como nos disse Adorno e Horkheimer (1991). Deste modo, essa racionalidade se expande e domina o estilo de pensar científico e suas formas de intervir no mundo, acelerando e enfatizando o progresso tecnológico aliado à eficiência econômica. Entendemos que essa relação entre economia e produção científica é problemática ao traficar para o campo da ciência os anseios das intempéries do competitivo mercado, orientado por produtividade e lucro. Marcuse (2009) diz que, "na medida em que a economia se torna um sistema tecnológico, a ciência se transforma num fator decisivo nos processos econômicos da sociedade. [...] A ciência literalmente abastece a economia" (p. 163). Desta maneira, o pensador alemão afirma que "o poder tecnológico tende à concentração do poder econômico" (MARCUSE, 1999, p. 76).

Nesse sentido, a crítica, a reflexão, a justiça social, a solidariedade e a ética não são valores "convidados" aos juízos elaborados sob a égide da racionalidade técnica, estando o desenvolvimento da ciência cada vez mais determinado pelos valores competitivos do mercado e da aceleração tecnológica. Consoante esta ideia, Soares (2002) explica que,

presos à lógica de uma racionalidade técnica, capaz de produzir o melhor e o pior dos mundos, acreditando ser a razão prática a única forma de lidar com a realidade e consigo mesmo, o sujeito, construtor deslumbrado da técnica, se expôs, aceleradamente, como objeto de desconstrução de si mesmo. [...] Cientifização, racionalização - aumento de eficiência de valores exclusivamente funcionais da 'idade tecnológica' - foram otimizados ao extremo com toda sutileza possível, apontando na direção do triunfo da 'razão instrumental' (p. 40).

Assim, a racionalidade dominante na sociedade é internalizada pelo homem e este opera no mundo seguindo seus valores fundamentais que instrumentalizam e modelam nosso modo de pensar o mundo e atuar sobre ele. Habermas (1968), em capítulo de homenagem aos 70 anos de Marcuse, descreve o posicionamento do homenageado sobre o caráter falho da racionalidade no que se refere a sua atuação unicamente no sentido de realizar a "correta eleição entre estratégias, a adequada utilização de tecnologias e a pertinente instauração de sistemas (em situações dadas para fins estabelecidos)" (p. 46). Ou seja, apesar da submissão de diversas esferas sociais ao controle, que poderia pressupor um caráter racional, esta submissão redunda em parcial racionalidade, estabelecendo um modelo que opera em nome da racionalidade, mas de "uma forma determinada de dominação política oculta" (p. 46) e, portanto, favorecendo a “institucionalização da dominação" (p.46) e impossibilitando a "[...] reflexão e reconstrução racional" (p. 46). Habermas, ao explicar sobre a centralidade da ação dirigida à fins na produção da racionalidade instrumental, afirma que:

\begin{tabular}{|c|c|c|c|c|}
\cline { 2 - 4 } & Ano 8 & n. 14 & Janeiro - Julho 2019 & p. $121-146$ \\
\hline
\end{tabular}


essa racionalidade estende-se, além disso, apenas às situações de emprego possível da técnica e exige, por isso, um tipo de ação que implica dominação quer sobre a natureza ou sobre a sociedade. A ação racional dirigida à fins é, segundo a sua própria estrutura, exercício de controles. Por conseguinte, a 'racionalização' das relações vitais segundo critérios desta racionalidade equivale a institucionalização de uma dominação que, enquanto política, se torna irreconhecível: a razão técnica de um sistema social de ação racional dirigida a fins não abandona o seu conteúdo político (p. 46).

Deste modo, a crítica feita ao conteúdo político da racionalidade decorre da dominação que se evidencia sobre seus objetos, reproduzida claramente na relação da ciência moderna entre pesquisador e pesquisado, sujeito e objeto de estudo, concebidos como separados em face aos métodos modernos da racionalização. Essa relação torna-se problemática quando as ciências sociais tomam esse modelo de distanciamento, próprio das ciências naturais, porém, agora, tendo o homem em ambos os polos: como pesquisador e feito pesquisado. Nossa crítica refere-se à percepção de que desde a relação da ciência com vistas à manipulação de seus objetos de estudo, esse domínio e tal controle racional se constituem como modelos de dominação dos homens para com os homens. Isto se ilustra na ação racional do empresário capitalista, que tem como objeto o trabalhador industrial ou empregado moderno, difundindo a exploração do homem e da natureza, pelo homem. Neste sentido, Marcuse afirma que: "[...] o conceito de razão técnica é talvez também em si mesmo ideologia. Não é a sua aplicação, mas já a própria técnica e dominação metódica, científica, calculada e calculante (sobre a natureza e sobre o homem)" (MARCUSE, 1998, p.46). Adorno e Horkheimer partilham dessa ideia ao afirmarem que "o que os homens querem aprender da natureza é como empregá-la para dominar completamente a ela e aos homens. Nada mais importa" (p. 18).

\section{A "Neutralidade" da Técnica e da Tecnologia segundo Marcuse - notas sobre os processos de dominação}

Objetivando privilegiar a discussão que envolve as noções de técnica e de tecnologia para os pensadores da Escola de Frankfurt, em especial Marcuse (1999), delineamos uma breve evolução destes conceitos no decorrer de sua obra. Inicialmente, em seus escritos, era possível perceber que Marcuse concebia a técnica como neutra, entendida como despretensiosamente associada à adaptação do homem à natureza, enquanto a tecnologia era concebida como a transformação da técnica para finalidades de dominação. No primeiro pensamento, a técnica guarda em si uma possibilidade de uso identificada com a libertação do homem. Posteriormente, “[...] revisando o marxismo à luz de novas forças históricas que entraram em cena” (PISANI,

\begin{tabular}{|c|c|c|c|c|}
\cline { 2 - 4 } Q Q Onialectus & Ano 8 & n. 14 & Janeiro - Julho 2019 & p. $121-146$ \\
\hline
\end{tabular}


2009, p. 137), no seu texto A Ideologia da Sociedade Industrial, em função do contato com as ideias de Heidegger, em A Questão da Técnica, e Husserl, em A Crise das Ciências Européias e a Fenomenologia Transcendental, seu posicionamento é atualizado e a neutralidade da ciência e da técnica é rejeitada. Marcuse (1973) expressa que

em face das particularidades totalitárias desta sociedade, a noção tradicional de tecnologia não pode mais ser sustentada. A tecnologia não pode, como tal, ser isolada do uso que lhe é dado; a sociedade tecnológica é um sistema de dominação que já opera no conceito e na elaboração das técnicas (p. 19).

Desta maneira, Marcuse se reposiciona em relação ao papel da técnica e sua lógica de dominação, considerando que a racionalidade instrumental permanece a ela associada. Velada por todo o aparato tecnológico que encarna o espírito progressista da ciência, da produtividade e da eficiência econômica, reside esta racionalidade que se justifica essencialmente por sua prevalência econômica. Assim, mediante o conceito de tecnicidade, Marcuse expressa ideias sobre a impossibilidade de manter sua noção anterior de técnica como "indiferente ou neutra". Para ele, a tecnicidade, um aspecto inerente à técnica, traduz-se em dominação. Como valor dominante, a capacitação técnica também se beneficiou de sua "propaganda", como tendência a ser seguida e dominada pelos trabalhadores, ainda que a dominação do homem também ocorresse, aparentemente, sem levantar suspeitas. Esta relação entre técnica e dominação é exposta por Benjamin (2012) ao explicar que

nada corrompeu mais as classes trabalhadoras alemãs do que a ideia de que elas estavam integradas na corrente dominante. O desenvolvimento técnico foi visto por elas como o declive da corrente que julgavam acompanhar. Daqui até a ilusão de que o trabalho na fábrica, visto como fazendo parte desse progresso técnico, representava uma conquista política, foi apenas um passo. A velha moral protestante do trabalho, agora em forma secularizada, comemorava com os trabalhadores alemães a sua ressurreição (p. 15).

Nas palavras de Benjamin (2012), é possível perceber que a técnica, enquanto conquista política, foi ofertada e aparentemente aceita de modo tanto entusiasmado e quanto voluntarioso - e isto por suscitar nas pessoas o sentimento de pertencimento e a impressão de participação no mundo moderno das fábricas. Deste modo aquilo que é dominante (no sentido de prevalecer e controlar) e a capacidade de dominação gradualmente universalizam-se por meio desta disposição e disponibilidade das populações em adotarem a tecnicidade como virtude a ser desenvolvida. A explicação de Marcuse (1992) sobre as condições criadas para a soberania da

\begin{tabular}{|c|c|c|c|c|}
\cline { 2 - 4 } & Ano 8 & n. 14 & Janeiro - Julho 2019 & p. $121-146$ \\
\hline
\end{tabular}


técnica como meio e fim último capazes de universalizar a dominação é vista no seguinte trecho:

\begin{abstract}
se levarmos em conta esse caráter existencial da tecnicidade, podemos falar de uma causa final tecnológica e de seu recalcamento pelo desenvolvimento social da técnica. [...] A técnica, desenvolvendo-se atualmente como instrumentalidade "pura", fez abstração da causa final: ela deixou de ser o objetivo do desenvolvimento tecnológico. Como consequência, a instrumentalidade pura, sem finalidade, tornou-se um meio universal de dominação (p. 135-6).
\end{abstract}

A negação deste componente da dominação é necessária para o redirecionamento que tencionamos provocar rumo a uma reconsideração de valores e conhecimentos avaliados hoje, predominantemente, como obsoletos. A banalização e a naturalização desta característica tornam esse aspecto da humanidade uma espécie de "gene dominante da racionalidade" ou um “a-historicismo inato" (ADORNO, 1992, p. 9), tamanha é sua prevalência. Esta marca impressa historicamente conserva em si um esquecimento de nosso passado e/ou um bloqueio de nossas possibilidades de mudança.

Em busca de se adaptar e se perpetuar como espécie, a dominação inicialmente direcionada sobre a natureza em prol do homem transformou-se também em dominação do homem sobre o homem na sociedade capitalista, como expusemos. Esta é encontrada nas relações entre grupos, ou seja, verificamos a dominação de povos sobre povos, nas colonizações pré e pós-industriais e nos monopólios comerciais vigentes nos dias de hoje. Esta dominação é empreendida em favor de interesses particulares e identificada como historicamente constituída, naturalizada pela posição histórica da natureza como objeto da dominação técnica repressiva, em oposição a sua vertente libertadora. Deste modo, Marcuse (1973) estabelece como meta utópica a pacificação, oriunda de uma utilização da dominação em seu caráter libertador. Ele explica que “[...] o propósito de pacificação determina o logos da técnica, ele altera a relação entre tecnologia e seu objeto primordial, a Natureza. Mas há dois tipos de domínio: o repressivo e o libertador. Este compreende a redução da miséria, da violência e da crueldade” (p. 218).

Desta maneira, Marcuse se posiciona de modo a indicar um uso não repressivo da Razão. Por meio de uma definição de uma nova relação da ciência com a natureza, esta, seria objeto de libertação: "Se a Natureza é em si um objeto racional e legítimo da Ciência, então ela é o objeto legítimo não apenas da Razão como poder, mas também da Razão como liberdade; não apenas de dominação, mas também de libertação" (p. 218). Deste ponto, Marcuse (1973) vislumbra uma reconfiguração dos valores empreendidos pela dominação, transformando-a em

\begin{tabular}{|c|c|c|c|c|}
\cline { 2 - 4 } Q Q Onialectus & Ano 8 & n. 14 & Janeiro - Julho 2019 & p. $121-146$ \\
\hline
\end{tabular}


uma dominação da racionalidade com fins de equilibrar o progresso, operando como fator de liberação. Sobre esta mudança necessária da racionalidade tecnológica, Marcuse afirma:

[...] a racionalidade tecnológica, despida de suas particularidades exploradoras, é o único padrão e guia do planejamento e do desenvolvimento dos recursos disponíveis para todos. A autodeterminação na produção e distribuição de bens e serviços vitais seria perdulária. A tarefa é técnica e, como uma tarefa verdadeiramente técnica, possibilita a redução da labuta física e mental. Nesse reino, o controle centralizado é racional se estabelece as precondições da autodeterminação significativa. Esta pode então tornar-se eficaz em sua própria esfera - nas decisões que envolvem a produção e a distribuição do excedente econômico, e na existência individual (p. 231).

A utopia descrita por Marcuse opõe-se e vem a substituir um sistema que em sua essência perpetuou a dominação do homem pelo homem. O estabelecimento desta ordem unidimesnionalizada ocorre porque "os instrumentos de produtividade e progresso, organizados em sistema totalitário, determinam não apenas as utilizações reais, mas também as possíveis" (p. 233). Desta maneira, a irracionalidade ganha contornos de racionalidade sofisticada. A dominação avançada é descrita como purificada ao se tornar eficaz, ou seja: "em sua fase mais avançada, a dominação funciona como administração. E nas áreas superdesenvolvidas de consumo em massa, a vida administrada se torna a boa vida de todos" (p. 234). No propósito de refletir sobre as alternativas futuras, Marcuse aponta para o caminho da pacificação da luta pela existência e, portanto, para o fim da dominação do homem sobre o homem:

uma vez que o desenvolvimento com a utilização de todos os recursos disponíveis para a satisfação universal das necessidades vitais é o requisito da pacificação, esta é incompatível com o prevalecimento de interesses particulares que se interpõem ao alcance dessa meta. A modificação qualitativa está condicionada ao planejamento para o todo contra esses interesses, e uma sociedade livre e racional só pode surgir nessas bases (p. 230).

A pacificação descrita, porém, implicaria na eliminação da dominação do homem pelo homem progressivamente racionalizada ao longo da história e revertida em favor de interesses particulares. Estes fins de lucratividade e produtividade obtidos por via da exploração indiscriminada da natureza dariam lugar a outras finalidades pensadas para o coletivo. Precisarse-ia estabelecer nova modalidade de relação, abandonando a condição de objeto da dominação repressiva. Adorno (1995) partilha de preocupações semelhantes sobre o futuro que a humanidade. Ele alerta que,

hoje, tais reflexões culminam na consideração sobre se a humanidade será capaz de evitar a catástrofe. São de vital importância para a humanidade as formas de sua própria constituição global, enquanto não se constitui e intervém um sujeito global consciente de si mesmo.

\begin{tabular}{|c|c|c|c|c|}
\cline { 2 - 4 } & Ano 8 & n. 14 & Janeiro - Julho 2019 & p. $121-146$ \\
\hline
\end{tabular}


Exclusivamente sobre isso recai a possibilidade de progresso, a possibilidade de afastar a catástrofe extrema, total. Nisso deveriam cristalizar-se todos os problemas relativos ao progresso (p. 39).

Marcuse expressa que "a sociedade seria racional e livre desde que fosse organizada, mantida e reproduzida por um sujeito histórico essencialmente novo" (p. 230). Ao operar racionalmente esta mudança, a história se recondicionaria correlatamente à posição da natureza, e, desta maneira, seria possibilitada seu redirecionamento de modo libertador. Com isto, Marcuse assinala que,

[...] o que está em jogo é a redefinição dos valores em termos técnicos, como elementos do progresso tecnológico. Os novos fins, como fins técnicos, operariam então no projeto e na construção da maquinaria e não apenas em sua utilização. Mais ainda, os novos fins podem reafirmar-se até mesmo na construção de hipóteses científicas - na teoria científica pura. Da quantificação das qualidades secundárias, a ciência passaria à quantificação dos valores (p. 217).

Portanto, para um equilíbrio entre as racionalidades distintas, capazes de promover um progresso orientado para o desenvolvimento das potencialidades humanas de modo livre, nos é afirmado por Marcuse (1973) “[...] uma redução tanto qualitativa como quantitativa do poder, a fim de criar o espaço para o desenvolvimento da produtividade sob incentivos autodeterminados" (p. 218). Tal mudança ocasionaria, utopicamente, uma libertação da energia física e mental hoje "[...] canalizada para o manuseio de mercadorias e serviços” (p. 224). Desta forma, "a libertação de energia de desempenhos exigidos para manter a prosperidade destrutiva significa baixar o alto padrão de servidão a fim de permitir aos indivíduos desenvolverem aquela racionalidade que pode tornar possível uma existência pacificada (p. 224).

Inicialmente, Marcuse considerou que o progresso técnico e o processo cada vez mais acelerado de automação, implicaria numa inevitável redução de mão-de-obra e tornaria obsoleta a necessidade de trabalhar em tempo integral. Como a energia utilizada no trabalho/labuta é retirada principalmente de Eros, com a diminuição deste trabalho, tal energia retornaria à esfera do erótico e ocuparia o conjunto do organismo, mobilizando, desta forma, a totalidade das atividades humanas. Como consequência, o trabalho continuaria indispensável, no entanto, não mais subordinado ao "princípio do desempenho" e à "mais repressão". O que seria eliminado é a "organização da existência humano como instrumento de trabalho" (p.85), o trabalho em si. Este seria erotizado, transformando-se em 'jogo' e possibilitando a criação de relações de trabalho novas e duráveis.

\begin{tabular}{|c|c|c|c|c|}
\cline { 2 - 4 } & Ano 8 & n. 14 & Janeiro - Julho 2019 & p. $121-146$ \\
\hline
\end{tabular}


A definição do nível de vida em termos de automóveis, televisões, aviões, e tratores é a do próprio 'princípio de desempenho'... o nível de vida poderia ser medido por outros critérios: a gratificação universal das necessidades humanas básicas e a liberdade contra a culpa e o medo tanto internalizado como externo, tanto instintivo como 'racional'. (p. p.86).

Entretanto, se em seu livro "Eros e Civilização", escrito em 1955, Marcuse tenta estabelecer as condições para o advento de uma utopia fundada na liberação de Eros, em sua obra posterior "A Ideologia da Sociedade Industrial - o homem unidimensional" escrito em 1964, ele põe o acento nas dificuldades crescentes à constituição do 'sujeito revolucionário', visto a aderência quase completa do indivíduo à ordem unidimensional, que com seu aparato tecnológico e uma sofisticada rede de comunicações de massa manipula e falsifica as consciências individuais, eliminando assim as condições subjetivas capazes de gerar uma atitude de oposição crítica à ordem estabelecida. Tal posicionamento pode ser constatado em seu prefácio à edição de 1966 de "Eros e Civilização":

Eros e Civilização: com esse título eu pretendia expressar uma ideia otimista, eufemística, aliás concreta: a convicção de que os resultados alcançados pelas sociedades industrias avançadas pudessem permitir ao homem inverter o rumo da evolução histórica, quebrar o vínculo fatal entre produtividade e destruição, liberdade e repressão - pudessem, em outras palavras, por o homem em condições de aprender a gaia ciência, ou seja, a arte de utilizar a riqueza social para modelar o mundo do homem segundo os seus instintos de vida, através de uma luta concentrada contra os agentes da morte. Essa visão otimista baseava-se na hipótese de que não mais predominassem os motivos que, no passado, haviam tornado aceitável o domínio do homem sobre o homem; que a escassez e a necessidade do trabalho como esforço fossem mantidos agora de modo apenas 'artificial', com a finalidade apenas de preservas o sistema de dominação. Naquele momento eu havia negligenciado ou minimizado o fato de que esses motivos, agora em processo de extinção, tinham sido enormemente reforçados (e não substituídos) por formas ainda mais eficientes de controle social. Precisamente, as forças que puseram a sociedade em condições de resolver a luta pela existência serviram para reprimir nos indivíduos a necessidade da libertação". (MARCUSE, 1975, p.90).

Portanto, Marcuse claramente decepciona-se com os rumos do progresso, em face das novas formas de dominação prevalentes nas sociedades modernas, as quais decretaram a “irracionalidade objetiva do sistema", já apontada na Dialética do Esclarecimento e referida aqui, anteriormente, a qual se funda, justamente, nessa discrepância entre "progresso tecnológico" e "progresso humanitário", em que ocorre uma distribuição irracional dos bens objetivos e subjetivos que a civilização já conquistou. Isto porque, apesar de todo o progresso tecnológico já alcançado, o modo como a riqueza social, o saber acumulado e as aptidões humanas foram orientadas não redundaram em "progresso humanitário" com vistas à extinção

\begin{tabular}{|l|c|c|c|c|}
\hline Govista Dialectus & Ano 8 & n. 14 & Janeiro - Julho 2019 & p. $121-146$ \\
\hline
\end{tabular}


progressiva da miséria e do trabalho alienado; mas ao invés, resultaram em uma subordinação cada vez maior do homem ao aparato produtivo e de consumo, concebido como um fim em si mesmo. (Marcuse, 1973; Adorno e Horkheimer, 1991).

Contemporaneamente, observamos a perpetuação da dominação, ainda de forma mais sofisticada e racionalizada em acordo com os avanços do capital financeiro. Sobre este processo de evolução da dominação, Marcuse expressa que:

\begin{abstract}
na realidade social, a dominação do homem pelo homem ainda é, a despeito de toda transformação, o contínuo histórico que une Razão pré-tecnológica e Razão tecnológica. Contudo, a sociedade que projeta e empreende a transformação tecnológica da natureza altera a base da dominação pela substituição gradativa da dependência pessoal (o escravo, do senhor; o servo, do senhor da verdade; o senhor, do doador do feudo etc.) pela dependência da 'ordem objetiva das coisas'(das leis econômicas, do mercado etc). Sem dúvida, a 'ordem objetiva das coisas' é, ela própria, o resultado da dominação, mas é, não obstante, verdade que a dominação agora gera mais elevada racionalidade - a de uma sociedade que mantém sua estrutura hierárquica enquanto explora com eficiência cada vez maior os recursos naturais e mentais e distribui os benefícios dessa exploração em escala cada vez maior (p.142).
\end{abstract}

A economia e o mercado, cada vez mais, mostram relações estreitas com a produção científica, ao ponto de as próprias pesquisas serem determinadas, em seus objetivos e desenvolvimento, não pelos cientistas, mas pelos seus financiadores, norteados pelo princípio de rendimento no mercado. De tal sorte que, os empreendimentos científicos pouco dependem de sua eficiência como incremento ou melhoria das carências humanas a serem aplacadas pelos seus resultados. Sua eficiência está ligada ao seu sucesso enquanto empreendimento mercadológico.

A não adesão à ordem mercantil vigente, identificada com o progresso tecnológico instrumentalizante resulta no " [...] banimento gradual dos sonhadores, dos pensadores utópicos, dos poetas, dos homens sensíveis, dos divergentes e outsiders de todo tipo para os domínios da loucura e da exclusão social" (SOARES, 1997, p. 3). As demandas por adaptação a essa ordem instrumental tornam a dominação cada vez mais naturalizada:

vivemos em um mundo que não gosta da revolta nem da crítica, que acredita plenamente na ordem natural das coisas e que pede a cada um e a todos para se adaptarem, por um simples "cálculo" individual. O mundo contemporâneo não gosta da "universalidade", tendo no dinheiro sua única exceção. Somos todos definidos como consumidores, não como cidadãos, muito menos como pessoas (SOARES, 2002, p. 38).

\title{
Considerações Finais
}

\begin{tabular}{|c|c|c|c|c|}
\cline { 2 - 4 } Q Dovista & Ano 8 & n. 14 & Janeiro - Julho 2019 & p. $121-146$ \\
\hline
\end{tabular}


Em face ao exposto, nosso entendimento cumplicia com o diagnóstico de que os (des)caminhos da ciência e da técnica, em sua relação com o homem e a natureza, tendem a um progressivo processo de dominação e desejo de controle - isto consiste, pois, em uma característica dominante do "homem da ciência", ou das "teorias tradicionais", na definição de Horkheimer (1983). É paradoxal, do ponto de vista humanitário e ético, que em face das capacidades técnicas já exponencialmente desenvolvidas, os homens não tenham conseguido tornar os problemas efetivamente coletivos, vinculados à questão central da desigualdade social. Entretanto, o paradoxo é apenas aparente. Sob a perspectiva em que nos situamos para a elaboração do diagnóstico referido por esse estudo, torna-se nítida a opção pelas razões mercantis no transcurso do desenvolvimento científico. Isso nos faz refletir sobre a abertura operada para atacar esses problemas, considerando que a exploração do homem pelo homem é o sustentáculo do sistema capitalista. Assim, como uma dada racionalidade justificou a superioridade ariana para Hitler, visões de mundo racionais pautadas na eficiência e no mero cálculo seguem justificando contemporaneamente a manutenção da barbárie, da miséria, da guerra, da exploração e da injustiça.

Boaventura Sousa Santos (2002) apresenta explicação de grande valia para nosso estudo sobre as frentes de desenvolvimento nas quais a sociedade progride. Seu pensamento guarda similaridade com as proposições marcuseanas sobre o progresso técnico e o progresso humanitário. Observamos nas ideias abaixo um singular modo de compreender os acontecimentos que parecem ter levado a paralisar a crítica e a intensificar a dominação e o controle. Ao falar do desenvolvimento do conhecimento, o autor exprime que

todo o acto de conhecimento é uma trajectória de um ponto A que designamos por ignorância para um ponto B que designamos por conhecimento. No projeto da modernidade podemos distinguir duas formas de conhecimento: o conhecimento-regulação cujo ponto de ignorância se designa por caos e cujo ponto de saber se designa por ordem e o conhecimento-emancipação cujo ponto de ignorância se designa por colonialismo e cujo ponto de saber se designa por solidariedade. Apesar de estas duas formas de conhecimento estarem ambas inscritas na matriz da modernidade eurocêntrica a verdade é que o conhecimento-regulação veio a dominar totalmente o conhecimento-emancipação (p. 29).

Quanto menos caminhamos rumo à emancipação, mais estaremos imersos sob o desejo (e práticas!) de regulação. Assim, entendemos que o exercício da lógica da dominação se beneficia da ignorância e da exploração colonialista que se opera, inclusive, dentro dessa dinâmica nas formas de conhecimento em que o poder se manifesta sob a égide da submissão, obediência, alienação e impotência.

\begin{tabular}{|c|c|c|c|c|}
\cline { 2 - 4 } & Ano 8 & n. 14 & Janeiro - Julho 2019 & p. $121-146$ \\
\hline
\end{tabular}


Em decorrência da suspeição levantada sobre as relações mercadológicas com a ciência, fica clara a defesa feita em prol de recobrarmos uma consciência ética condizente com os ideais de emancipação humana e a derrocada dos mitos. As dificuldades são inerentes à sistemática implementada para operar a mínima mudança nas atuais condições de reencantamento. É preciso resistir inventando uma criatividade e racionalidade outras. Ao tratar dessa sistemática à prova de reversão, Marcuse (1999) assim se pronuncia:

a questão é que atualmente o aparato ao qual o indivíduo deve ajustar-se e adaptar-se é tão racional que o protesto e a libertação individual parecem, além de inúteis, absolutamente irracionais. O sistema de vida criados pela indústria moderna é da mais alta eficácia, conveniência e eficiência (p. 82).

A tecnologia nos dispositivos móveis de comunicação representa, nos dias de hoje, fonte de "contato" com tudo o que já foi criado pela humanidade e também com aquilo que ainda não o foi, mas já se projeta ficcionalmente. A natureza e os homens são encontrados também em suas maneiras substitutivas e virtuais, que apaixonam o homem pelo espírito tecnológico sacralizado - e que é, hoje, anunciado como o "salvador da humanidade".

Em todos os âmbitos da atividade humana, o indivíduo contemporâneo é demandado a mostrar aptidões imediatas de modo a prescindir do pensamento reflexivo: o imperativo é o de reagir, mais que refletir; comprovar, mais que analisar; apresentar dados, mais que questionar; mostrar resultados, mais que produzir sentidos. O saber-fazer é substituído pela performance; a formação, pelo treinamento; a reflexão ética sobre os saberes e direcionamentos dos produtos da ciência, pela racionalidade instrumental mercantil.

O diagnóstico de Marcuse de que a técnica sempre encarna um Projekt, no qual são projetados os interesses dominantes da sociedade e suas intenções com relação aos homens e às coisas, segue atual:

A racionalidade tecnológica ter-se-á tornado racionalidade política [...]. O aparato técnico de
produção e distribuição não funciona como a soma total de meros instrumentos que possam ser
isolados de seus efeitos sociais e políticos, mas como um sistema que determina, a priori, tanto
o produto do aparato como as operações de sua manutenção e ampliação. [...]. A tecnologia serve
para instituir formas novas, mais eficazes e mais agradáveis de controle social e coesão social.
(MARCUSE, 1982, pp. 14-19).

Deste modo, em face da permanência, da exacerbação, do transbordamento e do exaurimento das desigualdades sociais e econômicas na contemporaneidade, concluímos que as facilidades auferidas pelos atuais recursos da tecnociência não propiciaram subsídios para um caminho rumo à emancipação. Pelo contrário: atrela-o cada vez mais à lógica do capital,

\begin{tabular}{|l|c|c|c|c|}
\cline { 2 - 4 } & Ano 8 & n. 14 & Janeiro - Julho 2019 & p. $121-146$ \\
\hline
\end{tabular}


capturando-o nos produtos da ciência aplicada e nos objetos de consumo. E isso com o agravante de vampirizar e sorver, cada vez mais, um tempo supostamente liberado do trabalho e da produção - trata-se, pois, de um mundo 24-7, de alerta onipresente, suscitado e excitado mediante próteses tecnológicas a demandar uma insaciável competitividade, sem quaisquer reflexões sobre seus fins. Hoje, como ontem, o "progresso tecnológico" segue não resultando em "progresso humanitário".

\section{Referências:}

ADORNO, Theodor. Mínima Moralia. São Paulo: Ática. 1992.

. Educação após Auschwitz. In: ADORNO, T.W. Educação e emancipaçãa. Rio de Janeiro: Paz \& Terra, 1995a. p. 119-138.

. Progresso. In: ADORNO, T.W. Palavras e sinais: modelos críticos 2. Petrópolis: Vozes, 1995b. p. 37-61.

\& HORKHEIMER. Dialética do esclarecimento: fragmentos filosóficos (1947). 2. Ed. Rio de Janeiro: Jorge Zahar Editor, 1991.

ALVES, Giovanni. Trabalho e Subjetividade: O Espírito Do Toyotismo na Era do Capitalismo Manipulatório. São Paulo: Boitempo, 2011.

BENJAMIN, Walter. Documentos de Cultura, documentos de barbárie. (Textos escolhidos). São Paulo: Cultrix, 1986.

SCHÖTTKER, D., BUCK-MORSS, S., HANSEN, M., Benjamin e a obra de arte: técnica, imagem, percepção. Rio de Janeiro: Contraponto, 2012.

CRARY, Jonathan. 24/7. Capitalismo tardio e os fins do sono. São Paulo: Cosac Naify, 2014.

FREITAG, Barbara. Teoria Crítica Ontem e Hoje, São Paulo: Brasiliense, 1988.

HABERMAS, Jurgen. Técnica e Ciência como Ideologia. Lisboa: Edições 70, 1968.

HORKHEIMER, Max. Teoria Tradicional e Teoria Crítica. In: HORKHEIMER, Max e ADORNO, Theodor. Textos Escolhidos,. São Paulo: Abril Cultural, 1983, p. 31-68.

Eclipse da Razão. São Paulo: Centauro, 2007.

KLEIN, Etienne. Questionando a Ciência in NOVAES, Adauto (org.). Ensaios sobre o Medo. São Paulo: Editora Senac São Paulo/ Edições Sesc SP, 2007, p. 253-266.

\begin{tabular}{|c|c|c|c|c|}
\cline { 2 - 4 } & Ano 8 & n. 14 & Janeiro - Julho 2019 & p. $121-146$ \\
\hline
\end{tabular}


LEOPOLDO E SILVA, Franklin. Descontrole do tempo histórico e banalização da experiência. Em NOVAES, Adauto (org.) Mutações. Rio de Janeiro: Ed. Agir, 2008a, p. 149-172.

LIMA, Aluisio Ferreira. Metamorfose, Anamorfose e Reconhecimento Perverso. São Paulo: FAPESP; EDUC, 2010.

MARCUSE, Herbert Ideologia da Sociedade Industrial. Rio de Janeiro: Zahar, 1973.

Eros e Civilização: uma interpretação filosófica do pensamento de Freud. Rio de Janeiro: Zahar, 1975.

Cultura e Sociedade. São Paulo: Paz e Terra, 1998.

Algumas Implicações Sociais da Tecnologia Moderna. In: Tecnologia, Guerra e Fascismo. Trad. Maria Cristina V. Borba. São Paulo: Ed. UNESP, 1999, p.73-104.

A Noção de Progresso à Luz da Psicanálise. In:. Cultura e Psicanálise. São Paulo: Paz e Terra, 2001, p.99-122.

64.

A Responsabilidade da Ciência in: scientiæ zudia, São Paulo, v. 7, n. 1, 2009, p. 159-

MATOS, Olgária. Discretas Esperanças. São Paulo: Editora Nova Alexandria, 2006.

NOVAES, Adauto. Entre dois Mundos in: NOVAES, A.. (org.) A Condição humana. Rio de Janeiro, Ed. Agir, 2009, p. 9- 37.

PISANI, Marília. Algumas considerações sobre ciência e política no pensamento de Herbert Marcuse. Scientiæ Zudia, São Paulo, v. 7, n. 1, 2009, p. 135-58.

ROUANET, Sérgio Paulo. As Razões do Iluminismo. São Paulo: Companhia das Letras, 1987. Nós, civilizações, sabemos que somos mortais in. NOVAES, Adauto. A condição humana. Rio de Janeiro, Ed. Agir, 2009. p. 185-198.

SANTOS, Boaventura de Sousa..Crítica da Razão Indolente. 4ed. São Paulo: Cortez, 2002.

SFEZ, Lucien. A Saúde Perfeita: crítica de uma nova utopia. São Paulo: Loyola, 1996.

SOARES, Jorge. Repensando a Noção de Progresso Globalizado. Conferência III Semana Gilberto Freyre, Recife, 1997.

. Em busca de uma "razão sensível" no reino da cultura de massa. In Logos: Comunicação e Universidade; Produção de Sentido na Contemporaneidade. Revista de Comunicação Social da UERJ, Ano 9. №. 17, 2002, p.33-44.

\begin{tabular}{|l|c|c|c|c|}
\cline { 2 - 4 } & Ano 8 & n. 14 & Janeiro - Julho 2019 & p. $121-146$ \\
\hline
\end{tabular}




\title{
VIDA E MORTE, PROGRESSO E UTOPIA EM HERBERT MARCUSE
}

\author{
Marília Mello Pisani ${ }^{1}$
}

\begin{abstract}
Resumo:
Neste artigo pretendo apresentar a crítica da sociedade industrial de Herbert Marcuse, em dois movimentos. Tomando como caso particular a indústria automobilística como generalização de uma forma de vida (e de morte), assim como o debate realizado sobre esse tema na década de 1970, discutirei o lugar da Utopia no pensamento de Herbert Marcuse como base para pensar os movimentos sociais contemporâneos e a própria Teoria Crítica. Para isso, mobilizo trabalhos de pesquisadores e pesquisadoras brasileiras(os), alguns textos inéditos de Marcuse e uma série de trabalhos que permitem articular uma teoria crítica do movimento social na chave da Grande Recusa e da revolução.
\end{abstract}

Palavras-chave: teoria crítica; grande recusa; antiracismo; feminismo; ecologia; Herbert Marcuse (1898-1979).

\section{LIFE AND DEATH, PROGRESS AND UTOPIA IN HERBERT MARCUSE'S}

\begin{abstract}
:
In this article I intend to present the criticism of the industrial society of Herbert Marcuse in two movements. Taking the automobile industry as a particular case for the generalization of a way of life (and death), as well as the debate on this theme in the 1970s, I will discuss the place of Utopia in Herbert Marcuse's thinking as a basis for thinking the social movements and Critical Theory itself. To this end, I mobilize the works of Brazilian researchers, some unpublished texts of Marcuse in Brazil, and a series of papers that allow articulating a critical theory of the social movement in the key of the Great Refusal and revolution.
\end{abstract}

Keywords: critical theory; great refusal; antiracism; feminism; ecology; Herbert Marcuse (1898-1979).

\section{Nota introdutória}

Este artigo pretende discutir a crítica da sociedade industrial de Herbert Marcuse à luz de suas concepções de Utopia e de Grande Recusa, articuladas ao seu modo de pensar os movimentos sociais contemporâneos do período de 1967-1979. A motivação desta escrita, entretanto, não vem de uma vontade em esclarecer o pensamento de Marcuse sobre estes problemas. O problema deste ensaio não emerge da tentativa de elucidação do pensamento de Marcuse. Na verdade, a força que mobiliza a mão e o corpo que escreve é derivada de uma necessidade vital e biológica de elaboração de um luto.

Maria Érbia Carnaúba faleceu no dia 26 de agosto de 2017 em um acidente de carro no

\footnotetext{
${ }^{1}$ Possui doutorado em Filosofia (UFSCar, 2008), mestrado em Filosofia (UFSCar, 2003), bacharelado e licenciatura em Ciências Sociais (UNESP, 1999). Atualmente é professora adjunta da Universidade Federal do ABC nos cursos de graduação em Filosofia e nos Bacharelados Interdisciplinares. Na pós-graduação, atua nos cursos de mestrado acadêmico em Filosofia e mestrado profissional em Filosofia (PROF-FILO). E-mail: marilia.m.pisani@gmail.com.
} 


\section{VIDA E MORTE, PROGRESSO E UTOPIA EM HERBERT MARCUSE}

Marília Mello Pisani

aeroporto do Viracopos, Campinas, quando levava a amiga Carolina Blasio (que havia defendido o doutorado em Filosofia no dia anterior) para pegar um avião. Em uma curva mal sucedida, o carro despencou com as duas de uma ponte, caindo de ponta cabeça e levando, em segundos, as duas vidas, em questão de segundos... Recebi a notícia na manhã do dia 27. Eu não conseguia acreditar. Não havia sentido nenhum no desaparecimento absoluto de Maria. Eu nunca mais a veria. Ela não estaria na banca, como titular externo, de meu primeiro orientando de mestrado a defender uma dissertação sobre Marcuse, como já estava agendado acontecer. Eu não teria nunca a oportunidade de discutir com ela a sua tese de doutorado defendida em março do mesmo ano. Maria seria, sem dúvida, uma das maiores pesquisadoras de Marcuse no Brasil. Maria e eu não tivemos a oportunidade da convivência, mas tínhamos vínculos profundos de respeito pelo trabalho que realizávamos e foi compartilhando o mesmo autor, e as mesmas angústias e esperanças, que Herbert Marcuse nos ligou. E é ele que chamo para nos ligar neste texto. Sinto como se as palavras que escrevo aqui permitissem fixar para além da passagem do tempo uma materialidade profunda de admiração e as saudades dela. As lágrimas são impossíveis de conter. Mas quero e preciso fazer isso. Porque eu não aceito a morte de Maria, ela não é um fato natural da vida. Eu recuso esta morte e desta recusa vem a força para este esforço de pensar, junto com Herbert Marcuse e com Maria Érbia, que isso não deveria ter acontecido. A sua morte é, nesse sentido, um signo. Sobre isso, farei uma longa citação de Marcuse, citação esta que ela com certeza conhecia muito bem e que me surpreende agora que ela seja o disparador fundamental deste texto, que é uma homenagem, uma despedida e uma celebração pela vida de Maria. No final de seu livro Eros e civilização: uma interpretação filosófica do pensamento de Freud (1999a), Marcuse escreve:

Não os que morrem, mas os que morrem antes de querer e dever morrer, os que morrem de agonia e de dor, são a grande acusação lavrada contra a civilização. Também servem de testemunho para a culpa irredimível da humanidade. A morte deles suscita a dolorosa consciência de que foi desnecessária, de que poderia ter sido de outra maneira. São precisos todos os valores e instituições de uma ordem repressiva para pacificar a má consciência dessa culpa. (...) Numa civilização repressiva, a própria morte torna-se instrumento de repressão. Quer a morte seja temida como uma constante ameaça ou glorificada como supremo sacrifício, a educação para o consentimento da morte introduz um elemento de abdicação da vida, desde o princípio - abdicação e submissão. Sufoca os esforços utópicos. (...) A Teologia e a Filosofia concorrem entre si na celebração da morte como uma categoria existencial: pervertendo um fato biológico para torná-lo uma essência ontológica, concedem suas bênçãos transcendentais à culpa da humanidade que ambas ajudam a perpetuar; assim, atraiçoam a promessa de utopia. Em contraste, uma Filosofia que não trabalha como dama de companhia da repressão reage ao fato

da morte com a Grande Recusa - a recusa de Orfeu, o libertador. A morte pode torna-se um símbolo da liberdade. (...) Os [seres humanos] podem morrer sem angústia se souberem que o que eles amam está protegido contra a miséria e o esquecimento. (...) Mas até o advento supremo da

\begin{tabular}{|l|l|l|l|l|}
\hline Revista 2 ialectus & Ano 8 & n. 14 & Janeiro-Julho 2019 & p. 147 - 168 \\
\hline
\end{tabular}




\section{VIDA E MORTE, PROGRESSO E UTOPIA EM HERBERT MARCUSE}

Marília Mello Pisani

liberdade não pode redimir aqueles que morrem de dor. É a recordação deles [e delas] e a culpa acumulada contra as suas vítimas que obscurecem as perspectivas de uma civilização sem repressão (Marcuse: 1999a: 203-204).

Como pesquisadora de Marcuse, Maria defendeu, em 2012, a dissertação de mestrado Marcuse e a Psicanálise: teoria crítica sob a análise da teoria da repressão (2012) onde trabalhou a noção de sociedade repressiva a partir dos conceitos de mais-repressão e de princípio de desempenho. Para isso, ela retomou a singular apropriação de Freud feita por Marcuse e articulou esse debate à gênese mesma da noção de Teoria Crítica, terminando com o capítulo intitulado "O retorno à utopia" que já indicava posteriores desdobramentos de sua pesquisa de doutorado, Teoria crítica e Utopia (2017). O cerne de sua produção intelectual é o apelo em demonstrar a importância da noção de Utopia de Marcuse para a Teoria crítica. No doutorado, ela esmiúça o percurso do conceito de utopia em Marcuse: o debate com Max Horkheimer, Theodor Adorno e Ernst Bloch e a aliança fundamental entre teoria e prática, que teria permitido a Marcuse estabelecer um diálogo muito próximo aos movimentos sociais a partir de 1967, como vemos no ensaio de Marcuse O Fim da Utopia, e que seguirá até o fim de sua vida, em 1979. Neste artigo pretendo seguir muito de perto o percurso proposto por ela, mas em termos que me permitam elaborar como a crítica da sociedade industrial e a noção de Grande Recusa poderiam nos ajudar a levar a sério a intenção que movimenta este modelo de Teoria crítica proposto por Marcuse: "de que a vida humana é digna de ser vivida, ou melhor, pode ser e dever ser feita digna de ser vivida. Esse juízo subjaz a todo esforço intelectual; é o a priori da teoria social e sua rejeição (que é e perfeitamente lógica) refuta a própria teoria” (Marcuse: 2015: 32).

\section{Carro e Morte: a generalização do automóvel como forma de vida}

(...) num bom automóvel a própria carroceria obedece à necessidade interna do motor, a expressão fisionômica dessas figuras obedece ao que está dentro. Ao que está dentro, e não à interioridade: é por isso que elas são bárbaras (Benjamin: 1994: 116).

O acidente que levou Maria não teve até este momento uma explicação satisfatória. Tentaram responsabilizá-la, por estar dirigindo de chinelos. Mas as explicações isoladas não dão conta. Há uma aliança de fatores: uma curva muito acentuada num trecho de entrada de um aeroporto, a pressa para deixar a amiga, uma ponte nova construída para embelezar o espaço, mais do que para proteger as/os motoristas. Uma ponte de vidro, que não foi capaz de segurar o

\begin{tabular}{|l|l|l|l|l|}
\hline Q Povista Dialectus & Ano 8 & n. 14 & Janeiro-Julho 2019 & p. $147-168$ \\
\hline
\end{tabular}




\section{VIDA E MORTE, PROGRESSO E UTOPIA EM HERBERT MARCUSE}

Marília Mello Pisani

carro, função de proteção que deveria ser prioritária na construção da ponte, ainda mais naquele lugar. Um muro fake projetado por uma empresa guiada pelas necessidades da moda das mercadorias. Os prédios de vidro não aquecem no inverno e são quentes no verão. Nos muros de vidro a transparência oculta a percepção de sua barbárie.

Recordando Walter Benjamin. Em Experiência e Pobreza (1994) ele mostra que o vidro aparece como o material por excelência da forma mercadoria na sociedade capitalista tecnologicamente desenvolvida: "Não é por acaso que o vidro é um material tão duro e tão liso, no qual nada se fixa. E também um material frio e sóbrio. As coisas de vidro não têm nenhuma aura. O vidro é em geral inimigo do mistério" (1994: 118). E se pergunta: os edifícios de vidro não professariam uma nova pobreza da experiência? Benjamin acompanha as mudanças na forma mercadoria, a passagem do interior burguês, com sua intimidade de bibelôs, cortinas com franjas, poltronas, esses "espaços de pelúcia", para o novo modelo industrial e tecnológico com a eliminação da interioridade, dos rastros, da memória e da própria experiência. Já não há o que narrar, tudo começa sempre de novo, não há tempo para se lembrar. A memória impregnada na materialidade das coisas e nas histórias contadas de geração a geração são eliminadas juntamente "com seu vidro e com a Bauhaus de aço": "eles criam espaços em que é difícil deixar rastros" (Benjamin: 1994: 118). Parafraseando o escritor Paul Scheebart, Benjamin escreve: "podemos falar de uma cultura de vidro. O novo ambiente de vidro mudará completamente os homens." (1994: 118).

Benjamin escreveu essas palavras em 1933. Quarenta anos depois, o ecologista francês René Dumont escreveu o livro A Utopia ou a Morte (1975) no qual apresentou um diagnóstico severo daquilo que Walter Benjamin começou a entrever, a saber, a submissão total da vida humana e da natureza à necessidade de um modelo de desenvolvimento econômico centrado na exploração de matéria prima e no lucro, na produção de desigualdades e na concentração de renda, enfim, a mola propulsora do capitalismo. O diagnóstico é radical, assim como as soluções propostas por ele. Tomando o carro como o modelo por excelência deste processo, Dumont consegue estabelecer as mediações que fazem do carro o objeto privilegiado para a compreensão das formas contemporâneas de vida.

A escolha pelo carro como mercadoria foi resultado de uma decisão econômica estratégica. Em torno do automóvel se construiu a vida em amplo sentido e se produziu o mercado monopolizado da locomoção humana baseado no petróleo. Este modelo produtivo define a cartografia dos territórios e o uso dos espaços, com seus viadutos, pontes, ruas, estradas,

\begin{tabular}{|c|c|c|c|c|}
\hline Revista Dialectus & Ano 8 & n. 14 & Janeiro - Julho 2019 & p. $147-168$ \\
\hline
\end{tabular}




\section{VIDA E MORTE, PROGRESSO E UTOPIA EM HERBERT MARCUSE}

Marília Mello Pisani

estacionamentos, fábricas, oficinas e postos de combustíveis, entre outros. Estas políticas econômicas de desenvolvimento foram tomadas por pequenos grupos de interesse articulados em torno do Clube de Roma (Dumont: 1975: 60-61) onde se decidiu acerca da gestão mundial dos recursos naturais e energéticos, das populações e do modelo de desenvolvimento científico e tecnológico. O impacto dessas tomadas de decisões exteriores afetam profundamente as localidades.

Se tomarmos o exemplo da região do ABC paulista (sobretudo as cidades de Santo André e de São Bernardo do Campo), polo da indústria automobilística na década de 70-80, podemos analisar esta situação de dependência em outros tipos de acordos internacionais, como o Consenso de Whashington (Alves: 2009: 16-17). Luiz Roberto Alves nos ajuda a pensar sobre isso. Em seu texto Grande ABC: culturas que excedem o lugar culturalizado (2009) ele apresenta algumas das principais consequências culturais das diferentes alianças e tensões entre o capital e o trabalho na região. Do dirigismo paternalista sob a ditadura militar, que fomentou a grande indústria, às sociedades recém democratizadas, o modelo político econômico dependente das regulações do capital internacional levaram ao "despedaçamento das relações de trabalho, a fragmentação dos espaços urbanos e rurais, o fim das utopias e a submissão de tudo à economia e ao jogo do mercado. Certamente a cultura compôs e compõe o quadro de desencanto programado pelo Capital” (2009: 17). Nesse momento acontece, segundo o autor, uma nova rodada de apropriação da cultura pelo Capital, a partir do chamado capital cultural ou humano, com consequências profundas para a região. Esse exemplo mostra o quanto a dependência de modelos econômicos exógenos pode afetar a vida nas localidades distantes das tomadas de decisões.

A exportação desse modelo de vida para outras sociedades tem consequências graves e dificilmente reversíveis sem uma transformação radical, diz Dumont: "aumentamos a miséria do Terceiro Mundo", tornamos o ar irrespirável, "gastamos preciosos litros de ouro negro, que faltarão a nossos descendentes" (1975: 61). Segundo ele, cada carro produzido representa aço a menos para os arados dos camponeses e outras ferramentas que poderiam aumentar a sua produtividade local e a distribuição dos recursos necessários à vida. A escolha pelo carro implicaria, nessa perspectiva, a recusa de outros tantos modelos de desenvolvimento, de formas de vida e de culturas.

O aço, os outros materiais, os engenheiros, os técnicos e os operários que os constroem, todos os recursos raros e toda a atividade competente, se fossem dirigidos para outras finalidade, teriam já

\begin{tabular}{|l|l|l|l|l|}
\hline Qevista Dialeatus & Ano 8 & n. 14 & Janeiro-Julho 2019 & p. 147-168 \\
\hline
\end{tabular}




\section{VIDA E MORTE, PROGRESSO E UTOPIA EM HERBERT MARCUSE}

Marília Mello Pisani

podido prover por toda a parte uma indústria suficiente para cobrir o conjunto de necessidade essenciais dos países ditos em via de desenvolvimento. (...) Quanto ao Brasil, por muito pouco não fui ali atropelado, quando julgava que um sinal vermelho me protegia. Fala-se ultimamente sobre estes acidentes de carro e centenas de milhares de feridos (...) 'sacrificam-se sem pena a habitação, ensino, telefone, urbanismo, pesquisa cientifica, cultura artística, e a própria saúde pública’, para citar [algumas de suas] vítimas (Dumont: 1975: 61-62).

Segundo André Gorz, esta crítica do carro como modelo de desenvolvimento não é facilmente aceita nem pela direita nem pela esquerda: "por que o carro é tratado como uma vaca sagrada?", por que não é reconhecido como algo "antissocial"? (Gorz: 2005: 74-75). Por conta da ideologia que ronda o carro, que produz aquilo que Gorz chama de "mito automobilístico", apenas uma recusa radical deste modelo de locomoção monopolizada pela indústria de petróleo e suas adjacentes poderia religar as populações, os territórios e suas culturas, ou melhor, fazer da vida digna de se viver, como diria Marcuse. Para Gorz:

a generalização do carro particular golpeou os transportes coletivos, alterou o urbanismo e o habitat e transferiu ao carro certas funções que a sua própria difusão tornou necessárias. Será preciso uma revolução ideológica ('cultural') para quebrar esse círculo vicioso. Obviamente não se deve esperar isso da classe dominante (de direita ou de esquerda) (Gorz: 2005: 75).

Para ele há um paradoxo interno a esse mito do carro: o fato de que a liberdade de ir e vir que ele proporciona está indissociavelmente ligada às necessidades que o uso do carro implica, como congestionamentos, estacionamentos, multas e manutenção, o que, no final das contas, não se reverte em mais tempo hoje do quando se tinha outras alternativas, como bondes, charretes, carroças e bicicletas (ele se apoia no texto Energia e Equidade, de Ivan Ilich). A organização urbana, com seus bairros e locais de trabalho distantes, faz parte das necessidades mesmas do carro. Ou seja, a geografia das cidades é definida e construída para os carros, e não para as pessoas, a partir de uma necessidade vinda do capital monopolista que "transformou o supérfluo em necessário" (Gorz: 2005: 79). A aparente necessidade vital de se possuir carros, que produz a aparência de que o carro é símbolo de progresso, precisa ser desmistificada: primeiro, a partir do estudo de sua gênese (práticas, decisões, valores) e de como ele configura o mundo tal como vemos; e segundo, a partir do confronto entre o que é e as possibilidades de um outro desenvolvimento social materialmente possível, ou seja, das possibilidade negadas de desenvolvimento: "tão logo o carro assassinou o carro [quer dizer, os seus benefícios passam a ser confrontados com os custos], ele fez com que as alternativas de mudança desaparecessem, tornando compulsório, deste modo, o carro" (Gorz: 2005: 80).

René Dumont propõe que apenas por meio do pensamento utópico podemos ver as

\begin{tabular}{|l|l|l|l|l|}
\hline Q Rovista Dialactus & Ano 8 & n. 14 & Janeiro-Julho 2019 & p. 147-168 \\
\hline
\end{tabular}




\section{VIDA E MORTE, PROGRESSO E UTOPIA EM HERBERT MARCUSE}

Marília Mello Pisani

possibilidades negadas de um caminho alternativo para o desenvolvimento - "utopias mais ou menos realizáveis", ele diz. Seriam utópicas se "olhadas principalmente pelos ricos dos países ricos, e os ricos dos países pobres", que não admitirão renunciar a seus privilégios. Faço aqui um breve apanhado de algumas destas utopias realizáveis de Dumont: mudar a atitude com os países colonizados e explorados, para diminuir o abismo que os separa - por exemplo, por meio da anulação das dívidas, fornecimento de equipamentos, outra política de alimentos e energia; limitação e posterior supressão dos armamentos; redistribuição de renda, imposto internacional para grandes transações financeiras, interrupção dos ritmos infernais; reciclagem, imposto sobre energia e matéria prima; transportes coletivos; viagens aéreas racionalizadas e reduzidas como resultado do fomento a outros meios de locomoção; alimentação para todos; reforma agrária; nova política com relação aos oceanos (Dumont: 1975: 166-167). Tudo isso sob o princípio de que a natureza não é uma fonte inesgotável de energia; de que a vida humana e a natureza devem ser favorecidas; que o direito à dignidade e à vida devem ser efetivos.

André Gorz também afirma que apenas uma mudança em escala global seria eficiente neste sentido. Isso significaria não apenas oferecer transporte coletivo, mas, seria preciso poder

(...) dispensar por completo o transporte por se sentirem em casa em seus bairros, nas suas comunidades, nas suas cidades, construídos em escala humana, e por terem prazer em andar do trabalho para a casa a pé ou, se preciso for, de bicicleta. Nenhum meio de transporte e evasão veloz jamais compensará a desgraça de se viver em uma cidade inabitável em que ninguém se sente em casa em lugar algum, ou se passar somente para ir trabalhar ou, ao contrário, para se isolar e dormir (Gorz: 2005: 81).

As ruas da cidade dos carros ficam esvaziadas de noite, pois elas não são para estar, mas para passar. É justamente pelo enraizamento profundo deste modo de vida que a solução, se possível, deveria ser pensada em termos radicais, ou revolucionários, como afirma Gorz, apoiando-se em Marcuse: "Tal como respondeu Marcuse quando the perguntaram como as pessoas gastariam seu tempo após a revolução, quando o desperdício capitalista tivesse sido terminado: 'Vamos tratar de destruir as grandes cidades e construir novas e distintas. Isso nos manterá ocupados por um bom tempo" (Marcuse apud Gorz: 2005: 81). O fim da cidade dos carros como um princípio revolucionário - é disso que se trata. O texto de Gorz também foi escrito em 1973, tal como o de Dumont. A década de 70 é crucial para pensarmos a contribuição de Marcuse sobre as consequências da sociedade industrial avançada ou capitalismo monopolista e as formas de resistência.

\begin{tabular}{|c|c|c|c|c|}
\hline Qevista Dialectus & Ano 8 & n. 14 & Janeiro - Julho 2019 & p. $147-168$ \\
\hline
\end{tabular}




\section{VIDA E MORTE, PROGRESSO E UTOPIA EM HERBERT MARCUSE}

Marília Mello Pisani

Hoje é dia 20 de junho de 2018. As dezesseis horas e trinta minutos eu decidi sair para caminhar. Havia terminado a primeira parte do argumento do artigo, que coloca o carro no centro de uma crítica da civilização industrial, quando resolvi fazer uma breve caminhada para pensar na articulação do segundo movimento. Decidi pegar a Avenida Sumaré que, apesar de ser uma via de muito tráfego, tem uma pista de ciclismo e corrida bem ao meio, dividindo as duas faixas da rua. Quando cheguei e comecei a dar os primeiros passos, senti-me constrangida. O cheiro da gasolina exalava muito forte das fileiras de carro à direita e à esquerda. Insisto e resolvo caminhar assim mesmo, já que esta pista de corrida tem árvores centenárias belíssimas. No meio do caminho, desisto, intoxicada estou pelo escapamento dos carros. Mobilizada pela escrita deste texto, passo a perceber detalhes que me teriam passado despercebidos. Vejo uma moça que atravessa com seu carro em alta velocidade falando ao telefone celular, eu levo um susto com a batida que ela dá ao atravessar uma lombada; vejo à minha direita o motorista de um carro ameaçando jogar o veículo sobre a moto, que responde chutando o retrovisor. Logo em seguida passa um grande caminhão que carrega carros e onde posso ler, na carroceria, uma frase estampada bem em cima da foto de uma grande mão segurando um carro: "aqui seu carro está em boas mãos”; bem ao lado vejo uma bica de água pequena que escorre do morro por uma brecha na parede onde as famílias que moram na rua, mulheres, crianças, homens e idosos lavam suas roupas e tomam banho. Decido dar meia volta e sair dali imediatamente, porque aquilo tudo começa a me intoxicar. Tento mudar para a calçada, mas isso não ajuda em nada. A gasolina que corre nos motores também corre nas minhas veias. O carroceria de aço dos carros também é a imagem de nossos corpos.

Decido, finalmente, correr dali em direção ao Parque da Água Branca, em busca do oásis. No caminho me pego parada olhando um homem encerando com muito carinho o seu carro branco. Aperto o passo e chego ao parque. Este é um dos parques mais antigos de São Paulo, ele tem uma forte herança do ambiente rural do interior de São Paulo. Pássaros, muitas galinhas, galos e pintinhos, patos e patinhos, peixes, cavalos, gatos por todos os lados (gravei todos estes sons enquanto caminhava, para não esquecer desta beleza fundamental). Caminho entre as árvores, a umidade torna o ar puro, que entra pelo meu nariz e umedece a minha pele. Lembro de Maria e de Marcuse e da Utopia. Se o pensamento utópico tem seu direito em uma teoria crítica, não é por um esforço de elaboração de uma projeto futuro simplesmente, mas pela capacidade de perceber as condições mesmas da liberdade e da felicidade no presente (e também no passado esquecido).

\begin{tabular}{|c|c|c|c|c|}
\hline Revista Dialectus & Ano 8 & n. 14 & Janeiro - Julho 2019 & p. $147-168$ \\
\hline
\end{tabular}




\section{VIDA E MORTE, PROGRESSO E UTOPIA EM HERBERT MARCUSE}

Marília Mello Pisani

Fico com a imagem das pessoas no trânsito da cidade. A sociedade dos carros também é a sociedade das pessoas-carros, daquilo que André Gorz descreveu como o "egoísmo cruel e agressivo dos motoristas de carro que, a cada minuto, assassinam simbolicamente 'os outros', que aparecem a ele como obstáculos materiais à sua própria velocidade” (Gorz: 2005: 74). Lembro então que Marcuse trabalhou especialmente nestas duas dimensões: a profundida em que a racionalidade dominante é introjetada pelos indivíduos e a utopia como elemento fundamental para o pensamento crítico.

\section{Teoria Crítica e Utopia}

A tese de doutorado intitulada Teoria Crítica e Utopia (2017), de Maria Érbia Carnaúba, traz um levantamento cuidadoso dos diferentes momentos de desenvolvimento do conceito de Utopia em Marcuse, que, segundo ela, é um dos conceitos centrais de seu modelo de Teoria Crítica: a tese começa nos anos 30, trata do confronto e do debate com Max Horkheimer; desenvolve a relação com o diagnóstico da Dialética do Esclarecimento, defendendo que o livro O Homem Unidimensional não deve ser lido na chave do pessimismo e do fechamento total de alternativas, uma vez que haveria uma permanente tensão marcada pelo lugar da Utopia; e um terceiro capítulo em que ela trata das afinidades entre Herbert Marcuse e Ernst Bloch, autor de O Princípio Esperança, e desenvolve as implicações para pensar os movimentos sociais contemporâneos a partir de um deslocamento (histórico) do uso do conceito de Utopia. Esta articulação é inédita entre nós. Me interessa acompanhar este terceiro e último movimento de sua tese, onde ela mostra que há uma novidade na abordagem realizada ao longo dos anos 19671979. Importante frisar que a pesquisa de Carnaúba é uma das pioneiras em trabalhar com textos e materiais nunca antes publicados no Brasil. Sob a orientação com John Abromeit durante o estágio de doutorado sanduiche nos Estados Unidos (e de Marcos S. Nobre no Brasil) e próxima ao círculo de pesquisadores vinculados a International Herbert Marcuse Society (Arnold Farr, Andrew Lamas, Charles Reitz, Peter Erwin Jansen, Imaculada Kangussu, Silvio Carneiro, Robespierre de Oliveira, entre outros), ela teve contato com um material inédito e deve se tornar referência nos estudos de Marcuse no Brasil.

O período compreendido entre 1967-1979 é marcado por uma série de textos em que Marcuse articula o trabalho de uma vida com os movimentos sociais emergentes - em torno do tema da revolução e do sujeito revolucionário, do bloqueio da práxis, da relação entre teoria e prática, da utopia e da estética. Esses movimentos surgem fora do âmbito da

\begin{tabular}{|c|c|c|c|c|}
\hline Revista Dialectus & Ano 8 & n. 14 & Janeiro - Julho 2019 & p. $147-168$ \\
\hline
\end{tabular}




\section{VIDA E MORTE, PROGRESSO E UTOPIA EM HERBERT MARCUSE}

Marília Mello Pisani

Nova Esquerda Americana e em tencionamento com este, mobilizando outras estratégias e demandas vindas da juventude estudantil, das mulheres, dos negros e negras americanas/os, latinos e latinas, ecologistas. Esses movimentos não seguem o modelo da luta de classes tradicional ao marxismo e nem o modelo único da uma política representativa, pois nascem com demandas por outras formas de vida, exigindo uma mudança em sua base para além do desenvolvimento repressivo da sociedade do trabalho e das mercadorias - uma outra cultura e uma outra subjetividade. Quais formas de vida são demandadas por essa configuração histórica da Utopia? Que imagem de liberdade elas produzem?

Segundo Carnaúba, é nos fins dos anos 60, sobretudo com a publicação de Ensaio sobre a Libertação [1969] que "torna-se mais claro que Marcuse muda de diagnóstico de época e podemos dizer que a utopia volta a se destacar não apenas como conceito (que aparece muitas vezes), mas também como prática política. Como seria isso?” (Carnaúba: 2017: 259). A pergunta será desenvolvida retomando textos como Tolerância Repressiva, Contrarevolução e Revolta, Paris Lectures at Vincennes University, Marxismo e Feminismo, entre outros. Uma nova configuração conceitual ganha força, com os conceitos de "nova sensibilidade", de Grande Recusa e a dimensão estética.

Tentarei explorar estes conceitos não a partir da explicitação das definições teóricofilosóficas dadas nos textos, que são frágeis caso não mediadas com os movimentos sociais (Carnaúba: 2017: 250, 259). Estes conceitos tornam-se carapaças ocas, invólucros instrumentalizados se não localizados nas bases materiais e históricas com as quais eles se articulam. Eles precisam de corpo e de uma outra racionalidade. Seria nesse sentido que eu entendo que Marcuse cria conceitos eróticos, como tentativa de ligar Eros e Ciência, forma e conteúdo, razão e sensibilidade (como também Adorno desenvolve na Teoria Estética) ${ }^{2}$. Para isso, eu gostaria de relembrar, neste momento, que o nosso ponto de partida é o contexto da sociedade dos carros, das pessoas-carros com seu interior de aço. Como, da crítica da civilização industrial automobilística, é possível pensar a Utopia em Marcuse? As questões anteriores se articulam a essa no desafio de pensar o que poderia e deveria ter sido diferente, para que as mortes de Maria e de Carolina não sejam apenas mais duas na contabilidade geral dos acidentes automotivos.

Para Marcuse, um dos elementos fundamentais dos novos movimentos sociais é o

\footnotetext{
${ }^{2}$ Ver ensaio de Deborah Antunes e Marilia Pisani, "Rumo a um novo manifesto Um diálogo esquecido entre Herbert Marcuse e Theodor Adorno" (2015).

\begin{tabular}{|c|c|c|c|c|}
\hline Revita Aidectus & Ano 8 & n. 14 & Janeiro - Julho 2019 & p. $147-168$ \\
\hline
\end{tabular}
}




\section{VIDA E MORTE, PROGRESSO E UTOPIA EM HERBERT MARCUSE}

Marília Mello Pisani

potencial de recusa da racionalidade repressiva. Penso que podemos encontrar nesse diálogo os elementos necessários para uma Utopia erigida a partir da negação da sociedade dos carros.

Para isso, vou tomar como ponto de partida a crítica da biotecnologia reprodutiva realizada por Gertrude Steuernagel em Marcuse and Biotechnology (1998) e apresentar a reflexão realizada por Marcuse sobre os movimentos ecológicos e feministas, em Ecology and Revolution ([1972]2005) e Marxism and Feminism ([1974]2005). O movimento ecológico e o movimento das mulheres aparecem para Marcuse como a mais radical antítese ao capitalismo avançado e o local de onde pode surgir um novo conceito de revolução, nunca antes imaginado pela teoria marxista, como ele afirma em The Radical Transformation of Norms, Needs and Values (Marcuse: [1977]2017: 51) - porque ele ultrapassa a mudança meramente infraestrutural (socialização) dos meios de produção (tecnologia), para abarcar uma transformação subjetiva mais ampla, nos valores e nas necessidades (uma revolução cultural que poderia dar origem a um novo conceito de socialismo).

O ensaio de Steuernagel nos ajuda a focar uma questão importante da teoria crítica da tecnologia. Ela começa o texto localizando o debate americano recente (década de 90) sobre as leis que envolvem os direitos de propriedade na biotecnologia: reprodução assistida, tratamentos genéticos, clonagem. Um intenso debate público traz à tona, para a cientista política estudiosa dos direitos das Mulheres, que há uma diferença de tratamento nas questões genéticas quando o assunto é reprodução. O interessante do texto, para mim, neste momento, é o deslocamento que a abordagem de Marcuse permite para ela pensar o problema dos direitos genéticos e da propriedade privada: "Marcuse nos ajuda a descartar a ideia de que a tecnologia não é boa nem má em si mesma. Além disso, ele nos força a olhar o sistema atual em que a biotecnologia está inserida e ver como o atual desenvolvimento e implementação da biotecnologia estão sendo usados para servir aos interesses de uma sociedade não livre" (1998: s/).

Surgem então as perguntas incômodas: por que tantos recursos são dispendidos para que mulheres engravidem após a menopausa e para ajudar casais inférteis a conceberem filhos quando a superpopulação é um problema? Por que tantos recursos para ajudar mulheres de cinquenta e sessenta anos a terem filhos? Quem tem acesso às essas tecnologias reprodutivas? "Eu gostaria de sugerir que o desenvolvimento e implementação de tecnologias reprodutivas (...) servem aos interesses de necessidades falsas e distraem as pessoas das perguntas que uma sociedade opressiva não quer que sejam feitas" (1998: s/). Por que tantas mulheres estão adiando a gravidez? Seria porque a sociedade se organiza de tal modo que dificulta que as mulheres

\begin{tabular}{|c|c|c|c|c|}
\hline Qevista Dialectus & Ano 8 & n. 14 & Janeiro - Julho 2019 & p. $147-168$ \\
\hline
\end{tabular}




\title{
VIDA E MORTE, PROGRESSO E UTOPIA EM HERBERT MARCUSE
}

Marília Mello Pisani

tenham filhos na época em que seus corpos estão preparados para isso? Seria porque a sociedade repressiva impõe ao corpo uma produtividade antibiológica, portanto, contraria à vida? Seria porque a sociedade necessita perpetuar a dominação das mulheres através da identificação de seu valor com a reprodução? As tecnologias reprodutíveis não são neutras. Em $O$ Homem Unidimensional: estudos sobre a ideologia da sociedade industrial avançada ([1964] 2015), Marcuse escreve:

\begin{abstract}
Nessa sociedade, o aparato produtivo tende a se tornar totalitário no sentido em que ele determina não apenas as ocupações, habilidades e atitudes socialmente necessárias, mas também as necessidades e aspirações individuais. (...) A maneira pela qual a sociedade organiza a vida de seus membros envolve uma escolha inicial entre alternativas históricas que são determinadas pelo nível herdado de cultura material e intelectual. A própria escolha resulta do jogo de interesses dominantes. Ela antecipa modos específicos de transformar e utilizar o homem e a natureza e rejeita outros. (...) Enquanto universo tecnológico, a sociedade industrial avançada é um universo político, a mais recente etapa na realização de um projeto histórico específico - a saber, a experiência, a transformação e organização da natureza como mero material de dominação (Marcuse: 2015: 36).
\end{abstract}

Deste ponto de vista, não se trata de recusar a tecnologia reprodutiva. Steuernagel sugere que, se as mulheres tivessem a posse de todas as informações e riscos dos tratamentos, seria possível tomar uma decisão consciente pelo tratamento; mas isto é impossibilitado pelas próprias empresas farmacêuticas e seus especialistas. Trata-se, então, de entender o que produz a reprodução assistida como mercado e a quais valores e necessidades corresponde. $\mathrm{Na}$ biotecnologia, a mercantilização da vida ganha um aspecto surpreendente pela apropriação capitalista monopolista da informação genética e das bases mesmas da vida: da saúde, da alimentação, da educação, da locomoção, comunicação etc. "Uma visão libertadora da biotecnologia, baseada numa visão libertadora de ciência, dirigiria nossas energias para triunfar sobre a dor e a doença. Se nós podemos estender a vida, nós precisamos cuidar para que a vida valha a pena ser vivida" (Steuernagel: 1998: s/).

Para Marcuse, as forças sociais capazes de mobilizar uma imagem crítica de uma mudança infraestrutural aliada a uma transformação de valores estariam nos movimentos ecológicos e feministas (ao que ele articula ao movimento negro, a partir de Angela Davis) e ele aposta profundamente nisso em 1974: "eu acredito que o movimento de libertação das mulheres é, talvez, o mais importante e o mais potencialmente radical movimento político que nos temos, mesmo que a consciência desta fato não tenha ainda penetrado na consciência do movimento como um todo" (Marcuse: 2005: 165). Por que e qual imagem de liberdade produzem?

Em Marxismo e Feminismo (2005) Marcuse apresenta seus argumentos para defender a

\begin{tabular}{|l|l|l|l|l|}
\hline Q Povista Dialectus & Ano 8 & n. 14 & Janeiro-Julho 2019 & p. 147-168 \\
\hline
\end{tabular}




\section{VIDA E MORTE, PROGRESSO E UTOPIA EM HERBERT MARCUSE}

Marília Mello Pisani

dimensão revolucionária do feminismo e o que ele chama de "feminismo socialista" (2005: 170). Um primeiro elemento importante que ele destaca é a relação entre o movimento feminista e a Nova esquerda. Para Marcuse, a esquerda continuará fazendo as pazes com a opressão na medida em que não for capaz de absorver a radicalidade da mudança subjetiva que o feminismo revolucionário exige: por isso, podemos dizer, com Marcuse, que a esquerda é feminista ou não é revolucionária.

As mulheres não constituem uma "classe" no sentido originalmente atribuído pelo marxismo, apesar desta categoria atravessar profundamente a luta das mulheres. Mas haveria ainda assim uma autonomia do movimento das mulheres, que exige, da esquerda, incorporar uma mudança cultural e de valores profunda (nas práticas, nos valores e na linguagem) pela transformação social, assim como exige levar a sério a superação da sociedade patriarcal: “O movimento de libertação das mulheres será um processo doloroso, mas eu acredito que ele será necessário, uma etapa vital na transição para uma sociedade melhor para homens e mulheres" (Marcuse: 2005: 172).

A sociedade patriarcal é, para Marcuse, a sociedade da produtividade auto- impulsionada, da agressividade contra a natureza, da competitividade, de racionalidade formal abstrata e instrumental. Ela se confunde, nesse sentido, com a própria forma do Capital: abstração da forma valor em relação às necessidades de uso, a equivalência geral de corpos (mercadorias) diferentes sob o equivalente geral (formal) do dinheiro, a natureza (Terra, Força de trabalho) matematizada e quantificada, etc. Em Eros e Civilização (1999a) Marcuse aproxima este princípio racional patriarcal do mito de Prometeu - arquétipo do princípio de desempenho (rendimento), símbolo do progresso, do labor e da produtividade - ao qual contrapõe Pandora, Orfeu e Narciso, imagens de uma outra relação com a natureza e um outro princípio de realidade não repressivo: outra sexualidade, o canto como forma que apazigua as forças da natureza, a beleza desinteressada. Uma transformação nessas bases (culturais, psicológicas, éticas) exigiria uma reorganização total do aparato produtivo e do trabalho social. Em Natureza e Revolução ([1972] 1973) Marcuse tira incríveis implicações destas ideias - este texto é de grande importância para pensar este debate.

[A produtividade repressiva] tem sido a característica cada vez mais notória da dominação masculina; à medida que o princípio masculino tem sido a forma mental e física dominante, uma sociedade livre seria a negação definitiva deste princípio - seria uma sociedade 'fêmea'. Isto nada tem a ver com o matriarcado; a imagem da mulher como mãe é, em si mesma, repressiva; transforma um fato biológico num valor ético e cultural e, assim, apoia e justifica a repressão social da mulher. Em jogo está, antes, a [ascensão] de Eros sobre a agressão, em homens e mulheres; e isso significa, numa civilização dominada pelo homem, a 'feminilização do macho'. Expressaria a mudança decisiva dos instintos: o enfraquecimento da agressividade primária que, por uma combinação de fatores biológicos e sociais, tem governado a cultura patriarcal (Marcuse: 1973: 77).

\begin{tabular}{|c|c|c|c|c|}
\hline Qevista Dialectus & Ano 8 & n. 14 & Janeiro - Julho 2019 & p. $147-168$ \\
\hline
\end{tabular}




\title{
VIDA E MORTE, PROGRESSO E UTOPIA EM HERBERT MARCUSE
}

Marília Mello Pisani

Essa citação expressa em que medida Marcuse articula feminismo e revolução e onde estaria a potencialidade utópica do movimento. Há no feminismo lutas justas por igualdade econômica, política e social. Marcuse não recusa essas lutas, mas ele pergunta, para a mulheres, se é possível a liberdade dentro de uma sociedade guiada pelo princípio de desempenho e pela dinâmica de exploração do Capital. A radicalidade do feminismo estaria, para ele, na sua capacidade de redefinir os termos da liberdade e a própria noção de socialismo: "igualdade não é ainda liberdade" (2005: 170). Como liberdade, ele entende que a força dessa luta está na demanda por outra forma de vida, em que a vida seja um fim em si mesma, em que a natureza não seja matéria disponível, assim como os corpos e as mentes. Aqui o movimento feminista encontra o movimento ecológico naquilo que Marcuse chama de potencial radical e revolucionário: a saber, a luta pela terra e pela sbrevivência dos povos contra o "terricídio" (Marcuse: 1983: 57) - em inglês ecocide (Marcuse: 2005: 173) -, em nome de uma produtividade não destrutiva, pela autonomia dos seres vivos em relação ao lucro e às necessidades do Capital. Por isso que o movimento ecológico apareceria como uma oposição radical ao capitalismo, porque questiona a própria modalidade de produção e o estilo de consumo.

\begin{abstract}
A luta pela ampliação do mundo de beleza, de não-violência e de serenidade é uma luta política. A insistência nestes valores, em restaurar a Terra como meio ambiente humano, é não só uma ideia romântica, estética e poética, que concerne somente aos privilegiados; é hoje uma questão de sobrevivência. (...) A meta continua sendo o bem-estar, mas [conseguido] pela conquista de uma vida livre do terror, da escravidão em relação ao salário, da violência, do fedor, do barulho infernal de nosso mundo industrial capitalista. Não é o caso de embelezar o abominável, de ocultar a miséria, de desodorizar o mau cheiro, de plantar flores no cárcere, nos bancos, nas fábricas: não se trata de purificar a sociedade atual, e sim substituí-la (Marcuse: 2005: 175).
\end{abstract}

O caráter espontâneo dos movimentos sociais contemporâneos e a sua capacidade de autogestão [self-determination, autogestion] são modelos de outras formas de luta que deveriam ser, segundo ele, modelos para uma revisão da Esquerda (Marcuse: 2005: 173). Nessa revisão das lutas políticas, a Utopia aparece com uma forma de pensamento que nos ajuda a vislumbrar, ou melhor, relembrar, imagens de felicidade que poderiam guiar uma nova forma de fazer político.

Importante notar que as ideias de Marcuse não foram recebidas sem críticas pelas mulheres. Sobretudo o modo como ele lida com a ideia de natureza será alvo de recorrentes debates - afinal, mesmo entendendo o "feminino" como uma segunda natureza, ele funda e

\begin{tabular}{|c|c|c|c|c|}
\hline Revista Dialectus & Ano 8 & n. 14 & Janeiro - Julho 2019 & p. $147-168$ \\
\hline
\end{tabular}




\section{VIDA E MORTE, PROGRESSO E UTOPIA EM HERBERT MARCUSE}

Marília Mello Pisani

mantém uma ideia de natureza (seja biológica ou cultural) que será um dos pontos centrais da crítica de Donna Haraway no Manifesto ciborgue ([1989] 2009); de Gertrude Steuernagel em Marcuse, the Women's Mouvement, and Women's Studies (1994) e se torna a polêmica no debate entre Marcuse, Silvia Bovenschen e Marianne Schuller na entrevista Imágenes de la Feminilidad ([1978]1980). Penso que as críticas são pertinentes, porque atualizam as questões que o feminismo vai desenvolver após Marcuse; e porque mostram que, apesar de as qualidades femininas serem uma segunda natureza que, como "negação determinada", poderiam confrontar com o princípio de desempenho entendido como sociedade patriarcal, ainda assim penso que deve-se levar a sério aquilo que as mulheres dizem sobre si mesmas. Não é o caso de avançarmos nestas críticas, eu queria apenas pontuar e lembrar que há muito a ser desenvolvido.

\section{Vida e Utopia}

Em 2014, recebi um convite para compor a banca de qualificação do Doutorado de Maria Érbia. Recebi o trabalho, fiz minhas leituras e comentários, porém, na semana mesma da qualificação, eu tive um problema cirúrgico, fui internada por cinco dias e não pude comparecer. Nunca pudemos retomar essa conversa, apesar de termos tentado agendar diversas vezes. Lembro que eu tinha um ponto preciso que queria conversar com ela, mobilizada pelo entusiasmo das possibilidades de articular utopia, movimento social e feminismo. Lendo hoje a tese acabada, vejo que, independente dessa conversa, ela chegou no mesmo lugar que eu me entusiasmara naquele momento. Trata-se do lugar do feminismo socialista e negro [Black feminism] em Angela Davis para pensar/agir e avançar na contribuição de Marcuse para os movimentos sociais, levando em conta a importância da desnaturalização das formas de repressão (mais-repressão) raciais, de gênero e de classe para uma revisão do conceito de Utopia, tão central para a sua Teoria Crítica.

A Tese de Maria E. Carnaúba (2017) apresenta especialmente os debates de Marcuse com o feminismo socialista que ela mobiliza a partir de Angela Davis. Penso que a imagem de liberdade que ela apresenta a partir do movimento feminista pode encontrar desdobramentos no movimento feminista abolicionista e também na ecologia. Fica assim a impressão de que a Teoria crítica de Marcuse pode apontar para um terreno comum da política contemporânea, numa teoria dos movimentos sociais e da revolução.

Assim, no próprio movimento está contida a imagem não só de novas instituições sociais, mas

\begin{tabular}{|c|c|c|c|c|}
\hline Rovita Alatectus & Ano 8 & n. 14 & Janeiro - Julho 2019 & p. $147-168$ \\
\hline
\end{tabular}




\section{VIDA E MORTE, PROGRESSO E UTOPIA EM HERBERT MARCUSE}

Marília Mello Pisani

também de uma mudança de consciência, de uma mudança nas necessidades instintivas de homens e mulheres, livre das exigências da dominação e da exploração. E este é o potencial mais radical e subversivo do movimento. (...) O que está em jogo nesta transcendência é a negação dos valores exploradores e repressivos da civilização patriarcal. O que está em jogo é a negação dos valores impostos e reproduzidos na sociedade pela dominação masculina. E tal subversão radical de valores nunca pode ser o mero subproduto de novas instituições sociais. Deve ter suas raízes nos homens e mulheres que constroem as novas instituições (Carnaúba: 2017: 288).

Esta seria imagem de liberdade contida no feminismo que só pode se dar como prática de liberdade. É uma imagem formulada como narração de uma liberdade objetiva. Por isso a necessidade de uma outra forma, de uma outra linguagem.

Por que a questão racial é tão importante para a Grande recusa? Por que o movimento feminista e abolicionista é a expressão da Teoria crítica? Para Angela Davis, a "teoria crítica radical" (Davis: 2017: viii) de Marcuse está relacionada com a sua práxis como intelectual engajado; por sua vez, Marcuse escreve para Davis, em carta de 18 de novembro de 1970, que a prática engajada de Angela é a melhor expressão do que é o pensamento crítico e de como os conceitos filosóficos de liberdade e de justiça se realizam.

O mundo no qual você cresceu, seu mundo (que não é o meu) foi [repleto de] crueldade, miséria e perseguição. Reconhecer estes fatos não solicitou muita inteligência e sofisticação, mas imaginar que eles poderiam e devem ser transformados requer pensamento, pensamento crítico: saber como estas condições são superadas, quais forças as sustentam, e [quais] as possibilidades de liberdade e justiça. Isto, acredito, vocêê aprendeu em seus anos de estudo. E você aprendeu algo mais, a saber: que quase todas as figuras celebradas da civilização ocidental - a mesma civilização que escravizou seu povo - estava preocupada com uma coisa: a liberdade humana. (...) Então, você sentiu que a ideia filosófica, a menos que ela fosse uma mentira, deveria se transformar em realidade: que ela continha um imperativo moral a ser levado para a sala de aula, para o campus, e que vai adiante e ajuda os outros, sua própria gente a quem você̂ ainda pertence - a despeito (ou mesmo por causa) de seu sucesso no Establishment branco. Mas você lutou por nós também, a quem precisamos de liberdade e a quem quer a liberdade para todos aqueles que ainda não são livres. Nesse sentido, sua causa é nossa causa (Marcuse: 2005: 50).

Para Angela Davis, há uma forte relação entre a Grande Recusa e os movimentos abolicionistas (Davis: 2017). A Black radical tradition de luta pela liberdade seria a manifestação histórica da Grande Recusa. Pois esta não seria uma luta apenas dos negros, mas de todos/todas aqueles/aquelas que recusam as estruturas de opressão e lutam pela liberdade: se o capitalismo é também "capitalismo racial”, e também capitalismo generificado, então isto precisa ser levado a sério nas lutas políticas e pela Esquerda. Por isso, o feminismo negro [Black feminism] aparece para Davis como um dos mais importante movimentos, pela sua capacidade de localizar a ideia de liberdade como compreensão e recusa da experiência profunda de

\begin{tabular}{|c|c|c|c|c|}
\hline Revista Dialectus & Ano 8 & n. 14 & Janeiro - Julho 2019 & p. $147-168$ \\
\hline
\end{tabular}




\section{VIDA E MORTE, PROGRESSO E UTOPIA EM HERBERT MARCUSE}

Marília Mello Pisani

produção do corpo e da vida sob a violência e a injustiça da escravidão e do preconceito racial. Isso quer dizer que o povo negro que lutou pela sua liberdade deve ser a medida da cidadania e da pessoa: "Mas se podemos enriquecer ainda mais nossos sonhos, o que aconteceria se nós imaginássemos que a mulher negra como a medida da humanidade?” (Davis: 2017: x).

Há uma ligação profunda e passível de ser mapeada historicamente entre a escravidão do povo negro africano (conforme Mulheres, Raça e Classe (2016) de Angela Davis), a queima das mulheres na Idade média (conforme Calibã e a Bruxa: mulheres, corpo e acumulação primitiva (2017) de Silvia Federici) e o genocídio indígena (conforme A Queda do Céu: palavras de um xamã Yanomani (2015) de Davi Kopenawa e Bruce Albert) como formas fundamentais de exploração do trabalho e da riqueza que estão na base da acumulação capitalista e das formas atuais de vida, já naturalizadas. O discurso que oculta a profundidade da gênese histórica da violência se torna ideológico no sentido de encobrimento da verdade. De onde surge da necessidade de desnaturalização dessas formas de opressão como Grande recusa. Segundo Silvio Carneiro, a "Grande Recusa é a verdade da falsidade do todo social” (2015: 332):

A black music traz consigo novos elementos para se pensar o contentamento: o contraste com o sofrimento que não deveria estar lá... Marcuse encontra na arte negra um material estético que organiza na resistência swingada que traz consigo o sofrimento dos corpos, uma nova racionalidade. (...) Marcuse reconhece na arte do movimento negro não apenas uma arte política, mas a arquitetura de uma sociedade livre que se prepara na constituição de sua forma estética (Carneiro: 2015: 338).

No livro Hegel e o Haiti (2017), Susan Buck-Morss nos apresenta movimentos fundamentais para uma renovação da Teoria crítica e do pensamento crítico em uma perspectiva antiracista. Este livro me parece uma autoreflexão da Teoria crítica sobre si mesma na perspectiva de uma Grande Recusa. Logo nas primeiras páginas ela denuncia a especialização e o isolamento acadêmico do conhecimento e justifica a sua abordagem do filósofo Hegel, especialmente a passagem da dialética do senhor/escravo na Fenomenologia do Espírito, a partir da Revolução do Haiti - que foi, segundo Angela Davis, a primeira democracia racial do Ocidente (Davis: 2017: ix). Sobre isso, Susan Buck-Morss escreve: “caso certas constelações de fatos consigam penetrar fundo o bastante na consciência intelectual, ameaçarão não apenas as narrativas veneráveis, mas também as entrincheiradas disciplinas acadêmicas que as reproduzem" (2017: 34). Ao longo do livro ela mostra, a partir da materiais históricos, que Hegel estava acompanhando muito de perto, através de jornais e relatos, a Revolução haitiana sem, no

\begin{tabular}{|c|c|c|c|c|}
\hline Q Rovista Oialectus & Ano 8 & n. 14 & Janeiro - Julho 2019 & p. $147-168$ \\
\hline
\end{tabular}




\section{VIDA E MORTE, PROGRESSO E UTOPIA EM HERBERT MARCUSE}

Marília Mello Pisani

entanto, mencionar uma só passagem sobre o acontecimento histórico. Essa relação entre o acontecimento e o conceito entra definitivamente na ideia de liberdade de Hegel e na dialética do reconhecimento. Porém, na medida em que invisibiliza a história e suas vozes (2017: 79), e na medida em que seu pensamento vai ficando mais sistemático e mais acadêmico, ele se mete em uma contradição exemplar que o conduz ao racismo de seus últimos trabalhos. A cena que fecha o livro de Buck-Morss pode nos ajudar a situar esta contradição.

A Revolução Francesa havia acabado de acontecer. A luta pela liberdade, igualdade e fraternidade tinha ganhado força histórica. Ao mesmo tempo, estes ideais permearam as colônias europeias. O povo do Haiti foi o primeiro a levar a sério as implicações universais destas demandas na luta contra a escravidão pela liberdade. Porém, os franceses dependiam economicamente da colônia, ou seja, estes ideais não podiam universalizar-se sem quebrar o monopólio da apropriação de matéria prima e do trabalho através da violência pelas metrópoles europeias. Soldados franceses são enviados ao Haiti para reprimir a revolta, mas, quando chegam, os ex-excravos cantam o hino nacional francês. $\mathrm{O}$ racismo europeu, ancorado na luta de classes, escolheu por não levar adiante a universalização do conceito de liberdade; com isso criou-se uma cisão profunda entre a consciência da opressão no discurso e as ações que poderiam colocar em questão os privilégios. Este mecanismo psicológico, que tem gênese material, é o cerne de vários debates importantes, como Franz Fanon (o modo como ele vai ler a dialética do senhor/escravo), Lélia Gonzalez (conceito de denegação no racismo brasileiro), Neusa Santos Souza (quando, mobilizada pela necessidade de um discurso sobre si mesma, volta-se para a experiência da pessoa negra no Brasil). Trabalhos que precisam ser trazidos e desenvolvidos em uma Teoria crítica feita a partir do Brasil.

(...) os soldados franceses que, enviados à colônia por Napoleão, ao ouvirem esses ex-escravos contando a Marselhesa, perguntaram-se em voz alta se não estariam lutando do lado errado; o regimento polonês... desobedeceu a suas ordens e recusou a afogar os seiscentos dominguenses capturados (...). E se, a cada vez que a consciência dos indivíduos ultrapassasse os limites das constelações atuais de poder e percebesse o significado concreto da liberdade, este fosse avaliado como um momento, ainda que transitório, da realização do espirito absoluto? Quais outros silêncios teriam que ser quebrados? Quais histórias in-disciplinadas teriam ainda que ser contadas? (Buck-Morss: 2017: 118).

A Grande Recusa de Marcuse impulsiona o pensamento filosófico a um deslocamento profundo a partir da nossa história. São necessárias ações que modifiquem os lugares institucionais e subjetivos que continuam a propagar os silenciamentos. Ações que desnaturalizem as violências e que reabilitem historicamente os ideais objetivos de liberdade e

\begin{tabular}{|l|l|l|l|l|}
\hline Gevista Dialectus & Ano 8 & n. 14 & Janeiro-Julho 2019 & p. $147-168$ \\
\hline
\end{tabular}




\section{VIDA E MORTE, PROGRESSO E UTOPIA EM HERBERT MARCUSE}

Marília Mello Pisani

felicidade. As hierarquias raciais devem ser abolidas, tanto quanto as de gênero e as de classe. Através dessas três categorias de análise, com Marcuse, podemos fazer a mediação dialética necessária, entre parte e todo, num mundo histórico, portanto, engendrado. As coisas poderiam ser diferentes. Por que elas são assim? Quais práticas e acordos, quais ideias e valores produziram esta realidade que favorece a agressividade e a dialética bloqueada de progresso e destruição? Quais fazem a sua manutenção? Onde estariam as/os agentes políticos de uma transformação radical nessas bases?

Marcuse remonta à gênese do passado mitológico, à antropologia, às artes, aos movimentos sociais e culturais vistos por ele como emergência de uma nova sensibilidade revolucionária. Nisso encontra o terreno comum da libertação da natureza e do corpo como ideal ético e político, como vemos em Natureza e Revolução (1973). E quando ele faz isso, ele liga as lutas por outas formas de vida, seja a luta pela terra do Movimentos Sem Terra (MST-Brasil), sejam as lutas indígenas no Brasil, que se erguem há séculos numa defesa radical da natureza e que me parece ser, hoje, a imagem mais potente de uma Grande Recusa.

Ações estão sendo feitas nesse sentido, mesmo com toda a pressão dos grupos políticos e dos meios de comunicação de massa para esconder e demonizar as formas de resistência. $\mathrm{O}$ trabalho de muitos e muitas segue nesse sentido e eu gostaria de citar a pesquisadora Lea Tosold (com quem venho aprendendo tanto sobre todas estas questões). No final de sua tese de doutorado (2018) sobre desnaturalização da violência e autodeterminação dos povos indígenas (um trabalho inspirador para as pesquisas de Marcuse no Brasil), ela discute teoria política à luz da luta e da resistência do povo Munduruku. Ao final do trabalho ela anexa uma série de cartas escritas por esses povos aos governantes e ao povo brasileiro tentando apresentar e justificar a sua luta contra a construção de hidroelétrica Belo Monte no Rio Tapajós - um projeto que uniu esquerda e direita, mercado, agronegócio, mineiros, capital produtivo e financeiro em torno de um modelo de desenvolvimento e de progresso unidimensional. Tidos como contrários ao desenvolvimento, esses povos perguntam:

Nós somos a gente que vive nos rios em que vocês querem construir barragens. Nós somos Munduruku, Juruna, Kayapó, Xipaya, Kuruaya, Asurini, Parakanã, Arara, pescadores e ribeirinhos. Nós somos da Amazônia e queremos ela de pé. Nós somos brasileiros. O rio é nosso supermercado. Nossos antepassados são mais antigos que Jesus Cristo. Vocês estão apontando armas contra a nossa cabeça. Vocês sitiam nossos territórios com soldados e caminhões de guerra. Vocês fazem o peixe desaparecer. Vocês roubam os ossos dos antigos que estão enterrados em nossas terras. Vocês fazem isso porque têm medo de nos ouvir. De ouvir que não queremos barragem. De entender porque não queremos barragem. (Carta do povo munduruku referente à ocupação de Belo Monte, Vitória do Xingu (PA), de 2 de maio de 2013. Apud Tosold: 2018: 279).

\begin{tabular}{|l|l|l|l|l|}
\hline Revista Q Dialectus & Ano 8 & n. 14 & Janeiro-Julho 2019 & p. $147-168$ \\
\hline
\end{tabular}




\section{VIDA E MORTE, PROGRESSO E UTOPIA EM HERBERT MARCUSE}

Marília Mello Pisani

A energia virá apenas para favorecer as grandes empresas, como as mineradoras e as multinacionais. A hidrelétrica não gerará energia para as pequenas populações que não têm condições de pagar energia cara. Então, com a barragem construída, virão mais outros grandes projetos de destruição: a ferrovia, a hidrovia do rio Tapajós para escoar grãos de soja, para exportar para o exterior. (...) O governo, com seu projeto, não traz "progresso e nem desenvolvimento", só traz a morte. (Carta aberta do povo munduruku do Alto e Médio Tapajós em apoio à luta de (r)existência guarani- kaiowá e ka'papor, de 15 de julho de 2015 apud Tosold: 2018: 308-309).

Os povos indígenas sabem de onde vem a Grande Recusa e o que é que mobiliza a urgência e a força do pensamento utópico. Esse pensamento não existe em alguma esfera transcendental, eles são atuais, eles existem aqui e agora nas histórias de resistências. E são esses valores e práticas que indicam o caminho para uma cosmologia da não violência e da beleza que não dissocia presente, passado, futuro (e que coloca em risco as vidas do presente em nome de uma ideia de futuro que não contempla a sobrevivência). A sociedade industrial avançada, com sua poluição e desperdício programado, com seu ideal de progresso necropolítico, coloca a vida à serviço de morte. Por isso, eu não aceito a morte de Maria Érbia Carnaúba, eu não aceito a morte das crianças nas favelas do Rio, a morte das mulheres e do povo negro, nem a morte de Marielle Franco, ou de qualquer pessoa ou ser da natureza que tenha tido a vida tornada indigna. Há mediações importantes que ligam estas mortes e o desafio está em conseguir elaborá-las. Maria Érbia sabia, com toda sua luta, que Marcuse é um auxiliar potente para esses enfrentamentos. Vive Maria Érbia Carnaúba, não apenas entre os Manacás do jardim, mas em nós e entre nós.

\section{Referências:}

Alves, Luiz Roberto. Grande ABC: culturas que excedem o lugar culturalizado. Santo André: Alpharrabio edições, 2009.

Benjamin, Walter. "Experiência e pobreza". In.: Magia e Técnica, Arte e Política (Obras escolhidas). São Paulo: Editora Brasiliense, 1994.

Buck-Morss, Susan. Hegel e o Haiti. São Paulo: edições n -1, 2017.

Carnaúba, Maria Érbia. Marcuse e a psicanálise: teoria crítica sob a análise da teoria da repressão. Dissertação de Mestrado. Campinas: UNICAMP, 2012.

Teoria Crítica e Utopia. Tese de Doutorado. Campinas: UNICAMP, 2017.

Carneiro, Silvio. R. Poder sobre a vida: Herbert Marcuse e a biopolítica. Tese de Doutorado. São Paulo: USP, 2014.

Davis, Angela. "Foreword: Abolition and Refusal". In.: Herbert Marcuse and Contemporary

\begin{tabular}{|l|l|l|l|l|}
\hline Q Povista Dialectus & Ano 8 & n. 14 & Janeiro-Julho 2019 & p. 147-168 \\
\hline
\end{tabular}




\section{VIDA E MORTE, PROGRESSO E UTOPIA EM HERBERT MARCUSE}

Marília Mello Pisani

Social Movements. Editado por Lamas, Andrew; Todd, Wolfson; Funke, Peter N. Filadelfia, Londres, Toquio: Temple University Pressa, 2017.

. "Marcuse's Legacies". In.: Herbert Marcuse: a critical reader. Editado por Abromeit, John; Cobb, Mark. New York: Routledge, 2004.

Mulheres, raça e classe. São Paulo: Boitempo editorial, 2016. Dumont, René. A utopia ou a morte. Rio de Janeiro:Paz e Terra, 1975.

Federici, Silvia. Calibã e a bruxa: mulheres, corpo e acumulação primitiva. Tradução Coletivo Sycorax. São Paulo: Elefante, 2017.

Gonzalez, Lélia. "Racismo e sexismo na cultura brasileira". In.: Revista Ciências Sociais Hoje, Anpocs, p. 223-244, 1984.

Gorz, André. “A ideologia social do automóvel”. In Ludd, Ned (org.). Apocalipse motorizado: a tirania do automóvel em um planeta poluído. São Paulo: Conrad Editora do Brasil, 2005.

Haraway, Donna. "Manifesto ciborgue: ciência, tecnologia, e feminismo-socialista no final do século XX". In.: Antropologia do ciborgue: as vertigens do pós-humano. Belo Horizonte: Editora Autêntica, 2009.

Kopenawa, Davi; Albert, Bruce. A queda do céu: palavras de um xamã yanomami. São Paulo: Companhia das letras, 2015.

Marcuse, Herbert. Transvaluation of values and radical social change: five lectures, 1966- 1976. Editado por: Jansen, Peter E.; Surak, Sarah; Reitz, Charles. Toronto: International Herbert Marcuse Society, York University, outubro de 2017.

O homem unidimensional: estudos sobre a ideologia da sociedade industrial avançada. São Paulo: Edipro, 2015.

. The New Left and the 1960s. Editado por Kellner, Douglas. New York: Routledge, 2005 .

. Eros e civilização: uma interpretação filosófica de Freud. Rio de Janeiro: Zahar, 1999a.

. "Algumas implicações sociais da tecnologia moderna". In.: Tecnologia Guerra e Fascismo. Editado por Douglas Kellner. Snao Paulo: edotira UNESP, 1999 b.

"Ecologia e crítica da sociedade moderna". In.: Herbert Marcuse: a grande recusa hoje. Petrópolis: Editora Vozes, 1999c.

“A ecologia é revolucionária”. In.: Oitenta, número 8, p. 55-58, 1983.

Contra Revolução e Revolta. Rio de Janeiro: Zahar, 1973.

\begin{tabular}{|c|c|c|c|c|}
\hline Q Rovista Oialectus & Ano 8 & n. 14 & Janeiro - Julho 2019 & p. $147-168$ \\
\hline
\end{tabular}


. Counter-Revolution and Revolt. Boston: Bacon Press, 1972.

. On Essays of Liberation. Beacon Press, 1969.

1966.

. Eros and Civilization: a philosophical inquiry into Freud. Boston: Bacon Press,

Marcuse, Herbert; Habermas, Jurgen; Bovenschen, Silvia; Schuller, Marianne, y otros. Conversaciones con Herbert Marcuse. Barcelona: Gedisa, 1980.

Pisani, Marilia. "Marcuse está superado? A grande recusa a Marcuse ou porque ainda é preciso falar em revolução". In Zuin, Antonio A. S.; Franco, Renato; Lastória, Luiz A. C.. Teoria Crítica no Brasil e na América Latina. São Paulo: Nankin, 2016.

; Antunes, Deborah. "Rumo a um novo manifesto: um diálogo esquecido entre Herbert Marcuse e Theodor Adorno". In.: Revista ArteFilosofia, n. 18. Ouro Preto: UFOP, 2016.

Santos, Neusa Souza. Tornar-se negro: ou, as vicissitudes da identidade do negro brasileiro e a ascensão social. Rio de Janeiro; Graal, 1983.

Steuernagel, Gertrude. "Marcuse, the Women's Movement, and Women's Studies”. In.: From de New Left to the Next Left. Editado por Bokina, John; Lukes, Thimoty. University Press of Kansas, 1998. . "Marcuse and biotechnology". In.: Negations, winter 1998, pp. 44-55.

Tosold, Lea. Autodeterminação em três movimentos: a politização de diferenças sob a perspectiva da desnaturalização da violência. Tese de Doutorado. São Paulo: USP, 2018. 


\title{
A ARTE DA FANTASIA, A PARTIR DE HERBERT MARCUSE
}

Imaculada Kangussu ${ }^{1}$

\begin{abstract}
Resumo:
O presente ensaio versa sobre a fantasia como obra de arte, tendo como base as reflexões de Herbert Marcuse. Primeiramente, apresenta as relações entre arte e fantasia, a partir da leitura que Marcuse faz de Freud. Em seguida, explicita e enfatiza a potência da fantasia relativa à produção de imagens libertadoras. E conclui com a ideia de que a liberdade experimentada através das obras de arte pode ser uma espécie de sinédoque para a liberdade maior.
\end{abstract}

Palavras-chaves: Freud. Surrealistas. Imaginação. Obras de arte. Dimensão estética.

\section{THE FANTASY OF THE ART, FROM HERBERT MARCUSE'S}

\begin{abstract}
:
This essay deals with the idea of phantasy as a work of art, based on Herbert Marcuse's reflections. First, it presents the relationship between art and phantasy, from Marcuse's reading of Freud. After this, it makes explicit and stresses the power of phantasy concerning the creation of liberating images. And it concludes with the idea that the freedom experienced through the work of art can be a kind of sinedoque of a wider freedom.
\end{abstract}

Keywords: Freud. Surrealists. Imagination. Works of art. Aesthetic dimension.

Sem uma especulação e uma teorização metapsicológica - quase diria, sem uma atividade da fantasia - não poderíamos avançar um passo.

FREUD, Análise terminável e interminável

O conceito de fantasia desenvolvido por Herbert Marcuse vai bastante além da ideia prosaica segundo a qual a fantasia é uma forma menor de operação mental condenada, nas articulações da realidade, a ser o lugar das meras ilusões. De acordo com o filósofo, a potência de fantasiar realiza um trabalho produtivo, não opera arbitrariamente, nem é livre de determinações: é um processo psíquico sujeito a limites materiais e a vínculos bastante definidos, baseados nas condições sociais e ligados à realidade objetiva.

Em Eros e Civilização (Eros and Civilization [1955]), Marcuse parte da apresentação feita por Freud, no texto sobre os "Dois princípios de funcionamento mental". Segundo Freud,

Com a introdução do princípio de realidade, um modo de atividade do pensamento foi separado: ele ficou livre do teste da realidade e permaneceu subordinado ao princípio de prazer apenas. É o

1 Imaculada Maria Guimarães Kangussu fez mestrado e doutorado em Filosofia, na Faculdade de Filosofia e Ciências Humanas da Universidade Federal de Minas Gerais (UFMG), e pós-doutorado na School of Arts and Science da New York University (NYU), como bolsista da CAPES. Dedica-se ao estudo de estética, filosofia da arte e teorias críticas. Leciona no Instituto de Filosofia, Artes e Cultura da Universidade Federal de Ouro Preto (UFOP). Email: lekangussu@gmail.com. 
ato de fantasiar (das Phantasieren), que começa com as brincadeiras das crianças e depois continua como divagação, abandonando sua dependência de objetos reais. ${ }^{2}$

Marcuse ressalta que quando o processo psíquico, originalmente unificado na busca do prazer, é cindido pela percepção da necessidade de recurso ao mundo exterior, a parte da psique que passa a agir segundo o princípio de realidade "obtém o monopólio de interpretar, manipular e alterar a realidade - de governar recordações e esquecimento, e mesmo de definir o que a realidade é e como deve ser usada e alterada". ${ }^{3}$ Conforme a teoria freudiana, o aparelho psíquico, que em um primeiro momento mantinha-se unido e dirigia toda sua energia à obtenção de prazer, é cindido pelo princípio de realidade e passa a ser guiado pela parte que a ele submete-se: é ela quem estabelece as normas, os objetivos, os valores, os juízos. A outra parte nascida dessa divisão desenvolve a faculdade de fantasiar, compreende a atividade mental mais autônoma em relação ao critério de realidade, permanece ligada apenas ao princípio de prazer, mesmo na consciência adulta desenvolvida, e continua potencialmente livre, porém ao preço de tornar-se irrealista, ser considerada inútil, inverídica, mero jogo, devaneio; enquanto a razão prevalece, útil e correta, mesmo que, na maior parte das vezes, repressora e desagradável.

Segundo Marcuse, a potência de fantasiar preserva a liberdade de falar a linguagem do prazer, dos desejos, da gratificação, e mantém a estrutura e as tendências psíquicas originais, anteriores à cisão provocada pela percepção simultânea da existência da realidade exterior e de si mesma como indivíduo dela separado e dela dependente. O filósofo observa que, percebido a partir da introdução do princípio de realidade, o principium individuationis reprime as pulsões primárias, enquanto a fantasia guarda o desejo de reunir o que foi cindido, através da dissolução deste mesmo principium individuationis.

Apesar de irrealista e inverídica, a fantasia realiza a mais decisiva função de toda estrutura psíquica: a de ligar os estratos profundos, arcaicos e inconscientes com os mais elevados produtos da consciência humana, na perspectiva de Marcuse, as obras de arte. A arte pode remodelar a aparência da realidade, recuperando com isso sua conotação original de técnica (techné), isto é, conhecimentos necessários para se produzir algo. É na capacidade de realizar o trânsito amplo

2 FREUD. "Formulações sobre dois princípios de funcionamento mental" [1911], em Edição Standard Brasileira das Obras Psicológicas Completas de Sigmund Freud, volume XII, p.240. Citado por Marcuse em Eros and Civilization: a Philosophical Inquiry into Freud, p.140. Na tradução brasileira, Eros e civilização. Uma interpretação filosófica do pensamento de Freud; p.132.

3 MARCUSE. Eros and Civilization, p.141. Na tradução brasileira, Eros e civilização, p.133. O grifo é meu, e a tradução das citações retiradas deste texto também.

\begin{tabular}{|c|c|c|c|c|}
\hline Revista Dinlectus & Ano 8 & n. 14 & Janeiro - Julho 2019 & p. $169-182$ \\
\hline
\end{tabular}


Imaculada Kangussu

entre pulsões arcaicas e refinamento expressivo que reside a potência da fantasia pela qual se interessa filósofo. Em suas palavras, "a metapsicologia freudiana recoloca [restores] a imaginação em seus direitos". ${ }^{4}$ Esta afirmação, à qual voltaremos, é uma contribuição dos surrealistas.

A originalidade das reflexões de Marcuse reside no fato de ele ligar o processo mental denominado por Freud como das Phantasieren àquele que, de acordo com Kant, é realizado pela faculdade da imaginação (Einbildungskraft). Interessa-nos trazer à luz esse movimento posto que o próprio filósofo não o esclareça, apenas o apresente em Eros e Civilização. A partir dessa obra, Marcuse quase sempre utiliza o termo "imaginação", mantendo neste a faculdade de fantasiar, conforme caracterizada pelas reflexões freudianas, sem explicitar ou redefinir o conceito. A força criativa desta união entre Kant e Freud fica assim obscura, nas obras tardias. Em Eros $e$ Civilização, o autor usa o termo "fantasia" (phantasy), às vezes seguido da palavra "imaginação" (imagination) entre parênteses, outras vezes (como no comentário a Freud acima citado) utiliza apenas “imaginação”, prenunciando a união que fará entre as duas faculdades. Depois desse livro, raramente escreve phantasy, sem, entretanto, abandonar seu sentido semântico, que passa a incidir no que ele também denominará "imaginação". É ainda importante ressaltar que Marcuse nunca escreve fantasy nem fancy, termos correntes em inglês, e, ao usar phantasy, indica a origem grega do conceito.

De acordo com o filósofo, a fantasia - como processo psíquico fundamental - tem um valor de verdade próprio, identificado com a sua capacidade de ultrapassar os antagonismos da realidade e de visar à conciliação do indivíduo com o todo, do sonho com a razão, do desejo com sua efetivação. A possibilidade deste tipo de harmonia foi removida, pelo princípio de realidade, para a dimensão da utopia, enquanto a fantasia insiste em torná-la real. Como se houvesse um saber envolvido neste desejo, julga Marcuse,

para preservar no presente, como meta, o que ainda não está presente, a fantasia é necessária. Que a fantasia se relacione de modo essencial com a filosofia, resulta da função que foi designada sob o título de imaginação pelos filósofos, particularmente por Aristóteles e Kant. Devido a sua capacidade única de "intuir" um objeto mesmo ausente, de criar algo a partir do fundamento material dado do conhecimento, a imaginação indica um elevado grau de independência, a liberdade em meio a um mundo de não-liberdade. ${ }^{5}$

Nesse trecho, onde os dois termos - fantasia e imaginação - estão presentes, fica clara a mencionada identificação de ambas, realizada por Marcuse. Por sua potência de transcender o

4 Ibidem, p.143. Na tradução brasileira, p.134.

5 MARCUSE. "Philosophie und kritische Theorie", em Kultur und Gesellschaft I, p.122. Na tradução brasileira, "Filosofia e Teoria Crítica", em Cultura e Sociedade, v.1, p.155.

\begin{tabular}{|c|c|c|c|c|}
\hline Rovista Dialectus & Ano 8 & n. 14 & Janeiro - Julho 2019 & p. $169-182$ \\
\hline
\end{tabular}


presente e imaginar o futuro, a fantasia possui a capacidade de apresentar o sujeito a partir do que ele efetivamente pode ser. A força de recusar e de transcender a realidade dada revela a relação entre processo criativo e resistência. Quando entrelaçado com o poder cognitivo da fantasia, "o pensamento transforma-se em jogo, jeu interdit; o esprit de sérieux cede lugar à gaya scienza, à embriaguez e ao riso", escreve nosso autor, e até Hegel, "o mais sério dos filósofos, sabia disto bem". ${ }^{6}$ Entretanto, ressalta Marcuse, "deixar a fantasia livre para a construção de um mundo mais belo e mais feliz permanece privilégio das crianças e dos loucos".7

As verdades da fantasia são realizadas quando ela toma forma objetiva nas obras de arte e cria um novo universo de percepção e de compreensão, ao mesmo tempo, objetivo e subjetivo. A experiência estética exige um modo próprio de percepção, a ser alcançado através do encontro entre o indivíduo e a obra, através de uma espécie de jogo entre ambos, do qual o sujeito sai transformado pelo objeto e pelo modo da experiência. O modo próprio de percepção, exigido pela obra de arte, provoca uma mudança no modo de perceber e pode - a partir da transformação no modo da experiência - transformar a própria visão de mundo do fruidor. As obras de arte atualizam a forma da liberdade, e negam a não-liberdade presente na estrutura de onde surgiram. A função cognitiva da fantasia evidenciada na arte, o mais visível e evidente retorno do reprimido, segundo Marcuse, está ligada à negação da lógica da dominação predominante na vida humana. "Desde o despertar da consciência da liberdade, não há obra de arte genuína que não revele seu conteúdo arquetípico: a negação da não-liberdade". ${ }^{8}$ Toda obra de arte é negação.

Entretanto, mesmo considerando as obras de arte como um exercício de liberdade e como portadoras de uma recusa ao mundo existente, essa função crítica esbarra no limite da forma estética, no prazer por ela provocado: a expressão artística reconcilia a negação - sedimentada em sua expressão formal - com a realidade antagônica. "A qualidade estética do prazer (enjoyment)", escreve Marcuse, "é inseparável da essência da arte, não importa quão trágica, quão intransigente a obra seja". ${ }^{9}$ Sob o véu da arte, mesmo a expressão do horror pode provocar o gozo - como já observara Aristóteles no início da Poética. Ainda assim, i.e, mesmo provocando prazer, a arte é oposição, é a expressão e o retorno do reprimido em imagem libertadora. Com sua mera presença, até a mais conformista das obras indica um sinal de incompletude no que estava dado.

6 MARCUSE. "Love Mystified: A Critique of Norman O. Brown, em Negations, p.228-229.

7 MARCUSE. "Philosophie und kritische Theorie", p.122. Na tradução brasileira, "Filosofia e Teoria Crítica", p.155.

8 MARCUSE. Eros and Civilization, p.144. Na tradução brasileira, p.135.

9 Ibidem, p.145. Na tradução brasileira, p.135.

\begin{tabular}{|c|c|c|c|c|}
\hline Rovita Dialectus & Ano 8 & n. 14 & Janeiro - Julho 2019 & p. $169-182$ \\
\hline
\end{tabular}


A partir da década de 1950, pode-se perceber o repúdio das vanguardas às tradicionais formas miméticas da arte na tendência ao abandono da figuração, do discurso linear, da tonalidade tradicional em favor da tonalidade livre, da descontinuidade discursiva, da abstração, e da adoção de novas formas que não provocam prazer imediatamente, mas, ao contrário, quando e se o fazem, isso exige mediações e reflexões, Marcuse observa uma radicalização dos movimentos artísticos na direção de evitar a reconciliação formal imediata alcançada através do prazer estético.

Como Freud, o filósofo percebe que, enquanto a arte pode ser considerada a forma mais sublimada de expressão das fantasias e, portanto, de oposição ao princípio de realidade, formas menos sublimadas encontram espaços nos sonhos, devaneios, piadas, brincadeiras. A grande diferença existente entre a teoria freudiana e suas próprias reflexões, para Marcuse, diz respeito ao fato de, na primeira, as imagens da fantasia expressarem desejos relativos a um passado primevo, tanto do gênero quanto do indivíduo, presentes em todas as civilizações, na medida em que o processo civilizatório só se desenvolve a partir da cisão da unidade psíquica originalmente toda voltada ao prazer, cuja imagem desejável permanece impressa, como pegadas, nos registros mnemônicos. Entretanto, enquanto na metapsicologia freudiana libertar-se da repressão implica a volta a estágios passados dos processos psíquicos e biológicos, e a partir desse ponto de vista, a ideia de um princípio de realidade menos repressivo torna-se indissociável da necessidade de regressão a estágios anteriores ao princípio de individuação, a estágios sub-históricos, e mesmo sub-humanos; para Marcuse, ao contrário, as imagens da fantasia podem dizer respeito mais ao futuro ainda não conquistado do que à recuperação do passado. Nessa perspectiva, um princípio de realidade menos repressivo pode ser realizado historicamente a partir do desenvolvimento da consciência - que não significa apenas regressão. Posição que o afasta de Freud, para quem tudo isso pareceria, "no máximo, uma bela utopia". ${ }^{10}$

Cabe perceber que não se trata, ao contrário das opiniões de comentadores apressados, de negar a necessidade de submeter-se ao princípio de realidade, e sim de rever e criticar a forma da realidade adotada por tal princípio, com o qual se tem necessariamente de estabelecer acordos. Marcuse é bastante atento às simultâneas independência e interdependência existentes na relação entre a interioridade dos indivíduos e o mundo exterior, entre as fantasias e a realidade na qual esta se insere.

Se aceitarmos que a realidade com a qual lidamos é constituída a partir de coordenadas simbólicas, parece preciso pensar com Marcuse que o que pode ser questionado não é o fato de o

10 Ibidem, p.147. Na tradução brasileira, p.137.

\begin{tabular}{|c|c|c|c|c|}
\hline Revista Q Didectus & Ano 8 & n. 14 & Janeiro - Julho 2019 & p. $169-182$ \\
\hline
\end{tabular}


indivíduo precisar reprimir seus impulsos diante da realidade exterior, da qual depende sua própria existência, e sim o nível de repressão por ela exigido. Trata-se de diferenciar - na composição da chamada "realidade" - as determinações da natureza e as das culturas. Em outras palavras, tratase de diferenciar natureza e estruturas históricas. E se aceitarmos que a estrutura sociocultural é criada através de coordenadas simbólicas, o que parece ser desígnio fatal da natureza pode ser apenas design histórico - sem desconsiderar o quanto a história tem sido fatal. O filósofo não pretende negar a necessidade de submeter-se à realidade exterior e sim perceber a forma contingente desta e, com isso, revelar a possibilidade de se criar outras formas de organização da realidade. O próprio Freud, em A civilização e seus descontentes, atribui o sofrimento humano a três fontes, são elas: (1) a força superior da natureza, (2) o destino de nossos corpos à decadência, (3) a inadequação de nossos métodos para regular as relações humanas na família, na comunidade e no Estado; e considera que, enquanto as duas primeiras são provenientes de fontes naturais, a última é, strictu senso, produto da história.

Conforme já foi observado, faz-se necessário, portanto, distinguir as determinações da realidade provenientes da natureza daquelas instituídas ao longo da história, mesmo diante da impossibilidade de se separar completamente umas das outras. As críticas que acusam Marcuse da tentativa - fadada ao fracasso - de abolir toda e qualquer forma de repressão ficam sem fundamento quando se percebe que o alvo do filósofo são aquelas formas repressoras naturalmente desnecessárias e socialmente degradantes. Alvo baseado na necessidade de se lançar luz sobre o fato de, muitas vezes, as leis inventadas pela humanidade serem consideradas como se fossem provenientes das leis da natureza, o contingente ser considerado como necessário, o histórico como natural. As estruturas sociais emergem de sistemas cujas hierarquias das funções e relações sociais assume - ou pretende assumir - a forma da razão objetiva, e a norma passa a ser identificada como a própria vida da sociedade. Nas palavras do filósofo,

os vários modos de dominação (do homem e da natureza) resultam em várias formas históricas do princípio de realidade. Por exemplo, uma sociedade na qual os membros trabalham normalmente para viver requer outros modos de repressão do que uma sociedade na qual o trabalho é terreno exclusivo de um determinado grupo. De modo similar, a repressão será diferente em escopo e grau conforme a produção social seja orientada para o consumo individual ou para o lucro; a economia de mercado prevaleça ou a economia planejada; a propriedade seja privada ou a comum. ${ }^{11}$

As diferenças fazem-se sentir na constituição do princípio de realidade na medida em que este está incorporado em um sistema de instituições, relações sociais, leis (escritas e não escritas)

$11 \quad$ Ibidem, p.37. Na tradução brasileira, p.52.

\begin{tabular}{|l|c|c|c|c|}
\hline Govidem, Oialectus & Ano 8 & n. 14 & Janeiro - Julho 2019 & p. $169-182$ \\
\hline
\end{tabular}


e valores determinantes na orientação das pulsões individuais. O "corpo" do princípio de realidade apresenta diferenças em estágios de civilização diferentes. E se, por um lado, qualquer forma de princípio de realidade demanda considerável grau e amplitude de controle repressivo das pulsões; por outro lado, instituições e interesses históricos específicos introduzem controles adicionais, particulares, além daqueles indispensáveis à associação social humana. Nas reflexões do filósofo, esse excesso merece uma duplicação terminológica dos conceitos: os controles considerados supérfluos, advindos de formatos específicos de dominação, são denominados por Marcuse de "mais-repressão" (surplus-repression). O termo explicita a diferença entre o grau de repressão pulsional socialmente necessária, daquela requerida por um determinado sistema de dominação. A mais-repressão é fruto das restrições necessárias a uma determinada forma de dominação social, e é distinta, portanto, “de repressão (básica): as 'modificações' dos instintos necessários à perpetuação da raça humana na civilização". ${ }^{12}$ A necessidade de repressão presente em qualquer forma de civilização, uma vez que a gratificação total e imediata das pulsões é incompatível com a própria sobrevivência, é diferenciada daquela relativa ao estabelecimento, ou consolidação, de privilégios. Horowitz qualifica de "obtusa e preconceituosa" toda crítica que acusa Marcuse de propor a eliminação de toda e qualquer repressão e que desconsidera o desdobramento do conceito por ele realizado. ${ }^{13} \mathrm{O}$ termo adotado, mais-repressão, remete sem dúvida ao conceito de maisvalia, cunhado por Marx, e revela como a necessidade de repressão básica, imposta pela natureza, foi fermentada pelas estruturas sociais ao longo da história e transformou-se em mais-repressão.

Como uma espécie de trincheira contra a imposição desnecessária de mais-repressão, o filósofo insiste na força cognitiva da fantasia e ressalta seus elos indissolúveis com todas as outras funções psíquicas. A fantasia é a "atividade criativa da qual fluem as respostas a todas as questões respondíveis" ${ }^{14}$, registra Marcuse, citando os Tipos psicológicos, de Jung, para quem a fantasia é "a mãe de todas as possibilidades na qual todas as oposições mentais, tanto quanto o conflito entre mundos interno e externo, são unidas". ${ }^{15}$ A fantasia salta sobre o abismo existente entre as irreconciliáveis demandas do sujeito e o mundo objetivo, e o faz não apenas voltada para o passado e sim com vistas a possibilidades futuras. Entretanto, ressalta o filósofo, Jung, como Freud, também enfatiza, sobretudo, o traço regressivo da fantasia e descreve o pensamento onírico como uma regressão à percepção original, que "move-se de maneira retrógada em direção à

12 Ibidem, p.35. Na tradução brasileira, p.51.

${ }^{13}$ HOROWITZ. Repression. Basic and Surplus-repression in Psychoanalytic Theory: Freud, Reich and Marcuse, p.3. A esse respeito, cf. KANGUSSU. Leis da liberdade, p.93 a 96.

14 MARCUSE. Eros and Civilization, p.148. Na tradução brasileira, p.138.

15 JUNG. Psychological Types, p.96. Apud MARCUSE. Eros and Civilization, p.148. Na tradução brasileira, p.138.

\begin{tabular}{|l|c|c|c|c|}
\hline Qenista Dialectus & Ano 8 & n. 14 & Janeiro - Julho 2019 & p. $169-182$ \\
\hline
\end{tabular}


Imaculada Kangussu

matéria-prima (raw material) da memória". ${ }^{16}$ Distintamente, conforme vimos, Marcuse pensa a fantasia como portadora de uma ambiguidade temporal, simultaneamente retrospectiva e expectante, dirigida pela e à realidade histórica. E considera seu teor de verdade não apenas em relação com o passado, como também dirigido ao futuro. "Em sua recusa a aceitar as limitações impostas à liberdade pelo princípio de realidade, em sua recusa a esquecer o que pode ser, reside a função crítica da fantasia". ${ }^{17}$

A ênfase no que pode ser, no ainda-não, no nunc stans fundador do princípio de esperança na filosofia de Ernst Bloch, ressoa forte no movimento surrealista, conforme se percebe na seguinte passagem do Manifesto do surrealismo: "reduzir a imaginação à escravidão, mesmo que fosse àquilo que, grosseiramente, se chama felicidade, é privar-se de tudo que se encontra, no fundo de si, de justiça suprema. Somente a imaginação nos diz o que pode ser". ${ }^{18}$ Marcuse observa que os surrealistas vão além da metapsicologia freudiana ao considerarem que o sonho pode ser aplicado na solução de problemas fundamentais da vida, que "a adesão intransigente ao estrito valor de verdade da imaginação compreende a realidade mais completamente". ${ }^{19}$ Na perspectiva surrealista, adverte Ferdinand Alquié, “a razão adulta, social, cotidiana, não se contenta em oprimir o homem, ela o trai". ${ }^{20}$ E segundo Andre Breton, "é verdadeiramente para nossa fantasia que vivemos", ${ }^{21}$ de modo que, de acordo com o surrealista francês, deve-se dar graças a Freud, pois, "na trilha de suas descobertas, esboça-se, enfim, uma corrente de opinião a favor da qual o explorador humano poderá levar mais longe suas investigações, autorizado que está a não levar em conta realidades sumárias. A imaginação talvez esteja prestes a reclamar seus direitos". ${ }^{22}$ No comentário de Alquié,

O que Breton condena é o pragmatismo, a busca calculada e calculadora de uma felicidade limitada e prudente, que pede a renúncia ao sonho e às exigências essenciais do desejo. É para cuidar desta felicidade que a maior parte dos homens consente, precisamente, em separar a beleza de suas vidas, em tê-la por abstrata e formal, em pregá-la no muro para contemplá-la aos domingos, vivendo, durante a semana, como diz ainda Breton, "a vida dos cachorros". 23

16 JUNG. Psychology of the Unconscious, p.13-14. Apud MARCUSE. Eros and Civilization, p.148. Na tradução brasileira, p.138. "No desenvolvimento da psicologia de Jung, suas tendências obscurantistas e reacionárias tornaram-se predominantes e eliminaram os insights críticos da metapsicologia freudiana”. Ibidem.

17 MARCUSE. Eros and Civilization, p.149. Na tradução brasileira, p.138.

18 BRETON. Les Manifestes du Surréalisme, p.15. Na tradução brasileira, Manifesto do Surrealismo, p.169. Citado em MARCUSE. Eros and Civilization, p.149. Na tradução brasileira, p.138.

19 MARCUSE. Eros and Civilization, p.149. Na tradução brasileira, p.139.

20 ALQUIÉ, Ferdinand. La Philosophie du Surréalisme, p.117.

21 BRETON. Les Manifestes du Surréalisme, p.37. Na tradução brasileira, p.180.

${ }^{22}$ Ibidem, p.25. A última frase é citada em MARCUSE. Eros and Civilization, p.149. Na tradução brasileira, p.138.

23 ALQUIÉ. Op. cit., p.19.

\begin{tabular}{|c|c|c|c|c|}
\hline Rovista Dialectus & Ano 8 & n. 14 & Janeiro - Julho 2019 & p. $169-182$ \\
\hline
\end{tabular}


$\mathrm{O}$ fato de as proposições expressas nas fantasias artísticas serem não-verdadeiras, em termos da organização dos fatos dada, faz parte da essência de sua verdade. Marcuse reproduz a passagem onde Whitehead afirma que "a verdade de que alguma proposição a respeito de uma ocasião real é não-verdadeira pode expressar a verdade vital como realização estética. Ela expressa a 'grande recusa' que é sua característica primordial". ${ }^{24}$ A "grande recusa" acontece através da expressão de uma verdade sem lugar na chamada realidade em curso e, portanto, considerada mentira, ou no mínimo, irrealidade, ficção, mera fantasia. Neste sentido, a "verdade vital" realiza-se esteticamente como expressão de uma verdade que ainda não é considerada como tal e que só encontra espaço na ficção. Vale lembrar a afirmação lacaniana de que a verdade tem a estrutura de ficção...

Perceber a obra de arte como lócus da expressão de uma verdade que ainda é considerada não verdadeira ajuda a entender as dificuldades enfrentadas pelas chamadas vanguardas, que confrontam o público com suas obras "difíceis". A "grande recusa" afirma a distinção entre o atual e o verdadeiro. Interessa a Marcuse ressaltar que o atual não é o verdadeiro, a realidade não é o real. Com o auxílio luxuoso das maiúsculas alegorizantes, a Grande Recusa é, posteriormente, adotada pelo filósofo como conceito fundamental para negar o que é dado como realidade e para configurar uma atitude que se distingue radicalmente do positivismo. A Grande Recusa à realidade oferecida como tal faz vir à tona a atualidade do desejo reprimido e só pode ser formulada impunemente na fantasia e na linguagem artística. Em contextos pretensamente mais realistas, como na teoria política, e mesmo na filosofia, ela é difamada como utopia, como ideia sem lugar, lamenta o filósofo. Essa ação de relegar a Grande Recusa ao dado para o terreno utópico é essencialmente um movimento de mais-repressão. Distintamente, se o desenvolvimento pulsional orientar-se para o presente histórico da civilização madura - e não apenas para o passado sub-histórico - "a própria noção de utopia perde seu sentido", ${ }^{25}$ na medida em que a carência humana, ananke, Lebensnot, considerada por Freud como a base do princípio de realidade, foi sensivelmente amortizada pelo progresso material da civilização. O problema é que, às evidentes e maravilhosas conquistas tecnocientíficas objetivas, que permitem solucionar as necessidades materiais em escala global, não correspondeu o desenvolvimento subjetivo análogo, capaz de promover a utilização dessas conquistas universalmente, colocando-as ao alcance de quem delas

24 WHITEHEAD. Science and the Modern World, p.197. Citado em MARCUSE. Eros and Civilization, p.149. Na tradução brasileira, p.139. O texto já fora citado pelo filósofo, dez anos antes, em "Algumas considerações sobre Aragon" [1945], em MARCUSE. Tecnologia, guerra e fascismo; p.270.

25 MARCUSE. Eros and Civilization, p.150. Na tradução brasileira, p.139.

\begin{tabular}{|l|c|c|c|c|}
\hline Rovita Dialectus & Ano 8 & n. 14 & Janeiro - Julho 2019 & p. $169-182$ \\
\hline
\end{tabular}


precisar. Com isso, a "escassez e imaturidade permanecerem grandes o suficiente para evitar a realização do princípio 'a cada um de acordo com sua necessidade'." ${ }^{26}$ A definição da qualidade de vida em termos estritamente materiais justifica facilmente a manutenção da mais-repressão. Para pensar outro paradigma, Marcuse relembra a afirmação de Baudelaire, segundo a qual "a verdadeira civilização [...] não está no gás, nem no vapor, nem nas mesas giratórias. Está na diminuição do pecado original". ${ }^{27}$ Acusado, em 1969, por utilizar a ideia de "pecado original", Marcuse explica:

\begin{abstract}
isso quer dizer que o conceito, que eu não aceito, tornou-se verdadeiramente uma forma motriz no desenvolvimento da civilização. Neste sentido, pode-se dizer, sem portanto aceitar a verdade do conceito de pecado original, que a civilização se define pela redução gradual das consequências do pecado original. Creio que esta é uma das melhores definições de civilização. Infelizmente, ainda não é um fato. ${ }^{28}$
\end{abstract}

Em uma civilização madura, a riqueza material e intelectual permitiria a gratificação das necessidades sem que esta fosse sistematicamente obstruída pela dominação. "Há uma distinção muito antiga entre dominação e administração: de um lado o desenvolvimento da sujeição dos homens a uma autoridade privilegiada e, do outro lado, uma administração racional". ${ }^{29}$ Ainda que o sistema estabelecido não pareça opressivo para a parcela privilegiada da população, o filósofo observa que "a base repressiva e exploradora do sistema o infecta como um todo". ${ }^{30} \mathrm{Em}$ uma administração racional, "Eros, as pulsões de vida, seria libertado num grau sem precedentes". 31

Marcuse considera a oposição à hipótese de que a fantasia, mesmo quando expressa na dimensão estética, possa validar um princípio de realidade:

\footnotetext{
Como a imaginação, que é sua faculdade mental constitutiva, o reino da estética é essencialmente "irrealista": ele reteve sua liberdade diante do princípio de realidade ao preço de ser inefetivo na realidade. Valores estéticos podem funcionar na vida para adorno e elevação cultural, ou para hobbies privados, mas viver com esses valores é privilégio dos gênios ou marca de boêmios decadentes. ${ }^{32}$
}

26 Ibidem, p.151. Na tradução brasileira, p.140. A frase citada é de Marx.

27 BAUDELAIRE. Meu coração desnudado (Mon Coeur Mis à Nu), LIX, p.110. Citado em MARCUSE. Eros and Civilization, p.153. Na tradução brasileira, p.141-142. Tanto no original, quanto na tradução, a citação está com o número trocado (aparece como XXXII).

28 MARCUSE, "Cinquième Entretien", entrevista realizada em Rencontre Internationales de Genève, em 1969, e publicada em La Liberté et l'Ordre Social. Neuchâtel: Éd. De la Baconnière, 1970; p.276.

29 Ibidem, p.273.

30 Ibidem, p.267.

31 MARCUSE. Eros and Civilization, p.154; na tradução brasileira, p.142.

32 Ibidem, p.172; na tradução brasileira, p.156.

\begin{tabular}{|l|c|c|c|c|}
\hline Qovista Qialectus & Ano 8 & n. 14 & Janeiro - Julho 2019 & p. $169-182$ \\
\hline
\end{tabular}


E também das crianças, das mulheres e dos loucos, escreve o filósofo, na sequência. "É claro que a fantasia não pode ter um efeito direto sobre a realidade; mas na medida em que ela modifica a 'atitude subjetiva para com a realidade', ela indiretamente modifica a realidade". 33 Diante de tal situação, Marcuse mostra que a desqualificação dos valores estéticos é mais uma tentativa de abafar as verdades inimigas do princípio de realidade baseado na mais-repressão. A dimensão estética encontra-se em íntima associação com sensibilidade, beleza, arte, fantasia e liberdade. Nela, fica preservada a verdade dos sentidos, ficam reconciliadas as faculdades "inferiores" com as "superiores", sensualidade e prazer convivem com intelecto e razão.

$\mathrm{Na}$ sociedade capitalista, a corrida para aumentar a produção material e o lucro hierarquiza as faculdades humanas considerando as abstratas "superiores", e as sensíveis e mais ligadas às pulsões "inferiores". Tal valorização da abstração sinaliza o alto teor de fantasia presente no terreno onde se estabelecem os valores. Dentro dessa hierarquia, "a razão aparece essencialmente como um princípio de renúncia". ${ }^{34} \mathrm{E}$ a liberdade é definida como a desejada autonomia da razão em relação aos sentidos e aos impulsos, como escravização destes aos procedimentos exigidos pelo sistema produtivo adotado. Ser livre é ser capaz de não ceder aos próprios desejos. A base psicológica do progresso da civilização encontra-se na transformação repressiva da estrutura psíquica original. "Dessa transformação não resulta apenas a conversão do organismo em instrumento de trabalho desprazeroso", adverte Marcuse, mas principalmente "a subordinação da felicidade e da satisfação à produtividade". ${ }^{35}$ A técnica que se pretendia libertária submete a humanidade a seu regime. Ao invés de libertar, a máquina submete os seres humanos ao funcionamento maquinal. Se, por um lado, o progresso técnico é um valor positivo e condição fundamental para o progresso da humanidade em sentido mais amplo, por outro lado não é condição suficiente, pois não é evidente que leve a este. O progresso técnico, pretensamente livre de valores, contém um valor bem determinado, ligado à produtividade, considerada o mais alto valor na sociedade industrial moderna. "A produtividade é inseparável do princípio moderno de progresso". 36

Nessa estrutura, Marcuse assinala que o princípio de realidade converte-se no, por ele denominado, "princípio de performance". E com isso seu pensamento vai além do freudiano, pois, se por um lado, como percebe Freud, a adaptação ao princípio de realidade mantém o organismo

\footnotetext{
MARCUSE. Sovietic Marxism, p.134; na tradução brasileira, Marxismo Soviético, p.124.

MARCUSE. "A noção de progresso à luz da psicanálise", em Cultura e Psicanálise, p.117.

35 Ibidem, p.123.

36 Ibidem, p.115.
}

\begin{tabular}{|l|l|l|l|l|}
\hline Qevista Dialectus & Ano 8 & n. 14 & Janeiro - Julho 2019 & p. $169-182$ \\
\hline
\end{tabular}


vivo no mundo externo (criado pela natureza e modificado pela cultura) e "uma organização repressiva das pulsões é subjacente a todas as formas históricas do princípio de realidade na civilização" ${ }^{37}$; por outro lado, enquanto na metapsicologia freudiana uma forma específica de realidade é considerada necessária, Marcuse insiste em salientar a contingência dessa forma e, para superar o caráter fatalista da teoria de Freud, realiza, mais uma vez, a duplicação de um conceito, sem abandoná-lo. A expressão freudiana que não diferencia as vicissitudes biológiconaturais das histórico-sociais é emparelhada com a que assinala as diferenças entre ambas: o princípio de realidade freudiano - produzido pela percepção da necessidade, posta pelo mundo objetivo, de reprimir as pulsões - que não pode ser ignorado, é diferenciado do princípio de performance, que destaca a historicidade do teor de repressão considerado necessário ao funcionamento da sociedade capitalista. O primeiro, cunhado por Freud, diz respeito à repressão; o segundo, criado por Marcuse, à mais-repressão. O princípio de performance implica normas $\mathrm{e}$ padrões reguladores do comportamento, das relações e da própria posição do ser humano na sociedade, segundo a performance competitiva do indivíduo.

A racionalidade em curso é a do princípio de performance, e a tentativa de formular um construto teórico de cultura capaz de ir além desse princípio tem sido considerada irrazoável. Aliás, desde o início da civilização ocidental, muito antes de o princípio de realidade ter se transformado no de performance, a razão já era considerada como instrumento de controle, de dominação, de repressão pulsional, e antagônica a todo terreno da sensorialidade, do prazer, dos impulsos, da fantasia, considerado como território a ser subjugado. Conforme Marcuse,

Quaisquer que sejam as implicações da concepção grega original de Logos como a essência do ser, desde a canonização da lógica aristotélica, o termo fundiu-se com a ideia de razão ordenadora, classificadora, dominadora. E essa ideia de razão tornou-se, cada vez mais, antagônica daquelas faculdades e atitudes que são mais receptivas do que produtivas, que tendem à gratificação mais do que à transcendência que permanecem fortemente vinculadas ao princípio de prazer. Estas aparecem como o irrazoável e irracional que deve ser conquistado e contido para servir ao progresso da razão. Razão é assegurar, através da cada vez mais efetiva transformação e exploração da natureza, a realização das potencialidades humanas. Mas, no processo, o fim parece recuar diante dos meios: o tempo dedicado ao trabalho alienado absorve o tempo para as necessidades individuais - e define as próprias necessidades. O Logos destacase como lógica da dominação. Quando então a lógica reduz as unidades de pensamento a sinais e símbolos, as leis do pensamento convertem-se, finalmente, em técnicas de cálculo e manipulação. ${ }^{38}$

Ainda assim, assinala Marcuse, o triunfo da lógica da dominação nunca foi total nem inconteste: "quando Freud enfatizou o fato fundamental de a fantasia (imaginação) reter uma

MARCUSE. Eros and Civilization, p.34. Na tradução brasileira, p.50.

38 MARCUSE. Eros and Civilization, 111-2. Na tradução brasileira, p.108.

\begin{tabular}{|l|c|c|c|c|}
\hline Renita Dialectus & Ano 8 & n. 14 & Janeiro - Julho 2019 & p. $169-182$ \\
\hline
\end{tabular}


verdade que é incompatível com a razão, ele estava seguindo uma longa tradição histórica. A fantasia é cognitiva na medida em que preserva a verdade da Grande Recusa". ${ }^{39}$

As estranhas verdades da fantasia permanecem vivas nos mitos, no folclore, nos contos de fadas, na literatura, nas canções populares e em outras formas que transformam nosso modo de perceber e, com isso, de entender e organizar a realidade. Assim, encarnada na arte, a fantasia retroage sobre a realidade e a transforma. Seria difícil imaginar um mundo sem nada homérico, hercúleo, ou quixotesco, e houve épocas em que os personagens que dão corpo a tais atributos nem existiam. Ainda que a ideia de que a fantasia forneça padrões para atitudes existenciais tenha sido e ainda seja considerada "mera fantasia", no sentido mais prosaico da expressão, símbolos e arquétipos, lendas e poemas são aceitos como luminares, mesmo quando considerados como expressão de estágios há muito ultrapassados. Na contramão dessa perspectiva, Marcuse amplia o papel da fantasia e encontra registros anteriores dessa ampliação, quando observa, por exemplo, que "a afirmação de Novalis de que 'todas as faculdades e forças internas, e todas as faculdades e forças externas, devem ser deduzidas da imaginação produtiva', tem permanecido uma curiosidade - como o programa surrealista de pratiquer la poésie" ${ }^{40}$ Deste modo, a fantasia aparece como uma atividade mental produtiva capaz de criar um mundo que ainda não existe. E nesta apresentação do desejo que ainda não se realizou reside sua potência libertadora.

\section{Referências:}

ALQUIÉ, Ferdinand. Philosophie du surrealisme. Paris: Flammarion, 1977.

BAUDELAIRE, Charles. Meu coração desnudado. Tradução de Aurélio Buarque de Holanda Ferreira Rio de Janeiro: Ed. Nova Fronteira, 1981.

Mon coeur mis à nu, em Oeuvres postumes, vol. II. Paris: Ed. Conrad, 1952.

BRETON, André. Les manifestes du surréalisme. Paris: Ed. Du Sagittaire, 1946.

"Manifesto do Surrealismo, 1924", em TELES, Gilberto Mendonça. Vanguarda europeia e modernismo brasileiro. Rio de Janeiro: Vozes, 1978.

FREUD, Sigmund. "Formulações sobre dois princípios de funcionamento mental" [1911], em Edição standard brasileira das obras psicológicas completas de Sigmund Freud, volume XII. Rio de Janeiro: Imago, 1976.

39 Ibidem, 159. Na tradução brasileira, p.146.

40 Ibidem, 160. Na tradução brasileira, p.147. A citação de Novalis encontra-se em NOVALIS. Schriften III (Jena: Eugen Diederichs, 1923), p.375.

\begin{tabular}{|c|c|c|c|c|}
\hline Rovita Aialectus & Ano 8 & n. 14 & Janeiro - Julho 2019 & p. $169-182$ \\
\hline
\end{tabular}


HOROWITZ, Gad. Repression. Basic and surplus-repression in psychoanalytic theory: Freud, Reich and Marcuse. Toronto: University of Toronto Press, 1977.

KANGUSSU, I. Leis da liberdade. A relação entre estética e política na obra de Herbert Marcuse. São Paulo: Loyola, 2008.

MARCUSE, Herbert. "Algumas considerações sobre Aragon”, em Tecnologia, guerra e fascismo. Trad. Maria Cristina Vidal Borba. São Paulo: UNESP, 1999.

1970.

. “Cinquième entretien”, in La liberté et l'ordre social. Neuchâtel: Éd. De la Baconnière,

Eros and Civilization: a Philosophical Inquiry into Freud. Boston: Beacon Press, 1955.

Zahar, 1969

Eros e civilização. Uma interpretação filosófica do pensamento de Freud. Rio de Janeiro:

. "Filosofia e Teoria Crítica", em Cultura e sociedade, v.1. Trad. Isabel Loureiro et al. São Paulo: Paz e Terra, 2001.

1969.

Marxismo soviético. Uma análise crítica. Trad. Carlos Weber. Rio de Janeiro: Saga,

Negations: essays in critical theory. Boston: Beacon Press, 1968.

. "A noção de progresso à luz da psicanálise", em Cultura e psicanálise. Trad. Isabel Loureiro. São Paulo: Paz e Terra, 2001.

Suhrkamp, 1965.

"Philosophie und kritische theorie", em Kultur und Gesellschaft I. Frankfurt: Soviet marxism; a critical analysis. New York: Vintage Books, 1961.

NOVALIS. Schriften III. Jena: Eugen Diederichs, 1923.

WHITEHEAD, Alfred North. Science and the modern world. Cambridge: University Press, 1926.

\begin{tabular}{|l|l|l|l|l|}
\hline Qevista Dialectus & Ano 8 & n. 14 & Janeiro - Julho 2019 & p. $169-182$ \\
\hline
\end{tabular}




\title{
O TEATRO ADMINISTRADO NA SOCIEDADE UNIDIMENSIONAL
}

Leonardo Augusto Madureira de Castro ${ }^{1}$

Isabella Fernanda Ferreira ${ }^{2}$

\begin{abstract}
Resumo:
Marcuse busca lançar luz ao esclarecimento da sociedade administrada a qual vivemos e a qual ninguém é capaz de se inserir sem afetação. Apesar de ser um grande defensor da Arte e, naturalmente, do Teatro, Marcuse nos aponta os vestígios da industrialização daquela, vestígios estes dos quais o Teatro não está imune e pelos quais também é modificado, instrumentalizado e administrado, uma vez que em seu processo de produção atende à mencionada sociedade administrada. A partir de uma rápida revisão bibliográfica dos textos de Marcuse e de autoras e autores como Chaves, Teodoro e Esteves, pode-se perceber a constante busca pela emancipação do Teatro desta sociedade unidimensional, ao mesmo tempo que a Arte é levada a se subjugar aos comandos da industrialização da cultura. Para isso é necessário, entender o conceito de administração e de pensamento unidimensional proposto por Marcuse para enfim compreender como o frankfurtiano percebe tais lapsos nas produções artísticas.
\end{abstract}

Palavras-chave: Teatro. Marcuse. Unidimensionalização. Administração.

\section{THE THEATER MANAGED IN THE UNIDIMENSIONAL SOCIETY}

\begin{abstract}
:
Marcuse seeks to shed light on the enlightenment of the managed society to which we live and which no one is able to insert without affectation. In spite of being a great defender of the Art and, of course, of the Theater, Marcuse points us the vestiges of the industrialization of that one, traces of these of which the Theater is not immune and by which also it is modified, instrumentalized and administered, since in its process to the aforementioned managed company. From a quick bibliographical revision of the texts of Marcuse and of authors and authors like Chaves, Teodoro and Esteves, one can perceive the constant search for the emancipation of the Theater of this one-dimensional society, at the same time that Art is led to subjugate to the commands of the industrialization of culture. For this, it is necessary, to understand the concept of management and one-dimensional thinking proposed by Marcuse to finally understand how the Frankfurdian perceives such lapses in artistic productions.
\end{abstract}

Keywords: Theater. Marcuse. Unidimensionalization. Administration.

Quando pensamos em arte e sociedade não podemos desvincular os processos de construção paralelos de ambos. O estudante de arte e o de sociedade sempre se depara com pontos em comum em que um contribui na coordenação e no esclarecimento do outro. Quando

1 Leonardo Augusto Madureira de Castro é ator e arte educador, graduado em Artes Cênicas e Dança pela Universidade Estadual de Mato Grosso do Sul (UEMS) e mestre em Educação Social pela Universidade Federal de Mato Grosso do Sul (UFMS/CPAN). E-mail: leodecastro92@gmail.com

2 Isabella Fernanda Ferreira é Doutora em Educação pela UNESP de Araraquara. Docente Permanente do programa de Pós-graduação em Educação da UFMS/CPAN. Docente Colaboradora no Programa de Pósgraduação em Educação da UFMS/FAED. Uma das fundadoras e também coordenadora na Rede Nacional/Internacional de Pesquisa "NEXOS Teoria Crítica e Pesquisa Interdisciplinar" dividida pelas cinco regiões do País. Líder do "NEXOS Teoria Crítica e Pesquisa Interdisciplinar - Centro-Oeste/Norte". Membro como pesquisadora do Consórcio Internacional de Programas de Teoria Crítica organizado pela Filósofa Judith Butler. E-mail: bella.fernandaferreira@gmail.com 
se busca o conceito de Pensamento Unidimensional desenvolvido por Marcuse (1973) em sua obra "A ideologia da sociedade industrial: o homem unidimensional" nos deparamos com estes pontos. Para Marcuse (1973), as repressões estão unidas à cultura capitalista, e essa mesma cultura é responsável pela sociedade industrializada, o que leva os sujeitos a aceitarem a sua condição, o que ele explica ao criar o conceito de "Pensamento Unidimensional". A sociedade industrializada em que vivemos tem influência direta no pensamento dos seres humanos, à medida que eles aceitam ser controlados por ela.

Tal nível de pensamento unidimensionalizado, segundo o autor, dá-se pelo racionalismo exacerbado criado para organizar e administrar a sociedade de maneira totalitária. Ele interpreta o conceito como uma racionalidade irracional da sociedade (MARCUSE, 1973), que se prende em seus próprios paradigmas. Esses paradigmas acabam sendo disseminados também pela mídia de massas. No teatro, essas mídias podem auxiliar no processo de 'unidimensionalização' do pensamento quando não ocorre, por exemplo, uma preocupação com a pesquisa estética da arte teatral e da temática pretendida. Nessa nossa sociedade administrada, todos os pensamentos, ideais, ideias e até mesmo ideologias políticas servem a um propósito e, portanto, não são dotadas de neutralidade. Quando encaramos esse propósito como subserviência, constatamos ainda mais o sentido da instrumentalização desses termos que são, por consequência, administradores do pensamento humano. Todos temos ideais, ideias, ideologias e pensamentos objetivados, racional ou subjetivamente.

Esta instrumentalização pode ser observada em todas as vertentes artísticas. Discutiremos aqui, neste artigo, como o teatro também é administrado por esta sociedade unidimensional.

\section{Do Teatro racionalizado e administrado}

A racionalização e os processos administradores do teatro podem ser analisados por meio dos conceitos de pensamento unidimensional e sociedade administrada, propostos por Marcuse (1973). O pensamento unidimensional é o tipo de pensamento racional que se desenvolve por ações de uma sociedade industrial, cujos sistemas todos convertem para a doutrinação do pensamento dos sujeitos. O frankfurtiano conceitua os sujeitos como sendo homens unidimensionais, justamente por viverem e perpetuarem a sociedade unidimensional fazendo parte dela e, ainda mais, fomentando a sua expansão e manutenção. Os produtores do pensamento unidimensional são aqueles que lucram com a vida industrializada e aqueles que

\begin{tabular}{|l|l|l|l|l|}
\cline { 2 - 5 } & Ano 8 & n. 14 & Janeiro-Julho 2019 & p. $183-199$ \\
\hline
\end{tabular}


dela usufruem (ou melhor, são manipulados por ela).

O pensamento unidimensional é sistematicamente promovido pelos elaboradores da política e seus provisionadores de informação em massa. O universo da palavra, dêstes e daqueles, é povoado de hipóteses autovalidadoras que, incessante e monopolisticamente repetidas, se tornam definições ou prescrições hipnóticas. (MARCUSE, 1973, p. 44).

Tudo na sociedade unidimensionalizada converge, segundo Marcuse (1973), para a sua perpetuação. O autor apropria-se do termo "administrado" para explicar tais relações, porque a sociedade é administrada conforme os valores e ideologias da sociedade industrializada massificadora que, por sua vez, mantém-se como hegemonia dominante, não dando suporte algum para que o indivíduo nela inserido deixe de fazer parte dessa malha reificadora. Esse tipo de administração é dado em nível ideológico, o que converge para o pensamento em todos os campos sociais pertencentes às sociedades. Tamanho é o seu poder que, além das estruturas sociais, atinge a intimidade, a subjetividade e o pensamento do ser unidimensionalizado, indivíduo que, por ter sido tão afetado, deixa de ser indivíduo autônomo e passa a pensar conforme as regras estabelecidas pela sociedade, sem perspectivas de novos horizontes. $\mathrm{Ou}$ seja, a sociedade industrializada obriga o indivíduo a usar antolhos, mantendo-o com uma visão, um pensamento, uma ação, uma opinião política, uma vida unidimensional.

Ainda segundo o mesmo autor, esse processo se dá pela industrialização de todos os bens e serviços sociais, assim como na produção da arte. Tal industrialização dicotomiza as reais necessidades daquelas inventadas pela indústria, cegando o consumidor, fazendo-o acreditar que precisa dos produtos culturais oferecidos por essa hegemonia. E isso se dá ao infinito. Quanto mais ela produz bens reificadores, mais ela unidimensionaliza a sociedade, mais ela é programada racionalmente para se manter, ou seja, mais reforça o seu caráter administrador.

A sociedade industrial recente aumentou, em vez de reduzir, a necessidade de funções
parasitárias e alienadas (para a sociedade em seu todo, se não mesmo para o indivíduo). Os
anúncios, as relaçães públicas, a doutrinação e o obsoletismo planejado não mais são custos
improdutivos gerais, mas elementos dos custos básicos de produção. Para ser eficaz, tal produção
de desperdício socialmente necessário exige a racionalização contínua - a utilização incessante
de técnicas avançadas e ciência. [...] A produtividade crescente do trabalho cria um crescente
produto excedente que, quer particular, quer centralmente destinado e distribuído, permite um
consumo aumentado - não obstante o desvio aumentado da produtividade. Enquanto prevalecer
essa constelação, ela reduzirá o valor de uso da liberdade, não havendo razão alguma para insistir
na autodeterminação se a vida administrada fôr confortável e até "boa". (MARCUSE, 1973, p.
63).

Essa paralisia do pensamento só acontece porque o indivíduo se acostumou à "boa vida" mencionada por Marcuse (1973). Em seu livro "A ideologia da sociedade industrial: o homem

\begin{tabular}{|c|c|c|c|c|}
\hline Rovista Dialectus & Ano 8 & n. 14 & Janeiro - Julho 2019 & p. $183-199$ \\
\hline
\end{tabular}


unidimensional", o autor explica que quem é contrário à sociedade pode muito bem ser excluído e rechaçado por ela.

[...] no período contemporâneo, os controles tecnológicos parece serem a própria personificação da Razão para o bem de todos os grupos e interêsses sociais - a tal ponto que tôda contradição parece irracional e tôda ação contrária parece impossível.

Não é, portanto, de admirar que, nos setores mais desenvolvidos dessa civilização, os contrôles sociais tenham sido introjetados a ponto de até o protesto individual ser afetado em suas raízes. A negativa intelectual e emocional de "prosseguir" parece neurótica e impotente. (MARCUSE, 1973, p. 30).

O processo de controle mantém-se totalitário, onipotente e onipresente. O homem unidimensionalizado aceita com impensada facilidade participar desse sistema. Torna-se uma engrenagem dele. "Em sua fase mais avançada, a dominação funciona como administração. E nas áreas superdesenvolvidas de consumo em massa, a vida administrada se torna a boa vida de todos [...].” (MARCUSE, 1973, p. 234).

\begin{abstract}
A perda das liberdades económicas e políticas que foram as conquistas reais dos dois séculos passados pode parecer pequeno dano num Estado capaz de tornar a vida administrada segura e confortável. ${ }^{3}$ Se os indivíduos estão satisfeitos a ponto de se sentirem felizes com as mercadorias e os serviços que lhes são entregues pela administração, por que deveriam 186les insistir em instituições diferentes para a produção diferente de mercadorias e serviços diferentes? E se os indivíduos estão precondicionados de modo que as mercadorias que os satisfazem incluem também pensamentos, sentimentos, aspirações, por que deveriam desejar pensar, sentir e imaginar por si mesmos? É bem verdade que as mercadorias materiais e mentais oferecidas podem ser ruins, extravagantes, imprestáveis - mas Geist ${ }^{4}$ e conhecimento não são argumentos eficazes contra a satisfação das necessidades. (MARCUSE, 1973, p. 63-64, grifo do autor, nota nossa).
\end{abstract}

Esse é o precursor da possibilidade dessa sociedade. Marcuse (1973) deixa claro que o indivíduo "gosta" de ser manipulado.

Provavelmente não se percebe, por enquanto, a fragilidade ideológica, a malha de sistemas que leva o ser humano a um único comportamento de massa (mesmo dentro das mais variadas 'tribos'). Para explicar o fenômeno, Marcuse (1973) utiliza-se dos avanços tecnológicos e da apropriação da natureza, incluindo a humana, pela ciência:

[...] a tecnologia se tornou o grande veículo de espoliação - espoliação $\mathrm{cm}$ sua forma mais madura e eficaz. A posição social do indivíduo e sua relação com os demais não apenas parecem

\footnotetext{
3 (Nota original) Ver p. 24.

4 Espírito, mente.
}

\begin{tabular}{|c|c|c|c|c|}
\hline Q Rovista Dialectus & Ano 8 & n. 14 & Janeiro - Julho 2019 & p. $183-199$ \\
\hline
\end{tabular}


determinadas por qualidades e leis objetivas, mas também essas leis e qualidades parecem perder seu caráter misterioso e incontrolável; aparecem como manifestações calculáveis da racionalidade (científica). O mundo tende a tornar-se o material da administração total, que absorve até os administradores. A teia da dominação tornou-se a teia da própria Razão, e esta sociedade está fatalmente emaranhada nela. E os modos transcendentes de pensar parece transcenderem a própria Razão. (MARCUSE, 1973, p. 162, grifo do autor).

Quando a dominação da administração total transcende a razão, o autor explica que surge uma nova forma de prisão, a alteração dos sentidos de racionalidade e irracionalidade. Essa alteração conceitual emaranha o pensamento do indivíduo em uma rede burocrática que, apesar de ter sido desenvolvida para facilitar a vida de todos, aprisiona o indivíduo em processos que dificultam a sua existência.

\begin{abstract}
A sociedade unidimensional em desenvolvimento altera a relação entre o racional e o irracional. Contrastado com os aspectos fantásticos e insanos de sua irracionalidade, o reino do irracional se torna o lar do realmente racional - das Ideias que podem "promover a arte da vida". Se a. sociedade estabelecida controla tôda comunicação normal, validando-a ou invalidando-a de conformidade com as exigências sociais, então os valôres estranhos a essas exigências podem talvez não ter qualquer outro meio de comunicação a não ser o meio anormal da ficção. (MARCUSE, 1973, p. 227).
\end{abstract}

Talvez a arte livre, como menciona o autor, esteja subjugada a tais condições, mas, como arte livre, é negação, resistência. Promove ações para buscar sair das zonas controladas pela administração unidimensional. Mas a guerra ideológica mascara-se na falsa democracia em que vivemos.

\begin{abstract}
Inegàvelmente, uma administração totalitária pode promover a exploração eficiente dos recursos; o estabelecimento nuclear-militar pode garantir emprêgo a milhões por meio de enorme poder aquisitivo; a labuta e as úlceras podem ser o subproduto da aquisição de riqueza e responsabilidade; erros e crimes mortais por parte dos líderes podem ser meramente o estilo de vida. Pode-se estar disposto a admitir a loucura econômica e política - e se compra essa loucura. A tolerância do pensamento positivo é tolerância imposta - [...] pelo poder e eficiência esmagadores e anônimos da sociedade tecnológica. Como tal, ela permeia a consciência geral e a consciência da crítica. A absorção do negativo pelo positivo é validada na experiência diária, que obscurece a distinção entre aparência racional e realidade irracional. (MARCUSE, 1973, p. 209-210).
\end{abstract}

Apesar de o obscurantismo afetar a cultura, ainda há possibilidades de se produzir e se encontrar a cultura superior. Chaves e Ribeiro (2014) avaliam:

A arte pode ser revolucionária em vários sentidos. Em sentido restrito, quando apresenta uma mudança radical no estilo e na técnica (vanguarda), "antecipando ou refletindo mudanças

\begin{tabular}{|l|l|l|l|l|}
\cline { 2 - 4 } & Ano 8 & n. 14 & Janeiro-Julho 2019 & p. $183-199$ \\
\hline
\end{tabular}


substanciais na sociedade" (Marcuse, 1977/1999, p. 12) ${ }^{5}$, como aconteceu com o expressionismo e o surrealismo, que "anteciparam a destrutividade do capitalismo monopolista" (p. 12). Mas também [...] em sua configuração estética, quando apresenta ausência de liberdade do existente e indica as forças que se rebelam contra isso; quando rompe com a realidade reificada e aponta horizontes de transformação; quando subverte as formas de percepção e compreensão e deixa transparecer um teor de verdade, de protesto e de promessa na linguagem e na imagem. (CHAVES et al., 2014, p.14-15).

Para Marcuse (1973), ainda existe certa esperança para a arte, mas os vestígios da arte superior estão pouco a pouco sendo engolidos pela besta reificadora da sociedade capitalista. Isso porque a realidade está, até certo ponto, em um estado além da sua própria cultura.

O que está ocorrendo agora não é a deterioração da cultura superior numa cultura de massa, mas a refutação dessa cultura pela realidade. A realidade ultrapassa sua cultura. O homem [...] resolveu muitos problemas insolúveis. Mas também traiu as esperanças e destruiu a verdade que eram preservadas nas sublimações da cultura superior. Na verdade, a cultura superior estêve sempre em contradição com a realidade social [...]. As duas esferas antagônicas da sociedade sempre coexistiram; a cultura superior sempre foi acomodativa, enquanto a realidade raramente foi perturbada por seus ideais e sua verdade. (MARCUSE, 1973, p. 69-70).

Para ilustrar o seu pensamento, Marcuse (1973) apropria-se da discussão sobre a música de sua contemporaneidade, já quase que universalmente reificada, para tratar do contexto "arte" em geral. Não nos cabe analisar a música em si, mas é bem provável que a administração da música contemporânea tenha o mesmo intuito, até bem mais que nos anos 1970.

Se as comunicações em massa misturam harmoniosamente e, com freqüência, imperceptivelmente, arte, política, religião e filosofia com anúncios, levam essas esferas da cultura ao seu denominador comum - a forma de mercadoria. A música da alma é também a música da arte de vender. O que importa é o valor de troca, e não o da verdade. Em tôrno dele gira a racionalidade do status quo, e tôda racionalidade alienígena se submete a êle. (MARCUSE, 1973 , p. 70, grifo do autor).

Segundo o frankfurtiano, existem ainda os neoconversadores, que acreditam que é válida e benéfica a apropriação da arte pela indústria. O capital acaba, segundo Marcuse (1973, p. 76-77), transformando a possibilidade de aproximação cultural das pessoas em uma ótima oportunidade para mudar a ideologia de tais obras, por analogias e instrumentalização, para outros fins, em geral comerciais. A racionalização em favor do lucro em relação à obra artística a faz aproximar-se de seu público, mas ela já se aproxima sofrendo intervenções, tanto em sua produção quanto em sua finalidade.

5 Marcuse, H. A dimensão estética (M. E. Costa, Trad.). Portugal: Ed. 70, (Original publicado em 1977) 1999.

\begin{tabular}{|c|c|c|c|c|}
\cline { 2 - 5 } & Rovista & Jialectus & Janeiro-Julho 2019 & p. $183-199$ \\
\hline
\end{tabular}




\begin{abstract}
É bom o fato de quase todos podem ter atualmente as belas-artes ao seu alcance, simplesmente ligando o seu receptor ou entrando numa loja. Contudo, elas se tornam, nessa difusão, dentes de engrenagem de uma máquina de cultura que refaz seu conteúdo. A alienação artística sucumbe, juntamente com outras formas de negação, ao processo de racionalidade tecnológica. A modificação revela sua profundidade e o grau de sua irreversibilidade quando vista como um resultado do progresso técnico. (MARCUSE, 1973, p. 76-77).
\end{abstract}

Concordando com o autor, a ordem estabelecida tem o poder de alienar a arte em sua forma mais pura, para transformá-la. A arte propicia que o indivíduo enxergue a sua realidade com outros olhos. "A alienação artística é a transcendência consciente da existência alienada uma alienação de "nível superior" ou interposta" (CHAVES et al. apud MARCUSE, 2014, p. 20-21), sendo assim, "Essa alienação é emancipatória: “Alienação de uma sociedade alienada, em virtude da qual ela se dissocia metodicamente daquela e cria o universo [...] em que se [...] expressa a verdade" (Kangussu, 2010, p. 207) ${ }^{6}$." (CHAVES et al., 2014, p. 16). Arte, para Marcuse (1973), é negação.

Na verdade, a alienação não é a única característica da arte. [...] O lugar da obra de arte numa cultura pré-tecnológica e bidimensional é muito diferente do que numa civilização unidimensional, mas a alienação caracteriza tanto a arte afirmativa como a negativa. A distinção decisiva não é a psicológica entre arte criada na alegria e arte criada na tristeza [...] mas entre realidade artística e realidade social. O rompimento com a segunda [...] é uma qualidade essencial até mesmo da arte mais afirmativa [...] A "cultura superior" em que essa alienação é notória tem seus próprios ritos e seu próprio estilo. [...] (MARCUSE, 1973, p. 74-75).

Tais estilos são aqueles que, como cultura superior, buscam em sua forma, e principalmente em seu conteúdo, possibilidades de uma representação desalienante. Marcuse (1973) relembra Brecht e sua relação ideológica, conferindo ao teatro o conceito de "Teatro Político".

\begin{abstract}
Bertolt Brecht esboçou os fundamentos teóricos para esses esforços. O caráter total da sociedade estabelecida confronta o dramaturgo com a questão sobre se ainda é possível representar o mundo contemporâneo no teatro" - isto é, representa-lo de tal modo que o espectador reconheça a verdade que a peça se destina a transmitir. Brecht responde que o mundo contemporâneo só pode ser assim representado se é representado como sujeito a modificação ${ }^{7}$ - como o estado de negatividade que deve ser negado. [...] mas o teatro é e deve ser divertimento e prazer. Contudo, divertimento e aprendizado não são opostos; o divertimento pode ser uma das maneiras mais eficazes de se aprender. [...] Não são necessários empatia e sentimento, mas distância e reflexão. (MARCUSE, 1973, p. 77-78).
\end{abstract}

6 KANGUSSU, I. Marcuse, vida e arte. In HADDOCK-LOBO, R. (Org.), Os filósofos e a arte. Rio de Janeiro: Rocco, p. 205-219, 2010.

7 (Nota original) Bertolt Brecht. Schriffen zum Theater (Berlim e Frankfurt Suhrkamp 1957), pp. 7, 9.

\begin{tabular}{|l|l|l|l|l|}
\cline { 2 - 5 } & Ano 8 & n. 14 & Janeiro-Julho 2019 & p. $183-199$ \\
\hline
\end{tabular}


Marcuse (1973) explica o excerto em que cita Brecht, demonstrando o que aquele chama de "função" da Arte, ao definir os objetivos da arte em uma sociedade irracional.

\begin{abstract}
A ênfase dada à relação entre arte e técnica indica a racionalidade específica da arte.
[...] a arte cria outro universo de pensamento e prática contra o existente e dentro dêle. Mas, em contraste com o universo técnico, o universo artístico é de ilusão, aparência, Schein ${ }^{8}$. Contudo, essa aparência é semelhança com uma realidade que existe como a ameaça e a promessa da realidade estabelecida. ${ }^{9}$ Em várias formas de máscara e silêncio, o universo artístico é organizado pelas imagens de uma vida sem temor - de máscara e em silêncio porque a arte não tem podêres para criar essa vida e até mesmo para representá-la adequadamente. [...] Quanto mais espetacularmente irracional se torna a sociedade, tanto maior a racionalidade do universo artístico. (MARCUSE, 1973, p. 220, grifo do autor, nota nossa).
\end{abstract}

O autor evidencia hipóteses para a racionalidade da arte, propondo ser "[...] visualizada como validada pela transformação científico-tecnológica do mundo e funcionando nela." (MARCUSE, 1973, p. 221), reduzindo assim os sistemas reificadores da sociedade administrada.

Segundo Hegel ${ }^{10}$, a arte reduz a contingência imediata na qual um objeto (ou uma totalidade de objetos) existe, para um estado no qual o objeto assume a forma e a qualidade de liberdade. Tal transformação é redução porque a situação contingente sofre exigências que são externas e que se interpõem à sua livre realização. Essas exigências constituem um "aparato", visto como não são meramente naturais, mas, antes, sujeitas a modificação e a desenvolvimento livres e racionais. Assim, a transformação artística viola o objeto natural, mas o violado é, êle próprio, opressivo; assim, a transformação estética é libertação. (MARCUSE, 1973, p. 220-221).

Entendemos como Teatro racionalizado e administrado aquele que é pensado de modo unidimensionalizado para o alcance de um determinado fim, seja ele pedagógico, ideológico, artístico ou puramente prazeroso. Este Teatro é calculado de modo que, tanto quem o produz, quanto quem o apreende, se tornem sujeitos (ativos e passivos) de uma "doutrinação" que, por sua vez, é baseada no fim para o qual o Teatro foi planejado. Marcuse (1973), em seu livro "A ideologia da sociedade industrial", no primeiro capítulo "As novas formas de controle", já avalia como a sociedade, com sua razão, cultura e ideologia, torna-se administrada pelos

8 Nesse caso, pode ser traduzido como "máscara".

9 (Nota original) Ver capítulo 3.

10 (Nota original) Hegel. Vorlesungen über die Aesthetik, em Sâmtliche Werk, ed. H. Glockner (Stuttgart, Frommann, 1929), vol. XII, pp. 217 e seg. Ver também a tradução de Osmaston, em Hegel, The Philosophy of Fine Art (Londres, Bell and Sons, 1920), vol. I, p. 214.

\begin{tabular}{|l|l|l|l|l|}
\cline { 2 - 5 } & Ano 8 & n. 14 & Janeiro-Julho 2019 & p. $183-199$ \\
\hline
\end{tabular}


processos de industrialização social, que é cada vez mais ensimesmada, vítima e algoz de sua própria reificação.

Uma falta de liberdade confortável, suave, razoável e democrática prevalece na civilização industrial desenvolvida, um testemunho de progresso técnico. De fato, o que poderia ser mais racional do que a supressão da individualidade na mecanização de desempenhos socialmente necessários, mas penosos [...]? (MARCUSE, 1973, p. 23).

A falta de liberdade é até percebida, mas, por ora, é forte demais para ser combatida. $\mathrm{O}$ cerceamento de outras possibilidades sociais é conjuntura para que o homem se mantenha preso a um pensamento totalitário em si mesmo. Essa completude não o torna autônomo. Muito pelo contrário, afasta-o de sua emancipação como indivíduo de uma sociedade administrada. Ele não tem tempo para sentir, humanizar-se, o que determina os processos de reificação ainda mais comuns.

\begin{abstract}
Quanto mais racional, produtiva, técnica e total se torna a administração repressiva da sociedade, tanto mais inimagináveis se tornam os modos e os meios pelos quais os indivíduos administrados poderão romper sua servidão e conquistar sua própria libertação. Sem dúvida, a idéia de impor a Razão a uma sociedade inteira é paradoxal e escandalosa - embora se possa discutir a correção de uma sociedade que ridiculariza essa idéia enquanto transforma sua população em objetos de administração total. Tôda libertação depende da consciência de servidão e o surgimento dessa consciência é sempre impedido pela predominância de necessidades e satisfações que se tornaram, em grande proporção, do próprio indivíduo. O processo substitui sempre um sistema de precondicionamento por outro; o objetivo ótimo é a substituição de falsas necessidades por outras verdadeiras, o abandono da satisfação repressiva. (MARCUSE, 1973, p. 28).
\end{abstract}

Marcuse (1973) denuncia o medo e a sombra com que a sociedade industrial afeta o indivíduo, o sujeito, coisifica o subjetivo e prende-o em uma trama econômico-social da qual é impossível escapar.

Defrontamos novamente com um dos aspectos mais perturbadores da civilização industrial desenvolvida: o caráter racional de sua irracionalidade. Sua produtividade e eficiência, sua capacidade para aumentar e disseminar comodidades, para transformar o resíduo em necessidade e a destruição em construção, o grau com que essa civilização transforma o mundo objetivo numa extensão da mente e do corpo humanos tornam questionável a própria noção de alienação. As criaturas se reconhecem em suas mercadorias; encontram sua alma em seu automóvel, $h i$-fi, casa em patamares, utensílios de cozinha. O próprio mecanismo que ata o indivíduo à sua sociedade mudou, e o contrôle social está ancorado nas novas necessidades que ela produziu. (MARCUSE, 1973, p. 29-30. Grifo do autor).

Sendo assim, como explica o autor, as necessidades não são mais necessidades, pois são

\begin{tabular}{|l|l|l|l|l|}
\cline { 2 - 4 } & Ano 8 & n. 14 & Janeiro-Julho 2019 & p. $183-199$ \\
\hline
\end{tabular}


criadas a partir de pressupostos não inerentes a todo ser humano. A sociedade industrializada passa por constantes atualizações, que a mantêm afastada do desenvolvimento emancipatório de seus membros. Uma fragmentação é imposta pela unidimensionalidade do pensamento, ou seja, pelo modo de produzir do homem com propósitos administrados para a manutenção de um sistema que gera a espoliação dos sujeitos pelos próprios sujeitos. Tudo gira em torno da vontade do sistema de se manter como dono do indivíduo, ou seja, transformando-o em coisa, para, assim, manipulá-lo a seu bel prazer.

O aparato produtivo e as mercadorias e serviços que êle produz "vendem" ou impõem o sistema social como um todo. Os meios de transporte e comunicação em massa, as mercadoras casa, alimento e roupa, a produção irresistível da indústria de diversões e informação trazem consigo atitudes e hábitos prescritos, certas reações intelectuais e emocionais que prendem os consumidores mais ou menos agradàvelmente aos produtores e, através dêstes, ao todo. Os produtos doutrinam e manipulam; promovem uma falsa consciência que é imune à sua falsidade. E, ao ficarem êsses produtos benéficos à disposição de maior número de indivíduos e de classes sociais, a doutrinação que êles portam deixa de ser publicidade; torna-se um estilo de vida. É um bom estilo de vida - muito melhor do que antes - e, como um bom estilo de vida, milita contra a transformação qualitativa. Surge assim um padrão de pensamento e comportamento unidimensionais no qual as idéias, as aspirações e os objetivos que por seu conteúdo transcendem o universo estabelecido da palavra e da ação são repelidos pela racionalidade do sistema dado e de sua extensão quantitativa. (MARCUSE, 1973, p. 32, grifo do autor).

O teatro que, ideologicamente, luta contra isso, também cai nas malhas obscuras do pensamento unidimensional, à medida que não é produzido nem recebido de modo a refletir essas mudanças de paradigmas sociais. O que também faz jus ao que Marcuse (1973) explicita quando aborda questões sobre o pensamento unidimensional. Trata-se de "[...] uma sociedade na qual tanto os sujeitos como os objetos constituem instrumentos num todo que tem a sua razão de ser nas realizações de sua produtividade cada vez mais poderosa.” (MARCUSE, 1973, p. 42).

É justamente aí que se justifica a instrumentalização do Teatro. Ele é projetado e administrado para amenizar os efeitos secundários da industrialização social e, ao sê-lo, acaba por se tornar um meio, um instrumento, uma simples ferramenta. Como ferramenta, o Teatro não muda nada, apenas perpetua esse mal-estar. Vira escravo dos escravos da civilização industrial que, assim como eles, possui as mesmas características, pois o Teatro se transforma e modifica segundo o ser humano se transforma e se modifica. Do mesmo modo que o Teatro é reificado e, por isso, administrado com fins específicos na sociedade, quem o promove dessa maneira é também reificado, como uma engrenagem que gira a outra. "Esta é a forma pura de servidão: existir como um instrumento, como uma coisa." (MARCUSE, 1973, p. 49)

\begin{tabular}{|c|c|c|c|c|}
\cline { 2 - 5 } & Ano 8 & n. 14 & Janeiro-Julho 2019 & p. $183-199$ \\
\hline
\end{tabular}


No pensamento marcuseano, é inadmissível aceitar o Teatro como engrenagem de uma sociedade industrial porque Teatro é Arte. De acordo com Chaves e Ribeiro (2014):

Para Marcuse, a arte é política, apresenta universalidade, alteridade, transcendência, forma estética e negação e confirmação da realidade. A arte é objetivação e não trabalho alienado, ela realiza a sublimação e provoca sensibilidade, diferenciando-se da mercadoria que se apropria da cultura, fazendo-a esvaziar-se em seu sentido. (CHAVES et al., 2014, p. 12).

O Teatro é, talvez, a Arte mais humanizada e humanista, que melhor expressa os sentimentos do ser social e coloca todos os sistemas em xeque. Porém, o Teatro é feito por humanos, e por consequência, acaba se tornando voz da ideologia dos homens. Em uma sociedade industrializada, a produtividade, a mercadoria, o lucro é a ideologia.

Desde que correspondam à realidade em questão, o pensamento e o comportamento expressam uma falsa consciência, reagindo à preservação de uma falsa ordem dos fatos e contribuindo para ela. E essa falsa consciência se corporificou no aparato técnico prevalecente, o qual, por sua vez, a reproduz. [...] Contudo, o aparato derrota o seu próprio objetivo se êste é criar uma existência humana com base numa natureza humanizada. E se êsse não é o seu propósito, sua racionalidade se torna ainda mais suspeita. Mas ela é também mais lógica porque, de início, o negativo está no positivo, o desumano está na humanização, a escravização na libertação. Essa dinâmica é a da realidade e não da mente, mas de uma realidade na qual a mente científica teve papel decisivo em unir a razão teórica e prática. (MARCUSE, 1973, p. 142-143).

Uma dinâmica dialética que acaba se perdendo com o pensamento unidimensionalizado, ou seja, que mantém uma única dimensão, na qual, não se distingue humano de coisa, Teatro de ferramenta.

Nesse universo, a tecnologia também garante a grande racionalização da não-liberdade do homem e
demonstra a impossibilidade "téenica" de a criatura ser autônoma, de determinar a sua própria vida. Isso
porque essa não-liberdade não parece irracional nem política, mas antes uma submissão ao aparato técnico
que amplia as comodidades da vida e aumenta a produtividade do trabalho. [...] A dinâmica incessante do
progresso técnico se tornou permeada de conteúdo político e o Logos da técnica foi transformado em
Logos da servidão contínua. A fôrça libertadora da tecnologia - a instrumentalização das coisas - se torna
o grilhão da libertação; a instrumentalização do homem. (MARCUSE, 1973, p. 154-155, grifo do autor).

O progresso técnico da sociedade invade e subjuga até o momento mais pessoal e humano de alguém, reifica seu pensamento, condiciona seus desejos e suas ideias de necessidade para algo que não lhes é intrinsicamente necessário. Surge nesse contexto, a arte unidimensionalizada, pensada e produzida sem distinguir meios de fins, sem criar novas possibilidades de pensamento e de crítica. Nos questionamos em como é possível que a Arte

\begin{tabular}{|l|l|l|l|l|}
\cline { 2 - 5 } & Ano 8 & n. 14 & Janeiro-Julho 2019 & p. $183-199$ \\
\hline
\end{tabular}


seja administrada desta maneira, ou seja, como ela foi subjugada por um pensamento reificador e por quem foi subjugada. Marcuse (1973) busca a resposta apontando a disseminação deste controle aos mais poderosos que esta sociedade pode criar.

O pensamento unidimensional é sistemàticamente promovido pelos elaboradores da política $\mathrm{e}$ seus provisionadores de informação em massa. O universo da palavra, dêstes e daqueles, é povoado de hipóteses autoavaliadoras que, incessante e monopolìsticamente repetidas, se tornam definições ou prescrições hipnóticas. (MARCUSE, 1973, p. 34).

Estes manipuladores da política e das informações de massa agravam a disseminação do pensamento unidimensionalizado ao repetirem diariamente as ideologias, reforçando-as com os produtos que ela mesma produz. Esta sociedade produz produtos alienantes e ao distribuílos contribuem para sua reprodução.

Esteves (2010), em sua dissertação de mestrado, sobre a obra de Marcuse, vê-se uma preocupação com o conceito de mimese, comum aos estudos teatrais, no qual, o ser humano, por imitação compreende e se adapta ao mundo.

É este sentido de mimese mais próximo à ideia de adaptação ao mundo para conquista da autopreservação, de ser dominado pelo mundo a partir da adaptação a ele, que Marcuse lança mão em One-dimensional man.

No primeiro capítulo de seu livro, Marcuse articula a produção e a distribuição de mercadorias em massa mediante a eficácia tecnológica com a produção de falsas necessidades superimpostas a átomos sociais manipulados sob a sociedade totalitária não-terrorista e argumenta que o resultado foi a absorção dos indivíduos pela realidade. Mais que "introjetar" da sociedade industrial avançada para si, os indivíduos se identificam com ela: há uma "mimese: uma identificação imediata do indivíduo com a sua sociedade e, através dela, com a sociedade em seu todo"12. (ESTEVES, 2010, p. 106, grifo do autor).

Por outro lado, conforme Ferreira (2015), a mimese faz parte da constituição da arte:

Toda expressão artística, independente da sua natureza e do tempo histórico na qual está inserida a sua produção, necessita de dois elementos que são imanentes à sua constituição: a mimese e a racionalidade. A mimese se refere diretamente à manifestação da subjetividade do artista e à racionalidade ao modo como ele organiza tecnicamente toda a sua irracionalidade. Nessa relação,

11 (Nota original) 0 termo introjeção supõe a existência de uma dimensão psíquica separada e mesmo antagônica à dimensão exterior e subentende a existência de uma liberdade interior. Porém, Marcuse argumenta que a realidade tecnologia invadiu e desbastou a dimensão interior, anulando o "Eu" e retirando dele o poder crítico da razão. MARCUSE, H. One-dimensional man: studies in: The ideology of advanced industrial Society. 2o printing. London/New York: Routledge, 2002, p. 12.

12 (Nota original) MARCUSE, H. Mimesis: na immediate identification of the individual with his Society and, through it, with the Society as a whole. Ibidem, p. 12.

\begin{tabular}{|c|c|c|c|c|}
\hline Revista Q Didectus & Ano 8 & n. 14 & Janeiro - Julho 2019 & p. $183-199$ \\
\hline
\end{tabular}


a técnica se constitui o elemento de mediação entre a mimese e a racionalidade dos artistas no momento da produção de suas obras.

Conforme Adorno $(1988)^{13}$, esses dois elementos constitutivos na produção de uma obra artística devem se manifestar em uma relação dialética de permanente tensão, ou seja, não deve imperar nenhum elemento de maneira absoluta sobre o outro para que a obra produzida consiga ser verdadeiramente expressiva.

A garantia da permanência da tensão dialética entre os elementos miméticos e racionais na produção de uma obra de arte se apresenta cada vez mais obstaculizada pela problemática social a que Adorno e Horkheimer (1985) denominaram de indústria cultural. (FERREIRA, 2015, p. 335-336).

Esta problemática enfatiza processos de depreciação da memória artística da obra de arte em si. Já não se conhece mais as origens das obras e sim sua constituição atual dentro de uma sociedade industrializada. E isso, por si só, já desvincula a arte de seu propósito, incluindo o da mimese, ou seja, a de também ser recordação. Chaves e Ribeiro (2014) explicam: A arte preserva a recordação, que é o solo no qual ela tem a sua origem. Decorre, então, a
necessidade de a imaginação deixar aparecer o outro (possível). A decepção e a aparência são
qualidades da realidade, antes de o serem da arte. A arte, no entanto, não encobre essas
dimensões, mas as revela. A verdade da obra consiste na ilusão evocada, na insistência em criar
um mundo no qual o terror da vida é recordado e interrompido. (CHAVES et al., 2014, p. 17).

É intrínseco à Arte o olhar para os fatos (bons e ruins) que acontecem em nossa sociedade. Parece-nos, que até esta característica, a da mimese, ajuda o ser social a apreender melhor sua realidade. O que a torna muito mais difícil de combater, principalmente por ser mais uma engrenagem do pensamento unidimensional, que propõe o Teatro, a mimese, para conversar com os problemas sociais em comum e, ao fazê-lo, reinventar o que já está inventado. Este reinvento do que não é necessário são as falsas necessidades acusadas por Marcuse (1973).

Para Marcuse, a produção e a distribuição, tecnológicas e eficazes, de falsas necessidades, mimetizam os átomos sociais com a sociedade industrial avançada e ensejaram uma realidade unidimensional prescrevendo os hábitos que eles devem ter, oferecendo-lhes um estilo de vida que veicula a realidade unidimensional. Assim, esta não é somente reflexo da etapa monopolista do capitalismo, a realidade unidimensional é, ela mesma, o modo pelo qual a ordem se mantém [...]. (ESTEVES, 2010, p. 107-108).

Em seu livro "Eros e Civilização", Marcuse (1975) traz um panorama filosófico sobre a obra de Freud para demonstrar inclusive que a lógica da dominação está presente por ações

13 Adorno, T. W. (1988). Teoria estética. Lisboa: Edições 70.

\begin{tabular}{|c|c|c|c|c|}
\cline { 2 - 5 } & Ano 8 & n. 14 & Janeiro-Julho 2019 & p. $183-199$ \\
\hline
\end{tabular}


humanas de dominação de todo o conteúdo humano, incluindo a libido, o prazer tanto carnal quanto metafísico, as relações humanas, tudo, tudo faz parte da lógica da dominação, inclusive a própria razão, o próprio pensar racional. Marcuse explica:

A razão tem por finalidade garantir, através de uma transformação e exploração cada vez mais efetiva da natureza, a realização das potencialidades humanas. Mas, no processo, a finalidade parece recuar diante dos meios: o tempo dedicado ao trabalho alienado absorve o tempo para as necessidades individuais - e define as próprias necessidades. O Logos destaca-se como a lógica de dominação. Assim, quando a lógica reduz as unidades de pensamento a sinais e símbolos, as leis do pensamento convertem-se, finalmente, em técnicas de cálculo e manipulação. (MARCUSE, 1975, p. 108).

O tempo destinado à transformação do homem e à elevação das coisas do espírito mais uma vez é anulado pela lógica da dominação. O Teatro em si é por fim pensado com lógica, mas com a lógica da manipulação, tanto do tempo despendido, quanto da sua finalidade, tanto do modo como os profissionais da educação se dispõem a trabalhar o Teatro na escola quanto dos processos de criação propostos. Tudo está, segundo Marcuse (1975) dominado pela sociedade industrializada. Em "Eros e Civilização", Marcuse (1975) desenvolve uma ideia de que a Arte poderia ser a reconciliadora entre o Eros e o Logos, entre espírito e matéria.

Certo, há um modo de trabalho que oferece um elevado grau de satisfação libidinal, cuja execução é agradável. E o trabalho artístico sempre que genuíno parece brotar de uma constelação instintiva não-repressiva e visar finalidades não-repressivas tanto assim que o termo sublimação parece requerer considerável modificação se o aplicarmos a esse gênero de trabalho. (MARCUSE, 1975, p. 88).

Neste livro, Marcuse (1975) ainda buscava entender a Arte como potencializadora da denúncia contra a sociedade unidimensionalizada. Faz isso partindo do princípio que o prazer que a Arte proporciona ao ser humano contém em seu princípio formas transformadoras da razão, contra a reificação do ser humano, à favor de sua humanização partindo de sua capacidade de sentir prazer, ao mesmo tempo que combatia o trabalho da indústria cultural.

\footnotetext{
Os grupos e os ideais grupais, as filosofias, as obras de arte e literatura que ainda expressam, sem transigências, os temores e esperanças da humanidade, situam-se contra o princípio de realidade predominante; constituem a sua absoluta denúncia. (MARCUSE, 1975, p. 102).
}

Por fim, entende inclusive a Arte, ao mesmo tempo, como ponto dinâmico de emancipação e da unidimensionalidade do pensamento.

\begin{tabular}{|c|c|c|c|c|}
\cline { 2 - 5 } Govista & Ano 8 & n. 14 & Janeiro-Julho 2019 & p. $183-199$ \\
\hline
\end{tabular}


A arte é, talvez, o mais visível retorno do reprimido, não só no indivíduo, mas também no nível histórico-genérico. A imaginação artística modela a memória inconsciente da libertação que fracassou, da promessa que foi traída. Sob o domínio do princípio de desempenho, a arte opõe à repressão institucionalizada a imagem do homem como um sujeito livre; mas num estado de nãoliberdade, a arte só pode sustentar a imagem da liberdade na negação da não-liberdade. Desde o despertar da consciência de liberdade, não existe uma só obra de arte autêntica que não revele o conteúdo arquetípico: a negação da não-liberdade. (MARCUSE, 1975, p. 135)

E o repete, buscando "saídas" também em seu ensaio "A arte na sociedade unidimensional" quando introduz seu texto com timidez, mas firmeza quando afirma que a Arte

[...] é na verdade a única linguagem revolucionária que hoje nos resta.

Isso pode soar romântico, e muitas vezes me censuro por ser talvez demasiado romântico em avaliar o poder radical, libertador da arte. [...] Entretanto, a sobrevivência da arte pode vir a ser o único elo frágil que hoje conecta o presente com a esperança do futuro. (MARCUSE, In: LIMA, 2000, p. 259-260).

Marcuse (2000) nos indica o potencial da arte como promotora da emancipação da sociedade mecanizada. Marcuse ainda explica:

\begin{abstract}
A fim de que se faça mais claro o que estou querendo dizer, discuto em primeiro lugar em que sentido a arte é uma faculdade cognitiva dotada de uma verdade intrínseca e em que sentido a linguagem da arte revela uma verdade oculta e reprimida. Sugerirei que a arte, em sentido extremo, fala a linguagem da descoberta. (MARCUSE, In: LIMA, 2000, p. 263).
\end{abstract}

Porém o próprio Marcuse (1975), em “A ideologia da sociedade industrial”, desenvolve a ideia de que até a Arte se subjuga e que a própria subjetividade alcançada por ela tenha sido unidimensionalizada. Em "Eros e Civilização", Marcuse (1975) em suas análises, demonstra que a Arte sempre se fazia forte e potente no campo das ideias e dos ideais das obras de arte, mas que dificilmente persuadiria o todo social (industrializado) para repensar sua ideologia.

A arte desafia o princípio de razão predominante; ao representar a ordem da sensualidade, invoca uma lógica tabu a lógica da gratificação, contra a da repressão. Subentendido na forma estética sublimada, o conteúdo não-sublimado transparece: a vinculação da arte ao princípio de prazer. A investigação das raízes eróticas da arte desempenha um importante papel na Psicanálise; contudo, essas raízes estão mais na obra e função da arte do que no artista. (MARCUSE, 1975, p. 165).

Marcuse (1975) já apresentava essa dificuldade da Arte em extrair da obra esse princípio do prazer que por ventura seria de grande relevância nas possibilidades de "saídas" da sociedade

\begin{tabular}{|c|c|c|c|c|}
\hline Gevista Dialectus & Ano 8 & n. 14 & Janeiro - Julho 2019 & p. $183-199$ \\
\hline
\end{tabular}


unidimensional, e passa a olhar a Arte com outra posição, como nos aponta Teodoro (2012), em "O papel da arte apresentado por Herbert Marcuse em A ideologia da sociedade industrial."

\begin{abstract}
A capacidade da arte de manter viva a perspectiva de realização do princípio de prazer através da dimensão estética e da reconciliação entre espírito e matéria, apresentada anteriormente por Marcuse em Eros e Civilização, é refutada em A ideologia da sociedade industrial por uma primazia total do princípio de realidade que transforma a arte em um mecanismo subjugado às regras da sociedade dominante. Dessa forma, a arte perde sua capacidade de oposição à realidade estabelecida e passa a ser instrumento mantenedor da dominação social. A dimensão estética, antes considerada utópica e subversiva, se vê subjugada à unidimensionalização aparentemente hegemônica, que afeta a sociedade. (TEODORO, 2012, p. 121, grifo do autor).
\end{abstract}

Parece que é preciso ter uma função, é necessário um fim específico para se "utilizar" o Teatro. Pensa-se como administrar a Arte para que esta "sirva a".

\begin{abstract}
Na perspectiva do campo artístico, a premissa anterior da arte como a capacidade de suscitar outra dimensão, mais prazerosa, diferente da realidade, é deixada de lado, pois, na sociedade industrial, até mesmo a imaginação torna-se coisificada. A arte torna-se uso do aparato técnico de dominação, a tecnologia põe a coloca a serviço da ideologia dominante. Dessa forma, o caráter negativo da obra de arte perde-se em meio à positividade da crescente indústria que a transforma em puro entretenimento. (TEODORO, 2012, p. 138).
\end{abstract}

Pensemos adiante para entender esse lugar do Teatro para talvez vislumbrar futuramente outro lugar. Horkheimer (2002) afirma, na conclusão de "Meios e Fins" que:

\begin{abstract}
A filosofia hoje deve enfrentar a questão de se o pensamento pode permanecer senhor de si mesmo nesse dilema e preparar assim a sua solução teórica ou se contentará em exercer o papel de metodologia vazia, apologética ilusória ou receita garantida [...]. (HORKHEIMER, 2002, p. $62)$.
\end{abstract}

Talvez a mesma provocação feita pelo frankfurtiano seja necessária à expressão da Arte que aqui coube análise, sendo possível trocar o termo "filosofia" por "Teatro" neste mesmo excerto. Talvez essa provocação seja necessária inclusive para definir-se de vez ou lançar ainda mais o olhar do Teatro para a obscuridade. Talvez o Teatro tenha voltado para a caverna platônica e está agora sob serviço das projeções que bailam nas paredes da consciência social a que estamos todos nós sujeitos, ou pelo menos na consciência daqueles que estão envolvidos com o ambiente escolar. Esta caverna platônica, por sua vez é todo o aparato industrial que se move, como que fechando cada vez mais a saída desta caverna. É preciso um "brilho" dentro dela para que a Arte, e em consequência o Teatro, produzidos nas salas de aula possam encontrar

\begin{tabular}{|l|l|l|l|l|}
\cline { 2 - 5 } & Ano 8 & n. 14 & Janeiro-Julho 2019 & p. $183-199$ \\
\hline
\end{tabular}


seu caminho de afastamento da reificação. Afastamento que nos termos marcuseanos pode se estabelecer por uma educação que no seu "caminhar" não se preocupe somente com a educação intelectual, mas também, com a educação dos instintos relacionando razão e imaginação.

\section{Referências:}

CHAVES, J.; RIBEIRO, D. Arte em Herbert Marcuse: formação e resistência à sociedade unidimensional. In: Revista Psicologia \& Sociedade, 26(1), 2014, p. 12-21.

ESTEVES, Anderson Alves. Sociedade administrada em Herbert Marcuse. Dissertação de Mestrado em Filosofia. PUC-SP. São Paulo, 2010.

FERREIRA, Isabella Fernanda. A ciber (cultura) e o redimensionamento da experiência (semi)formativa na produção artística de hiper (textos). In: A Psicologia Social e os atuais desafios ético-políticos no Brasil. Porto Alegre: ABRAPSO, 2015, p. 326-345.

MARCUSE, H. A ideologia da sociedade industrial: o homem unidimensional. Rio de Janeiro: Zahar Editores. $4^{\mathrm{a}}$ Ed. 1973.

Eros e civilização: uma interpretação filosófica do pensamento de Freud. Rio de Janeiro. 6 ${ }^{\text {a }}$ Ed. Zahar Editores. 1975.

A arte na sociedade unidimensional. In: LIMA, Luis Costa (Org.). Teoria da Cultura de Massa. $6^{\text {a }}$ edição revista. São Paulo: Editora Paz e Terra, 2000.

A dimensão estética. 1977. Lisboa: Editora 70, 2007.

TEODORO, J. B. F. O papel da arte apresentado por Herbert Marcuse em A ideologia da sociedade industrial. IN: Griot - Revista de Filosofia, Bahia - Brasil, v.5, n.1, 2012.

\begin{tabular}{|l|l|l|l|l|}
\cline { 2 - 4 } & Ano 8 & n. 14 & Janeiro-Julho 2019 & p. $183-199$ \\
\hline
\end{tabular}




\title{
EROS ÀS AVESSAS: PANSEXUALISMO E DESSUBLIMAÇÃO REPRESSIVA $^{1}$
}

\author{
Rafael Cordeiro Silva ${ }^{2}$
}

\begin{abstract}
Resumo:
O artigo pretende explanar o conceito de Eros como uma categoria social no pensamento de Herbert Marcuse. Nesse sentido, o erotismo tem um significado político para o autor, pois indica a possibilidade de libertação das formas sociais repressivas. Na primeira seção, faço um breve relato da relação de Marcuse com a psicanálise, anterior a seu contato mais intenso com Freud. Na segunda seção, mostro o caráter essencialmente político e social de Eros, através da reconstrução da teoria marcusiana da mudança social. Em seus escritos, Marcuse também menciona as formas pervertidas de manifestação de Eros, representadas pelo pansexualismo e pelo que ele denomina dessublimação repressiva. Nesse contexto, pretendo discutir o que essas 'perversões' significam. $\mathrm{O}$ pansexualismo é analisado em Eros e civilização e em outros escritos da década de 1950 e 1960. Pretendo discutir também se o conceito de pansexualismo se encaixaria ou não na perspectiva libertária que o filósofo quis significar com a politização de Eros. À dessublimação repressiva o filósofo dedica o terceiro capítulo de $O$ homem unidimensional. Da mesma forma, o significado da dessublimação repressiva também será discutido na terceira seção do artigo. Na conclusão, mostro que Marcuse entende que o pansexualismo e a liberação sexual sem tabus não podem ser vistos como libertação política, são apenas formas pernósticas de manifestação de Eros.
\end{abstract}

Palavras-chave: Marcuse. Eros. Dessublimação repressiva. Perversões. Pansexualismo.

\section{INVERTED EROS: PANSEXUALISM AND REPRESSIVE DESUBLIMATION}

\begin{abstract}
:
The article explains the concept of Eros as a social category in Herbert Marcuse's thought. Eroticism has political meaning for the author. It indicates the possibility of liberation from forms of social repression. In the first section I provide a brief account of Marcuse's association with psychoanalysis, before his more intensive contact with Freud. In the second section I show the essentially political and social character of Eros with a reconstruction of Marcusian theory of social change. In his writings, Marcuse refers to the perverted forms of Eros represented by pansexualism and by what he calls repressive desublimation. In this context, I discuss the meanings of these perversions. The significance of repressive sublimation is more fully discussed in the third part of the article. Marcuse also dedicates his third chapter of One-dimensional Man to repressive desublimation. Pansexualism is analyzed from Eros and Civilization and other writings of the 1950s and 60s. Additionally discussed is the concept of whether pansexualism refers to the libertarian perspective that the philosopher intended by the politicization of Eros. In conclusion, I demonstrate that Marcuse understands that pansexualism and liberation without taboos cannot be seen as political liberation. They are only pernostic forms of the manifestation of Eros.
\end{abstract}

Keywords: Marcuse. Eros. Repressive desublimation. Perversions. Pansexualism.

1 Este artigo é o desenvolvimento de palestra apresentada no "Colóquio Filosofia e erotismo", ocorrido em dezembro de 2016, na cidade de Goiás e promovido conjuntamente pela UFU e UFG-Campus Goiás Velho.

2 Graduado, mestre e doutor em Filosofia pela UFMG, é Professor Titular do Instituto de Filosofia da UFU, onde leciona, desde 1993, na Graduação em Filosofia e no Programa de Pós-graduação em Filosofia (Mestrado). Coordenador do grupo de pesquisa "Teoria Crítica e Filosofia social", registrado no CNPq. E-mail: rcsilva@ufu.br. 
Em 1955, Marcuse publica Eros e civilização. A obra utilizou a psicanálise freudiana para fundamentar uma teoria social orientada para a abolição de estruturas repressivas, que impediriam o livre desenvolvimento das potencialidades humanas. Tal desenvolvimento só seria possível em um ambiente ao mesmo tempo erótico e libertador. Gostaria, dessa forma, de explorar a apropriação que Marcuse faz de Freud, de modo específico seu conceito de Eros, para mostrar que o significado do erotismo para o filósofo não pode, de modo algum, ser identificado com o sentido corrente do termo, nem tampouco ser confundido com as diversas formas de liberação sexual hoje permitidas. Estas seriam formas pernósticas à manifestação de Eros e serviriam justamente ao que proclamam se opor, a saber, à repressão social. Elas constituem o que denomino Eros às avessas. A argumentação seguirá a seguinte estratégia:

1 - Começarei apontando referências à sexualidade e a Eros nos escritos do autor anteriores a Eros e civilização, obra que consagrou o uso do termo no jargão do filósofo. 2 - Na segunda seção, pretendo discorrer sobre a teoria marcuseana da mudança social a partir de sua recepção de Freud. Aqui mostrarei o quanto Eros tem um caráter social e político para Marcuse.

3 - Na terceira seção, vou explorar os conceitos de dessublimação repressiva e pansexualismo. Ambos seriam para Marcuse formas pernósticas de Eros, pois se restringiriam ao círculo da genitalidade, do qual ele pretendeu escapar. Também farei uma pequena digressão sobre as perversões, para mostrar que elas não se adequam ao denominei formas pernósticas.

1 - Primeiras incursões na psicanálise anteriores a Eros e civilização

Marcuse é um filósofo social e político e não um psicanalista. Mas, desde a década de 1930, por conta de sua participação no Instituto de Pesquisa Social, ele manteve relações com a psicologia e a psicanálise. Nessa década, o Instituto desenvolveu uma pesquisa que gerou os Estudos sobre autoridade e família, publicados em 1936, em que a interpretação de Freud feita por Erich Fromm constituiu a referência teórica principal. ${ }^{3}$ Fromm guiou estes estudos. Ele considerou a psicanálise freudiana como uma psicologia materialista, "que facilitou o

3 Essa pesquisa fora proposta por Horkheimer, quando ele assumiu a direção do Instituto. No seu discurso de posse, intitulado "A situação atual da filosofia social e as tarefas de um Instituto de Pesquisa Social", ele afirmou a intenção de tomar como grupo de análise os operários qualificados e os empregados na Alemanha. Ele entendeu ser esse grupo uma "totalidade menor no todo da sociedade". Um dos objetivos da pesquisa interdisciplinar era verificar "a transformação ocorrida na estrutura psíquica de seus membros singulares" (HORKHEIMER, 1999, p.131). Um dos resultados da pesquisa foi a constatação da baixa consciência revolucionária dos trabalhadores alemães.

\begin{tabular}{|l|l|l|l|l|}
\hline Q evista Dialectus & Ano 8 & n. 14 & Janeiro - Julho 2019 & p. $200-212$ \\
\hline
\end{tabular}


desvelamento daquelas tendências pulsionais ocultas, que motivaram o comportamento humano e que se tornaram expressas na forma de ideologias" (GEOGHEGAN, 1981, p.41). Marcuse participou de forma indireta da pesquisa, chegando a escrever um capítulo para o livro que dela resultou. Sua contribuição versou sobre como o conceito de autoridade encontrou expressão filosófica. ${ }^{4} \mathrm{Um}$ dos resultados da pesquisa foi aferir a baixa consciência revolucionária dos trabalhadores alemães.

Embora conhecesse as linhas mestras da psicanálise freudiana desde a década de 1920 e sua interpretação à luz de Fromm, Marcuse sentia-se mais atraído por Reich cujas ideias pareciam estar mais próximas de suas preocupações. Assim, ele "viu na sexualidade uma força tão poderosa que tinha o potencial em última instância de destruir a ética do trabalho repressivo que sustentou o capitalismo" (GEOGHEGAN, 1981, p.42). ${ }^{5}$ A dimensão explosiva da sexualidade não foi uma preocupação dos Estudos. E interessava mais a Marcuse a "natureza revolucionária da sexualidade" (GEOGHEGAN, 1981, p41). ${ }^{6}$

Em 1938, Marcuse publica na revista do Instituto - a Zeitschrift für Sozialforschung o artigo "Para a crítica do hedonismo". Como observa Kellner (1984, p.155), temas freudianos emergem nesse escrito. A seguinte passagem evidencia a presença de Freud: "A entrega não racionalizada, não sublimada às relações sexuais constituiria a mais poderosa entrega à fruição enquanto tal e a total desvalorização do trabalho pelo trabalho" (MARCUSE, 1997, p.186).

Outra referência encontra-se em "Algumas implicações sociais da tecnologia moderna", publicado em 1941. Como no "Para a crítica do hedonismo", Freud não é mencionado. Marcuse afirma:

As relações entre os homens são cada vez mais mediadas pelo processo da máquina. Mas os equipamentos mecânicos que facilitam o contato entre os indivíduos interceptam e absorvem sua

4 Trata-se do texto "Estudo sobre autoridade e família", originalmente publicado em 1936. Republicado em Ideen zu einer kritischen Theorie der Geselschaft, em 1969, pela editora Suhrkamp de Frankfurt. No Brasil, o livro foi publicado em 1972, com o título Ideias para uma teoria crítica da sociedade, pela Zahar Editores.

${ }^{5}$ Um ponto de vista diferente é apresentado por Kellner (1984, p.154-155). Ele relata uma conversa com Marcuse, datada de marco de 1978, em que o filósofo afirma que a primeira obra de Reich que ele leu foi Psicologia de massas do fascismo e não se lembrava de ter lido qualquer trabalho anterior do psicanalista. Marcuse acrescentou que ele e outros membros do Instituto de Pesquisa Social acreditaram que Reich se moveu muito rapidamente das condições subjetivas para as condições objetivas e 'simplificou enormemente' o fascismo ao afirmar que a repressão sexual criou personalidades que eram suscetíveis ao fascismo. Fazia também parte dessa simplificação o entendimento de que o sucesso do fascismo fosse atribuído a sua capacidade de manipular personalidades reprimidas. Marcuse afirmou que faltava uma análise socioeconômica mais adequada para explicar o fascismo. Não obstante essas afirmações, também é notório a falta de referência econômica mais aprofundada nos escritos de Freud.

6 Um aspecto interessante da apreciação de Reich encontra-se no "Epílogo" a Eros e civilização, chamado "Crítica do revisionismo neofreudiano". Reich é considerado um representante da ala esquerda dos movimentos de cisão com Freud. É o único teórico que escapa das críticas de Marcuse. Ele afirma (1981, p.205): “A mais séria tentativa realizada para desenvolver a teoria crítica social implícita em Freud foi a de Wilhelm Reich, em seus primeiros escritos". A mesma consideração não recebe Fromm, que é duramente criticado. 
libido, desta forma distanciando-a do reino por demais perigoso no qual o indivíduo se encontra livre na sociedade (1999, p.81).

As duas passagens citadas mencionam elementos da psicanálise. Entretanto, ela não aparece como um fundamento teórico do pensamento de Marcuse. O primeiro texto discute o hedonismo a partir da perspectiva materialista; o segundo discute as consequências da racionalidade tecnológica a partir de múltiplas referências autorais, sendo Max Weber a fonte mais conhecida.

2 - A incursão na psicanálise freudiana e sua utilização para a teoria da mudança social

Depois da saída de Marcuse do Instituto de Pesquisa Social, na década de 1940, ele se lançou ao estudo independente e aprofundado de Freud. A partir de então, ele começou a direcionar a psicanálise para seus interesses e a ver nela implicações sociológicas e filosóficas. O estudo de Freud foi orientado para aquela perspectiva explosiva e política da sexualidade que o levara anteriormente a Reich. Freud se mostrou mais sólido ${ }^{7}$. Por isso, Marcuse se apropriou de alguns conceitos da psicanálise freudiana para dar suporte à sua teoria emancipatória da sociedade que ele começara a gestar nessa época e que veio a lume com a publicação de Eros e civilização, em 1955. Um deles foi a teoria das pulsões. Ela afirma a existência de dois arquétipos - Eros e Tânatos - que são forças, princípios metafísicos a reger a vida humana. A intenção de Marcuse era pensar a possibilidade de uma formulação sócio teórica em que a sociabilidade estivesse alicerçada em Eros.

Em primeiro lugar, é necessário assinalar que Freud usou o termo Eros em dois sentidos: o primeiro deles era mais restrito e coincidia com sexualidade; o outro era mais amplo e significava força. Marcuse percebe essa distinção e vai usá-la em sua teoria. É a ideia de Eros como movimento, como força que atrai a atenção do filósofo e que ao mesmo tempo o distancia de Reich. Eros, portanto, não é só sexualidade. É mais do que isso, é movimento.

Enquanto forças, Eros e Tânatos buscam a continuação do movimento: Eros é movimento para a vida, Tânatos é movimento para a morte. São potências atuantes no princípio de prazer, cada qual com sua forma específica de satisfação.

7 Paul A. Robinson enfatiza a grandeza de Marcuse quando se o compara com Reich, ao afirmar que "[Norman O.] Brown e Marcuse levaram a cabo uma análise sistemática da teoria psicanalítica, a fim de revelarem as suas implicações críticas, mesmo revolucionárias. Ambos foram muito além de Reich ou Roheim na sondagem das sutilezas dialéticas do pensamento de Freud e ambos chegaram a conclusões mais extremas e 'utópicas' do que as que podemos encontrar em um ou outro dos primeiros exegetas freudianos da esquerda". (ROBINSON, 1971, p.116-117)

\begin{tabular}{|l|l|l|l|l|}
\hline Qevista Dialectus & Ano 8 & n. 14 & Janeiro - Julho 2019 & p. $200-212$ \\
\hline
\end{tabular}


Marcuse também aceita a divisão, proposta por Freud, entre princípio de prazer e princípio de realidade. No princípio de prazer, Eros busca a plena satisfação pela obtenção incessante do prazer e sob esse aspecto essa força não conhece limitações morais, sociais e de forma. Portanto, Eros é amoral, associal e polimorfo. Daí seu caráter polimorfo perverso. Por seu turno, Tânatos busca o fim da vida, se essa significa dor e desprazer. A pulsão de morte é assim energia destrutiva. É importante notar que no princípio de prazer não se pode falar de vida biológica tal como a conhecemos, pois Eros e Tânatos são, enquanto tais, contrários ao processo civilizatório. "Eros incontrolado é tão funesto quanto a sua réplica fatal, a pulsão de morte... A civilização começa quando o objetivo primário - isto é, a satisfação integral das necessidades - é efetivamente abandonado" (MARCUSE, 1981, p.33).

No princípio de realidade, Eros e Tânatos estão presentes, mas de maneira modificada. Tornam-se forças dominadas e dirigidas para a conservação da vida. Eros é transformado em genitalidade e posto a serviço da reprodução no casamento monogâmico. A monogamia é vista como um produto da cultura, não é obra de Eros enquanto força. A dinâmica pulsional está presente tanto na constituição do indivíduo como da sociedade. No plano individual ou ontogenético, a prevalência do princípio de realidade sobre o princípio de prazer implica a renúncia à satisfação imediata e sua substituição pela satisfação relativamente garantida. Desde cedo, a criança aprende a refrear seus impulsos, a respeitar aqueles que ela estima, em especial o pai, que é o representante da autoridade, do princípio de realidade dentro de casa. Ela resolve o complexo de Édipo e sua relação conflituosa de amor e ódio com o pai. A proibição do desejo incestuoso pela mãe representa a derrota da pulsão morte, pois nesse desejo está implícito o querer retornar ao útero materno, que é um estádio de ausência de desprazer e de dor.

No plano civilizatório ou filogenético, Freud recorre à tese antropológica da horda primitiva. Segundo essa tese, os filhos nutrem relações de amor e ódio pelo pai primordial: amor, traduzido pela relação de filia, daí o termo filiação; ódio, pois o pai toma o prazer para si pelo deleite com as mulheres e impõe a labuta para os filhos. Agindo dessa forma, o pai déspota introduz uma ordem no bando original, fundada na injusta divisão entre prazer e labuta. Por isso os filhos se rebelam contra a autoridade paterna, matam o pai e o devoram em um banquete simbólico, estabelecendo assim o clã dos irmãos. Agora, eles se tornam senhores de seu prazer e vivem sem regras. Essa fase dura pouco, pois logo os irmãos percebem que é impossível viver sem qualquer princípio de autoridade. Daí surge o sentimento de culpa pela morte do pai e a proibição do incesto como tabu sobre as mulheres. Ambos resultam da transformação repressiva da pulsão de morte. A ordem é então restituída com a entronização simbólica do pai.

\begin{tabular}{|l|l|l|l|l|}
\hline Q Rovista Dialectus & Ano 8 & n. 14 & Janeiro - Julho 2019 & p. $200-212$ \\
\hline
\end{tabular}


No princípio de realidade, Eros passa a significar a tendência para a constituição de grupos cada vez mais amplos, sendo, portanto, força de geração de sociabilidade. A pulsão de morte deixa de ser energia destrutiva e torna-se socialmente útil no indivíduo como consciência moral. Na sociedade ela aparece camuflada como dominação da natureza em que a espécie humana se vale dos recursos naturais para criar as condições de sua existência. Em um grau elevado, essa pulsão se transforma em destruição da natureza ou também em ódio destrutivo a algum grupo socialmente reconhecido ou declarado. Isso explica, em grande medida, o ódio racial, religioso ou sexual, ódio ao diferente, que não raro explode sob formas violentas.

A descrição dos processos individual e social da origem da repressão pretende acentuar a posição universalista da tese freudiana: a frustração e a renúncia são características da vida em sociedade que impede a liberdade e felicidade plena dos indivíduos. A infelicidade e ausência de liberdade seriam, segundo Freud, condições perenes de todos os indivíduos. Esta é uma tese pessimista.

Marcuse pretende fundamentar a tese contrária. Se o seu intuito é mostrar a possibilidade de abolir as estruturas repressivas, ele precisa "flexibilizar" o pessimismo de Freud em relação às tendências civilizatórias repressivas. Assim, ele limita o caráter universalista da proposição freudiana e o torna histórico, para evidenciar a transitoriedade da organização civilizacional vigente. Se o princípio de realidade se tornar uma categoria histórica e, portanto, mutável, pode-se supor a possibilidade de sua transcendência. Assim, esse princípio é subdividido em dois conceitos: o primeiro ele designa "princípio de rendimento ou desempenho", ou seja, a forma histórica do princípio de realidade; o segundo é o que ele denomina "mais-repressão", a saber, toda cota adicional para além daquela repressão básica necessária ao processo civilizatório. Essa repressão básica diz respeito à internalização consciente nos indivíduos das restrições ao prazer imediato, que se dá sobretudo na infância.

Dessa forma, a liberdade passa a ser definida em termos históricos. Não mais a satisfação pulsional imediata, mas aquela em que as necessidades são satisfeitas com o mínimo de frustração. Marcuse interpreta a necessidade (Ananké) como algo estritamente material, distante da noção que evoca perda, dor física, finitude e morte - aspectos metafísicos presentes nas considerações metapsicológicas de Freud. Sob esse prisma materialista, ele reitera que a forma histórica pela qual se permite a satisfação da necessidade é o trabalho.

Porém, o trabalho é alienado. Esse ponto de vista está assentado na herança marxista de Marcuse, cuja definição acentua o alheamento do trabalhador em relação ao que ele produz. $\mathrm{Na}$ lógica capitalista, quem produz não detém o produto; este pertence a quem tem os meios de produção, ou seja, ao capitalista. Por outro lado, a alienação tem também um sentido

\begin{tabular}{|l|l|l|l|l|}
\hline Qovista Dialectus & Ano 8 & n. 14 & Janeiro - Julho 2019 & p. $200-212$ \\
\hline
\end{tabular}


psicanalítico, pois sob essas mesmas formas, o trabalho não é fonte e prazer, mas de frustração. Nos dias atuais, trabalhar significa realizar inúmeras tarefas, muitas delas percebidas como sem sentido, ou atuar nas frentes de produção tendo em vista o cumprimento de metas preestabelecidas. Ainda que Freud tenha assinalado o prazer que originalmente esteve associado ao trabalho ${ }^{8}$, fato decisivo é que esta dimensão de prazer se perdeu no processo civilizatório. A situação a ser atacada é, portanto, a do trabalho alienado. De um ponto de vista teórico, Marcuse vai buscar no Marx dos Grundrisse e nos escritos metapsicológicos de Freud os fundamentos que apontam para a superação do trabalho alienado.

Nos Grundrisse, Marx supôs que o desenvolvimento científico e o progresso técnico fariam com que a produção de riqueza dependesse cada vez menos do trabalhador e do tempo de trabalho. Marcuse vê aí a libertação do trabalho alienado e a possibilidade de o tempo livre vir a ser a condição do indivíduo e não o tempo de trabalho.

O trabalho alienado, no sentido freudiano, requer o desvio de energia pulsional, para que se torne menos frustrante. Assim, Eros é desviado de sua meta como forma de compensação pelo desprazer. Esse desvio é o que se denomina sublimação. Marcuse cita uma passagem de $O$ Ego e o Id, em que Freud sugere que esse processo de sublimação afeta o equilíbrio entre Eros e Tânatos. Se por um lado a sublimação cria cultura, por outro, ela também pode ser causa de manifestações destrutivas nessa interpretação que Marcuse acentua.

Após a sublimação, o componente erótico deixa de ter o poder de subjugar a totalidade dos elementos destrutivos que estavam previamente combinados com ele, e [tais elementos] são libertados na forma de inclinações para a agressão e a destruição (MARCUSE, 1981, p.87 apud FREUD, 1950, p.80).

A superação do trabalho alienado pelo desenvolvimento tecnológico poderia levar à libertação de Eros. Essa dupla libertação faria o homem ser definido como o executor de um trabalho orientado segundo sua capacidade lúdica e criativa. Esse homem seria responsável pela construção de um ambiente erótico, suas ações se dariam segundo essa perspectiva. Por isso, a proposta de Marcuse consistiria na...

recuperação de grande parte da energia pulsional desviada para o trabalho alienado, e a sua libertação no sentido de satisfazer as necessidades dos indivíduos cujo desenvolvimento seria autônomo e não mais manipulado. Seria também uma dessublimação - mas uma dessublimação que, em vez de destruir as manifestações "mais espiritualizadas" da energia humana, antes as projetaria como possibilidades de satisfação feliz (MARCUSE, 1969, p.109-110. Itálico no original).

8 Com base em Freud, Marcuse (1969, p.136) afirma: “O homem começa a trabalhar porque obtém prazer no trabalho - e não apenas depois de realizado o trabalho". A mesma ideia aparece também quando Marcuse (1981, p.185) diz que "a ideia de uma tendência erótica para o trabalho não é estranha à psicanálise".

\begin{tabular}{|l|c|c|c|c|}
\hline Q & Anista & Janeiro - Julho 2019 & p. $200-212$ \\
\hline
\end{tabular}


Essa recuperação está assentada em bases materiais. A automação aumentaria substancialmente a quantidade e a qualidade do que é produzido. Essa é uma evidência suficiente para Marcuse afirmar que o desenvolvimento das forças produtivas permite o incremento da riqueza social "até ao ponto em que as frustrações e os encargos impostos aos indivíduos aparecem sempre, o mais possível, como inúteis e irracionais" (MARCUSE, 1969, p.107). Conforme Marx previra, nas sociedades industrialmente desenvolvidas, não é o trabalho humano o elemento definidor da riqueza.

Entretanto, Marcuse enfatiza que o princípio de desempenho vigente está ancorado em um ideal de produtividade que ultrapassa em muito a simples satisfação das necessidades. Produz-se de modo irracional; não apenas para satisfazer as necessidades básicas ou biológicas do ser humano - alimentos, vestimentas e moradia - mas se produzem também bombas atômicas, armas de destruição em massa, quinquilharias inúteis, lixo cultural etc. Tamanha diversidade evidencia que a produtividade não está orientada para a realização do ser humano, mas, sim, do capital.

Dessa forma, a dessublimação sugerida pelo filósofo está em oposição ao termo sublimação que é empregado por Freud. Por sublimação pode-se entender um processo pelo qual a libido se desvia do objeto sexual e é direcionada para outros tipos de satisfação. É uma inibição quanto à meta da pulsão, mas cuja satisfação é encontrada em realizações pessoais ou sociais. Por exemplo, a arte, o amor altruísta e celibatário, a religião e as realizações dos cientistas são formas de sublimação. Sob esse aspecto, a sublimação resulta útil para a vida em sociedade. Ela também responde pela formação da consciência e autonomia de cada um de nós. Renunciar ao amor pela mãe é também uma forma de sublimação. Portanto, segundo Freud, a sublimação faz parte da cultura humana, ela constrói as manifestações do espírito e o processo civilizatório.

Já a dessublimação seria, para Marcuse, o retorno da energia pulsional erótica para sua forma anterior em que ela estava em equilíbrio com a pulsão de morte. Essa dessublimação não anularia as chamadas manifestações espiritualizadas da humanidade - a arte e a ciência - mas seria a condição de possibilidade da existência pacificada entre o homem e a natureza, por exemplo.

Para que a dessublimação se torne possível, é necessário que o trabalho deixe de ser alienado. Aqui se sai do plano estritamente conceitual psicanalítico e se chega ao campo das possibilidades históricas, ainda que estas sejam também teóricas. É fato a automação é “o grande catalisador da sociedade industrial avançada" (MARCUSE, 2015, p.69). Ela permite a

\begin{tabular}{|l|l|l|l|l|}
\hline Q Rovista Dialectus & Ano 8 & n. 14 & Janeiro - Julho 2019 & p. $200-212$ \\
\hline
\end{tabular}


abundância quantitativa e essa aponta para a perspectiva da mudança qualitativa, que corresponde à superação do modo de produção capitalista.

O desenvolvimento das forças produtivas da técnica e da ciência levaria ao aumento da riqueza produzida. Isso significaria a possibilidade de satisfação das necessidades básicas humanas com o mínimo esforço e frustração. Essa riqueza produzida também poderia ser mais justamente distribuída entre os povos, de modo que cessaria a competição desnecessária entre as nações. Baseado no grande desenvolvimento tecnológico e na realidade cada vez mais abrangente dos processos de automação, Marcuse pontifica uma tendência possível à redução drástica da jornada de trabalho. Em outros momentos ele é mais radical ao sugerir a abolição do trabalho alienado. O filósofo parece supor um mundo em que as máquinas realizariam o trabalho, reduzindo o papel humano ao comando delas. Então, se a sublimação foi responsável tanto pela continuidade do trabalho alienado quanto pelo desenvolvimento técnico-científico, este progresso agora acena para a possibilidade de dessublimação. A consequência está em que Eros seria força criadora de sociabilidade, daí o surgimento de um novo princípio erótico de realidade. E nesse sentido não seria utópico pressupor o aspecto libidinal do trabalho nem tampouco a vida como concreção de uma obra de arte. Então, segundo Freud, a sublimação cria cultura; para Marcuse, a dessublimação amplia a cultura, fazendo dela uma cultura voltada para a pacificação da existência - termo muito caro ao autor.

Da mesma forma, o tempo não seria mais definido pelo trabalho, que é algo linear: nascemos, crescemos e temos de trabalhar para satisfazer nossas necessidades. Esse tempo é igualmente alienado como o trabalho que a ele se liga. O tempo passaria a ser pleno e coincidiria com "a duração da satisfação, a duração da felicidade individual, o tempo como tranquilidade" (MARCUSE, 2001, p.119). A duração da satisfação não é medida pelo relógio. A libertação do trabalho com o consequente fomento das potencialidades humanas, o exercício do lado lúdico de todos nós corresponderia ao que o autor entende ser um novo princípio de realidade. A fruição como experiência fundamental do tempo livre seria a realização daquela liberdade que Freud imaginara impossível no processo civilizatório.

Aí está a realização do erotismo. É a construção de um ambiente em que Eros é uma força que rege as relações dos seres humanos entre si e destes com a natureza; em que a maisrepressão caducou, tornou-se desnecessária, porque a repressão pulsional e o progresso cumpriram sua função histórica. Esse é o sentido de Eros. Há um foco político, pois a teoria marcuseana da mudança social - cuja centralidade está na realização de um meio erótico indica ser possível seu cumprimento histórico. Apesar de se tratar de uma teoria, Marcuse acreditou em sua efetivação, daí seu componente político. Ainda que esboços dessa efetivação

\begin{tabular}{|l|l|l|l|l|}
\hline Q Rovista Dialectus & Ano 8 & n. 14 & Janeiro - Julho 2019 & p. $200-212$ \\
\hline
\end{tabular}


só aparecessem uma década depois, sob a forma da discussão dos agentes políticos da mudança social, o que vale registrar é o momento histórico de construção dessa teoria. Conforme assinala Kellner (1984, p.156), o mérito de Marcuse consistiu em apresentar uma proposta no cenário norte americano desfavorável a concepções teóricas de esquerda e em que...

\begin{abstract}
as teorias sociais dominantes eram 'positivistas', limitando-se em sua maior parte a descrever os 'fatos', e 'afirmativas', celebrando e legitimando a ordem social existente ... Eros e Civilização foi uma tentativa resoluta de manter aberto o espaço de emancipação em um período que não prometeu nenhuma forma de mudança radical prevista anteriormente por Marcuse e a maioria dos marxistas clássicos.
\end{abstract}

3 - Pansexualismo e dessublimação repressiva ou Eros a favor do princípio de desempenho

Poder-se-ia pensar que a proposta de Marcuse de construção de um ambiente erótico defende o pansexualismo, ou que sua teoria da mudança social preconizaria uma sociedade de maníacos sexuais, já que "todas as forças e todos os comportamentos eróticos que haviam sido restringidos e dessexualizados pelo princípio de realidade repressivo poderiam ser reativados" (MARCUSE, 2001, p.132). $\square$ ão se trata disso, pois, na verdade o pansexualismo corresponde a uma explosão de energia pulsional repressiva e não a uma força que rege as relações. A proposta do filósofo "envolve não uma simples descarga, mas uma transformação da libido... É uma propagação e não uma explosão de libido" (MARCUSE, 1981, p.177. Itálico no original).

Em poucas ocasiões Marcuse faz referência ao pansexualismo. Quando o faz, a ideia de fundo é mostrar que isso não é uma prática libertadora. O pansexualismo diz respeito a uma atração sexual entre pessoas que independe do sexo ou da identidade de gênero. Enquanto tal, o pansexualismo não consegue escapar do círculo da genitalidade, algo que Marcuse critica em sua teoria. "O pansexualismo (...) pertence essencialmente à imagem da sociedade repressiva" (MARCUSE, 2001, p.133). Da mesma forma, como assinala Ghiraldelli Jr (2011, p.11), é possível que a mesma crítica de pansexualismo tenha sido dirigida também a Freud, para quem a noção de Eros era muito mais ampla do que qualquer identificação com relações sexuais físicas. E essa noção freudiana é partilhada por Marcuse. O pansexualismo remete apenas à negação das relações sexuais tradicionais consagradas no casamento monogâmico e que ganharam sua marca definitiva com a instituição da família burguesa. Não é, portanto, a negação da repressão e do fardo a que todos os indivíduos parecem condenados na sociedade industrial avançada.

\begin{tabular}{|l|l|l|l|l|}
\hline Q ovista Dialectus & Ano 8 & n. 14 & Janeiro - Julho 2019 & p. 200-212 \\
\hline
\end{tabular}


A concepção de um princípio erótico de realidade também esbarra naquilo que o autor denomina dessublimação repressiva. A crescente dessublimação verificada em vários setores da vida social coloca a seguinte questão: isso significa a preponderância de Eros, o promotor da vida? Aqui se chega ao ponto central da argumentação. Marcuse o desenvolve em $O$ homem unidimensional, livro de 1964. Um dos conceitos relevantes dessa obra é o que o autor denominou "forças de contenção". Elas são entendidas como mecanismos políticos, sociais, econômicos e psicológicos que dificultam ou impedem o salto qualitativo e a libertação. Tais forças estão presentes sobretudo na sociedade industrial avançada, também chamada sociedade afluente, atuando como mecanismos, atuando como mecanismos ideológicos em favor do Establishment. As características dessa sociedade são o conforto e a grande capacidade de consumo por parte da população. Tal sociedade veicula para seus cidadãos a ideia de que ela realiza a liberdade de todos e em todos os aspectos: liberdade econômica, liberdade política, liberdade religiosa e assim por diante.

Todavia, o aspecto que mais importa é a consideração de que esta sociedade realiza inclusive a liberdade sexual das pessoas. A liberalização dos costumes sexuais parece indicar um avanço rumo à construção de uma sociedade emancipada. Libertar-se da rigidez imposta pela moralidade burguesa - rigidez que propaga a virgindade para a mulher e o casamento monogâmico - tem sido assinalado como um avanço. No entanto, Marcuse insiste tratar-se de uma "dessublimação comercial", uma "liberalização controlada", porque...

realça a satisfação obtida com aquilo que a sociedade oferece... Nessa forma de liberação a energia libidinal muda sua função social: (...) ela perde a qualidade que, segundo Freud, é sua qualidade erótica essencial, a saber, o elemento de emancipação no que se refere ao social (MARCUSE, 1998, p.106).

A dessublimação é repressiva porque favorece o sistema repressivo. É um artifício que “amplia a liberdade enquanto intensifica a dominação" (MARCUSE, 2015, p.98). Imaginar-se burlando a moralidade estabelecida só porque se sai com a secretária atraente ou com o colega de trabalho e, para viabilizar essa escapada extra ou pré-conjugal, existem lugares disponíveis e comercializados para esse fim e igualmente artefatos fetichistas, que hipoteticamente serviriam para "apimentar" a relação, não constitui um gesto libertário para Marcuse. Não traduz o que ele entende por erotismo. Ao contrário, é sexo administrado, correlato do mundo administrado e, portanto, pernóstico para a constituição de uma existência verdadeiramente erótica.

Se o pansexualismo e a dessublimação repressiva são pernósticos à concepção de um Eros fundante de um novo princípio, há um aspecto ambíguo ainda a ser considerado. Marcuse fala

\begin{tabular}{|l|l|l|l|l|}
\hline Q Povista Dialectus & Ano 8 & n. 14 & Janeiro - Julho 2019 & p. $200-212$ \\
\hline
\end{tabular}


das perversões. Ele assinala algumas delas: o narcisismo, a coprofilia, a homossexualidade e o sadismo. Com exceção deste último, cujas limitações devem ser consideradas - por exemplo, as manifestações de sadismo dos nazistas contra os judeus, ciganos e outras minorias - todos formam parte do comportamento polimorfo-perverso de Eros e são vistos como recusa ao princípio de desempenho, pois evocam aspectos da sexualidade que não estão relacionados com a reprodução monogâmica. Nessas formas, o caráter político-emancipatório não fica claro, não parece haver referência à noção mais ampla de Eros como agente de um novo princípio de realidade, desenvolvida ao longo de Eros e civilização e outros escritos da mesma época.

Ao falar das perversões como crítica ao princípio de desempenho - pois este necessita do sexo genital com fins de procriação da espécie - Marcuse ainda não tinha elaborado o conceito de dessublimação repressiva. Quando o conceito emergiu, em 1963, de modo implícito no escrito "A obsolescência da psicanálise" e explicitamente em O homem unidimensional, tal dessublimação foi tratada como comercialização do sexo, como transgressão permitida pela sociedade em que práticas genitais, embora não visem à reprodução, são propaladas e incentivadas pelo princípio de desempenho. O conceito de dessublimação repressiva excluiu as perversões.

Portanto, Marcuse enxerga em Eros uma dimensão político-emancipatória. Eros teria uma natureza revolucionária que ultrapassaria a manifestação de práticas libidinosas permitidas e não permitidas para os padrões morais estabelecidos. Do lado oposto, Eros invertido ou às avessas seria a prática sexual consentida pelo Establishment, como forma de provocar a sensação de liberdade, que, no entanto, é falsa.

\section{Referências:}

FREUD, Sigmund. The Ego and the Id. Londres: Hogarth Press, 1950.

GEOGHEGAN, Vicent. Reason and Eros: The Social Theory of Herbert Marcuse. Londres: Pluto Press, 1981.

\begin{tabular}{|l|l|l|l|l|}
\hline Q Rovista Dialectus & Ano 8 & n. 14 & Janeiro - Julho 2019 & p. $200-212$ \\
\hline
\end{tabular}


GHIRALDELLI JR, Paulo. Como a filosofia pode explicar o amor. São Paulo: Universo dos Livros, 2011.

HORKHEIMER, Max. A situação da filosofia social e as tarefas de um Instituto de Pesquisas Sociais. Praga: Estudos Marxistas, 7, 1999, p.121-132.

KELLNER, Douglas. Herbert Marcuse and the Crisis of Marxism. Berkeley/Los Angeles: University of California Press, 1984.

MARCUSE, Herbert. Algumas implicações sociais da tecnologia moderna. In:

Tecnologia, guerra e fascismo. Tradução de Maria Cristina V. Borba. São Paulo: Ed. UNESP, 1999, 71-104. \& Koogan, 1981.

. Eros e civilização. 8. ed. Tradução de Álvaro Cabral. Rio de Janeiro: Guanabara

. O homem unidimensional. Tradução de Robespierre de Oliveira, Deborah Christina Antunes e Rafael Cordeiro Silva. São Paulo: Edipro, 2015.

A noção de progresso à luz da psicanálise. In:

Cultura e psicanálise. Tradução de Wolfgang L. Maar, Robespierre de Oliveira e Isabel Loureiro. São Paulo: Paz e Terra, 2001, p.112-138.

A obsolescência da psicanálise. In: . Cultura e sociedade. V. 2. Tradução de Wolfgang L. Maar, Isabel Loureiro e Robespierre de Oliveira. São Paulo: Paz e Terra, 1998, p.91-111.

Para uma crítica do hedonismo. In: Cultura e sociedade. Tradução de Isabel Maria Loureiro. São Paulo: Paz e Terra, 1997, v.1, p.161-199.

Teoria das pulsões e liberdade. In: MARCUSE, Herbert; FROMM, Erich e MILLER, Karl. Marcuse polémico. Tradução de Fernando Midões. Lisboa: Presença, 1969, p.101-147

MARX, Karl. Grundrisse: manuscritos econômicos de 1857-1858: esboços da crítica da economia política. Supervisão editorial de Mario Duayer; tradução de Mario Duayer e Nélio Schneider (com a colaboração de Helga Werner e Rudiger Hoffman). São Paulo: Boitempo; Rio de Janeiro: Ed. UFRJ, 2011.

ROBINSON, Paul A. A esquerda freudiana: Wilhelm Reich, Gesa Roheim, Herbert Marcuse. Tradução de Álvaro Cabral. Rio de Janeiro: Civilização Brasileira, 1971. 


\title{
AS MINORIAS COMO O NEGATIVO, O MOVIMENTO DAS MULHERES E O ESPAÇO DIGITAL
}

\author{
Deborah Christina Antunes ${ }^{1}$
}

\begin{abstract}
Resumo:
A partir da importância dada pelos teóricos da Escola de Frankfurt aos grupos que são sistematicamente perseguidos, e ao mesmo tempo, do reconhecimento de que sua existência se realiza como uma função específica de manutenção da sociedade burguesa, como parte da dialética de sua existência, realizamos aqui um estudo empírico inspirado na ideia da necessidade de mergulharmos nos detalhes concretos para compreender a realidade e, desse modo, ter a possibilidade de operar transformações efetivas em sua base. Trata-se de análises realizadas a partir de um debate de um grupo feminista no Facebook, em busca de suas possibilidades emancipadoras, adentrando na esfera de uma tradição mais empírica dos estudos em Teoria Crítica, sem deixar de lado a reflexão conceitual.
\end{abstract}

Palavras-chave: Minorias; Negativo; Feminismo; Theodor W. Adorno; Herbert Marcuse.

\section{MINORITIES AS THE NEGATIVE, THE WOMEN'S MOVEMENT AND DIGITAL SPACE}

\begin{abstract}
:
From the importance given by the theorists of the Frankfurt School to groups that are systematically persecuted, and at the same time from the recognition that their existence is realized as a specific function of maintaining bourgeois society, as part of their inner dialectic, we realize here an empirical study inspired by the idea of the need to delve into the concrete details to understand reality and, thus, to have the possibility to operate effective transformations at its base. These are analyzes made from a debate of a feminist group on Facebook, in search of their emancipatory possibilities, entering into the sphere of a more empirical tradition of studies in Critical Theory, without leaving aside the conceptual reflection.
\end{abstract}

Keywords: Minority; Negative; Feminism; Theodor W. Adorno; Herbert Marcuse.

Para Herbert Marcuse, mulher honorária.

Na primavera de 1956, Horkheimer e Adorno planejaram escrever em conjunto uma nova versão do Manifesto Comunista, de Marx e Engels. A certa altura dos diálogos que foram registrados por Gretel Adorno, Horkheimer afirmou categoricamente: "nós somos a favor do caótico, daquilo que não foi incluído" (Adorno \& Horkheimer, 2011, p.27); Embora Adorno

1 Psicóloga (Unesp/Bauru), mestre em Educação e doutora em Filosofia (UFSCar), com período sanduíche na Universidade da Califórnia Berkeley. Professora Adjunta da Universidade Federal do Ceará, campus Sobral e do Programa de Pós-Graduação em Psicologia (UFC Fortaleza). Autora de "Por um conhecimento sincero no mundo falso: Teoria Crítica, Pesquisa Social Empírica e The Authoritarian Personality" (Paco Editorial, 2014). Bolsista produtividade da Fundação Cearense de Apoio ao Desenvolvimento Científico e Tecnológico - FUNCAP (BPI 09/2018 - processo n. BP3-0139-00147.01.00/18). E-mail: deborahantunes@ gmail.com. 
discorde da palavra "caótico" com receio de sua ampla defesa, Horkheimer aponta para a ideia de que o não incluído supostamente preserva a si mesmo apaixonado - embora não se saiba até que ponto essa paixão de fato possa negar a sociedade burguesa de modo radical. Nesse momento, ele traz à baila novamente a importância dada, por esses teóricos críticos, não à figura idealizada de um proletariado que se auto libertaria, mas àqueles grupos que são sistematicamente perseguidos - estando empregados ou não - ao mesmo tempo que sua existência se realiza como uma função específica de manutenção da sociedade burguesa.

Se os hegelianos de esquerda, que produziram suas análises em uma época de modernização capitalista da Alemanha, perceberam o proletariado como uma nova força negativa (revolucionária) que poderia realizar sua filosofia, os frankfurtianos vivenciaram exatamente o oposto: o enfraquecimento da classe trabalhadora como potência revolucionária. (Jay, 2008). Isso porque, para Horkheimer (1986), ela estava dividida entre trabalhadores que se sentiam plenamente integrados - e, portanto, teriam algo a perder - e aqueles que permaneceram fora do mercado de trabalho, mas que não tinham qualquer ideia de formas possíveis de organização. Horkheimer reconhece que "a miséria dos trabalhadores continua sendo a condição e o fundamento dessa forma de sociedade; mas o tipo de trabalhador já não é mais daquele que necessita de uma transformação urgente" (p.87).

Tendo uma vida dedicada à luta das minorias como uma resposta estrutural intelectual e política à dinâmica da violência, da supremacia branca, do patriarcado, do poder estatal, do mercado capitalista e das políticas imperialistas, em 2015, Angela Davis (2016) retomou essa ênfase de modo amplo quando apontou que o movimento dos imigrantes e refugiados seria o movimento de nosso século; ele denuncia globalmente o racismo, o genocídio, o colonialismo. Para além dos campos de concentração, genocídio é compreendido desde o final da Segunda Guerra Mundial, como todo ato cometido com a intenção de destruir, no todo ou em parte, um grupo religioso, racial, étnico, nacional. Isso inclui assassinato, espancamento, assédio moral, imposição de métodos contraceptivos, e marginalização no acesso às condições de sobrevivência de membros desses grupos, no intuito de acabar com eles existencialmente. (Davis, 2016). O colonialismo, por sua, vez, refere-se às conquistas imperialistas que se expandiram nos diversos continentes, como América, Ásia e África, que “submeteram populações nativas inteiras, incorporando-as à sua organização estatal através da superioridade bélica" (Chaves, 1971, p.151), bem como a transferência de grupos populacionais contra seu próprio interesse e para fins de exploração. As minorias, embora muitas vezes

\begin{tabular}{|l|c|c|c|c|}
\cline { 2 - 5 } & Ano 8 & n. 14 & Janeiro - Julho 2019 & p. $213-234$ \\
\hline
\end{tabular}


quantitativamente superiores, são caracterizadas por uma relação de dominação e descriminação.

Não é por acaso que o estudo do preconceito marca uma das maiores pesquisas empíricas realizadas por Adorno, "A personalidade autoritária" herdeira dos estudos anteriores que enfocaram o caráter autoritário existente nas classes trabalhadoras - como "A classe trabalhadora na Alemanha de Weimar", de Erich Fromm realizado no final da década de 1920, e "Autoridade e Família", coordenado por Horkheimer no início da década de 1930. O preconceito e suas estereotipias, resultantes das condições objetivas de uma vida orientada pela escassez e pelo medo, pela destruição e pela dominação, se apresentam com uma função psicológica e social que marca profundamente as subjetividades: trata-se de um modo de orientação em um mundo já caótico e incompreensível, e também uma forma de tentar manter os, poucos é verdade, privilégios (supostamente) adquiridos dentro de uma organização social incapaz de garantir a existência daqueles que a ela pertencem (ou que são ditos pertencer) apesar dos chamados avanços tecnológicos. Exatamente por isso, o preconceito denuncia a existência de algo "ameaçador" naqueles que, via de regra, são reconhecidos como pertencentes a grupos específicos. Judeus, negros, deficientes, homossexuais, ciganos eram presos em campos de concentração nazistas. Judeus, negros, armênios, orientais, latinos e latinoamericanos, indígenas eram alvos de preconceitos nos Estados Unidos no mesmo período, e historicamente.

Havia uma placa nas praias de Nova Iorque, em meados do século XX, assim como em outros lugares América afora, onde lia-se: "proibido cachorros, negros e judeus", outras versões traziam: "proibido cachorros, negros e mexicanos". Dizia-se que negros e judeus tinham um cheiro ofensivo (Adorno et al, 1969). Mulheres ainda hoje são culpadas pelas violências que vivenciam, apontando que há algo nelas passível de provocar/ofender o outro. Lembro Horkheimer e Adorno (1985, p. 161) nos "Elementos do Antissemitismo" da Dialética do Esclarecimento,

[...] costumes estranhos que lembram a terra prometida, a beleza que lembra o sexo, o animal execrado como repugnante porque provoca a promiscuidade), tudo isso atrai sobre si o desejo de destruição dos civilizados que jamais puderam realizar totalmente o doloroso processo civilizatório. Os que exercem um domínio crispado sobre a natureza veem na natureza atormentada o reflexo provocante da felicidade impotente.

Sartre, em seu texto sobre a questão judaica, aponta que essa provocação que se sente no corpo, embora, para ele, tenha origem na mente, se coloca de modo tão profundo e completo

\begin{tabular}{|c|c|c|c|c|}
\cline { 2 - 5 } Q Q Dialectus & Ano 8 & n. 14 & Janeiro - Julho 2019 & p. 213-234 \\
\hline
\end{tabular}


que se estende ao reino fisiológico mesmo, tal como ocorre na histeria (Sartre, 1966, p.11); e a histeria, como coloca Lacan (1992), é o domínio do que não pode ser deflorado, do que não faz parte do discurso normativo, hegemônico do que é, do que existe.

O medo e sua transferência inconsciente fazem parte de uma relação complexa entre o medo do "estranho" e seu preenchimento por um imaginário a respeito de um grupo específico (Adorno et al. 1969). Horkheimer e Adorno (1985, p. 170) apontam partir de Freud, que "[...] o que repele por sua estranheza é, na verdade, demasiado familiar. São os gestos contagiosos dos contatos diretos reprimidos pela civilização". A apresentação do medo do estranho pela idiossincrasia não ocorre por acaso. Ela remete a processos e desejos reprimidos na história da civilização que retornam no indivíduo e se expressam como ódio ao diferente, que em verdade é por demais familiar:

[...] a natureza que não se purificou nos canais da ordem conceitual para se tornar algo dotado de finalidade; o som estridente do lápis riscando a lousa e penetrando até a medula dos ossos; o haut goût (gosto intenso) que lembra a sujeira e a putrefação; o suor que poreja a testa da pessoa atarefada; tudo o que não se ajustou inteiramente ou que fira os interditos em que se sedimentou o progresso secular tem um efeito irritante e provoca uma repugnância compulsiva" (Horkheimer; Adorno, 1985, p. 168).

$\mathrm{Na}$ idiossincrasia, determinados órgãos escapam ao domínio do sujeito e obedecem a estímulos biológicos fundamentais; a reação é a recusa e o desprezo imediatos como esquemas arcaicos de auto conservação. Quando Horkheimer e Adorno (1985) discutem essa questão, se referem ao judeu e ao seu princípio de individuação fisionômico, o nariz:

[...] nas ambíguas inclinações dos prazeres do olfato sobrevive ainda a antiga nostalgia pelas formas inferiores da vida, pela união imediata com a natureza ambiente, com a terra e o barro. De todos os sentidos, o ato de cheirar - que se deixa atrair sem objetualizar - é o testemunho mais evidente da ânsia de se perder no outro e com ele se identificar. Por isso o cheiro, tanto como percepção quanto como percebido (ambos se identificam no ato), é mais expressivo do que os outros sentidos. Ao ver, a gente permanece quem a gente é, ao cheirar, a gente se deixa absorver. É por isso que a civilização considera o cheiro como uma ignomínia, como sinal das camadas sociais mais baixas, das raças inferiores e dos animais abjetos. (Horkheimer; Adorno, 1985, p. 171-172).

A neurociência explica isso: o sentido do olfato é o único que, através dos neurônios genuínos presentes nos receptores olfativos, penetra diretamente e sem intermediários nos cérebros reptiliano e límbico, os mais primitivos de nosso sistema nervoso central e responsáveis pela auto conservação, pela sexualidade, pela agressividade. O olfato foi o

\begin{tabular}{|l|l|l|l|l|}
\cline { 2 - 5 } & Ano 8 & n. 14 & Janeiro - Julho 2019 & p. $213-234$ \\
\hline
\end{tabular}


primeiro meio de acesso ao mundo externo das criaturas primitivas. (Ribas, 2006). Cheiros evocam memórias de forma instintiva e emocional, desafiando aqueles que caracterizam sua espécie pelo desenvolvimento do neocortex, da habilidade cognitiva e intelectual, pela pura racionalidade e astúcia. Lidar com o desconhecido, com o incontrolável em nós - embora nosso, embora familiar - é por demais angustiante. Daí o desejo de destruir esse outro que denuncia em mim aquilo com o qual já não posso lidar. Como é possível ao homem civilizado, moldado a partir de conceitos e certezas fixos e invariáveis permitir-se mover para o oposto, para uma experiência incerta que os conceitos não alcançam? E não é essa justamente a proposta de Adorno em sua Dialética Negativa, a de que possamos nos mover em relação ao não conceitual, ainda que através dos conceitos, mas sem reduzir o não conceitual a conceitos? O movimento em direção àquilo que não pode ser abarcado pelos conceitos é o negativo da dialética adorniana. O conceito, a racionalidade na qual ele emerge, jamais apreenderá seu objeto particular. Este também jamais preencherá seu conceito nesta forma de organização social, no entanto: "A emancipação da sociedade [relativamente ao antissemitismo] depende da possibilidade de elevar ao conceito o conteúdo da idiossincrasia e de tomar consciência de seu absurdo" (Horkheimer; Adorno, 1985, p. 168).

Peço licença para uma digressão conceitual.

$* * *$

Adorno compreende que o conceito é sempre, em alguma medida, diverso do que está subsumido nele. Tanto em seu curso, quanto em seu livro Dialética Negativa, ele $(2009 ; 2010)$ explica que, na lógica dialética, quando B é definido como um A ele é também diferente de e mais do que A, o conceito sob o qual ele está subsumido por meio de um julgamento predicativo. Assim, por exemplo, o conceito de liberdade contém um ponteiro em direção a algo que vai além daquelas liberdades individuais, sem que se compreenda o que é exatamente esse elemento adicional. O conceito é sempre mais e menos do que os elementos incluídos nele:

O juízo de que alguém é um homem livre refere-se, pensando de maneira enfática, ao conceito de liberdade. Esse conceito, contudo, é por sua vez mais do que aquilo que é predicado desse homem, tanto quanto todo homem, por meio de outras determinações, é mais do que o conceito de sua liberdade. Seu conceito não diz apenas que podemos aplica-lo a todos os homens singulares definidos como livres. Aquilo que nutre esse conceito é a ideia de um estado no qual os singulares teriam qualidades que não poderiam ser atribuídas aqui e agora a ninguém. Dizer que alguém é livre tem sua especificidade no sous-entendu (implícito) de que lhe é atribuído algo impossível porque esse algo se manifesta nele; esse elemento que ao mesmo tempo salta aos olhos e é secreto anima todo juízo identificador que de alguma maneira é válido. O conceito de liberdade fica aquém de si mesmo no momento em que é aplicado empiricamente. Ele mesmo deixa de ser então o que ele diz. No entanto, precisa ser confrontado com isso. Uma tal confrontação o conduz a uma contradição consigo mesmo. (ADORNO, 2009, p. 131).

\begin{tabular}{|l|l|l|l|l|}
\cline { 2 - 5 } & Ano 8 & n. 14 & Janeiro - Julho 2019 & p. $213-234$ \\
\hline
\end{tabular}


O segundo significado do elemento de contradição concerne à preocupação com a natureza contraditória do próprio objeto, da realidade. Assim, a essência do modelo de sociedade antagônica na qual se vive é que ela não é uma sociedade com contradições ou a despeito de suas contradições, mas sim em virtude de suas contradições. A sociedade baseada no lucro produz sua própria existência. O princípio de dominação da natureza se estende e permanece na dominação dos homens pelos homens; seu reflexo mental é o princípio da identidade que atrai para sua esfera de influência toda alteridade que lhe é apresentada. Tratase de uma contradição imanente, que constitui a natureza do próprio objeto: "a dialética é negativa em virtude da negatividade de seu objeto" (ADORNO, 2010, p. 165); por isso, ela depende da comprovação dessa negatividade, não podendo ser aplicada a ele, de fora. Por outro lado, a própria primazia do objeto deve ser, a todo tempo, também comprovada:

\begin{abstract}
A possibilidade de uma Dialética Negativa depende da prova da primazia do objeto. Ela também não pode ser um princípio absoluto para a dialética ou uma retomada de um realismo ingênuo: ela é válida apenas na inter-relação. Se a primazia do objeto se libertasse da dialética e fosse postulada de forma positiva - acompanhada pelos uivos triunfantes da cumplicidade - então a filosofia regressaria ao dogma estúpido da reprodução ou reflexo da realidade [...]. Novamente, um princípio, uma "máxima", seria hipostasiada e o pensamento reduziria tudo que existe a um denominador comum. (ADORNO, 2010, p. 200).
\end{abstract}

Desses dois significados, compreende-se que a necessidade da contradição como elemento central emerge tanto do objeto, quanto do pensamento que, em sua forma de conceito, é incapaz de alcançar a totalidade daquilo a que ele se refere. Um modo de reflexão e análise que a incorpora não é nada além do que um executor, um modo de pensar que se dedica ao que seu material disponibiliza. (ADORNO, 2010). Como Adorno (2003, p. 33) aponta em Ensaio como forma, trata-se de "pensar a coisa, desde o primeiro passo, com a complexidade que lhe é própria, tornando-se um corretivo daquele primitivismo obtuso, que sempre acompanha a ratio corrente".

$* * *$

Há que se admitir aqui, então, certa culpa desses grupos historicamente perseguidos não sem enfatizar que essa culpa é seu maior trunfo. Ou seja, não quero com isso dizer que a supressão da barbárie, ou ainda uma harmonização e um apaziguamento das relações sociais e das contradições da sociedade dependam de uma atitude vorazmente adaptativa às regras do

\begin{tabular}{|l|l|l|l|l|}
\cline { 2 - 5 } & Ano 8 & n. 14 & Janeiro - Julho 2019 & p. $213-234$ \\
\hline
\end{tabular}


jogo. Sartre também nos lembra que nenhuma assimilação basta para se poder estar seguro de pertencer à sociedade.

[...] o judeu dança como os outros a dança da honradez e da respeitabilidade; aliás, ele não é escravo de ninguém, livre cidadão num Estado que autoriza a livre concorrência, nenhuma dignidade social, nenhum cargo do Estado lhe são interditos, ele receberá a Legião de Honra, será grande advogado, ministro. Mas no mesmo momento em que ele chega ao topo da sociedade legal, outra sociedade amorfa, difusa e onipresente mostra-se a ele de relance e se oculta. Ele sente de maneira muito particular a vaidade das honrarias e da fortuna, pois o maior sucesso não lhe permitirá jamais ter acesso a essa sociedade que se pretende verdadeira; ministro, será um ministro judeu, ao mesmo tempo uma excelência e um intocável (Sartre, 1966, p. 79-80).

Parafraseio Sartre: Presidente, será uma presidente(a) mulher. Medalhista, será uma medalhista negra. Professor, será um professor homossexual. Estudante será um estudante indígena, cotista e assim por diante. E não é que essas diferenças apontadas simplesmente fortalecem qualquer identidade, mas seu efeito localiza-se em marca-los como "intocáveis", aqueles que sempre irão pertencer às classes mais baixas, sujas, ignorantes - as dos não civilizados. Embora o preconceito contra as minorias nunca tenha deixado de se manifestar, nos momentos de crise econômica (de sistema), como o que o mundo está vivenciando desde 2008, ele se arrefece: países fecham suas portas para estrangeiros e diminuem a possibilidade de sobrevivência de pobres, negros, mulheres, indígenas e LGBTs ao descontinuar políticas que enfocam ao menos uma tentativa de superação das injustiças sociais - e o fazem como medida de proteção: proteção de uma determinada ordem social contra o não-idêntico. Isso nos diz muito.

Quando Horkheimer e Adorno (1985) fizeram sua análise do antissemitismo, eles apontaram duas doutrinas opostas sobre os judeus, ao mesmo tempo falsas e verdadeiras. A primeira dizia que, para os fascistas, os judeus não são uma minoria, mas sim a anti-raça, o princípio negativo em si mesmo: de sua exterminação dependeria a felicidade de todos. A segunda aponta os judeus como povo livre de características nacionais e raciais, que formaria um grupo baseado na opinião e na tradição. A primeira tese só é verdadeira porque o fascismo a tornou. Vítimas e algozes são intercambiáveis: qualquer um pode tomar o lugar do assassino caso se converta em norma. A multiplicidade das vítimas também deixa entrever que o suposto "fator problemático" do outro é mais universal do que se poderia desconfiar. A segunda, só é verdadeira na Ideia, mas “ao colocar a unidade dos homens como já realizada por princípio, ela ajuda a fazer apologia do existente" (p.158).

\begin{tabular}{|l|c|c|c|c|}
\cline { 2 - 5 } & Ano 8 & n. 14 & Janeiro - Julho 2019 & p. $213-234$ \\
\hline
\end{tabular}


A adaptação, ainda que sempre deficitária, das minorias à lógica do sistema que lhes é imposto reforça a possibilidade de que ao fim e ao cabo elas se identifiquem com o existente o que torna seu conteúdo negativo impotente, na medida em que perpetua a própria sociedade burguesa, ainda que através de sua negação: “o entrelaçamento dialético do esclarecimento e da dominação, a dupla relação do progresso com a crueldade e a libertação, que os judeus tiveram que provar nos grandes esclarecedores bem como nos movimentos populares democráticos, também se mostra no ser dos próprios assimilados" (p.158).

Não é possível afirmar que Adorno acreditava no potencial revolucionário das minorias como algo dado. Na pesquisa sobre a personalidade autoritária ele percebeu que mesmo as minorias já haviam também se identificado com o poder e discriminavam-se entre si, ao invés de se juntarem contra o inimigo comum: haviam membros das minorias com fortes tendências conformistas e abertamente antissemitas, por exemplo. Ali ele parte do

[...] pressuposto de que a - amplamente inconsciente - hostilidade resultante da frustração e da repressão, e socialmente desviada de seu verdadeiro objeto, precisa de um objeto substituto através do qual ele pode obter um aspecto realístico e então esconder, como se diz, as manifestações mais radicais de um bloqueio da relação do sujeito com a realidade (Adorno et al, 1969, p. 607-608).

É preciso assumir a complexidade da existência na sociedade antagônica. Não para fundar um viés pessimista, mas para encontrar possibilidades de superação. Somos ao mesmo tempo as minorias e nossos próprios algozes. Os algozes têm em si mesmo tudo aquilo que negam e acusam nas minorias; embora o equilíbrio de forças em ambos não seja o mesmo. Por isso, elas (nós), como grandes espelhos refletimos a imagem que não se quer ver. Somos tábuas de projeção. Denunciadoras. Aquelas que interrogam, questionam com sua existência verdades anunciadas e por isso apontam para a existência de diferentes possibilidades que não se sabe. E essa é, como um sintoma, marca de uma repressão e uma função libertadora, na medida em que se torna possível compreender e elaborar esse processo. A verdade nunca se pode dizê-la senão pela metade. Lembrando Lacan (2009, p. 23), "A dimensão do sintoma é isso que fala. Fala inclusive com os que não sabem ouvir. E não diz tudo, nem mesmo aos que sabem".

A negação também não deve ser hipostasiada. Ela não é destino nem da classe trabalhadora, nem das diversas minorias, senão o que se faz na luta histórica que se estabelece num jogo de forças internas e externas. Por isso, gostaria de voltar à tese de Horkheimer do início e questionar: quem pode, hoje, ser considerado não incluído? O representante do negativo

\begin{tabular}{|c|c|c|c|c|}
\cline { 2 - 5 } & Ano 8 & n. 14 & Janeiro - Julho 2019 & p. $213-234$ \\
\hline
\end{tabular}


enquanto tal que escapa aos antagonismos da libertação e da dominação? Quem pode hoje, ser considerado incluído? Os sujeitos da história não são pessoas melhores, e aqui eu recordo o Galileu Brechtiano que nos lembra da infelicidade daqueles que buscam seus heróis: nos adaptamos e assimilamos ainda que permaneçamos nas margens, por medo do sofrimento, e não para preservar a salvo uma verdade que porventura carregamos.

\section{Como encontrar saídas ou linhas de fuga?}

É bastante conhecida a tese de que, para Adorno, a possibilidade de emancipação se dá unicamente pela via a arte. A arte seria capaz de, através da experiência estética, libertar o não idêntico. Eu proponho que, para Adorno, é possível construir saídas ou possibilidades emancipatórias pela via da ciência, mas de uma ciência esteticamente orientada, uma vez que ele apresenta em sua Teoria Estética a ideia de que embora arte e ciência não devam ser fundidas “[...] as categorias que são válidas em cada uma não são absolutamente diferentes" (Adorno, 1997, p. 131) e ambas estão aptas a buscar a utopia em virtude da negatividade do material, mas apenas se renunciarem a busca por reconciliação. Assim como na arte, a ciência precisa integrar em si o comportamento estético e negativo de perceber mais nas coisas do que elas são. Ela deve extrair "o fenômeno de sua existência e trazê-lo para a autorreflexão; esta seria a reflexão do que está petrificado nas ciências e não uma ciência especializada localizada para além delas [das coisas]. (p. 262). Essa é a ideia das pesquisas empíricas realizadas por Adorno.

Trago aqui então um estudo empírico inspirado na ideia da necessidade de mergulharmos nos detalhes concretos para compreender a realidade e, desse modo, ter a possibilidade de operar transformações efetivas em sua base. Gostaria de mostrar a vocês algumas análises que fiz a partir de um debate de um grupo feminista, em busca de suas possibilidades emancipadoras. Adentro então, nesse momento, na esfera de uma tradição mais empírica dos estudos em Teoria Crítica existente desde a fundação do Instituto de Pesquisa Social de Frankfurt.

As minorias como o negativo: análise de um diálogo em um grupo feminista no Facebook Caracterização da Amostra

\begin{tabular}{|l|l|l|l|l|}
\cline { 2 - 4 } & Ano 8 & n. 14 & Janeiro - Julho 2019 & p. $213-234$ \\
\hline
\end{tabular}


O diálogo analisado, parte de um trabalho mais amplo que visa a compreender as "novas" subjetividades mediadas e mediadoras pelos/dos meios de comunicação digitais. Ele foi retirado de um grupo feminista com uma página no Facebook, chamada "Feminismo sem demagogia - Original". A página foi escolhida para esse estudo por conta do número de pessoas ativas nela. É a página sobre feminismo que mais tem adeptos ativos dentre os usuários brasileiros dessa rede social virtual: 1.073.217 (Um milhão, setenta e três mil, duzentas e dezessete pessoas) curtem a página. Desses, 821.6 Mil são ativos (90\% mulheres e 10\% homens).

92 milhões de brasileiros acessam o Facebook mensalmente, segundo dados fornecidos pela própria rede social ${ }^{2}-45 \%$ da população brasileira. É importante lembrar que, de acordo com os dados do IBGE no último senso, 54,9\% dos lares brasileiros têm acesso à internet, chegando a 95,4 milhões de pessoas ${ }^{3}$. Dentre as pessoas com acesso à internet no Brasil, a grande maioria frequenta mensalmente essa rede social: $96,44 \%$.

Os dados estatísticos disponibilizados pelo Facebook foram acessados através de sua ferramenta Facebook Audience Insight, uma ferramenta que analisa estatisticamente todos os dados cadastrados pelos usuários na rede e transforma esses dados em informações utilizáveis para o mapeamento de possíveis clientes para produtos e serviços específicos. É uma ferramenta de mapeamento de perfis para o mundo dos negócios. Diz a página que explica a ferramenta cuja chamada é "Seu negócio com o Facebook Audience Insights": "Quanto mais percepções dos clientes você tem, melhor você está equipado para enviar mensagens significativas para eles. Esse é o pensamento por trás do Facebook Audience Insights, uma nova ferramenta desenhada para ajudar os comerciantes a aprender mais sobre seu público-alvo, incluindo informações agregadas sobre geografia, demografia, comportamento de compra e muito mais"4.

Os dados numéricos apontam a diferença significativa entre a quantidade simples de pessoas ativas na página "Feminismo sem demagogia - Oficial" e o total de usuários brasileiros ativos da rede Facebook. Trata-se de uma parcela de $0.9 \%$, mas que é já suficientemente relevante para que a ferramenta produza dados estatísticos sobre esse "agrupamento" (o que não ocorre com páginas com número menor de adeptos). Numericamente, até aqui, podemos considerar o grupo feminista como uma minoria dentro da população e da amostra gerada,

\footnotetext{
${ }^{2}$ https://www.facebook.com/business/news/BR-45-da-populacao-brasileira-acessa-o-Facebook-pelo-menosuma-vez-ao-mes

${ }^{3}$ http://g1.globo.com/tecnologia/noticia/2016/04/internet-chega-pela-1-vez-mais-de-50-das-casas-no-brasilmostra-ibge.html

4 https://www.facebook.com/business/news/audience-insights

\begin{tabular}{|l|l|l|l|l|}
\hline Q Povista Qialectus & Ano 8 & n. 14 & Janeiro - Julho 2019 & p. 213 - 234 \\
\hline
\end{tabular}
}


muito embora o percentual de mulheres usuárias do Facebook no Brasil seja de 53\%. Ou seja, de um total de 48.760 .000 milhões de mulheres ativas do Facebook, cerca de 735.8 Mil são adeptas do "Feminismo sem demagogia - original": 1,5\%. 1,5\% das mulheres que usam o Facebook são "Feministas sem demagogia", ou seja, têm alguma aproximação ou interesse na página feminista com mais adeptos nessa rede.

Mas, qual a diferença de perfil entre esses $1,5 \%$ de mulheres que curtem "Feminismo sem demagogia - Oficial" e as demais? As mulheres pertencentes a esses 1,5\% são mais novas do que as demais: $65 \%$ delas têm entre 18 e 24 anos, enquanto apenas $28.2 \%$ do total de mulheres no Facebook estão nessa faixa etária, e o percentual de mulheres nesse grupo decresce na medida em que a faixa etária aumenta.

As páginas mais curtidas por esses dois grupos podem também nos dar algumas indicações relevantes. As páginas mais curtidas pelas mulheres no Facebook são: $O$ Boticário, Bolsa de Mulher, Risqué, Mary Kay Brasil, Melhor com Saúde, Natura, Lojas Renner, Caio Castro, [Quem disse, Berenice?] e Pantene Brasil - a maioria de empresas de produtos destinados ao público feminino. Já as páginas mais curtidas por aqueles 1,5\% são: Feminismo sem demagogia - Original, Não me Kahlo, Empodere duas mulheres, Diários de uma feminista, Deboas na Revolução, Arquivos Feministas, Feminismo Político, Quebrando o Tabu, Diário Feminista e Desconstruindo conceitos - páginas ligadas ao feminismo ou temas políticos de esquerda. Podemos inferir, então, que o público da página em questão é um público interessado e/ou identificado com questões de esquerda, especialmente as feministas. Aqui nós temos um dado de extrema relevância: embora as mulheres componham o grupo das minorias, em termos de relação de dominação e discriminação, elas não apenas não aderem significativamente ao movimento social em questão, como voltam seus interesses para o consumo de mercadorias que ditam o que é o próprio ser mulher.

É interessante também observar o perfil em relação ao nível de escolaridade. Ambos os grupos são formados, em sua maioria, por mulheres com nível superior, embora dentre as que frequentam o grupo "Feminismo sem demagogia - Oficial", haja um percentual significativamente maior de mulheres com pós-graduação ( $41 \%$ a mais do que grupo geral de mulheres no Facebook, embora represente apenas 5\% das adeptas do grupo). A atividade laboral a qual se dedicam é também significativamente diversa: as mulheres envolvidas com o grupo em questão trabalham $28 \%$ a mais no setor público, $23 \%$ a mais na área de cuidados pessoais, $18 \%$ a mais nas áreas de vendas e artes/entretenimento, $14 \%$ a mais nas áreas de

\begin{tabular}{|l|c|c|c|c|}
\cline { 2 - 4 } & Ano 8 & n. 14 & Janeiro - Julho 2019 & p. $213-234$ \\
\hline
\end{tabular}


educação, serviços sociais e administração, além de 100\% a mais em empregos temporários, comparadas às demais mulheres no Facebook.

Em termos geográficos, as mulheres do grupo "Feminismo sem demagogia - Original", distribuem-se de norte a sul do país, em todas as regiões, mas são proporcionalmente mais numerosas nas cidades de Porto Alegre (48\%), Belém (29\%), Rio de Janeiro (16\%), Recife (14\%), Fortaleza (10\%) e Curitiba (4\%).

Resumidamente, as mulheres adeptas do feminismo sem demagogia, portanto, tendem a ser mais novas do que o grupo de mulheres em geral, a voltar mais seus interesses para outros grupos políticos e feministas e ter um nível de escolaridade mais alto. Elas também trabalham mais em setores como educação, serviço público, artes, esportes e entretenimento, e cuidado pessoal. Parece ser um grupo mais "liberal" (não no sentido econômico) que se destaca da população geral de mulheres. É desse grupo que foi obtido o debate que será analisado a seguir. A página "Feminismo sem demagogia - Original", é definida por sua criadora como

[...] um espaço destinado ao debate a respeito do feminismo pelo viés MARXISTA, e opressão machista/capitalista sobre as mulheres. O espaço está aberto para todas as mulheres, cis e não cis, e homens que queiram compor como aliados a luta e que fique claro, somente homens que queiram compor como aliados, respeitando o protagonismo das mulheres [...] As feministas da esquerda revolucionária Marxista entendem a luta contra o machismo como uma luta inseparável da luta de classes. Entendemos que o feminismo é uma parte importante da luta, pois impulsiona as demandas específicas das mulheres.

Entendemos que é extremamente importante que homens compreendam que a luta das mulheres deve ser apoiada por eles também. Que homens e mulheres devem aliar-se para a luta contra divisão de classes, contra esta elite (que é a verdadeira minoria), que se pôs ao topo do sistema econômico e se beneficia das discriminações sobre as diferenças, inclusive fortalecendo dentro deste cenário a desqualificação da mulher e o elogio à superioridade do homem com a clara intenção de nos separar, de nos pôr em guerra uns contra os outros sem notarmos que, enquanto isso, o inimigo real deita e rola sobre nossas costas cansadas e arqueadas do peso desta opressão que nos impuseram. Só os trabalhadores, homens e mulheres, atuando em conjunto num movimento revolucionário poderão destruir a sociedade de classes e com ela a opressão sobre as mulheres de forma definitiva.

O debate que vou analisar foi realizado a partir do desabafo, do dia 5 de agosto de 2016, de uma moça, estudante secundarista, que foi compartilhado no dia 13 por uma das administradoras na página "Feminismo sem demagogia - Original". Os dados foram colhidos na rede no dia 18 de agosto. Em seu relato a estudante disse:

Moçxs gostaria de relatar a vcs algo horrível q me aconteceu ontem. Sou secundarista na escola Estadual XXXX e ontem um professor proferiu um discurso absurdamente machista. Ele começou comentando na sala com os alunxs q mulher quer ter direitos iguais, mas q não se aposentava com a mesma idade q os homens. Eu respondi dizendo q nós Mulheres temos td o serviço do lar (q por questões culturais e sociais nos é conferido) e não eramos remuneradas, e antes q eu pudesse continuar, ele replicou dizendo q ele limpava a própria casa dele e q se nós

\begin{tabular}{|c|c|c|c|c|}
\hline Rovista Dialectus & Ano 8 & n. 14 & Janeiro - Julho 2019 & p. $213-234$ \\
\hline
\end{tabular}




\begin{abstract}
Mulheres limpamos a casa é uma questão de escolha. E quando eu achei q ele não poderia ser mais machista, ele disse q mulher q apanha, apanha porque gosta e q não se separa porque só pensa no pau do homem. Sinceramente ontem foi uns dos piores dias, me senti humilhada, não tenho nem adjetivos para definir meus sentimentos naquele momento. Nunca havia pensado que poderia escutar tamanho machismo no meu ambiente escolar no qual passo maior parte do dia. E que me fz pensar se é realmente um lugar para educar.

\#meuprofessormachista.
\end{abstract}

Até o momento em que os dados foram coletados, esse compartilhamento havia recebido 203 manifestações através dos emoticons: 118 curtidas, 54 carinhas zangadas, 30 carinhas chorando e uma (01) carinha "uau"/espanto. Além disso, foram 34 comentários feitos por 24 pessoas diferentes sobre o relato: 21 mulheres e 03 homens. Uma leitura primeira do debate travado espontaneamente pelos frequentadores da página nos faz perceber a existência de quatro categorias iniciais de manifestação/discurso. 1. Discurso a favor do professor - 06; 2. Discurso contra o professor- $16 ; 3$. Discurso a favor da aluna- $03 ; 4$. Discurso contra a aluna- 02 . Todo o debate gira em torno daquele que teria ou não razão em suas colocações, com a exceção de 03 manifestações que não dizem respeito ao debate em si mesmo.

\title{
1. Discursos a favor do professor
}

“O que ele falou não é machismo, é verdade. Nós deveríamos nos aposentar na mesma idade que homens, não dá pra ser vista como igual me aposentando 5 anos mais cedo, ainda mais eu que tenho empregada doméstica e trabalho menos que o meu marido" (FHR).

"Minha vida pode não ser o padrão da sociedade, mas leis não devem ser feitas de modo que possa injustiçar alguém. Quem deu o direito de mulheres votarem, criaram a lei Maria da Penha e a lei do feminicídio foram todos homens, e daí? Um homem que é pai solteiro vai ter que trabalhar 5 anos a mais mesmo fazendo todas as tarefas de casa sozinho? Devemos ignorar esse tipo de pai só Pq ele é uma minoria? Não né. A lei tem que ser justa” (FHR).

"Não discordo muito dele não... Mulher apanha porque quer sim... Levou uma vez e continua $\mathrm{Pq}$ ? A maioria morre Pq continuou... É um horror! E quando a mulher limpa a casa... $\mathrm{Na}$ boa tem que ensinar desde cedo homem e mulher a fazer isso... Discurso machista para mim seria dizer que isso era obrigação de mulher e ele não falou" (MES).

"Eu acho que homens e mulheres deveriam sim se aposentar na mesma idade. Se até agora as mulheres exigiram seus direitos elas tbm tem que exigir os mesmos deveres ué. E essa desculpa de que mulher faz dupla jornada é desculpa esfarrapada, os filhos ela pode muito bem contratar uma babá, mesma coisa em relação às tarefas domésticas contratar uma diarista ou dividir com o marido/companheira mas se ela não exige isso e faz tudo por conta própria já é

\begin{tabular}{|c|c|c|c|c|}
\cline { 2 - 5 } & Ano 8 & n. 14 & Janeiro - Julho 2019 & p. 213-234 \\
\hline
\end{tabular}


problema dela então, sem falar que não são todas que tem filhos [...] é aí que a gente vê que não são apenas as mulheres que sofrem a "desigualdade"!! Obs: não sou machista antes que me venham chamar disso, apenas acho que todos devem ter o mesmo direito independente do gênero. Se os homens estivessem se aposentando mais cedo q as mulheres eu bateria a boca da mesma forma! Apoio certas coisas em q o feminismo prega mas tbm não sou obrigada a concordar com tudo não" (MPW).

“O professor só disse a verdade!” (LF).

"As mesmas que apanham do marido fazem filas pra visita-los na cadeia... (RP homem).

Podemos notar nos discursos apresentados que, via de regra, toma-se uma experiência individual como signo do geral. Quando FHR diz de sua experiência de mulher que trabalha menos e possui "empregada" e quando a mesma fala de um suposto homem, pai solteiro, que trabalha e faz absolutamente tudo sozinho em sua vida privada e familiar, ela usa de exemplos individuais - o último possivelmente imaginário - para justificar seu posicionamento. Não há qualquer tentativa de relacionar as experiências individuais com os processos sociais e históricos. Isso possivelmente leve LF e FHR a se sentirem à vontade para afirmar a existência de uma "verdade" absoluta que teria sido dita pelo professor e que não deve ser questionada. O discurso da verdade indica o um desconhecimento dos processos históricos; quando FHR diz que os direitos que hoje as mulheres possuem foram-lhe dados/concedidos por homens, ela desconsidera as próprias lutas feministas pelo direito ao voto e pela cidadania. É possível que FHR recorra às suas vivências particulares exatamente na falta de um conhecimento abrangente da história e seus processos, inclusive da história do grupo ao qual pertence. Essa mesma falta parece levar à inversão dos conceitos de injustiça, minoria, e desigualdade, este último trazido por MPW para justificar sua defesa de tempos iguais de aposentadoria para homens e para mulheres, já que toda mulher teria a possibilidade de terceirizar o cuidado dos filhos, da casa e da família, naturalizando o processo de exploração do trabalho. Aqui a mulher que trabalha fora teria não apenas o direito, mas o dever, de operar como funcionária do sistema também ao explorar o trabalho de outra mulher; isso porque MPW não cogita a possibilidade da existência de "um diarista", mesmo porque são as mulheres que historicamente são responsabilizadas pelos cuidados domésticos, remunerados ou não. Nesse sentido, MPW contradiz-se ao indicar o quão livres as mulheres são para escolher realizar esses cuidados. Nota-se que, nos discursos, o sistema de exploração do trabalho torna-se infinito - e a mulher que não fizer parte dele

\begin{tabular}{|l|l|l|l|l|}
\cline { 2 - 4 } Q & Ano 8 & n. 14ta & Janeiro - Julho 2019 & p. 213 - 234 \\
\hline
\end{tabular}


(supostamente por escolha, por não contratar uma funcionária para si) é culpabilizada pela exploração (dupla) que sofre.

Além disso, nos discursos de MPW e de RP, as mulheres também são culpadas, não apenas pela realização do trabalho doméstico, mas pela violência doméstica da qual são vítimas. Todos os processos sociais, históricos e culturais de subjugação moral, violência psicológica e física e os afetos envolvidos - além da dependência afetiva e financeira - são desconsiderados. É interessante notar também que MPW faz questão de indicar sua identificação com as lutas feministas, embora não concorde com todos os seus aspectos (aqui não é possível identificar com quais aspectos ela concorda), e tenta se defender de qualquer julgamento, ao dizer "não sou machista"; mesmo porque assumir esse posicionamento direta e abertamente a levaria a contradições demasiadamente escancaradas para quem assume uma adesão ao feminismo. Afirmar que "todos devem ter o mesmo direito, independente de gênero" é negar direitos a quem historicamente tem a sua existência violada devido exatamente ao gênero, ou mais propriamente ao sexo.

É preciso reconhecer, contudo, que o discurso da igualdade como verdade tem uma dupla possibilidade. A ideologia burguesa o tornou uma verdade, na medida em que cada vez mais ambos os sexos passam a ter formas similares de adequação ao sistema. No entanto, essa mesma ideologia deixa entrever suas contradições ao negar as diferenças constituintes e constitutivas da mulher na sociedade de classes.

Outro aspecto importante que deve ser apontado é que, mesmo fazendo parte de um grupo feminista de posicionamento enfaticamente marxista, não há qualquer questionamento dos processos de exploração do trabalho nesse sistema de produção, e os discursos a favor do professor parecem envolver uma "guerra entre os sexos", que a descrição do grupo já havia indicado como problemática. Passa-se ao largo de questionar a real necessidade de um tempo de trabalho tão longo e exaustivo.

\section{Discursos contra o professor}

"Eu iria direto para a diretoria, até onde sei escola não é para ensinar machismo" (TTD). "FHR, essa é boa na interpretação de texto! E ainda defende os homens que batem nas mulheres! Bolsiminion de merda!” (TDS).

"Se fosse eu, eu batia boca com ele até ele se calar e ainda gravava tudo só pra expor esse infeliz, há algum tempo atrás um professor meu disse em uma sala cheia de mulheres que 'homem morria mais $\mathrm{Pq}$ era mais corajoso do que mulher, e que também se arriscava mais em

\begin{tabular}{|c|c|c|c|c|}
\cline { 2 - 5 } Q Q Dialectus & Ano 8 & n. 14 & Janeiro - Julho 2019 & p. 213-234 \\
\hline
\end{tabular}


algumas profissões", ele deu o exemplo de que se o pneu do carro de uma mulher furar em uma estrada enquanto tiver chovendo ela não sai do carro para não borrar a maquiagem, eu como não fico calada disse que uma mulher não sai do carro para trocar pneu $\mathrm{Pq}$ não somos irresponsáveis e imprudentes que nem um homem, e eu estava sercada de mulheres e elas olharam para o professor e começaram a sorrir, e ele ficou envergonhado se virou e continuou a aula e nunca mais tocou no assunto!" (JC).

“Gente, não deixem isso acontecer, se os professores de vocês estão falando qualquer preconceito juntem a sala e levem direto para a secretaria, pode não dar em nada, por enquanto, mas se outras salas continuarem a reclamar a pessoa acaba sendo tirada de lá" (DG - homem).

"Que absurdo, joga o nome dele na net. Infelizmente algumas pessoas aprendem pelo amor, outras só passando vergonha mesmo" (HF).

"São canalhas que tem inveja de mulher Pq queriam na verdade ser uma, já falo logo para nascer de novo ou ir em busca da realização do sonho da vida deles que completará as suas vidas, ou seja, ir atrás de uma cirurgia de mudança de sexo. Daí param de ter inveja e raiva de mulher. Mulheres têm bem mais problemas de saúde que os homens, a droga da TPM e menstruação e menopausa que acabam com as mulheres, todo o revertério hormonal e desgastes na gravidez..." (EJS).

“A mulherada tem que largar de ser besta, principalmente se for casada com um lixo invejoso desse que na verdade queria ser mulher e não gosta de ser homem. Para de se sobrecarregarem e dividam as obrigações. É isso mesmo, hoje em dia os homens como esse cara querem mulheres para os sustentar, se você faz todo o serviço doméstico faz o homem pagar todas as despesas. Mas não, tem mulher burra que além da jornada dupla, cuidar da casa, só nas costas dela, ainda divide as despesas, uma coisa ou outra vc tem que escolher. Senão um boa vida desse ainda vai querer sua aposentadoria para ele" (EJS).

Os discursos que se colocam contrários à fala e ao posicionamento do professor parecem sofrer da mesma falta de análise histórica que sofrem os discursos analisados anteriormente, na categoria que seria, a priori, oposta à esta. No entanto, tanto a forma, quanto o conteúdo (digase de passagem, de caráter absolutamente vazio), parecem ser bastante semelhantes. No último trecho apresentado, EJS faz coro com o discurso de culpabilização da mulher ao dizer que a mulher que trabalha fora e cuida da casa é "burra" e o homem "esperto" vai se aproveitar de alguém assim, necessária e naturalmente. Aqui, a figura do homem também aparece naturalizada e fora de seu contexto social e cultural. Se as mulheres são chamadas de "burras", os homens são chamados de "canalhas" na postagem anterior, onde o machismo é encarado

\begin{tabular}{|c|c|c|c|c|}
\hline Qonista Dialectus & Ano 8 & n. 14 & Janeiro - Julho 2019 & p. $213-234$ \\
\hline
\end{tabular}


como "desejo de ser mulher", em uma tentativa rasteira de psicologizar esse fenômeno histórico de dominação do outro e de si mesmo. Nesse sentido, também são naturalizados os chamados "problemas de saúde da mulher", sem que sequer se indique que as formas de vida o que inclui o mundo do trabalho - têm influência direta nos modos de manifestação das alterações hormonais que fazem parte do ciclo reprodutivo feminino: alimentação, exposição a hormônios, situações geradoras de estresse e ansiedade etc.

O que surpreende aqui é que, além da culpabilização da mulher, transparece nesse caso um discurso de ódio voltado para a própria mulher que se posicionou de modo diverso: FHR foi chamada por TDS de "Bolsominion", em uma clara alusão ao modo com que são chamadas, de modo estereotipado e a partir de uma figura do entretenimento, pessoas que são favoráveis às ideias de um determinado político brasileiro de direita. Essa linguagem da estereotipia nos remete diretamente ao pensamento do ticket já caracterizado por Horkheimer e Adorno (1985) em "Elementos do antisemitismo" e por Adorno e colaboradores (1969) na personalidade autoritária. No ticket, o pensamento é bloqueado e substituído por clichês que servem de apelos orientadores num mundo que não se compreende; não há espaço para abertura ao outro e possibilidade de vê-lo como alguém além dos estereótipos através dos quais se faz uma primeira e derradeira leitura. Interessante é que a própria analogia "bolsominions" faz referência à essa estereotipia no outro. Essa falta de abertura nos faz desistir de qualquer possibilidade de diálogo, daí a necessidade sempre colocada de busca por uma autoridade que seja capaz, em algum momento (agora ou depois), de solucionar a questão: expulsar o outro, banir sua circulação do mesmo espaço que circulo e, ao mesmo tempo, me proteger e manter na situação de menoridade em que permaneço. Por isso, TTD e DG se posicionam de modo a indicar a necessidade de sempre "denunciar" o caso, seja na diretoria, seja na secretaria, não para que o diálogo possa acontecer com a participação de mais atores, mas para que a pessoa "acabe sendo tirada de lá".

O princípio de eliminação do outro também opera através de um determinado posicionamento de "justiceiro": à falta de diálogo responde-se com a exposição do outro nas redes sociais, como numa espécie de vingança. O sujeito "machista" deve pagar a humilhação que faz às mulheres com sua própria humilhação, prolongando e reproduzindo um ciclo eterno de subjugação, ridicularização e dominação típicos do estado de coisas atual. Mais uma vez, a "crítica" realizada pelos interlocutores desse diálogo sequer toca na problemática da relação entre os sexos na sociedade de classes. O que temos aqui é uma espécie de identificação com o agressor - mecanismo de defesa descrito por Anna Freud e bastante referido por Adorno em

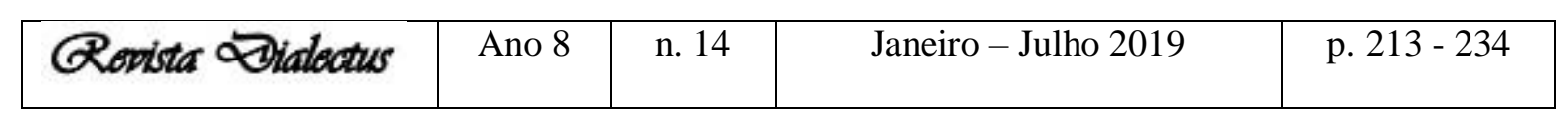


seus estudos sobre o preconceito - que se faz notar de modo eficaz na forma com que os oprimidos se atacam mutuamente e esquecem-se de se posicionar contrariamente frente ao que de fato é a causa da opressão. Esse mesmo mecanismo foi descrito por Leo Lowenthal nos campos de concentração nazistas.

\section{Discursos contra a aluna}

"Estuda, se forma, trabalhe e não se relacione com um homem que pense como ele, ué. Seja empoderada, querida! Saia desse mundinho do jardim da infância, onde todo mundo só fala coisinha bonitinha e coisa que nos agrada. Esteja preparada para a vida, porque durante toda ela, você vai ver pessoas que te enojam e pessoas que dizem coisas que você não gosta. Eu já tive que ouvir professor meu pregando comunismo... Já tive que ouvir professor dizendo que existe mulher de testículos... Já tive que ouvir professor meu defendendo Dilma... Nem por isso vim me vitimizar" (LF).

"Então, eu me enojo de professor que fica em sala de aula passando SUA OPINIÃO, SEU PONTO DE VISTA como verdade absoluta aos alunos que estão lá para aprender. Dessa forma, esses alunos não aprendem a questionar, pois não conhecem todos os lados e, sim o que o professor quer que conheçam. Nem por isso me vitimizando e dizendo que sou vítima oprimida" (LF).

Essa frequentadora da página se manifestou atacando diretamente a estudante autora do desabafo, mesmo que não tenha sido ela quem compartilhou seu texto nesse grupo. LF "aconselhou" a estudante a se "empoderar" através do estudo, da formação e do trabalho, para não precisar se relacionar com homens como o "professor" denunciado. Tal empoderamento é indicativo de uma liberdade que seria conquistada através do dinheiro, da possibilidade de aumento de seu poder aquisitivo. "Esteja preparada para a vida", diz LF, aconselhando a estudante a operar certo "princípio de realidade", de "adaptação" ao que existe. Além de pregar o empoderamento através de um discurso em que se coloca em posição de superioridade, LF chama a estudante de infantil e não aprofunda a questão, tomando a ideia de infantil como inadequada, quando, de outro modo, o infantil poderia muito bem nos indicar possibilidades impensadas pela visão já adaptada e a imaginação já bloqueada do adulto.

Em sua segunda postagem, ela deixa claro que compreendeu o posicionamento do professor como uma "questão de opinião", de "ponto de vista" e, portanto, legítimo de ser colocado como qualquer outra opinião política - embora ela diga sentir 'nojo' de professor que manifesta seus posicionamentos em sala de aula, como se os alunos não tivessem outros

\begin{tabular}{|l|c|c|c|c|}
\cline { 2 - 5 } & Ano 8 & n. 14 & Janeiro - Julho 2019 & p. $213-234$ \\
\hline
\end{tabular}


momentos em que podem experienciar os diversos posicionamentos existentes. É claro que a profissão de ensinar garante ao professor certo espaço de autoridade, mas lidar com a autoridade faz também parte do processo formativo, inclusive quando se faz necessário questionar preconceitos arraigados.

\section{Discursos a favor da aluna}

"trabalhe e não se relacione com homem que pense como ele". Essa foi triste! O que uma coisa tem haver com a outra? Não estamos aqui para aceitar esse tipo de coisa, nada impede de continuarmos a termos professores assim em mestrado e doutorado e patrão assim. Na vida nem sempre dá pra escolher com quem se relacionar. Temos que combater esse tipo de comportamento sim, e não fingir que não está ouvindo. Ouvir professor defendendo Dilma? De que isso importa? Ele não tem direito a posicionamento político? Por que uma pessoa iria se vitimizar por ter um professor defendendo Dilma (não me sentiria vítima de nada se um professor defendesse o Aecio, apenas pensaria que ele tem problemas)? Oxe! (AC).

"essa aí deve ser apoiadora da "escola sem partido", no qual o professor não pode mais falar sobre política na sala de aula, exatamente para manter as coisas como estão. Ah esses meninas passivas que acham que o mundo vai mudar só com contemplação... Ninguém é obrigada a aceitar nada não, moça, inclusive você podia ter debatido com seu professor ao invés de ficar fazendo cara feia e reclamando no facebook. Ninguém está se vitimizando aqui, o espaço é pra desabafar mesmo" (DAC).

"A minha resposta é sempre eu não me importo em me aposentar mais tarde, mas quero igualdade salarial" (PRA).

Essas manifestações de defesa da estudante (as duas primeiras), foram em resposta aos ataques realizados por LF. AC questionou exatamente a suposta relação entre trabalho e liberdade, denunciando que a independência financeira da mulher não está diretamente relacionada com a conquista de sua liberdade. Por isso, o comportamento machista deve ser combatido. AC também problematiza a diferença entre um posicionamento político (onde se expressa diretamente a respeito de uma política formal de estado) e um posicionamento preconceituoso que enquadra e cerceia o outro e sua existência. Já DAC responde LF utilizandose de expressões tendenciosas, na tentativa de desabonar a interlocutora, ao invés de manter o diálogo sustentado por argumentos críticos: ela julga que LF seria adepta da proposta de "escola sem partido", e a chama de "passiva". Contudo, LF não se posiciona de forma passiva, ao contrário, seu conselho de empoderamento é totalmente ativo - o que poderia ser questionado

\begin{tabular}{|c|c|c|c|c|}
\hline Qonista Dialectus & Ano 8 & n. 14 & Janeiro - Julho 2019 & p. $213-234$ \\
\hline
\end{tabular}


é a possibilidade que ele tem de, de fato, operar transformações nessa sociedade ao se realizar do mesmo modo que o sistema operante. Em seus textos sobre Educação e Emancipação, Adorno (1995) aponta esse como um dos problemas da emancipação: a organização em que vivemos e a ideologia dominantes opera o obscurecimento das consciências pelo existente e a adaptação é exigida num movimento contínuo pela realidade que produz "pessoas ajustadas". PRA, ao se colocar a favor da estudante, simplesmente compartilha com as demais que para ela o importante é conseguir igualdade salarial. Novamente os discursos passam ao largo do questionamento da sociedade - o que nos faz lembrar do conceito marcuseano de sociedade unidimensional e do fechamento do universo do discurso mesmo dentre aqueles que se propõem a estar na luta pela libertação de grupos sociais historicamente oprimidos.

\section{Considerações finais}

Esse pequeno debate nos traz uma fotografia de um momento específico naquele grupo. Ele parece, inicialmente, contradizer a ideia de que exista qualquer possibilidade emancipatória advinda das minorias e suas lutas, na medida em que fica clara a contradição entre a ideia de libertação, base da luta feminista, e o modo estereotipado e rígido com que o debate se estabelece. A ideia, contudo, aqui, não é traçar um perfil das chamadas "massas" no intuito de desabonar seus movimentos com pretensões libertárias - o que ocorre com bastante frequência nos estudos sobre os movimentos populares desde Le Bon. Apontar pura e simplesmente a irracionalidade no interior dos movimentos revolucionários serve à manutenção do estado de coisas atual. É exatamente nesse sentido que os movimentos de direita traçam suas críticas aos movimentos de esquerda: apontam suas contradições na tentativa de arruinar seu potencial negativo. Bastante significativa é a última postagem feita na página "fake" criada para desabonar esse movimento. Existe uma página de mesmo nome, com cerca de 4 mil curtidas, criada e movimentada por opositores ao movimento feminista. Ali, um dos administradores da página postou, no dia 30 de março:

"É com muita insatisfação que venho as comunicar sobre algo muito importante. No meio da militância feminista sofremos opressões por várias partes, isso é, desde a sociedade patriarcal, até as "mulheres" que não aceitam o feminismo, até mesmo das que te chamam de "mana" e pelas costas te fuzilam. Sem contar das que já não buscam por igualdade, mas sim pelo caos, deixando claro a misandria, o ódio puro aos homens. E é por este meio que comunico à vocês sobre o FIM da militância feminista, pelo motivo de que, até mesmo no próprio meio há opressões, sendo impossível de militar desta forma, com tanta falsidade e traição. São

\begin{tabular}{|l|c|c|c|c|}
\cline { 2 - 4 } & Ano 8 & n. 14 & Janeiro - Julho 2019 & p. $213-234$ \\
\hline
\end{tabular}


impostos padrões no feminismo (por quem diz fugir de padrões), e não aceitamos hipocrisias. Então manas, prestem bem atenção se é esse meio que vocês querem mesmo seguir, e cuidado com quem diz estar do seu lado, pois eu jamais vi um movimento tão falso, sujo e hipócrita como este! Aqui deixo essa mensagem de alerta para vocês, e anunciando o fim do que já deveria ter acabado, ou do que jamais existiu, a luta pela igualdade, o FEMINISMO!"

Esse tipo de argumento é encontrado com bastante frequência nos discursos daqueles que se colocam em posição conservadora. No estudo sobre a personalidade autoritária e hoje na política brasileira - para pegar um exemplo bastante próximo - as críticas feitas à democracia são utilizadas como justificativa para abolir a democracia e não para construí-la processualmente por meio da autorreflexão e da autocrítica. É como se os erros cometidos na democracia minassem toda e qualquer possibilidade de sua realização. Isso é uma falácia do pensamento antidemocrático.

O próprio fato de que, hoje, as pessoas têm se reunido cada vez mais em torno de temas específicos em prol da libertação nos indica a existência de possibilidades que devem ser exploradas e que não existiram em outros momentos históricos. E os caminhos para tal libertação deve ser traçado a partir do já existente.

Não podemos acreditar ingenuamente, contudo, que o potencial negativo, que a teoria tão eficazmente aponta existir nas minorias, encontrará livremente na história seu momento de realização. Teríamos nesse caso uma dialética “positivisada”. É preciso encarar com maturidade as contradições da existência aqui e agora. Não devemos fechar os olhos para os dados empíricos que devem ser analisados criticamente para a compreensão do presente e das possibilidades do futuro. No prefácio ao livro que relata a pesquisa de Adorno e colaboradores sobre o preconceito, Horkheimer nos fala do receio de muitos teóricos críticos de que as análises realizadas ali pudessem ser utilizadas contra as próprias minorias, para bloquear os processos de transformação da sociedade. Mas é ele mesmo quem ali nos alerta que esse é um medo que deve ser superado: uma análise crítica, sistemática e sincera do existente precisa enfrentar seus próprios fantasmas. A tomada de consciência de seu próprio engodo é condição necessária para a efetividade da luta pela libertação - e nisso a pesquisa empírica criticamente orientada tem um papel de extrema relevância. O reconhecimento de nossos determinantes, contradições e situação no mundo atual pode nos ajudar a liberar aquele potencial negativo que hoje encontra ainda poucas brechas de realização.

“A esperança de que o horror terreno não tenha a última palavra é, sem dúvida, um desejo não científico" (Horkheimer, 2008, p. 26), escreveu Horkheimer no prefácio de $A$

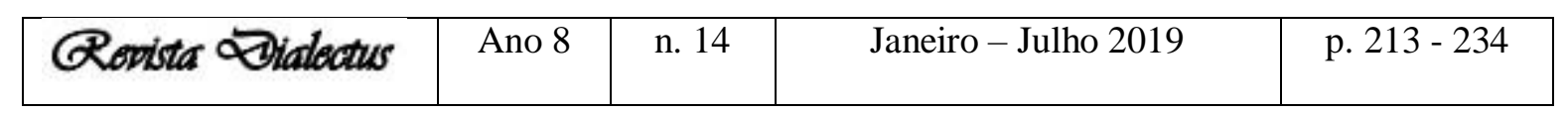


imaginação dialética, de Martin Jay. Que possamos somar forças, na luta pela liberdade, ao trabalho realizado por Adorno, Marcuse e outros pesquisadores da Escola de Frankfurt - que realizemos pesquisas que ainda não têm lugar na universidade "com a convicção de que formular o negativo" é "mais importante do que construir carreiras acadêmicas".

A primeira coisa que temos que fazer, como intelectuais, professores, estudantes de Teoria Crítica, é questionar nosso estranhamento frente às formas "desconhecidas" de saber e de existência, aquelas que não entendemos, que não alcançamos por conta de nossos próprios padrões de pensamento. Finalizo com a pergunta: Quem ousará atingir o não conceitual?

\section{Referências:}

ADORNO, T.W. Dialética negativa. Trad. Marco Antonio Casanova. Rio de Janeiro: Jorge Zahar Ed., 2009.

Lectures on negative dialectics. Trad. Rodney Livingstone. Cambridge/Malden: Polity Press, 2010.

. et al. The authoritarian personality. New York: WW Norton, 1969.

HOKRHEIMER, M. Towards a new manifesto. London/New York: Verso, 2011.

CHAVES, L. G. M. Minorias e seu estudo no Brasil. Revista de Ciências Sociais, Fortaleza, v. 1, n. 1, p. 149- 168, 1971. Disponível em: http://www.repositorio.ufc.br/handle/riufc/4487. Acesso em agosto de 2016.

DAVIS, A. Y. Freedom is a constant struggle: Ferguson, Palestine and the foundations of a movement. Chicago: Haymarket Books, 2016.

HORKHEIMER, M. Ocaso. Barcelona: Anthropos, 1986.

ADORNO, T.W. Dialética do esclarecimento: fragmentos filosóficos. Rio de Janeiro: Jorge Zahar, 1985.

JAY, M. A imaginação dialética: história da Escola de Frankfurt e do Instituo de Pesquisas Sociais 1923-1950. Rio de Janeiro: Contraponto, 2008.

LACAN, J. O mestre e a histérica. In: Lacan, J. O seminário, livro 7: o avesso da psicanálise 1969-1970. Rio de Janeiro: Zahar, 1992.

. O homem e a mulher. In: Lacan, J. O seminário, livro 18: de um discurso que não fosse semblante. (1971). Rio de Janeiro: Zahar, 2009.

RIBAS, G. C. Considerações sobre a evolução filogenética do sistema nervoso, o comportamento e a emergência da consciência. Rev. Bras. Psiquiatr. São Paulo, v.28, n.4, p.326-338, Dec. 2006.

\begin{tabular}{|l|l|l|l|l|}
\cline { 2 - 4 } & Ano 8 & n. 14 & Janeiro - Julho 2019 & p. $213-234$ \\
\hline
\end{tabular}


SARTRE, J.P. Anti-semite and jew. New York: Schocker Books, 1966.

\begin{tabular}{|l|l|l|l|l|}
\hline Q & Ano 8 & n. 14 & Janeiro - Julho 2019 & p. 213 - 234 \\
\hline
\end{tabular}




\section{A CARTA DE FEUERBACH A HEGEL}

Adriana Veríssimo Serrão ${ }^{1}$

As três cartas que nos finais de 1828 acompanham o envio da dissertação De ratione, una, universali, infinita apresentada por Ludwig Feuerbach à Universidade de Erlangen, embora de desigual relevo quanto ao conteúdo filosófico, formam no seu conjunto um documento de especial interesse para a compreensão da biografia intelectual de Feuerbach.

A carta a Schelling, à época professor em Munique, é concisa, cerimoniosa e meramente circunstancial $^{2}$. Para Johann Paul Harl, professor em Erlangen e membro do júri, Feuerbach redige uma sinopse desenvolvida que explicita o tema central da dissertação - a demonstração da essência da razão - e recapitula alguns tópicos argumentativos. Unicamente o pensar corresponde à essência da razão, porque só quando pensa o indivíduo se desliga de si mesmo para se ligar a outros seres pensantes, tornando-se assim membro de uma comunidade sem divisões, não limitada por uma ordem superior, nem interrompida interiormente por nenhuma diferença. Se a sensação está presa ao senciente - quando sinto, "eu sou eu" - e nos sentimentos, como o amor e a amizade, sou "eu com outros", conservando cada um, o eu e o outro, a respectiva individualidade, ao pensar, o indivíduo participa de uma esfera comum onde se anulam as condições privada, pessoal ou intersubjectiva, tornando-se num ser universal. Deste modo, o pensar, tal como a consciência que o acompanha, não deve ser considerado uma faculdade subjectiva, mas sim uma actividade comunitária, una e infinita.

A determinação da razão enquanto pensamento e o primado da cogitatio sobre o cogito não se colocam, neste primeiro trabalho, no quadro de uma filosofia do conhecimento. Traçando uma direcção constante ao longo da obra posterior, a reflexão sobre a natureza da razão é conduzida numa perspectiva onto-antropológica, como condição real da possibilidade da fundação, e da manutenção, da comunidade humana. A unidade universal da razão é, por isso, equiparada, sem mais, à unidade universal dos homens - "a unidade dos homens nada mais exprime ou significa do que a unidade da própria razão" - e esta, por sua vez, protagonizada pela Humanidade enquanto um género - "ao pensar, eu próprio sou o género humano, não o homem singular que sou quando sinto, vivo, ajo, nem um certo homem qualquer (este ou

\footnotetext{
1 Doutora em Filosofia, Universidade de Lisboa, Departamento de Filosofia, Centro de Filosofia da Universidade de Lisboa. E-mail : adrianaserrao@fl.ul.pt

2 Carta a Friedrich Wilhelm Joseph von Schelling (18 de Dezembro de 1828); L. Feuerbach. Gesammelte Werke (= GW), hrsg. von Werner Schuffenhauer, Berlin, Akademie Verlag, 1967 e ss., vol.17, pp. 113-114.
} 
aquele), mas ninguém." ${ }^{13} \mathrm{O}$ pensar é simultaneamente a essência da razão e a essência do homem.

A imagem mais usada para retratar esta visão da imanência não é a do tempo sucessivo, mas a do espaço simultâneo, omni-englobante, ilimitado e sem partes, no qual as consciências subjectivas, embora separadas em diferentes lugares físicos, estão permanentemente reunidas no elemento da consciência universal; assim, enquanto uns dormem, outros estão a pensar, continuando a actividade pensante a envolvê-los, sem nunca sofrer interrupções. Outro argumento da dissertação retomado nesta carta invoca o erro como marca do limite e sinal da distância entre finito e infinito: se o indivíduo isolado fosse, ou tivesse em si, o pensar, nada mais haveria para além dele, deixando de existir o erro, ao contrário do sentir que nunca erra, dada a coincidência do senciente com as suas sensações ${ }^{4}$.

A carta dirigida a Hegel destaca-se pela amplitude reflexiva. Em vez de um resumo das teses, Feuerbach transforma-a numa indicação programática, no enunciado das grandes linhas para o futuro da filosofia. Invocando a qualidade de aluno presencial em Berlim, entre o semestre de Verão de 1824 e o semestre de Inverno de 1825-26, onde frequenta, com excepção das Lições de Estética, todos os cursos de Hegel - "Lógica e Metafísica", "Filosofia da Religião", "Filosofia da História Universal", "Direito Natural e Ciência Política", "Filosofia do Espírito ou Antropologia e Psicologia", "História da Filosofia", "Filosofia da Natureza ou Física Racional"5 -, Feuerbach assume a apropriação do "espírito especulativo" colhido nos

\footnotetext{
3 De ratione, una, universali, infinita, GW, vol. 1, respectivamente p. 96 e p. 12. Com a dissertação manuscrita De infinitate, unitate atque communitate rationis, Feuerbach obtém em 25 Junho de 1828 o grau de doutor em Filosofia. A versão impressa, revista e ampliada, com o título De ratione, una, universali, infinita foi apresentada como Habilitationsschrift e defendida com sucesso em provas públicas a 6 de Dezembro, com a finalidade de obter a licentia docendi para ensinar como Privatdozent. Concedida a 13 de Fevereiro de 1829, a licença régia para dar "lições sobre temas (Gegenstände) da filosofia" iniciaria o curto período de professor de "História da Filosofia" e "Lógica e Metafísica" na Friedrich-Alexander-Universität de Erlangen.

4 Carta a Johann Paul Harl (início de Dezembro de 1828), GW, vol. 17, pp. 109-113.

5 Para a reconstituição dos anos universitários, veja-se a Introdução de Werner Schuffenhauer ao volume 1 dos Gesammelte Werke. Entre as principais biografias intelectuais de Feuerbach, com importantes informações sobre a fase estudantil, são de consultar: Karl Grün, Ludwig Feuerbach in seinem Briefwechsel und Nachlaß, sowie in seiner philosophischen Charakterentwicklung, Leipzig und Heidelberg: C. F. Winter Verlag, 1874, vol. I; Wilhelm Bolin, Ludwig Feuerbach. Sein Wirken und seine Zeitgenossen. Mit Benutzung ungedruckten Materialsl, Stuttgart: Cotta, 1891; Wilhelm Bolin, "Biographische Einleitung" in: Ausgewählte Briefe von und an Ludwig Feuerbach. Zum Säkulargedächtnis seiner Geburt, Leipzig: Otto Wigand, 1904, Bd. 1, pp. 3-211; depois em: Ludwig Feuerbach. Sämtliche Werke, Bd. XII, Stuttgart, 1964; Adolf Kohut, Ludwig Feuerbach. Sein Leben und seine Werke. Mit ungedruckten Briefen von L. Feuerbach und Anselm Ritter v. Feuerbach, Leipzig: Fritz Eckard, 1909; Gustav Radbruch, Die Familie Feuerbach, eine geistige Dynastie. Gestalten und Gedanken. Acht Studien, Leipzig, 1944; 2. a ed. ampliada: Zehn Studien,
}

\begin{tabular}{|l|l|l|l|l|}
\cline { 2 - 4 } & Ano 8 & n. 14 & Janeiro-Julho 2019 & p. $235-247$ \\
\hline
\end{tabular}


ensinamentos e ideias do mestre, mas já na figura de um pensador livre, não de um seguidor escolar.

Será importante recordar o contexto desta estreita relação de discípulo a mestre, que longe de ter acontecido ocasionalmente foi escolhida por Feuerbach, quando ainda estudante de teologia em Heidelberg solicitara ao pai autorização para a transferência de curso e de universidade. Mudar de teologia para filosofia significava tout court estudar a filosofia em Berlim e com Hegel. Anuência difícil, fruto de demorada ponderação por parte de Paul Johann Anselm, já porque o diploma de teologia permitiria o acesso imediato a um lugar de pastor, garantindo a colocação profissional de um membro de uma família numerosa, já porque o seu racionalismo crítico rejeitava a posição de uma filosofia única e definitiva:

[...] mais tarde ou mais cedo estarás inteiramente certo de que [...] nunca existiu uma filosofia única, mas sempre e só filósofos; de que há, sempre houve e sempre haverá tantas filosofias quantas as cabeças pensantes que procuram compreender de si para si mesmas o inconcebível e o inapreensível; quem corta artificialmente o sistema das suas opiniões através de "ses" e "porques" e "portantos" e o vende como uma ciência (objectiva), ou mesmo como a ciência das ciências, ou é um sofista ou alguém confundido na auto-ilusão ${ }^{6}$.

Em contraste, a insistência, dramatizada pelo jovem de vinte e um anos, sublinhava o desinteresse pelas aulas e a insatisfação com matérias que se repartiam entre a aridez da exegética bíblica e obscuridade do misticismo. Dos professores de Heidelberg, apenas a orientação especulativa de Karl Daub permitia vislumbrar um conceito filosófico de Deus, anunciando-se por esta via, não pelo cepticismo moralizante dos kantianos, nem pelo sentimentalismo exaltado dos românticos, o ansiado encontro com a Ciência ${ }^{7}$ : "tudo me chama para Berlim e para longe de Heidelberg" ${ }^{8}$. Também a Daub confessa o seu desapontamento com a estreiteza dos temas teológicos e deixa claro que o desejo da filosofia, mais do que um objecto de estudo, se confunde o ideal de abraçar a inteireza da vida - "abstraindo da sua existência

Stuttgart, 1954; Uwe Schott, Die Jugendentwicklung Ludwig Feuerbachs bis zum Fakultätswechsel 1825. Ein Beitrag zur Genese der Feuerbachschen Religionskritik. Mit einem bibliographischen Anhang zur Feuerbach-Literatur, Göttingen: Vandenhoeck \& Ruprecht, 1973; Hans-Martin Sass, Ludwig Feuerbach in Selbstzeugnissen und Bilddokumenten, Reinbeck bei Hamburg: Rowohlt, 1978; Joseph Winiger, Ludwig Feuerbach. Denker der Menschlichkeit. Eine Biographie, Berlin: Aufbau Taschenbuch Verlag, 2004; Francesco Tomasoni, Ludwig Feuerbach. Biografia intelletuale, Brescia: Morcelliana, 2011.

\footnotetext{
Carta de Paul Johann Anselm von Feuerbach (20 de Abril de 1825), GW, vol. 17, p. 82.

Carta a Paul Johann Anselm von Feuerbach (Outono de 1823), GW, vol. 17, pp. 33-38.

8 Carta a Paul Johann Anselm von Feuerbach (8 de Janeiro de 1824), GW, vol.17, p. 42.
}

\begin{tabular}{|l|l|l|l|l|}
\cline { 2 - 4 } & Ano 8 & n. 14 & Janeiro-Julho 2019 & p. $235-247$ \\
\hline
\end{tabular}


empírica, o filósofo é homem absolutamente universal" ${ }^{9}$-, numa visão da totalidade identificada pelos pólos do Homem e da Natureza:

Eu sou como uma alma ávida e ambiciosa que quer abarcar em si e consumir tudo, não porém como um agregado empírico, mas sim como totalidade sistemática; o meu exigir é ilimitado, incondicionado: quero gravar a Natureza no meu coração, em face de cuja profundidade o cobarde teólogo recua, cujo sentido o físico compreende mal, cuja salvação unicamente o filósofo leva a cabo. Quero gravar no meu coração o Homem, mas o Homem inteiro... ${ }^{\mathbf{1 0}}$.

A doutrina de Hegel corresponderá inteiramente à expectativa alimentada do encontro com abertura mental do filósofo e à descoberta do amplo mundo do espírito, desde logo associada à filosofia no seu mais alto expoente, como ciência da apreensão da realidade em um todo sistemático, mesclando-se a afinidade intelectual com a mais elevada imagem da pessoa do professor:

\begin{abstract}
Sim, mantive com Hegel uma relação mais íntima, mais proveitosa do que com qualquer outro dos nossos antepassados espirituais, porque o conheci pessoalmente; fui durante dois anos o seu ouvinte, o seu ouvinte atento, incondicional, entusiasmado. Não sabia o que queria e devia fazer, tão desfeito e dilacerado estava quando cheguei a Berlim; mas mal o ouvira durante meio ano, já a minha cabeça e coração se encontravam recompostos por ele; sabia o que devia e queria fazer: Não teologia, mas filosofia! Não tagarelar e delirar, mas aprender! Não acreditar, mas pensar! Foi com ele que cheguei à consciência de mim e à consciência do mundo. Foi a ele que chamei outrora o meu segundo pai, tal como a Berlim o meu lugar de nascimento espiritual. Foi o único homem que me deixou sentir e perceber o que é um professor, o único em quem encontrei o sentido para esta palavra antes tão oca, a quem me senti ligado pela profunda gratidão. [....] O meu professor foi, portanto, Hegel, eu, o seu aluno; não o nego, reconheço-o ainda com gratidão e alegria, talvez hoje melhor do que outrora. ${ }^{11}$
\end{abstract}

Não é difícil colher em múltiplos depoimentos autobiográficos convergentes o que teria sido, no geral, o resultado dessa frequência. Não tanto a aprendizagem de conteúdos, a preferência dirigida para uma ou outra disciplina específica, quanto o contacto com o puro trabalho do pensamento, o acesso a um método que se servia exclusivamente do pensar e rejeitava o recurso à intuição e à fé, método esse condensado na lógica enquanto organon da filosofia, como escreve o irmão no termo do ciclo berlinense:

9 Carta a Karl Daub (29 de Janeiro de 1825), GW, vol.17, p. 62.

10 Carta a Paul Johann Anselm von Feuerbach (22 de Março de 1825), GW, vol.17, pp. 71-72.

11 Werner Schuffenhauer, "'Verhältnis zu Hegel'. Ein Nachlaßfragment von Ludwig Feuerbach", Deutsche Zeitschrift für Philosophie, Berlin, 30 (1982), 509-510. O requerimento dirigido ao Rei solicitando a autorização para ensinar contém o registo das cadeiras feitas e o elenco dos professores de Berlim: Schleiermacher e Neander em Teologia, van der Hagen e Böckh em Filologia, Erman em Física, Ideler em Matemática e Astrognosia, Ranke em História, von Henning em Teoria da Cor; Carta a Luís I, Rei da Baviera (5 de Agosto de 1828), GW, vol. 17, p. 101.

\begin{tabular}{|l|l|l|l|l|}
\cline { 2 - 4 } & Ano 8 & n. 14 & Janeiro-Julho 2019 & p. $235-247$ \\
\hline
\end{tabular}


Já estou despachado do Hegel; com excepção da Estética frequentei todas as suas lições, frequentei a Lógica mesmo duas vezes. Mas a Lógica de Hegel é como que o corpus juris, as Pandectas da filosofia; ela contém a filosofia inteira, tanto a antiga como a moderna, segundo os seus princípios de pensamento; ela é acima de tudo a apresentação do seu método. O mais importante é precisamente apoderar-se não apenas do conteúdo, mas também do método de uma filosofia. ${ }^{12}$

Entre a saída de Berlim e a matrícula em Erlangen, onde, dando cumprimento aos regulamentos bávaros, deveria terminar o curso, medeia uma fase mal conhecida. Numa escola dominada por um forte núcleo de pietistas e em cujo corpo docente, parco em bons professores de filosofia, apenas pontificavam kantianos sem brilho, os "críticos" preocupados em determinar "se e como se pode ver, antes de se ver"13, Feuerbach dedica esse último ano a cadeiras de ciências da Natureza - botânica, anatomia, fisiologia -, mas não de filosofia. Redigida num ambiente pouco estimulante, a tese sobre a universalidade da razão trazia à Baviera a influência de Berlim e lançava sobre o doutorando vindo de fora a suspeição de adepto da filosofia especulativa. Perfilhar um espírito especulativo significava, porém, para ele algo muito diferente de um hegelianismo obediente. Significava prosseguir a racionalização consumada por Hegel como termo de um ciclo histórico, e nessa medida finalizada, para a ampliar, passando uma outra ordem das coisas, isto é, levando a filosofia para fora da filosofia. A tensão entre acabamento - o saber de si do pensar consumado no interior do pensar - e inacabamento - a necessidade de transpor os limites da escola para ganhar corpo no todo da Humanidade - é o motor do andamento futurizante impresso no motivo da realização (Verwirklichung) e mundanização (Verweltlichung) da ideia. Porque só a filosofia especulativa, porque realizada em si mesma, se podia realizar fora dela, mas sem se realizar fora dela, não estaria cumprida na sua vocação e capacidade de racionalização do mundo.

A instauração desta consciência universal a ser assumida pela Humanidade no seu conjunto não poderia emergir da continuidade com os procedimentos da filosofia académica. A incarnação do Logos, que congrega como eixo principal os diversos tópicos desta carta-manifesto, deveria ser conduzida por uma nova "espécie de filosofar", interveniente e não só compreensiva, combativa e não só hermenêutica. A descida do "céu" à "terra" não se cumpre por via estético-literária como expressão de intuições poéticas, nem se limita a uma vulgarização da filosofia. Como radicação da verdade e preparação do futuro, responde à urgência do tempo e ganha uma feição prática.

12 Fragmente zur Charakteristik meines philosophischen curriculum vitae, GW, vol.10, p. 155.

13 Carta ao irmão Eduard (Dezembro de 1827), GW, vol.17, p. 95.

\begin{tabular}{|l|l|l|l|l|}
\cline { 2 - 4 } & Ano 8 & n. 14 & Janeiro-Julho 2019 & p. $235-247$ \\
\hline
\end{tabular}


Das duas principais linhas que configuram a mentalidade da época moderna, aqui enunciadas como esboço de uma filosofia da história, ambas centradas na subjectividade - o "eu penso" cartesiano e o "eu creio" luterano - só a primeira teria sido verdadeiramente superada como princípio da filosofia, e apenas no interior dela. Repousando sobre o si-mesmo (Selbst), divino e humano, sustentado num eu firme, substancializado, o cristianismo é o reduto da subjectividade endeusada, reproduzida à escala humana e levada ao clímax na figura da alma imortal persistindo num além fora do tempo mundano. Daí que a religião se coloque face à filosofia não só como concepção do mundo concorrente, mas sobretudo como efectivo obstáculo que quebra o continuum do género humano e nele introduz focos de cisão; como antítese da filosofia, é o "outro da razão". Porque entra mais fundo na humanidade dos homens, exercendo mais forte influência sobre a consciência comum ao apelar a representações, sentimentos e crenças, promessas de salvação individual num mundo melhor, o fundamento da religião tem de ser pura e simplesmente erradicado.

Tal como para Platão o caminho para a verdade não poderia coexistir com a influência sedutora dos divulgadores de mitos, sendo imperioso o seu afastamento dos muros da cidade, para Feuerbach, a fundação de uma nova época governada pela luz exclusiva da razão tem como condição primeira o desaparecimento da subjectividade como modo da intuição (Anschauungsweise). O anúncio de um combate sem tréguas, sem conciliação possível, entre poderes lutando pela dominação e cuja vitória final só será alcançada com a destronação da autonomia do Selbst imprime à carta a Hegel um tom eminentemente político.

Está fora de causa, no actual estado da recepção de Feuerbach, circunscrever o interesse deste texto à discussão erudita sobre o seu hegelianismo ou examinar a fidelidade da pretensa recepção de Hegel, controvérsia que marcou décadas da literatura. O silenciamento da subjectividade do absoluto hegeliano a favor de um absoluto comunitário e objectivo; a ausência da dialéctica a favor da aniquilação do contrário numa unidade total e sem diferenças; a inflexão antropológica na eleição do género como único portador do espírito - são sinais evidentes de que Feuerbach não está já a expor Hegel, mas a delinear marcos de um percurso pessoal. Dois anos mais tarde, a primeira grande obra, os Gedanken über Tod und Unsterblichkeit, articulará subjectividade e dualismo como duas faces da mesma atitude de

\begin{tabular}{|l|l|l|l|l|}
\cline { 2 - 4 } & Ano 8 & n. 14 & Janeiro-Julho 2019 & p. $235-247$ \\
\hline
\end{tabular}


cisão, logo, de irracionalidade, na crítica conjunta à ideia de imortalidade da alma e à desvalorização da Natureza decorrente da posição do espírito criador $^{14}$.

Formulados com clareza, numa expressão livre da formalidade contida da carta, três motivos de divergência com princípios fundamentais do pensamento de Hegel, compõem o fragmento coetâneo, ou ligeiramente anterior porque datado de 1827-28, com o título "Zweifel". Em primeiro lugar, a reabilitação da Natureza como ser imediato, liberta do estatuto de "posta pelo espírito" ou derivada de um acto espiritual prévio. Em segundo, a impossível conciliação da filosofia e da religião, distinguindo-se na religião, por um lado, a "fé", por outro, as "doutrinas da fé", ou seja, a teologia. Por último, a transformação da filosofia como consciência recapitulativa do passado em filosofia dirigida para o futuro.

\section{Dúvida}

Como se relaciona o pensar com o ser, a Lógica com a natureza? Está fundada a transição daquela a esta? Onde está a necessidade, onde está o princípio desta passagem? Sem dúvida que, no interior da Lógica, vemos determinações simples como ser, nada, algo, finito, infinito, essência, fenómeno transitarem umas nas outra e superarem-se, mas elas são em si mesmas determinações abstractas, unilaterais, negativas; uma pergunta apenas: como pode então a ideia, enquanto a totalidade que abarca em si todas estas determinações, ser posta em igual categoria precisamente com estas determinações finitas? A necessidade da progressão lógica é a própria negatividade das determinações lógicas. Mas o que é então o negativo na ideia absoluta, completa? O facto de ela ser apenas e ainda no elemento do pensar? De onde é que sabes que há ainda um outro elemento? Da Lógica? De modo algum; pois precisamente a partir de si a Lógica apenas sabe de si, apenas sabe do pensar. Logo, o outro da Lógica só pode ser deduzido da Lógica não logicamente, mas ilogicamente, i.e., a Lógica apenas transita na natureza, porque o sujeito pensante, encontra previamente uma existência imediata, uma Natureza e é constrangido, dado o posicionamento natural, a reconhecê-la. Se não houvesse uma Natureza, nunca a imaculada virgem Lógica produziria uma a partir de si.

Como se relaciona a filosofia para com a religião? - Hegel insiste muito na concordância da filosofia com a religião, nomeadamente com as doutrinas da religião cristã, embora capte a religião apenas como um patamar

14 Sobre o debate do hegelianismo do jovem Feuerbach, que marcou, por via indirecta, uma fase da descoberta do pensamento de Feuerbach, devem consultar-se: Simon Rawidowicz, Ludwig Feuerbachs Philosophie. Ursprung und Schicksal, Berlin: W. De Gruyter, 2.a ed. 1964 [1.a ed.: 1931], pp. 9-20; Claudio Cesa, Il giovane Feuerbach, Bari: Laterza, 1963; Max W. Wartofsky, Feuerbach. Cambridge/ London/ New York/ Melbourne: Cambridge University Press, 1977; Claudio Cesa, Introduzione a Feuerbach, Roma: Laterza, 1978; Manuel Cabada Castro, Feuerbach y Kant. Dos Actitudes antropológicas, Madrid: Comillas, 1980, pp. 21-23; Alexis Philonenko, La jeunesse de Feuerbach. Introduction à ses positions fondamentales (1828-1841), 1. vol. Paris : Vrin, 1990; Gabriel Amengual, "Gattungswesen als Solidarität. Die Auffassung vom Menschen in der Bestimmung des Gattungswesens als Begriff und Grundlegung der Solidarität", in: Ludwig Feuerbach und die Philosophie der Zukunft. Berlin: Akademie Verlag, 1990, pp. 345-367; Christine Weckwerth, Ludwig Feuerbach. Zur Einführung, Hamburg: Junius Verlag, 2002.

\begin{tabular}{|l|l|l|l|l|}
\cline { 2 - 5 } & Ano 8 & n. 14 & Janeiro-Julho 2019 & p. $235-247$ \\
\hline
\end{tabular}


do espírito. As religiões existentes contêm sem dúvida muito de repugnante e incompatível com a verdade, mas não deveria a própria religião ser captada de modo mais geral e a concordância da filosofia com ela ser posta apenas no reconhecimento e justificação de certas doutrinas? Existe alguma outra concordância?

Como se relaciona a filosofia de Hegel com o presente e o futuro? Não é ela o mundo passado como mundo de pensamento? É ela mais do que uma recordação da Humanidade daquilo que foi, mas não é mais? ${ }^{15}$

Não se conhece qualquer resposta de Hegel a esta carta impregnada de ousadia e originalidade. Seja qual for a perspectiva de análise adoptada - anúncio do espírito do tempo e documento inaugural do movimento Jovem-hegeliano ou embrião do pensamento maduro de Feuerbach -, a carta de Feuerbach a Hegel permanece, pelo seu ímpeto interveniente e pelo radicalismo de um projecto de racionalidade integral, um documento ainda e sempre aberto à interpretação ${ }^{16}$.

A Carta de Feuerbach a Hegel foi publicada pela primeira vez por Karl Grün em Ludwig Feuerbach in seinem Briefwechsel und Nachlaß, sowie in seiner philosophischen Charakterentwicklung, Leipzig und Heidelberg: C. F. Winter Verlag, 1874, vol. I, pp. 214-219. A presente tradução segue o texto dos Gesammelte Werke, na edição de Werner Schuffenhauer,

15 Fragmente zur Charakteristik meines philosophischen curriculum vitae, GW, vol.10, 155-156.

16 Entre as múltiplas análises e interpretações diversas desta Carta: Horst Stuke, Philosophie der Tat. Studien zur Verwirklichung der Philosophie bei den Jung-hegelianern und wahren Sozialisten, Stuttgart: Ernst Klett Verlag, 1963; Joachim Ritzkowski, Ludwig Feuerbachs Angriff gegen das Christentum. Die Bedeutung des Frühwerks Feuerbachs für die Religionskritik, Berlin: 1969 (Diss. Phil.), pp. 18-19; Peter Cornehl, Die Zukunft der Versöhnung. Eschatologie und Emanzipation in der Aufklärung, bei Hegel und in der Hegelschen Schule, Göttingen: Vandenhoeck \& Ruprecht, 1971, pp. 218-221; Erich Thies, "Die Verwirklichung der Vernunft. Ludwig Feuerbachs Kritik der spekulativ-systematischen Philosophie", Revue Internationale de Philosophie 26, n. ${ }^{\circ} 101$ (1972), pp. 283-293; Hans-Jürg Braun, Die Religionsphilosophie Ludwig Feuerbachs. Kritik und Annahme des Religiöse, Stuttgart-Bad Cannstatt: Friedrich Frommann Verlag-Günther Holzboog, 1972, pp. 41-43; Heinz-Hermann Brandhorst, Lutherrezeption und bürgerliche Emanzipation. Studien zum Luther- und Reformationsverständnis im deutschen Vormärz (1815-1848) unter besonderer Berücksichtigung Ludwig Feuerbachs, Göttingen: Vandenhoeck und Ruprecht, 1981, pp. 96 ss; Wofgang Essbach, Die Junghegelianer. Soziologie einer Intellektuellengruppe, München: Wilhelm Fink Verlag, 1988, pp. 169-172; Ursula Reitemeyer, Philosophie der Leiblichkeit. Ludwig Feuerbachs Entwurf einer Philosophie der Zukunft, Frankfurt a.M.: Suhrkamp, 1988, pp. 17-24; Charles A. Wilson, Feuerbach and the Search for Otherness, New York/ Bern/ Frankfurt a. M. / Paris: Peter Lang, 1989, pp. 123-130; José Barata-Moura, A "realização da razão". Um programa hegeliano?, Lisboa; Caminho, 1990, pp. 39-42.

\begin{tabular}{|c|c|c|c|c|}
\hline Q Rovista Dialectus & Ano 8 & n. 14 & Janeiro - Julho 2019 & p. $235-247$ \\
\hline
\end{tabular}


Berlin: Akademie Verlag, 1967 e ss, vol. 17, pp. 103-108, que inclui as notas à margem constantes do manuscrito.

\section{A Georg Wilhelm Friedrich Hegel}

Ansbach, 22 de Novembro de 1828

Excelentíssimo Senhor

Mui venerado Professor

Tomo a liberdade de enviar a Vossa Senhoria a minha dissertação. Não por lhe atribuir qualquer valor particular ou por imaginar que ela tenha algum interesse em si mesma e para o espírito de Vossa Senhoria; apenas lha envio, porque eu, o autor, me encontro para consigo na relação especial de um discípulo directo, uma vez que frequentei durante dois anos os seus cursos em Berlim e porque gostaria tão-só de lhe testemunhar por este meio a minha elevada estima e veneração pessoal, que lhe devo enquanto meu mestre e que reconheço com alegria também como minha obrigação. Mas justamente esta relação especial de discípulo directo produz ao mesmo tempo em mim a timidez com que lhe dirijo o meu trabalho. Porque quando o discípulo não testemunha nem expressa a elevada estima e a autêntica veneração pelo seu mestre mediante actos exteriores ou palavras e sentimentos, mas apenas pelas suas obras, só o conseguirá precisamente mediante obras que tenham sido elaboradas segundo o espírito do seu professor, que sejam dignas desse espírito como o de um aluno e que preencham as exigências que se depositam num discípulo directo. Ora, justamente perante a minha obra, se é que a minha dissertação é digna deste nome, eu próprio reconheço demasiado bem o que é deficiente, insuficiente, falível e censurável, não a devendo por isso considerar, antes pelo contrário, como uma obra adequada às exigências que só eu próprio me impus e àquelas que o seu magistério de dois anos, tão instrutivo e rico de ensinamentos, produziu. Se é certo que o motivo de muitas falhas e deficiências deve ser procurado em geral apenas nos estreitos limites do âmbito, da finalidade e da linguagem de uma dissertação, e para mais no domínio da filosofia, e que tanto de criticável se desculpa por si mesmo, todavia eu só posso perdoar-me esta minha liberdade de lhe apresentar a minha dissertação pela consciência, que publicamente confesso, de ela respirar no todo e no geral um espírito especulativo, de ela (certamente como um mero

\begin{tabular}{|l|l|l|l|l|}
\cline { 2 - 4 } & Ano 8 & n. 14 & Janeiro-Julho 2019 & p. $235-247$ \\
\hline
\end{tabular}


fragmento arrancado por uma circunstância exterior) ser o produto de um estudo que ao apreender e acolher em si a alma, a própria força produtiva e autónoma, consiste numa assimilação e formação viva, quer dizer, essencial (não formal), livre (porque de modo algum arbitrária, que vai escolhendo e tirando daqui e dali), das ideias ou conceitos que formam o conteúdo das obras e exposições orais do Senhor Professor; pela consciência de que as ideias produzidas ou despertadas por si em mim e expressas na sua filosofia não se mantêm lá no alto, no geral, acima do sensível e do fenómeno, mas continuam a actuar em mim de maneira criadora, saindo por assim dizer do céu da sua pureza incolor, da sua luz imaculada, da sua beatitude e unidade consigo mesmas para se afundarem e ganharem forma numa intuição que penetra o particular, que no fenómeno e face ao fenómeno supera e vence os fenómenos; e ainda pela consciência de que esta minha dissertação, pelo menos no geral e embora de um modo muitíssimo imperfeito, ainda bastante grosseiro e deficiente, de um modo que não evita o abstracto, traz contudo em si um vestígio de uma espécie de filosofar a que se poderia chamar a realização* e mundanização da ideia, a ensarcose ou a incarnação do Logos puro. Ora, apesar da limitação do meu trabalho, que eu próprio reconheço e sinto, esta consciência dá-me a coragem de o apresentar a Vossa Senhoria. Estou também firmemente convencido de que esta espécie de filosofar, que ainda não desligada nem liberta de mim mesmo se vislumbra mal neste trabalho, que está presente dentro de mim ainda em estado embrionário e talvez nunca chegue, pelo menos por meu intermédio, à existência e à configuração acabada, chegou ao seu tempo ou (o que é o mesmo) se funda no próprio espírito da filosofia moderna e da filosofia mais recente, proveio desse mesmo espírito. Pois se se trata da filosofia tal como é denominada pelo Senhor Professor, não como um assunto da escola mas da Humanidade, se o espírito, pelo menos o da mais recente filosofia, exige e obriga a romper as barreiras de uma escola e tornar-se numa visão universal, histórico-mundial e revelada, e se precisamente nesse espírito reside não apenas a semente de um melhor exercício e de uma melhor actividade literária, mas ainda a semente de um espírito universal que se proclama na realidade, como que a semente de um novo período da história, trata-se então agora de fundar, por assim dizer um reino ${ }^{*}$, o reino da ideia, do pensamento que é consciente de si mesmo e que se contempla a si mesmo em tudo o que existe; trata-se de derrubar do seu trono dominador o Eu, o si-mesmo, que especialmente

\footnotetext{
[nota à margem]: mas não deve ser de modo algum a popularização ou a tradução do pensar numa intuição contemplativa, nem dos pensamentos em imagenzinhas ou sinais.

** [nota à margem]: o fundador deste reino não terá certamente um nome, não será um indivíduo, ou será este indivíduo, o único que existe, o espírito do mundo.
}

\begin{tabular}{|l|l|l|l|l|}
\cline { 2 - 4 } & Ano 8 & n. 14 & Janeiro-Julho 2019 & p. $235-247$ \\
\hline
\end{tabular}


desde o começo da era cristã tem dominado o mundo e se tem apreendido como o único espírito que existe, e fazendo-se valer como absoluto reprimiu o verdadeiro espírito absoluto e objectivo, para que a ideia seja e domine efectivamente, para que uma só luz brilhe em tudo e através de todas as coisas e o velho reino de Ormuz e Ahriman - o dualismo em geral - seja vencido, não pela crença numa Igreja fora do mundo, virada sobre si, ou pela ideia de uma única substância, ou em geral por um modo de filosofar que tem um além, um negativo, uma relação de exclusão para com um outro (o que sempre aconteceu na história até hoje), mas pelo conhecimento da razão que tem consciência de si como sendo toda a realidade, una e universal, existente e cognoscente, real, omnipresente, da razão que não está separada nem cindida de si mesma por nenhuma diferença. Chegará então, e terá finalmente de chegar, este domínio exclusivo da razão; a filosofia que desde há milhares de anos trabalhava para o seu acabamento e realização, mas que ao elevar-se sempre por graus encerrava sempre o Todo, o Universo (ou como se lhe queira chamar) numa determinidade particular, num conceito determinado, e que assim deixava necessariamente ficar fora dela um outro (fosse ele a determinidade e a própria existência em geral, fosse a religião, ou a Natureza, ou o Eu, etc.), que finalmente agora captou o próprio todo num todo e o exprimiu na forma de um todo, tem agora finalmente de conseguir que não subsista mais um segundo ou um outro, seja com a ilusão, o direito e a exigência a ser uma segunda verdade, como a verdade da religião, etc.; formas e concepções milenárias que desde a primeira criação natural atravessam toda a história como princípios fundamentais têm de desaparecer, já que chegou, embora ainda não se tenha tornado manifesto, o conhecimento da sua nulidade e finitude, e tudo se tornará ideia e razão. Trata-se agora de um novo fundamento das coisas, de uma nova história, de uma segunda criação em que não mais existirá o tempo além e fora do pensamento, mas em que a razão se tornará a forma universal da intuição das coisas. Se, como se pode claramente provar, o homem se torna culpado da mais louca contradição quando se limita a falar das coisas como separadas e cindidas do pensamento e, mais ainda, quando afirma que o pensar é algo de subjectivo e de não-real, quando, pelo contrário, o homem tal como as próprias coisas não existem de modo algum fora do pensar, pois o pensar é o que tudo engloba, o verdadeiro espaço universal de todas as coisas e sujeitos e, além do mais, cada coisa e sujeito só são o que são por meio da representação e no pensamento que se tem deles, é claro que se o $\mathrm{Eu}$, o si-mesmo (bem como a infinita multiplicidade que a ele se liga) é suprimido no conhecimento como o absolutamente firme, como princípio universal e determinante do mundo e da intuição, ele desaparece da própria

\begin{tabular}{|l|l|l|l|l|}
\cline { 2 - 4 } & Ano 8 & n. 14 & Janeiro-Julho 2019 & p. $235-247$ \\
\hline
\end{tabular}


intuição; é então claro que o si-mesmo deixa de ser o que fora até aí; acaba mesmo por morrer. Por isso, não se trata agora de um desenvolvimento dos conceitos na forma da sua universalidade, na sua pureza separada e no seu ser-em-si isolado, mas de aniquilar verdadeiramente as anteriores concepções histórico-mundiais acerca do tempo, morte, aquém, além, eu, indivíduo, pessoa, e da pessoa intuída fora da finitude, no absoluto e como absoluta, a saber, como Deus, etc.; concepções essas nas quais está contido o fundamento da história até hoje e também a fonte do sistema das representações cristãs, tanto ortodoxas como racionalistas; trata-se de sondar o fundamento da verdade e de aí fazer penetrar em vez delas o conhecimento como intuição imediatamente presente e determinante do mundo, que na filosofia moderna se encontra confundido com um reino do em-si e do além sob a forma da verdade e da universalidade nua. É por isso que o cristianismo não pode ser considerado como a religião acabada e absoluta, que só pode consistir no reino da realidade da ideia e da razão existente. $\mathrm{O}$ cristianismo nada mais é do que a religião do si-mesmo puro, da pessoa enquanto único espírito que em geral existe e é por isso apenas o oposto do mundo antigo. Que significado tem, por exemplo, a Natureza nesta religião? Que posição desprovida de espírito e de pensamento tem nela a Natureza? E contudo é justamente esta ausência de espírito e de pensamento um dos seus pilares fundamentais. Sim, a Natureza está lá como inconcebida, misteriosa, inapreendida na unidade do ser divino, de tal modo que unicamente a pessoa (não a Natureza, o mundo, o espírito) celebra a sua salvação, que deveria consistir no conhecimento dela. É por isso que a razão ainda não se salvou no cristianismo. Por isso, também a morte, sendo embora um acto meramente natural, é ainda considerada de um modo inteiramente espiritual pelo mais indispensável jornaleiro na vinha do Senhor, para quem a obra da salvação só está completa para o perfeito discípulo e companheiro de Cristo. Sendo que o fundamento e a raiz de cada religião reside na filosofia, num modo de intuição determinado apenas no qual a religião se sustenta, é possível demonstrar da maneira mais precisa e mais concludente o que é finito e negativo, o que é pressentido pelo próprio cristianismo como um além. De uma maneira geral, todas as religiões não foram até hoje senão a presença imediata, a aparição e o fenómeno do espírito universal de uma filosofia que se mantém como una na diferença dos sistemas, por exemplo, a filosofia grega; o cristianismo foi o fenómeno da filosofia pós-grega que se propagou na forma de uma finitude fixa. No entanto, o esforço de cada um deveria neste momento tender para que o espírito exista como espírito e para que, na sua manifestação, nada seja senão ele mesmo. Mas vou interromper, com receio de ultrapassar os limites da modéstia

\begin{tabular}{|l|l|l|l|l|}
\cline { 2 - 4 } & Ano 8 & n. 14 & Janeiro-Julho 2019 & p. $235-247$ \\
\hline
\end{tabular}


e do respeito, se quisesse, meu profundamente venerado Professor, retê-lo mais longamente comigo, com a exposição das minhas ideias, dos meus esforços e do meu pensamento. $\mathrm{Na}$ esperança de que queira acolher com benevolência esta minha carta e o envio da minha dissertação, que mostra, pelo menos na generalidade, um estudo filosófico e um esforço para a presentificação imediata de ideias abstractas, fico no mais profundo respeito e sincera veneração

De Vossa Senhoria muito reconhecido Ludwig Feuerbach, Dr. em Filosofia

Permito-me ainda notar que para não incomodar Vossa Senhoria com uma carta demasiado extensa, abstive-me de falar em pormenor da minha dissertação e de mencionar em particular o que eu próprio ainda reconheço como incorrecto e imperfeito, bem como de salientar o tema principal que tenho agora presente com inteira clareza, embora tivesse sido também importante para mim eliminar muita coisa má, pelo menos por meio da expressa indicação e consciência, antes que Vossa Senhoria honrasse o meu trabalho lendo-o. Pela mesma razão, evitei uma carta pormenorizada, como o tema em si teric certamente exigido.

O presente artigo reproduz, com ligeiras modificações, a primeira publicação em Razão e Liberdade. Homenagem a Manuel José do Carmo Ferreira, Lisboa: Centro de Filosofia da Universidade de Lisboa, 2009, pp. 1309-1321.

\begin{tabular}{|l|l|l|l|l|}
\cline { 2 - 4 } Q & Ano 8 & n. 14 & Janeiro-Julho 2019 & p. 235-247 \\
\hline
\end{tabular}




\title{
O MÉTODO NARRATIVO DE HERMANN HESSE E O TRATAMENTO DAS IDEIAS DE NIETZSCHE
}

\author{
Raylane Marques Sousa ${ }^{1}$ \\ Eduardo Ferreira Chagas ${ }^{2}$
}

\begin{abstract}
Resumo:
O ensaio expõe o método utilizado por Hermann Hesse para composição de sua narrativa, mostrando os vários momentos em que ele o empregou em obras determinantes de sua fase tardia e o tratamento que deu, particularmente, às ideias de Nietzsche. Para alcançar esse objetivo, examinamos cinco escritos de Hesse, de modo a provar que, por meio da sintetização de elementos opostos, oponentes e complementares, por ele feita, podemos conhecer sua forma de orientar a narrativa que revela seu modo de interpretar a realidade.
\end{abstract}

Palavras-chave: Método narrativo em Hesse; Hermann Hesse; Hesse e Nietzsche.

\section{THE NARRATIVE METHOD OF HERMANN HESSE AND THE TREATMENT OF NIETZSCHE IDEAS}

\begin{abstract}
:
The essay exposes the method used by Hermann Hesse to compose his narrative, showing the several instances in which he resorted to it in his major works that marked the late phase of his artistic life and the treatment he gave particularly to Nietzsche's ideas. To reach this goal, five Hessian writings were examined in order to propose that through his synthesis of conflicting elements, that oppose and complement each other, it is possible to discover how he shapes and directs his narrative which in turn reveals his way of interpreting reality.
\end{abstract}

Keywords: Narrative method in Hesse; Hermann Hesse; Hesse and Nietzsche.

\section{Por que lemos Hesse?}

Lemos, recentemente, cinco obras do escritor alemão Hermann Hesse (18771962). Começamos com "O jogo das contas de vidro" (1943), continuamos com "Com a maturidade fica-se mais jovem” (1990), estendemos com "Demian” (1919), passamos por “O lobo da estepe" (1927) e encerramos com "Sidarta" (1922). Tínhamos acabado de ler a primeira obra e estávamos no início da segunda, mas resolvemos retornar à primeira e

1 Doutoranda em História pelo Programa de Pós-Graduação em História da Universidade de Brasília (PPGHIS-UnB). Bolsista Capes. Endereço eletrônico: marques.raylane@ gmail.com.

2 Doutor em Filosofia pela Universidade de Kassel, Alemanha. Professor Associado IV da Graduação e Pós-Graduação do Curso de Filosofia da Universidade Federal do Ceará (UFC) e Colaborador do Programa de Pós-Graduação em Educação Brasileira da Faculdade de Educação da Universidade Federal do Ceará (FACED-UFC). Bolsista do CNPq. Endereço eletrônico: ef.chagas@ uol.com.br. 
extrair, aqui e acolá, palavras, formulações ou passagens, que nos permitissem questionar e compreender a composição dessa obra. As razões que nos fizeram voltar à primeira obra são evidentes. Hesse não é um escritor óbvio! Sua narrativa não é tão fácil de compreender, as referências à arte, à musica, à história, à literatura, às ideias de Nietzsche são abundantes e, por vezes, obscuras, além de seu discurso alegórico. Esses motivos nos atraíram e nos envolveram de tal forma que procuramos entender os mecanismos internos não apenas de uma obra, mas dos principais escritos que perfazem o pensamento tardio de Hermann Hesse.

"O jogo das contas de vidro" é "a sua sublime obra de maturidade, que bebeu em todas as fontes da cultura humana, ocidentais e orientais" 3 , segundo Thomas Mann, e essa apreciação é suficiente para despertar a curiosidade do leitor e da leitora para esse livro que, apesar do cenário infeliz e pouco auspicioso em que foi escrito, particularmente o da Europa entre as duas grandes guerras, rendeu a Hesse o Prêmio Nobel de Literatura, em 1946.

Ao lermos a sua longa introdução, é possível observar e sentir que se trata de um romance erudito, filosófico e altamente espiritualizado, o que faz com que ele ultrapasse os tempos e ganhe ares de universalidade. Espiritualizado, isso mesmo, o livro tem, sem dúvida, um forte componente espiritual, alegórico e não corporificado, pertencente apenas ao domínio da consciência, do psicológico.

A palavra "espiritual" tem um sentido completamente diferente do que a maioria das pessoas imagina! Quando Hesse discorre sobre o "despertar espiritual" de seu personagem José Servo nos seis primeiros capítulos da obra, o termo "espiritual" não se relaciona somente ao âmbito religioso, eclesiástico, místico. Faz referência também à faceta artística (fantasia, musicalidade, compasso, colorido, plasticidade) do Jogo de Avelórios, a altas habilidades cognitivas (lógica cristalina, percepção objetiva e penetrante, precisão e exatidão) características dos jogadores das contas de vidro, à profundidade da mente (forte energia psíquica, domínio dos impulsos e aspirações, meditação) do povo destinado à Cela Silvestre, ao humor irregular (tendência a se subtrair

3 MANN, Thomas. Hermann Hesse - homenagem ao seu $70^{\circ}$ aniversário. In: $O$ escritor e sua missão. Rio de Janeiro: Zahar, 2011, p. 138.

\begin{tabular}{|l|c|c|c|c|}
\hline Q Povista Dialectus & Ano 8 & n. 14 & Janeiro - Julho 2019 & p. $248-263$ \\
\hline
\end{tabular}


socialmente, necessidade imperiosa de solidão, aversão à incoerência da vida gregária) dos vocacionados à Escola da Elite, etc. Portanto, dos muitos sentidos que o termo expressa, entendemos que o espiritual não tem conotação negativa. A nosso ver, o termo "espiritual", nessa obra madura de Hesse, ora aponta para a esfera religiosa, ora para a pessoa dotada de inteligência muito capaz, ora para os "tesouros" da mente humana. Assim, a palavra em questão articula, pelo menos, três sentidos ao longo do livro: espiritualização, inteligência e linguagem/gramática.

Passemos, agora, para a palavra "despertar". Com esta palavra, Hesse queria descrever não uma única experiência, a experiência de seu personagem José Servo ao se tornar Magister Ludi. Se assim fosse, que sentido teria repisá-la nos seis últimos capítulos da obra, depois de ter José Servo finalmente assumido o cargo de mestre do Jogo de Avelórios? Nenhum. Seria só mais uma palavra dando sequência à sua narrativa. O fato é que, nessa obra, Hesse emprega um método oculto de utilização das palavras, o da associação com estágios variáveis de amadurecimento do homem. Do capítulo seis ao doze, ele utiliza a expressão "despertar" e a substitui por "degraus", e então o apelo ao conhecimento de si próprio, que nos faz lembrar os ensinamentos de Sócrates, e do posto que José Servo ocupa dentro da organização castálica e na sociedade continua até o fim do romance. Hesse deixa transparecer que o sentido da palavra vai se transformando no desenrolar da narrativa, conforme José Servo adquire conhecimento de sua posição e de sua vocação especial e única, ao passo que seus estágios de amadurecimento como homem se tornam cada vez mais relativos.

Despertar não é uma simples expressão na narrativa de Hesse, são fases, e o que há por trás dessas fases não é uma abstração, e sim um homem. Mas qual é exatamente a relação entre o conceito de despertar da consciência, enquanto consciência de si mesmo ou autoconsciência no sentido socrático, as fases de desenvolvimento e o homem? Isso não é tão fácil de responder. Conhecer a si mesmo, como antigamente Sócrates solicitava aos seus discípulos, é a primeira exigência feita pelos mestres e professores da ordem de Castália a José Servo para que este se torne Magister Ludi. A meditação é uma qualidade dos jogadores de avelórios. Quanto a essa qualidade de José Servo, não precisamos dizer muito. Seus constantes exercícios de autoconhecimento logo lhe revelaram a verdade de sua realidade na ordem castálica e na sociedade, uma realidade totalmente apartada do mundo tangível. É por isso que ele não quer mais ali continuar. José Servo abdica de seu título de Mestre Ludi, mas não desiste jamais de seu plano de estudos do Jogo de

\begin{tabular}{|l|l|l|l|l|}
\hline Q Povista Dialectus & Ano 8 & n. 14 & Janeiro - Julho 2019 & p. $248-263$ \\
\hline
\end{tabular}


Raylane Marques Sousa / Eduardo Ferreira Chagas

Avelórios. Ele medita que os degraus do "despertar" intelectual por ele galgados são, na verdade, experimentos variáveis para fazê-lo conhecer seu destino como homem modesto. E, como demonstra Hesse ao final do romance, o personagem de José Servo aceita seu destino, sem reservas.

\section{II}

Hesse esconde um método de associação de palavras antônimas e sinônimas também nas breves histórias, nas recordações íntimas, nos poemas em prosa e em verso, nos aforismos e nos curtos tratados filosóficos por ele escritos em diferentes etapas de sua vida e reunidos por Volker Michels na coletânea "Com a maturidade fica-se mais jovem", publicada em 1990. "Essa coletânea sobre a velhice começa com observações feitas por Hesse aos 43 anos. São impressões sobre a primavera e a renovação da natureza, registradas por um homem no estágio intermediário da vida, consciente da transitoriedade e da inconstância do mundo visível no qual se insere sem oferecer resistência"4, conforme diz Michels, e essa descrição basta para que o leitor e a leitora se lancem sobre esse livro. Um exemplo do emprego de tal método, nesse conjunto de textos, parece-nos ser o que o escritor faz no poema intitulado "Envelhecer", que citamos abaixo:

A futilidade que o jovem aprecia

Foi também por mim venerada,

Penteado, gravata, elmo e espada,

E muito mais a mulher esguia.

Só agora vejo com clareza,

Posto que, velho rapaz,

De nada disso sou mais capaz.

Só agora vejo com clareza,

De tais desejos a suma esperteza.

Lá se vão as gravatas e permanentes,

Levando consigo toda a magia;

4 MICHELS, Volker. Epílogo. In: HESSE, Hermann. Com a maturidade fica-se mais jovem. Rio de Janeiro, São Paulo: Record, 2018, p. 150.

\begin{tabular}{|l|c|c|c|c|}
\hline Q Povista Dialectus & Ano 8 & n. 14 & Janeiro - Julho 2019 & p. $248-263$ \\
\hline
\end{tabular}


Mas o que além disso consegui,

Sabedoria, virtude e meias quentes,

Ah, logo depois também perdi,

E minha terra ficou fria.

Para os velhos é bom e são

Borgonha tinto ao pé da lareira,

E depois uma morte ligeira -

Porém só mais tarde, hoje não!

Por sua disposição, o poema parece representar o homem como uma escala de amadurecimento (cronológico e psicológico) inevitavelmente apontada para o fim (a morte). Porém, tal escala pode levá-lo ao aperfeiçoamento ou à decadência, depende de como ele conduz a própria vida até a linha de chegada. De acordo com este poema, quando jovem, o homem aprecia coisas fúteis e deslumbrantes (penteado, gravata, mulheres), pois tem força de sobra para isso (elmo e espada). Dispõe de muito tempo e vigor para viver todas essas coisas, mas é tolo e ignorante e não sabe ainda como aproveitá-las bem. Quando rapaz maduro, busca algo mais útil e confortável (sabedoria, virtude e meias quentes), pois já não tem a disposição do jovem (de nada disso sou mais capaz). Vê as coisas com mais clareza e é menos afeito à combatividade e mais inclinado à reflexão, aos ensinamentos e à sabedoria. Só que o tempo é esperto, tudo isso se esvai rápido (logo depois também perdi) e o que resta é frio e solidão. Quando velho, preocupa-se com o corpo e a saúde (é bom e são Borgonha tinto ao pé da lareira), pois sabe que já não tem tanta força e disposição para aproveitar os prazeres da vida. Experimenta o tempo com urgência, como se estivesse com os dias contados (e depois uma morte ligeira), mas quer prolongá-lo (porém, só mais tarde, hoje não!), pois a vida tem sentido e vale a pena ser completado.

É claro que nesse poema contém um esboço de uma percepção da realidade paradoxal, atrás do qual se imagina um fim apocalíptico para o homem. Mas essa não é a proposta de Hesse. Ele dá a entender que a maior aquisição do homem seria a sabedoria e que aproveitar bem e de maneira saudável os dias dependeria dessa virtude. No entanto, essa virtude só é possível quando se chega à fase do rapaz maduro, quando se vê tudo com agudeza, quando se entende que a sabedoria é melhor que a força, quando o

\begin{tabular}{|l|l|l|l|l|}
\hline Q Povista Dialectus & Ano 8 & n. 14 & Janeiro - Julho 2019 & p. $248-263$ \\
\hline
\end{tabular}


passatempo e o consolo são as meias quentes. A seu ver, se o homem não enxerga no envelhecimento uma evolução, mas sim a aproximação de um fim apocalíptico, é sinal de que ele não alcançou a virtude da sabedoria, então só lhe resta mesmo a abreviação dos dias e a morte, a decadência cronológica e psicológica.

O exame desse poema indica, portanto, que Hesse vê o envelhecimento como um benefício. E esse benefício é duplo, a saber: a aquisição da sabedoria com o avançar dos anos e a construção de um sentido não apocalíptico para o fim da vida. Numa primeira leitura, o poema parece não dar margem a uma concepção do envelhecer como benefício. Mas quando se leva em consideração que a vida tem um bom sentido, e envelhecer com sabedoria é construir esse sentido, ou ao menos reconhecê-lo, então essa visão apocalíptica do envelhecimento não é a interpretação autorizada para esse poema.

Outro, semelhante, é o poema intitulado “Escutar". Ao lê-lo, percebemos o quanto Hesse utiliza um método oculto de sintetização de palavras opostas, oponentes e complementares para tornar a sua obra esférica, de forma e conteúdo harmônicos, um paradoxo intelectual muito interessante. O poema é o que exibimos abaixo:

Um sopro tão novo, um ruído tão suave,

Perpassa pelo céu nebuloso,

Delicado, como o adejar de uma ave,

Como odor de primavera, tão medroso.

Vindas do amanhecer da vida,

Sopram lembranças de outrora,

Como a borrasca no mar caída,

Que o agita e vai-se embora.

Do hoje o ontem se distancia,

Do há muito esquecido chega perto,

Do mundo remoto, da fantasia,

Onde existe um jardim aberto.

Meu bisavô talvez esteja entre nós,

De um sono milenar se erguendo,

Falando com a minha voz,

\begin{tabular}{|l|l|l|l|l}
\hline Revista Dialectus & Ano 8 & n. 14 & Janeiro - Julho 2019 & p. $248-263$
\end{tabular}


No meu sangue se aquecendo.

Talvez haja uma mensagem lá fora

Que para mim acaba de chegar;

Talvez antes de uma nova aurora,

Em minha casa eu possa estar.

Analisemos o que o escritor quis transmitir com os versos em tela. O que realmente significa "escutar" para ele? Se ele quisesse apenas dizer que escutar é ouvir a vibração delicada dos ventos, o som do agitar-se de leve de uma ave, o ruído colérico das lembranças de outrora, melhor seria então deixarmos para lá, porque tudo isso parece muito claro no poema. Mas se o significado não é tão simples assim, será que podemos realmente apreendê-lo? Hesse é muito mais profundo do que a maioria dos leitores e leitoras costuma pensar, porém, sim, é possível compreendê-lo!

Hesse frequentemente emprega um método oculto de junção de palavras opostas, oponentes e complementares em suas realizações. Tanto nesse poema como no anterior, ele descortina a riqueza de seu método, da fusão dos opostos, oponentes e complementares em uma unidade, da sua combinação de elementos distintos e similares no calor da realidade observada. Esse poema significa tudo e tudo contém. Significa o mistério da existência, da natureza, da memória, dos tempos, da dádiva da percepção dos sons, como é o adejar das asas de uma ave para os ouvidos, o lufar dos ventos, o ruído das lembranças e a voz inconfundível do bisavô que se levanta de um sono milenar. A experiência de escutar o voejar das aves, o lufar dos ventos, o ruído violento das lembranças, a voz do bisavô que carrega a existência, tudo isso só ocorre, porém, quando o hoje se distancia do ontem. A experiência, em si, só se torna um fenômeno inteligível, o mistério revelado, quando o presente e o passado não se confundem mais e não são mais a mesma coisa.

Essa experiência é, para Hesse, como um sopro do passado em direção ao presente, a lembrança do passado que agita tudo no presente e depois vai embora, a quebra entre o tempo passado e o tempo presente, o salto do passado para o presente, é o grande mistério existencial que se descortina em uma não menos simbólica experiência sonora. O céu fechado, mas que ainda permite um sopro de novidade, um ruído delicado perpassálo, as lembranças do passado que ainda incomodam o presente, o hoje que se afasta do que passou, mesmo que se aproxime cada vez mais da fantasia, são indícios de tempos

\begin{tabular}{|l|l|l|l|l|}
\hline Q Povista Dialectus & Ano 8 & n. 14 & Janeiro - Julho 2019 & p. $248-263$ \\
\hline
\end{tabular}


quebrados e desarmoniosos. O sopro vital e as lembranças de outrora produzem uma atmosfera de alta tensão. No centro dessa atmosfera, a experiência sonora é determinante. Tal qual o bisavô, que se levanta de um sono milenar, falando com voz familiar e se aquecendo com o sangue dos vivos, a boa nova chega antes do amanhecer, na pausa para um novo dia, ou antes do despertar de um novo amanhã. A cada dia, o sopro vital e suas lembranças são entrelaçados em uma nova experiência sonora. Esse jogo, que Hesse sutilmente descreve nesse poema, encerra palavras opostas, oponentes e complementares, a compreensão sonora do mistério da existência nas grandes e pequenas manifestações da natureza, a unidade e a quebra dos tempos, as lembranças agitadas, as vivências passadas, a síntese de sensações, certa proximidade do esquecimento e da morte, certa acomodação do sentimento de esperança e dos impulsos vitais.

\section{III}

Igualmente Hesse emprega seu método oculto de fusão de opostos, oponentes e complementares em "Demian", obra publicada sob o pseudônimo de Emil Sinclair, em 1919. "Demian é o título de um livro estranhamente obscuro e profundo, que fala da juventude de uma maneira peculiarmente ramificada que penetra até as trevas da alma" ${ }^{5}$, de acordo com Stefan Zweig, e essa descrição possui o necessário para que o leitor e a leitora busquem conhecê-lo em toda a sua complexidade e riqueza.

O conteúdo do romance consiste em uma narrativa sobre a fusão de dois mundos, o mundo "iluminado" e "paradisíaco" de Emil Sinclair e o mundo "sombrio" e "perverso" de Franz Kromer. A síntese desses dois primeiros mundos resulta em um terceiro, o mundo particular de Max Demian. Este terceiro mundo é o caminho que conduz o homem a si mesmo. O que significa esse caminho em direção a si próprio? É simplesmente a história de um homem que aspira a ser ele mesmo, à maneira nietzschiana.

Hesse utiliza o método de sintetização de opostos, oponentes (Caim e Abel; Deus e Diabo; permitido e proibido; vida e espírito; bem e mal; feio e belo), como nos belos aforismos de Heráclito, e complementares (Demian corresponde a Sinclair, e vice-versa) para narrar a história de como dois mundos antagônicos se confundem originando um terceiro mundo, ao passo que Sinclair torna-se o que realmente é. As características desse

5 ZWEIG, Stefan. Jogos de espelhos: Hermann Hesse. In: O Mundo Insone e outros ensaios. Tradução: Kristina Michahelles. Organização e textos adicionais: Alberto Dines. Rio de Janeiro: Zahar, 2013, p. 8.

\begin{tabular}{|c|c|c|c|c|}
\hline Rovista Dialectus & Ano 8 & n. 14 & Janeiro - Julho 2019 & p. $248-263$ \\
\hline
\end{tabular}




\section{O MÉTODO NARRATIVO DE HERMANN HESSE E O...}

Raylane Marques Sousa / Eduardo Ferreira Chagas

outro mundo são luz e escuridão, fantasias e perigos, bem-estar e insegurança, valentia e covardia, culpa e redenção. Esse mundo diferente significa ainda algo mais, não é um simples mundo criado pelo Sinclair da juventude, é o próprio Sinclair já homem feito e maduro, e o que há dentro dele não são sentimentos aprendidos, e sim experimentados. Mas como Sinclair pode ser homem e mundo ao mesmo tempo? Esse problema não é tão fácil de dirimir. Sinclair é homem à medida que segue pelo caminho que o conduz a si mesmo, pelo caminho que lhe desenraiza do caminho juvenil e lhe impulsiona para a maturidade. É mundo à medida que sua consciência deixa de se restringir ao mundo irreal e fictício da infância e se abre para o mundo adulto em derredor, o mundo duro dos instintos vitais em que é mais dificultoso dar o passo que leva à frente.

No que concerne a esse terceiro mundo da consciência, há algo que ainda precisa ser esclarecido. Ao se tornar o que realmente é, Sinclair, no entanto, não abandona o "mundo luminoso" nem o "mundo sombrio", mas logo esses mundos se acham em conflito dentro dele e, dessa forma, exercem poder sobre ele. Só que nesse combate interno de Sinclair não há um mundo vencedor e um mundo perdedor, os dois mundos protestam e se aniquilam, e, no exterior, ele equaciona às vezes a questão nos seguintes termos: se não é possível viver recluso no mundo irreal para sempre e se não há facilidade no mundo real para dar o passo adiante, então não resta outro caminho senão deixar que os mundos se digladiem e se aniquilem.

O caminho de Sinclair em direção a si mesmo exige essa disputa e destruição de mundos, à maneira nietzschiana. "Quem quiser nascer tem que destruir um mundo". Para destruir um mundo, é necessária, antes de tudo, a vontade, pois, apesar de a vontade não ser plenamente livre, se ela busca o que tem realmente sentido e valor para ela, então consegue o mais difícil: fazer com que o homem conheça a si mesmo. Ocorre o seguinte: pouco a pouco, a vontade de Sinclair o encoraja com muitos de seus interesses, os quais não só ampliam o seu campo de ação e de experiência, mas também a sua reflexão, com isso demonstrando, em síntese, que ele não cabe mais em seu pequeno mundo. Sinclair agora não reverencia mais às crenças ligadas ao mundo luminoso, nem teme as práticas relacionadas ao mundo sombrio, mas delas se utiliza para liquidar esses mundos, ou seja, para conhecer a si mesmo.

De um modo geral, o Sinclair que consegue interpretar a si mesmo não é, como demonstra Hesse na introdução do livro, o homem que sabe, mas o homem que busca sempre. Se o jovem Sinclair não buscasse conhecer a si mesmo, ele nunca teria chegado

\begin{tabular}{|l|l|l|l|l|}
\hline Q Povista Dialectus & Ano 8 & n. 14 & Janeiro - Julho 2019 & p. $248-263$ \\
\hline
\end{tabular}


a ser um homem completo, total, então só lhe restaria ser considerado metade homem, em tudo e por todos.

\section{IV}

Assim como nas obras já listadas, Hesse utiliza seu método oculto de junção de opostos, oponentes e complementares no romance ousado e terrivelmente belo "O lobo da estepe", publicado em 1927. O autor escreveu essa obra quando tinha 50 anos, não para falar dos dramas da profundeza da alma e da vontade de suicídio de pessoas que chegam a essa faixa etária, mas de problemas particulares a essa fase tardia da vida. "Contudo, parece-me que de todas as minhas obras", diz ele, "O lobo da estepe é a que

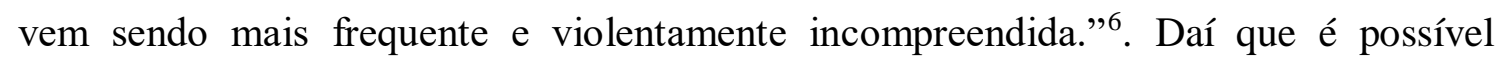
observar a preocupação do escritor com a forma com a qual seus leitores e leitoras compreenderam a sua história do Lobo da Estepe, uma vez que muitos deles, ao tentar interpretá-la, confundiram suas palavras simpáticas acerca do perfil psicológico de Harry Haller com um tratado em favor do suicídio.

Mesmo que Hesse tivesse escrito um tratado sobre o suicídio, ele não merece ser mal interpretado e ter seu pensamento distorcido. As suas palavras não representam nem a metade daquilo que ele queria expressar, e o seu posfácio nos assegura que ele não tinha a intenção de com essa criação conduzir às pessoas ao autoextermínio. Ele próprio afirmou que o romance caiu em mãos de leitores jovens demais para compreender a sua real pretensão com “O lobo da estepe”. Essa obra não é uma expressão da negação da vida, embora relate episódios de dor, enfermidades e desilusões. É, ao contrário, uma história de afirmação e de redenção da vida, à maneira nietzschiana.

A respeito do que aqui estamos tentando esboçar, "O lobo da estepe" é outra realização em que se encontra o método oculto de Hesse. Ao contrário do que a maioria dos leitores e leitoras pode supor, é a obra que mais oferece subsídios para se pensar tal método. Observamos nela uma sofisticação no modo de criar do escritor, uma preocupação em integrar opostos, oponentes e complementares numa história difícil e altamente sensível. Nesse manuscrito, Hesse conta a história de Harry Haller, um homem de cerca de 50 anos que era insociável, frio, objetivo, selvagem e muito tímido, era o que

6 HESSE, Hermann. Posfácio. In: O lobo da estepe. Tradução de Ivo Barroso. Rio de Janeiro: BestBolso, 2018 , p. 249.

\begin{tabular}{|l|l|l|l|l|}
\hline Q Povista Dialectus & Ano 8 & n. 14 & Janeiro - Julho 2019 & p. $248-263$ \\
\hline
\end{tabular}


ele chamou de Lobo da Estepe. Porém, essa figura, apesar de toda a sua esquisitice, era além do convencional, inteligente e de fisionomia espiritual. Entre essas duas naturezas, Hesse situa Haller, sem necessariamente escolher uma ou outra. Como lobo da estepe, Haller era um "gênio do sofrimento", de capacidades ilimitadas, pois, apesar de suas dores, sofrimentos e "quebrantamento da vontade", esforçava-se heroicamente para continuar neste mundo. Já como pensador e homem amante dos livros, ele era agradável, respeitoso e vivia uma vida de interesses espirituais.

Hesse utiliza seu método para fazer o esboço de uma natureza e outra e mostrar que a junção delas produz um homem mais forte e mais afirmativo do mundo espiritual, um homem que vive a oscilar entre dois mundos e dois tempos e que sua redenção é aprender a conviver normalmente com a natureza do lobo da estepe e a natureza espiritual, assim como espremido entre o tempo passado e o tempo presente. No entanto, e ao contrário do que muitos leitores e leitoras desatentos pensam, Hesse não criou um personagem suicida, niilista, completamente incapaz de viver neste tempo e sempre em busca do além-mundo, mas decidiu por juntar as duas formas de natureza e as duas designações de tempo em Herry Heller, demonstrando que a doença anímica desse personagem era uma neurose de sua própria época e que não escolhia os débeis e de natureza frágil, mas, ao contrário, os mais fortes, os de natureza mais tenaz, ambiciosa e ousada, os mais seletivos e capazes de suportar pacientemente certos dessabores da vida, um pensamento completamente influenciado por Nietzsche.

Essas duas naturezas que Hesse descreve compõem, portanto, Harry Heller. Nesse sentido, com intenção de evidenciar a profundidade da natureza de seu personagem principal, o autor junta as características do lobo da estepe e do homem amante dos livros, demonstrando que o verdadeiro sofrimento de Heller se esconde ali onde se chocam as duas naturezas ou os dois mundos. Um homem eremita, que tivesse de viver em festas superlotadas, certamente se sentiria tão deslocado quanto um homem erudito que tivesse de viver sem seus livros. Para Hesse, há momentos em que o homem oscila entre duas naturezas, ou estilos de vida, e este homem deixa de crer na vida, perde a noção de salvação, de redenção. Essa falta de crença na vida, de escape para os sofrimentos, não atinge a todos os homens da mesma forma e no mesmo grau. Na visão de Hesse, a classe artística é a que mais sofre com essa contínua e mortal inimizade entre uma "natureza divina" e uma "natureza satânica".

\begin{tabular}{|l|l|l|l|l|}
\hline Q Povista Qialectus & Ano 8 & n. 14 & Janeiro - Julho 2019 & p. $248-263$ \\
\hline
\end{tabular}


No caso de Heller, a sua natureza teve de sofrer as desgraças de sua época, ela teve de suportar as suas crises existenciais e pessoais. O personagem principal de Hesse pertence ao grupo que se comprime entre duas naturezas, dois mundos, duas épocas, que não compartilha dos objetivos do mundo moderno em que vive, que não entende as representações artísticas e culturais de seu ambiente, que acha as atuais músicas vulgares e americanizadas. Esse é precisamente o motivo que leva Heller a não se considerar participante de seu tempo, à maneira nietzschiana. Mas isso não significa que para ele a vida não tenha nenhum sentido. Não significa que ele leve uma vida suicida.

Numa leitura superficial, parece que Hesse constrói um personagem que procura o tempo todo atentar contra a própria vida. Todavia, prosseguindo no exame da obra, percebemos que o autor se previne em relação a esse tipo de interpretação. Hesse deixa claro que o seu personagem tem uma porta aberta, uma maneira de fugir do problema que o incomoda. Para encontrar essa saída de emergência, Heller não poderia pertencer a determinado grupo de suicidas, aos tipos de homem que são considerados suicidas pela própria essência de seu eu, os quais vivem em relação perigosa com a morte. Heller pertencia a um grupo diferente de suicidas, os quais não mantinham necessariamente relação intensa com a morte. Ele não exibe, mas tem um eu forte, ambicioso e ousado. A sua redenção acontece na vida. Ele não está disposto a eliminar-se, a extinguir-se, a voltar ao princípio de tudo. Pelo contrário, ele faz de sua debilidade uma força, de seu caminho de morte um caminho de vida, um pensamento tomado de Nietzsche.

Heller fez de seu sofrimento uma filosofia que era, na verdade, uma afirmação da vida, à maneira nietzschiana. Mas como era essa filosofia que supervalorizava a vida? Essa filosofia é uma espécie de aceitação orgulhosa das duas naturezas que disputam entre si. E quem a prática é um homem que pensa e que vive o sofrimento. $\mathrm{O}$ fato de pensar e de viver o sofrimento provém das duas naturezas, tanto da do lobo da estepe quanto da do homem amante dos livros. Portanto, a junção das duas naturezas é que gera a filosofia como afirmação da vida de Herry Heller. O método de junção de oposto, oponentes e complementares de Hesse se encontra, pois, nesse livro, embora de forma oculta, e é responsável pela sua composição.

\begin{tabular}{|l|l|l|l|l|}
\hline Q Povista Dialectus & Ano 8 & n. 14 & Janeiro - Julho 2019 & p. $248-263$ \\
\hline
\end{tabular}


Raylane Marques Sousa / Eduardo Ferreira Chagas

Já com o romance indiano "Sidarta”, Hesse foge completamente daquele método que até então vinha esboçando em seus livros. Nas outras obras, ele sempre associava palavras, ideias, conceitos opostos, oponentes e complementares, mas, em "Sidarta", ele inaugura um método circular de pensamento, também à maneira nietzschiana. Sua ideia de um método circular não é sem sentido, ela se baseia numa teoria do eterno retorno: é o distanciar-se do seu eu por intermédio da meditação e o reencontrar-se com o seu eu, ao fim e ao cabo de tudo.

Depois de histórias polêmicas como a do jovem Sinclair, que oscila entre o mundo de luz e o mundo de trevas, e a do velho Haller, que oscila entre a natureza de lobo e a natureza de homem erudito, aqui ele narra a história de um homem obstinado em busca de si mesmo, da perfeição espiritual. Se nos livros anteriores "Hesse sempre lançava perguntas ao mundo ansiosamente; em Sidarta, pela primeira vez, busca responder"?, assevera Stefan Zweig. Ele empreende um movimento semelhante ao do ciclo vital, quando jovem assume uma postura inquiridora, quando adulto escreve respostas para as perguntas outrora levantadas, quando maduro entende o sentido de tais perguntas e o caminho para tais respostas. Seu livro "Sidarta" expressa todo esse giro, simplesmente completa o seu ciclo vital.

Interpretar esse giro não é tão simples. A obra procura responder a questões como esta: “é possível alcançar a perfeição?”, a que o autor responde afirmativamente, mas com ressalvas, ao final da história. O que a diferencia das outras obras do autor é tão somente a necessidade implacável do personagem principal de encontrar uma resposta satisfatória para essa pergunta. Na primeira parte do volume, Hesse apresenta que apenas os homens de espírito sábio, resistente e puro são capazes de peregrinar dias, meses, anos, a vida inteira, se preciso for, em busca de tal estado de perfeição e alcançá-lo. Sidarta é um desses homens de espírito sábio, forte e vazio de tudo, de fome, de sede, de desejos, de sonhos, de alegrias e de pesar, que vive distanciado de si mesmo, isto é, com o pensamento desindividualizado, cujo único propósito da vida é somente alcançar no seu ser a quinta-essência, o mistério dos mistérios, a perfeição. Na medida que se exercita na sua desindividualização e se esvazia de seu eu, ele sente o apelo à sua perfeição, à sua eternidade, e acaba mortificando os seus sentidos, as suas recordações, desprendendo-se da própria vida. Mas Sidarta não palmilha todo o caminho da desindividualização para

7 ZWEIG, Stefan. Jogos de espelhos: Hermann Hesse. In: O Mundo Insone e outros ensaios. Tradução: Kristina Michahelles. Organização e textos adicionais: Alberto Dines. Rio de Janeiro: Zahar, 2013, p. 11.

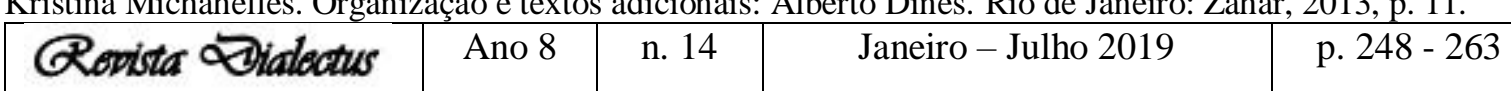


morrer vazio; ao contrário, embora seu trajeto lhe afaste de seu eu, ao fim da vida o reconduz até ele.

Hesse amadurece a sua ideia do eterno retorno através da vida de seu personagem principal e então direciona o seu questionamento sobre a perfeição da natureza humana à metáfora da sede de conhecimento, às vezes tentando explicar seriamente que é sim possível ao homem chegar a esse estado de espírito através da meditação e de um grande número de perguntas, às vezes rindo da insensatez de quem foge de si mesmo e tortura todo o seu ciclo de vida para alcançar tal estado de "não eu", mas nunca pondo de lado a vontade de saber, de aprendizagem, que está presente em qualquer criatura, e que é inimiga mortal dessa noção de eterno retorno do mesmo.

Se a sede de conhecimento de Sidarta o mantém no trajeto certo, se o conduz a um estado de espírito perfeito, se o faz movimentar-se por um caminho com numerosos degraus e que sobe sempre, não lhe é possível movimentar-se em círculos; é a força do conhecimento que o faz escapar ao ciclo, é sua realidade que rompe as ligaduras da repetição, é sua possibilidade de questionar a si próprio que o afasta da doutrina do eterno retorno do mesmo. Não é possível ser inteiriço, sem lacunas, límpido, perfeito por meio da repetição, por meio da exclusão do eu e da liquidação das lembranças, e sim por meio da aceitação da realidade e da vida.

A sede de conhecimento de Sidarta é sim algo semelhante a um ciclo, ele se autoquestiona, de um questionamento nasce outro, diferente, e no instante seguinte, pelo fato de perceber que não sabe nada a seu respeito, conhece a si mesmo. Mas esse ciclo não é totalmente fechado, há uma pequena lacuna, uma brecha minúscula, que destrói as rédeas da repetição e permite a entrada do elemento estranho, do novo, do ainda não pensado e não experimentado. A ideia do ciclo de Hesse é mais uma ilustração de que Sidarta pode aprender por si mesmo, ser seu próprio aluno, conhecer seus segredos, e assim chegar ao autoconhecimento. Não significa a eterna repetição para a perfeição, é simplesmente a continuação para o conhecimento de si.

Hesse também emprega o seu método de pensamento baseado na tese nietzschiana do eterno retorno através da metáfora do rio, exposta da segunda parte do volume. Sidarta, tomado ainda pela vontade de conhecer a si mesmo e já separado de Govinda e de Buda e sua doutrina, continua a alimentar dúvidas acerca da perfeição, não quer mais sacrificar seu eu e seus sentidos; ele quer viver, mesmo passando por momentos de insensatez, por

\begin{tabular}{|l|l|l|l|l|}
\hline Q Povista Dialectus & Ano 8 & n. 14 & Janeiro - Julho 2019 & p. $248-263$ \\
\hline
\end{tabular}


erros e vícios, por desgostos, tristezas e desilusões, e fazer tudo de mais estúpido possível, ou seja, até praticar o suicídio, para enfim retornar ao seu eu, a razão de toda a sua aflição. O rio é a metáfora de uma vida nova, a qual, por sua vez, ficou velha e morreu, uma vez que a água corre sempre e, no entanto, ainda está lá, é sempre a mesma, a cada instante, e, contudo, se renova sem parar. Sidarta quer aprender a ouvir as vozes do rio, mas isso parece tão ingênuo quanto os desejos de uma criancinha. No entanto, a sua vontade de aprender com o rio não é sem sentido, não significa que ele está delirando ou fora de si, mas está pensando exclusivamente na sua própria experiência de vida. Ele não quer ouvir do rio qualquer tipo de ensinamento ou conselho de como viver melhor a vida; não é isso, o que ele quer é dizer que o rio está em toda a parte, na fonte e na foz, no mar e na serra, simultaneamente, ou que no rio tudo passa, tudo se flui, como Heráclito diz, mas o rio permanece, e para ele só existe o eterno presente, nada de antes ou depois; o que ele quer é ser visto como um rio, ou seja, ele não quer repartir a realidade, mas superá-la.

Ao comparar Sidarta ao rio, portanto, Hesse almeja dizer que todas as aflições pelas quais passou o seu personagem principal em busca do autoconhecimento pertenciam a um tempo circular não vicioso e que passariam como a correnteza do rio, quando ele conseguisse distinguir as suas inúmeras vozes, que em determinado momento esclareceriam todas as imagens de sua vida, da meninice à velhice, do nascimento à morte, fazendo dela uma verdadeira sabedoria do eu, uma realidade enfim una, harmônica e perfeita.

\section{Referências:}

HESSE, Hermann. O jogo das contas de vidro. Tradução de Lavinas Abranches Viotti e Flávio Vieira de Souza. Rio de Janeiro: BestBolso, 2017.

HESSE, Hermann. Demian. Tradução e posfácio de Ivo Barroso. Rio de Janeiro: Record, 2018.

HESSE, Hermann. Com a maturidade fica-se mais jovem. Rio de Janeiro, São Paulo: Record, 2018.

HESSE, Hermann. O lobo da estepe. Tradução de Ivo Barroso. Rio de Janeiro: BestBolso, 2018.

\begin{tabular}{|l|l|l|l|l|}
\hline Q Povista Dialectus & Ano 8 & n. 14 & Janeiro - Julho 2019 & p. $248-263$ \\
\hline
\end{tabular}


Raylane Marques Sousa / Eduardo Ferreira Chagas

HESSE, Hermann. Posfácio. In: O lobo da estepe. Tradução de Ivo Barroso. Rio de Janeiro: BestBolso, 2018, p. 249-250.

HESSE, Hermann. Sidarta. Tradução de Herbert Caro. Rio de Janeiro: BestBolso, 2018. MANN, Thomas. Hermann Hesse - homenagem ao seu $70^{\circ}$ aniversário. In: $\mathbf{O}$ escritor e sua missão. Rio de Janeiro: Zahar, 2011, p. 134-141.

MICHELS, Volker. Epílogo. In: HESSE, Hermann. Com a maturidade fica-se mais jovem. Rio de Janeiro, São Paulo: Editora Record, 2018, p. 149-152.

ZWEIG, Stefan. Jogos de espelhos: Hermann Hesse. In: O Mundo Insone e outros ensaios. Tradução: Kristina Michahelles. Organização e textos adicionais: Alberto Dines. Rio de Janeiro: Zahar, 2013, p. 1-13.

\begin{tabular}{|l|l|l|l|l|}
\hline Govista Dialectus & Ano 8 & n. 14 & Janeiro - Julho 2019 & p. $248-263$ \\
\hline
\end{tabular}




\title{
HISTÓRIAS DE OUTUBRO: TROTSKI E A REVOLUÇÃO RUSSA
}

\author{
Fábio José de Queiroz ${ }^{1}$ \\ Frederico Jorge Ferreira Costa ${ }^{2}$
}

\begin{abstract}
Resumo:
A revolução está presente. Outubro resiste em suas personagens, em seus fatos e, também, nos escritos que a retomam e a imortalizam. Há personagens que se confundem com os fatos e a escrita a respeito da Revolução de Outubro na Rússia. Leon Trotski a viveu como personagem e historiador. Neste artigo analisamos o papel desempenhado por Trotski na Revolução de Outubro tomando como referência não somente sua ação militante durante os acontecimentos de 1917, mas, do mesmo modo, seu subsídio teórico marxista a esse importante movimento revolucionário do século XX. Baseados nessa reflexão de Trotski, e no conjunto de seus acertos teórico-políticos, concluímos que ele ainda tem algo a dizer aos movimentos anticapitalistas do século XXI.
\end{abstract}

Palavras-chave: Trotski; Revolução de Outubro; Militância; História.

\section{STORIES OF OCTOBER: TROTSKI AND THE RUSSIAN REVOLUTION}

\begin{abstract}
:
The Revolution is present. October resists in its personages, in its facts and also in the writings that take it back and immortalize it. There are personages who are confused with the facts and the writing about the October Revolution in Russia. Leon Trotsky lived it as a personage and a historian. In this article we analyze the role played by Leon Trotski in the October Revolution in Russia, taking as a reference not only to its militant action during the events of 1917, but, even so, his allowance theoretical marxist of this important revolutionary movement of the 20th century. Based on this reflection of Trotsky, and in the set of his theoretical-political correctness, we conclude that it still has something to say to the anti-capitalist movements of the 21 st century.
\end{abstract}

Keywords: Trotski; October Revolution; Militancy; History.

\section{Introdução}

A revolução está presente. Outubro é rememorado em suas personagens, em seus fatos e, também, nos escritos que a retomam e a imortalizam. Há personagens que se destacam, caso de Leon Trotski ${ }^{3}$ (1879-1940), ele a viveu como personagem e historiador. Em todos os momentos do processo revolucionário russo Trotski esteve no centro dos acontecimentos: presidente do soviete (conselho operário) nas revoluções de 1905 e 1917; dirigente do Comitê

1 Doutor em Sociologia (UFC), Professor do Departamento de História da Universidade Regional do Cariri (URCA) e do Mestrado Profissional em Ensino de História (ProfHistória), com Pós-Doutoramento em Educação pela Universidade Federal do Ceará (UFC). É coordenador do grupo de pesquisa Marx, Classes Sociais, Ideologia, Estado e Revolução. E-mail: fabioqueirozurca@ gmail.com

2 Doutor em Educação. Professor da Faculdade de Educação de Itapipoca da Universidade Estadual do Ceará (FACEDI/UECE). Pesquisador colaborador do Instituto de Estudos e Pesquisas do Movimento Operário (IMO). Membro do Programa de Pós-graduação em Educação (PPGE/UECE) e do Mestrado Acadêmico em Serviço Social, Trabalho e Questão Social (MASS/UECE). Coordenador do Grupo de Pesquisas Ontologia do Ser Social, História, Educação e Emancipação Humana (GPOSSHE). E-mail: frederico.costa@ uece.br

3 Codinome de Lev Davidovich Bronstein. 
Militar Revolucionário do soviete, que organizou a insurreição de outubro de 1917; dirigente do Exército Vermelho durante a guerra civil e a intervenção externa; responsável pela reconstrução do sistema de transportes e comunicações e, principal opositor a Stálin, expressão da degeneração burocrática, no partido e na URSS. À vista disso, nos apoiamos nessa constatação para examinar as relações de Trotski com a Revolução de Outubro.

Trotski não apenas se revelou como um dos líderes de Outubro, mas, também, se destacou como um dos historiadores da revolução. Nele, ação e ciência histórica se aliam de modo admirável. Essa fusão do militante e do historiador seria suficiente, quem sabe, para validar a opção com a qual resolvemos trabalhar neste estudo. Ademais, o fato de ele haver sofrido uma sórdida campanha de desqualificação político-histórica, encabeçada pela burocracia soviética, incorpora outro elemento não desprezível a justificar essa inclinação teórica.

Desse modo, nosso alvo é o estudo dos nexos de Trotski com a Revolução de Outubro de 1917, na Rússia, considerando o papel por ele desempenhado nos acontecimentos, bem como a análise que empreendeu acerca do processo revolucionário. Por outro lado, com o intuito de proporcionar maior rigor ao trabalho de pesquisa histórica, optamos por recorrer às conclusões de outros autores acerca da revolução e do papel histórico de Trotski, notadamente de inferências de Rosa Luxemburgo, John Reed, Pierre Broué e Victor Serge, elegendo, deliberadamente, interpretações mais clássicas como apoio às soluções teóricas pessoais que tecemos ao longo deste artigo.

\section{Trotski ou o outubro de um homem}

Como já sugerido, Trotski viveu a Revolução de Outubro duas vezes: primeiro, no papel de líder dessa epopeia do século XX; depois, como historiador - um dos "memoriadores" - de uma narrativa épica cujas repercussões ainda hoje são objetos de reflexão. A análise de Trotski está contida sobremaneira na monumental obra História da revolução russa, um livro, ao mesmo tempo, extenso, com mais de 1000 páginas, e intenso, pela recuperação e reconstituição dos fatos tendo como substrato as análises de um dos protagonistas dos acontecimentos.

Sabe-se que Trotsky retorna do exílio em maio de 1917, quando o czarismo havia caído como resultado do triunfo da Revolução de Fevereiro. Trata-se de um processo insurrecional que modifica as instituições políticas sem tocar nos fundamentos econômicos nos

\begin{tabular}{|l|l|l|l|l|}
\cline { 2 - 5 } & Ano 8 & n. 14 & Janeiro - Julho 2019 & p. $264-277$ \\
\hline
\end{tabular}


quais repousa a sociedade. Nesse momento, o país é administrado pelo governo provisório, formado de representantes de distintos partidos, a começar dos socialistas até os democratas burgueses mais típicos, sem nos esquecer de sobras políticas do antigo regime que insistiam em sobreviver.

Nesse instante, o partido bolchevique está permeado de contradições que o dilaceram. Lênin havia voltado do exílio e, em pouco tempo, travado uma luta contra a maioria da direção do partido na qual se faz vitorioso. A tática leninista se impõe como tática dos bolcheviques. Nesse rearmamento do partido não há espaço para apoio ao governo provisório - um apanhado mal-ajambrado de representantes da burguesia e do proletariado: "Nenhum apoio ao Governo Provisório, explicar a completa falsidade de todas as suas promessas" (LÉNINE, 1978, p. 14).

Lênin rompe com a ideia de uma longa etapa de transição que se estende da vitória da revolução política até o triunfo do proletariado. Nisso, ele se aproxima do conteúdo essencial da teoria da revolução permanente associada ao nome de Trotski. Este, evidentemente, não pertencia aos círculos bolcheviques. Era dirigente de um grupo denominado interdistrital. Quando essas mudanças se operam no âmbito da linha estratégica leninista, progressivamente, os dois agrupamentos se aproximam, e em pouco tempo, o grupo interdistrital adere ao partido de Lênin, Zinoviev e Kamenev.

Da parte de Trotski ocorre uma mudança que não deve ser menosprezada. Depois de longos anos de desconfiança com relação ao modelo de partido leninista, ele reavalia seu ponto de vista anterior, e desde então, segundo Lênin, não houve ninguém mais bolchevique do que o dirigente da ex-interdistrital. De imediato, Leon Trotski é alçado ao Comitê Central (CC) bolchevique e, como membro desse organismo, participa de toda elaboração da tática que finda com a derrubada do governo provisório e a vitória da revolução proletária.

Anos depois, com a degeneração política do primeiro Estado operário vitorioso ${ }^{4}$, obtém peso e volume a campanha de difamação contra Trotski, que começa na cúpula do aparelho estatal soviético e se espalha pelo Partido Comunista da URSS, pela III Internacional, pela mídia e por milhões de fios que ligam as necessidades da burocracia aos meios mais rápidos de veiculação de anúncios, comunicados e exortações. Em uma célebre biografia de Lênin,

\footnotetext{
4 Trotski imortalizou a categoria de Estado Operário para a ex-URSS, acrescentando-lhe a designação de degenerado ou burocratizado. Não se tratava mais de um Estado capitalista, mas de um Estado de transição, que tanto poderia recuar como avançar. A história assinalou o seu brutal recuo.

\begin{tabular}{|l|c|c|c|c|}
\hline Rovita Dialectus & Ano 8 & n. 14 & Janeiro - Julho 2019 & p. $264-277$ \\
\hline
\end{tabular}
}


preparada por um coletivo de autores do Instituto de Marxismo-Leninismo, ligado ao CC do PCUS, lê-se:

\begin{abstract}
Mas Trotski tomou uma posição perigosa para os destinos da revolução. Sem se pronunciar abertamente contra a resolução do CC acerca da insurreição armada, continuou a semear ilusões constitucionais dentro do partido, insistindo no adiamento da insurreição até à realização do II Congresso dos Sovietes, o que de fato significava torpedear a insurreição. (Instituto de Marxismo-Leninismo anexo ao CC do PCUS, 1984, p. 285).
\end{abstract}

Eis uma iniciativa exemplar de se torpedear a imagem de uma liderança revolucionária, apresentando-a como hesitante, às vésperas da tomada do poder. Toma-se uma mediação tática, proposta por Trotski, como demonstração de suas "ilusões constitucionais". O que ele indicava é que não deveria se descartar a hipótese de que a tomada do poder pudesse se dar formalmente pelas mãos de uma organização soviética. A esse respeito, ele se pronuncia:

Assim, se bem que quiséssemos fazer coincidir a tomada do poder com o $2^{\circ}$ Congresso dos Sovietes, de modo nenhum tivemos a esperança ingênua de que este, por si só, pudesse resolver a questão do poder. Este fetichismo da forma soviética era-nos completamente alheio. (TROTSKI, 1979, p. 70).

Como se percebe nessa passagem, nada tão distante da tática de Trotski do que "uma posição perigosa para os destinos da revolução" na qual ele, por suposto, continuasse "a semear ilusões constitucionalistas". Não por acaso, a passagem do poder do domínio do governo provisório para as mãos de um novo governo, hegemonizado pela fração bolchevique, deu-se pela intermediação do Comitê Militar Revolucionário, no espírito da tática de Trotski, que, naquilo que havia nela de mais essencial, coincidia com a tática de Lênin. Do contrário, por que este haveria de concordar com a indicação de Trotski como uma das principais lideranças, senão a principal, da insurreição de outubro, considerando não somente a "posição perigosa para os destinos da revolução" que decorreria de sua tática, mas, também, de suas "ilusões constitucionalistas"?

Essa discussão, indevidamente engendrada e nutrida pelo stalinismo, grosso modo, reaparece, de maneira eventual, não apenas nos velhos manuais de história que repõem antigas controvérsias do campo da esquerda, mas até em celeumas mais recentes, notadamente quando se reabilita o dualismo entre a excelência e a justeza de Lênin em oposição às hesitações de Trotski. A história demonstra à exaustão o lugar do indivíduo na história, e a historiografia da Revolução Russa, amiúde, ratifica a importância de Lênin para que as coisas se dessem da maneira que se deram e não de outras maneiras quaisquer. Nisso parece não haver indício para, seja qual for a polêmica, alguma discussão mais séria se instaurar. Trata-se, no entanto, de algo

\begin{tabular}{|l|l|l|l|l|}
\cline { 2 - 5 } & Ano 8 & n. 14 & Janeiro - Julho 2019 & p. $264-277$ \\
\hline
\end{tabular}


distinto de uma atitude de venerar a Lênin e amaldiçoar a Trotski. Um estudo rigoroso da história não admite esse tipo de ilação. Ou, pelo menos, não deveria.

Rosa Luxemburgo, contemporânea dos dois revolucionários, acolheu a ideia da importância que esses dois homens adquiriram no processo que se estende da preparação ao triunfo da Revolução de Outubro, coroando o que ela nomeia de ofato mais marcante da guerra mundial. Quanto a isso, a marxista polonesa parece não ter dúvida. Aliás, para ela, "também não há dúvida de que as cabeças inteligentes que dirigem a Revolução Russa", não são outras senão as de Lênin e Trotski (Luxemburgo, 2011, p. 179).

Por que Rosa situaria Lênin e Trotski no mesmo plano histórico? Pensamos que a história das divergências de Lênin e Trotski nem sempre pode ser entendida como a dos erros do segundo e a dos acertos do primeiro. Essa história como mistificação não parece se fiar em um bom método marxista. Por isso, a atitude cuidadosa de Rosa Luxemburgo não tem qualquer relação com as falsificações stalinistas que ora tentaram apagar a imagem de Trotski do imaginário revolucionário, ora buscaram deformar seu retrato histórico. Os erros de Trotski são humanos e característicos de um homem de ação, e esse aspecto da questão não deveria ser empregado seja para removê-lo do tablado histórico, seja para deturpar seu papel nos acontecimentos.

Nesse sentido, a leitura de um livro escrito não apenas por um autor não russo, mas redigido no calor dos acontecimentos, ajuda de vez a escudar Trotski não apenas do fogo cerrado de seus inimigos, mas, também, do fogo amigo daqueles que, em certos casos, se apresentam como "trotskistas". Trata-se do livro "Dez dias que abalaram o mundo", do jornalista estadunidense John Reed. Ele viveu os dias decisivos que constituíram o prólogo, os fatos fundamentais e os dias posteriores da Revolução de Outubro. Reed informa ao leitor, por exemplo, que "Em nome do Comitê Militar Revolucionário, Trotski declarou que o Governo Provisório não existia mais" (REED, 2002, p. 131). Como entregar nas mãos de um homem com posições perigosas para revolução, tarefa tão determinante para os destinos dessa mesma revolução?

Aliás, como tomar o revolucionário ucraniano na condição de quase um conciliador com a ordem existente, permeado de ilusões constitucionais, quando ele sobe a tribuna - em nome dos comunistas-bolcheviques - para afirmar que "Coalizão nem sempre quer dizer força" (REED, 2002, p. 195) ou bramir perante os membros da duma: "Vós não sois mais os representantes do povo" (REED, 2002, p. 167). Eis o papel cumprindo por Trotski nos acontecimentos cruciais que definem a dinâmica da revolução! Aliás, é ele como presidente do

\begin{tabular}{|l|c|c|c|c|}
\cline { 2 - 5 } Q Dovista & Ano 8 & n. 14 & Janeiro - Julho 2019 & p. $264-277$ \\
\hline
\end{tabular}


Soviet de Operários e Soldados que, junto com o presidente do Comitê Militar Revolucionário, assina a ordem para "armar os operários com todas as armas disponíveis" e "observar a mais rigorosa disciplina e estar postos para apoiar por todos os meios o exército da revolução" (REED, 2012, p. 235). ${ }^{5}$

Com o desfecho da insurreição praticamente definido, Trotski se dirige ao PréParlamento e de lá anuncia que o velho poder está morto. É hora de o novo poder se erigir. Com referência a esse episódio, o testemunho de um contemporâneo desse episódio é indicativo da participação decisiva de Leon Trotski nos dias que corriam e nas deliberações que lhes ditavam um rosto:

Trotski acabara de provocar, na tribuna do pré-parlamento, a retirada dos bolcheviques da assembleia. Sua voz metálica tinha lançado à mais alta autoridade da república o desafio dos proletários e dos camponeses. (SERGE, 2007, p. 73)

Eis o retrato de um homem que, longe de vacilar ante suas tarefas, as cumpria com desassombro. $\mathrm{O}$ mito stalinista de um Trotski que quase fugia ao outubro que lhe desafiava parece mais uma anedota acanhada do que uma hipótese que devesse ser levada a sério. Paradoxalmente, esse espírito estreito ainda alimenta as imaginações pouco precavidas. As conexões de Reed e Serge com os acontecimentos de 1917 ajudam a desfazer parte expressiva da mitologia que se construiu ao redor da participação de Trotski no momento mais decisivo do século XX.

De qualquer modo, pode ocorrer de o leitor mais exigente contra-argumentar que essas ações são públicas e refletem unicamente a obediência de Trotski às decisões do Comitê Central bolchevique e não necessariamente o resultado de suas convicções pessoais. Outra vez, Reed nos fornece elementos mais do que razoáveis no que diz respeito à coerência entre as decisões do partido e a consciência de Davidovitch como teórico marxista e militante revolucionário. Aqui, é preciso pôr em evidência o fato de que, talvez, nenhum estrangeiro adentrou tão profundamente o coração dos acontecimentos como John Reed. Para ele, franquearam-se as portas da revolução, desde a superfície dos episódios até a vida interna da

5 O papel de Trotski, no momento da insurreição e instalação do governo revolucionário, é de tal modo proeminente que a própria nomenclatura de "comissários do povo", usada para designar as funções dos novos membros governamentais, segundo Broué, é proposta por ele e "apoiada com entusiasmo por Lênin". Nos detalhes mais simples se recupera o lugar privilegiado que Trotski ocupou nos acontecimentos de 1917. O rechaço à participação dos bolcheviques no pré-parlamento, cujo papel é obstruir o curso da insurreição em movimento, é encabeçado por Trotski, o que, uma vez mais, descontrói a hipótese de sua rendição ao legalismo democrático-burguês. A esse respeito, Lênin é categórico: "Trotski era partidário do boicote. Bravo, camarada Trotski! (...) Viva o boicote!" (BROUÉ, Pierre. O partido bolchevique, São Paulo: Sundermann, 2014, p. 94).

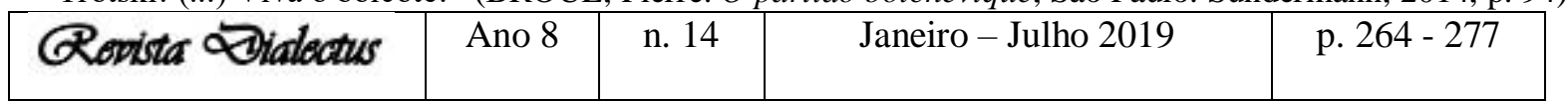


organização bolchevique. Ele conviveu com os líderes revolucionários, mediu a pulsação de cada um deles e arrancou informações que inteiraram o mundo a respeito do fato mais colossal nascido do ventre da Primeira Guerra Mundial. Nem o que se passava no âmbito da direção máxima do partido bolchevique lhe era estranho:

Mas o Comitê Central do Partido Comunista estudava a insurreição. Passou a noite do dia 23 reunido. Estavam presentes todos os intelectuais do partido, os dirigentes e os delegados dos operários e da guarnição de Petrogrado. Entre os intelectuais, só Lênin e Trotski estavam pela insurreição. (REED, 2002, p. 78).

"Entre os intelectuais, só Lênin e Trotski estavam pela insurreição”. A força dessa frase coincide com as apreciações históricas que, posteriormente, Trotski faria com relação ao seu papel nos acontecimentos de 1917. Há uma coerência entre os relatos e as análises de Reed e Trotski. Logo, o autor de História da revolução russa não engendrou uma história na qual se autoglorificava. A propósito, essa não é a única passagem do livro do jornalista em que a firme atitude de Trotski é ressaltada. Além de adotar uma posição vigorosa nos dias que precederam à organização da insurreição, nos dias que se seguiram ao triunfo da ação insurrecional, ele não deixou de crer - assim como Lênin - de que era possível assegurar o poder arrancado das mãos da burguesia. John Reed descreve essa convicção nos seguintes termos: "Excetuando Lênin, Trotski, os operários de Petrogrado e os soldados, ninguém acreditava que os bolcheviques poderiam manter-se no poder por mais de três dias". (REED, 2002, p. 166).

Em vista disso, é pouco consistente o empenho em menosprezar a conduta de Leon Trotski ao longo do processo revolucionário de 1917. Ao contrário de claudicação, a sua atitude é categórica, peremptória. Historicamente, os ventos que pretendem derrubá-lo nos parecem frágeis. Sopram e depois se desviam quase envergonhados de sua delicada vulnerabilidade.

\section{Trotski como analista de Outubro}

Na obra As lições de abril, Leon Trotski constata o que, para ele, seria um problema não desprezível, qual seja:

Se é verdade que na revolução de Outubro tivemos sorte, outro tanto não se poderá dizer do seu lugar na nossa literatura. Ainda não dispomos de uma única obra que dê um quadro geral da revolução de Outubro, fazendo sobressair os seus principais momentos de ponto de vista político e organizativo. (TROTSKI, 1979, p. 7).

\begin{tabular}{|l|l|l|l|l|}
\cline { 2 - 5 } & Ano 8 & n. 14 & Janeiro - Julho 2019 & p. $264-277$ \\
\hline
\end{tabular}


Para ele, Outubro é uma experiência que tem a nos ensinar. Esse é o seu pressuposto básico. Nasce daí a sua compreensão de que é necessário estudá-la. O livro As lições de outubro é produto direto dessa linha de raciocínio. Ademais, as deformidades do regime burocrático e a sua negligência com a ideia de verdade como regra de ouro dos que escrevem a respeito da história, sem dúvida, o induziram a se deter meticulosamente sobre os fatos que marcaram o ano de 1917 na Rússia. Decorre desse esforço a monumental obra História da revolução russa, elogiada inclusive por historiadores muitos comprometidos com seu ofício, dentre eles, Perry Anderson.

Neste artigo, não tomaremos como referência o amplo arco de obras de Trotski no qual a temática da Revolução de Outubro está inserida. Partiremos, fundamentalmente, dos dois livros antes citados: As lições de outubro e História da revolução russa. Nestas duas obras estão compiladas as principais conclusões de Leon Trotski com relação ao significado da revolução liderada pelos bolcheviques. Nos limites deste trabalho, elas nos parecem mais do que suficientes com vistas a oferecer ao leitor a visão histórico-teórica do autor a respeito de acontecimentos que, ainda hoje, dividem águas no campo da esquerda. Com a passagem recente do centenário da revolução, as polêmicas não tendem a sair de cena, mas, inversamente, devem ocupar os seus lugares no amplo tablado que se liga ao balanço desse notável acontecimento. As ideias de Trotski, no que diz respeito a Outubro, são partes indivociáveis de querelas históricas que cobram também seu lugar no debate. Portanto, vamos ao debate e às questões que ele suscita.

De Plano, uma conclusão teórico-histórica sobressai das páginas de As lições de outubro. Ela diz respeito aos vínculos da revolução com a guerra. Sobre isso, Trotski esclarece:

Precisamente por não ter dado lugar a uma pressão reformista, a guerra criara uma situação revolucionária. Das duas uma: ou se seguia a burguesia até o fim, ou então levantavam-se as massas contra ela, arrancando-lhe o poder. (TROTSKI, 1979, p. 29).

Trotski entende que um partido marxista, e os bolcheviques constituíam um partido marxista, não renuncia as reformas, entendendo que estas se referem sempre a questões secundárias. No caso da guerra, a burguesia jogava a sua sorte como classe dominante, e a questão do poder estava posta nitidamente. Quando essa questão está posta não há lugar para reformas. Em 1917, não havia espaço para reformas nem na Rússia dos czares nem na Rússia dos Kerenskins. A situação revolucionária que se abriu - decorrente da aceleração da luta de classes - colocou o problema do poder de modo cristalino. O fracasso de mencheviques e de socialistas revolucionários se fundamentava precisamente na ausência de possibilidades de uma

\begin{tabular}{|c|c|c|c|c|}
\cline { 2 - 4 } & Ano 8 & n. 14 & Janeiro - Julho 2019 & p. $264-277$ \\
\hline
\end{tabular}




\section{HISTÓRIAS DE OUTUBRO: TROTSKI E A REVOLUCÃO RUSSA}

Fábio José de Queiroz / Frederico Jorge Ferreira Costa

solução reformista para crise aberta com a guerra. O êxito bolchevique começa com o retorno de Lênin e com a mudança que ele imprime à orientação dos bolcheviques. Até então, a fração bolchevique trabalhava com um cenário em que a realidade se expressava mediante um processo lento e arrastado de aprofundamento da democracia (produto da Revolução de Fevereiro). É Lênin que se impõe contra essa "fórmula decorada" e levanta como tarefa a preparação para conquista do poder. Essa mudança de linha estratégica é o alicerce no qual se apoia o partido para, meses depois, organizar a insurreição vitoriosa. Essa parece a Trotski uma das principais lições que explicam o desenlace de outubro.

O que essa questão, efetivamente, demonstra é que: (1) A situação objetiva não pode ser desprezada. Não é possível que a revolução triunfe sem que antes disso se imponha uma situação revolucionária. A guerra e os seus desdobramentos estão na base da eclosão da situação revolucionária, mas essa não conduz, necessariamente, ao triunfo da revolução. (2) A começar daí decorre o aspecto subjetivo de todo processo. A existência do partido bolchevique e como ele foi sendo temperado nas situações mais difíceis da luta de classes, em última hipótese, desempenharam papel não ínfimo no processo revolucionário. Acontece que esse partido não nasceu pronto no forno da história. O seu núcleo dirigente hesitou em diversos momentos da luta política. Trotski não negligenciou no trato dessa questão. (3) Por fim, Lênin exerceu uma tarefa exemplar não apenas com vistas ao rearmamento programático do partido, mas auscultando a movimentação da classe operária, para não deixar escapar o momento no qual o partido deveria encarregar-se de organizar a insurreição. Em síntese, essa conjunção entre situação objetiva (guerra e situação revolucionária), existência do partido bolchevique (mais do que uma doutrina, um sistema de educação revolucionária, como crê Trotski) e o papel do indivíduo na história (Lênin), com efeito, exerceu papel essencial no desfecho do outono russo.

Eis o curso típico da Revolução de Outubro. Não há como não ver nele uma questão inescapável: o olhar arguto de uma personagem que soube tirar dos acontecimentos que viveu as conclusões mais vivas e capazes de interessar aos que, vivendo noutro tempo, se veem diante da contingência de entendê-los e analisá-los. Em As lições de outubro, Trotski nos oferece uma primeira leitura dessa experiência peculiar da história do século XX. Essa leitura, contudo, pode servir apenas de pretexto para que o leitor e o crítico busquem o necessário aprofundamento das questões que, de maneira quase sumária, estão tratadas no livro. Decorre disso, a conveniência de tomarmos nas mãos um segundo texto do autor: História da revolução russa.

\begin{tabular}{|l|l|l|l|l|}
\cline { 2 - 4 } & Ano 8 & n. 14 & Janeiro - Julho 2019 & p. $264-277$ \\
\hline
\end{tabular}


No último livro, Trotski decorre longamente sobre o processo revolucionário, a datar de fevereiro e se estendendo até a vitória da Revolução de Outubro. Interessa-nos aqui, antes de tudo, a parte do livro que se prolonga do capítulo 34 (as massas sob ataque) até o capítulo 47 (o congresso da ditadura soviética) mais a conclusão. No caso do capítulo 34, Trotski desenvolve um raciocínio que já pode ser antevisto em As lições de outubro. Num raciocínio oposto a certo marxismo mecanicista (que só enxerga as premissas objetivas), ele escreve que:

As causas imediatas dos eventos de uma revolução são as mudanças na consciência das classes em luta. As relações materiais da sociedade apenas definem o canal dentro do qual estes processos acontecem. (TROTSKI, 2007, p. 693).

A virtude bolchevique, em larga medida, se mostrou na capacidade de recolher impressões cada vez mais precisas das mudanças que se processavam na consciência das classes em luta. Isso expresso, aqui se tem a base sobre a qual se modificou a tática bolchevique ao longo dos meses que precederam a insurreição vitoriosa. Nesse período, os bolcheviques só aumentaram sua força de atração, e nesse processo, nunca trataram com descaso a experiência independente das massas. Esse segundo elemento, de certo modo, ajuda a explicar o primeiro. Nessa perspectiva, as experiências de vida das massas, em última instância, deram convicção a Lênin e aos bolcheviques - minoritários na superestrutura - de que sua tática insurrecional era correta. Em suma, esse enlace do partido com o proletariado é determinante no curso dos acontecimentos e explica como seus 240 mil membros se mostraram capazes de arrastar atrás de si dezenas de milhões de homens e mulheres a uma conquista tão admirável.

Mas, não faltou flexibilidade tática aos leninistas para trazer para o lado da revolução, por exemplo, milhões de camponeses que, em tempo algum, ficaram ao alcance da influência bolchevique. A aliança com a esquerda dos socialistas revolucionários e a aceitação de seu programa agrário são provas palpáveis da agilidade política bolchevique. Nessa tática, era fundamental estar com os camponeses - maioria absoluta do povo russo. A respeito do campesinato, Trotski enfatizava que "A civilização transformou o campesinato em seu animal de carga. A burguesia, em longo prazo, apenas mudou a forma da cangalha" (TROTSKI, 2007, p. 785). Partindo desse fundamento histórico, os bolcheviques levantaram a necessidade da aliança dos trabalhadores urbanos com o campesinato pobre como condição necessária para emancipação de ambos. O partido do proletariado não havia de prescindir do concurso dos camponeses. Essa aritmética era imprescindível para revolução. E, assim, deu-se em 1917.

\begin{tabular}{|l|l|l|l|l|}
\cline { 2 - 4 } & Ano 8 & n. 14 & Janeiro - Julho 2019 & p. $264-277$ \\
\hline
\end{tabular}


Além da ligação com as massas urbanas e da aliança com os camponeses, os bolcheviques se apoiaram numa sólida argamassa teórica. Trotski não passou ao largo dessa questão. Ele discorreu sobre esse tema, diversas vezes, ao longo do livro e, a esse respeito, há passagens que são emblemáticas, como a que reproduzimos abaixo:

\footnotetext{
Uma época de poderosos levantes sociais não dá espaço para charlatães. Aqui a experiência histórica, mesmo iluminada pela intuição, não é suficiente. Aqui, deve-se ter uma doutrina sintética compreendendo as interações das principais forças históricas. Deve-se ter um método materialista que permita descobrir, por trás de sombras móveis de programas e palavras de ordem, o movimento real das classes da sociedade. (TROTSKI, 2007, p. 936).
}

Nota-se que a teoria se embebe do movimento real das classes da sociedade. Logo, não é um todo amorfo e desconectado. Se em condições de rotina, a teoria como teoria sobrevive, e até se estende, em tempos de "poderosos levantes sociais", ela só sobrevive e se estende em suas múltiplas relações com as principais forças históricas. Eis o conteúdo mais profundo do marxismo que nutria o partido bolchevique. Nesse quadro, o seu método materialista se mostrou vital para os que não só desejavam entender como funcionava a sociedade, mas como era possível transformá-la. Era o caso de Lênin, de Trotski e dos bolcheviques. No mais,

\footnotetext{
Graças a uma favorável combinação das condições históricas, domésticas e internacionais, o proletariado russo foi encabeçado por um partido de extraordinária clarividência política e têmpera revolucionária sem exemplo. Apenas isso permitiu a uma classe jovem e pouco numerosa realizar uma tarefa histórica de proporções sem precedentes. (TROTSKI, 2007, p. 937).
}

Cremos que essa citação sintetiza admiravelmente as principais conclusões que Trotski apresenta ao longo dos capítulos que servem de fundamento e inspiração a esse momento da análise. Evidentemente, o texto de Davidovitch é mais nuançado, e nos limites de um artigo como este, a tendência é vê-lo, de alguma maneira, empobrecido. Logo, os que tenham a pretensão de criticá-lo, abstenham-se dessa tarefa, ou a transfiram para o autor deste artigo. Por fim, quanto aos que se limitam a criticar a ação bolchevique pela conquista do poder, Trotski lembra simplesmente que ela "foi a mais popular insurreição de massas de toda a História" (idem, p. 984). De certa maneira, esse intervalo de pouco mais de um século e as controvérsias que dele se desprendem, por si mesmo, já certifica a conveniência do juízo histórico de Leon Trotski.

\begin{tabular}{|l|l|l|l|l|}
\cline { 2 - 5 } & Ano 8 & n. 14 & Janeiro - Julho 2019 & p. $264-277$ \\
\hline
\end{tabular}




\section{Notas conclusivas: Trotski é contemporâneo do século XXI}

Quando bate na porta da história um pouco mais de cem anos da Revolução Russa, de fato, convém ao historiador girar a maçaneta e deixá-la entrar. Eis a atitude que adotamos neste artigo, no qual nos fundamentamos em uma questão específica - o lugar teórico e militante de Trotski nos acontecimentos de 1917 - para tratar do problema com o máximo de amplitude.

O que é certo, em todo caso, é que Leon Trotski tem seu nome ligado ao mais célebre e memorável acontecimento do século XX: a Revolução Russa. Na prática, Trotski destinou à revolução o melhor de suas forças físicas e mentais, rememorou o seu itinerário por meio de uma análise fascinante que, mesmo no transcurso de um século do fato histórico em questão, não há como a memória a respeito desse homem e da história com a qual ele se confunde, de fato, ser esquecida, dobrada ou estilhaçada. Ademais, a retomada de seus textos acerca da revolução é sempre um bafejo generoso para todo aquele que se sente revitalizado diante de qualquer análise em que imaginação intelectual e rigor analítico se cruzam como partes constituintes de um mesmo objeto. Por fim, segue válida a sua reflexão de que, efetivamente,

(...) o historiador não cometerá erros se disser que, em 25 de outubro, não apenas a luz elétrica foi cortada da tipografia governamental, mas uma importante página se abriu na História da Humanidade. (TROTSKI, 2007, p. 1020).

Página de um livro por natureza inconcluso, o qual deve ser escrito pelas massas exploradas e oprimidas. Nessa escrita, diversa e multicor, a pena do revolucionário bolchevique, ucraniano e judeu pode contribuir com os contornos da luta emancipatória pelo socialismo.

De acordo com Coggiola (1995), foi depois de sua morte, orquestrada pela burocracia stalinista, que o pensamento de Trotski esculpido pela revolução russa, teve, em suas linhas estratégicas, sua confirmação espetacular: 1) nos países atrasados, a revolução só foi vitoriosa naqueles em que houve um transcrescimento da revolução democrática em revolução socialista, com a recusa de todo compromisso estratégico com a burguesia e o imperialismo (Cuba e Vietnã, por exemplo); 2) contra os teóricos stalinistas, neostalinistas, socialdemocratas ou "terceiro-mundistas", a revolução proletária provou a sua vigência objetiva nas metrópoles imperialistas: na Europa Ocidental no imediato pós-guerra foram necessárias inéditas concessões da burguesia às massas para contê-la, e, também, na mesma região no período que vai do maio francês de 1968 até à revolução portuguesa de 1974-1975; 3) as frentes populares provaram ser uma política de derrota, conduzindo ao aborto da revolução e, nos casos extremos

\begin{tabular}{|l|l|l|l|l|}
\cline { 2 - 5 } & Ano 8 & n. 14 & Janeiro - Julho 2019 & p. $264-277$ \\
\hline
\end{tabular}


à vitória fascista: Europa Ocidental no pós-guerra, Portugal 1974-1975, Chile 1970-1973, Nicarágua na década de 1980;4) Na ausência de uma direção revolucionária mundial os processos revolucionários abortaram, ou quando vitoriosos nacionalmente, não deram início à revolução mundial ou a sua extensão continental, levando-as ao isolamento e à degeneração; 5) a burocratização dos Estados operários na URSS, Europa Oriental e Ásia conduziu essas sociedades a um completo impasse.

Essa breve síntese do pensamento trotskista apenas indica que o historiador e militante da Revolução Socialista Russa abre-nos uma porta rica de possibilidades e faz-nos um convite: a vitória é possível, Outubro está presente!

\section{Referências}

BROUÉ, Pierre. O partido bolchevique. São Paulo: Sundermann, 2007.

Instituto de Marxismo-Leninismo anexo ao CC do PCUS. Biografia de V. I. Lénine. Lisboa; 276 Moscou: Edições “Avante!”; Edições Progresso, 1984.

COGGIOLA, Osvaldo. Prefácio. In: MANDEL, Ernest. Trotsky como alternativa. São Paulo: Xamã, 1995.

LÉNINE, V. I. Sobre as tarefas do proletariado na presente revolução. In: LÉNINE, V. I. Obras escolhidas em três tomos, 2. Lisboa; Moscovo: Edições “Avante!”; Edições Progresso, 1978.

LÊNIN, V. I. Últimos escritos e diário das secretarias. São Paulo: Sundermann, 2012.

LUXEMBURGO, Rosa. Textos escolhidos, v. II, Isabel Loureiro (Org.). São Paulo: Editora da Unesp, 2011.

REED, John. 10 dias que abalaram o mundo. Porto Alegre: L\&PM, 2002.

SERGE, Victor. O ano I da Revolução Russa. São Paulo: Boitempo, 2007.

TROTSKI, Leon. As lições de outubro. Lisboa: Edições Antídoto, 1979.

\begin{tabular}{|l|l|l|l|l|}
\cline { 2 - 4 } & Ano 8 & n. 14 & Janeiro - Julho 2019 & p. $264-277$ \\
\hline
\end{tabular}


História da revolução russa, tomo II, partes 2 e 3. São Paulo: Sundermann, 2007.

\begin{tabular}{|l|l|l|l|l|}
\hline Q & Ano 8 & n. 14 & Janeiro - Julho 2019 & p. 264 - 277 \\
\hline
\end{tabular}




\title{
A RELAÇÃO TRABALHO-EDUCAÇÃO NO PENSAMENTO DE MARX: UM ESTUDO DOS MANUSCRITOS ECONÔMICO-FILOSÓFICOS (1844)
}

\author{
José Salvador de Almeida ${ }^{1}$ \\ Eduardo Ferreira Chagas ${ }^{2}$
}

\begin{abstract}
Resumo:
Este artigo objetiva demonstrar e explicitar a relação entre trabalho-educação no pensamento de Marx, a partir de um estudo dos Manuscritos econômico-filosóficos (1844), especificamente, do manuscrito intitulado, a saber: Trabalho Estranhado e Propriedade Privada. Neste trabalho, apresentamos, inicialmente, o debate de Marx com a economia nacional e, na sequência, a teoria sobre o estranhamento na essência do trabalho [trabalho estranhado] e, por fim, a relação trabalho-educação para este pensador materialista. Durante o desenvolvimento da referida pesquisa, adotamos como procedimento metodológico o método dialético-crítico-reflexivo, pois tal método, no nosso entendimento, permite uma melhor compreensão dos escritos de Marx. Ao final da pesquisa, evidenciamos que existe uma relação íntima entre trabalho-educação no pensamento de Marx, pois a educação deve proporcionar ao homem (trabalhador) uma relação imediata e de reconhecimento entre o trabalho (atividade vital consciente e livre) e a produção, isto é, entre o trabalhador e os objetos da produção. No capitalismo, tal relação, portanto, se apresenta como uma relação hostil e estranha, pois o trabalhador não se reconhece no produto do seu próprio trabalho, uma vez que este trabalho se apresenta como trabalho estranhado.
\end{abstract}

Palavras-chaves: Relação trabalho-educação. Marx. Trabalho estranhado. Homem. Capitalismo.

\section{THE RELATIONSHIP BETWEEN LABOR AND EDUCATION IN MARX'S THOUGHT: A STUDY FROM HIS ECONOMIC-PHILOSOPHICAL MANUSCRITPS (1844)}

\begin{abstract}
:
This article aims to demonstrate the relationship between labor and education in Marx's thought, from a study of his Economic and Philosophical Manuscripts (1844), specifically, the one entitled: Estranged Labor and Private Propriety. In This work, we present, initially, Marx's debate with national economy and, consequently, his estrangement's theory in the essence of labor [estranged labor] and, ultimately, the laboreducation relationship of this materialist thinker. During the development of this research, we have adopted as methodological procedure the reflexive-critic-dialectic method as a result of understanding that it allows us to better comprehend his manuscripts. At the end of this research, we have demonstrated that exists a profound relationship between labor and education in Marx's thought because education ought to make it possible for man (worker) a direct relationship of recognition between labor (a vital, conscient and free activity) and production or, in other words, between workers and their production. In the capitalist society, such relationship, although, is presented as an estranged and hostile one, once the workers do not recognize themselves in their own production.
\end{abstract}

Keywords: Labor-education relationship. Estranged Labor. Man. Capitalism. Marx.

1 Mestrando em Educação pela Universidade Federal do Ceará (UFC). E-mail: salvadoralmeida002@gmail.com.

2 Doutor em Filosofia pela Universidade Alemã de Kassel; Professor de Graduação e Pós-Graduação do Curso de Filosofia da Universidade Federal do Ceará (UFC); Colaborador do Programa de PósGraduação da Faculdade de Educação (FACED) da UFC e Colaborador do Programa de Pós-Graduação do Mestrado Acadêmico em Filosofia da Universidade Estadual do Ceará (UECE). Bolsista do CNPQ. E-mail: ef.chagas@uol.com.br. 


\section{INTRODUÇÃO}

Ao iniciar a escrita do manuscrito, a saber: Trabalho estranhado $e$ propriedade privada, localizado na obra Manuscritos econômico-filosóficos (1844) ${ }^{3}$, Marx, em seu processo de análise das categorias, leis e conceitos da economia nacional ${ }^{4}$, considera a própria linguagem da economia nacional e constata que quando se trata da realidade material, concreta, tais categorias, leis e conceitos não encontram uma sintonia, isto é, que a realidade da vida humana discorre da teoria apresentada por essa ciência, pois segundo Marx (2010), a partir da própria linguagem da economia nacional, verificase que o trabalhador baixa a condição de mercadoria e à da mais miserável mercadoria, que a miséria do trabalhador se apresenta na vida real, concreta e material em oposição à grandeza da sua produção e que o resultado é que, no final das contas, toda a sociedade decompõe-se em duas classes distintas, a classe dos proprietários e dos trabalhadores sem propriedade.

Pois, segundo Marx,

A economia nacional parte do fato dado e acabado da propriedade privada. Não explica o mesmo. Ela percebe o processo material da propriedade privada, que passa, na realidade (Wirklichkeit), por fórmulas gerais, abstratas, que passam a valer como leis para ela. Não concebe (begreift) estas leis, isto é, não mostra

3 Afirma Sobral que: "Os Manuscritos escritos por Marx em 1844 partem de uma dupla motivação: uma iniciativa de compreender a economia política comparada à filosofia; e uma tentativa de dar orientação a um movimento revolucionário crescente na Europa. A primeira permitiu a Marx estabelecer uma visão coordenada entre os dois campos. A segunda, um desdobramento da anterior, não se caracterizou, pois, esta obra permaneceu sem ser publicada. [...].” (SOBRAL, 2005, p. 13).

4 Segundo Jesus Ranieri, na nota de tradução n 2, dos Manuscritos econômico-filosóficos, "A opção por "economia nacional", em vez de "economia política" é do próprio Marx. Economistas burgueses ingleses e franceses utilizavam, correntemente, political economy e économie politique, mas aos alemães era mais próximo o termo Nationalökonomie. O próprio Marx teria pronunciado, também nos Anais franco-alemães, quando da caracterização da diversidade e de desenvolvimentos das diferentes cidades francesas e inglesas, comparada às alemãs, algo a respeito da oposição entre economia política e economia nacional. Somente mais tarde ele irá converter, nos seus escritos, o conceito de "economia nacional" para "economia política". Importa salientar igualmente que "economia nacional" diz respeito, dependendo do contexto, tanto ao sistema econômico quanto às suas teorizações." (MARX, 2010, p. 19).

\begin{tabular}{|l|l|l|l|l|}
\hline Q Povista Dialectus & Ano 8 & n. 14 & Janeiro - Julho 2019 & p. 278 - 294 \\
\hline
\end{tabular}


como têm origem na essência da propriedade privada. [...]. (MARX, 2010, p. 79).

Diante de tal acusação, convicto de suas palavras, Marx percebe e afirma que a economia nacional não apresenta nenhuma explicação que encontre sua verdade na vida real, ou seja, não mostra a origem dessas leis assentadas na realidade objetiva, material.

A economia nacional, ciência fundamentadora do capitalismo, não apresenta, conforme Marx, esclarecimentos a respeito do fundamento da divisão entre trabalho e capital, entre capital e terra. Quando, por exemplo, fala da concorrência, apresenta sua explicação a partir de circunstâncias exteriores. Pergunta Marx: "Até que ponto estas circunstâncias exteriores, aparentemente casuais, são apenas a expressão de um desenvolvimento necessário?”. (MARX, 2010, p. 79).

Ainda, de acordo com Marx, a troca aparece para a economia nacional como um fato meramente acidental. Assim, Marx (2010) afirma que as únicas rodas que o economista nacional põe em movimento são a ganância e a guerra entre os gananciosos, a concorrência.

Uma vez que a economia nacional, no entendimento de Marx, não explica por não entender a conexão do movimento, ela colocou em oposição à doutrina da concorrência à doutrina do monopólio, a doutrina da liberdade industrial à doutrina da corporação, a doutrina da divisão da posse da terra à doutrina da grande propriedade fundiária, pois concorrência, liberdade industrial, divisão da posse da terra eram concebidas apenas como consequências acidentais, deliberadas, violentas e não como consequências necessárias, naturais do monopólio, da corporação e da propriedade feudal.

Após constatar, no primeiro momento, a impotência da economia nacional, no tocante a elaboração de suas próprias teorias e leis para a explicação da realidade, Marx aprofunda seu processo de análise, agora, no segundo momento, em que busca entender o motivo da interconexão essencial entre a propriedade privada, a ganância, a separação de trabalho, capital e propriedade da terra, de troca e concorrência, de valor e desvalorização do homem, de monopólio e concorrência, etc., de todo esse estranhamento com o sistema do dinheiro.

Na busca pelo entendimento desta explicação, Marx chama a atenção para que

\begin{tabular}{|l|l|l|l|l|}
\hline Govista Dialectus & Ano 8 & n. 14 & Janeiro - Julho 2019 & p. $278-294$ \\
\hline
\end{tabular}


Não nos desloquemos, como [faz] o economista nacional quando quer esclarecer [algo], a um estado primitivo imaginário. Um tal estado primitivo nada explica. Ele simplesmente empurra a questão para uma região nebulosa, cinzenta. Supõe na forma do fato (Talsache), do acontecimento, aquilo que deve deduzir, notadamente a relação necessária entre duas coisas, por exemplo entre a divisão do trabalho e troca. Assim o teólogo explica a origem do mal pelo pecado original (Sündenfall), isto é, supõe como um fato dado e acabado, na forma da história, o que deve explicar. (MARX, 2010, p. 80).

E continua afirmando que "Nós partimos de um fato nacional-econômico, presente". (MARX, 2010, p. 80).

O trabalhador se torna tanto mais pobre quanto mais riqueza produz, quanto mais a sua produção aumenta em poder e extensão. O trabalhador se torna uma mercadoria tão mais barata quanto mais mercadorias cria. Com a valorização do mundo das coisas (Sachenwelt) aumenta em proporção direta a desvalorização do mundo dos homens (Menschenwelt). O trabalho não produz somente mercadorias; ele produz a si mesmo e ao trabalhador como uma mercadoria, e isto na medida em que produz, de fato, mercadorias em geral." (MARX, 2010, p. 80).

Na citação acima, verificamos a partir da constatação de Marx que o trabalhador, na sociedade capitalista, se torna uma mercadoria tão mais barata quanto mais mercadorias ele cria, ou seja, quanto mais riqueza (uma enorme coleção de mercadorias) o trabalhador produz, mais pobre e miserável ele se torna. O mundo das coisas (mercadorias) possui mais importância do que o mundo dos homens. Nesse processo, o trabalhador produz a mercadoria ao mesmo tempo em que produz a si mesmo, e ao trabalhador como uma mercadoria.

\section{O ESTRANHAMENTO NA ESSÊNCIA DO TRABALHO ${ }^{5}$ [TRABALHO ESTRANHADO}

5 Concordamos com Sobral na seguinte afirmação "O trabalho é apresentado de maneira dúplice nos Manuscritos: a primeira refere-se ao trabalho como uma característica específica do capitalismo, pois está determinado pela sobrevivência, pelas necessidades mais rudimentares, separado da verdadeira necessidade que é o estabelecimento de uma vida humana. O ser humano só adquire sentido, no capitalismo, como ser que trabalha por um salário. A segunda característica é a concepção de trabalho como um dos aspectos da atividade humana. O trabalho é então considerado como um elemento que deve servir ser humano, que deve ser usufruído como atividade que realiza uma parte das potencialidades humanas; para isso, é preciso que tenha sido superada a alienação, o caráter estranho do trabalho, permitindo que ele possa ser dirigido pelo esforço consciente do homem, e que a finalidade última seja a satisfação deste e não a satisfação de elementos externos, como o capital, a mercadoria e o dinheiro." (SOBRAL, 2005, p. 17).

\begin{tabular}{|l|l|l|l|l|}
\hline Q Povista Dialectus & Ano 8 & n. 14 & Janeiro - Julho 2019 & p. $278-294$ \\
\hline
\end{tabular}


Marx (2010) chega à conclusão que, na sociedade capitalista, o objeto que o trabalho produz, o seu produto, se lhe defronta como um ser estranho, como um poder independente do produtor. Que o produto do trabalho é o trabalho que se fixou num objeto, fez-se coisal, é a objetivação do trabalho. Que a efetivação do trabalho é sua objetivação. Esta efetivação do trabalho aparece, nas palavras de Marx, ao estado nacional-econômico como desefetivação do trabalhador, a objetivação como perda do objeto e servidão ao objeto, a apropriação como estranhamento ${ }^{6}$, como alienação.

Nessa forma de sociedade, o trabalhador ao produzir o objeto, o seu produto, esse mesmo objeto produzido se lhe defronta como um ser estranho, isto é, independente do trabalhador. Assim, nesse estranhamento do trabalhador com o seu produto, objeto, tem-se, justamente, o contrário da relação ideal, pois a efetivação aparece, aqui, como

6 De acordo com o tradutor dos Manuscritos econômico-filosóficos, da editorial Boitempo, Jesus Ranieri (2004), “[...] é preciso destacar a distinção sugerida, nesta tradução, entre alienação (Entäusserung) e estranhamento (Entfremdung), pois são termos que ocupam lugares distintos no sistema de Marx. É muito comum compreender-se por alienação um estado marcado pela negatividade, situação essa que só poderia ser corrigida pela oposição de um estado determinado pela positividade emancipadora, cuja dimensão seria, por sua vez, completamente compreendida a partir da supressão do estágio alienado, esse sim aglutinador tanto de Entäusserung quanto de Entfremdung. No capitalismo, os dois conceitos estariam identificados com formas de apropriação do excedente do trabalho e, consequentemente, com a desigualdade social, que aparece também nas manifestações tanto materiais quanto espirituais da vida do ser humano. Assim, a categoria alienação cumpriria satisfatoriamente o papel da categoria universal que serve de instrumento para a crítica de conjunto do sistema capitalista. Na reflexão desenvolvida por Marx não é tão evidente, no entanto, que esse pressuposto seja levado às suas últimas consequências, pois os referidos conceitos aparecem com conteúdos distintos, e a vinculação entre eles, geralmente sempre presente, não garante que sejam sinônimos. E é muito menos evidente ainda que sejam pensados somente para a análise do sistema capitalista. Entäusserung significa remeter para fora, extrusar, passar de um estado a outro qualitativamente distinto. Significa, igualmente, despojamento, realização de uma ação de transferência, carregando consigo, portanto, o sentido da exteriorização (que, no texto ora traduzido, é uma alternativa amplamente incorporada, uma vez que sintetiza o movimento de transposição de um estágio a outro de esferas de existência), momento de objetivação humana no trabalho, por meio de um produto resultante de sua criação. Entfremdung, ao contrário, é objeção socioeconômica à realização humana, na medida em que veio, historicamente, determinar o conteúdo do conjunto das exteriorizações - ou seja, o próprio conjunto de nossa socialidade - através da apropriação do trabalho, assim como da determinação dessa apropriação pelo advento da propriedade privada. Ao que tudo indica, a unidade Entäusserung - Entfremdung diz respeito à determinação do poder do estranhamento sobre o conjunto das alienações (ou exteriorizações) humanas, o que, em Marx, é possível perceber pela relação de concentricidade entre as duas categorias: invariavelmente as exteriorizações (Entäusserungen) aparecem no interior do estranhamento, ainda que sejam inelimináveis da existência social fundada no trabalho humano." (MARX, Karl. Manuscritos econômico-filosóficos; tradução, apresentação e notas Jesus Ranieri. [4a reimpr.] - São Paulo: Boitempo, 2010).

\begin{tabular}{|l|l|l|l|l|}
\hline Govista Dialectus & Ano 8 & n. 14 & Janeiro - Julho 2019 & p. $278-294$ \\
\hline
\end{tabular}


desefetivação do trabalhador, a objetivação como a perda e servidão ao objeto, a apropriação como estranhamento.

Marx, então, percebe que esta inversão se apresenta como algo natural para a economia nacional e que a servidão do trabalhador ao objeto, produto do trabalho, tem consequências nefastas para a realidade concreta e material. Pois, no modo capitalista de produção ${ }^{7}$,

\begin{abstract}
A efetivação do trabalho tanto aparece como desefetivação que o trabalhador é desefetivado até morrer de fome. A objetivação tanto aparece como perda do objeto que o trabalhador é despojado dos objetos mais necessários não somente à vida, mas também dos objetos do trabalho. Sim, o trabalho mesmo se torna um objeto, do qual o trabalhador só pode se apossar com os maiores esforços e com as mais extraordinárias interrupções. A apropriação do objeto tanto aparece como estranhamento (Entfremdung) que, quanto mais objetos o trabalhador produz, tanto menos pode possuir e tanto mais fica sob o domínio do seu produto, do capital. (MARX, 2010, p. 80-81).
\end{abstract}

Logo, com base nesta exposição, percebe-se que o trabalhador, conforme afirma Marx, desce cada vez mais a condição da mais miserável mercadoria. O mundo das coisas (objetos produzidos pelo trabalho humano) passa a ser valorizado em detrimento do mundo dos homens. O trabalhador torna-se cada vez mais pobre numa relação inversa a sua grandeza e potência no processo de produção. A mercadoria, ao assumir "vida própria" passa a controlar o mundo dos vivos. O operário produz o objeto, porém, o objeto já não está em seu poder de usufruto, pois esse objeto não pertence a ele e sim a outro, ou seja, ao burguês, ao dono da fábrica, aos capitalistas.

Ainda, de acordo com a citação acima, o próprio trabalho, segundo assevera Marx, se torna um objeto e que o trabalhador para se apossar dele deve realizar os maiores esforços. Assim, Marx afirma (2010) que quanto mais o trabalhador se desgasta trabalhando, tanto mais poderoso se torna o mundo objetivo, alheio que ele cria diante de si, tanto mais pobre se torna ele mesmo, seu mundo interior, e tanto menos pertence a si

7 Na produção capitalista o homem é pura força de trabalho, qualitativamente indiferenciável do restante dos meios e produção: já não é identificável pela forma de seu trabalho. O produto do trabalho separase do trabalhador, converte-se em objeto alheio, torna-se estranho a ele. No âmbito da propriedade privada produz-se o fenômeno geral do estranhamento, pelo qual as forças e os produtos se subtraem ao controle e ao poder dos indivíduos, transforma-se em forças contrapostas aos homens. O trabalho, portanto, configura-se ontologicamente de forma estranhada; [...]. (CHAGAS, 1994, p. 26).

\begin{tabular}{|l|l|l|l|l|}
\hline Govista Dialectus & Ano 8 & n. 14 & Janeiro - Julho 2019 & p. $278-294$ \\
\hline
\end{tabular}


próprio. É do mesmo modo na religião. Quanto mais o homem põe em Deus, tanto menos ele retém em si mesmo.

Diz Marx:

[...] A exteriorização (Entausserung) do trabalhador em seu produto tem o significado não somente de que seu trabalho se torna um objeto, uma existência externa (äussern), mas, bem além disso, [que se torna uma existência] que existe fora dele (ausser ihm), independente dele e estranha a ele, tornando-se uma potência (Macht) autônoma diante dele, que a vida que ele concedeu ao objeto se lhe defronta hostil e estranha. (MARX, 2010, p. 81).

Entendemos, a partir do exposto acima, que durante a exteriorização (do trabalhador em seu produto) o trabalho do trabalhador se torna objeto, uma existência externa, e que existe fora dele, isto é, existe independente dele e estranha a ele. Esse objeto, fruto do trabalho (exteriorização) do trabalhador aparece agora como uma potência autônoma, estranha e hostil diante de seu criador, a ponto de "ganhar vida própria”.

Ao examinar mais de perto a objetivação, a produção do trabalhador, e nela o estranhamento, a perda do objeto, a perda do seu produto, Marx afirma (2010) que o trabalhador nada pode criar sem a natureza, sem o mundo exterior sensível. Pois, esta última é a matéria na qual o seu trabalho se efetiva, na qual o trabalho é ativo, porque é a partir da qual e por meio da qual que o trabalho produz.

Ainda, de acordo com Marx,

\begin{abstract}
Quanto mais, portanto, o trabalhador se apropria do mundo externo, da natureza sensível, por meio do seu trabalho, tanto mais ele se priva dos meios de vida segundo um duplo sentido: primeiro, que sempre mais o mundo exterior sensível deixa de ser um objeto pertencente ao seu trabalho, um meio de vida do seu trabalho; segundo, que o [mundo exterior sensível] cessa, cada vez mais, de ser meio de vida no sentido imediato, meio para a subsistência física do trabalhador. (MARX, 2010, p. 81).
\end{abstract}

Portanto, segundo esse duplo sentido, Marx assevera que "o trabalhador se torna, portanto, um servo do seu objeto”. (MARX, 2010, p. 81). No primeiro momento, porque ele recebe um objeto do trabalho, ou seja, recebe trabalho. No segundo momento, porque recebe meios de subsistência. Portanto, para que possa existir, em primeiro lugar, como trabalhador e, em segundo lugar, como sujeito físico.

Assim, Marx (2010) acredita e afirma que o auge dessa servidão é que somente como trabalhador ele pode se manter como sujeito físico e apenas como sujeito

\begin{tabular}{|l|l|l|l|l|}
\hline Govista Dialectus & Ano 8 & n. 14 & Janeiro - Julho 2019 & p. $278-294$ \\
\hline
\end{tabular}


físico ele é trabalhador. Nessa forma de sociedade, a condição para a garantia da vida do homem (trabalhador) passa a ser o trabalho. Logo, se ele trabalha vive e se vive trabalha.

Nessa forma de organização social, fundamentada no trabalho (estranhado),

\begin{abstract}
O estranhamento do trabalhador em seu objeto se expressa, pelas leis nacionaleconômica, em que quanto mais o trabalhador produz, menos tem para consumir; que quanto mais valores cria, mais sem-valor e indigno ele se torna; quanto mais bem formado o seu produto, tanto mais deformado ele fica; quanto mais civilizado seu objeto, mais bárbaro o trabalhador; que quanto mais poderoso o trabalho, mais impotente o trabalhador se torna; quanto mais rico de espírito, mais pobre de espírito e servo da natureza se torna o trabalhador. (MARX, 2010, p. 82).
\end{abstract}

Verifica-se que, o trabalhador, nessa forma de sociedade, participa diretamente do processo de produção da riqueza material, porém no tocante a distribuição dessa riqueza, ele participa de forma unilateral, pois ao trabalhador só lhe é dado àquilo que lhe assegura sua existência como trabalhador e servo do capital. Uma forma de sociabilidade desigual, violenta e nociva ao desenvolvimento do ser humano. Tal forma de sociabilidade garante a desigualdade intensa e profunda entre os homens, pois sua estrutura permite, inevitavelmente, a perpetuação das contradições sociais, em especial, a existência das classes antagônicas, a saber, os burgueses (que se deleitam com a posse da riqueza produzida a partir do trabalho da maioria) e os proletários (que nada possuem e vivem na miséria material e espiritual).

Por que, então, a economia nacional oculta o estranhamento na essência do trabalho? Nas palavras de Marx, "a economia nacional oculta o estranhamento na essência do trabalho porque não considera a relação imediata entre o trabalhador (o trabalho) e a produção”. (MARX, 2010, p. 82).

Marx (2010), sem expressar dúvida, afirma que nessa sociedade do trabalho (sociedade capitalista), o trabalho produz maravilhas para os ricos, mas produz privação para o trabalhador. Produz palácios, mas cavernas para o trabalhador. Produz beleza, mas deformação para o trabalhador. Substitui o trabalho por máquinas, porém lança uma parte dos trabalhadores de volta ao trabalho bárbaro e faz da outra parte máquinas. Produz espírito, mas imbecilidade para o trabalhador.

Mais uma vez, Marx salienta a contradição existente entre o que o trabalhador produz e o que de fato o trabalhador recebe. Que a riqueza da sociedade produzida pelo trabalhador se contrapõe a forma de vida miserável do trabalhador nesta relação.

\begin{tabular}{|l|l|l|l|l|}
\hline Govista Dialectus & Ano 8 & n. 14 & Janeiro - Julho 2019 & p. $278-294$ \\
\hline
\end{tabular}


É importante perceber que o estranhamento, examinado até aqui, por Marx, a exteriorização do trabalhador apresenta-se, sob apenas um de seus aspectos, a saber: a relação do trabalhador com os produtos de seu trabalho, porém, de acordo com Marx, o estranhamento não se mostra somente no resultado (no produto final), mas também, e principalmente, no ato da produção, dentro da própria atividade produtiva. Pergunta Marx, "Como poderia o trabalhador defrontar-se alheio (fremd) ao produto da sua atividade se no ato mesmo da produção ele não se estranhasse a si mesmo?" (MARX, 2010, p. 82). A título de resposta, o próprio Marx argumenta que,

[...] O produto, é sim, somente o resumo (resumé) da atividade, da produção. Se, portanto, o produto do trabalho é a exteriorização, então a produção mesma tem de ser a exteriorização ativa, a exteriorização da atividade, a atividade da exteriorização. No estranhamento do objeto do trabalho resume-se somente o estranhamento, a exteriorização na atividade do trabalho mesmo. (MARX, 2010, p. 82).

Marx continua em busca de compreender o processo do estranhamento e lança, agora, pela segunda vez, mais uma pergunta, "Em que consiste, então, a exteriorização (Entäusserung) do trabalho?” (MARX, 2010, p. 82). E como resposta apresenta:

Primeiro, que o trabalho é externo (äusserlich) ao trabalhador, isto é, não
pertence ao seu ser, que ele não se afirma, portanto, em seu trabalho, mas nega-
se nele, que não se sente bem, mas infeliz, que não desenvolve nenhuma
energia fisica e espiritual livre, mas mortifica sua physis e arruína o seu
espírito. O trabalhador só se sente, por conseguinte e em primeiro lugar, junto
a si [quando] fora do trabalho e fora de si [quando] no trabalho. Está em casa
quando não trabalha e, quando trabalha, não está em casa. O seu trabalho não
é, portanto, voluntário, mas forçado, trabalho obrigatório. O trabalho não é,
por isso, a satisfação de uma carência, mas somente um meio para satisfazer
necessidades fora dele. Sua estranheza (Fremdheit) evidencia-se aqui [de
forma] tão pura que, tão logo inexista coerção física ou outra qualquer, foge-
se do trabalho como de uma peste. O trabalho externo, o trabalho no qual o
homem se exterioriza, é um trabalho de autossacrificio, de mortificação.
Finalmente, a externalidade (Ausserlichkeit) do trabalho aparece para o
trabalhador como se [o trabalho] não fosse seu próprio, mas de um outro, como
se [o trabalho] não lhe pertencesse, como se ele no trabalho não pertencesse a
si mesmo, mas a um outro. Assim como na religião a autoatividade da fantasia
humana, do cérebro e do coração humanos, atua independentemente do
indivíduo e sobre ele, isto é, como uma atividade estranha, divina ou diabólica,
assim também a atividade do trabalhador não é a sua autoatividade. Ela
pertence a outro, é a perda de si mesmo.” (MARX, 2010, p. 82-83).

O trabalhador não se afirma no seu trabalho, uma vez que o trabalho se apresenta como algo externo e independente ao trabalhador, isto é, não pertence ao

\begin{tabular}{|l|l|l|l|l|}
\hline Q Povista Dialectus & Ano 8 & n. 14 & Janeiro - Julho 2019 & p. 278 - 294 \\
\hline
\end{tabular}


trabalhador como atividade integrada ao seu ser. O que deveria ser afirmação torna-se, então, negação, o trabalhador não se reconhece nessa forma de trabalho. Assim, na primeira oportunidade que tem para fugir do trabalho, tão logo inexista coerção física ou qualquer outra, afirma Marx, "foge-se do trabalho como de uma peste". (MARX, 2010, p.83). O ato do estranhamento sobre o trabalho faz também com que o trabalhador não se reconheça no produto do trabalho. Este produto atua como um objeto estranho, poderoso e independente sobre o trabalhador. O próprio trabalho externo, no qual o homem se exterioriza, passa a ser, nas palavras de Marx, um "trabalho de autosacrifício, de mortificação”. (MARX, 2010, p. 83). O próprio trabalho aparece para o trabalhador como se não lhe pertencesse, mas a outro.

Após a detalhada exposição do estranhamento do trabalhador e de sua produção, no contexto da sociedade capitalista, Marx pergunta: "Se o produto do trabalho me é estranho, [se ele] defronta-se comigo como poder estranho, a quem pertence então?” (MARX, 2010, p.86); “Se minha própria atividade não me pertence, é uma atividade estranha, forçada, a quem ela pertence, então?” (MARX, 2010, p.86).

Como resposta, Marx argumenta: “A outro ser que não eu.” (MARX, 2010, p. 86). E continua a perguntar, “Quem é este ser?” (MARX, 2010, p. 86); “Os deuses?” (MARX, 2010, p. 86). Na sequência, responde o pensador materialista:

[...] Evidentemente nas primeiras épocas a produção principal, como por exemplo a construção de templos etc., no Egito, na Índia, México, aparece tanto a serviço dos deuses, como também o produto pertence a eles. Sozinhos, porém, os deuses nunca foram os senhores do trabalho. Tampouco a natureza. E que contradição seria também se o homem, quanto mais subjugasse a natureza pelo seu trabalho, quanto mais os prodígios dos deuses se tornassem obsoletos mediante os prodígios da indústria, tivesse de renunciar à alegria na produção e à fruição do produto por amor a esses poderes. (MARX, 2010, p. 86).

Marx (2010) conclui, então, a título de resposta e chega a seguinte afirmação, a saber, que esse ser estranho ao qual pertence o trabalho e o produto do trabalho, para o qual o trabalho está ao seu serviço e para a fruição do qual está o produto do trabalho, só pode ser o homem mesmo. Portanto, se o produto do trabalho não pertence ao trabalhador e se o resultado do seu trabalho não é para seu usufruto, então, pode-se concluir que, só pode pertencer a outro homem, que não é um trabalhador. Diz Marx, "Se sua atividade lhe é martírio, então ela tem de ser fruição para um outro e alegria de viver 
para um outro. Não os deuses, não a natureza, apenas o homem mesmo pode ser este poder estranho sobre o homem". (MARX, 2010, p. 86).

Marx (2010) afirma que, como resultado do trabalho estranhado, o homem (o trabalhador) só se sente como um ser livre e ativo em suas funções animais, comer, beber e procriar, quando muito ainda habitação, adornos etc., e em suas funções humanas só se sente como animal. O animal se torna humano, e o humano, animal, ou seja, uma inversão nociva capaz também de estranhar o homem do seu próprio caráter genérico.

\section{A RELAÇÃO ENTRE O TRABALHO-EDUCAÇÃO NO PENSAMENTO DE MARX}

A teoria de Marx sobre o estranhamento na essência do trabalho [trabalho estranhado] foi apresentada, em detalhes, na primeira parte deste artigo (2 O ESTRANHAMENTO NA ESSÊNCIA DO TRABALHO [TRABALHO ESTRANHADO], p. 4). Portanto, aqui, nesta seção, explicitaremos, então, a relação entre o trabalho estranhado e educação no pensamento de Marx.

$\mathrm{Na}$ presente pesquisa, defendemos que Marx expõe, inicialmente, sua teoria sobre o estranhamento na essência do trabalho nos Manuscritos econômico-filosóficos (1844), especificamente, no final do primeiro manuscrito intitulado [Trabalho estranhado e propriedade privada], após uma longa exposição das categorias econômicas da economia nacional.

Na obra, Marx apresenta, em caráter revelador, as consequências nefastas do estranhamento na essência do trabalho para desenvolvimento pleno das capacidades humanas. Pois, para Marx, na sociedade capitalista, o trabalhador baixa a condição da mais miserável mercadoria e o seu preço está totalmente relacionado aos custos de sua produção. A atividade vital humana aparece no capitalismo apenas sob a forma de emprego. O homem passa a viver em função de um mero trabalho (emprego) de tal forma que sua vida depende totalmente deste último.

Neste escrito, Marx examina, inicialmente, o estranhamento da atividade humana prática, o trabalho sob dois aspectos, a saber: 1) A relação do trabalhador com o produto do trabalho como objeto estranho e poderoso sobre ele [trabalhador]. Para Marx, esta relação é ao mesmo tempo a relação com o mundo exterior sensível, ou seja, com os objetos da natureza como um mundo alheio [não pertencente ao trabalhador] que se lhe defronta hostilmente. 2) A relação do trabalho com ato da produção no interior do

\begin{tabular}{|l|l|l|l|l|}
\hline Govista Dialectus & Ano 8 & n. 14 & Janeiro - Julho 2019 & p. $278-294$ \\
\hline
\end{tabular}


trabalho. Para Marx, esta relação é a relação do trabalhador com a sua própria atividade como uma atividade estranha, isto é, não pertencente ao trabalhador. Aqui, a atividade se manifesta como miséria, a força como impotência, a procriação como castração. Diz Marx: "A energia espiritual e física própria do trabalhador, a sua vida pessoal - "pois o que é vida senão atividade" - como uma atividade voltada contra ele mesmo, independente dele, não pertencente a ele. [...].” (MARX, 2010, p. 83).

Após examinar o estranhamento da atividade humana prática sob esses dois aspectos, Marx afirma, ainda que, o trabalho estranhado faz, por conseguinte: 3 ) do ser genérico do homem, tanto da natureza quanto da faculdade genérica espiritual dele, um ser estranho a ele, um meio da sua existência individual. Pois, segundo Marx, o trabalho estranhado estranha do homem o próprio corpo, assim como estranha do homem a natureza fora dele, tal como a sua essência espiritual, a sua essência humana. 4) uma consequência imediata de o homem estar estranhado do produto do seu trabalho, de sua própria atividade vital e de seu ser genérico é o estranhamento do homem pelo próprio homem. Pois, Marx assevera que quando o homem está frente a si mesmo, defronta-se com ele o outro homem. Assim, diz Marx: "O que é produto da relação do homem com o seu trabalho, produto de seu trabalho e consigo mesmo, vale como relação do homem com outro homem, como o trabalho e o objeto do trabalho de outro homem." (MARX, 2010, p. 86).

Marx desenvolve, então, sua concepção sobre a categoria trabalho diferente da concepção desenvolvida pela economia nacional. Pois, entendemos que, para Marx, o trabalho (atividade humana prática) deve proporcionar uma relação de reconhecimento entre o trabalhador e o objeto por ele produzido, ou seja, diferente da relação produzida pelo trabalho estranhado de tal forma que o trabalhador tenha domínio sobre esta relação. Neste domínio, o trabalhador deve além de se reconhecer no objeto, ao mesmo tempo, também dominá-lo e não ser por ele dominado. Assim, deduzimos e afirmamos que a relação do homem com os objetos exteriores a ele se daria numa relação de reconhecimento e não de estranhamento. Para Marx, o trabalho não deve se apresentar ao homem como uma atividade estranha, porque, entendemos que por meio do trabalho o homem se libertou das condições naturais (impostas pela natureza). A atividade humana prática (trabalho) deve se apresentar como uma alienação (positiva) primordial capaz de desenvolver o conjunto das objetivações humanas, ou melhor, a atividade humana prática como riqueza humana, a força como potência, a procriação como procriação. Portanto, o 
trabalho deve estar a serviço do desenvolvimento pleno das capacidades humanas, pertencente totalmente ao homem como uma atividade humana de autodesenvolvimento e autoformação.

Entendemos que Marx a partir do trabalho estranhado se depara com o estranhamento do homem pelo próprio homem. No capitalismo, forma histórica de organização social, o estranhamento estudado por Marx se apresenta na vida prática, real e concreta dos homens e suas consequências são apresentadas em tom de denúncia nos Manuscritos econômico-filosóficos (1844).

Para Marx, a atividade humana prática é responsável pelo autoreconhecimento e auto-desenvolvimento humano. Deve unir o homem ao seu próprio corpo, a natureza fora dele e sua essência humana.

Portanto, defendemos que, ao analisar o estranhamento na essência do trabalho, Marx não realiza uma análise abstrata, separada das relações reais. Tal análise, nesse sentido, possui uma articulação com a vida real, concreta e material produzida pelos próprios homens, ou seja, a mesma está diretamente articulada com o modo de produção, com a vida social, histórica, política e econômica.

Marx não parte de um estado primitivo imaginário para compreensão da realidade social, pois, para o pensador alemão, um "tal estado primitivo nada explica". (MARX, 2010, p.80).

Marx parte da realidade concreta e material dos homens e percebe que nessa forma de sociedade "o trabalhador se torna tanto mais pobre quanto mais riqueza produz" (MARX, 2010, p. 80). ; “O trabalhador se torna uma mercadoria tão mais barata quanto mais mercadorias cria" (MARX, 2010, p.80). ; uma forma de sociedade que supervaloriza o mundo das mercadorias e desvaloriza o mundo dos homens. Pois, na sociedade capitalista, conforme assevera Marx, "O trabalho não produz somente mercadorias; ele produz a si mesmo e ao trabalhador como uma mercadoria, e isto na medida em que produz, de fato, mercadorias em geral." (MARX, 2010, p. 80).

Portanto, diz Marx:

Este fato nada mais exprime, senão: o objeto (Gegenstand) que o trabalho produz, o seu produto, se lhe defronta como um ser estranho, como um poder independente do produtor. O produto do trabalho é o trabalho que se fixou num objeto, fez-se coisal (sachlich), é a objetivação (Vergegenständlichung) do trabalho. A efetivação (Verwirklichung) do trabalho é a sua objetivação. Esta efetivação do trabalho aparece ao estado nacional-econômico como desefetivação (Entwirklichung) do trabalhador, a objetivação como perda do 
objeto e servidão ao objeto, a apropriação como estranhamento (Entfremdung), como alienação (Entäusserung).” (MARX, 2010, p. 80).

Marx revela, na passagem acima, o estranhamento na essência do trabalho e, na ocasião, esclarece como ocorre o processo de empobrecimento da classe trabalhadora por meio do trabalho nas condições impostas pelo capitalismo. Ao revelar que a efetivação do trabalho aparece, no capitalismo, como desefetivação, a objetivação como perda do objeto e, ao mesmo tempo, servidão ao objeto, a apropriação como estranhamento, como alienação, entendemos que o próprio homem cria o estranhamento na essência do trabalho. Assim, perguntamos, então, qual a relação entre o estranhamento na essência do trabalho [trabalho estranhado] e educação no pensamento de Marx?

Defendemos que se encontra implícito no pensamento de Marx, em especial, neste manuscrito (Trabalho estranhado e propriedade privada), a relação entre o trabalho estranhado com a sua concepção de educação, pois, ao revelar que o trabalho nas condições impostas pela sociedade capitalista impede o desenvolvimento pleno das capacidades humanas, Marx fundamenta, assim, a relação necessária entre o trabalho e a educação para o desenvolvimento pleno das capacidades humanas, porém, diferente da lógica do capital. Vejamos, então, melhor este argumento.

Marx afirma que na sociedade capitalista,

A efetivação do trabalho tanto aparece como desefetivação que o trabalhador é desefetivado até morrer de fome. A objetivação tanto aparece como perda do objeto que o trabalhador é despojado dos objetos mais necessários não somente a vida, mas também dos objetos do trabalho. [...]. (MARX, 2010, p. 80).

Pois, para Marx, o que deveria ser a efetivação do trabalhador, torna-se, então, desefetivação, uma vez que o trabalhador não se reconhece no produto do seu próprio trabalho. Assim, na sociedade do capital, o trabalho (estranhado) torna-se um empecilho ao autodesenvolvimento humano. Não desenvolve o homem, muito pelo contrário, atrofia e se torna algo nocivo e pernicioso para o trabalhador, ou melhor, o próprio trabalho se torna algo agressivo ao trabalhador.

No capitalismo, o trabalhador não possui liberdade para produzir. Este produz sob as determinações de outro homem, estranho a ele. O trabalhador não possui os objetos mais necessários para a realização do trabalho, pois estes objetos foram historicamente expropriados. Assim, entendemos que Marx ao defender a tese da união da educação com a produção material, em meados de 1848, no Manifesto Comunista (1848), percebe-se

\begin{tabular}{|l|l|l|l|l|}
\hline Govista Dialectus & Ano 8 & n. 14 & Janeiro - Julho 2019 & p. $278-294$ \\
\hline
\end{tabular}


que, tal união é necessária para a retomada consciente e responsável do homem sobre o trabalho, isto é, que tal união deveria contribuir no processo de desalienação do homem em relação, inicialmente, ao processo de produção, para deste ponto, gradualmente, o homem retornar ao próprio homem, isto é, ao homem social.

Embora não tenha dedicado um escrito ou até mesmo um manuscrito sobre o tema da educação, porém, entendemos que tal temática não passou despercebida na produção teórica de Marx durante a elaboração dos Manuscritos econômico-filosóficos (1844) e de outras obras da juventude e da maturidade. Pois, diante da importância dos Manuscritos de 1844, e, principalmente, do pensamento filosófico de Marx, é possível delinear princípios para a sustentação de uma educação de caráter humanístico para este pensador alemão.

Portanto, diante da teoria do estranhamento, encontramos, em Marx, o princípio primordial para fundamentar a concepção de educação, a saber; a concepção filosófica humanista presente, principalmente, nos Manuscritos econômico-filosóficos (1844). Pois, tal concepção é a planta fundamental para a construção de uma nova sociedade que tem como ponto de partida a crítica consciente das contradições reais do capitalismo $^{8}$ e a atividade prática revolucionária para a transformação da realidade existente.

Nesse sentido, percebe-se que tal transformação parte do existente e não do idealizado, ou seja, parte de uma intervenção responsável e consciente dos homens sobre a realidade material para uma transformação radical das condições dadas anteriormente que sustentam a sociedade do capital, pois, para Marx, a sociedade capitalista é uma sociedade, assim, como outras formas de organizações sociais, constituída e organizada social e historicamente, ou melhor, a forma de organização social na sociedade capitalista é uma construção humana e assim como foi construída pode também ser destruída pelo próprio homem.

8 “.... Nos seus poderosos estudos, artigos e discursos, Marx mostra concretamente qual é a situação material dos homens no capitalismo em desenvolvimento e o que será no futuro. Com séria exatidão, que expressa o rigor dos juízos científicos e morais, Marx expõe as desumanas condições de vida a que o capitalismo submete os seus escravos. Também mostra como o egoísmo da propriedade e o meio da catástrofe condicionam a classe dominante e exploradora. Estas questões históricas morais e humanitárias na caracterização das relações existentes aparecem muito claras nas análises de Marx. Questões que se referem à situação dos homens na época capitalista e que possuem uma grande importância para a pedagogia." (SUCHODOLSKI, 1976, p.121).

\begin{tabular}{|l|l|l|l|l|}
\hline Q Rovista Dialectus & Ano 8 & n. 14 & Janeiro - Julho 2019 & p. 278 - 294 \\
\hline
\end{tabular}


Ao criticar a forma como o trabalho se manifesta no capitalismo, Marx proclama: "Sim, o trabalho mesmo se torna um objeto, do qual o trabalhador só pode se apossar com os maiores esforços e com as mais extraordinárias interrupções”. (MARX, 2010, p. 81). Marx defende, então, a construção de uma sociedade de valorização do homem. Tal sociedade deve ser construída pelo próprio homem liberto do estranhamento. Assim, o trabalho, socialmente constituído, deve proporcionar ao trabalhador toda a riqueza produzida em poder e extensão. Pois, para Marx, o trabalho produz a si mesmo e ao próprio homem.

Diante da fundamentação acima, a educação possui um papel relevante e uma conexão direta e necessária com o trabalho produtivo, criador de valores de uso, pois entendemos que é impossível pensar a construção de uma nova sociedade humana sem refletir sobre a socialização dos valores produzidos social e historicamente. Nesse sentido, reforçamos que o trabalho deve ser compreendido também como uma atividade formativa responsável pelo desenvolvimento pleno das capacidades humanas.

Neste processo formativo, a educação ${ }^{9}$ deve proporcionar ao homem (trabalhador) uma relação imediata entre o trabalho e a produção, isto é, entre o trabalhador e os objetos da produção. O homem deve desenvolver no trabalho sua energia física e espiritual de forma livre, o trabalho deve ser, então, voluntário, e não obrigatório como se apresenta no capitalismo. Assim, o trabalho, a atividade vital, deve satisfazer as carências humanas mediante sua realização. Pois, para Marx, o trabalho deve se apresentar ao homem como sua autoatividade, ou seja, sua autorealização, porque o trabalho, a "atividade consciente e livre é o caráter genérico do homem.” (MARX, 2010, p.84).

\section{Referências:}

\footnotetext{
9 “A educação dos homens constitui, pois, um importante processo da autoprodução dos homens no decurso do seu trabalho social produtivo. Mas, como ensina o materialismo histórico, este processo não decorre de modo linear. Pelo contrário, realizar-se mediante lutas e contradições. [...]”. (SUCHODOLSKI, 1976, p. 94). Ainda, de acordo com Suchodolski, “[...] A verdadeira educação deve ter como base a participação do indivíduo no movimento do progresso histórico e não apenas nas divergências ideológicas. Por isso, a teoria pedagógica deve estar isenta de qualquer posição idealista, de qualquer individualismo a propósito da ação histórica das massas.” (SUCHODOLSKI, 1976, p. 44).
}

\begin{tabular}{|l|l|l|l|l|}
\hline Q Povista Dialectus & Ano 8 & n. 14 & Janeiro - Julho 2019 & p. $278-294$ \\
\hline
\end{tabular}


AMORIM, Maria Luísa de Aguiar. Trabalho e formação humana em Marx. Fortaleza: Expressão Gráfica e Editora, 2014.

CHAGAS, Eduardo Ferreira. A natureza dúplice do trabalho em Marx: trabalho útilconcreto e trabalho abstrato. In: Outubro - Revista do Instituto de Estudos Socialistas. No 19. Campinas - São Paulo, 2011.

KONDER, Leandro. Marx - Vida e obra. São Paulo: Paz e Terra, 1999.

MANACORDA, Mario Alighiero. Marx e a pedagogia moderna. São Paulo: Cortez: 1991.

MARX, Karl. ENGELS, Friedrich. Manifesto Comunista. Organização e introdução de Osvaldo Coggiola. São Paulo: Editorial Boitempo, 2007.

MARX, Karl. Manuscritos Econômico-Filosóficos. Tradução, apresentação e notas de Jesus Ranieri. São Paulo: Boitempo Editorial, 2010.

MARX, Karl. O Capital: Crítica da Economia Política - Livro I: O processo de produção do capital. Vol. I. Tradução de Reginaldo Sant'Ana - 26 a edição. Rio de Janeiro: Civilização Brasileira, 2008.

MARX, Karl. O Capital: Crítica da Economia Política - Livro I: O processo de produção do capital. Tradução: Rubens Enderle. São Paulo: Boitempo Editorial, 2011.

Marx, Karl; ENGELS, Friedrich. Textos sobre educação e ensino. Campinas: SP: Navegando, 2011. (organizador: José Claudinei Lombardi).

MÉSZÁROS, Istvan. A educação para além do capital. [tradução Isa Tavares]. - 2. Ed.São Paulo: Boitempo, 2008.

NOGUEIRA, Maria Alice. Educação, saber, produção em Marx e Engels. $2^{\mathrm{a}}$ ed. - São Paulo: Cortez, 1993.

RANIERI, Jesus José. Alienação e estranhamento em Marx: dos Manuscritos econômico - filosóficos de 1844 à ideologia alemã / Jesus José Ranieri. Campinas, SP: [s.n.], 2000.

SOBRAL, Fábio Maia. Concepção circular de homem em Marx: um estudo a partir dos Manuscritos Econômico-Filosóficos de 1844. São Paulo: Editora Nojosa, 2005.

SUCHODOLSKI, Bogdan. Teoria Marxista da Educação. Tradução de Maria Carlota Melo. Editorial Estampa, Lisboa, 1976. 


\section{Apresentação da tradução do Prefácio de 1967 de "Prefácio à edição francesa de "O Homem Unidimensional" 1}

Estrutura Temática do Prefácio de 1967 de “O Homem Unidimensional” de Herbert Marcuse"

Alberto Dias Gadanha

A. Introdução:

Conforme a nossa compreensão da obra "O homem Unidimensional" como uma exposição da História da Filosofia Contemporânea a partir do distanciamento da filosofia de um pensamento negativo, o Prefácio de 1967 tem a partir de nossa leitura como tese principal a asserção de que diante do sistema de produtividade destrutiva de valores essenciais humanos, como a Razão e a Liberdade; a Filosofia Crítica procura as razões dessa destruição sistêmica e ainda e mais importante, as possibilidades de se organizar uma sociedade fundada na solidariedade Humana.

A Estrutura Temática do Prefácio de 1967 está composta de Tema Geral, Temas e Subtemas, conforme o mostra o Gráfico 1:

1. TEMA GERAL é a conclusão obtida pela capacidade de síntese do leitor após todo o processo de leitura, de análise das especificidades e da angústia em construir um significado, o mais adequado à palavra-primeira, ao logos do texto, ao que é expresso pelo autor do texto. Em sequência serão apresentados na ordem do processamento os elementos que permitirão a conclusão num Tema Geral.

2. Palavras-chave. Levantamento das palavras-chave, dos conceitos ou ideias utilizadas no texto, conforme Gráfico 5: "Palavras-chave referentes a cada um dos parágrafos".

3. Itens dos Subtemas. Exposição das afirmações encontradas nos parágrafos, afirmações construídas a partir das palavras-chave no cenário apresentado pelo autor no parágrafo. As asserções construídas pelo autor aparecem nesta estrutura como os itens subordinados aos subtemas, (exemplo 1.1.1.).

4. Subtema. O significado da compreensão totalizante das asserções a que se refere o item 3. será denominado nesta estrutura de "Subtema", (ex. 1.1.). Por coincidência, favorecida pelo ascetismo do autor do texto, cada parágrafo pareceu sintetizar uma definição explícita, uma afirmação singular, uma particularidade que aqui no "Prefácio de 1967" aparece como reflexo de elemento que fora destacado na própria obra "O Homem Unidimensional" de 1964. Os "Subtemas" devem expor a afirmação significativa do conteúdo de um parágrafo. Somente o subtema 2.1. sintetizou o conteúdo de dois parágrafos, o $4^{\circ} \S$ e o $5^{\circ} \S$, síntese propiciada pela exigência da integração dos elementos constitutivos do conceito de "libertação", a saber, seu princípio, seu processo e seu fim. A partir de um pressuposto sistêmico que contempla três dos significados de causa que nos ensinou Aristóteles: a causa material, o princípio da libertação conforme o $\S 5$; seu processo, a causa eficiente e a causa final, o objetivo

\footnotetext{
${ }^{1}$ Herbert Marcuse «L’Homme unidimensionnel, Études sur l'idéologie de la société industrielle» Traduit de l'anglais par Monique Wittig et l'auteur - 1968 - Collection Arguments , 288 pages. Tradução de Dr. Alberto Dias Gadanha (UECE), Djibril Ernesto Pereira (Mestrando em filosofia/UFC) e Renê Ivo da Silva Lima (Mestrando em filosofia/UFC). Tradução publicada com permissão de Peter Marcuse, Executor Testamentário da Propriedade Intelectual de Herbert Marcuse, cujo consentimento é necessário para qualquer publicação futura.

${ }^{2}$ Doutor em filosofia (Programa interinstitucional da UFPB, UFRN e UFPE) e professor do departamento de filosofia da Universidade Estadual do Ceará (UECE). Coordenador do Grupo de pesquisa Atualidade do pensamento político de Herbert Marcuse (GP-MARCUSE/UECE)
} 
da libertação como nos solidifica Marcuse no parágrafo 4. Esses três elementos aparecem em dois parágrafos, por isso foram sintetizados em só subtema, o 2.1. referente aos parágrafos 4 e 5).

5. Tema. Os temas compreenderão, sintetizarão, os parágrafos cujos conteúdos específicos terão um significado aglutinador, um significado comum. Esta etapa da construção temática depende da capacidade de compreensão do leitor, o critério de sua eficiência é se o leitor conseguiu construir a partir dos parágrafos, com suas palavras, os temas elementos fundamentais para a construção do Tema Geral.

B. Sumário da Estrutura Temática do PREFÁCIO-1967 de "O HOMEM UNIDIMENSIONAL de Herbert Marcuse"

Tema Geral: Diante do Sistema de Produtividade Destrutiva dos valores essenciais humanos, como a Razão e Liberdade; a Filosofia Crítica procura as razões dessa destruição sistêmica e ainda e mais importante, as possibilidades de se organizar uma Sociedade fundada na Solidariedade Humana.

1. Liberdade Administrada e Repressão Instintiva tornam-se fontes renovadas da Produtividade Agressiva.

1.1. SOCIEDADE FECHADA: Contradição Total à Essência da Palavra e da Ação Humanas - $(\S 1)$

1.1.1. Administração e Controle: Disciplina, integra as dimensões da existência pública e privada

1.1.2. Produtividade destrutiva: objetivo $=$ Valor de Troca, não Valor de Uso

1.1.3. As Forças de Controle assimilam os Elementos Explosivos do Inconsciente

1.1.4. Forças e Interesses Opostos são Controlados e Convertidos em Fator de Coesão e Afirmação

1.1.5. Os indivíduos e as classes aceitam e reproduzem a repressão suportada (mímesis)

1.1.6. O Processo de Integração se dá sem terror, a Democracia consolida a Dominação

1.2. O SISTEMA DAS MERCADORIAS exporta a sua forma de vida e seus valores. (§2)

1.2.1. Não - Liberdade e Repressão Funcional

1.2.2. Não há mais distinção conceitual entre "negócios e política", "lucro e prestígio", "necessidade e publicidade"

1.2.3. Relações libidinais com os agressivos engenhos motorizados e com a estética falsa dos shoppings

1.3. Perpetuação do Sistema de Não-Liberdade e Repressão (§3)

1.3.1. Reificação Total e Feitichismo Total da Mercadoria

1.3.2. Quantidade de Mercadorias dificulta o rompimento com essa forma de vida

1.3.3. Formas de Racionalização e Interiorização da Repressão.

2. Alteração da Libido em Valor de Troca, negação de uma Sociabilidade em que a Libertação é seu princípio, meio e fim.

2.1. Necessidades Instintivas por Libertação, mediadas e imediatas ( $\S 4 / 5)$

2.1.1. Princípio: Libertação começa como necessidade não-sublimada (§5)

2.1.2. Meio: Ao progredir até esse fim, a própria Liberdade é necessidade instintiva. $(\S 4)$

\begin{tabular}{|l|l|l|l|l|}
\hline Qevista Qialectus & Ano 8 & n. 14 & Janeiro - Julho 2019 & p. $295-309$ \\
\hline
\end{tabular}


Alberto Dias Gadanha / Djibril Ernesto Pereira / Renê Ivo da Silva Lima

2.1.3. Fim: A melhor satisfação das necessidades. (§4)

2.2. A Libido foi integrada como Valor de Troca no Processo de Produção Agressivo (§6)

2.2.1. Instinto de vida, Liberdade não-sublimada, exige uma liberdade política social.

2.2.2. Direcionamento da energia erótica à sensualidade genital

2.2.3. Impedimento da Transcendência de Éros.

3. Mesmo tendo, o proletariado perdido seu poder material revolucionário, uma sociedade qualitativamente diferente é exposta por rebelião instintivo-política.

3.1. Apresentação Conceitual de uma sociedade qualitativamente diferente da atual repressiva. (§ 7)

3.1.1. Eis uma Rebelião instintivo-política da juventude contra a sociedade da abundância, (mas sem poder material, §8.)

3.1.2. A dimensão profunda desta luta contra o sistema compensará seu caráter difuso e sua debilidade numérica.

3.1.3. Administração Repressiva mutila o organismo e ativa a agressão.

3.1.4. Cooperação e solidariedade, diferenças qualitativas da transcendência política, própria da energia erótica.

3.1.5. Pelo Princípio de Realidade da Paz, a vida torna-se seu próprio objetivo, tornarse felicidade.

3.1.6. O princípio da paz libertaria a base biológica dos valores estéticos.

3.1.7. Os valores estéticos, negação determinada dos valores dominantes.

3.2. As conquistas técnicas e científicas poderiam alterar o poder material da rebelião contra o processo atual de produção. (§8)

3.2.1. O sistema está mobilizado contra a interrupção de suas necessidades afirmativas.

3.2.2. O poder material está ligado ao sistema de necessidades, não mais sob o controle operário.

3.2.3. Os especialistas em sistemas poderiam ser os herdeiros históricos do proletariado.

3.2.4. A modificação da mentalidade desses beneficiados bem remunerados seria um milagre de lucidez.

4. TAREFA: Compreender, Despertar e Organizar a Solidariedade Humana contra a brutalidade da política de repressão global.

4.1. Até quando o controle total conseguirá sustar as forças revolucionárias. (§9)

4.1.1. Contradição entre o caráter social das forças produtivas e sua organização particular.

4.1.2. Contradição quanto à utilização destrutiva da riqueza social.

4.1.3. A neutralização, absorção das forças realizadoras, é próprio do processo vigente de produção.

4.2. As chances do Futuro dependem da explosão das contradições ainda artificialmente neutralizadas $(\$ 10)$

4.2.1. Capacidade de Rendimento do Sistema dá Suporte POLÍTICA DE REPRESSÃO GLOBAL.

4.2.2. Reviravolta na Evolução do Sistema Capitalista devido à exposição do Vietnam e à Rebelião Juvenil.

4.2.3. POLÍTICA DE REPRESSÃO GLOBAL Crime contra a Humanidade, posta à prova.

\begin{tabular}{|l|l|l|l|l|}
\hline Qevista Dialectus & Ano 8 & n. 14 & Janeiro - Julho 2019 & p. 295 - 309 \\
\hline
\end{tabular}


Alberto Dias Gadanha / Djibril Ernesto Pereira / Renê Ivo da Silva Lima

4.2.4. Reviravolta do Sistema expõe uma coincidência entre fatores objetivos e subjetivos.

4.2.5. A possibilidade do futuro depende de cessar a expansão da produção destrutiva. 4.3. Trabalho Intelectual: Compreender, Despertar e Organizar a Solidariedade Humana. $(\S 11)$

4.3.1. Solidariedade fator decisivo, contra a produtividade integradora do capitalismo. 4.3.2. Contra-Movimento Global para enfrentar o Crime Global contra a Humanidade.

4.3.3. Compreensão e Organização da Solidariedade contra a brutalidade e a exploração inumanas.

\begin{tabular}{|l|l|l|l|l|}
\hline Qevista Qialectus & Ano 8 & n. 14 & Janeiro - Julho 2019 & p. $295-309$ \\
\hline
\end{tabular}




\section{Gráfico 1. Tema Geral, Temas e Subtemas da Estrutura Temática.}

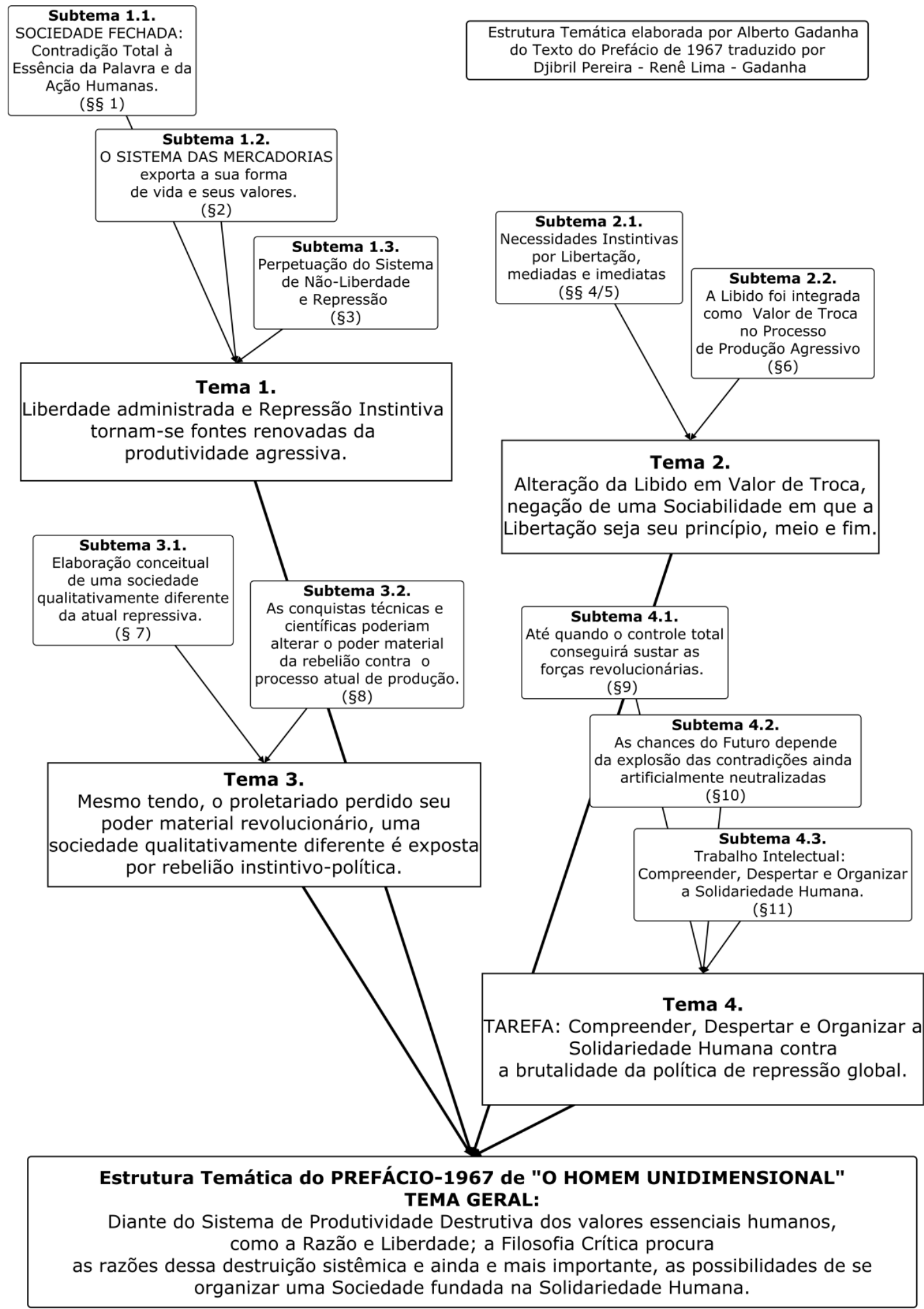

\begin{tabular}{|l|l|l|l|l|}
\hline Revista Qialectus & Ano 8 & n. 14 & Janeiro - Julho 2019 & p. $295-309$ \\
\hline
\end{tabular}




\section{Gráfico 2. Tema 1. Liberdade Administrada e Repressão Instintiva tornam-se fontes} renovadas da Produtividade Agressiva.

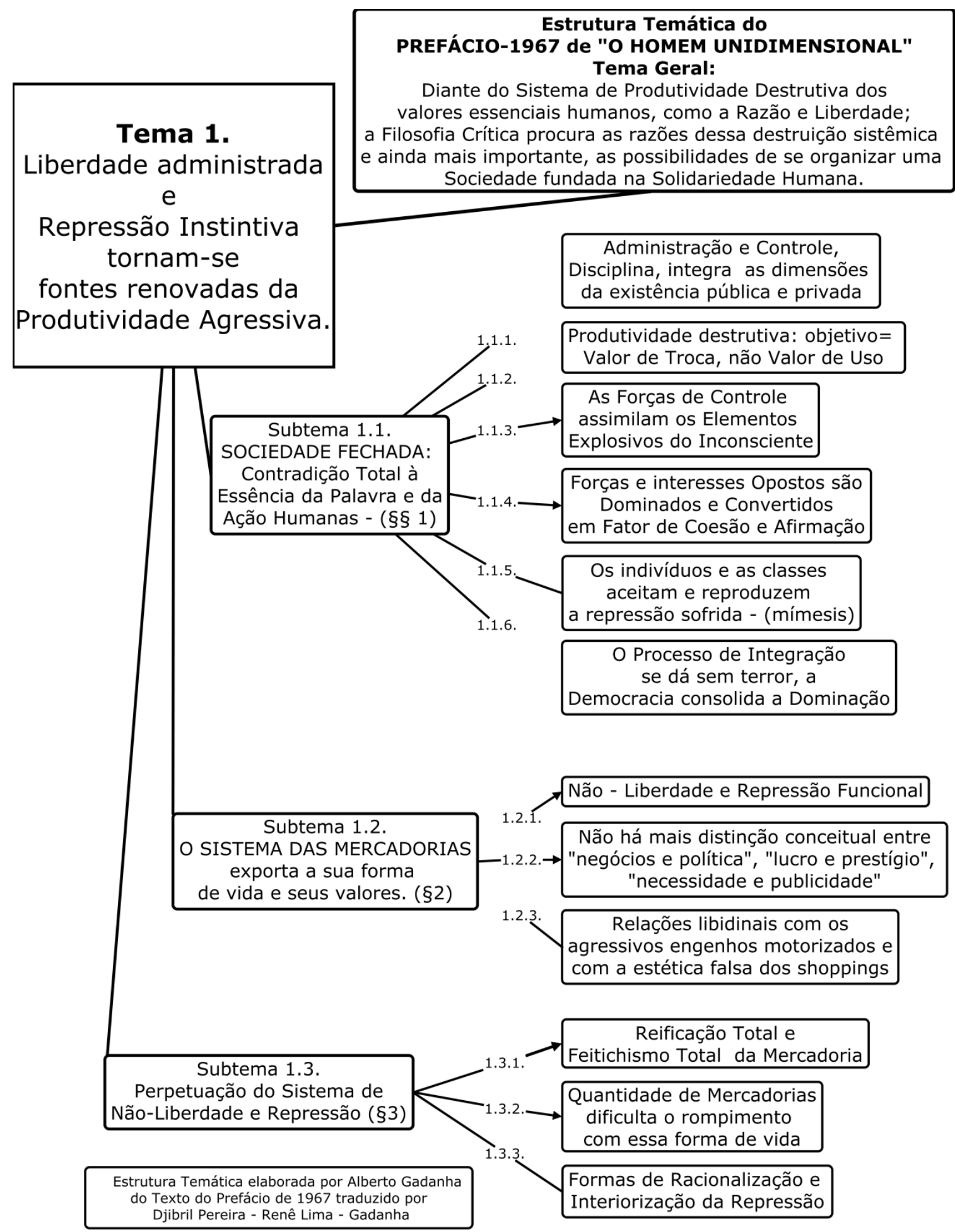

\begin{tabular}{|l|l|l|l|l|}
\hline Gevista Dialectus & Ano 8 & n. 14 & Janeiro - Julho 2019 & p. $295-309$ \\
\hline
\end{tabular}




\section{E. Gráfico 3 .}

Tema 2 Alteração da Libido em Valor de Troca, negação de uma Sociabilidade em que a Libertação é seu princípio, meio e fim.

Tema 3. Mesmo tendo, o proletariado perdido seu poder material revolucionário, uma sociedade qualitativamente diferente é exposta por rebelião instintivo-política.

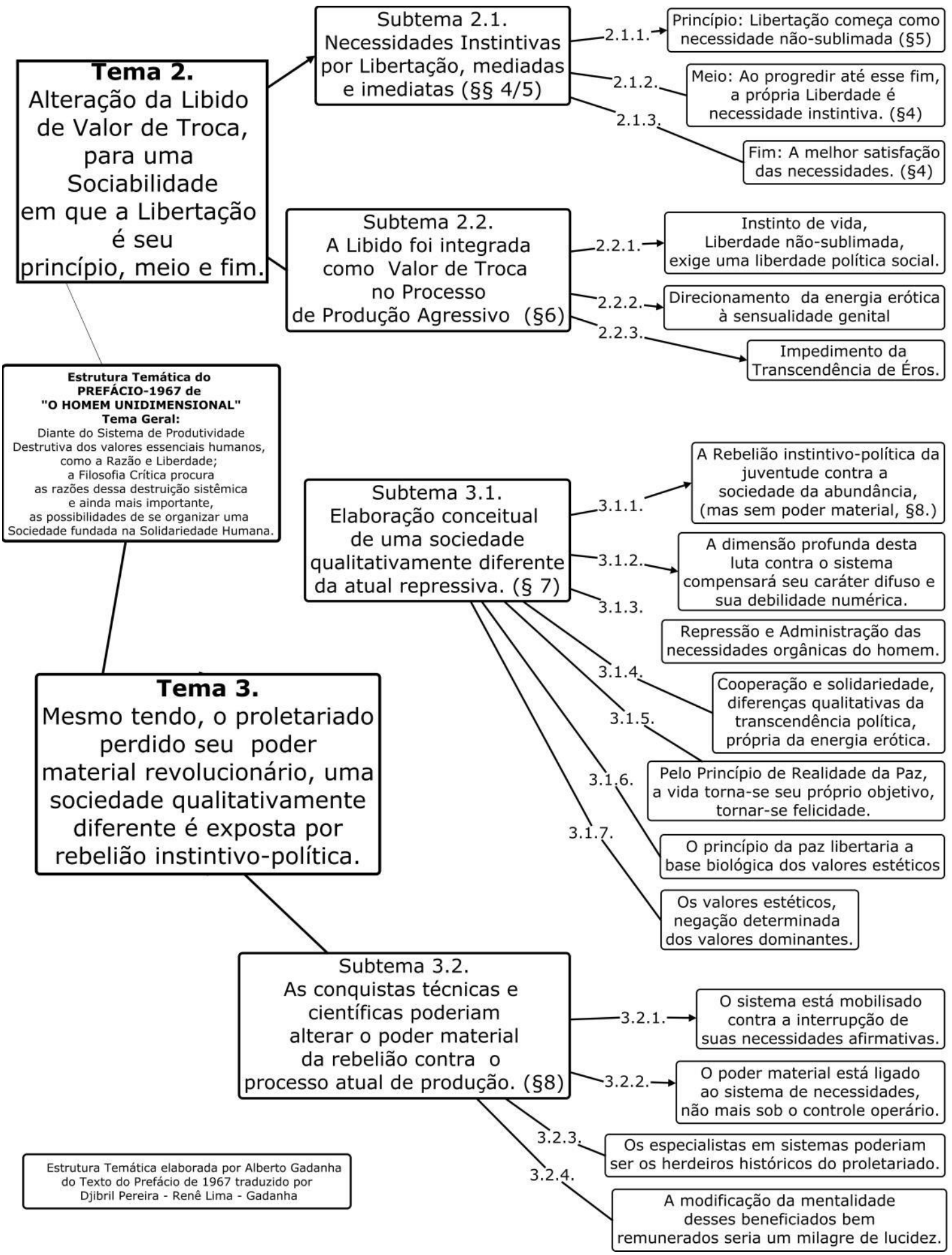


Alberto Dias Gadanha / Djibril Ernesto Pereira / Renê Ivo da Silva Lima

\section{F. Gráfico 4.}

Tema 4. TAREFA: Compreender, Despertar e Organizar a Solidariedade Humana contra a brutalidade da política de repressão global.

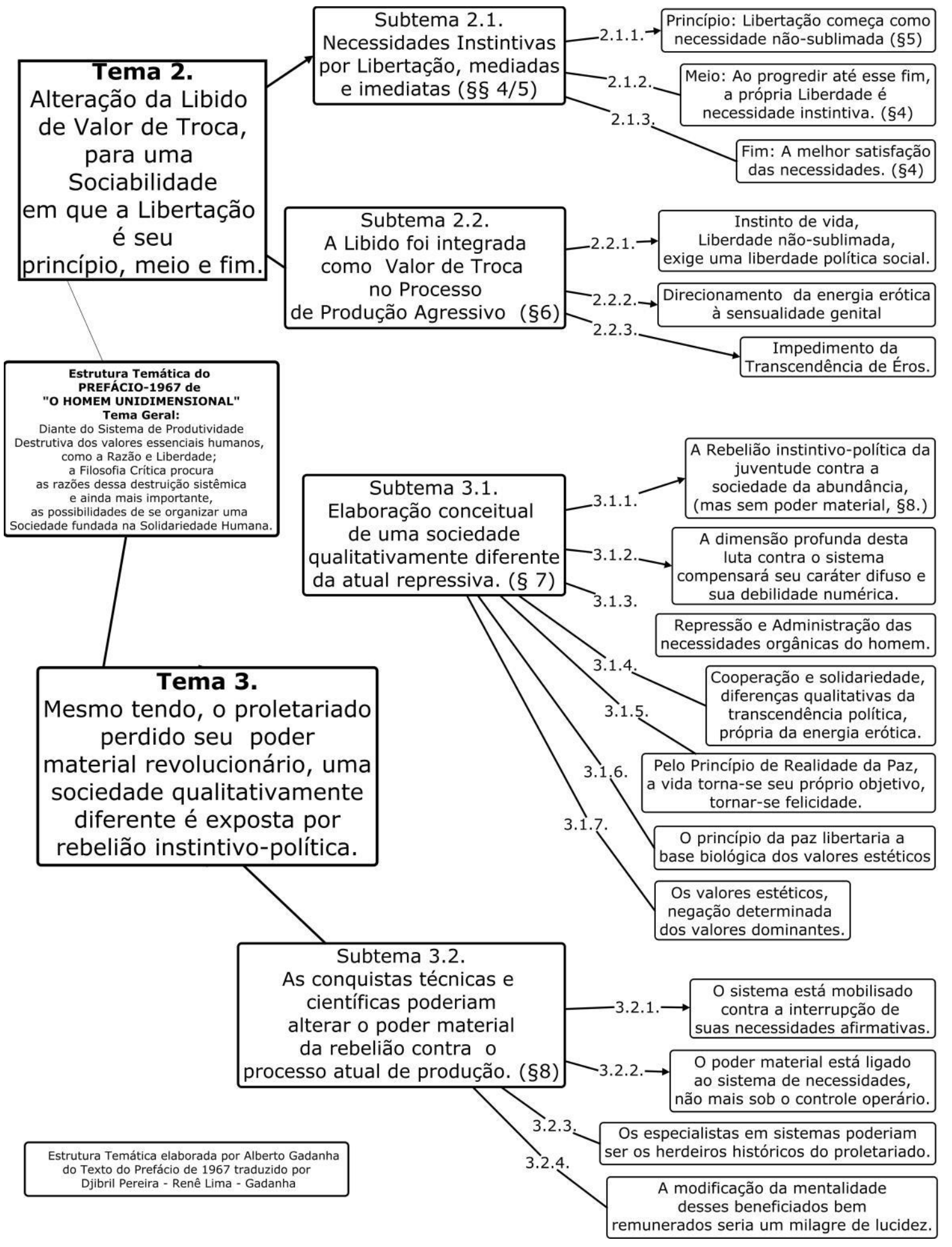

\begin{tabular}{|l|l|l|l|l|}
\hline Revita Dialectus & Ano 8 & n. 14 & Janeiro - Julho 2019 & p. $295-309$ \\
\hline
\end{tabular}


Alberto Dias Gadanha / Djibril Ernesto Pereira / Renê Ivo da Silva Lima

\author{
G. Gráfico 5.
}

Palavras-Chave referentes a cada um dos parágrafos.

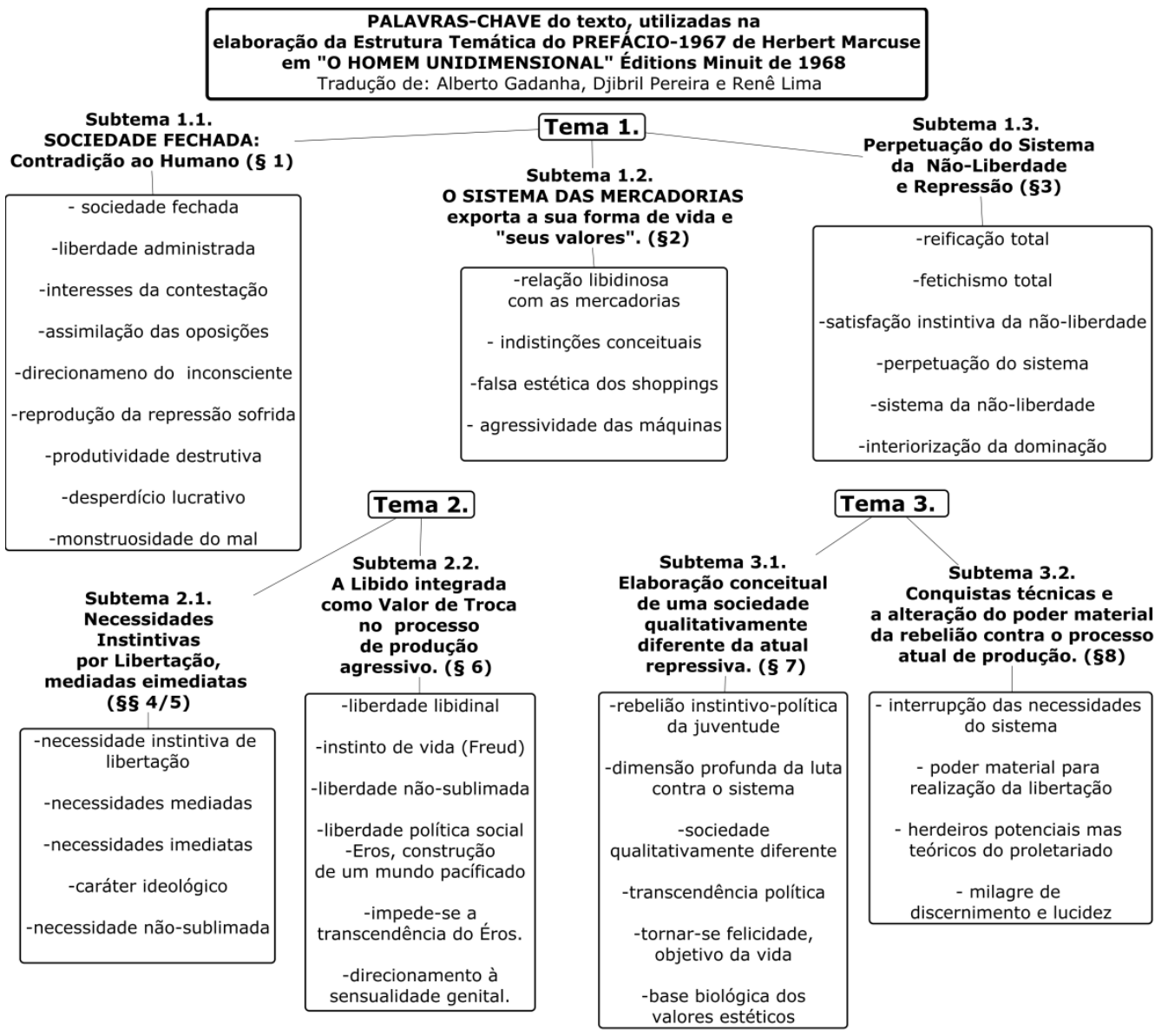

Tema 4.

Subtema 4.1. Até quando o controle tota conseguirá sustar as forças revolucionárias. (§9)

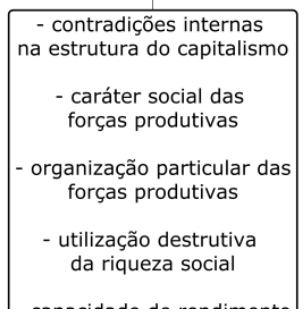

Subtema 4.2. As chances do Futuro depende da explosão das contradições do sistema $(\S 10)$

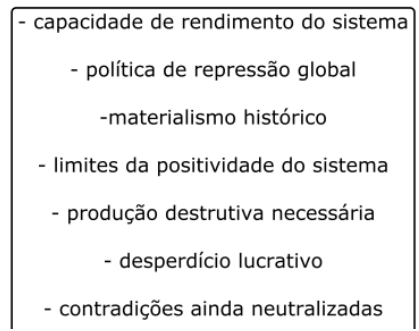

\begin{tabular}{|l|l|l|l|l|}
\hline Gevista Qialectus & Ano 8 & n. 14 & Janeiro - Julho 2019 & p. $295-309$ \\
\hline
\end{tabular}


Alberto Dias Gadanha / Djibril Ernesto Pereira / Renê Ivo da Silva Lima

\section{HERBERT MARCUSE}

\section{Prefácio de Fevereiro de 1967 À edição francesa de "O Homem Unidimensional"}

Analisei neste livro algumas tendências do capitalismo americano que conduzem a uma "sociedade fechada" - fechada porque ela disciplina e integra todas as dimensões da existência, privada e pública. Dois resultados desta sociedade são de uma importância particular: a assimilação das forças e dos interesses opostos num sistema que, nas etapas anteriores do capitalismo, já se opuseram; e a administração e a mobilização metódicas dos instintos humanos, o que torna assim os elementos explosivos e "anti-sociais" do inconsciente, socialmente dirigíveis e utilizáveis. O poder do negativo, amplamente incontrolado nos estágios do desenvolvimento anterior da sociedade, é dominado e torna-se um fator de coesão e de afirmação. Mais que nunca os indivíduos e as classes reproduzem a repressão sofrida. Porque o processo de integração acontece, essencialmente, sem terror aberto: a democracia consolida a dominação mais firmemente que o absolutismo; liberdade administrada e repressão instintiva tornam-se fontes sem cessar, renovadas, da produtividade. Sobre tal fundamento a produtividade torna-se destruição, destruição que o sistema pratica "verso ao exterior" em escala planetária. Na destruição desmedida, do Vietnam, do homem e da natureza, do habitat e da nutrição, correspondem o desperdício lucrativo das matérias primas, dos materiais e forças de trabalho, o envenenamento, igualmente lucrativo da atmosfera e da água na rica metrópole do capitalismo. A brutalidade do neo-socialismo tem sua contrapartida na brutalidade metropolitana: na rudeza das estradas e nos estádios, na violência da palavra e da imagem, na impunidade da política, que ultrapassou de muito a linguagem orweliana, nos maltratos não punidos - e até no assassinato impune - daqueles que se defendem... A frase sobre a "banalidade do mal" chegou a revelar-se desde há muito tempo como sem sentido: o mal se mostra na nudez de sua monstruosidade como contradição total à essência da palavra e da ação humanas.

A sociedade fechada em seu interior se abre para o exterior pela expansão econômica, política e militar. É mais ou menos uma questão de semântica saber se esta expansão é do imperialismo ou não. Ali igualmente, é a totalidade que está em movimento: nesta totalidade a distinção conceitual entre os negócios e a política, o lucro e o prestígio, as necessidades e

\begin{tabular}{|l|l|l|l|l|}
\hline Q Povista Dialectus & Ano 8 & n. 14 & Janeiro - Julho 2019 & p. $295-309$ \\
\hline
\end{tabular}


Alberto Dias Gadanha / Djibril Ernesto Pereira / Renê Ivo da Silva Lima

a publicidade, não é mais de modo algum possível. Se exporta um "modo de vida" ou este mesmo se exporta na dinâmica da totalidade. Com o capital, os computadores e o saber fazer (know how) aportam os outros "valores": relações libidinosas com a mercadoria, com as agressivas máquinas motorizadas, na estética falsa do supermercado.

Não é o materialismo desta forma de vida que é falso, mas a não liberdade e a repressão que ela encobre: reificação total no fetichismo total da mercadoria. Torna-se cada vez mais difícil de romper esta forma de vida na qual a satisfação aumenta em função da quantidade de mercadorias. A satisfação instintiva no sistema da não-liberdade auxilia o sistema a se perpetuar. Tal é a função social do nível de vida crescente nas formas racionalizadas e interiorizadas da dominação.

A melhor satisfação das necessidades é certamente a tarefa e o objetivo de toda libertação, mas, ao progredir em direção a tal objetivo, a própria liberdade deve tornar-se uma necessidade instintiva e, enquanto tal, deve mediar as demais necessidades, tanto as necessidades mediadas quanto as necessidades imediatas.

É necessário suprimir o caráter ideológico e empoeirado desta reivindicação: a libertação começa com a necessidade não sublimada, ali onde ela foi inicialmente reprimida.

Enquanto tal ela é libidinal: Eros enquanto "instinto de vida" (Freud), contra-força primitiva oposta à energia instintiva agressiva e destrutiva e à sua ativação social. É no instinto de liberdade não-sublimada que mergulham as raízes da exigência de uma liberdade política social; exigências de uma forma de vida em que a própria agressão e a destruição sublimadas estarão a serviço do Eros, a saber, à construção de um mundo pacificado. Séculos de repressão instintiva cobriram este elemento político de Eros: a concentração da energia erótica na sensualidade genital impede a transcendência do Eros para outras "zonas" de corpo e para seu meio ambiente, ela impede a sua força social revolucionária e formadora. Ali onde hoje a libido é desenvolvida como uma tal força, ela deve servir ao processo de produção agressivo e suas exigências: ela se integra como valor de troca. Em toda parte reina a agressão da luta pela existência: em escala individual, nacional, internacional, esta agressividade determina o sistema de necessidades.

Por isso, é de uma importância que excede em muito os efeitos imediatos, que a oposição da juventude contra a "sociedade da abundância" liga rebelião instintiva e rebelião

\begin{tabular}{|l|l|l|l|l|}
\hline Qevista Dialectus & Ano 8 & n. 14 & Janeiro - Julho 2019 & p. 295 - 309 \\
\hline
\end{tabular}


Alberto Dias Gadanha / Djibril Ernesto Pereira / Renê Ivo da Silva Lima

política. A luta contra o sistema, que não é conduzida por nenhum movimento de massas, que não é impulsionada por nenhuma organização efetiva, que não é dirigida por nenhuma teoria positiva, ganha com esta ligação uma dimensão profunda que compensará, pode ser um dia, seu caráter difuso e a debilidade numérica desta oposição. O que se busca aqui - sua elaboração conceitual que só está num estado de lenta gestação -, isto não é mais nem outra coisa do que uma sociedade fundada sobre outras relações de produção (mesmo que tal transformação da base permaneça como condição necessária da libertação): trata-se de uma sociedade na qual as novas relações de produção, e a produtividade desenvolvida a partir das mesmas, sejam organizadas pelos homens cujas necessidades e metas instintivas seja a "negação determinada" daquelas que reinam na sociedade repressiva; assim, as necessidades não-sublimadas, qualitativamente diferentes, darão a base biológica sobre a qual poderão ser desenvolvidas livremente. A diferença qualitativa se manifestaria na transcendência política da energia erótica, e a forma social desta transcendência seria a cooperação e a solidariedade no estabelecimento de um mundo natural e social que, ao destruir a dominação e a agressão repressiva, se colocaria sob o princípio de realidade da paz; somente com ele a vida pode tornar-se seu próprio objetivo; isto é, tornar-se felicidade. Um princípio como este de realidade libertaria também a base biológica dos valores estéticos, porque a beleza, o repouso, a harmonia, são necessidades orgânicas do homem cuja repressão e a administração mutilam o organismo e ativam a agressão. Os valores estéticos são igualmente, enquanto receptividade da sensibilidade, negação determinada dos valores dominantes: negação do heroísmo, da força provocadora, da brutalidade, da produtividade acumuladora do trabalho, da violação comercial da natureza.

As conquistas da ciência e da técnica tornaram teoricamente e socialmente possível a interrupção de necessidades afirmativas, agressivas. Contra esta possibilidade, é o sistema enquanto totalidade que está mobilizado. Na oposição da juventude, rebelião ao mesmo tempo instintiva e política, a possibilidade da libertação é atingida, mas lhe falta, para que ela se realize, o poder material. Este não pertence não mais à classe operária que, na sociedade de abundância, está ligado ao sistema de necessidades, mas não a sua negação ${ }^{3}$.

\footnotetext{
${ }^{3}$ Bem entendido existe igualmente uma oposição no interior da classe operária americana: contra as condições de trabalho, contra o trabalho parasitário, embrutecimento, contra a hierarquia nas fábricas, contra a queda de qualidade. Mas, esta oposição está isolada do contra-movimento político, tanto no interior dos Estados Unidos

\begin{tabular}{|l|l|l|l|c|}
\hline Revita Dialectus & Ano 8 & n. 14 & Janeiro - Julho 2019 & p. 295 - 309 \\
\hline
\end{tabular}
}


Alberto Dias Gadanha / Djibril Ernesto Pereira / Renê Ivo da Silva Lima

Seus herdeiros históricos seriam mais estas categorias que de um modo crescente, ocupam as posições de controle no processo social de produção, e que o podem parar mais facilmente, a saber os sábios, os técnicos, os especialista, os engenheiros, etc. Mas estes não são mais que herdeiros muito potenciais e muito teóricos, porque eles são ao mesmo tempo os beneficiários bem remunerados e satisfeitos do sistema; a modificação de sua mentalidade constituiria um milagre de discernimento e de lucidez.

Esta situação significa que o sistema do capitalismo em seu conjunto esteja imunizado contra qualquer mudança? Me acusaram de negar a existência de contradições internas na estrutura do capitalismo. Creio que meu livro mostra tão claramente que estas contradições, ainda existem, e tornaram-se até mais fortes, mais gritantes do que nos estágios anteriores do desenvolvimento. As contradições tornaram-se totais. Sua forma mais geral, a contradição entre o caráter social das forças produtivas e sua organização particular, entre a riqueza social e sua utilização destrutiva, determina esta sociedade em todas as dimensões e em todos os aspectos da sua política. Nenhuma contradição social, entretanto, mesmo a mais forte, explode-se "por si mesma": a teoria deve poder mostrar e avaliar as forças e os fatores objetivos. Tentei mostrar no meu livro que a neutralização ou a absorção das forças realizadoras - que operam nos domínios tecnicamente mais desenvolvidos do capitalismo não é somente um fenômeno superficial, mas nasce do próprio processo de produção, sem modificar sua estrutura fundamental capitalista. A sociedade existente conseguirá conter as forças revolucionárias, por tanto tempo que ela conseguirá produzir cada vez mais "manteiga e canhões" e zombar da população com a ajuda de novas formas de controle total.

Esta política de repressão global, de que depende a capacidade de rendimento do sistema, está cada vez mais posta duramente à prova. Em todo caso, a guerra no Vietnam tomou tais proporções que elas podem fazer dela uma reviravolta na evolução do sistema capitalista. Por duas razões: Primeiro, o excesso de brutalidade, de agressão, de mentira a que o sistema teve de recorrer para assegurar sua estabilidade, atingiu uma medida tal que a

quanto internacionalmente. Somente uma tal solidariedade poderia visar à totalidade do sistema. Tanto que subsiste o isolamento, - muitas vezes efetivamente organizado -, a oposição da classe operária permanece "economista", isto é, permite o controle da administração do sistema. Deste modo, o sistema pode "administrar" toda a oposição.

\begin{tabular}{|l|l|l|l|l|}
\hline Qovista Dialectus & Ano 8 & n. 14 & Janeiro - Julho 2019 & p. $295-309$ \\
\hline
\end{tabular}


Alberto Dias Gadanha / Djibril Ernesto Pereira / Renê Ivo da Silva Lima

positividade do existente encontra aí seu limite: o sistema em seu conjunto, revela-se ser este "crime contra a humanidade" que está localizado particularmente no Vietnam. Em segundo, a aparição do limite está igualmente visível, pelo fato que, pela primeira vez em sua história, o sistema encontra forças resistentes que não são "de sua própria natureza"; estas forças não o liberam de um combate competitivo para a exploração em seu próprio terreno, mas significam em sua própria existência, em suas necessidades vitais, a negação determinada do sistema contestando-o e combatendo-o como um todo. É aqui que reside a coincidência de fatores objetivos e de fatores subjetivos da reviravolta. E, como não há mais para o sistema capitalista um verdadeiro "exterior" - se bem que mesmo o mundo comunista determinante e contra-determinante está compreendido na economia e a política capitalista -, a resistência da FNL, é de fato, a contradição interna que explode. O fato de que os homens, os mais pobres da terra, apenas armados, tecnicamente os mais atrasados, ponham em cheque -, e isso durante anos - a máquina de destruição, a mais evoluída tecnicamente, a mais eficaz, a mais destruidora de todos os tempos, permanece um sinal histórico-mundial, mesmo que estes homens sejam enfim derrotados, o que é verossímil, uma vez que o sistema de repressão da "sociedade da abundância" sabe melhor que seus críticos liberais, o que está em jogo e que está pronto para operacionalizar todas suas forças. Estes "condenados da terra", estas pessoas as mais frágeis sobre os quais pesa toda a carga do sistema, existem em todo lugar: são populações inteiras, eles não têm nada a perder, a não ser, sua própria vida, ao se sublevar contra o sistema dominante. Contudo, totalmente sós, eles não podem se libertar: contra todo romantismo, o materialismo histórico deve insistir no papel decisivo do poder material. $\mathrm{Na}$ situação atual, nem a União Soviética, nem a China popular parecem querer ou ser capazes de exercer uma verdadeira contra-pressão: não é o jogo aterrorizador com a "solução final" da guerra atômica, mas, no caso da União Soviética, esta pressão política e diplomática que poderia ao menos frear a agressão que se reproduziu em escala ampliada. Uma tal contrapolítica poderia também ativar a oposição na Europa ocidental. Há um verdadeiro movimento operário, na França e na Itália, que poderia ainda ser mobilizado porque não está ainda integrado, compassado ao sistema. Enquanto isto não se realiza, a oposição nos EstadosUnidos, com todas suas fragilidades e sua falta de orientação teórica, permanece, talvez, como o único ponto precário entre o presente e seu futuro possível. A chance do futuro depende de cessar a expansão produtiva e lucrativa (política, econômica e militarmente); em

\begin{tabular}{|l|l|l|l|l|}
\hline Qevista Qialectus & Ano 8 & n. 14 & Janeiro - Julho 2019 & p. 295 - 309 \\
\hline
\end{tabular}


Alberto Dias Gadanha / Djibril Ernesto Pereira / Renê Ivo da Silva Lima

seguida poderiam explodir as contradições ainda neutralizadas no processo de produção do capitalismo: em particular, a contradição entre a necessidade econômica de uma automação progressiva desencadeadora do desemprego tecnológico e a necessidade capitalista do desperdício e da destruição sistemáticas das forças parasitárias, desencadeando o crescimento do trabalho parasitário.

A expansão que preserva o sistema, ou pelo menos o fortalece, só pode ser sustada por um contra-movimento internacional e global. Por todas as partes se manifesta a interpenetração global: a solidariedade resta como o fator decisivo, também aqui Marx tem razão. E é esta solidariedade que foi quebrada pela produtividade integradora do capitalismo e por "todo-o-poder" de sua máquina de propaganda, de publicidade e de administração. Despertar e organizar a solidariedade enquanto necessidade biológica de manter-se juntos contra a brutalidade e a exploração inumanas, esta é a tarefa. Ela começa com a educação da consciência, do saber, da observação e do sentimento que compreendem o que está para vir: o crime contra a humanidade. A justificação do trabalho intelectual reside nesta tarefa, e hoje o trabalho intelectual tem necessidade de ser justificado.

\begin{tabular}{|l|l|l|l|l|}
\hline Gevista Dialectus & Ano 8 & n. 14 & Janeiro - Julho 2019 & p. $295-309$ \\
\hline
\end{tabular}




\section{Da ontologia à tecnologia. As tendências da sociedade industrial. ${ }^{*}$}

Herbert Marcuse

As páginas seguintes apresentam ideias desenvolvidas durante um curso ocorrido em 195859, na École Pratique des Hautes Études. Elas fazem parte de um livro - a publicar - que se dedica ao estudo de certas tendências fundamentais da sociedade industrial mais avançada, particularmente a dos Estados Unidos. ${ }^{1}$ Essas tendências parecem engendrar um modo de pensamento e de comportamento que reprime ou rejeita todos os valores, aspirações e ideias que não estão conformes à racionalidade dominante. Consequentemente, uma dimensão inteira da realidade humana se encontra suprimida: a dimensão que permite aos indivíduos e às classes desenvolver uma teoria e uma prática de superação e arrostar [envisager] a "negação determinada" de sua sociedade. A crítica radical, a oposição eficaz - tanto intelectuais quanto políticas - agora se encontram integradas ao status quo; a existência humana parece se tornar "unidimensional". Uma tal integração não se explica apenas pelo surgimento da mass culture, do Organization man, dos Hidden Persuaders etc. Essas noções pertencem a uma interpretação puramente ideológica, que ignora a análise dos processos fundamentais: os processos que solapam o alicerce sobre o qual a oposição radical poderia se desenvolver.

Mas essa atrofia da própria base da superação histórica, a neutralização das forças negadoras, que aparecem como a realização suprema da sociedade industrial, estariam enraizadas na própria estrutura da civilização técnica ou seriam apenas obra de suas instituições repressoras? Teria a tecnicidade [technicité] transformado tão profundamente o capitalismo e o socialismo a ponto de noções marxistas e anti-marxistas acerca do desenvolvimento técnico ora se encontrarem invalidadas? A atrofia do processo de superação anunciaria a possibilidade de uma absorção das forças negadoras, anunciaria o adestramento das contradições inerentes a essas forças pela

\footnotetext{
* MARCUSE, Herbert. De l'ontologie à la technologie. Les tendances de la société industrielle. Arguments, Paris, vol.4, no 18, p. 54-59, 1960. Tradução publicada com permissão de Peter Marcuse, executor testamentário da Propriedade Intelectual de Herbert Marcuse, cujo consentimento é necessário para qualquer publicação futura. $\mathrm{O}$ material suplementar e anteriormente não publicado da obra de Herbert Marcuse se encontra majoritariamente nos arquivos da Goethe Universität. Esse material está sendo publicado pela Routledge Publishers, da Inglaterra, em uma série de seis volumes editada por Douglas Kellner, bem como pela zu Klampen Verlag, em uma série alemã editada por Peter-Erwin Jansen. A Propriedade Intelectual de Herbert Marcuse detêm todos os direitos de publicação. Este texto foi traduzido por João Paulo Andrade Dias, Mestre em Filosofia pela Universidade Federal de Uberlândia.

${ }^{1}$ Cf. Hegels Ontologie und die Grundlegung einer Theorie des Geschichtlichkeit. Frankfurt: Klostermann Verlag, 1932; Reason and Revolution. London: Milford, 1941; Eros and Civilisation. A Philosophical Enquiry into Freud. Boston: Beacon Press, 1955; Soviet-Marxism. New York: Columbia University Press, 1958.
} 
dominação tecnológica do mundo, por um nível de vida cada vez mais elevado, enfim, por uma administração universal da sociedade? Ou anunciaria o contrário da fase em decurso, uma fase em que a mudança quantitativa virá a se tornar mudança qualitativa?

Tais são as questões que guiaram nossa análise, que, ao tomar a transformação políticoeconômica da sociedade técnica como ponto de partida, se apoia sobre esse plano e ali examina as diferentes formas de atrofia do processo de superação: a forma do comportamento convencional, a forma da linguagem, da cultura tradicional e da filosofia analítica e neo-positivista.

Se o novo método científico destruiu a ideia de um universo ordenado segundo um fim, uma estrutura finalista, ele também invalidou um sistema social hierarquizado, em que as ocupações e aspirações do indivíduo eram predeterminadas por causas finais. A nova ciência, em sua neutralidade, abstraiu uma organização da vida que privava de liberdade a imensa maioria dos homens. Em seu esforço para estabelecer a estrutura físico-matemática do universo, ela igualmente abstraiu o indivíduo concreto, o "corpo sensível”. Aliás, tal abstração foi plenamente validada por seu resultado: um sistema lógico de proposições que guia a utilização e a transformação metódicas da natureza, e que tende a tornar a natureza um universo controlado pelo poder do homem.

Ao reduzir a realidade - ou torná-la redutível - às estruturas físico-matemáticas, a "verdade" tão somente se remete ao que pode ser aferido e calculado, bem como às proposições que exprimem essas condições. Essa realidade se constitui segundo suas próprias leis, mesmo que elas sejam somente leis "estatísticas". O homem pode compreendê-las, agir de acordo com elas e mesmo lhes fazer sua ocupação, utilizá-las, ainda que tais leis não tenham qualquer relação com sua própria existência individual ou social - elas tão somente o governam à medida em que ele próprio é pura matéria físico-biológica. Sob seus outros aspectos, o Homem é eliminado da natureza, ou melhor, a realidade que o método científico visa e reconhece é uma realidade independente da facticidade individual e social.

Talvez falar de "fundamentos metafísicos" da ciência moderna seja justificável. Recentemente, A. Koyré destacou de modo enfático os aspectos ontológicos e não-empíricos da ciência de Galileu. Ao menos até Newton, a tradição pitagórica, platônica e aristotélica permanece suficientemente poderosa para outorgar uma "filosofia" ao método científico. Desde sua origem, pode-se dizer que a própria noção de leis físicas universais e passíveis de unificação conserva a

\begin{tabular}{|c|c|c|c|c|}
\hline Qevista Dialectus & Ano 8 & n. 14 & Janeiro - Julho 2019 & p. $310-319$ \\
\hline
\end{tabular}


ideia - aliás, proscrita - de finalidade. Esta, contudo, torna-se uma finalidade cada vez mais vazia, uma finalidade da esfera do cálculo [calculabilité] e da previsão [prévisibilité] puros e simples finalidade que, nela mesma, não possui télos, nem estrutura propensa a um télos. Esse caráter calculável, essa previsibilidade, segundo seus próprios movimentos e termos, relacionam-se com o homem enquanto este calcula e prevê o movimento do mecanismo. Cálculo e previsão constituem a "ordem", ainda que se trate tão somente da ordem estatística. A densidade e opacidade dos “objetos”, da objetividade, parecem se evaporar. Não há mais natureza ou realidade humana como cosmos substancial. Tudo se passa como se, no método científico avançado, o pensamento tivesse se purificado dos objetos que se lhe opõem: eles apenas remanescem como “intermediários convenientes", como "modelos" e "invariáveis", como "postulados culturais inúteis". ${ }^{2} \mathrm{Ou}$, para citar uma fórmula operacional pela última vez: a matéria da física não é mais a avaliação das "qualidades objetivas do mundo exterior e material, antes, tais qualidades são apenas os resultados obtidos pelo cumprimento de tais operações". ${ }^{3}$ A totalidade dos objetos do pensamento e da prática está previamente concebida, "projetada" como organisation: para além de toda certeza sensível, sua verdade é assunto de convenção, de eficácia, de "coerência interna", e a experiência fundamental não é mais experiência concreta, prática social em seu conjunto, mas prática administrativa, organizada pela tecnologia.

Essa evolução reflete a transformação do mundo natural em mundo técnico. Não se trata de mero jogo de palavras se digo: a tecnologia substituiu a ontologia. O novo modo de pensamento anula a tradição ontológica, cuja ideia central foi resumida por Hegel: o Logos, a Razão, é o denominador comum de sujeito e objeto como síntese de contrários. Esta síntese se realiza na luta teórica e prática, na transformação do mundo dado em mundo livre e racional: eis a obra da História. Com essa ideia, a ontologia idealista englobava a tensão entre sujeito e objeto, a oposição entre um e outro. A realidade da razão era a evolução dessa tensão nos diferentes modos de ser. Assim, o sistema mais decididamente monista conservava a ideia de uma substância que se desdobra em sujeito e objeto, isto é, a ideia de uma realidade dupla, dualista, antagônica. A transformação da realidade natural em realidade técnica solapa o próprio alicerce desse dualismo. É verdade que a filosofia científica da modernidade parte da noção cartesiana de duas substâncias:

\footnotetext{
${ }^{2}$ QUINE, V. From a logical point of view. Cambridge: Harvard University Press, 1953, p. 44.

3 DINGLER, H. Philosophy of Physics, 1850-1950. Nature. Vol. 168, 1951, p. 630, 1951.

\begin{tabular}{|c|c|c|c|c|}
\hline Q Rovista Dialectus & Ano 8 & n. 14 & Janeiro - Julho 2019 & p. $310-319$ \\
\hline
\end{tabular}
}


res cogitans e res extensa. Entretanto, como a "matéria" - de que se constitui a última - é cada vez mais compreendida no interior de fórmulas matemáticas - cuja aplicação, por sua vez, "reconstitui" essa matéria -, a res extensa perde seu caráter de substância. Ela se torna estrutura matemática em si, enquanto o Ego, a res cogitans, torna-se cada vez mais o próprio objeto [le sujet] da observação e do cálculo quantitativo. Um novo monismo aparece, mas, dessa vez, sem substância. A tensão entre sujeito e objeto, o caráter dualista e antagônico da realidade tendem a desaparecer e, com eles, também a "bidimensionalidade" da existência humana, a capacidade de arrostar [envisager] um outro modo de existência na realidade, de superar a facticidade em direção a suas possibilidades reais. A capacidade [faculté] de viver segundo duas dimensões era um dos traços constitutivos do homem na civilização pré-tecnológica. Essa superação da facticidade em direção a uma mudança qualitativa da realidade $n a$ realidade era muito diferente da transcendência religiosa, que supera a própria realidade; era também muito diferente da transcendência científica, que tão somente supera a facticidade em direção à sua transformação quantitativa. No mundo tecnológico, a capacidade de compreender e viver essa transcendência histórica está gravemente atrofiada. $\mathrm{O}$ homem não pode mais existir segundo duas dimensões: ele se torna unidimensional. Não há nada além de uma única dimensão da realidade, que, em sentido estrito, é realidade sem substância, ou melhor, realidade em que a substância é na forma técnica. Esta se torna o conteúdo da realidade, sua essência. Toda significação, toda proposição é validada no interior do contexto do comportamento dos homens e das coisas - contexto unidimensional de operações efetivas, teóricas ou práticas.

À primeira vista, poder-se-ia crer que a "desnaturação" da realidade está mascarada pela terrível força com a qual o mundo técnico resiste à vontade e ao pensamento do indivíduo; que o puro e simples peso da matéria sobre a qual o homem deve agir - e que age sobre o homem nunca esteve tão sobrecarregado. Mas esse peso, ele é o peso do próprio homem. É em razão da prática do próprio homem que o mundo técnico está congelado em uma "segunda natureza", uma schlechte Unmittelbarkeit, uma má imediatidade - talvez mais hostil e destrutiva que a primeira natureza, a natureza pré-técnica. A realidade técnica não possui outra substância que o sujeito. Mas o sujeito, que faria da realidade técnica o mundo de sua liberdade e de sua razão, existe tão somente em potência: ele existe "em si", mas não "para si". Por consequência, a realidade técnica está privada de seu logos, ou melhor, seu logos aparece como vazio de realidade, como uma forma

\begin{tabular}{|c|c|c|c|c|}
\hline Qevista Dialectus & Ano 8 & n. 14 & Janeiro - Julho 2019 & p. $310-319$ \\
\hline
\end{tabular}


lógica sem substância. O positivismo contemporâneo, a semântica, a lógica simbólica, a análise linguística definem e depuram o universo do discurso para que técnicos, especialistas e experts que calculam, ajustam e igualam o utilizem sem nunca se perguntar para quem, nem por quê. Eles se ocupam com o fazer funcionar [faire marcher] das coisas, não com atribuir finalidade a esse movimento. Nem a ciência, nem a técnica possuem valores nelas mesmas: elas são "neutras" em relação a todos os valores e a todos os fins que, a partir de fora, pode-se lhes atribuir. Essa neutralidade, contudo, é positiva: a realidade é valor, precisamente avaliada enquanto se a conhece como forma pura (ou como pura matéria: nesse contexto, os dois termos, além de serem opostos, convergem) que se presta a todos os fins. O ente assume o caráter ontológico da instrumentalidade: em sua própria estrutura: ele está suscetível a todos os usos e todas as modificações.

Seriam essas noções inerentes à própria ciência? Não seriam elas, na verdade, mais adequadas às condições de experiência da sociedade em que o método científico se desenvolveu? Fazer demonstração do elo entre a ciência matemática e operacional, de um lado, e o capitalismo em ascensão, de outro, não esgota o problema. Este merece novo exame.

O elo entre sociedade e ciência é bastante conhecido. Enquanto a ciência se libertava a si mesma, enquanto ela libertava a natureza de todas as forças "externas" e constituía a objetividade como meio em si, meio puro e universal, uma liberdade análoga se produziu nas relações sociais: o homem se viu livre de toda dependência individual e "externa", ele entrava no processo social como elemento abstrato e universal - até mesmo quantificável - da força de trabalho. No decurso desse processo, o aspecto concreto das possibilidades e necessidades individuais - as qualidades secundárias! - é reduzido a um denominador comum, quantificável, base objetiva da troca, da moeda: reduzido a meios [moyens] e âmbitos [milieux] universais.

O paralelismo entre o desenvolvimento social e o desenvolvimento científico revela a partilha de um princípio: a eficácia. O método científico viu nela a mais certa garantia de sua legitimidade. Mas não há - nem poderia haver - eficácia per se! No processo social, a finalidade (da eficácia) é a produção dos bens de consumo, que visam a satisfação, e o valor de troca é o meio universalmente quantificável que integra os sujeitos e os objetos nesse processo. Parece, contudo, que a ciência nunca deveria se comprometer com tais fins. Eis aí uma grande ilusão, pois, em sua própria concepção, a ciência moderna se inclinava em direção a um fim. Antes de tudo, ela abstrai os fins que the parecem incompatíveis não com a "realidade", mas com a realidade industrial em

\begin{tabular}{|c|c|c|c|c|}
\hline Qevista Dialectus & Ano 8 & n. 14 & Janeiro - Julho 2019 & p. $310-319$ \\
\hline
\end{tabular}


ascensão. Ela serve aos meios eles próprios: à tecnicidade [technicité]. A ciência moderna construiu um universo de instrumentalidades intelectuais e físicas, um sistema verdadeiramente "hipotético". Mas, como tal, um sistema de instrumentalidades depende de um outro sistema: um universo de fins. Isso que aparece como exterior, como alheio à terminologia da ciência, revela-se parte de sua própria estrutura, de seu método e de seus conceitos: de sua objetividade.

É necessário, pois, rejeitar a noção de neutralidade da técnica, rejeitar a afirmação de que a técnica está além do bem e do mal, de que ela é a própria objetividade, passível de se utilizar socialmente sob todas as formas. É certo que uma máquina, um instrumento técnico, podem ser considerados neutros, como pura matéria. Mas a máquina, o instrumento, nunca podem existir fora de um conjunto, de uma totalidade tecnológica; eles tão somente existem como elemento de uma "tecnicidade", e a tecnicidade é um "estado do mundo", um modo de existência do homem e da natureza. Heidegger sublinhou que o "projeto" do mundo como instrumentalidade precede - e deve preceder - a técnica enquanto conjunto de instrumentos. É necessário que o homem conceba a realidade como tecnicidade antes de poder agir sobre ela como técnico. Contudo, esse conhecimento "transcendental" possui uma base material: ele se encontra assentado tanto sobre as necessidades materiais quanto sobre a incapacidade da sociedade de satisfazer e desenvolver essas necessidades. Quero insistir no fato de que a abolição da angústia, a pacificação da vida e o prazer essencialmente fazem parte das próprias necessidades vitais. Desde sua origem, o projeto técnico se atém às exigências dessas necessidades: essas exigências estão na noção de harmonia dos mundos, nas leis físicas, na noção do Deus matemático - ideia extremada de igualdade universal por meio de toda desigualdade! Essas exigências estão na própria noção de ciência moderna, que requer o livre jogo das faculdades intelectuais ante os poderes repressivos. Se se tem em conta esse caráter existencial da tecnicidade [caractère existentiel de la technicité], pode-se falar de uma causa final tecnológica e do recalque [refoulement] dessa causa final pelo desenvolvimento social da técnica.

A questão então colocada procura saber se a neutralidade em relação a todos os valores é verdadeiramente uma noção científica, isto é, se a neutralidade é uma exigência inerente à própria estrutura da ciência moderna. Ora, minha posição é de que a neutralidade da técnica - que é tão somente uma manifestação da neutralidade da ciência - é um conceito político, e que a sociedade industrial nitidamente desenvolveu a técnica em um sentido contrário àquele que é realmente o

\begin{tabular}{|c|c|c|c|c|}
\hline Qevista Dialectus & Ano 8 & n. 14 & Janeiro - Julho 2019 & p. $310-319$ \\
\hline
\end{tabular}


dela. Com efeito, a tecnicidade enquanto projeto histórico possui um sentido interno, sentido que lhe é próprio: ela tão somente projeta a instrumentalidade como meio de livrar o homem do labor e da angústia, de pacificar a luta pela existência. Essa é a causa final da transformação metódica do mundo que está implicada na tecnicidade. Ora, a técnica, ao se desenvolver como o faz atualmente, isto é, como instrumentalidade "pura", abstraiu essa causa final: esta deixou de ser o fim do desenvolvimento tecnológico. Como consequência, a instrumentalidade pura, sem finalidade, tornou-se um meio universal de dominação.

Certamente, a tecnicidade exige a dominação, seja mediante o adestramentro da natureza enquanto força hostil, violenta, destruidora, seja pelo adestramento do homem enquanto parte dessa natureza ou seja por meio da exploração de recursos naturais para a satisfação das necessidades. A sociedade industrial exerce - e com razão - essa dominação tecnológica. Mas, desde que a sociedade abstraiu a causa final da tecnologia, a própria técnica perpetuou a miséria, a violência e a destruição.

A interdependência entre forças produtivas e destrutivas, que caracteriza a técnica como dominação, tende a suprimir toda diferença entre um emprego "normal" e um emprego "anormal" da tecnologia. É precária a diferença entre os experimentos "técnicos" e "científicos" dos nazistas e o seu emprego dito democrático, justificado em nome da própria defesa. Um projétil remanesce um projétil, destrua ele Londres ou Moscou; M. von Braun remanesce M. von Braun, trabalhe ele para a Maison Brune ou para a Maison Blanche. A ausência de finalidade na técnica se manifesta igualmente na política, outra esfera em que ela é, também, ao mesmo tempo suspeita e contestável.

Se a transformação da realidade em mundo técnico não aboliu a dominação do homem pelo homem, isso ocorreu porque a tecnicidade, ao se desenvolver de modo tal, continuou a fazer da vida mero meio para se viver. A tecnicidade é bem mais profunda e bem mais antiga que a própria técnica. Atualmente, o progresso técnico permanece sob a forma do trabalho alienado, de uma produtividade repressiva. A tecnicidade se tornou o método mais eficaz, o mais frutífero para submeter o homem a seu instrumento de trabalho.

Através da tecnicidade, de novo a sociedade assegura a repressão primitiva do homem pelo homem: o prazer é sacrificado em nome do "princípio de realidade". Quanto mais essa repressão é ameaçada pelo progresso técnico, tanto mais é necessário exercê-la de maneira mais eficaz e intensa. Com efeito, parece que as conquistas da civilização industrial tornaram a repressão cada

\begin{tabular}{|c|c|c|c|c|}
\hline Qevista Dialectus & Ano 8 & n. 14 & Janeiro - Julho 2019 & p. $310-319$ \\
\hline
\end{tabular}


vez menos necessária; se confrontada com a possibilidade real de abolição do labor, cada vez mais essa repressão parece irracional. Gostaria de insistir aqui no imenso alcance político da obra de Freud como análise da dialética fatal do progresso.

A sujeição do homem ao trabalho constitui o próprio processo da civilização. Nesse processo, o organismo humano deixa de ser um instrumento de satisfação para se tornar um instrumento de trabalho e renúncia: a satisfação é deslocada, o prazer, sacrificado. Os instintos [les instincts primaires] do homem estão voltados apenas para a saciedade imediata e o repouso, isto é, para a tranquilidade dessa condição de saciedade. Assim, eles se opõem à necessidade do trabalho, do labor, condições indispensáveis para a satisfação em um mundo onde reinam a escassez de bens e a fome. A sociedade deve, então, desviar os impulsos [les impulsions] de seu fim imediato e lhes submeter ao "princípio de realidade", que é o próprio princípio da repressão [príncipe même de la répression].

O homem, então, torna-se um instrumento de trabalho. Ele é produtivo. Mas essa produtividade está sempre acompanhada de sofrimento e destruição, marcas da violência cometida contra o próprio homem em sua constituição biológica. O progresso da civilização repousa sobre essa modificação essencial da "natureza" do homem. Doravante, os indivíduos fizeram da repressão [la répression] seu projeto e empreendimento próprios (Superego, sentimento de culpa, etc.). Suas próprias pulsões [instincts] se tornaram repressivas: elas são a base biológica e mental que sustenta e perpetua a repressão política e social. Na medida em que a reorganização social das pulsões [instincts] reprime a espontaneidade, o erotismo, ela também fortalece as pulsões de destruição e morte [instincts de destruction et de mort]. Transformados em agressividade mais ou menos controlada e útil, essas pulsões [instincts] se tornam uma força inerente ao progresso da civilização. Assim, o processo da civilização é um duplo processo dialético, que intervém tanto no domínio da economia política, quanto nos domínios biológicos e mentais, cada um sustentando e fortalecendo o outro. Todo progresso, todo crescimento da produtividade está acompanhado de uma repressão progressiva e de uma destruição produtiva. A divisão social do trabalho engendra essa dialética fatal, por meio da qual, por assim dizer, todo progresso da razão carrega consigo sua própria irracionalidade, todo ganho de liberdade, uma nova forma de servidão, e toda produção, uma restrição igualmente eficaz. Ora, essa dialética se torna explosiva na civilização industrial avançada. À medida em que a sociedade domina a natureza e aumenta os recursos materiais e \begin{tabular}{|l|l|l|l|l|}
\cline { 2 - 5 } Q & Ano 8 & n. 14 & Janeiro - Julho 2019 & p. 310 - 319 \\
\hline
\end{tabular} 
intelectuais de que o homem pode dispor, a dupla repressão se torna menos necessária como condição do progresso. As conquistas da técnica e a produtividade do trabalho poderiam reduzir consideravelmente a distância entre as necessidades e sua satisfação. Um mundo verdadeiramente pacificado poderia nascer, um mundo em que a vida não seria simplesmente meio para se viver, mas vida em si e para si. A repressão, contudo, continua e deve continuar, pois sem ela não haveria mais trabalho alienado; por sua vez, sem trabalho alienado não haveria mais crescimento da produtividade repressiva, que se tornou a força motriz da sociedade.

Enfim, resta-me sugerir algumas conclusões, cujo caráter especulativo não escondo.

Admiti que as tendências repressivas da sociedade industrial avançada resultam do desenvolvimento da tecnicidade como projeto político, projeto de dominação. Essa dominação, que a tecnicidade implica, manifesta-se de modo duplo:

1) Dominação da Natureza: exploração racional de recursos naturais, etc.;

2) Dominação do Homem: exploração racional do trabalho produtivo.

Segundo sua lógica interna, o projeto técnico deveria se cumprir mediante sua anulação: a necessidade da dominação deveria desaparecer. A vitória sobre a escassez de bens e a miséria deveria permitir a "abolição do trabalho", permitir que se coloque a produtividade a serviço do consumo, permitir que nós possamos abandonar a luta pela existência em favor do conteúdo mesmo dessa existência. Forças notáveis se levantam contra um tal porvir da tecnicidade: por meio de todo progresso e de todo aperfeiçoamento das condições de vida, perpetuam-se a dominação e a destruição. Mais ainda: a dominação e a destruição se tornam condições do progresso. Sublinhei que a organização social das pulsões [instincts] desempenha papel fundamental nesse processo: o homem perpetua sua própria dominação. Toda repressão social repousa sobre uma repressão "biológica". Por consequência, toda libertação pressupõe uma revolução, uma reviravolta da ordem das pulsões [instincts] e das necessidades: um novo princípio de realidade. Essa transvaloração dos valores [total transfert des valeurs] afetaria a existência da natureza, bem como a do homem.

O Homem e a Natureza permanecem sempre como os dois termos de uma relação dialética, como fatores de uma totalidade dialética. A organização social influencia tanto a natureza quanto o homem. Não há possibilidade de libertação e pacificação da existência humana sem libertação e pacificação da natureza. Há uma dominação do homem que é repressiva e uma outra dominação

\begin{tabular}{|l|l|l|l|l|}
\cline { 2 - 4 } & Ano 8 & n. 14 & Janeiro - Julho 2019 & p. 310 - 319 \\
\hline
\end{tabular}


do homem que é libertadora, assim como há uma outra dominação da natureza que, ao colocar a organização social ante sua própria miséria, torna-se também libertação, suprime a violência e a destruição da natureza. Esse outro modelo foi realizado pela civilização em seus jardins, seus parques e suas "reservas protegidas". Fora dessas pequenas porções de terra, ela tratou a natureza da mesma forma como tratou o homem: um instrumento da produtividade repressiva. "Essa agressão conquistadora possui o traço de uma violação da natureza". ${ }^{4}$ A frase anterior, tão frequentemente tomada como simples chavão, como uma imagem antiga do romantismo e da utopia, exprime, na verdade, a relação essencial entre a destruição do homem e a destruição da natureza. O homem permanece senhor e escravo, sujeito e objeto da dominação, ainda que o exercício da dominação tenha se transferido às maquinas e sido voltado novamente contra a natureza. "A máquina é somente um meio. O fim é a conquista da natureza, a domesticação das forças naturais por meio de uma primeira servidão: a máquina é uma escrava que serve para fazer outros escravos. Uma tal inspiração poderia se encontrar com uma exigência de liberdade para o homem. Mas é difícil se libertar quando se transfere a escravidão a outros seres - homens, animais

ou máquinas. Reinar uma multidão de máquinas subjugando o mundo inteiro é ainda reinar, e todo reino supõe a aceitação de esquemas de servidão."5

${ }^{4}$ SIMONDON, Gilbert. Du mode d'existence des objets techniques. Paris: Aubier, 1958, p. 127.

${ }^{5}$ Ibid.

\begin{tabular}{|l|l|l|l|l|}
\cline { 2 - 4 } & Ano 8 & n. 14 & Janeiro - Julho 2019 & p. 310 - 319 \\
\hline
\end{tabular}


Autora: Ideusa Celestino Lopes

Titulação: Professora Doutora. Cursando pós-doutorado na Universidade Federal do Ceará com a supervisão do prof ${ }^{\circ}$ Dr. Evanildo Costeski

Afiliação Institucional: Universidade Estadual Vale do Acaraú - UVA /CE/Sobral

E-mail: ideusalopes@gmail.com

\section{RESENHA}

\section{FÍSICA DE ARISTÓTELES}

ARISTOTELE. Fisica. Texto grego a fronte. Curatore R. Radice. Milano: Bompiani, editore, 2011. Pág. 1.134. (Collana: Il pensiero occidentale)

A obra Fisica de Aristóteles, ainda não está totalmente traduzida para o português, apenas os Livros I e II. O texto é composto por oito Livros no total. A coletânea de textos que conhecemos como Física, faz parte das obras denominadas acromáticas, ou seja, uma série de apontamentos que poderiam ser desenvolvidos numa possível apresentação oral. Não existe uma continuidade linear entre os Livros, apesar de ter um fio condutor, que é a discussão sobre a Physis. Mas essa é uma característica que se encontra também, por exemplo, na Metafísica, que deve ser lida com esta mesma reserva. Um exemplo que coloca tal estrutura em evidência são os Livros I e VII, que podem ser considerados completos e autônomos. As partes que compõe o texto foram recolhidas e sistematizadas por dirigentes da escola peripatética, considera-se que Andrônico di Rodi (I a.C.) teria feito a seleção e organização do material.

O objeto de discussão da Fisica é a natureza e as coisas que são da natureza. O que Aristóteles caracteriza como sendo natureza? O que tem em 
si mesmo o princípio do movimento. O termo movimento compreende geração e corrupção; alteração; crescimento e diminuição; translação. A questão central, portanto, do texto é uma investigação sobre os princípios e as condições estruturais do devir, colocados como tema de consideração filosófica. Neste sentido, há uma preocupação com os fundamentos do devir. Trata esse tema nos três primeiros Livros, mostrando o que é o movimento e em que modo ele é inegável e evidente.

Aristóteles está dialogando com os pré-socráticos, que consideravam a Physis como expressão do real na sua totalidade. No entanto, nas suas investigações, faz uma indagação sobre a totalidade e sobre a natureza, distinguindo-as. Mas apesar dessa separação, considera importante a investigação dos princípios para fundação de uma física, como ciência.

Outro interlocutor é Platão, que considera como sendo impossível uma ciência do devir, pois o objeto da ciência deveria ser o imutável e o permanente, o ser. Para Aristóteles, não obstante, o ser é devir, neste texto expõe as razões para se compreender o devir como inteligibilidade. Ao propor a física como ciência se contrapõe diretamente a Platão e Parmênides.

A obra está dividida em oito Livros. No Livro I, defende a construção de uma nova ciência, a Física. Ao apresenta-la como ciência, delineia que a sua tarefa deve ser a de investigar as causas e os primeiros princípios, ou seja, indagar sobre a estrutura que torna inteligível o devir. Mas ao fazer uma abordagem sobre a física como ciência se contrapõe diretamente a Platão e aos Eleatas (Parmênides e Melisso), que negam o estudo da física como ciência do ser no devir. Aborda a tese eleática da unidade e imobilidade do Ser. Analisa em seguida as teses dos que colocam o infinito como princípio, ou infinitos elementos como princípio. Defende que se deve assumir um

\begin{tabular}{|l|l|l|l|l|}
\hline Q Povista Dialectus & Ano 8 & n. 14 & Janeiro - Julho 2019 & p. 320 - 328 \\
\hline
\end{tabular}


número finito de princípios como fundamento do devir. Aborda também algumas teses dos physis que defendiam os contrários como sendo princípios. Aristóteles faz a defesa de que o devir é princípio, assim sendo, seria preciso identificar se esses são um ou mais de um; finitos ou infinitos e se pertencem a um único ou a múltiplos gêneros. Refuta a possibilidade de que os princípios possam ser um ou em número infinito.

\section{Livro II}

A análise sobre os princípios do devir e do devir como princípio, iniciada no Livro I tem continuidade neste segundo Livro. Faz uma abordagem sobre o significado de natureza (physis), como sendo princípio e causa do movimento (kìnesis); apresenta a diferença entre os entes que são da natureza dos que pertencem à arte (técnica). Os primeiros têm em si mesmo o princípio do movimento. A partir dessa argumentação distingue os âmbitos da física e da matemática. $\mathrm{O}$ físico estuda a forma, mas em referência à matéria. Neste Livro, introduz a doutrina das quatro causas como princípio de explicação dos eventos naturais, dando destaque à causa final.

\section{Livro III}

Indaga sobre a estrutura do movimento. Divide o texto em dois momentos: num primeiro momento, dedica-se ao movimento de modo geral, indagando sobre os predicados comuns do movimento (infinito, lugar, vazio, tempo, contínuo), ou seja, sobre as condições estruturais sem as quais o movimento mesmo não pode ser concebido. Num segundo momento, trata especificamente do infinito (àpeiron) como sendo o predicado que é inerente a todas as determinações estruturais no movimento, enquanto contínuo (synechès). Inicia a abordagem sobre o conceito de contínuo, que não se conclui neste Livro, mas apenas no Livro VI.

\section{Livro IV}

Dar continuidade à discussão sobre o que ele chamou anteriormente de "predicados comuns" do movimento. O primeiro a ser tratado é o lugar, aborda o problema da sua existência e em seguida indaga sobre a sua essência. Sua intenção é esclarecer a diferença entre lugar e os seguintes

\begin{tabular}{|l|l|l|l|l|}
\hline Q Povista Dialectus & Ano 8 & n. 14 & Janeiro - Julho 2019 & p. 320 - 328 \\
\hline
\end{tabular}


termos: forma, matéria, intervalo e limite extremo. Segundo Aristóteles, essas são estruturas sem as quais o movimento não é possível. Apresenta a seguinte definição de lugar: como sendo "o primeiro limite imóvel daquele que contém". Trata também da relação que ocorre entre lugar e o todo. $\mathrm{O}$ mundo entendido como todo não tem um lugar, mas cada coisa determinada, por natureza, tem o seu lugar determinado.

O próximo tema a ser tratado é o tempo. Ao analisar os argumentos a favor e contra a existência do tempo, concebido como composto de passado e futuro, faz uma analise sobre a questão do instante, que deveria ser compreendido como indiscutivelmente presente, e como limite. Conclui, não obstante, que tanto a sua existência como a sua essência permanece uma aporia, e que é difícil sustentar que o tempo é movimento, mas também que não é sem movimento. Mas se o tempo for considerado como número pode ser definido como "número do movimento no intervalo entre antes e depois". Nesse sentido, as coisas são no tempo, quando medidas pelo tempo na sua existência, ou seja, as coisas sofrem ação do tempo, e são no tempo, somente enquanto possam ser ou não ser.

\section{Livro V}

Nesse livro tratará o movimento enquanto mudança (metabolé). Inicia introduzindo uma diferença entre mudança e movimento, mudança por si e por acidente; determina as espécies de mudança que procedem de um substrato a um substrato ou de um substrato para um não-substrato, ou seja, entre geração e corrupção. Compreende que movimento se dá de um substrato para um outro substrato, descartando que exista um movimento do não-ser. Discute também a diferença entre movimento e repouso (privação do movimento). Identifica como sendo três as categorias do movimento: qualidade (alteração), quantidade (crescimento e diminuição) e lugar (deslocamento). Trata também do tema da unidade do movimento, como contínuo, e da sua unicidade, como sendo uniforme.

Livro VI

Retoma a discussão sobre o contínuo, que está intrinsicamente ligada aos "paradoxos" de Zenão, que defende o devir como contraditório. Procura demonstrar que o corpo em movimento não se move através de uma

\begin{tabular}{|l|l|l|l|l|}
\hline Q Povista Dialectus & Ano 8 & n. 14 & Janeiro - Julho 2019 & p. 320 - 328 \\
\hline
\end{tabular}


quantidade infinita de processos ou etapas. Tendo como pressuposto que as grandezas não são compostas por pontos ou o tempo por instantes indivisíveis. Refuta, portanto, o argumento da flecha, que percorre certa distância, aparentemente, mas no final das contas está em repouso. Pois entende que o contínuo é um aspecto importante na constituição do movimento que envolve o sujeito, o espaço e o tempo.

Em seguida faz uma análise e uma demonstração da continuidade da grandeza, que tem como consequência que as partes são sempre divisíveis. O tempo também é constituído pelo contínuo. A infinitude deve ser atribuída a um dos dois, ou seja, à grandeza ou ao tempo. Defende a seguinte posição: nenhum contínuo é composto pelo indivisível, mas por partes sempre divisíveis.

Afirma que a grandeza não é composta por pontos, nem o tempo por instantes, ou o movimento por unidade simples de movimento. Trata do instante no tempo, mostrando em que sentido ele é indivisível e idêntico. No instante não é possível nem o movimento nem o repouso, que acontecem somente no tempo. Passa ao exame da mudança, mostrando que não existe um "primeiro" termo no qual o objeto que muda completa a sua mudança. Segundo Aristóteles, existe uma circularidade entre mudança ocorrida e mudança que está ocorrendo. Faz uma análise do tempo a partir do movimento e do repouso, demonstrando que não existe um tempo primeiro do movimento, nem do repouso, mas em cada parte do movimento e do repouso, deve-se compreender o corpo como um inteiro.

A partir da recíproca implicação que existe entre tempo e movimento, tira como conclusão que em um tempo infinito não pode se desenvolver um movimento finito, nem um movimento infinito em um tempo finito. $\mathrm{O}$ infinito não pode ser pensado como ato, mas como potência.

\section{Livro VII}

Neste Livro Aristóteles aborda o movimento na relação entre o motor (o que move) e o que é movido. O ponto de partida é a proposição: "tudo aquilo que está em movimento, necessariamente é movido por si ou por outro". Introduz a existência de um primeiro motor e de um primeiro movimento. Determina que entre o que move e o que é movido não há

\begin{tabular}{|l|l|l|l|l|}
\hline Qevista Qialectus & Ano 8 & n. 14 & Janeiro - Julho 2019 & p. 320 - 328 \\
\hline
\end{tabular}


intermediário. O primeiro motor não está separado do que é movido, mas o motor é princípio do movimento.

Individualiza três tipos de movimento: local, quantitativo e qualitativo. Para tanto aborda os conceitos de impulso, força, repulsão, lançamento. Em seguida analisa o movimento de alteração, mas distinguido entre geração e corrupção, ou seja, geração e corrupção não são formas de alteração em geral, mas apenas de modo acidental. A alteração ocorre somente na parte sensível da alma. Por exemplo, o ato cognoscível não tem geração.

Na sequencia afronta o problema da comparação entre os movimentos: se se pode comparar um movimento com outro. Para Aristóteles não é possível comparar as coisas que são homônimas. A comparação somente é possível se a mudança ocorre na mesma velocidade. Os movimentos diferem ou por gênero, espécie ou número. Discute a questão da comparabilidade entre as varias formas de alteração e entre geração e corrupção.

Afirma também o caráter unitário do movimento, que deve ser considerado sempre no seu aspecto global e unitário. Individualiza os momentos que constitui o movimento: força do motor, grandeza do que é movido, distância e tempo. Demonstra que eles são inerentes ao ato do movimento. Nessa abordagem está confrontando o argumento de Zenão do "grão de milho".

\section{LIVRO VIII}

No último Livro, procura demonstrar a existência de um princípio primeiro do movimento, ou seja, o primeiro motor ou motor imóvel, que move sem ser movido. A argumentação parte da tese de que o movimento é eterno, ou seja, não tem início nem fim.

Nessa relação que envolve motor e movimento, Aristóteles aponta para um primeiro princípio absoluto do movimento, que deve ser eterno e imóvel. O que é movido por este princípio eterno, deve ser eternamente em movimento, enquanto efeito de uma causa eterna. Entre os movimentos existentes somente o movimento circular tem os requisitos da eternidade, uniformidade e identidade. Portanto, o movimento circular eterno pede um princípio por sua vez eterno, que seja imóvel e incorpóreo. O primeiro motor

\begin{tabular}{|l|l|l|l|l|}
\hline Q Povista Dialectus & Ano 8 & n. 14 & Janeiro - Julho 2019 & p. 320 - 328 \\
\hline
\end{tabular}


imóvel é identificado como estando na esfera mais externa do universo. Assim, a Fisica coloca como princípio primeiro de todo o movimento, um princípio metafisico. Um princípio primeiro que é eterno, imóvel, incorpóreo, ou seja, uma realidade que transcende a totalidade do devir, mesmo se a ele é estreitamente ligado.

O problema a ser resolvido: relacionar o Primeiro Motor com a afirmação da eternidade do devir e do mundo. Nesse aspecto está refutando Platão, que no Timeu afirma a origem do mundo e do devir a partir do Demiurgo. A questão da eternidade do movimento é desenvolvida inicialmente a partir da análise histórica dos pré-socráticos, os physicos, que de um modo geral afirmam a existência do devir. No entanto, não há unidade quanto à questão da eternidade. Aristóteles pretende demonstrar a eternidade do movimento, fundamentada em três pilares: definição, motor e eternidade do tempo.

A natureza é princípio de ordem, neste sentido, não estaria sujeita a variação, do ser e do não ser. Toda a argumentação sobre a não geração e não destruição, portanto, da eternidade do devir depende da posição da eternidade do tempo. Ou seja, da impossibilidade de um início absoluto do tempo ou um fim absoluto. O tempo não tem um começo e nem um fim.

Aristóteles faz uma forte crítica aos argumentos contra a eternidade do movimento, que envolve tanto as coisas animadas e os quatro elementos naturais, que se movem sempre do mesmo modo verso o lugar natural, eles têm em si uma disposição inata para receber o movimento. Mas ao mesmo tempo considera que o movimento dos elementos naturais é realizado por natureza, mas não por si. Faz distinção entre o que é movido por si, por outro, por natureza e contra a natureza. Ressalta também que existe uma diferença com respeito aos movimentos dos seres vivos. Introduz os graus da potência e do ato. Se não for impedido, o que é em potência passa a ato.

Faz uma discussão sobre se o motor move por si mesmo, ou por causa de outro, ou ainda, por motores intermediários. Para não ir ad infinito, de um motor que move outro, coloca a existência de um primeiro motor, que move sem ser movido. Demonstra que o primeiro motor move a si mesmo, esclarecendo ao mesmo tempo em que modo se move o motor que move a si mesmo. As partes do motor não estão reciprocamente em movimento, o

\begin{tabular}{|l|l|l|l|l|}
\hline Q Povista Dialectus & Ano 8 & n. 14 & Janeiro - Julho 2019 & p. 320 - 328 \\
\hline
\end{tabular}


motor não é composto de partes que movem a si mesmo, "não é possível que aquilo que move a si mesmo seja movido em modo tal que alguma das suas partes seja movida por outra". Em conclusão, o motor em sentido primário é imóvel. Defende a unicidade do motor imóvel e sua eternidade. Os astros, por sua vez, são motores movidos de tipo particular. Discute, portanto, em que modo o movimento é transmitido ao mundo.

Ao considerar que o movimento deve existir sempre sem interrupção, deve existir algo eterno que move como primeiro motor imóvel. Faz uma argumentação da eternidade do primeiro motor, mostrando de modo contrário a Platão, que o seu conceito de eternidade não é fundado sobre o conceito de alma, que move a si mesma.

Trata de indicar qual movimento o primeiro motor realiza. Em primeiro lugar, deve ser um movimento que é primeiro e contínuo. O movimento local é o primeiro entre os movimentos, e por ser primeiro, ele está implicado nos outros movimentos, ou seja, naquele do crescimento e da diminuição e naquele qualitativo. Conclui que nenhum outro movimento pode ser contínuo, com exceção do movimento local. São vários os movimentos locais, entre eles apenas um é primeiro e contínuo. O movimento retilíneo não é contínuo, por isso, esse tipo de movimento não tem nem mesmo unidade. Somente o movimento circular é contínuo e infinito. Nesse sentido, o movimento circular é o primeiro dos movimentos locais, portanto, tem prioridade em relação ao movimento retilíneo, pois este se destrói, enquanto o circular é eterno. O movimento circular tem continuidade e unidade.

Finalmente faz uma análise e demonstra quais características compete ao primeiro motor: não tem grandeza, ou seja, algo finito, de fato, não pode mover-se em um tempo infinito, nem ter uma força infinita. Percebe-se descontinuidade nos movimentos produzidos por um motor que é por sua vez movido. O primeiro motor é privado de grandeza e assim indivisível, e move o movimento eterno em um tempo infinito.

A Fisica faz uma análise geral sobre o movimento e o repouso na natureza, procura refutar tanto a tese dos que afirmam "tudo está em movimento" tese de Heráclito; bem como os que defendem "que tudo está em repouso", os Eleatas. Aristóteles procura afirmar que algumas coisas são

\begin{tabular}{|l|l|l|l|l|}
\hline Q Povista Dialectus & Ano 8 & n. 14 & Janeiro - Julho 2019 & p. 320 - 328 \\
\hline
\end{tabular}


sempre em repouso, outras sempre em movimento, outras às vezes em repouso e em outros momentos em movimento. O motor imóvel, no entanto, está sempre em repouso. Os elementos naturais se movem, mas também tendem para o repouso.

\begin{tabular}{|l|l|l|l|l|}
\hline Govista Dialectus & Ano 8 & n. 14 & Janeiro - Julho 2019 & p. $320-328$ \\
\hline
\end{tabular}

